\author{
UNIVERSIDADE DE BRASÍLIA \\ FACULDADE DE ARQUITETURA E URBANISMO
}

KATIA BROETO MILLER

\title{
MODELO PARAMETRIZADO DE ACV: \\ APLICAÇÃO EM SISTEMAS CONSTRUTIVOS COM ESTUDO DE CASO EM VEDAÇÕES VERTICAIS
}

Orientadora: Prof. ${ }^{a}$ Dr. ${ }^{a}$ Raquel Naves Blumenschein

Co-orientador: Prof. Dr. Armando de Azevedo Caldeira Pires

Brasília 


\title{
MODELO PARAMETRIZADO DE ACV: APLICAÇÃO EM SISTEMAS CONSTRUTIVOS COM ESTUDO DE CASO EM VEDAÇÕES VERTICAIS
}

\author{
Tese submetida à Faculdade de Arquitetura e Ur- \\ banismo da Universidade de Brasília como parte \\ dos requisitos necessários para a obtenção do \\ grau de Doutora em Arquitetura e Urbanismo.
}

Aprovada por:

Prof. ${ }^{a}$ Raquel Naves Blumenschein, D.S.c. (UnB) - Orientadora

Prof. Armando Caldeira Pires, D.S.c. (UnB-FT) - Co-orientador

Prof. ${ }^{\text {a }}$ Sandra Luz, D.S.c. (UnB Gama) - Examinadora Interna

Prof. ${ }^{a}$ Maria Vitória Duarte Ferrari, D.S.c. (UnB Gama) - Examinadora Interna

Prof. ${ }^{a}$ Rosa Maria Sposto, D.S.c. (UnB-FT) - Examinadora Interna

Prof. Sebastião Soares, D.S.c (UFSC) - Examinador Externo 
Dedico esta tese a todos que trabaIham em prol da ciência e que se esforçam por fazer um mundo melhor e mais sustentável. 
What you people call your natural resources our people call our relatives.

O que o seu povo chama de recursos naturais, o nosso povo chama de seus parentes (livre tradução).

Oren Lyons,

Líder espiritual do povo Onondaga 


\section{Agradecimentos}

Agradeço à minha família pelo apoio em toda a minha trajetória escolar. Em especial à minha mãe, Mery Margareth, que sempre me incentivou a estudar e que nunca achou que haviam limites para uma garota com poucos recursos financeiros e do interior.

Um agradecimento especial para meu marido, Frederico Franzosi, por ter me apoiado nessa longa trajetória, por cada momento dedicado a me ajudar de todas as formas que estavam em seu alcance.

Agradeço aos meus orientadores, Profa Raquel Naves Blumenschein e Prof. Armando Caldeira Pires pela disponibilidade, atenção dispensada, paciência, dedicação e profissionalismo. Além do apoio dado à concretização de dois sonhos: fazer este doutorado e estudar no exterior.

Agradeço também ao meu co-orientador, Owen Abbe, e à equipe do Centro de Produtos Sustentáveis da BRE, que me receberam na Inglaterra para o Doutorado Sanduíche e que me apoiaram em grandes decisões na reta final desta jornada.

Agradeço aos meus amigos da pós-graduação e aos meus amigos da vida, em especial à Profa Maria Vitória pelos debates sobre os temas relacionados à esta pesquisa e por me ajudar a organizar meus pensamentos.

Agradeço aos meus professores da PPG FAU-UnB que ajudaram uma desenhista industrial a entender a sustentabilidade no contexto da Arquitetura e do Urbanismo.

Agradeço à equipe do Laboratório do Ambiente Construído, Inclusão e Sustentabilidade por ter me proporcionarem a participação em vários projetos, que contribuíram para o meu aprendizado.

Agradeço ainda à equipe da Secretaria da PPG FAU-UnB que me apoiou em vários processos e que me atendeu com dedicação e rapidez.

Agradeço à Capes e ao CNPq pelo apoio financeiro desde o início do doutorado, incluindo as despesas com o doutorado sanduíche. 


\section{Resumo}

A Indústria da Construção é uma das cadeias produtivas mais importantes nos aspectos sociais, econômicos e ambientais. Esse setor gera empregos, tem uma significativa participação no PIB nacional e supre a demanda pelo ambiente construído. Por outro lado, possui impactos ambientais negativos que abrangem toda a cadeia. Tornar a Construção mais limpa e eficiente é uma tarefa urgente que demanda a inserção de ferramentas e metodologias que possam auxiliar na quantificação dos impactos ambientais e na escolha por opções mais sustentáveis. Esta pesquisa tem como objetivo elaborar um Modelo Tecnológico Parametrizado (MTP) de aplicação da metodologia de Avaliação do Ciclo de Vida (ACV) para o Sistema de Vedação Vertical Interna e Externa (SVVIE), considerando os requisitos de desempenho das vedações verticais externas. A metodologia seguiu os seguintes passos: (i) fundamentação teórica; (ii) levantamento do Estado da Arte; (iii) definição do subsistema da edificação a ser estudado, que é o Sistema Vedação Vertical, e em qual tipo de vedação seria aplicado o MTP; (iv) compilação dos requisitos de desempenho das vedações verticais externas no Brasil e no Reino Unido; (v) caracterização da tipologia das vedações para atendimento aos requisitos de desempenho; (vi) caracterização da cadeia produtiva das vedações; (vii) elaboração do MTP, por meio da parametrização do Inventário do Ciclo de Vida e da definição dos parâmetros de projeto; (viii) definição de contextos de análise, por meio da combinação dos parâmetros; e (ix) análise dos resultados, das comparações e das lacunas da aplicação do MTP. Na aplicação do MTP observou-se, no primeiro contexto de análise que compara duas tipologias brasileiras com diferentes parâmetros de projeto aplicados, que a tipologia que consome menos recursos possui um melhor desempenho ambiental. O segundo contexto de análise teve apenas dois parâmetros alterados: o tipo de bloco e a nacionalidade, o que permite avaliar melhor a funcionalidade e a importância dos parâmetros e que demonstra que a tipologia britânica aplicada ao Brasil possui um melhor desempenho ambiental comparando-se a sua aplicação no Reino Unido. Com esta pesquisa, conclui-se que os MTPs podem ser aplicados ao contexto da Construção, sobretudo para as vedações verticais externas que foram testadas nesta tese. A parametrização é fundamental para a elaboração de ACVs, avaliando os impactos potenciais desde a fase de projeto, simplificando o entendimento de uma grande quantidade de dados e informações e identificando fatores que influenciarão de forma mais significativa o impacto ambiental do produto. Conclui-se ainda que a ACV ainda é pouco disseminada no Brasil e que novos trabalham precisam ser desenvolvidos na área para que se possa contar com um inventário robusto e que torne a tarefa mais fácil e rápida, à medida que mais dados, parâmetros e informações estejam disponíveis.

Palavras chave: Avaliação do Ciclo de Vida parametrizada, modelo tecnológico parametrizado, vedação vertical, requisitos de desempenho. 


\section{Abstract}

The construction industry is one the most important supply chains regarding social, economic and environmental aspects. This industry creates Jobs, has a significant share of Gross Domestict Product and it supplies the demand for the built environment. On the other hand, it causes negative environmental impacts throughout its supply chain. Improve its economic and environmental efficiency is a hard but urgent task that demands to apply tools and methods that support quantifying of environmental impacts and choosing more sustainable options. The objective of this research is to develop a Parameterised Technological Model (PTM) applied to the Life Cycle Assessment (LCA) of External and Internal Wall System (EIWS), considering standardised performance requirements. The methodology followed these steps: (i) theoretical foundation; (ii) survey of State of Art; (iii) definition of building subsystem to be studied, which is the EIWS, and which type of wall will be the target of the PRM; (iv) compilation of performance requirements of walls considering Brazilian and British standards; (v) characterisation of the wall typologies that meet standard performance requirements/ (vi) characterisation of the supply chain to build walls; (vii) development of the PTM, by parameterising the Life Cycle Inventory and definition of design parameters; (viii) definition of analysis contexts, by combining parameters; and (ix) analysis of results, comparisons and gaps of the PTM application. During the application of the PTM we observe that in the first context of analysis, which compares two typical Brazilian typologies with different design parameters, that the typology that uses less resources has better environmental performance. The second context of analysis has essentially only two design parameters modifies: the type of brick and the nationality, which allows to evaluate better the functionality and importance of parameters and shows that the British typology applied in Brazil has a better environmental performance when compared to its application in United Kingdom, considering the performance requirements for each country. With this research, we conclude that the PTMs are applicable to the Construction Industry, especially for the External Walls that were tested in this thesis. The parameterisation is essential to develop LCAs, evaluating potential impacts since the design stage, simplifying the understanding of a large amount of data and information and identifying factors that influence more significantly the product environmental impact. We also conclude that LCA is poorly disseminated in Brazil and that new works need to be developed in this field to augment the national inventory and make future LCAs easier and more precise, insofar as more data parameters and information are available.

Keywords: Life Cycle Assessment, Parameterised Technological Model, Wall, Performance Requirements. 


\section{Resumen}

La Indústria de la Construcción es una de las cadenas productivas más importantes en los aspectos sociales, económicos e ambientales. Esto sector genera empleos, tiene una significativa participación en el PIB nacional y satisface la demanda por el medio construído. Por otra parte, posee impactos ambientales negativos que afectan a toda la cadena. Convertir la Construcción en processos más limpios y eficaces es una tarea urgente que demanda la inserción de herramientas y metodologías que puedan auxiliar en la cuantificación de los impactos ambientales y en la elección de opciones más sostenibles. Esta investigación tiene como reto elaborar un Modelo Tecnológico Parametrizado (MTP) para la aplicación de la metodologia de Evaluación del Ciclo de Vida (ECV) para Sistema de Aislamiento Vertical Interna y Externa, considerando los requisitos de eficencia de los aislamientos verticales externos. La metodología siguió los siguientes pasos: (i) fundamentación teórica; (ii) levantamiento del Estado del Arte; (iii) definición del subsistema de la edificación que será estudiada, que es el Sistema Aislamiento Vertical, e en cual tipo de aislamiento sará aplicado el MTP; (iv) recopilación de los requisitos de eficacia de los aislamientos verticales externos en Brasil y Reino Unido; (v) caracterización de la tipología de los aislamientos que cumplen con los requisitos de eficiencia; (vi) caracterización de la cadena productiva de los aislamientos; (vii) elaboración del MTP, a través de la parametrización del Inventario del Ciclo de Vida y de la definición de los parámetros del proyecto; (viii) definición de contextos de análisis, a través de la combinación de los parámetros; y (ix) el análisis de los resultados, comparaciones y lagunas en la aplicación del MTP.. En la aplicación del MTP, se observó, en el primer contexto de análisis que compara dos tipologías brasileñas con diferentes parámetros de proyecto aplicados, que la tipología que consume menos recursos, posee mejor eficiencia ambiental. El segundo contexto de análisis tuvo apenas dos parámetros alterados: el tipo de bloque y la nacionalidad, que permite evaluar mejor la funcionalidad y la importancia de los parámetros. El cual demuestra que la tipología británica aplicada en Brasil posee mejor eficiencia ambiental comparada con su aplicación en el Reino Unido. Con esta investigación se concluye que los MTPs pueden ser aplicados al contexto de la Construcción, sobre todo a los aislamientos verticales externos que fueron probados en esta tesis. La parametrización es fundamental para la elaboración de las ACVs, evaluando los impactos potenciales desde la fase de proyecto, simplificando la comprensión de una gran cantidad de datos e informaciones, y también identificando factores que influenciarán de un modo más significativo el impacto ambiental del producto. También se concluye que la ECV es poco difundida en Brasil y que nuevos trabajos deben de ser desarrollados en el área para que se pueda contar con un inventario más amplio que haga la tarea más fácil y rápida, en la medida en que más datos, parámetros e informaciones estén disponibles.

Palabras clave: Evaluación del ciclo de vida parametrizada, modelo tecnológico parametrizado, aislamiento vertical, requisitos de eficiencia. 


\section{LISTA DE FIGURAS}

Figura 1: Fluxograma do encadeamento lógico da pesquisa........................... 31

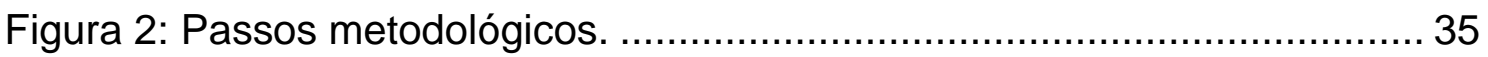

Figura 3: Etapas do planejamento do MTP. ................................................ 37

Figura 4: Passos metodológicos usados e resultados a serem obtidos. ........... 38

Figura 5: Etapas da ACV. Fonte: BSI, 2006a............................................... 42

Figura 6: Etapa 1 da ACV - Definição do objetivo e do escopo........................ 43

Figura 7: Etapa 2 da ACV - Análise do Inventário do Ciclo de Vida................. 43

Figura 8: Etapa 3 da ACV - Análise do Impacto do Ciclo de Vida................... 44

Figura 9: Etapa 4 da ACV - Interpretação. ................................................. 45

Figura 10: Metodologias, bancos de dados e softwares de ACV usados no contexto da CPIC

Figura 11: Distribuição geográfica dos artigos encontrados no Science Direct 51 Figura 12: Espacialização da produção acadêmica brasileira em ACV e

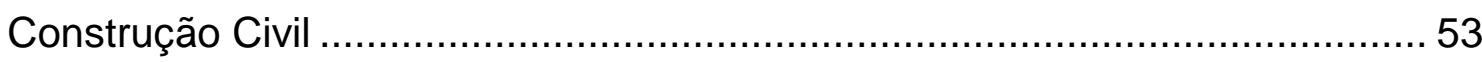

Figura 13: Distribuição das produções científicas em ACV na Construção...... 54

Figura 14: Fases da Avaliação do Ciclo de Vida. Fonte: JRC, 2010 ............... 55

Figura 15: Fluxograma do passo a passo e recomendações do ILCD para a

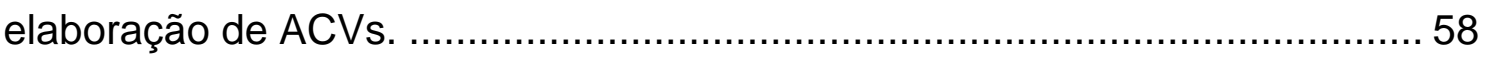

Figura 16: Esquema de elaboração de um modelo........................................ 60

Figura 17: Esquematização do modelo no contexto da ACV. .......................... 62

Figura 18: Fluxograma de como a modelagem do Ciclo de Vida Parametrizado e o Inventário Parametrizado são usados na ACV. Fonte: Mueller, 2004........ 64

Figura 19: Sistema edificação e sua divisão (Sabbatini et al, 2005). ............... 70

Figura 20: Proposta de classificação do SVVIE de acordo com o componente principal. Fonte: do autor.................................................................... 72

Figura 21: Deslocamentos limites e ocorrência de falhas. Fonte: do autor, baseado em ABNT (2013b) ................................................................. 74

Figura 22: Requisitos de impacto de corpo mole face externa. Fonte: do autor,

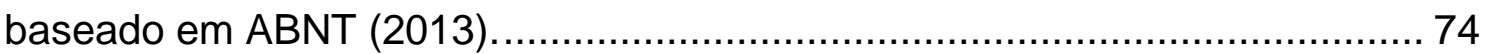

Figura 23: Requisitos de impacto de corpo mole face interna. Fonte: do autor,

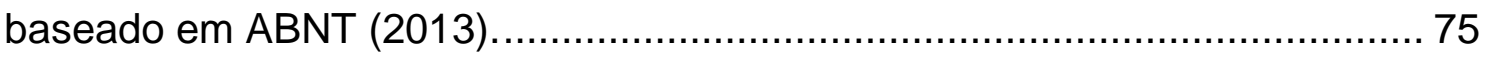


Figura 24: Requisitos para impactos de corpo duro nas faces internas e externas das vedações verticais. Fonte: do autor, baseado em ABNT (2013). 76 Figura 25: Requisitos TRRF sistematizados. Fonte: do autor, baseados em ABNT (2013b) e ABNT (2000) 76

Figura 26: Requisitos de reação ao fogo para faces internas das vedações e fachadas. Fonte: do autor, baseado em ABNT (2013b) 77

Figura 27: Critérios mínimos de desempenho térmico por Zona Bioclimática de acordo com procedimento simplificado de avaliação de avaliação térmica. Fonte: do autor, baseado em ABNT (2013b). 78

Figura 28: Requisitos de estanqueidade a água para SVVIE. Fonte: do autor, baseado em ABNt (2013b) 79

Figura 29: Critérios de desempenho acústico sistematizados considerando CBIC (2013) e ABNT (1987) 80

Figura 30: Vida Útil de Projeto para SVVIE. Fonte: do autor, baseado em ABNT (2013a) 81

Figura 31: Processo produtivo do bloco cerâmico 89

Figura 32: Tipos de blocos cerâmicos estruturais (ABNT, 2005b).................. 90

Figura 33: Blocos cerâmicos de vedação (ABNT, 2005a)............................... 91

Figura 34: Casa do Príncipe e sistema construtivo da vedação. Fonte: do autor. 99

Figura 35: Processo de construção da vedação de bloco cerâmico. Fonte: Wienerberger, 2014 100

Figura 36: Limites de um modelo tecnológico de ACV. Fonte: PE International, 2011 110

Figura 37: Estágios do ciclo de vida de um produto da construção. Fonte: BSI, 2014. 111

Figura 38: Modelos Concretos da Vedação de bloco cerâmico. Fonte: do autor. 112

Figura 39: Desenho da cadeia produtiva da vedação de bloco cerâmico Berço ao portão de fábrica com opções 113

Figura 40: Primeira versão do MTP 137

Figura 41: Processo de argamassa de chapisco do MTP inicial ..................... 138

Figura 42: Processo da argamassa 1:3 (cimento Portland e areia)..... 139 
Figura 43: Versão intermediária do MTP com os dados do Brasil e do Reino Unido

Figura 44: Modelo Tecnológico Parametrizado final. Fonte: dos autores....... 144

Figura 45: Ajustes no MTP final. Fonte: dos autores................................. 146

Figura 46: Valores relativos e absolutos das contribuições dos potenciais dos impactos ambientais totais do Contexto de Análise 1 ................................. 160

Figura 47: Comparação dos impacto potenciais dos processos das tipologias 1 e 2 quanto à categoria de impacto GWP. 161

Figura 48: Comparação dos impacto potenciais dos processos das tipologias 1 e 2 quanto à categoria de impacto $P O C P$ 162

Figura 49: Diferença relativa e absoluta entre os impactos potenciais de cada categoria de impacto para o Contexto de Análise 1 163

Figura 50: Valores relativos da contribuição de cada módulo de ACV para as categorias de impacto do Contexto de Análise 1 e Tipologia 1 164

Figura 51: Valores relativos dos potenciais impactos ambientais do Contexto de Análise 1 e Tipolgia 165

Figura 52: Valores relativos dos potenciais impactos ambientais do Contexto de Análise 1 e Tipolgia 2 167

Figura 53: Valores relativos da contribuição de cada módulo de ACV para o potencial de impacto ambiental do Contexto de Análise 1 e Tipologia 2........ 168 Figura 54:Valores relativos e absolutos das contribuições dos potenciais dos impactos ambientais totais do Contexto de Análise 2 170 Figura 55: Potencial de Acidificação na produção de $1 \mathrm{~kg}$ do bloco cerâmico poroso do Reino Unido 172

Figura 56: Categoria de impacto POCP por processo da tipologia britânica.. 172 Figura 57: Potencial de Depleção de recurso abiótico(fóssil) e a produção da

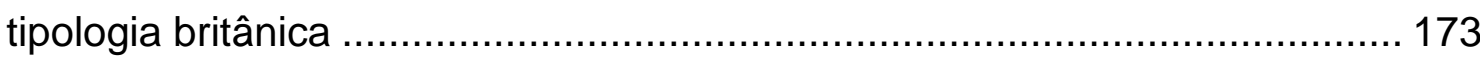

Figura 58: Potencial de Mudança Climática e a tipologia britânica ................ 173 Figura 59: Valores relativos dos potenciais impactos ambientais do Contexto de Análise 2 e Tipolgia aplicada ao Reino Unido 175

Figura 60: Valores relativos dos potenciais impactos ambientais do Contexto de Análise 2 e Tipolgia aplicada ao Brasil. 176 
Figura 61: Valores relativos da contribuição de cada módulo de ACV para o potencial de impacto ambiental do Contexto de Análise 2 e Tipologia aplicada

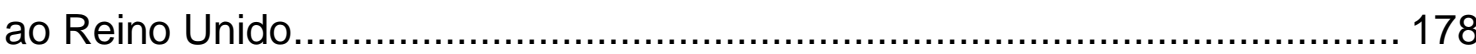
Figura 62: Valores relativos da contribuição de cada módulo de ACV para o potencial de impacto ambiental do Contexto de Análise 2 e Tipologia aplicada ao Brasil 179

Figura 63: Contribuição percentual de cada categoria de impacto no impacto potencial provocado pela cadeia produtiva do bloco cerâmico de cada fabricante 183

Figura 64: Impactos absolutos para cada fabricante considerando o Potencial de Mudança Climática. 183

Figura 65: Esquematização das novas etapas e passos metodológicos para a elaboração de MTPs. 189 


\section{LISTA DE QUADROS}

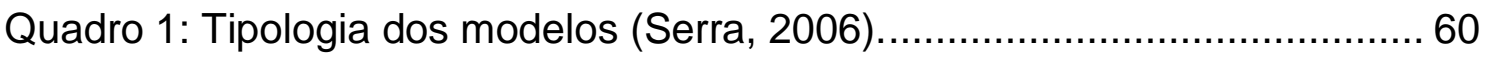

Quadro 2: Classificação das vedações verticais (BARROS et al, 2007).......... 71

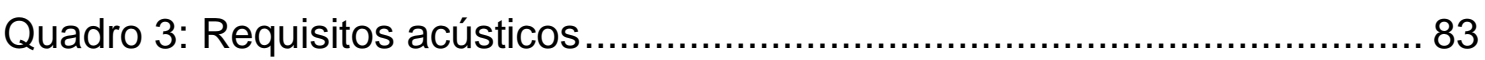

Quadro 4: Requisitos acústicos considerando valores obtidos em laboratório 83

Quadro 5: Parâmetros limites para envoltória ................................................ 84

Quadro 6: Resumo das especificações da habitação ideal, considerando requisitos térmicos para alguns elementos e sistemas ................................. 85

Quadro 7: Classificação das argamassas segundo sua função na construção 93

Quadro 8: Matriz de comparação das tipoligias das vedações dos protótipos do

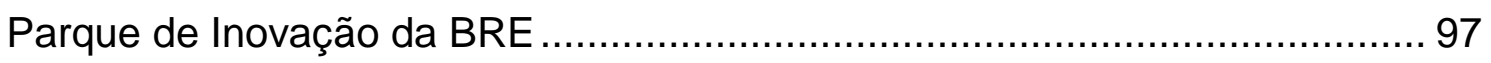

Quadro 9: Recortes da tipologia considerada para este estudo..................... 101

Quadro 10: Índice de redução sonora ponderado para vedações. Fonte: do autor, baseado em IPT (2011) apud CBIC (2013) ..................................... 106

Quadro 11: Tipologias de vedação e dados de transmitância térmica, capacidade térmica e atraso térmico. Fonte: do autor, baseado em ABNT

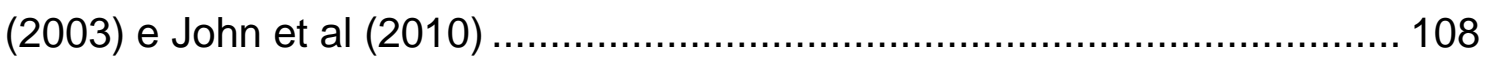

Quadro 12: Fatores de normalização da metodologia CML 2010 ................. 117

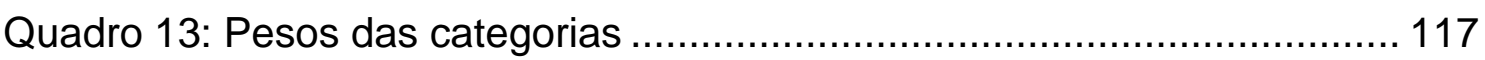

Quadro 14: Quadro de suposições adotadas nas comparações desta pesquisa

Quadro 15: Fluxos de referência para as comparações desta ACV............... 122

Quadro 16: Descrição dos processos e classificação em níveis de proximidade com o processo núcleo

Quadro 17: Exemplo dos dados coletados e disponíveis no Apêndice $H$...... 128

Quadro 18: Lista de processos utilizados na ACV da vedação de bloco

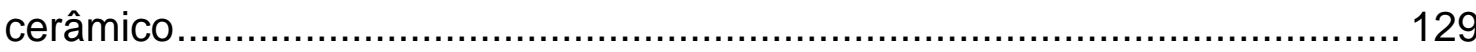

Quadro 19: Exemplo de parâmetro livre do total de parâmetros criados para o

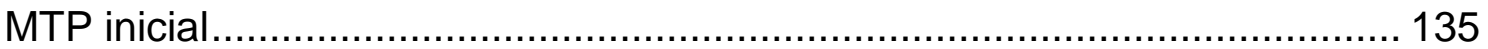

Quadro 20: Módulos de ACV e os itens considerados .................................. 142

Quadro 21: Os parâmetros e os contextos de comparação ............................ 147 
Quadro 22: Metodologias de ACV e os midpoints dos indicadores considerados

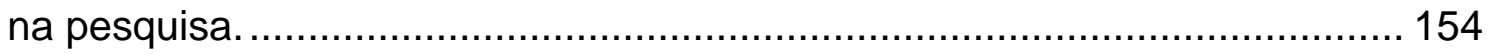

Quadro 23: Checagem de completude e de consistência ............................ 180

Quadro 24: Características do processo produtivo de cada fornecedor......... 184 


\section{LISTA DE TABELAS}

Tabela 1: Consumo de materiais das vedações de blocos cerâmicos estruturais (PINI, 2008b). 92

Tabela 2: Consumo de materiais nasvedações de blocos cerâmicos de vedação (PINI, 2008b). 92

Tabela 3: Tabela do Inventário do Ciclo de Vida do contexto de análise 1 por fluxo e por módulo de ACV 149 Tabela 4: Tabela do Inventário do Ciclo de Vida do contexto de análise 2 por fluxo e por módulo de ACV 150 


\section{LISTA DE SIGLAS E ABREVIAÇÕES}

ABNT - Associação Brasileira de Normas Técnicas

ACV - Avaliação do Ciclo de Vida

BauPG - Bauproduktegesetz (Atos dos produtos da Construção)

BEES - Building for Environmental and Economic Sustainability

BIM - Building Information Modelling

BRE - Building Research Establishment

BREEAM - Building Research Establishment Environmental Assessment Method

CAATEEB - Collegi d' aparelladors arquitectes técnics i Enginyers d'Edificaió de Barcelona

CAPES - Coordenação de Aperfeiçoamento de Pessoal

CBCS - Conselho Brasileiro de Construção Sustentável

CBIC - Câmara Brasileira da Indústria da Construção

CEN - European Committee for Standardization

CEN/TR - European Committee for Standardization Technical Report

CGEE - Centro de Gestão de Estudos Estratégicos

CIPA - Comissão Interna de Prevenção de Acidentes

$\mathrm{CNPq}$ - Conselho Nacional de Desenvolvimento Científico e Tecnológico

Conmetro - Conselho Nacional de Metrologia, Normalização e Qualidade Industrial

CP I - cimento Portland comum

CP V-ARI - cimento Portland de alta resistência inicial

CPD - Construction Products Directive

CPIC - Cadeia Produtiva da Indústria da Construção

CPI-S - cimento Portland comum com adição

CSTB - Centre Scientifique et Technique di Bâtiment

DF - Distrito Federal

DGBN - Deutsche Gesellschaft für nachhaltiges Bauen

DNPM - Departamento Nacional de Produção Mineral

ECO - Environmental European Construction Product

EN - European Standard

EPD - Environmental Product Declaration

ETA - European Technical Approval

EUA - Estados Unidos da Américo

GEDnet - Global Type III Environmental Product Declaration Network

hEN - Harmonised European Standards

HIS - Habitações de Interesse Social

HQE - Haute Qualité Environnementale 
IBAMA - Instituto Brasileiro do Meio Ambiente e dos Recursos Naturais Renováveis

IBICT - Instituto Brasileiro de Informação em Ciência eTecnologia

IBRAM - Instituto Brasília Ambiental

IBU - Institut fur Bautechnik Undwelt

ICV - Inventário do Ciclo de Vida

ILCD - International Reference Life Cycle Data System

Inmetro - Instituto Nacional de Metrologia, Qualidade e Tecnologia

ISO - International Organization for Standardization

ISO TC/207 - International Organization for Standardization Technical Committee

LCA - Life Cycle Assessment

LEED - Leadership in Energy and Environmental Design

MCTI - Ministério da Ciência, Tecnologia e Inovação

MDIC - Ministério do Desenvolvimento, Indústria e Comércio Exterior

MRPI - Milieu Relevant Product Informatie

NBR - Norma Brasileira

NIST - National Institute for Standards and Technology

ONU - Organização das Nações Unidas

PBACV - Programa Brasileiro de Avaliação do Ciclo de Vida

PCR - Product Category Rulers

PIB - Produto Interno Bruto

PRNT - Poder relativo de neutralização total

PVC - Policloreto de vinila

RCD - Resíduo da construção e demolição

REPA - Resource and Environmental Profile Analysis

RTS - Rakennustieto (Building Information)

SEMC - Swedish Environment Management Council

SETAC - Society of Environmental Toxicology and Chemistry

SICV Brasil - Inventário do Ciclo de Vida para a competitividade da Indústria

Brasileira.

VOC - Volatile Organic Compounds

TRRF - Tempo Requerido de Resistência ao Fogo

SVVIE - Sistemas de Vedação Vertical Interno e Externo

UNEP - United Nations Environment Programme

IBGE - Instituto Brasileiro de Geografia e Estatística

FAU - Faculdade de Arquitetura e Urbanismo

CDS - Centro de Desenvolvimento Sustentável

FGA - Faculdade UnB Gama

PGM - Programa de Gestão de Materiais 
Lacis - Laboratório do Ambiente Construído, Inclusão e Sustentabilidade MTP - Modelo Tecnológico Parametrizado

Senai - Serviço Nacional de Aprendizagem Industrial

IPEA - Instituto de Pesquisa Econômica Aplicada

MMA - Ministério do Meio Ambiente

DDT - Dicloro-difenil-tricloroetano

DAP - Declaração Ambiental de Produto

DGNB - Deutsche Gesellschaft für Nachhaltiges Bauen

GEE - Gases de Efeito Estufa

UEATC - European Union of Agrément

GFRC - Glass fiber reinforced concrete

ELC - Estado limite de serviço

VUP - Vida Útil de Projeto

GLP - Gás Liquefeito de Petróleo

TCPO - Tabelas de Composição de preços para Orçamento 


\section{Sumário}

Resumo __ vi

Abstract__ vii

Resumen __ viii

LISTA DE FIGURAS __ ix

LISTA DE QUADROS ___ Xiii

LISTA DE TABELAS __ XV

LISTA DE SIGLAS E ABREVIAÇÕES __ X Xvi

INTRODUÇÃO _ 24

0.1 . Enquadramento da pesquisa __ 29

0.2. Objetivos e hipótese da pesquisa _ 32

0.2 .1 . Hipótese _ 32

0.2.2. Objetivo __ 32

0.2.2.1. Objetivo Geral __ 32

0.2.2.2. Objetivos Específicos __ 32

0.3. Metodologia __ 33

0.3.1. Aspectos Conceituais _ـ 33

0.3.2. Aspectos metodológicos __ 33

0.4. Estrutura da tese 38

Capítulo 1: Conceitos Fundamentais __ 40

1.1. A Cadeia Produtiva da Indústria da Construção___ 40

1.2. Ecologia Industrial___ 41

1.2.1. Avaliação do Ciclo de Vida (ACV)___ 41

1.3. A importância da Ecologia Industrial e da Avaliação do Ciclo de

Vida na CPIC _ 46

1.3.1. ACV aplicada na seleção de materiais e produtos da CPIC ___ 47

1.4. Levantamento do Estado da Arte da ACV aplicada à CPIC __ 48

1.4.1. A ACV aplicada no mundo ___ 48

1.4.1. A ACV aplicada ao Brasil __ 52

1.5. A modelagem em ACV _ 54

1.5.1. O manual de aplicação da ACV: ILCD __ 54

1.5.2. A relação entre a modelagem do MTP e o manual ILCD ___ 55

1.5.3. Teoria Geral dos Modelos___ 59 
1.5.4. A modelagem em ACV

1.5.5. O Modelo Tecnológico Parametrizado na ACV 62

Síntese Analítica do Capítulo 1 66

Capítulo 2: Sistema Vedação Vertical Interna e Externa 69

2.1. Definição do sistema da edificação a ser estudado 69

2.1.1. A Edificação como um sistema 69

2.1.2. Definição, classificação e função do SVVIE 70

2.2. Requisitos de desempenho da ABNT NBR 15.575 73

2.2.1. Desempenho Estrutural 73

i. Deslocamentos e ocorrência de falhas 73

ii. Impactos de corpo mole 73

iii. Impactos de corpo duro 75

2.2.1. Segurança contra incêndio 75

2.2.2. Desempenho Térmico 78

2.2.3. Estanqueidade 79

2.2.4. Desempenho Acústico 79

2.2.5. Durabilidade e manutenibilidade 81

2.3. Requisitos de desempenho no Reino Unido 82

2.3.1. E: Resistência ao som 82

2.3.2. L: Conservação do combustível e da energia 84

2.3.3. Código para casas sustentáveis 85

2.4. A utilização da classificação e requisitos das vedações verticais 86

2.5. Definição dos elementos e componentes do SVVIE 87

2.6. Caracterização das Cadeias Produtivas dos componentes das vedações de blocos cerâmicos 88

2.6.1. Vedação de Bloco Cerâmico no Brasil 88

2.6.1.1. Extração da matéria-prima, fabricação e transporte 88

2.6.1.2. Bloco Cerâmico 90

2.6.1.3. Construção da Vedação de blocos cerâmicos 91

2.6.1.4. Argamassa Industrializada e tradicional 93

2.6.1.5. Extração da matéria-prima, fabricação e transporte das argamassas 95

i. Argamassa industrializada 95 
ii. Argamassa tradicional (MOV - massa virada em obra) 95

2.6.2. Vedações de Bloco Cerâmico no Reino Unido 96

2.6.2.1. Seleção da vedação britânica __ 96

2.6.1. A Casa do Príncipe ___ 96

2.6.1.1. Sistema Construtivo da Casa do Príncipe ___ 99

2.7. Fim da vida e benefícios da vedação de blocos cerâmicos___ 100

2.8. Recorte da pesquisa __ 101

Síntese analítica do Capítulo $3 \_101$

Capítulo 3: Modelagem - Objetivo e escopo _ـ 103

3.1. Objetivo 103

3.1.1. Aplicação, limitações e contexto decisório ___ 103

3.1.2. Públicos-alvo__ 104

3.1.3. Comparações, atores envolvidos, situação e documentos de referência _ 104

3.2. Escopo _ 105

3.2.1. Inconsistências, confidencialidades e resultados esperados __ 105

3.2.2. Função e unidade funcional _ـ 106

3.2.2.1. Os requisitos de desempenho térmico e acústico e a caracterização das tipologias da vedação de bloco cerâmico no Brasil e no Reino Unido _ 106

3.2.3. Limites do sistema___ 110

3.2.4. Elaboração de modelos concretos _ـ 111

3.2.1. Elaboração do objeto modelo (fluxograma da cadeia) __ 112

3.2.2. Listagem de exclusões e critérios de corte __ 114

3.2.3. Categorias de impacto _ـ 114

3.2.4. Método de AICV, normalização e ponderação ___ 116

3.2.5. Representatividades tecnológica, geográfica e temporal ___ 117

3.2.6. Fontes de dados, requisitos de qualidade e completude ___ 118

3.2.7. Comparações, cenários e alternativas _ـ 118

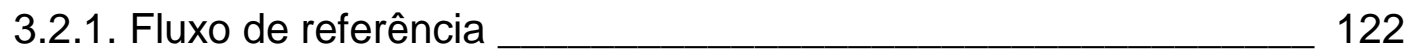

Síntese Analítica do Capítulo $3 \_122$

Capítulo 4: Modelagem - ICV e AICV _ 124

4.1. Inventário do Ciclo de Vida__ 124 
4.1.1. Identificação dos processos

4.1.2. Planejamento da obtenção dos dados

4.1.3. Coleta dos dados primários e secundários

4.1.3.1. Agregação e controle de qualidade dos dados 129

4.1.4. Seleção dos processos e planos 129

4.1.4.1. Migração dos dados 130

4.1.4.2. Criação de planos, processos e fluxos 132

4.1.5. Variáveis e parâmetros 132

4.1.6. Controle de qualidade dos dados e alocação 133

4.1.7. Modelagem e testes do modelo 133

4.1.7.1. Modelo Inicial 133

B) Análise crítica dos resultados e revisão das inconsistências 135

4.1.7.2. Modelo Intermediário 138

4.1.7.3. Ajustes no modelo final 145

4.1.8. Resultados de ICV 149

4.1.9. Interpretação dos resultados do ICV 152

4.2. Avaliação do Impacto do Ciclo de Vida 154

4.2.1. Classificação e Metodologia de conversão 154

4.2.2. Caracterização, Normalização e Ponderação 155

4.2.3. Resultados dos contextos de análise 155

Capítulo 5: Modelagem - Interpretação 159

\subsection{Identificação de problemas significativos e avaliação dos} resultados

5.1.1. Comparação 1: parâmetros das tipologias brasileiras 1 e 2 de vedação externa 159

5.1.2. Comparação 2: Tipologia britânica de vedação vertical externa aplicada ao Reino Unido e ao Brasil

5.2. Checagem de completude, consistência e sensibilidade 180

5.2.1. Checagem de completude e de consistência 180

5.2.2. Análise de sensibilidade 182

5.3. Relatório, revisão crítica, publicação e, ou aplicação 185

5.4. Contribuições para a metodologia de elaboração de um MTP 185 Conclusão 190 
Anexo 1: Zoneamento Bioclimático Brasileiro 204

Anexo 2: Regiões brasileiras para efeito de estanqueidade à água 205 Apêndices 206

Apêndice A: Levantamento de metodologias, bancos de dados e softwares de ACV usados na Construção no mundo 207 Apêndice C: Memória de cálculo 212 Apêndice D: Matriz de ocorrência das categorias de impacto por sistemas de EPD de materiais de construção na Europa, EN 15.804 e produções técnicocientíficas brasileiras 214

Apêndice E: Questionário desenvolvido para coleta de dados junto aos fabricantes de bloco cerâmico 215 Apêndice F: Síntese dos trabalhos acadêmicos identificados no currículo dos doutores da Plataforma Lattes do CNPq 223

Apêndice G: Resultados de ACV obtidos em busca com os melhores fornecedores da Construção no Brasil 226 Apêndice H: Tabela de dados coletados com as classificações, valores, unidades de medida e fonte do dado 227 Apêndice I: Lista de processos utilizados na ACV da vedação de bloco cerâmico 235

Apêndice J: Parâmetros livres e fixos inseridos no MTP inicial 239

Apêndice K: Parâmetros livres e fixos inseridos e retirados do MTP intermediário

Apêndice L: Parâmetros livres e fixos inseridos retirados da versão final do MTP 257 


\section{INTRODUÇÃO}

A sustentabilidade plena na relação que os seres humanos mantém com 0 mundo onde vivem é algo difícil e quase utópico de se obter. Do mesmo modo que o homem tem aperfeiçoado tecnologias e ferramentas para explorar os recursos naturais, transformá-los em benefícios para a comunidade e em resíduos que precisam ser metabolizados pela natureza, o conhecimento científico pode apoiá-lo também na tomada de decisão por processos produtivos que minimizem os impactos causados ao meio ambiente.

Um dos desafios do século XXI definido pela Organização das Nações Unidas (ONU) é garantir a sustentabilidade ambiental integrando os princípios do desenvolvimento sustentável às políticas e programas nacionais, revertendo a perda de recursos naturais e reduzindo as emissões dos gases do efeito estufa (ONU, 2012).

A natureza não é capaz de continuar suprindo a atual demanda de recursos do padrão de consumo da sociedade e das indústrias. Sendo assim, a capacidade de regeneração do planeta encontra-se comprometida pelo padrão de consumo dos mais de sete bilhões de habitantes (ONU, 2014).

O setor da Construção consome $50 \%$ dos recursos mundiais, sendo $40 \%$ da matéria-prima e energia e $17 \%$ da água potável e é responsável por 40\% dos resíduos sólidos gerados (EDWARDS, 2005; UNEP, 2007). Dados, que demonstram o impacto ambiental negativo desse setor, indicam que é um dos setores essenciais para a promoção da sustentabilidade.

Além de consumir grande quantidade de recursos naturais finitos do planeta e gerar um alto volume de poluição do solo, ar e água, a Cadeia Produtiva da Indústria da Construção (CPIC) ainda possui níveis muito baixos de reciclagem de seus resíduos.

Segundo Hendricks et al (2000), materiais reciclados não são muito utilizados no Brasil como material construtivo, mas é possível identificar o uso de materiais reciclados como agregados para a preparação de concreto ou subbase para pavimentação. Em 2000, haviam apenas cinco cidades no Brasil que possuíam sistemas de reciclagem, o que resultou na produção de 400 t/ano, o que corresponde a $8 \%$ de todo o resíduo produzido em Belo Horizonte. 
Em 2012, os municípios brasileiros, considerados na amostra ${ }^{1}$, coletaram 35 milhões de toneladas de RCD, o que implicou no aumento de 5,3\% em relação ao ano anterior. Porém, o serviço municipal coleta somente os resíduos lançados nos logradouros públicos, o que indica que a quantidade total é ainda maior e acende um alerta quanto à destinação dada a esse resíduo (ABRELPE, 2013).

A construção ainda é um dos setores mais importantes da economia brasileira com um crescimento de $1,60 \%$ no PIB setorial, em 2013, e geração de empregos de 73 mil vagas no mercado de trabalho no primeiro semestre de 2014, apesar do crescimento ter sido menor que em anos anteriores (CBIC, 2015; MTE, 2015). Em 2010, o crescimento do PIB setorial foi de $11,60 \%$ e do PIB total de 7,50\%, uma vez que 2010 foi o ano de recuperação da crise econômica, investimentos públicos no setor, tanto pelos programas habitacionais quanto pelo aumento do crédito para habitações e infraestrutura, e aceleração do mercado imobiliário (IBGE, 2012; SINDUSCON-SP, 2011).

Além da importância econômica dessa cadeia, a CPIC possui uma importância social que pode ser observada pelo fato das edificações serem uma necessidade inerente à civilização quando o homem sentiu a necessidade de construir como forma de proteção e sobrevivência.

Com o expressivo déficit habitacional atual e a taxa de crescimento populacional do país, estima-se que o Brasil precisa construir mais de 23,49 miIhões de novas moradias até 2022 para zerar esse déficit, o que corresponde a dois milhões de moradias por ano (CBIC, 2011b; SAE, 2010).

Tendo em vista a importância econômica, social e ambiental da CPIC, tanto nos aspectos positivos quanto negativos, constata-se a necessidade de analisar e compreender o desempenho ambiental dos materiais e produtos da construção e visualizar com mais clareza e detalhamento a matemática ecológica envolvida nesse processo, ou seja, os cálculos envolvidos na quantificação dos impactos ambientais.

Essas quantificações dos impactos ambientais são tratadas pela ciência Ecologia Industrial, que também considera os sistemas industriais integrados entre cadeias produtivas, como ecossistemas, nos quais resíduos de um

\footnotetext{
${ }^{1}$ A pesquisa realizada pela Abrelpe, em 2012, considerou um universo de 401 municípios.
} 
processo podem ser a matéria-prima de outro, formando um ciclo interdependente como nos sistemas vivos (GOLEMAN, 2009; CALDEIRA-PIRES, 2011).

Dentre as ferramentas utilizadas pela Ecologia Industrial destaca-se a Avaliação do Ciclo de Vida (ACV), em que um produto, material, processo ou serviço é analisado em todas as etapas do seu ciclo de vida, desde a extração da matéria-prima até o descarte final ou reaproveitamento do material, passando pela transformação e manufatura de materiais, acondicionamento e expedição, transporte e utilização pelo consumidor (VIGON et al, 1995).

A ACV aplicada ao contexto da CPIC pode contribuir para o planejamento de construções mais sustentáveis. A ACV permite avaliar o desempenho ambiental associado aos materiais e produtos, bem como divulgar os benefícios de práticas sustentáveis de construção (KEELER et al, 2010). Segundo Edwards (2005) os arquitetos e designers têm uma grande responsabilidade no processo de mudança de paradigma na sustentabilidade da Construção, principalmente com as escolhas e especificações de projeto mais sustentáveis.

No Brasil, o uso da metodologia de ACV enfrenta gargalos e desafios para a sua efetiva aplicação na Construção, principalmente pela complexidade da cadeia e pelas características das edificações.

Dentre essas características que tornam a cadeia mais complexa temse: longo ciclo de vida do produto, múltiplas funções, quantidade de diferentes componentes, produção local, singularidade das construções, impacto local, integração com a infraestrutura e reação dos materiais de construção com o meio ambiente durante o seu uso, podendo emitir substâncias tóxicas como os compostos orgânicos voláteis (COVs) presentes em tintas, vernizes e outros materiais de construção, os fumos tóxicos liberados em caso de incêndio e o chumbo e o amianto, substâncias cancerígenas presentes em materiais de construção e canalizações de abastecimento de água (BRIBIÁN et al, 2009; JOHN et al, 2006; TORGAL et al, 2010).

A falta de um banco de dados de ACV brasileiro é outro gargalo, que é agravado pelos custos iniciais relacionados à formação do banco, o que demanda recursos humanos e temporais. Porém, após os primeiros inventários e ACVs realizados, os dados coletados podem ser usados em outras pesquisas e avaliações, tornando o processo mais rápido e com custos cada vez menores. 
No Brasil, deu-se início a estruturação de um sistema de ACV com a concepção do Programa Brasileiro de Avaliação do Ciclo de Vida (PBACV), com a participação do Ministério do Desenvolvimento, Indústria e Comércio Exterior (MDIC), o Ministério da Ciência, Tecnologia e Inovação (MCTI) e, posteriormente, o Instituto Nacional de Metrologia, Qualidade e Tecnologia (Inmetro), em parceria com a academia. O PBACV busca desenvolver e adequar metodologias, formar massa crítica, sensibilizar os setores público e privado na perspectiva do Ciclo de Vida e aplicar esse conhecimento para a competitividade ambiental (CONMETRO, 2010).

No âmbito da construção, a Câmara Brasileira da Indústria da Construção (CBIC) lançou em 2011 o Programa Construção Sustentável que visa contribuir com o aperfeiçoamento e a implementação do PBACV, resultando em um sistema de avaliação de impactos ambientais na produção e consumo de bens e serviços no país (CBIC, 2011a).

O Laboratório do Ambiente Construído, Inclusão e Sustentabilidade (Lacis) da Faculdade de Arquitetura e Urbanismo (FAU), do Centro de Desenvolvimento Sustentável (CDS) e da Faculdade UnB Gama (FGA) possui um Programa de Gestão de Materiais (PGM) 3: Avaliação do Ciclo de Vida de Produtos da Construção, desenvolvido no âmbito do eixo de pesquisa CPIC, no qual se insere esta pesquisa. Além disso, o Lacis possui, como uma de suas premissas, a aceleração da absorção de tecnologias sustentáveis para a Construção, contribuindo para a absorção de um novo paradigma para a CPIC. Além de outras instituições como o Conselho Brasileiros de Construção Sustentável (CBCS) que também contribuem de forma significativa para a mudança desse paradigma.

Muitos trabalhos em ACV foram desenvolvidos em todo o Brasil, como será apresentado no levantamento do Estado da Arte, porém esses trabalhos desenvolvem estudos que preocupam-se em avaliar somente o contexto analisado, ou seja, não é possível ampliar a visualização dos impactos e a aplicação da ferramenta para além do trabalho desenvolvido.

No entanto, o desenvolvimento de ferramentas que promovam a inserção da ACV na Construção é incipiente, o que caracteriza uma demanda por iniciativas para a promoção da metodologia de ACV na construção no Brasil, 
considerando que essas ferramentas possibilitem calcular o desempenho ambiental das edificações, além da aceleração da absorção de tecnologias sustentáveis contribuindo para a efetiva implementação do PBACV e a sustentabilidade ambiental da Construção.

Edwards (2005) afirma que ainda falta uma prática arquitetônica que priorize as questões ecológicas e uma Indústria da Construção que baseie suas operações na sustentabilidade. Além disso, existe a falta de dados e aplicação de ferramentas e metodologias para conhecer o desempenho ambiental dos produtos e materiais para posteriormente auxiliar no processo de tomada de decisão na fase de projeto das edificações pelos arquitetos, engenheiros e designers.

Com isso, é preciso munir os profissionais com ferramentas que os auxilie na tomada de decisão para o desenvolvimento de projetos mais sustentáveis. O desempenho ambiental dos produtos e a rotulagem ambiental são definidos pela ISO 14.020 , sendo a ISO 14.025 a que define critérios para as declarações ambientais de produtos com base em informações de resultados de ACV, que é elaborada considerando a ISO 14.040 e ISO 14.044 (BSI, 2006a; 2006b, 2006c).

Para os produtos e materiais da Construção, tem-se as normas ISO 21.930 e a EN 15.804, que definem as declarações ambientais de produto no mundo e na Europa, respectivamente, desenvolvidas para produtos e materiais da Construção na Europa e EUA ou guias comparativos de desempenho ambiental com base em ACVs (BSI, 2007; 2014).

O Brasil encontra-se em uma fase preliminar às emissões dessas certificações, visto que o fluxo dessas declarações passa pelos Inventários do Ciclo de Vida, ACVs e preparação e emissão dessas declarações, sendo que cada uma dessas etapas exige padronização, harmonização e regulamentação específicas.

Para Edwards (2005), a ACV permite que a edificação possua um sistema que pode ser comparado com as características dos sistemas naturais, por meio da avaliação da interação em termos de recursos (entradas), como água, energia e materiais, que são consumidos, e de resíduos e poluição (saídas), que são produzidos. 
Devido ao atraso tecnológico que o país se encontra em relação a aplicação da ACV no contexto da Construção, observa-se a urgência na adoção da ACV como uma ferramenta para o cálculo do desempenho ambiental das edificações, bem como dos materiais, componentes, elementos e sistemas. Além disso, a ACV é uma tecnologia de alto custo para ser implementada onde muitos dados precisam ser coletados e disponibilizados em um banco de dados nacional para a posterior elaboração de ACVs.

Considerando os argumentos, uma das formas de se elaborar ACVs é usando Modelos Tecnológicos Parametrizados, que permitem a combinação de matérias-primas, insumos e plantas tecnológicas, por meio de processos parametrizados conforme as características da cadeia produtiva, e resultando em uma série de ACVs com as características fundamentais padronizadas, mas com diferentes resultados, dependendo das combinações utilizadas na modelagem do sistema.

A elaboração de modelos permite ainda a aceleração da inserção da ACV no contexto brasileiro, promovendo a absorção de tecnologias sustentáveis adaptadas conforme a realidade do país, tais como ferramentas, metodologias, arranjos produtivos, etc.

Sendo assim, a elaboração desses modelos traz duas vantagens para o contexto brasileiro: otimização e padronização da elaboração de ACVs, resultando na aceleração da inserção dessa metodologia em uma cadeia produtiva tradicionalista e pouco industrializada, mas que possui uma forte urgência para a promoção da sustentabilidade no setor da Construção.

Além disso, o detalhamento da elaboração dos modelos tecnológicos de aplicação de ACV é um tema novo, principalmente na Construção e no Brasil, e que carece de referencial teórico, sistematização e procedimentos metodológicos de elaboração desses modelos.

\subsection{Enquadramento da pesquisa}

Esta pesquisa desenvolve-se no âmbito do Programa de PósGraduação em Arquitetura e Urbanismo da Faculdade de Arquitetura e Urbanismo da Universidade de Brasília na linha de pesquisa Tecnologia e Sustentabilidade. Esta pesquisa faz parte do Programa Gestão de Materiais 3: ACV do 
Laboratório do Ambiente Construído, Inclusão e Sustentabilidade (Lacis FAU/CDS/FGA-UnB).

O enquadramento da pesquisa foi esquematizado conforme a Figura 1 e traz um resumo das questões-chaves abordadas nesta Introdução.

A primeira parte da Figura 1 mostra o raciocínio que foi construído para a introdução e justificativa da pesquisa. A segunda parte mostra a inquietação principal da pesquisa e que subsidia a construção da hipótese, que é apresentada na terceira parte da Figura 1.

Vinculado à hipótese tem-se as questões que esta pesquisa procura responder:

i. O Modelo Tecnológico Parametrizado pode ser um só para toda a Construção ou será definido pelos subsistemas? Ou ainda, precisa ser mais detalhado e especificado de acordo com a cadeia produtiva em que se insere, visto que o setor da construção possui uma grande variedade de insumos e diferentes níveis tecnológicos de industrialização dos fabricantes?

ii. Que lacunas precisam ser preenchidas para a utilização de Modelos Tecnológicos de aplicação da ACV na Construção no Brasil nos aspectos técnicos e ferramentais?

iii. Quais são as variáveis e parâmetros do Modelo Tecnológico Parametrizado?

iv. Que dados precisam ser levantados para a elaboração de ACV no contexto da Construção no Brasil?

v. Como elaborar um Modelo Tecnológico Parametrizado de tal forma que ele se torne o mais generalizado possível, para abranger o maior número de elementos e componentes, sem perder suas propriedades e validade das informações? 


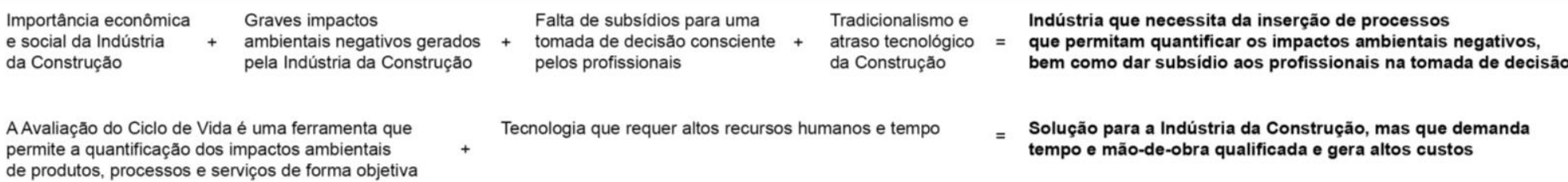

A Avaliação do Ciclo de Vida é uma ferramenta que

permite a quantificaç̃o dos impactos ambientais

de produtos, processos e serviços de forma objetiva

Solução para a Indústria da Construção, mas que demanda

tempo e mão-de-obra qualificada e gera altos custos

\section{INQUIETAÇÃO}

Como aplicar a caracterização do desempenho ambiental, por meio da metodologia de ACV no setor da Construção a fim de que se tenha produtos e materiais com seus impactos ambientais quantificados e que permitam uma tomada de decisão mais consciente pelos projetistas?

\section{HIPÓTESE}

A elaboração de Modelos Tecnológicos Parametrizados da Metodologia de Avaliação do Ciclo de Vida é viável e aplicável no setor da Construção.

\begin{tabular}{|c|c|c|}
\hline \multicolumn{3}{|c|}{ 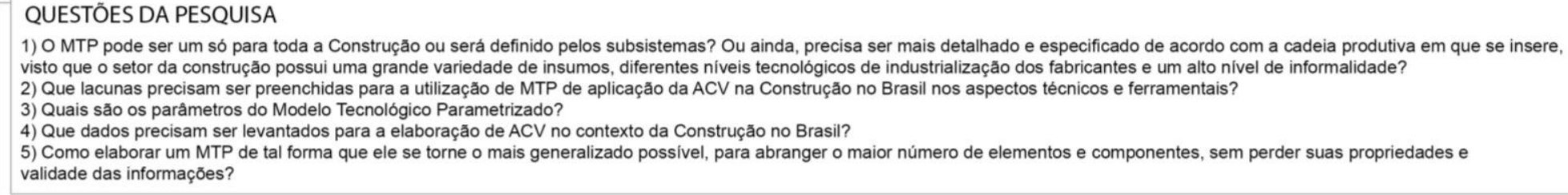 } \\
\hline$\downarrow$ & $\downarrow$ & $\nabla$ \\
\hline ONDE? & POR QUE? & COMO? \\
\hline \multirow{2}{*}{$\begin{array}{l}\text { Sistemas de } \\
\text { Vedação } \\
\text { Vertical }\end{array}$} & $\begin{array}{l}\text { As Vedações Verticais são um } \\
\text { importante subsistema da edificação: }\end{array}$ & Definição da Unidade Funcional \\
\hline & $\begin{array}{l}\text { - } 20 \% \text { do orçamento total de um edifício; } \\
\text { - Sequência executiva da obra; } \\
\text { - Representa maior volume de perdas na edificação. }\end{array}$ & $\begin{array}{l}\text { Desenho das cadeias produtivas das vedações verticais da extração da matéria-prima } \\
\text { a Construção da vedação (modelos concretos) considerando Brasil e Reino Unido }\end{array}$ \\
\hline \multicolumn{2}{|l|}{$\boldsymbol{v}$} & \\
\hline \multirow{3}{*}{$\begin{array}{l}\text { Paredes de } \\
\text { Alvenaria }\end{array}$} & $\begin{array}{l}\text { - Vedações verticais utilizadas no Brasil e no Reino Unido; } \\
\text { - Disponibilidade de dados para atender aos requisitos }\end{array}$ & 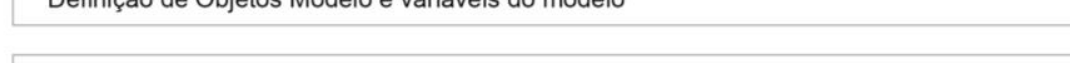 \\
\hline & $\begin{array}{l}\text { de desempenho } \\
\text { - Lentidão no processo de industrialização dos }\end{array}$ & Elaboração e aplicação do Modelo Tecnológico Parametrizado \\
\hline & edificações residenciais. & Análise dos resultados e comparações \\
\hline
\end{tabular}

Figura 1: Fluxograma do encadeamento lógico da pesquisa. 


\subsection{Objetivos e hipótese da pesquisa}

\subsubsection{Hipótese}

A elaboração de Modelos Tecnológicos Parametrizados (MTP) da Metodologia de Avaliação do Ciclo de Vida (ACV) é aplicável ao setor da Construção.

\subsubsection{Objetivo}

\subsubsection{Objetivo Geral}

Elaborar um Modelo Tecnológico Parametrizado (MTP) de aplicação da metodologia de Avaliação do Ciclo de Vida (ACV) para o Sistema de Vedação Vertical Interna e Externa (SVVIE), considerando os requisitos de desempenho das vedações verticais externas.

\subsubsection{Objetivos Específicos}

Os objetivos específicos desta pesquisa são classificados em conceituais, metodológicos e de análise.

i. Levantar o Estado da arte da ACV aplicada à construção nos setores público, produtivo e academia no Brasil e no mundo;

ii. Caracterizar as cadeias produtivas das vedações de bloco cerâmico e levantar dados relacionados a essas cadeias, elaborando modelos-concretos que servirão de base para a elaboração do MTP;

iii. Elaborar e aplicar o MTP do Sistema Vedação Vertical;

iv. Analisar os resultados da aplicação do MTP às vedações de bloco cerâmico considerando as comparações, os cenários e as lacunas;

v. Fornecer subsídios para a elaboração de MTPs no contexto da Construção no Brasil para outros subsistemas da edificação. 


\subsection{Metodologia}

A metodologia é composta pelos aspectos conceituais, metodológicos e ferramentais.

\subsubsection{Aspectos Conceituais}

Para a construção do MTP para o Sistema de Vedação Vertical são considerados os seguintes aspectos conceituais, que serão posteriormente detalhados no "Capítulo 1: Conceitos Fundamentais" que compõem esta tese:

i. Cadeia Produtiva da Indústria da Construção: conceito, divisão, importância, impactos ambientais e sociais negativos e impactos socioeconômicos positivos da cadeia;

ii. Ecologia Industrial: conceituação e ferramentas utilizadas;

iii. Avaliação do Ciclo de Vida: conceituação, etapas, características, importância para a construção;

iv. Teoria Geral dos Modelos: conceitos, classificações e como construir modelos.

\subsubsection{Aspectos metodológicos}

Antes de definir os aspectos metodológicos desta pesquisa, faz-se necessário explicar que a ampliação da aplicabilidade do MTP é fundamental para a pesquisa, pois torna o modelo o mais genérico possível sem que se perca as características essenciais da avaliação do desempenho ambiental da vedação vertical. Sendo assim, definiu-se que o Modelo tecnológico Parametrizado deveria ser aplicado às vedações verticais no Brasil e no exterior.

Para aplicar o MTP em um contexto de análise além das fronteiras do Brasil, foi realizado um estágio no exterior na Building Research Establishment (BRE), que é uma instituição britânica que desenvolve pesquisas e produtos em sustentabilidade da Construção.

Esse doutorado sanduíche foi realizado em seis meses (setembro/14 a fevereiro/15) e com o apoio financeiro do Programa de Doutorado Sanduíche no Exterior (PDSE). A coorientadora na BRE é o Dr. Owen Abbe, que é Diretor Associado da BRE em Avaliação do Ciclo de Vida na Construção. 
Esse estágio foi realizado no Centro para Produtos Sustentáveis, que é uma divisão da BRE responsável pelo desenvolvimento de ACVs de produtos e materiais da Construção. Essa divisão emite declarações ambientais de produto com base nos resultados de ACV, além de produzir ferramentas desenvolvidas com base em resultados de ACV que auxiliam na tomada de decisão no processo de especificação de produtos mais sustentáveis e atribuem créditos a edificações avaliadas conforme seu desempenho.

Considerando o contexto, os aspectos metodológicos desta pesquisa são fundamentação teórica, definição do subsistema da edificação a ser estudado (primeiro afunilamento da pesquisa), levantamento do Estado da Arte da ACV na Construção no Brasil e no mundo, definição do elemento do Sistema Vedação Vertical a ser estudado (segundo afunilamento da pesquisa), compilação dos requisitos de desempenho das vedações verticais externas no Brasil e no Reino Unido, caracterização da tipologia das vedações verticais para atendimento aos requisitos de desempenho, definição da Função e Unidade Funcional considerando os contextos de análise do Brasil e do Reino Unido, caracterização das cadeias produtivas dos blocos definidos para o estudo, elaboração dos modelos concretos, elaboração do objeto modelo, definição das variáveis e parâmetros do modelo, elaboração do MTP, definição de contextos de análise, aplicação do MTP, análise dos resultados, das comparações e das lacunas da aplicação do MTP nos contextos analisados (Figura 2).

\section{i. Fundamentação Teórica}

Os aspectos conceituais abordados no "Capítulo 1: Conceitos Fundamentais" geram os subsídios para o recorte do sistema da edificação a ser estudado e do elemento e componentes que farão parte da pesquisa.

\section{ii. Definição do Sistema}

Após a revisão teórica dos conceitos é feito o primeiro recorte da pesquisa. Essa definição do sistema segue os critérios de importância desse sistema para a edificação como um todo no âmbito econômico, ambiental e no desempenho da edificação, a disponibilidade de dados técnicos sobre esse sis- 
tema, a possibilidade de aplicação de Modelos Tecnológicos de ACV e a definição de uma unidade funcional.

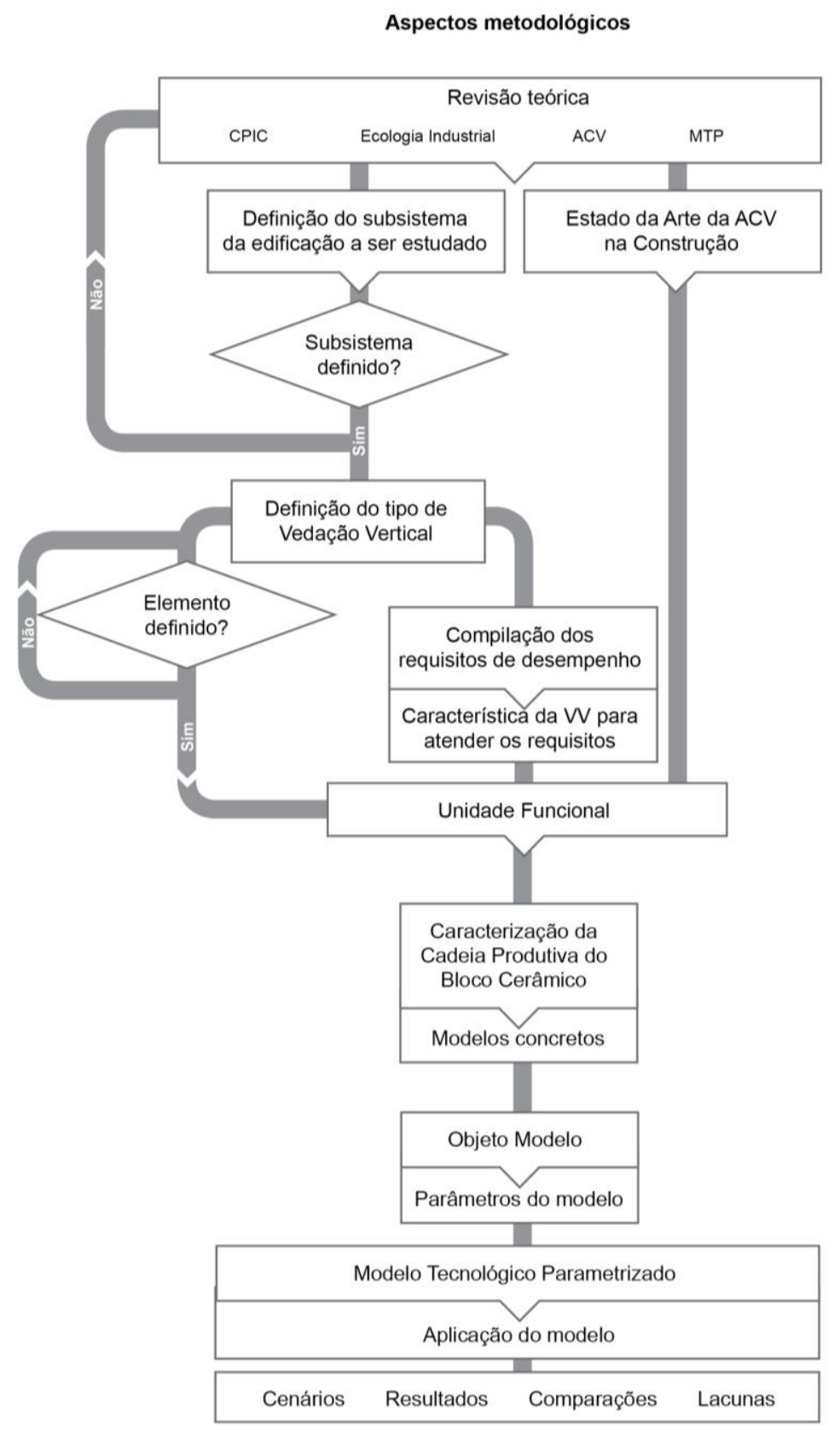

Aspectos técnicos

\) Bibliografia

> Bibliografia

Buscas para levantamento

do Estado da Arte

\) Bibliografia

NBR 15.575

NBR 14.432

D) NBR 15.220

NBR 10.152

ע) Bibliografia

Requisitos de desempenho

\) Manual ILCD

Estado da Arte

Visitas técnicas

Questionátio de dados

Modelo tecnológico

) Software GaBi $6^{\circ}$

Software Microsoft Office Excel ${ }^{\circ}$

Software Illustrator CS6

Software Illustrator CS6

1) Software $\mathrm{GaBi} 6^{\circ}$

Software Microsoft Office Excel ${ }^{\circ}$

Software Illustrator CS6

Software $\mathrm{GaBi} 6^{\circ}$

》) Software GaBi $6^{\circ}$

Figura 2: Passos metodológicos.

iii. Requisitos de desempenho do Sistema Vedação Vertical

Para a definição da função e da unidade funcional, para a elaboração do MTP, é necessário o levantamento dos requisitos de Desempenho Estrutural, Segurança contra incêndio, Desempenho Térmico, Desempenho Acústico, 
Estanqueidade à água e Durabilidade definidos na ABNT NBR 15.575, no Brasil, e pelas Building Regulations, no Reino Unido (ABNT, 2013a, 2013b; HM GOVERNMENT, 2010a). Além desse levantamento, é preciso caracterizar os elementos e componentes utilizados que cumpram cada um desses requisitos.

\section{iv. Levantamento do Estado da Arte}

Paralelo às etapas anteriores, construiu-se o Estado da Arte da aplicação da ACV nas Construções no Brasil e no mundo nos setores público, privado e academia. O levantamento do Estado da Arte contribui para a caracterização o estágio evolutivo da ACV na Construção por meio do levantamento das produções científicas em ACV aplicada a CPIC no mundo e no Brasil, iniciativas de ACV no setor produtivo e políticas públicas que tenham a metodologia envolvida nas suas premissas. $E$ também para a definição da unidade funcional a ser estudada, além da elaboração do próprio MTP.

v. Caracterização das cadeias produtivas e elaboração dos modelos concretos

Definida a unidade funcional, o próximo passo é a caracterização das cadeias produtivas dos componentes principais do elemento definido desde a extração da matéria-prima até a construção, bem como o levantamento dos dados dessas cadeias e o desenho do modelo tecnológico.

O resultado da caracterização dessas cadeias são os Modelos Concretos da pesquisa, ou seja, modelos baseados em objetos reais. Esses Modelos Concretos são o subsídio para a elaboração do MTP, onde serão apontadas as variáveis e os paraâmetros do modelo.

\section{vi. Modelagem do Modelo Tecnológico Parametrizado}

A elaboração desse modelo ainda tem como fundamentação as normas ISO 14.040 e 14.044 e o Manual International Reference Life Cycle Data System (ILCD), considerando as entradas e saídas da cadeia produtiva, as categorias de impacto ambiental e os processos (BSI, 2006a, 2006b; JRC, 2010).

O MTP é testado no contexto do Brasil e do Reino Unido onde são definidos os cenários e os contextos de análise, além de gerar resultados da 
quantificação dos impactos ambientais, comparações e apontar lacunas da aplicação da ACV na Construção no Brasil.

Essa etapa da pesquisa é realizada na instituição britânica BRE, que disponibilizou dados de seu banco de dados para a aplicação do modelo considerando os requisitos de desempenho ingleses e brasileiros e as tipologias definidas para o Brasil e para o Reino Unido.

Algumas análises consideraram os dados coletados no Brasil e outras utilizaram os dados fornecidos pela BRE, sendo que as últimas análises podem não possuir uma representatividade real para o Brasil em termos absolutos dos valores dos impactos, pois a base de dados aplica-se somente ao contexto britânico. Em termos relativos, os resultados podem ser ponderados e analisados fazendo as devidas considerações e observações a respeito da representatividade que esses resultados possuem.

No entanto, a aplicação desses dados no modelo permite avaliar sua aplicabilidade e pode apontar alterações e ajustes necessários. Esse exercício de aplicação do modelo também aponta as lacunas da aplicação da ACV no Brasil.

Sendo assim, para tornar mais clara a visualização do passo a passo do desenvolvimento de MTPs, foi feito uma esquematização com os principais passos para a elaboração de modelos parametrizados (Figura 3).

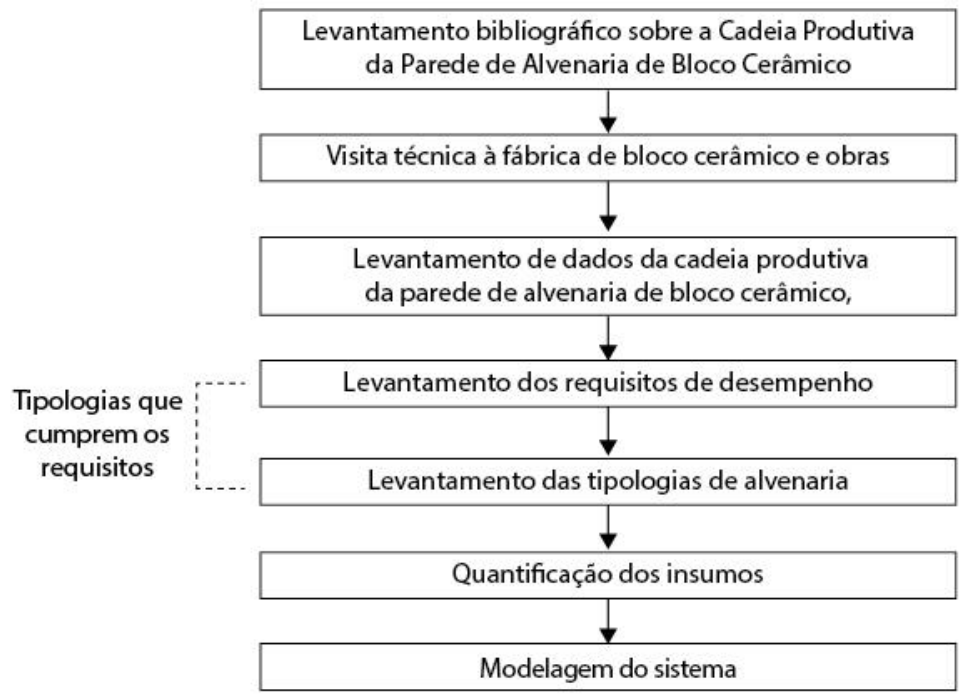

Figura 3: Etapas do planejamento do MTP. 


\subsection{Estrutura da tese}

Esta tese é composta por cinco capítulos e a relação entre os passos metodológicos e os resultados pode ser verificado na Figura 4.

\section{PASSOS METODOLÓGICOS}

\section{RESULTADOS}

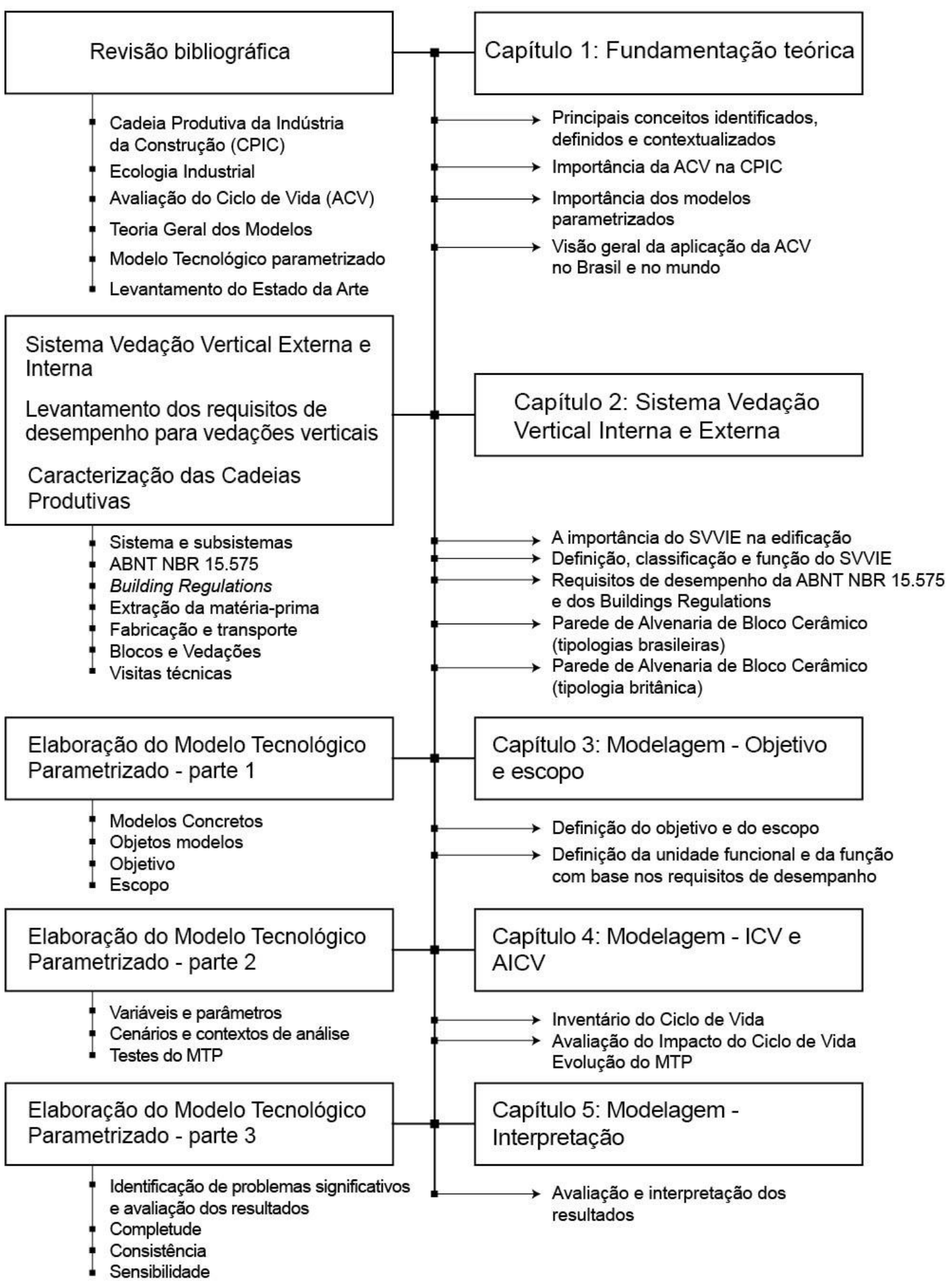

Figura 4: Passos metodológicos usados e resultados a serem obtidos. 
A Introdução apresenta o projeto de pesquisa com a apresentação do enquadramento da pesquisa, a hipótese, os objetivos geral e específicos e um resumo da metodologia aplicada.

No Capítulo 1 são apresentados os conceitos fundamentais: a CPIC no seu conceito mais amplo abrangendo a cadeia principal, auxiliar e de suprimentos; a Ecologia Industrial como o estudo dos fluxos de massa e energia; da ACV como uma ferramenta da Ecologia Industrial para a quantificação do desempenho ambiental de produtos, conceitos dessa metodologia e sua aplicação; a importância da ACV e da Ecologia Industrial para a CPIC; e o desenvolvimento de modelos, sobretudo os modelos parametrizados. Este capítulo também apresenta o levantamento do Estado da Arte da ACV no mundo e no Brasil no setor público, no setor privado e na academia.

No Capítulo 2 tem-se a conceituação do Sistema Vedação Vertical, importância, características e classificação. São descritos os critérios de desempenho ambiental das vedações para o Brasil e para o Reino Unido. São feitos os recortes da pesquisa para o tipo de sistema da edificação e o tipo de vedação a ser estudado. E, por fim, é feita a caracterização das cadeias produtivas das vedações de bloco cerâmico produzida no Brasil e no Reino Unido, desde a extração da matéria-prima até a construção da vedação.

No Capítulo 3 tem-se início a elaboração do MPT para as vedações verticais definidas no desenvolvimento da metodologia com a definição do objetivo e do escopo da ACV, as duas primeiras etapas da aplicação da metodologia. O Capítulo 4 traz o desenvolvimento das etapas de Inventário do Ciclo de Vida (ICV), onde é feita a coleta e modelagem dos dados, e a Avaliação do Impacto do Ciclo de Vida (AICV) onde os dados coletados são convertidos em categorias de impacto potenciais.

O Capítulo 5 traz a Interpretação, última fase da ACV, onde são analisados os impactos mais significantes da cadeia para as análises feitas. Por fim, tem-se as considerações finais que trazem a compilação dos principais resultados desta pesquisa, as contribuições e os desdobramentos possíveis a partir do trabalho desenvolvido. 


\section{Capítulo 1: Conceitos Fundamentais}

Este capítulo apresenta os principais conceitos para a fundamentação da pesquisa proposta, incluindo a Cadeia Produtiva da Indústria da Construção (CPIC), sua estrutura e características, importância socioeconômica e impactos ambientais. Este capítulo também apresenta os conceitos de Ecologia Industrial e de uma de suas ferramentas: a metodologia de Avaliação do Ciclo de Vida (ACV). São demonstradas as relevâncias da Ecologia Industrial e da ACV para a CPIC, considerando-se os impactos ambientais gerados por essa cadeia.

É feito um levantamento do Estado da Arte da ACV à CPIC, considerando as abrangência do mundo e do Brasil e os contextos do Setor Público, Setor Privado e a Academia.

Após o levantamento e a identificação da importância da abordagem de ACVs parametrizadas, é feito uma referenciação teórica de modelos, por meio da aplicação da ACV com o uso do manual ILCD e a identificação das etapas diretamente relacionadas com a modelagem; a Teoria Geral dos Modelos e Modelagem Parametrizada de ACV.

\subsection{A Cadeia Produtiva da Indústria da Construção}

A Cadeia Produtiva da Indústria da Construção (CPIC) pode ser conceituada como um conjunto de atividades articuladas desde os insumos até o produto final (MDIC, 2002). E pode ser dividida em: (i) cadeia principal, que produz edificações e obras de engenharia; (ii) cadeia de suprimentos, composta pela indústria de extração de recursos naturais e de produção de elementos e componentes; (iii) e cadeia auxiliar, composta pelas universidades, centros de pesquisa, consultorias e transportadoras (BLUMENSCHEIN, 2004).

Essa cadeia possui grande importância (i) social, como com seus altos índices de irregularidade e informalidade expressa pelo índice de $11,4 \%$ de trabalhadores informais, em 2014, ou pela demanda crescente pelo ambiente construído, seja para prover edificações ou obras de infraestrutura urbana; (ii) econômica, com o crescimento de $1,60 \%$ no PIB setorial, em 2013, e geração de 73 mil vagas no mercado de trabalho no primeiro semestre de 2014; e (iii) 
ambiental, onde é responsável pela emissão, em média, de $40 \%$ do $\mathrm{CO}_{2}$ no mundo e por consumir entre 15 e $50 \%$ dos recursos naturais disponíveis, como água, energia e matérias-primas (IBGE, 2015; CBIC, 2015; MTE, 2015; ATHENA, 2000; FREITAS, 2011; JOHN, 2000).

\subsection{Ecologia Industrial}

A humanidade ainda não sabe quais deverão ser as mudanças em seu estilo de vida para garantir a sobrevivência do planeta, entretanto a ciência Ecologia Industrial quantifica os impactos dos objetos, produtos, serviços e materiais produzidos pelo homem a partir da natureza (GOLEMAN, 2009). A Ecologia Industrial pode ser definida como:

\footnotetext{
" (...) o estudo dos fluxos de materiais e energia nas atividades industriais e de consumo, dos efeitos desses fluxos no meio ambiente, e a influência dos fatores econômicos, políticos, sociais e regulatórios dos fluxos no uso e transformação de recursos" (AYRES et al, 2002, p. 4).
}

Essa ciência faz uma analogia entre os sistemas vivos e os sistemas produtivos, utilizando os conceito de fluxos, principalmente o ciclo de materiais, nutrientes e energia. Sendo assim, o sistema industrial é como um organismo vivo complexo que se alimenta de recursos, digere-os, os transforma em produtos e elimina resíduos. Porém, no metabolismo industrial os fluxos de matéria e energia são mais densos e não existe um produtor primário como na biosfera. Uma das ferramentas usadas pela Ecologia Industrial para a análise de fluxos de massa e energia nos processos industriais é a ACV (AYRES et al, 2002).

\subsubsection{Avaliação do Ciclo de Vida (ACV)}

A ACV é uma ferramenta para avaliar as consequências ambientais e à saúde humana associadas a um produto, serviço, processo ou material ao longo de todo o seu ciclo de vida (do berço ao túmulo), desde a extração e processamento da matéria-prima até o descarte final, passando pelas fases de transformação e beneficiamento, transporte, distribuição, uso, reuso, manutenção e reciclagem. Essa metodologia permite desmembrar sistematicamente um bem manufaturado em componentes e processos, além de medir os impactos sobre a natureza (VIGON et al, 1995). 
A ACV é composta por quatro fases: definição de Objetivo e Escopo, Análise do Inventário do Ciclo de Vida, Avaliação dos Impactos e Interpretação dos Impactos (BSI, 2006a) (Figura 5).

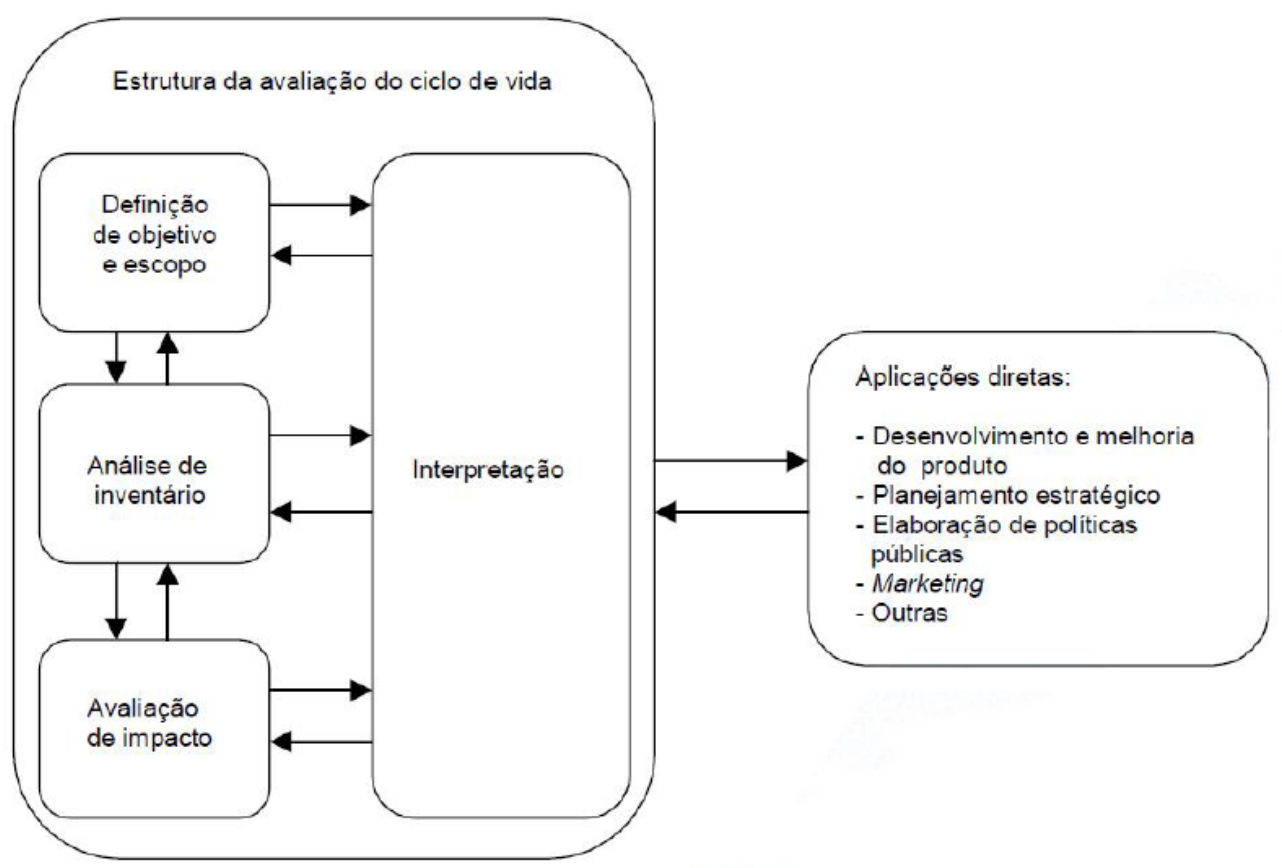

Figura 5: Etapas da ACV. Fonte: BSI, 2006a.

O objetivo deve ser claro e consistente com a aplicação pretendida, pois terá relação direta com resultado da análise e deve conter: aplicação prevista, limitações, contexto decisório, comparações, atores envolvidos, situação e relação de documentos de referência utilizados (JRC, 2010).

O escopo caracteriza o produto analisado, detalha premissas e define a metodologia de cálculo aplicada no estudo. Segundo JRC (2010), deve conter: (i) regras para o tratamento das inconsistências; (ii) função; (iii) unidade funcional; (iv) regras para informações confidenciais; (v) resultados esperados; (vi) fluxo de referência; (vii) limites do sistema; (viii) listagem de exclusões; (ix) critérios de corte; (x) categorias de impacto; (xi) método de AICV; (xii) método de normalização; (xiii) método de ponderação; (xiv) representatividade tecnológica, geográfica e temporal; (xv) fontes de dados; (xvi) requisitos de qualidade; (xvii) cálculo de incertezas; (xviii) completude; (xix) comparações; (xx) cenários; e (xxi) alternativas (Figura 6). 


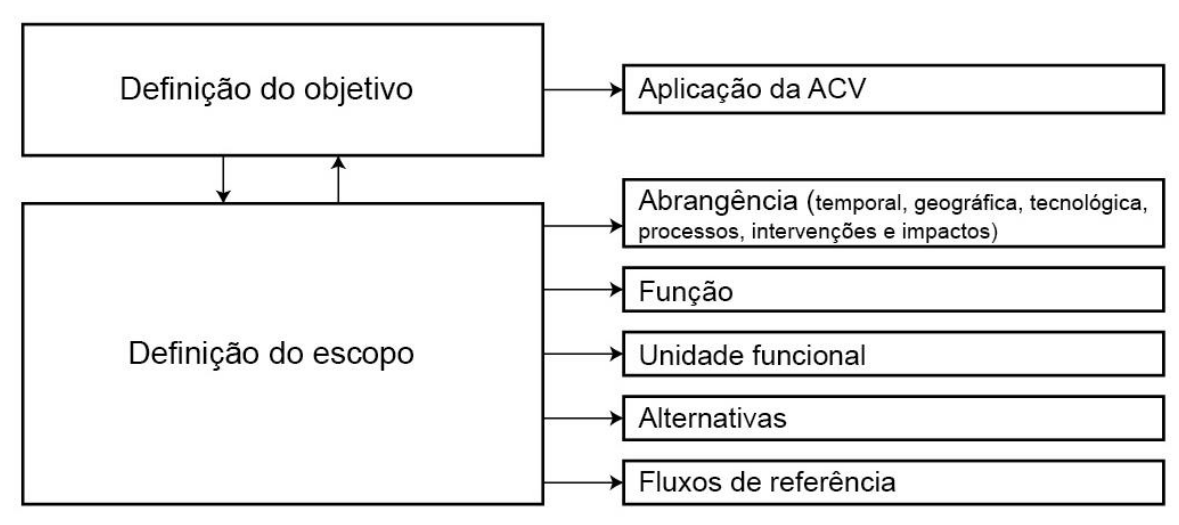

Figura 6: Etapa 1 da ACV - Definição do objetivo e do escopo

A Análise do Inventário do Ciclo de Vida é a fase da ACV que quantifica e compila todas as entradas e saídas do sistema. Essa fase contém o plano de obtenção de dados, a coleta de dados, a modelagem do sistema e a tabela do ICV (JRC, 2010).

Ferreira (2004) afirma que o processo da análise do inventário é iterativo, uma vez que os dados forem coletados outras demandas podem surgir, além de novos requisitos de dados e limitações identificadas para que o objetivo da análise seja atingido (Figura 7).

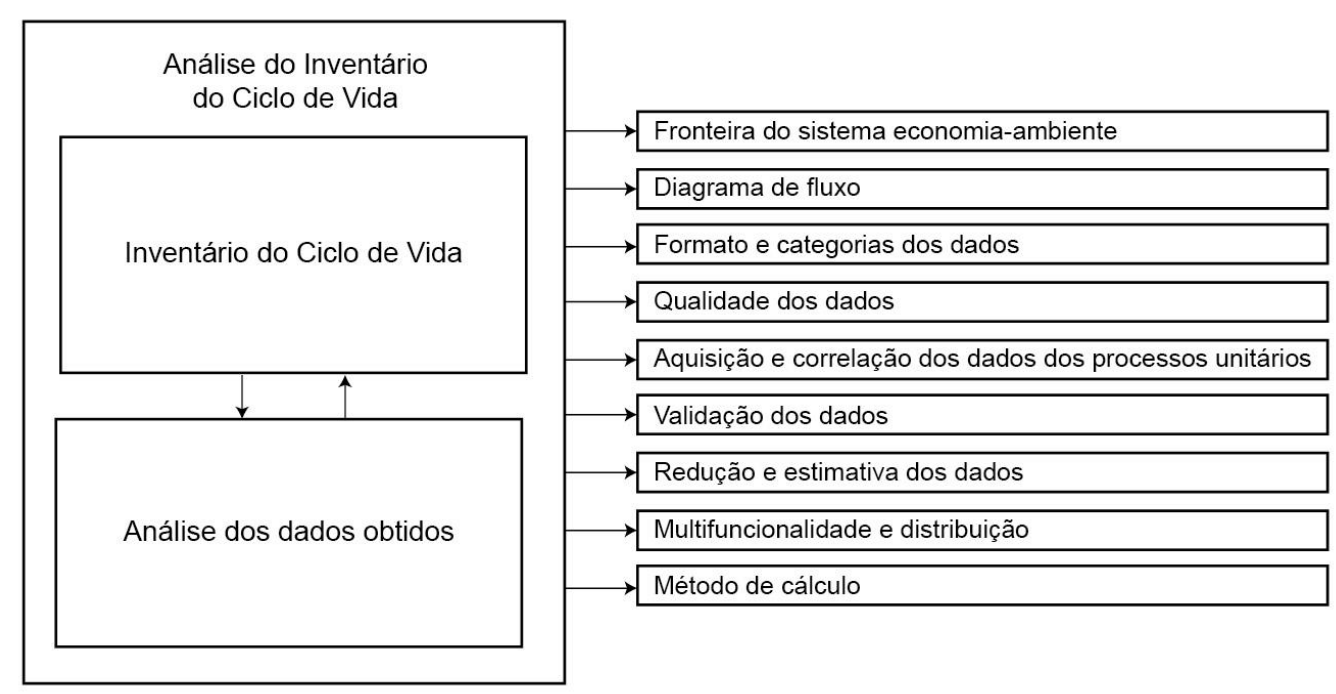

Figura 7: Etapa 2 da ACV - Análise do Inventário do Ciclo de Vida.

A Análise dos Impactos do Ciclo de Vida é a fase que identifica e avalia o montante e a significância do potencial do impacto ambiental. As etapas obrigatórias de uma AICV são a seleção das categorias de impacto, indi- 
cadores de impacto e modelo de caracterização; a classificação; e a caracterização (ABNT, 2009) (Figura 8). As etapas são:

Classificação: as emissões são classificadas de acordo com as categorias de impacto, que podem pertencer a mais de uma categoria;

Categorização: agrupa cada emissão em categorias de impacto definidas para a avaliação dos impactos;

Caracterização: descreve e quantifica o impacto ambiental do sistema analisado. Depois da fase de classificação do ICV são aplicados os fatores de caracterização para as quantidades mais relevantes. Além disso, é convertido para uma única unidade;

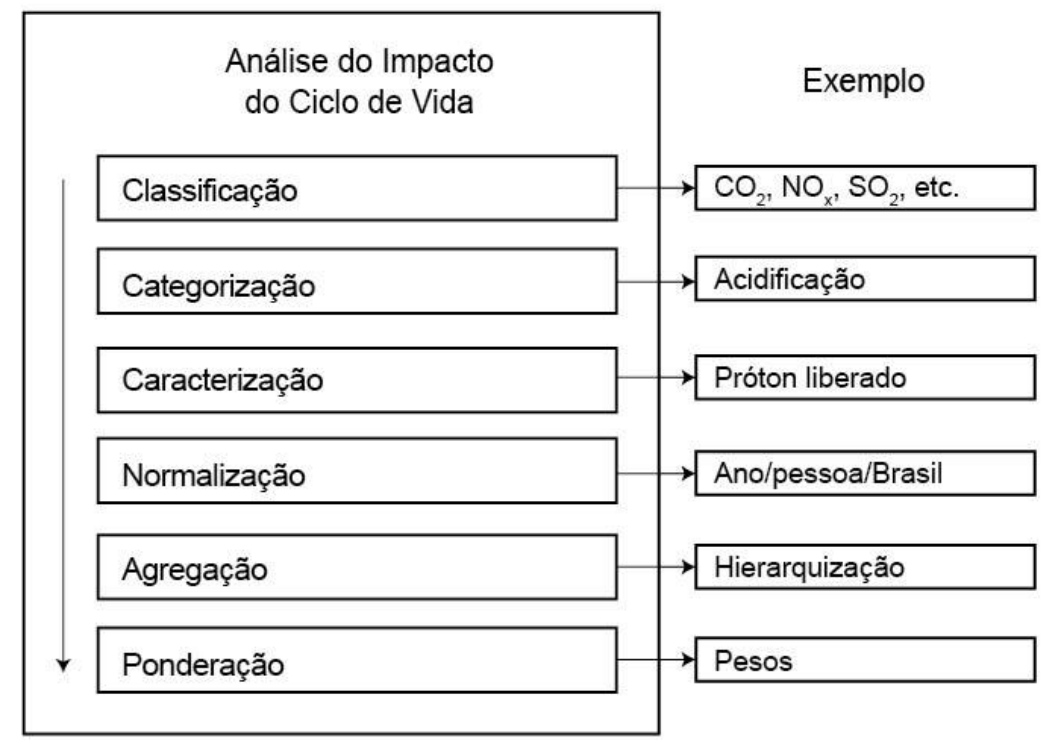

Figura 8: Etapa 3 da ACV - Análise do Impacto do Ciclo de Vida.

i. Normalização: mostra a magnitude do resultado do indicador de impacto relativa à quantidade de referência, considerando que a quantidade e a duração da emissão terão impactos diferentes em cada região;

ii. Agregação: ordena e classifica as categorias de impacto. Pode usar diferentes agrupamentos tais como: entradas e saídas; escala global, regional ou local; e alta, média ou baixa prioridade;

iii. Ponderação: compara diferentes resultados dos indicadores de impacto de acordo com a significância atribuída a esses indicadores. 
A fase de Interpretação consiste em checar se os resultados obtidos alcançaram o objetivo e escopo definidos (PE-INTERNATIONAL, 2009) (Figura 9). Possui duas etapas:

i. Identificação das questões relevantes: inventariar elementos importantes; identificar os indicadores de impacto que são de interesse especial ou cujo montante é preocupante; e identificar contribuições essenciais dos estágios do ciclo de vida para os resultados.

ii. Avaliação: o objetivo dessa fase é melhorar a confiabilidade do estudo. Possui três métodos: checagem de completude, checagem de sensibilidade e checagem de consistência.

A análise de completude avalia se os processos abrangem todos os fluxos principais, que podem ser declarados como: todos os fluxos, todos os fluxos relevantes, fluxo individual relevante, alguns fluxos relevantes não considerados e não enunciados (JRC, 2010; GABI 6, 2014).

A análise de consistência é feita por meio de balanço de massa para que se contabilize as diferenças entre as entradas e saídas dos processos. Segundo JRC (2010) não é recomendado que essa diferença seja maior que $10 \%$ em massa.

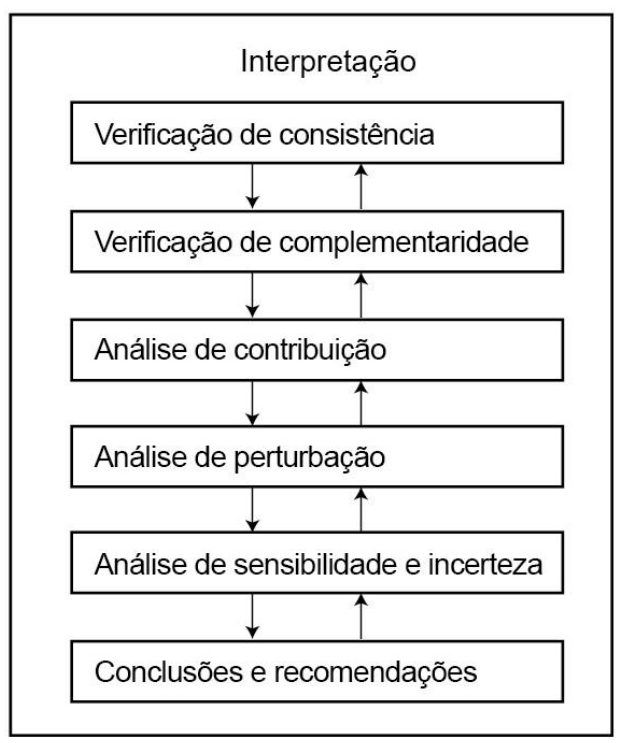

Figura 9: Etapa 4 da ACV - Interpretação. 
Nessa fase ainda deve-se fazer as conclusões, identificar limitações e recomendações do projeto repassando por todas as fases. No fim, prepara-se o relatório mostrando os resultados de forma clara, transparente e estruturada. Para essa fase usa-se a ISO 14.044 (BSI, 2006b) e faz-se uma revisão crítica dos resultados obtidos.

\subsection{A importância da Ecologia Industrial e da Avaliação do Ciclo de Vida na CPIC}

$\mathrm{Na}$ CPIC a analogia entre sistema vivo e não-vivo da Ecologia Industrial é utilizada por Blumenschein (2004) ao discutir que o organismo deve alimentar-se de recursos e eliminar resíduos de forma equilibrada. Sendo assim, a principal vantagem dessa abordagem é a introdução do conceito de movimento cíclico de recursos e resíduos gerados ao longo de toda a cadeia, com a ressalva de que nem todos os resíduos retornarão ao mesmo ciclo, mas podem inserir-se em outras cadeias.

Os materiais usados na CPIC e os produtos finais utilizam recursos ao longo de seu ciclo de vida, que têm como suporte um processo produtivo complexo envolvendo matérias-primas, insumos, recursos humanos, transporte etc. Nesse processo, observa-se que os impactos ambientais, muitas vezes, não são considerados ou até mesmo ignorados pelos atores envolvidos.

A produção dos materiais e produtos da CPIC caracteriza-se por uma atividade industrial intensa e o objetivo é obter a mesma função com uma menor unidade de massa por produto (CALDEIRA-PIRES et al, 2005). Sendo assim, tem-se na ACV, aplicada à CPIC, a busca de um novo tratamento ao projeto de produtos, ao manejo dos materiais e aos processos, no qual a busca pela otimização econômica, ambiental e social são fatores fundamentais.

A ACV aplicada ao contexto da CPIC possibilita planejar construções sustentáveis, permitindo a quantificação dos custos ambientais e econômicos associados aos materiais e edificações menos poluentes, bem como divulgar os benefícios das práticas sustentáveis de construção (KEELER et al 2010).

Entretanto, aplicar a metodologia da ACV a um edifício não é um processo simples como para outros produtos de consumo. Essa cadeia é dispersa com muitas fornecedores e ramificações. Além disso, os edifícios possuem ciclo de vida longo, têm funções múltiplas, contêm muitos componentes diferen- 
tes, são produzidos localmente, são únicos, causam impacto local e são integrados com a infraestrutura (BRIBIÁN et al, 2009; JOHN et al, 2006).

$\mathrm{Na}$ fase do pré-uso observam-se impactos ambientais na extração de matéria-prima e no processamento, produção e transporte, além dos impactos causados no processo construtivo. $\mathrm{Na}$ fase de uso, os problemas estão na operação da edificação, na manutenção e na interação entre os materiais construtivos e o meio ambiente. E na fase de pós-uso podem-se observar os impactos na demolição e descarte dos resíduos Considerar esses aspectos ambientais, no começo do desenvolvimento do produto, pode reduzir os impactos ambientais em até 70\% (BLUMENSCHEIN, 2004; PIGOSSO et al, 2007).

Apesar da importância da ACV aplicada às edificações, a ACV de materiais e insumos da construção é uma fase importante e que precisa anteceder à aplicação da metodologia na edificação em si. Norris, em entrevista a Goleman (2009), afirma que são poucos os produtos considerados verdes ${ }^{2}$ que passaram por uma avaliação que permite identificar quais são seus verdadeiros benefícios e ressalta a importância da aplicação da ACV para a obtenção de dados e informações precisos a respeito dos potenciais impactos ambientais de um produto, material, serviço ou atividade.

\subsubsection{ACV aplicada na seleção de materiais e produtos da CPIC}

Segundo John et al (2007) uma construção mais sustentável depende da seleção correta de materiais e componentes combinada ao correto detalhamento de projeto. Ferramentas de seleção de materiais devem considerar a gestão do processo de desenvolvimento do produto, a avaliação do desempenho ambiental do produto com base em ACV, a avaliação dos custos do ciclo de vida e critérios de avaliação de adequação social.

No Brasil, foram desenvolvidos métodos baseados em critérios simplificados para avaliação de edificações, que abrangem a avaliação de materiais e componentes enquanto integrantes da edificação avaliada. Uma das primeiras formas de avaliação foi o cálculo de energia incorporada nos materiais, mas esse método não considera impactos ambientais, como impactos da extração dos recursos e contribuições para a destruição da camada de ozônio.

\footnotetext{
2 Produtos considerados ecológicos e de baixo impacto ambiental, mas que, muitas vezes, possuem uma parcela de redução de impactos irrelevantes frente a outros impactos causados por sua cadeia produtiva.
} 
Com o avanço das pesquisas em ACV surgiram sistemas de avaliação da sustentabilidade de materiais e componentes da CPIC baseados nessa metodologia, tais como a metodologia Environmental Profiles ${ }^{3}$, o software BEES ${ }^{4} \mathrm{e}$ o Guia de especificações online e impresso Green Book ${ }^{5}$ (JOHN et al, 2007).

Ainda segundo John et al (2007), a ACV é a melhor ferramenta para a seleção de materiais com base na sustentabilidade ambiental e à medida que se aumente os dados coletados e disponibilizados, aumenta-se a precisão dos resultados obtidos e diminui-se os custos das avaliações.

\subsection{Levantamento do Estado da Arte da ACV aplicada à CPIC ${ }^{6}$}

\subsubsection{A ACV aplicada no mundo}

Os países desenvolvidos possuem legislações e instrumentos que contribuem para o desempenho ambiental das atividades produtivas. Um exemplo é a inserção da metodologia de ACV nas certificações de rótulos ambientais dos produtos na União Europeia (CALDEIRA-PIRES et al, 2005).

No contexto da CPIC, foram levantadas as metodologias, banco de dados e softwares de ACV que podem ser usados para os materiais de Construção e para os produtos finais da CPIC (Figura 10). As instituições, metodologias, banco de dados e softwares de ACV concentram-se nos países desenvolvidos. Nos países em desenvolvimento, a ACV encontra dificuldades para a sua difusão, uma vez que esses países não possuem bancos de dados nacionais e os bancos de dados dos países desenvolvidos não condizem com a realidade técnica, geológica, climática, tipos de produtos e densidade populacional dos países em desenvolvimento (CALDEIRA-PIRES et al, 2005).

\footnotetext{
${ }^{3}$ Metodologia desenvolvida pela Building Research Establishment para avaliação de materiais construtivos e, posterior, emissão de declarações ambientais de produtos da construção.

${ }^{4}$ Software gratuito de ACV desenvolvido pela National Institute for Standards and Technology (NIST) BuiIding and Fire Research Laboratory e que auxilia na seleção de materiais com menores impactos ambientais para edificações, tendo como base a relação custo-benefício.

${ }^{5}$ Guia de especificação de materiais desenvolvido pela Bulding Research Establishment Materials, tendo como base a ACV desses materiais. Contém a especificação de 1200 materiais em diferentes tipos de edificações.

${ }^{6}$ O levantamento completo do Estado da Arte da aplicação da ACV no mundo e no Brasil, bem como a metodologia utilizada neste levantamento e lições aprendidas encontra-se no artigo Comparison between European EPD issuing Systems and lessons learned to Latin American Countries (MILLER et al, 2013b) e The State of art the LCA in PCCI (MILLER et al, 2013b).
} 


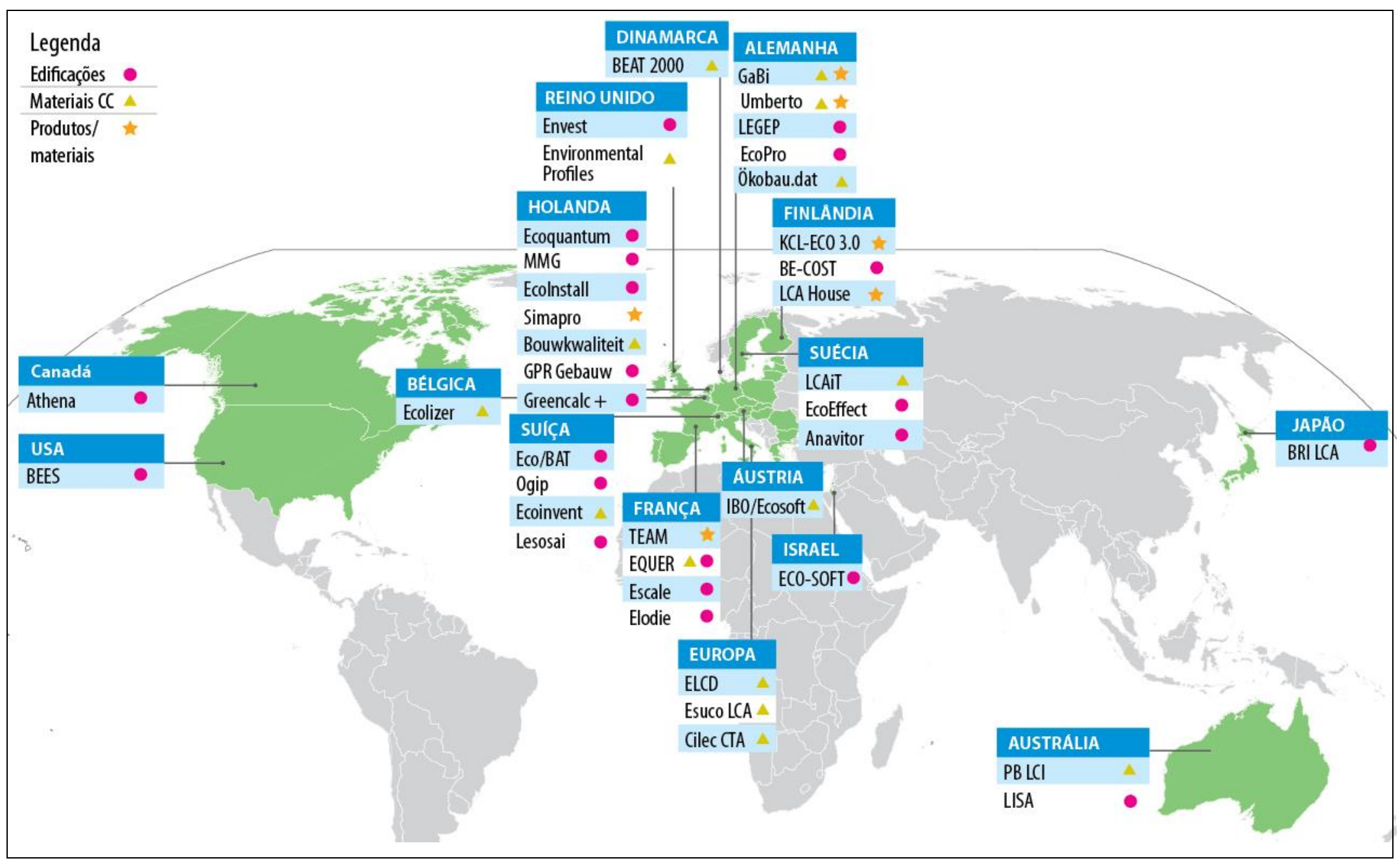

Figura 10: Metodologias, bancos de dados e softwares de ACV usados no contexto da CPIC 
Entretanto, os países da América Latina estão em processo de implementação de regulamentos ambientais que visam a redução da contaminação do ar, água e solo e que, em muitos casos, trazem a ACV como uma metodologia a ser utilizada para a quantificação dos impactos ambientais.

Para caracterizar a ACV no mundo, ainda foi feito um levantamento quanto à utilização de banco de dados e softwares indicados para a ACV de produtos/materiais da construção ${ }^{7}$ (Apêndice A). Nesse levantamento verificouse que os bancos de dados e softwares mais indicados e utilizados são o software Environmental Impact Estimator; o software BEES 3.0; e o GaBi 4.

No Setor Público a ACV é utilizada por diferentes países como o Reino Unido e a Alemanha. No levantamento feito, o Governo Britânico usa a ACV como uma ferramenta de auxílio para a elaboração de metas e parâmetros para políticas públicas com foco no desenvolvimento de economias mais sustentáveis. E a Alemanha utiliza a ACV para a emissão de certificações ambientais tipo III para produtos da construção e formação de um banco de dados público - Okobau.dat - disponível para download no sítio do Governo Alemão (GOVERNO ALEMÃO, 2012).

No Setor Privado a aplicação da ACV nos materiais e produtos da CPIC já é uma realidade em muitos países desenvolvidos e é um importante instrumento da ISO 14.025 que define as regras para a Rotulagem Ambiental Tipo III e que emitem as declarações ambientais de produtos (DAP).

Atualmente, os países europeus utilizam uma norma única para a emissão de certificações ambientais de produtos tipo III: a EN 15804, que permitiu uma abordagem mais abrangente para a inserção de produtos construtivos no mercado, formando um mercado comum, no qual se eliminam as barreiras técnicas, por meio da harmonização das legislações nacionais dos países da União Europeia para requisitos essenciais (BSI, 2014).

As DAPs informam sobre o desempenho ambiental, ressaltam fatores de preferência nas compras públicas e privadas e induzem a melhoria do perfil ambiental dos produtos, conduzindo à redução da pressão ambiental (ALMEI-

\footnotetext{
${ }^{7}$ Para esse levantamento, utilizou-se a lista de discussão da rede Linked in sobre ACV na construção e listagens de softwares e bancos de dados dos sites Building Ecology e U.S. Environmental Protection Agency (LINKED IN, 2012; BUILDING ECOLOGY, 2012; U.S. ENVIRONMENTAL PROTECTION AGENCY, 2012).
} 
DA et al, 2011). Essas informações subsidiam a tomada de decisão e o processo de especificação de materiais para arquitetos e engenheiros o que contribui para a sustentabilidade das edificações (MILLER et al, 2013a).

No Setor Acadêmico verificou-se que a produção acadêmica de 1993 a 2006 possui um crescimento constante e que a maioria das publicações concentram-se na ACV de edificações, sem do que as demais publicações tratam de ACVs de materiais e componentes da construção ou de análises de software e conceitos relacionados ${ }^{8}$. Os artigos foram especializados de acordo com o país de origem dos pesquisadores e universidades e a maior parte dos artigos concentram-se na Europa, Ásia e Oceania (

Figura 11).

Observou-se que algumas publicações traziam uma abordagem de ACV baseada na parametrização dos dados do ICV, mostrando diferentes benefícios para a aplicação da metodologia. Por isso, juntamente com a pesquisa pelos termos "LCA" e "Life cycle Assessment", foi feita uma pesquisa específica para modelagem de ACV com parametrização de dados. Devido a importância dessa abordagem para essa pesquisa, essas publicações serão detalhadas no item "Modelagem Parametrizada de ACV" deste capítulo.

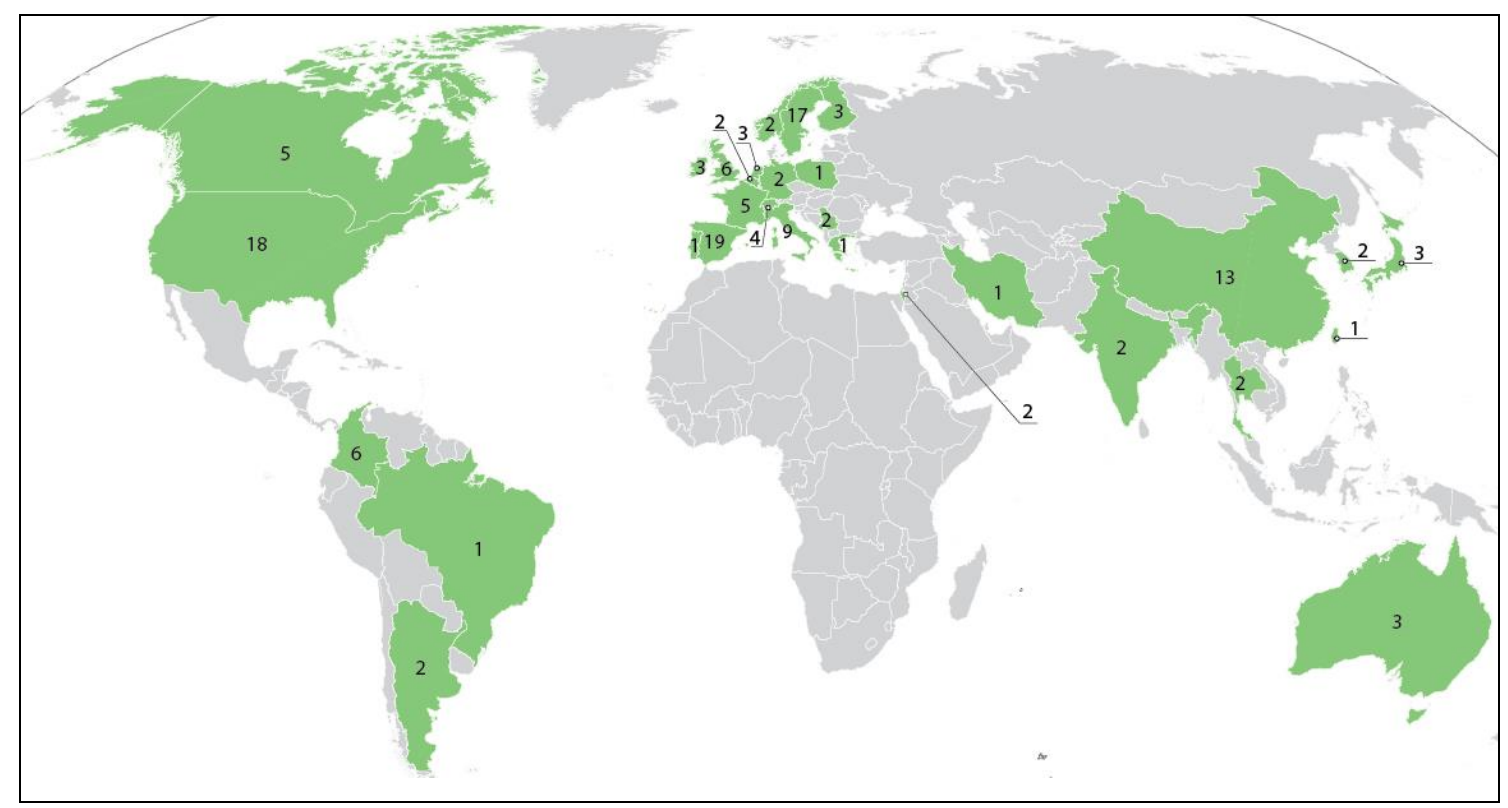

Figura 11: Distribuição geográfica dos artigos encontrados no Science Direct

\footnotetext{
${ }^{8}$ Pesquisa feita por amostragem.
} 


\subsubsection{A ACV aplicada ao Brasil}

No Setor Público no Brasil, a ACV tem sido utilizada para a produção de inventários do ciclo de vida, construção de um banco de dados e a criação do Programa Brasileiro de Avaliação do Ciclo de Vida (PBACV), que visa apoiar o desenvolvimento sustentável e a competitividade ambiental da produção industrial brasileira e promover o acesso aos mercados interno e externo (CAVALCANTI, 2009; CONMETRO, 2010).

O PBACV propõe uma base comum para a inserção dos dados dos ICVs dos setores construção, metais, eletroeletrônicos, energia, plásticos, combustível e agropecuário do Brasil. A concepção da base de dados brasileira está de acordo com os padrões internacionais de ICV, visto que o padrão adotado internacionalmente, ILCD, também foi adotado pelo PBACV, que facilita a troca de informações e a integração de dados e resultados de diferentes bases de dados que seguem o mesmo padrão. No programa existe um Grupo de Trabalho específico para a Construção dividido em Materiais, coordenado pela Federação das Indústrias do Estado de São Paulo (FIESP), e Edificações, coordenado pela CBIC.

No Setor Privado, ainda existem poucas e limitadas iniciativas da aplicação da ACV de forma direta. As iniciativas identificadas concentram-se em fazer inventários do uso de recursos e quantificar as emissões de GEE ou carbono corporativo - com poucos inventários disponibilizados para consulta; certificações ambientais de edificações e de produtos, como o LEED e o Selo Falcão Bauer'; melhoria do processo produtivo e retirada de substâncias tóxicas; negociações de crédito de carbono; ou (MILLER et al, 2013b) (APÊNDICE G).

Apesar das poucas iniciativas existentes em ACV para produtos e materiais da CPIC demonstradas neste levantamento, observam-se ações realizadas por instituições representantes da CPIC no setor produtivo, como a CBIC, a Caixa e o Conselho Brasileiro de Construção Sustentável (CBCS).

A CBIC lançou, em 2011, o Programa Construção Sustentável, que visa contribuir com o aperfeiçoamento e a implementação efetiva do PBACV, por meio do apoio às ações desenvolvidas pelo programa (CBIC, 2011a).

\footnotetext{
9 Instituição que elaborou um modelo de certificação destinado a comprovar e garantir a sustentabilidade dos produtos
} 
O guia Selo Azul da Caixa aborda o ciclo de vida dos edifícios e a importância de uma visão ampla quanto aos impactos causados pela construção. Os produtos e materiais da CPIC só poderão ter o seu desempenho ambiental avaliado com base na ACV. Entretanto, a aplicação da ACV depende do desenvolvimento de um banco de dados para o Brasil; definição de parâmetros; e a inserção da informalidade como um fator de sustentabilidade (JOHN, 2010).

Para a CBCS a ACV é uma ferramenta que permite a contabilidade ambiental da CPIC, mas que atualmente os produtos e materiais construtivos têm sido selecionados com base em critérios simplificados, ignorando-se as diferenças entre as empresas, como informalidade e ecoeficiência, e da fase de uso do material, como a durabilidade ( $\mathrm{HACHICH}$ et al, 2009).

O CBCS está desenvolvendo projetos de ACV para produtos de concreto e uma Plataforma Global de Avaliação do Ciclo de Vida, que reunirá diferentes setores para a construção de uma ferramenta para a tomada de decisão com base no desenvolvimento sustentado da cadeia (CBCS, 2012).

No Setor Acadêmico brasileiro foram identificadas poucas publicações no tema ACV e Construção (28 no total) e que, ao contrário da tendência mundial, a predominância é por ACVs de materiais e componentes. As produções acadêmicas foram espacializadas conforme a universidade, além de separadas por temática e se a produção era tese, dissertação ou artigo (Figura 12).

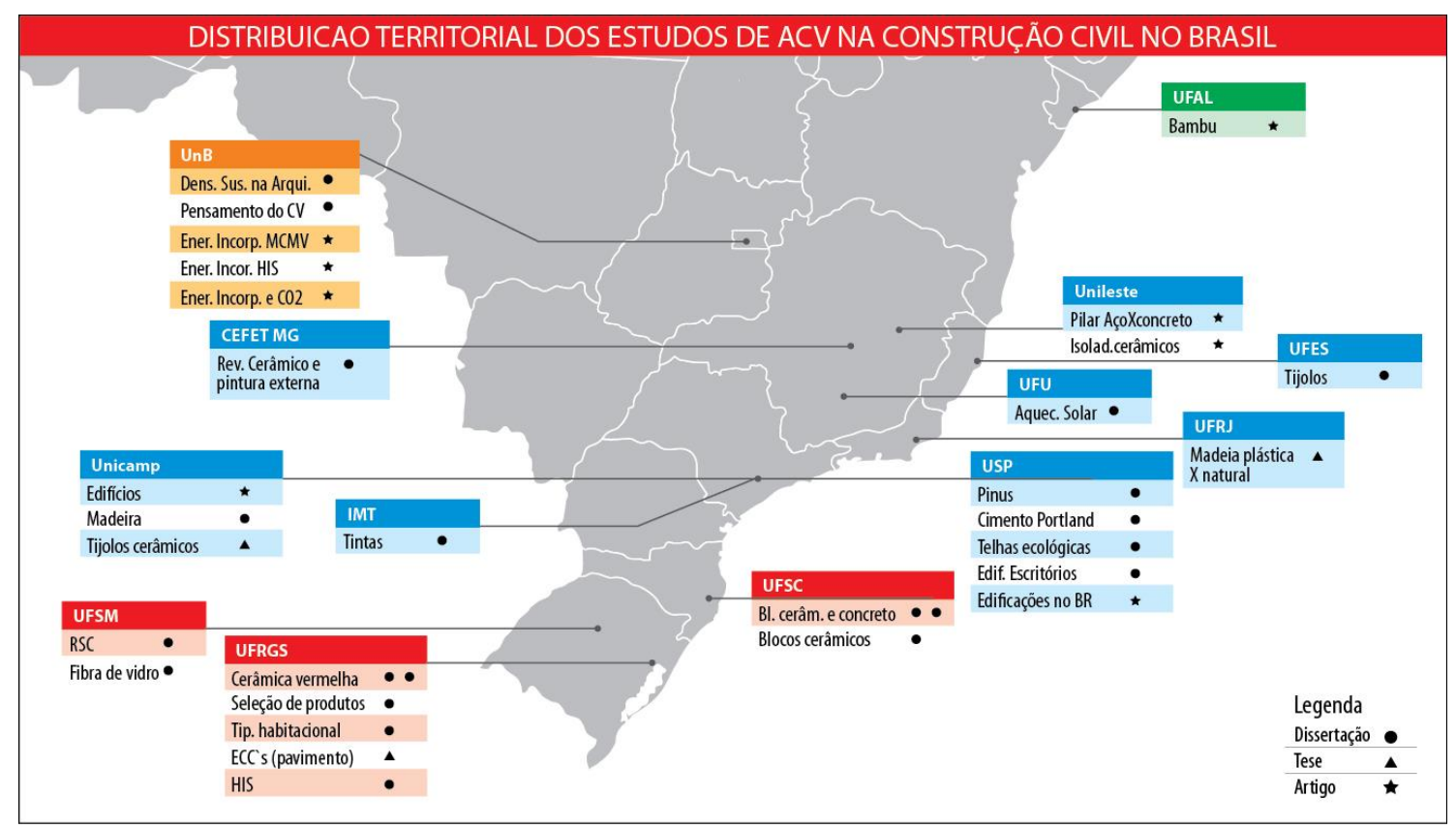

Figura 12: Espacialização da produção acadêmica brasileira em ACV e Construção Civil 
A maior parte das produções acadêmicas concentra-se nas regiões Sul e Sudeste, com algumas publicações isoladas espalhadas pelo país. As produções científicas brasileiras em ACV são constantes desde 2000, mas em pouca quantidade (Figura 13). Para uma melhor visualização das informações relevantes dessas produções acadêmicas, foi organizado o quadro resumo no Apêndice F.

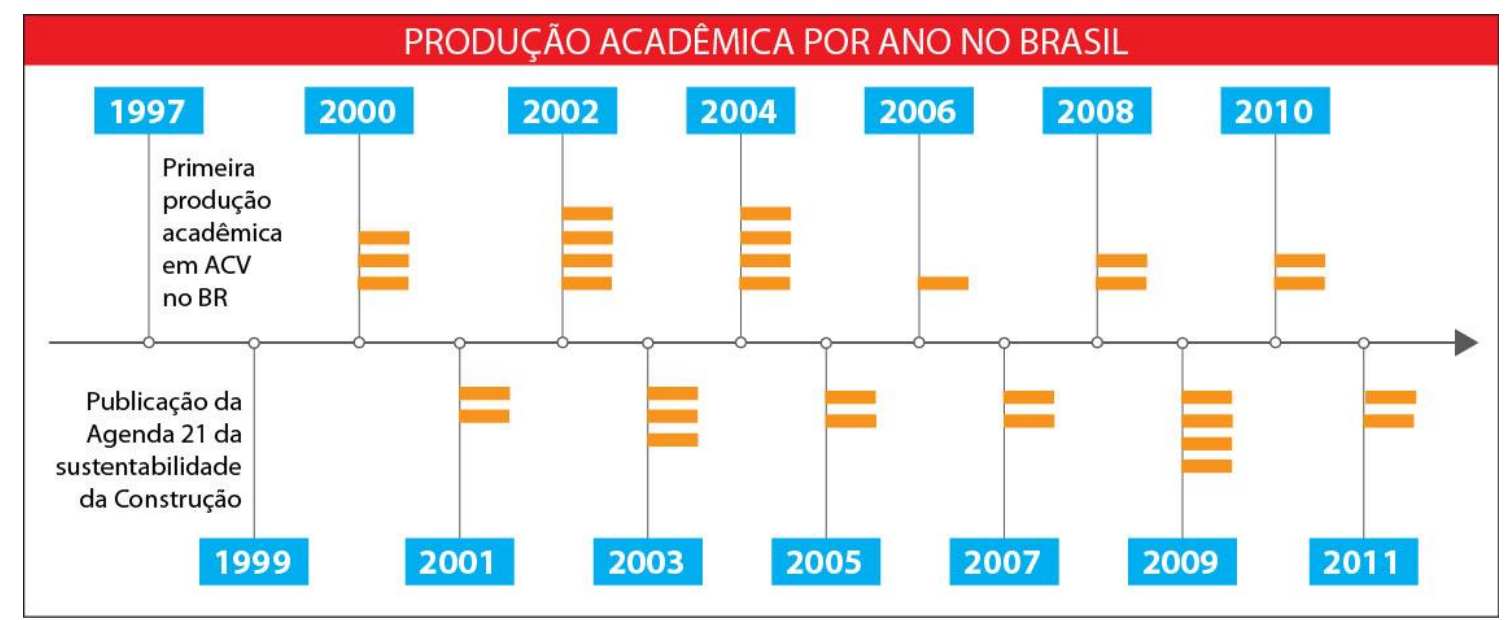

Figura 13: Distribuição das produções científicas em ACV na Construção

\subsection{A modelagem em ACV}

1.5.1. O manual de aplicação da ACV: ILCD

O International Reference Life Cycle Data System (ILCD) é uma série de documentos que seguem as normas internacionais de ACV (ISO 14040 e 14044) e que fornecem a base para garantir qualidade e consistência aos dados, aos métodos e às ACVs. Foi desenvolvido pelo Instituto para o Meio Ambiente e Sustentabilidade da European Commission Joint Research Centre (JRC) em cooperação com o Environment DG. Além do alinhamento com as normas, esses documentos foram definidos a partir de consultas públicas e a especialistas da área de vários países, incluindo o Brasil (JRC, 2010).

Esses documentos foram criados para tornar as regras e recomendações das normas internacionais de ACV mais práticas e fáceis de serem aplicadas, tendo em vista que a ACV pode usar diferentes métodos de cálculo, de obtenção de dados entre outras variáveis que poderiam comprometer a comparabilidade dos dados. 
A modelagem na ACV pode ser feita de forma atribucional, onde o processo é analisado tal qual ele é, e pode ser consequencial, onde são inseridas mudanças, melhorias ou estratégias no processo produtivo de tal forma que possa ser possível observar os potenciais impactos e consequências do modelo idealizado (JRC, 2010). Segundo a JRC (2010) uma ACV possui, resumidamente, as fases esquematizadas na Figura 14.

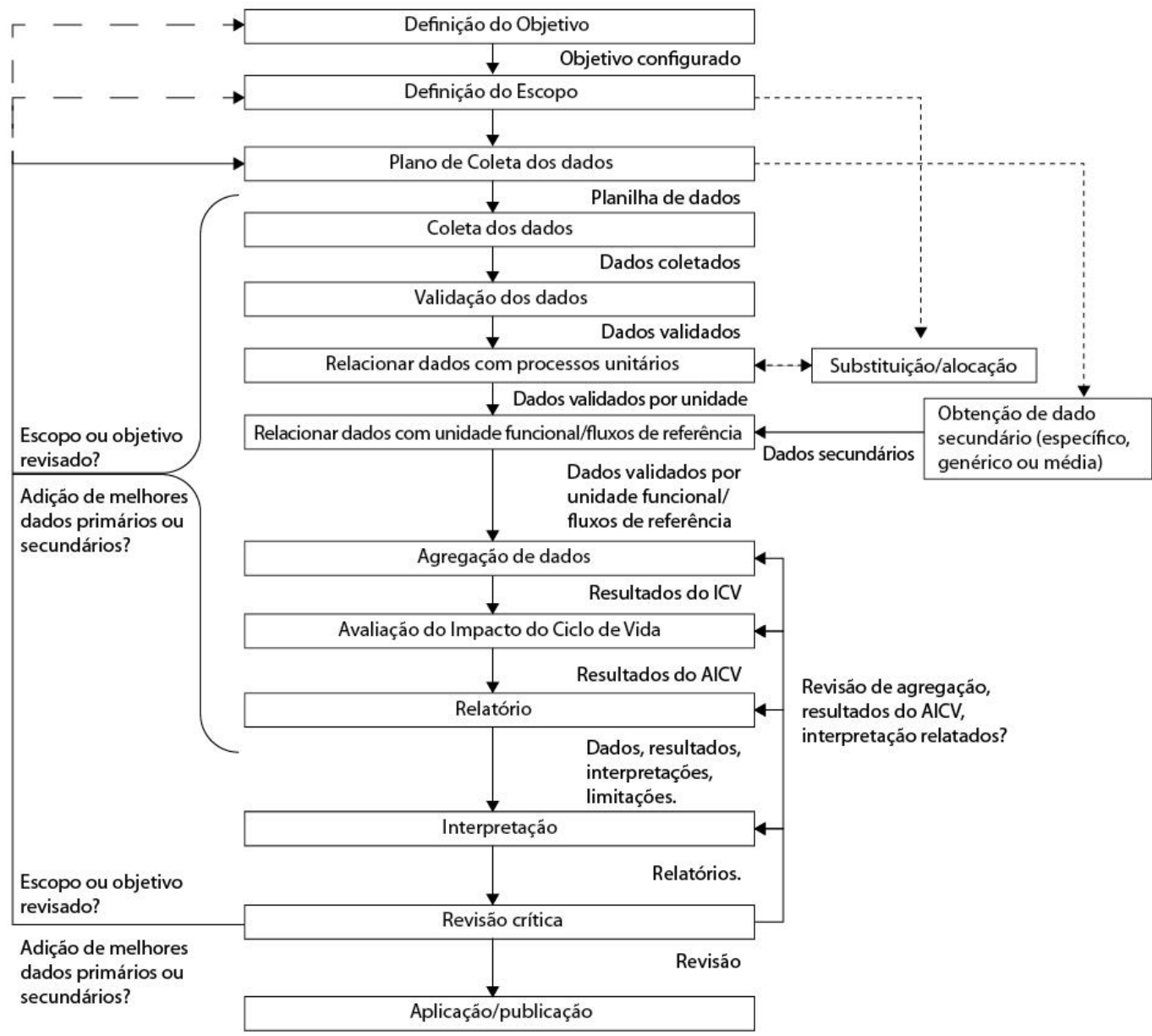

Figura 14: Fases da Avaliação do Ciclo de Vida. Fonte: JRC, 2010.

1.5.2. A relação entre a modelagem do MTP e o manual ILCD

A elaboração de um Modelo Tecnológico Parametrizado (MTP) deve seguir as diretivas dos manuais ILCD - principalmente o documento "Guia geral para a Avaliação do Ciclo de Vida" que mostra com detalhes a metodologia de ACV (JRC, 2010). Além das normas ISO NBR 14040 e ISO NBR 14044, a ACV aplicada à construção pode ser orientada pela ISO 21930 e a EN 15804 que definem as declarações ambientais de produtos da Construção no mundo e na Europa, respectivamente (ABNT, 2009a; 2009b; BSI, 2006b; 2014). 
Considerando-se os dados contidos na Figura 14 e o manual ILCD (JRC, 2011) foi elaborado um fluxograma de aplicação da metodologia com o passo a passo para a elaboração de ACVs e ICVs (Figura 15), onde está inserido o contexto de desenvolvimento de um MTP.

\begin{tabular}{|c|c|}
\hline 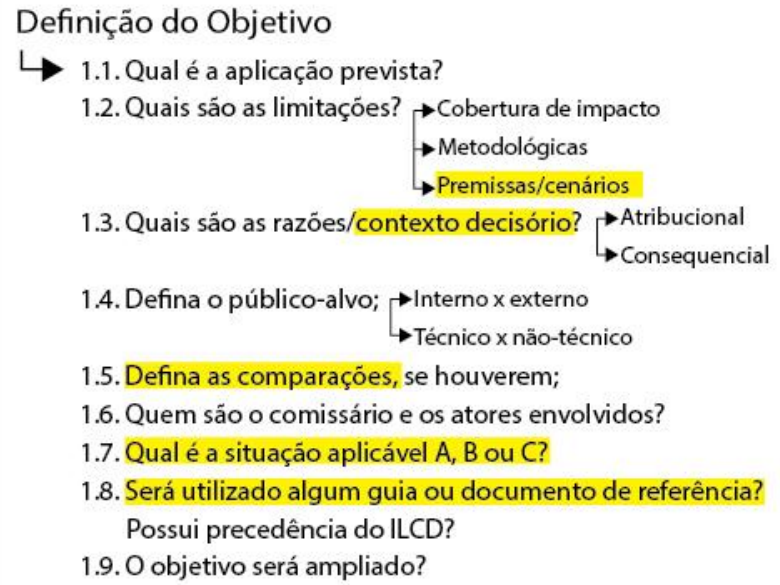 & $\begin{array}{l}\text { Legenda: } \\
\text { Influência direta } \\
\text { na modelagem }\end{array}$ \\
\hline
\end{tabular}

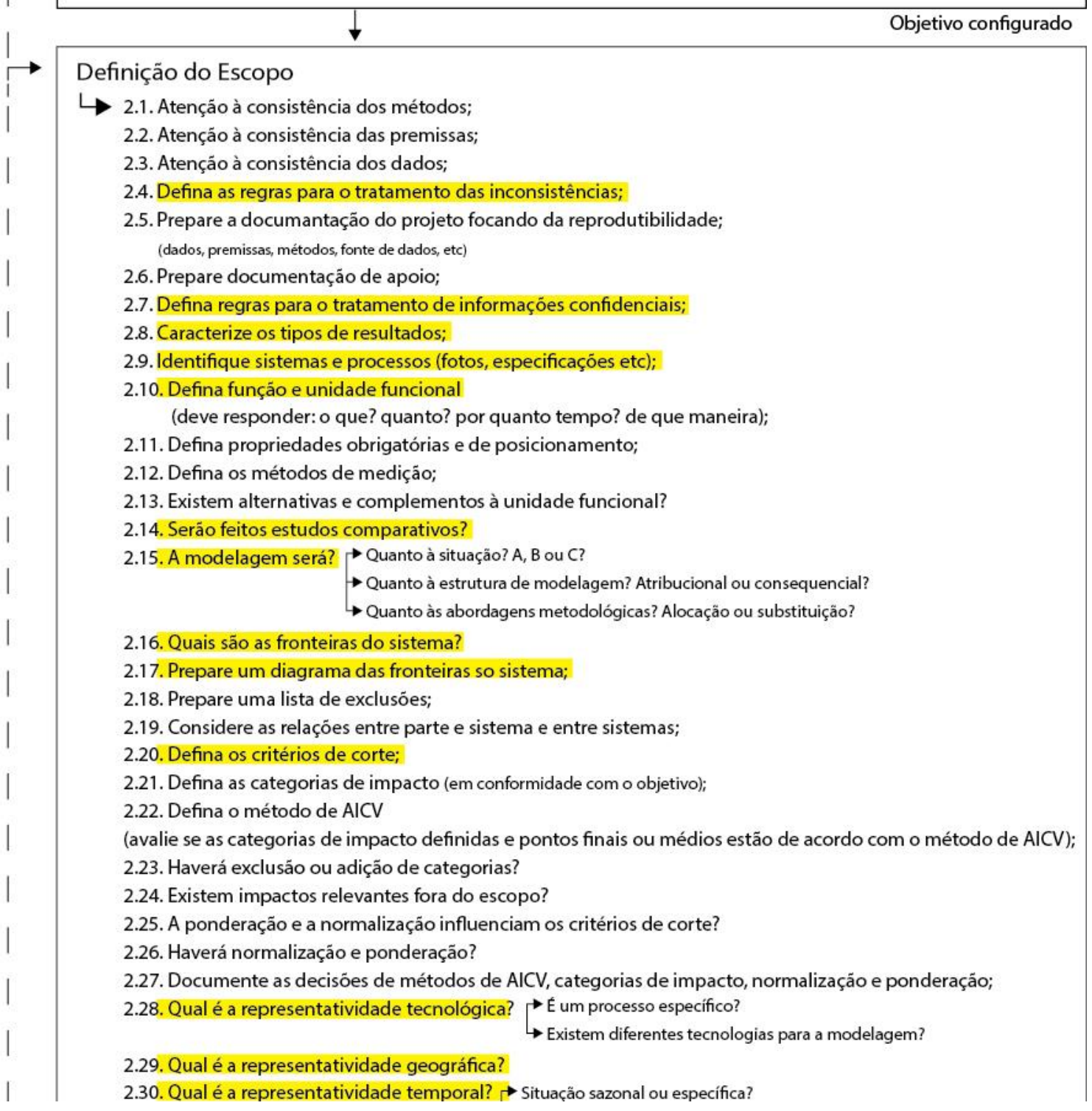




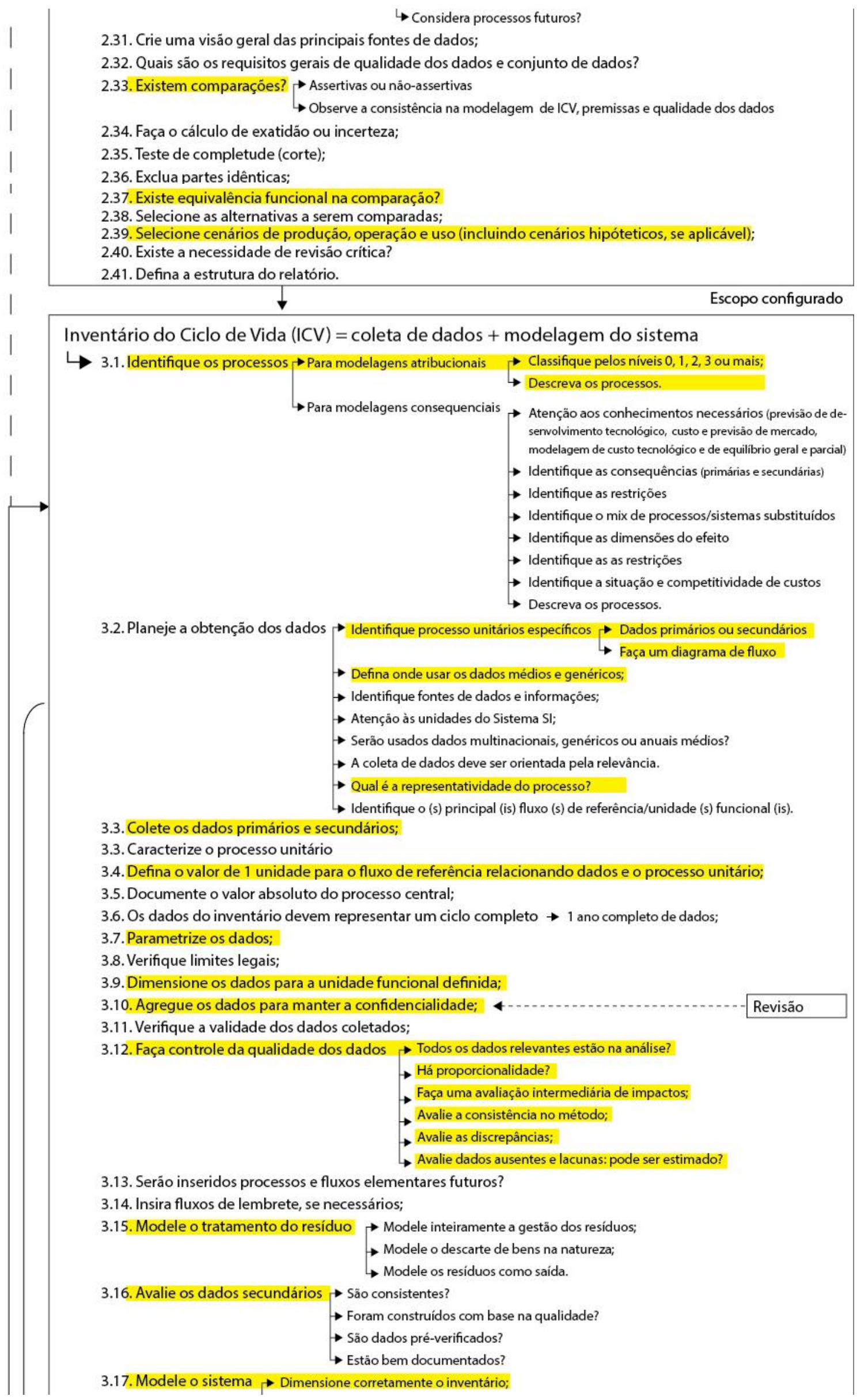




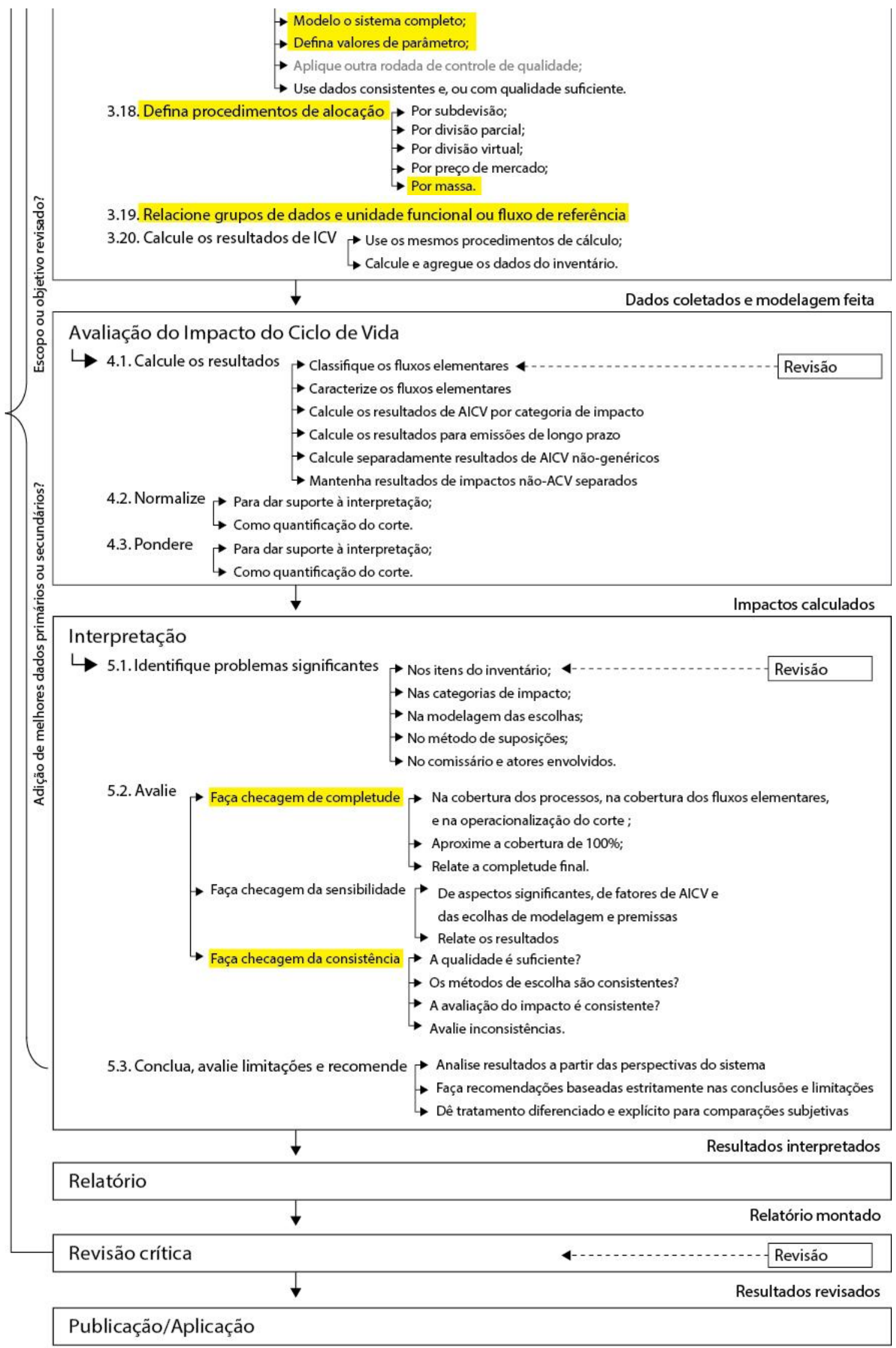

Resultados publicados e, ou aplicados

Figura 15: Fluxograma do passo a passo e recomendações do ILCD para a elaboração de ACVs. 
A Figura 15 mostra todas as etapas e recomendações do ILCD, segundo JRC (2010), na elaboração de uma ACV. Os itens que possuem uma relação direta com a modelagem de ACV foram destacados desse fluxograma.

\subsubsection{Teoria Geral dos Modelos}

Para auxiliar na elaboração da modelagem de ACV, foi feita uma busca por referencial teórico sobre o desenvolvimento de modelos. Por isso, este tópico traz uma breve descrição da teoria geral dos modelos.

Converter coisas concretas em imagens conceituais e expandi-las em modelos teóricos progressivamente complexos e cada vez mais fiéis aos fatos é o único método efetivo para apreender a realidade pelo pensamento. Como não é possível apreender a totalidade das coisas existentes, a ciência utiliza modelos, que representam uma visão simplificada do mundo (BUNGE, 1974; FOUREZ, 1998).

O objeto-concreto é o objeto real que será usado para análise, que pode ser uma coisa ou um fato. O objeto-modelo é a representação reducionista e esquemática (pictórica ou conceitual), pois não contém todas as características do objeto-concreto. E o modelo teórico é um sistema hipotéticodedutivo para a representação conceitual esquemática de um fato ou situação real, ou definido como tal.

O modelo também contém os mecanismos, ou seja, as relações de causa e efeito entre eles e o universo onde estão inseridos. Os modelos podem ser (i) uma representação esquemática de um objeto concreto ou (ii) uma teoria relativa a esta idealização, ou seja, um sistema hipotético dedutivo particular, que não pode ser figurativo a não ser por uma árvore dedutiva.

A construção do modelo precisa ter as seguintes construções: o objetomodelo $(\mathrm{m})$, representando os traços-chave de um objeto concreto $(\mathrm{r})$; o modelo teórico $\left(T_{s}\right)$, especificando o comportamento e, ou o mecanismo interno do objeto concreto, por meio de seu modelo; e a teoria geral $\left(T_{g}\right)$, acolhendo o modelo teórico e que deriva seu valor, bem como sua utilidade de diversos modelos teóricos que se pode construir com seu auxílio (Figura 16). 


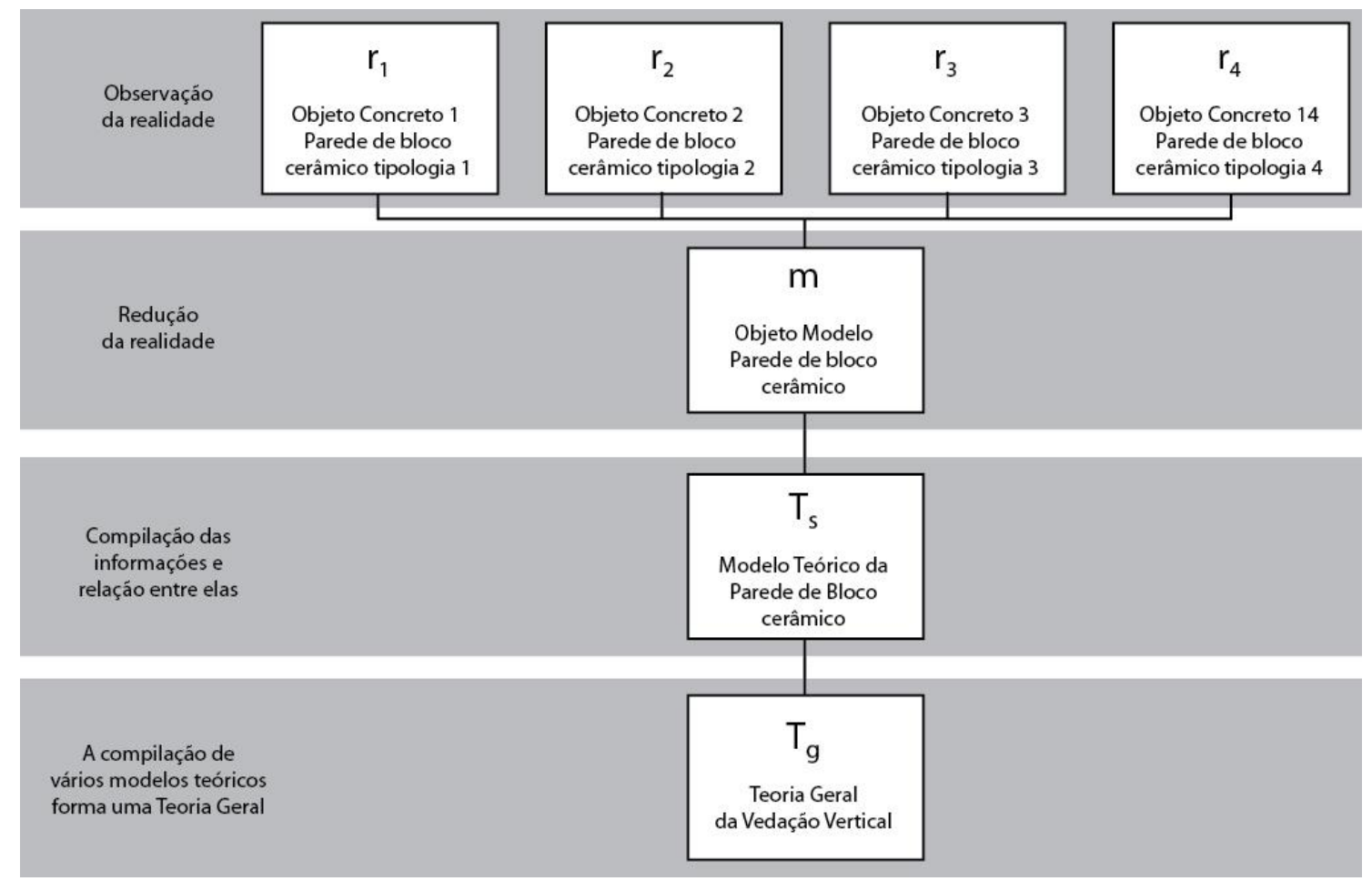

Figura 16: Esquema de elaboração de um modelo.

Para Echenique (1975), a definição de modelo é a representação da realidade feita através da expressão de certas características relevantes e onde a realidade consiste de objetos ou sistemas que existem, existiram ou possam existir. O autor classifica os modelos segundo três aspectos: "para quê", "do que é feito" e "inclusão do tempo". Considerando esses critérios, os modelos podem ser classificados como no Quadro 1.

Quadro 1: Tipologia dos modelos (Serra, 2006).

\begin{tabular}{|c|c|c|c|}
\hline \multirow[t]{5}{*}{ Para quê? } & \multicolumn{2}{|l|}{ Descritivo } & \\
\hline & \multirow[t]{2}{*}{ Preditivo } & Extrapolativo & \\
\hline & & Condicional & \\
\hline & \multirow{2}{*}{\multicolumn{2}{|c|}{ Explorativo }} & \\
\hline & & De planejamento & \\
\hline \multirow[t]{6}{*}{ Do que é feito? } & \multirow[t]{2}{*}{ Físicos } & Icônicos & \\
\hline & & Analógicos & \\
\hline & \multirow[t]{4}{*}{ Conceituais } & Verbais & \\
\hline & & Matemáticos & Analítico \\
\hline & & & Numérico \\
\hline & & & Estocástico \\
\hline \multirow[t]{2}{*}{ Inclui o tempo? } & Estáticos & & \\
\hline & Dinâmicos & & \\
\hline
\end{tabular}


O Modelo Tecnológico Parametrizado (MTP), proposto nesta pesquisa para aplicação de ACVs, pode ser classificado, segundo Echenique (1975), como:

i. Modelo Descritivo: por meio da esquematização, o modelo descreve o ciclo de vida do produto e material analisado;

ii. Modelo Preditivo Condicional: considera cenários futuros com o uso de ACV atribucional e parâmetros que condicionarão as combinações;

iii. Modelo Dinâmico: considera o fator temporal como limitador de sua abrangência;

iv. Modelo Físico Analógico: o modelo é uma representação material do objeto, cuja interpretação depende de um conjunto de regras. E é analógico por se apresentar como um esquema;

v. Modelo Conceitual: é um modelo verbal, pois necessita de um discurso verbal para ser explicado e entendido, e matemático, pois necessitam de parâmetros estabelecidos como fórmulas matemáticas, índices e funções lógicas.

\subsubsection{A modelagem em ACV}

A ACV deve cumprir quatro etapas: definição do objetivo e escopo, análise do inventário do ciclo de vida (ICV), avaliação do impacto do ciclo de vida (AICV) e interpretação (JRC, 2011).

A modelagem na ACV ocorre na fase da análise do ICV, onde os dados foram coletados e devem ser arranjados conforme as características do processo produtivo. A modelagem ainda inclui outros fatores que são definidos nas fases de objetivo e escopo, tais como a situação econômica onde o estudo está inserido, as alternativas, os fluxos de referência, etc.

Dentre todos os materiais pesquisados para o desenvolvimento desta pesquisa, não foi identificado um conceito consolidado sobre o que é o modelo parametrizado. Porém, é possível construir um conceito a partir das referências teóricas utilizadas.

Para Mueller et al (2004), os modelos parametrizados são úteis na medida em que primeiramente eles compactam uma grande quantidade de dados 
de inventário e depois relacionam os parâmetros de projeto com o inventário do ciclo de vida, o que aumenta o valor das informações analisadas.

Segundo Heck et al (2009), os bancos de dados e o inventário de ACV têm demonstrado uma crescente complexidade que, muitas vezes, torna difícil a manipulação das informações. Além disso, estendendo-se essa compreensão para os conjuntos de dados no espaço e no tempo e mantendo o controle sobre a consistência e exatidão das informações. Dessa forma, os bancos de dados e os inventários tornam-se ainda mais difíceis de serem operados e manipulado.

Para Heck et al (2009) uma das principais vantagens do uso dos parâmetros é poder classificá-los no tempo e no espaço e diferir os níveis tecnológicos de produção. Para isso, é necessário identificar os parâmetros chave e combiná-los conforme o processo produtivo.

Sendo assim, um modelo parametrizado pode ser conceituado, portanto, como aquele que recebe parâmetros tanto nos dados inventariados quanto na identificação de características específicas do processo produtivo, tornando o entendimento dos impactos ambientais, econômicos e sociais (a depender do tipo de ACV feita) mensuráveis ainda na fase de projeto do produto.

\subsubsection{O Modelo Tecnológico Parametrizado na ACV}

O MTP é elaborado na etapa de modelagem do ICV após a coleta dos dados, onde as informações das entradas são inseridas e precisam ser combinadas conforme parâmetros definidos (Figura 17).

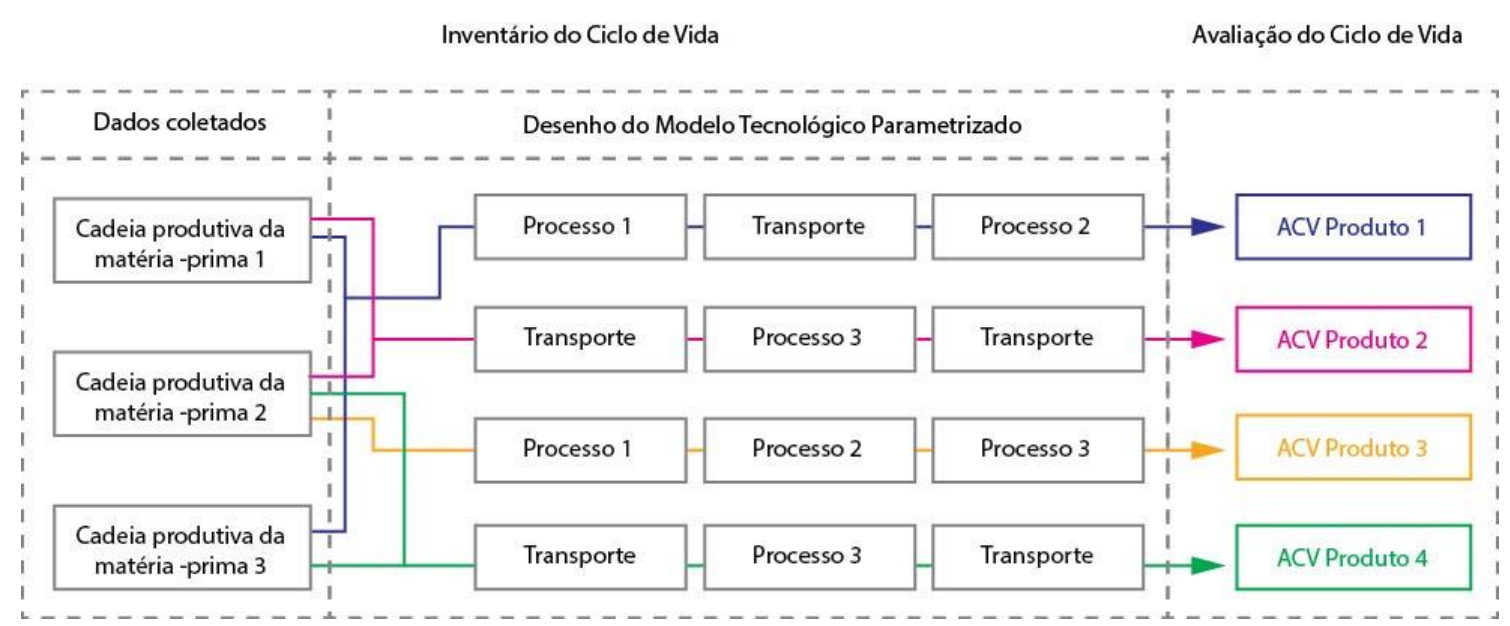

Figura 17: Esquematização do modelo no contexto da ACV. 
A combinação das matérias-primas, processos produtivos, tipo de energia, maquinário e equipamentos, por meio de conexões e parâmetros, permite a elaboração de várias ACVs, considerando a mesma unidade funcional e função, tendo em vista a comparação entre os desempenhos ambientais de vários contextos e, ou opções do produto.

Os modelos geralmente são construídos em softwares de ACV, que permitem a inserção de parâmetros em forma de fórmulas matemáticas, índices de eficiência dos materiais e insumos ou funções lógicas.

Utilizando o modelo é possível gerar resultados, por meio dos parâmetros, que podem ser comparados e analisados sob uma perspectiva comum, visto que as ACVs construídas com modelos possuem origem comum e consideram a mesma unidade funcional. A aplicação do modelo permite identificar as lacunas para a elaboração de ACVs, demonstrando de forma objetiva as necessidades para a aplicação da ACV no contexto das Vedações Verticais.

A fundamentação teórica e a metodologia para o desenvolvimento de MTPs ainda é carente de referencial teórico, o que também é uma contribuição importante desta pesquisa, visto que a metodologia utilizada pode ser futuramente testada em outros sistemas construtivos, subsistemas de edificações ou cadeias produtivas.

A modelagem parametrizada tem sido usada por diferentes autores como uma forma de aplicação de ACV avançada. Mueller publicou sua tese ${ }^{10} \mathrm{e}$ uma série de artigos sobre o desenvolvimento de inventários parametrizados para a ACV (MUELLER et al, 1999; 2004).

Mueller et al (2004) introduz o conceito de inventários parametrizados para a $\mathrm{ACV}$, descreve procedimentos gerais para a determinação da relação entre parâmetros de projeto e interações complexas de modo a encontrar conjuntos de soluções ótimas para os parâmetros de projeto.

Nessa publicação, os autores aplicaram o método de modelagem de ICV ( $\mathrm{LCl}$ modelling), considerando o Ciclo de Vida parametrizado (Life Cycle parameter) no desenvolvimento de motores trifásicos e o dividiram em duas etapas: parametrização do inventário e parâmetros do projeto (Figura 18).

\footnotetext{
${ }^{10}$ Apesar dos esforços para obter a tese de doutorado de Mueller, a pesquisa foi realizada no Imperial College of London e o material não está disponível para consulta.
} 


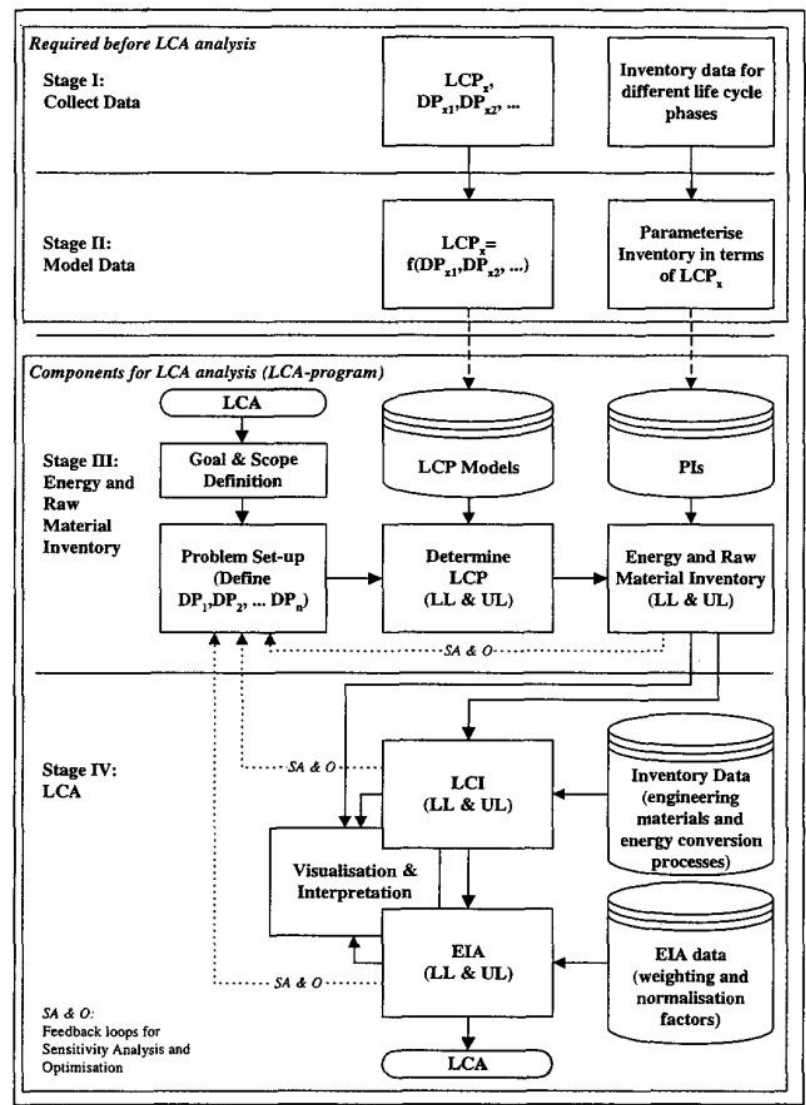

Figura 18: Fluxograma de como a modelagem do Ciclo de Vida Parametrizado e o Inventário Parametrizado são usados na ACV. Fonte: Mueller, 2004.

A primeira etapa é a parametrização do inventário de toda a gama de produtos, por exemplo: a composição relativa dos materiais usados no produto (massa ou volume), entradas e saídas da fabricação (o fator de parametrização é a saída da produção em número de unidades fabricadas); entradas, emissões e resíduos da fase de uso (os fatores de parametrização são a eficiência, emissões por unidade de energia).

A segunda etapa que está relacionada aos parâmetros de projeto, por exemplo a eficiência de motores trifásicos de indução crescem conforme a saída de torque aumenta. Mostrando os piores e melhores cenários para a fabricação do motor, por meio da alteração dos parâmetros de projeto.

O conceito principal do método é usar relações entre informações que o projetista pode combinar e determinar, de forma precoce, as variáveis do ICV que serão determinantes para o produto.

Além disso, todo o potencial do método, como ferramenta de análise, será atingido em um ambiente integrado onde os dados de ACV e custos são au- 
tomaticamente e sistematicamente atribuídos ao longo da cadeia produtiva (MUELLER et al, 1999). Sendo assim, os autores ressaltam a importância não apenas na avaliação ambiental do produto, mas também a avaliação econômica, onde são comparados os ganhos ecológicos e monetários para os diferentes arranjos na elaboração do produto.

Fato bastante relevante observado por Mueller et al (2004) é que dependendo da evolução tecnológica do processo produtivo é necessário alterar parâmetros de projeto, como também parâmetros do inventário. A medida que a cadeia for amadurecendo tecnologicamente, os parâmetros de produção tendem a ser alterados e alguns deles tornam-se praticamente constantes.

Outros autores também já discutiram a importância do ciclo de vida parametrizado. Segundo Keoleian (1994), um inventário parametrizado permite ao projetista buscar/comparar soluções ambientalmente mais sustentáveis na fase de projeto, visto que é possível fazer comparações entre diferentes arranjos/escolhas, o que permite uma maior intervenção para a busca de melhores soluções.

Segundo Blanc (2014), é necessário que se observe a quantidade de parâmetros para que se possa reduzi-los sempre que possível, visto que uma grande quantidade de parâmetros pode tornar o processo ainda mais complexo ao invés de deixa-lo mais inteligível.

Outro exemplo prático da aplicação dos parâmetros na ACV foi feito por Berberich (2013). A autora avaliou diferentes tipos de conectores, quanto à categoria de potencial de mudança climática (GWP), utilizando parâmetros livres e fixos e demonstrou que os parâmetros mais significantes para o impacto desses produtos são a massa de plástico e o total de ouro utilizado no produto, variando em mais de 3 vezes o impacto para conectores com ouro e 30 vezes o impacto de conectores sem ouro.

Os parâmetros podem ser do inventário, em que os dados são parametrizados (como a eficiência do uso de energia ou de água), ou parâmetros do projeto, onde as escolhas feitas influenciam no processo decisório (como o tipo de energia usado, combustíveis, distâncias percorridas, etc) (MUELLER, 2004).

Essa nomenclatura adotada por Mueller (2004) pode ser comparada aos termos utilizados por PE International (2009), que define os parâmetros como 
fixos ou livres, sendo fixos os parâmetros que possuem valores definidos ou que são obtidos por meio de fórmulas matemáticas. E os parâmetros livres aqueles que são definidos por fórmulas condicionais que alteram e influenciam as massas e os volumes de entradas e saídas e, consequentemente, os impactos do processo do produto.

Os parâmetros podem ser globais, do plano ou do processo. Os parâmetros globais são parâmetros aplicados a todo o banco de dados. Os parâmetros do plano são aplicados para modificar um ou mais processos que estão contidos no plano, e, no caso desta pesquisa, são utilizados para definir os contextos de análise. Os parâmetros de processo permitem mudar as características de uma instância de processo e estão conectados aos fluxos, alterando a quantidade de um fluxo (PE INTERNATIONAL, 2009).

\section{Síntese Analítica do Capítulo 1}

A CPIC é um setor da indústria muito importante para o país tanto social quanto economicamente. No entanto, essa cadeia causa impactos ambientais negativos ao Meio Ambiente agravados pela demanda por ambiente construído e pela não incorporação de critérios de sustentabilidade nos processos produtivos das cadeias de suprimentos, principal e auxiliar.

A Ecologia Industrial e a ACV são recursos que podem auxiliar a CPIC a quantificar seus impactos, bem como propor soluções e mudanças capazes de reduzir o alto consumo de energia e recurso natural e as altas taxas de emissão de resíduos da construção e demolição gerados em toda a cadeia produtiva.

O uso da metodologia de ACV pode auxiliar na tomada de decisão e escolhas ambientalmente mais sustentáveis, contribuindo para a construção de edificações menos poluentes e a sustentabilidade da CPIC. A aplicação dessa metodologia requer um banco de dados nacional de inventários do ciclo de vida de produtos e materiais que possa ser combinado para a elaboração de ACVs de acordo com parâmetros, plantas industriais, entradas e saídas.

A ACV é uma tecnologia difundida nos países desenvolvidos e que empregam mais recursos em pesquisa, desenvolvimento e inovação. No Brasil, a 
ACV é uma área pouco explorada, principalmente devido a falta de dados, informações e parâmetros para a sua aplicação.

Muitos materiais carecem de pesquisa quanto ao seu ciclo de vida e a ACV empregada a edificações é pouco disseminada. Com o levantamento das publicações, observa-se que o Brasil está em uma fase inicial da ACV frente aos estudos desenvolvidos no mundo, visto que a maior parte das produções acadêmicas trata de ACV para materiais e componentes e não de edificações.

A ACV de materiais é uma etapa anterior e essencial para a realização de ACV de edificações e infraestrutura, uma vez que irá nutrir de dados as análises e formar os ICVs. Outro ponto importante é a falta de teses de doutorado com o tema ACV de materiais da construção, demonstrando a demanda por estudos mais aprofundados.

O levantamento demonstrou também que algumas produções científicas utilizaram bancos de dados internacionais, mas isso pode trazer falta de precisão nos resultados finais obtidos através desses dados, que são construídos a partir dos processos produtivos e matriz energética de seus países de origem. Sendo assim, há a necessidade de elaboração de um banco de dados brasileiro para o desenvolvimento de ACV auxiliadas por softwares, uma vez que os softwares permitem maior agilidade, confiabilidade e precisão nos cálculos.

Com o levantamento do Estado da Arte, conclui-se que existem iniciativas no desenvolvimento da ACV no Brasil, mas ainda falta muito para ser estudado e estruturado nessa área, sobretudo no setor da Construção, onde os níveis de poluição são altos gerados por toda a cadeia e a demanda pelo espaço construído é crescente e fundamental.

$\mathrm{Na}$ etapa de ICV são necessários o levantamento e a modelagem dos dados, onde deve-se elaborar um modelo a partir na análise e observação das informações. Para isso, fez-se uma pesquisa bibliográfica sobre a teoria dos modelos, a classificação dos modelos e as etapas.

A modelagem é uma importante etapa na ACV e destacam-se as seguintes vantagens da modelagem avançada de ACV, por meio do ciclo de vida parametrizado: (i) avaliação dos impactos potenciais desde a fase de projeto de um produto; (ii) inserção de outras variáveis como a econômica; (iii) simplifica- 
ção do entendimento de uma grande quantidade de dados e informações; e (iv) identificação de fatores que influenciarão de forma mais significativa o impacto ambiental do produto dependendo das escolhas do projeto e que poderão ser moldados conforme um melhor desempenho.

O ILCD (JRC, 2010) detalha a metodologia de ACV e muitas etapas e critérios obrigatórios, recomendados e importantes influenciam diretamente na modelagem de ACV e devem, cuidadosamente, serem desenhados para que 0 objetivo do estudo esteja integralmente relacionado com os resultados obtidos. 


\section{Capítulo 2: Sistema Vedação Vertical Interna e Externa}

Este capítulo conceitua a edificação como um sistema constituído por subsistemas, elementos e componentes, enfatizando o Subsistema Vedação Vertical Externa e Interna (SVVIE) que é o foco da pesquisa, além da justificativa pelos recortes feitos.

São apresentados os critérios de desempenho do Brasil e do Reino Unido, por meio da norma ABNT NBR 15.575 e normas complementares e das regulações de construções, que serão utilizados no Capítulo 3 para a definição da função e da unidade funcional considerando os requisitos dos Desempenhos Térmico e Acústico.

Além disso, este capítulo apresenta as cadeias produtivas dos componentes das vedações construídas com os blocos cerâmicos, argamassa de assentamento, chapisco e argamassa de emboço desde a extração da matériaprima até a construção da vedação, passando pela fabricação e transporte.

Os componentes das tipologias de vedação foram resumidos aos blocos, argamassa de assentamento, chapisco e argamassa de emboço, tendo em vista que a simplificação dos componentes foi necessária para a elaboração do Modelo Tecnológico Parametrizado de Vedações desta pesquisa.

\subsection{Definição do sistema da edificação a ser estudado}

Nesta pesquisa a edificação é abordada como um sistema composto de subsistema ou sistemas, elementos, componentes e materiais, conforme abordagens de autores na área da construção (ABNT, 2013a; ABNT, 2013b; BARROS et al, 2007; SABBATINI et al, 2005). Desta forma, nesta parte da pesquisa é feita uma breve introdução sobre o conceito de sistemas e a inserção da Vedação Vertical como um sistema da edificação, bem como a sua importância e a justificativa pela definição do objeto de estudo.

\subsubsection{A Edificação como um sistema}

A ABNT (2013a) afirma que um sistema é a maior parte funcional do edifício. Um sistema é o conjunto de componente e elementos que devem 
atender a uma macrofunção que a define, por exemplo: fundações, vedações verticais, instalações hidrossanitárias, coberturas, entre outros.

Ainda segundo a ABNT (2013a) um elemento é a parte de um sistema com funções específicas, geralmente, composto por componentes, por exemplo: vedação vertical, estrutura de cobertura etc. Por fim, o componente é a unidade integrante de um elemento da edificação e deve atender a funções específicas, por exemplo: bloco de alvenaria, telhas etc. Essa hierarquia está esquematizada com alguns exemplos na Figura 19.

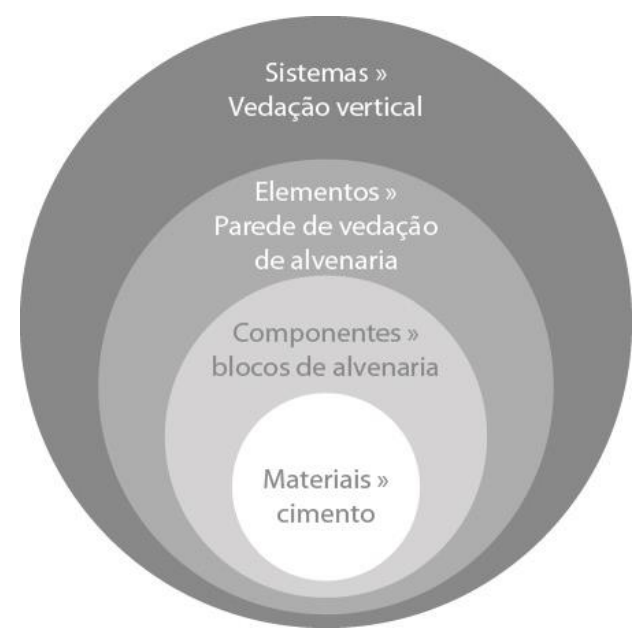

Figura 19: Sistema edificação e sua divisão (Sabbatini et al, 2005).

Também para Sabbatini et al (2005) a edificação é um sistema dividido em subsistemas, elementos, componentes e materiais construtivos. Para Barros et al (2007) os sistemas de uma edificação são fundações, estrutura, vedações verticais, esquadrias, instalações, revestimentos das vedações verticais, vedações horizontais, revestimentos das vedações horizontais, cobertura, impermeabilização e outros. Apesar das esquadrias e revestimentos serem partes inerentes às vedações verticais, essas partes são tratadas como subsistemas diferentes sob o ponto de vista construtivo, devido a sequência de execução no contexto geral da obra.

2.1.2. Definição, classificação e função do SVVIE

A ABNT (2013b) define o SVVIE como:

“(...) partes da edificação habitacional que limitam verticalmente a edificação e seus ambientes, como as fachadas e as paredes ou divisórias internas" (ABNT, 2013b, p. 7). 
Considerando essa definição, as vedações verticais criam as condições de habitabilidade para o edifício, protegendo os ambientes internos contra a ação indesejável de agentes externos e são suporte e proteção para os sistemas prediais (CARDOSO et al, 2007).

A construção possui uma grande variedade de vedações, variando conforme os materiais, os métodos construtivos, o nível de industrialização, as funções etc. Essas vedações podem ser classificadas de diferentes formas, como demonstrado no Quadro 2.

Quadro 2: Classificação das vedações verticais (BARROS et al, 2007).

\begin{tabular}{|c|c|c|c|c|}
\hline \multicolumn{5}{|c|}{ Classificação das Vedações Verticais } \\
\hline Função & Envoltória externa & $\begin{array}{l}\text { Compartimentação } \\
\text { interna }\end{array}$ & $\begin{array}{l}\text { Separação entre unida- } \\
\text { des e área comum }\end{array}$ & - \\
\hline $\begin{array}{l}\text { Técnica de } \\
\text { execução }\end{array}$ & $\begin{array}{c}\text { Por conformação: cons- } \\
\text { truídas no local com uso } \\
\text { de água (wet construc- } \\
\text { tion); }\end{array}$ & $\begin{array}{l}\text { Acoplamento a seco: } \\
\text { moldadas a seco sem } \\
\text { o uso de água (dry } \\
\text { construction) }\end{array}$ & $\begin{array}{l}\text { Acoplamento úmido: } \\
\text { produzida com elemen- } \\
\text { tos pré-moldados ou } \\
\text { pré-fabricados de con- } \\
\text { creto. }\end{array}$ & - \\
\hline Mobilidade & $\begin{array}{l}\text { Fixas: imutáveis e, em } \\
\text { caso de transformação, } \\
\text { os elementos constituin- } \\
\text { tes dificilmente são re- } \\
\text { cuperáveis; }\end{array}$ & $\begin{array}{l}\text { Desmontáveis: passí- } \\
\text { veis de serem des- } \\
\text { montadas com pouca } \\
\text { degradação dos com- } \\
\text { ponentes; }\end{array}$ & $\begin{array}{l}\text { Removíveis: constituída } \\
\text { de elementos modulares } \\
\text { que permitem monta- } \\
\text { gem e desmontagem } \\
\text { sem degradação. }\end{array}$ & $\begin{array}{l}\text { Móveis: divisórias } \\
\text { usadas para a } \\
\text { simples comparti- } \\
\text { mentação de am- } \\
\text { bientes. }\end{array}$ \\
\hline $\begin{array}{l}\text { Densidade } \\
\text { superficial }\end{array}$ & $\begin{array}{l}\text { Leves: baixa densidade } \\
\text { superficial com o limite } \\
\text { convencional de } 100 \\
\mathrm{~kg} / \mathrm{m}^{2} \text {. Não são estrutu- } \\
\text { rais }\end{array}$ & $\begin{array}{l}\text { Pesadas: densidade } \\
\text { superficial superior ao } \\
\text { limite convencional de } \\
100 \mathrm{~kg} / \mathrm{m}^{2} . \text { Podem ser } \\
\text { estruturais ou não. }\end{array}$ & - & - \\
\hline $\begin{array}{l}\text { Estrutu- } \\
\text { ração }\end{array}$ & $\begin{array}{l}\text { Estruturadas: vedações } \\
\text { que necessitam de uma } \\
\text { estrutura reticular de } \\
\text { suporte para os compo- } \\
\text { nentes. }\end{array}$ & $\begin{array}{l}\text { Auto-portante: veda- } \\
\text { ções que não necessi- } \\
\text { tam de uma estrutura } \\
\text { de suporte }\end{array}$ & $\begin{array}{l}\text { Pneumáticas: vedações } \\
\text { sustentadas por injeção } \\
\text { de ar comprimido. }\end{array}$ & - \\
\hline $\begin{array}{l}\text { Continuidade } \\
\text { do pano }\end{array}$ & $\begin{array}{l}\text { Monolíticas: a absorção } \\
\text { dos esforços é feita pelo } \\
\text { conjunto dos elementos }\end{array}$ & $\begin{array}{c}\text { Modulares: a absor- } \\
\text { ção dos esforços é } \\
\text { feita pelos componen- } \\
\text { tes individualmente } \\
\text { devido aos elementos } \\
\text { de junta }\end{array}$ & - & - \\
\hline Acabamento & $\begin{array}{l}\text { Revestimento incorpo- } \\
\text { rado }\end{array}$ & $\begin{array}{l}\text { Revestimento a poste- } \\
\text { riori }\end{array}$ & Sem revestimento. & - \\
\hline $\begin{array}{l}\text { Continuidade } \\
\text { superficial }\end{array}$ & $\begin{array}{l}\text { Descontínuas: as juntas } \\
\text { ficam aparentes; }\end{array}$ & $\begin{array}{l}\text { Contínuas: as juntas } \\
\text { não são aparentes. }\end{array}$ & - & - \\
\hline
\end{tabular}

Há, portanto, uma complexa gama de possibilidades de vedações verticais que, em alguns aspectos, se sobrepõem o que dificulta a apreensão dessa totalidade. Apesar de já existirem classificações para as vedações, essas classificações não permitiram a visualização da capilaridade dos tipos de vedações e o apoio a caracterização funcional de forma precisa. Considerando o contexto, elaborou-se uma classificação que possibilita essa visualização e mostra alguns exemplos de cada classificação (Figura 20). 


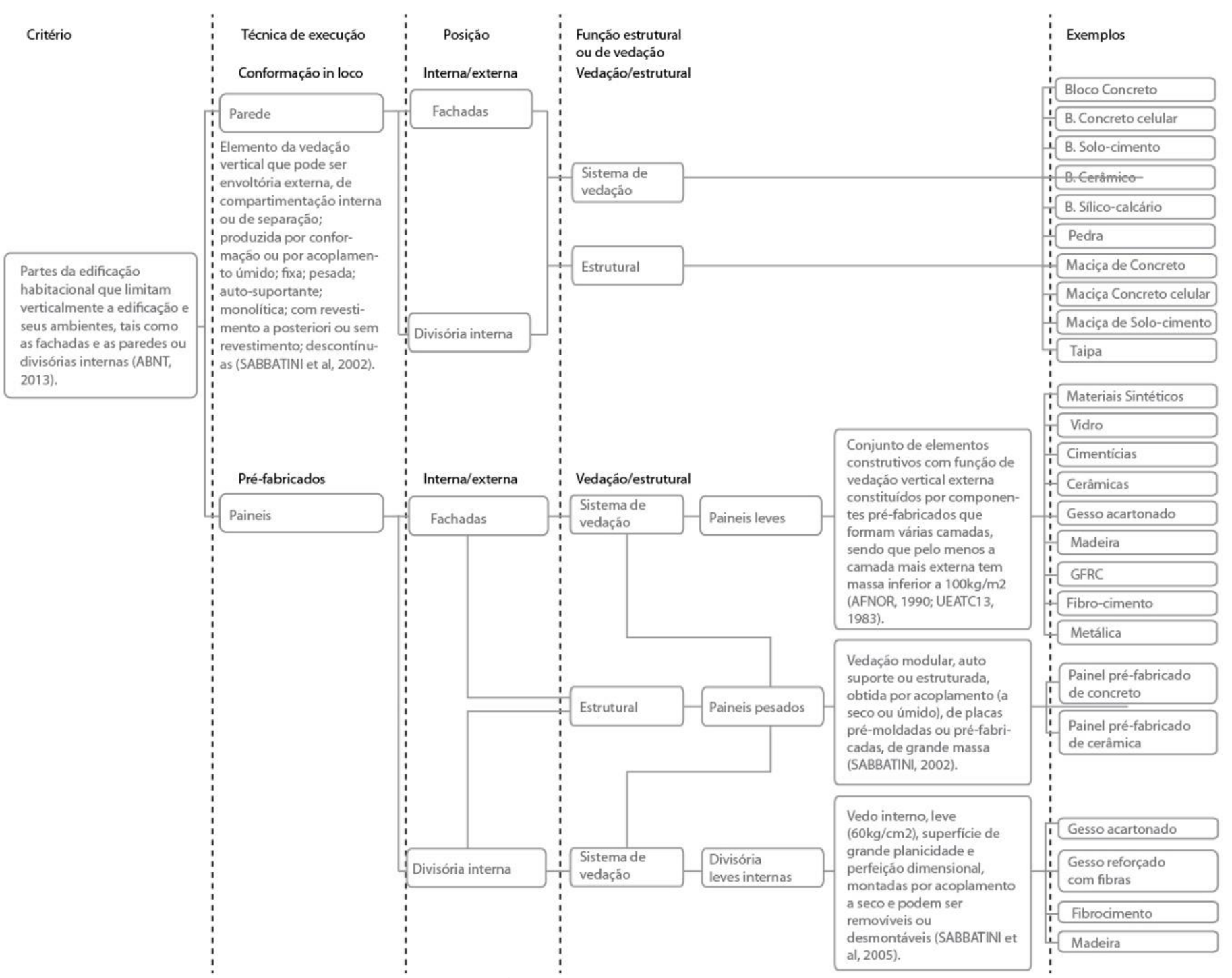

Figura 20: Proposta de classificação do SVVIE de acordo com o componente principal. Fonte: do autor. 
A classificação elaborada permite visualizar a capilaridade dos tipos de vedações verticais mais utilizadas no contexto brasileiro. No entanto, esta classificação não pretende esgotar as possibilidades de tipos de vedação vertical existentes, mas apenas proporcionar uma visão ampla sobre os tipos e os componentes principais mais utilizados para esse sistema.

\subsection{Requisitos de desempenho da ABNT NBR 15.575}

A ABNT NBR 15.575 define as propriedades necessárias dos elementos da construção, independentemente do material constituinte. Essa abordagem é fundamental para a ACV, pois o foco passa a ser a função. Os requisitos relacionados ao SVVIE são Desempenho Estrutural, Segurança contra incêndio, Desempenho Térmico, Desempenho Acústico, Estanqueidade, Durabilidade e manutenibilidade e Uso e operação (ABNTa, 2013).

\subsubsection{Desempenho Estrutural}

As vedações verticais com ou sem funções estruturais devem atender às exigências da ABNT NBR 15.575 (ABNTa, 2013) em relação à estabilidade e segurança das construções, com os requisitos de deslocamento e limites de falha. Além de exigências em relação ao uso e ocupação do imóvel, por meio das resistências aos impactos de corpo mole e corpo duro (CBIC, 2013).

\section{i. Deslocamentos e ocorrência de falhas}

Considerando as combinações passíveis, como cargas gravitacionais, ação do vento e temperatura, o SVVIE deve atender aos limites de deslocamento instantâneo $\left(\mathrm{d}_{\mathrm{h}}\right)$ e residuais $\left(\mathrm{d}_{\mathrm{hr}}\right)$, sem apresentar falhas que caracterizem o estado-limite de serviço (Figura 21).

ii. Impactos de corpo mole

Esses impactos procuram representar ações decorrentes do uso da edificação, vandalismo etc, que não podem ser transpassados, sofrer ruptura ou instabilidade, apresentar fissuras, escamações, delaminações ou outras faIhas que comprometam o estado de utilização (ABNT, 2013b). Esses requisitos estão divididos em vedações externas e internas conforme Figura 22 e Figura 23). 


\begin{tabular}{|c|c|c|c|}
\hline & $\begin{array}{c}\text { Cargas verticais: } \\
\mathrm{S}_{\mathrm{d}}=\mathrm{S}_{\mathrm{gk}}+0,7 \mathrm{~S}_{\mathrm{qk}}+\mathrm{S}_{\mathrm{wk}} \\
\text { (desconsiderar Swk no caso } \\
\text { de alívio de compressão) }\end{array}$ & $\begin{array}{l}\text { Não ocorrência de falhas; } \\
\mathrm{d}_{\mathrm{h}} \leq \mathrm{h} / 500 \\
\mathrm{~d}_{\mathrm{hr}} \leq \mathrm{h} / 2500\end{array}$ & (i)() (4) \\
\hline \multirow[t]{3}{*}{$\begin{array}{l}\text { Desempenho estrutural } \\
\text { Deslocamento e } \\
\text { ocorrência de falhas }\end{array}$} & $\begin{array}{l}\text { Cargas permanentes } \\
\text { e deformações impostas } \\
\qquad \mathrm{S}_{\mathrm{d}}=\mathrm{S}_{\mathrm{gk}}+\mathrm{S}_{\mathrm{ek}}\end{array}$ & s: $>\quad \begin{array}{l}\text { Não ocorrência de falhas } \\
\text { tanto nas paredes quanto } \\
\text { nas interfaces da parede } \\
\text { com outros componentes }\end{array}$ & (i)(e)(a) $f \mathrm{~s}$ \\
\hline & $\begin{array}{l}\text { Cargas horizontais: } \\
\mathrm{S}_{\mathrm{d}}(\mathrm{a})=0,9 \mathrm{~S}_{\mathrm{gk}}+0,8 \mathrm{~S}_{\mathrm{wk}}\end{array}$ & $\begin{array}{l}\text { Não ocorrência de falhas; } \\
d_{h} \leq h / 500 \\
d_{h r} \leq h / 2500 \\
d_{h} \leq h / 350 \\
d_{h r} \leq h / 1750\end{array}$ & $\begin{array}{ll}\text { (e) } \\
\text { (e) } \\
\text { (e) } \mathrm{f}\end{array}$ \\
\hline & $\begin{array}{c}\text { Paredes } \\
\text { (componentes visíveis) }\end{array}$ & $>\quad \mathrm{L} / 250$ ou $\mathrm{H} / 300$ & (i)(e) \\
\hline \multirow[t]{3}{*}{$\begin{array}{l}\text { Desempenho estrutural } \\
\text { Deslocamentos- } \\
\text { limites }\end{array}$} & $\begin{array}{c}\text { Paredes e } \\
\text { acabamentos rígidos }\end{array}$ & $\mathrm{L} / 500$ ou $\mathrm{H} / 500$ & (i)(e) \\
\hline & $\begin{array}{c}\text { Paredes e } \\
\text { acabamentos flexíveis }\end{array}$ & $>\quad \mathrm{L} / 400$ ou $\mathrm{H} / 400$ & (i)(e) \\
\hline & $\begin{array}{l}\text { Legenda } \\
\text { Residencial A1, A2 e A3 } \\
\text { ff Vedaçáo de fechamento } \\
\text { s Vedaçáo estrutural } \\
\text { (i) Vedaçáo interna } \\
\text { (e) Vedaçáo externa } \\
\text { (4) Entre unidades } \\
\text { e áreas comuns }\end{array}$ & \multicolumn{2}{|c|}{$\begin{array}{l}\mathrm{d}_{\mathrm{h}} \text { Deslocamento horizontal instantâneo } \\
\mathrm{d}_{\mathrm{hr}} \text { deslocamento residual horizontal } \\
\mathrm{S}_{\mathrm{gk}} \text { Solicitaçáo característica devida às cargas permanentes } \\
\mathrm{S}_{\mathrm{ek}} \text { Valor caracteristico da solicitaçào devido à deformaçăo } \\
\text { especíica do material } \\
\mathrm{S}_{\mathrm{qk}} \text { Valor característico da solicitaçáa devido às cargas } \\
\text { acidentaias ou sobrecarga de uso } \\
\mathrm{S}_{\mathrm{wk}} \text { Valor caracteristico da solicitaçăo devido ao vento } \\
\mathrm{H} \text { Altura do elemento estrutural } \\
\mathrm{L} \text { Văo teórico do elemento estrutural }\end{array}$} \\
\hline
\end{tabular}

Figura 21: Deslocamentos limites e ocorrência de falhas. Fonte: do autor, baseado em ABNT (2013b)

\begin{tabular}{|l|}
\hline Desempenho estrutural \\
Impacto de \\
corpo mole
\end{tabular}

\begin{tabular}{|c|c|c|c|c|}
\hline $\begin{array}{l}\text { Impacto externo } \\
\text { para edifícios } \\
\text { multipisos }\end{array}$ & $\begin{array}{l}960 J \\
480 J \\
360 J \\
240 J \\
\\
180 J \\
120 J\end{array}$ & $\begin{array}{l}\text { Náo ocorrência de ruína } \\
\text { Náo ocorrenncia de falhas } \\
\text { (estado limite de serviço) } \\
\text { Náo ocorrenecia de falhas } \\
\text { (estado limite de serviço) } \\
\text { Limitaçáo dos deslocamentos } \\
\text { horizontais: } \mathrm{dh} \leq \mathrm{h} / 250 \text { e dhr } \leq \mathrm{h} / 1250 \\
\text { Náo ocorrencia de falhas } \\
\text { (estado limite de serviço) }\end{array}$ & (e) & 5 \\
\hline $\begin{array}{l}\text { Impacto face } \\
\text { interna para } \\
\text { edifícios } \\
\text { multipisos }\end{array}$ & $\begin{array}{l}480 J \\
240 J \\
180 J \\
120 J\end{array}$ & $\begin{array}{l}\text { Náo ocorrência de ruína nem o } \\
\text { ultrapasse da parede pelo corpo } \\
\text { percurssos de impacto } \\
\text { (estado-limite útimo) } \\
\text { Náo ocorrência de falhas } \\
\text { (estado limite de serviço) } \\
\text { Náo ocorrência de falhas } \\
\text { (estado limite de serviço) } \\
\text { Limitaçáo dos deslocamentos } \\
\text { horizontais: } \mathrm{d} \leq \mathrm{h} / 250 \mathrm{edhr} \leq \mathrm{h} / 1250 \\
\end{array}$ & (e) & $\mathrm{s}$ \\
\hline $\begin{array}{l}\text { Impacto externo } \\
\text { para casas } \\
\text { térreas }\end{array}$ & $\begin{array}{l}960 J \\
720 J \\
480 J \\
360 J \\
240 J\end{array}$ & $\begin{array}{l}\text { Suportar (Nivis I l e S) } \\
\text { Suportar (Nivel M) } \\
\text { Náo ocorrência de falhas } \\
\text { Náo ocorrência de falhas } \\
\text { (estado limite de serviço) } \\
\text { Limitaçăo dos deslocamentos } \\
\text { horizontais: } \mathrm{d} \text {. } \leq \mathrm{h} / 250 \text { e } \mathrm{dhr} \leq \mathrm{h} / 1250\end{array}$ & (e) & $s$ \\
\hline $\begin{array}{c}\text { Impacto face interna } \\
\text { para casas térreas }\end{array}$ & $\begin{array}{l}480 \mathrm{~J} \\
180 \mathrm{~J} \\
\end{array}$ & $\begin{array}{l}\text { Náo ocorrência de ruína } \\
\text { Năo ocorrência de falhas }\end{array}$ & (e) & $\mathrm{s}$ \\
\hline $\begin{array}{l}\text { Impacto externo } \\
\text { para edifícios } \\
\text { multipisos }\end{array}$ & $\begin{array}{l}480 \mathrm{~J} \\
360 \mathrm{~J} \\
240 \mathrm{~J} \\
\\
180 \mathrm{~J} \\
120 \mathrm{~J}\end{array}$ & $\begin{array}{l}\text { Não ocorrência de ruína } \\
\text { (estado-limite último) } \\
\text { Não ocorerencia de falhas } \\
\text { (estado limite de serviço) } \\
\text { Não ocorrência de falhas } \\
\text { (estado limite de serviço) } \\
\text { Limitação dos deslocamentos } \\
\text { horizontais: } \mathrm{d}_{\mathrm{h}} \leq \mathrm{h} / 125 \mathrm{e} \mathrm{d}_{\mathrm{hr}} \leq \mathrm{h} / 625 \\
\text { Não ocorrência de falhas } \\
\text { (estado limite de serviço) }\end{array}$ & (e) & $f$ \\
\hline
\end{tabular}

Figura 22: Requisitos de impacto de corpo mole face externa. Fonte: do autor, baseado em ABNT (2013). 


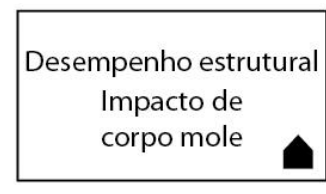

\begin{tabular}{|c|c|c|c|c|}
\hline $\begin{array}{l}\text { Impacto face } \\
\text { interna para } \\
\text { edifícios } \\
\text { multipisos }\end{array}$ & $\begin{array}{l}360 \mathrm{~J} \\
180 \mathrm{~J} \\
120 \mathrm{~J}\end{array}$ & $\begin{array}{l}\text { Náo ocorrência de ruptura nem } \\
\text { o trapasse da parede pelo } \\
\text { corpo percurssor de impato } \\
\text { (estado-limite último) } \\
\text { Náo ocorrência de falhas } \\
\text { (estado limite de serviço) } \\
\text { Limitaçăo dos deslocamentos } \\
\text { horizontais: } \mathrm{d}_{\mathrm{h}} \leq \mathrm{h} / 125 \text { e } \mathrm{d}_{\mathrm{hr}} \leq \mathrm{h} / 625\end{array}$ & (e) & \begin{tabular}{|l|}
$f$ \\
\end{tabular} \\
\hline $\begin{array}{c}\text { Impacto externo } \\
\text { para casas } \\
\text { térreas }\end{array}$ & $\begin{array}{l}960 J \\
720 J \\
360 J \\
240 J \\
240 J\end{array}$ & $\begin{array}{l}\text { Suportar (Níveis l e S) } \\
\text { Suportar (Nivel M) } \\
\text { Náo ocorrência de falhas } \\
\text { Náo ocorrência de falhas } \\
\text { (estado limite de serviço) } \\
\text { Limitaçáo dos deslocamentos } \\
\text { horizontais: } \mathrm{d}_{\mathrm{h}} \leq \mathrm{h} / 125 \text { e } \mathrm{d}_{\mathrm{hr}} \leq \mathrm{h} / 625 \\
\end{array}$ & (e) & \begin{tabular}{|l|}
$f$ \\
\end{tabular} \\
\hline $\begin{array}{l}\text { Impacto face interna } \\
\text { para casas térreas }\end{array}$ & $\begin{array}{l}360 J \\
120 J\end{array}$ & $\begin{array}{l}\text { Náo ocorrência de ruína } \\
\text { Náo ocorrência de falhas }\end{array}$ & (e) & $f$ \\
\hline $\begin{array}{c}\text { Casas térreas, } \\
\text { sobrados e } \\
\text { edifícios multipisos }\end{array}$ & $\begin{array}{l}360 J \\
240 J \\
180 J \\
\\
120 J\end{array}$ & $\begin{array}{l}\text { Náo ocorrência de ruína } \\
\text { (estado-limite último) } \\
\text { Permitidas falhas localizadas } \\
\text { Năo cocorrência de falhas } \\
\text { (estado-limite de serviço) } \\
\text { Náo ocorrência de falhas } \\
\text { (estado limite de serviço) } \\
\text { Limitaçáo dos deslocamentos } \\
\text { horizontais: } \mathrm{d}_{\mathrm{h}} \leq \mathrm{h} / 250 \text { e } \mathrm{d}_{\mathrm{hr}} \leq \mathrm{h} / 1250\end{array}$ & (i) & \begin{tabular}{|l|} 
\\
\end{tabular} \\
\hline $\begin{array}{c}\text { Casas térreas, } \\
\text { sobrados e } \\
\text { edifícios multipisos }\end{array}$ & $120 \mathrm{~J}$ & $\begin{array}{l}\text { Náo ocorrência de ruína } \\
\text { (estado-limite último) } \\
\text { Permitidas falhas localizadas } \\
\text { Náo ocorrência de falhas } \\
\text { (estado limite de serviço) } \\
\text { Limitaçáo dos deslocamentos } \\
\text { horizontais: } \mathrm{d}_{\mathrm{h}} \leq \mathrm{h} / 125 \text { e dhr } \leq \mathrm{h} / 625\end{array}$ & (i) & $f$ \\
\hline
\end{tabular}
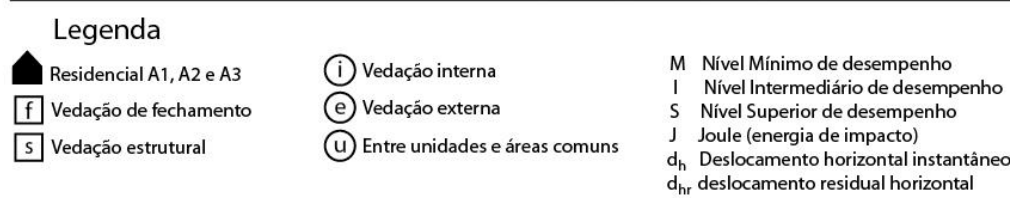

Figura 23: Requisitos de impacto de corpo mole face interna. Fonte: do autor, baseado em ABNT (2013).

iii.Impactos de corpo duro

Esses impactos também procuram representar acidentes de utilização da edificação, vandalismo etc. Os testes feitos com esfera de aço de $5 \mathrm{~cm}$ (impactos de utilização) e 6,5 cm (impactos de segurança) não podem transpassar os elementos e provocar ruptura ou instabilidade. Os elementos impactados não podem sofrer fissuras, escamações, delaminações ou outras falhas que comprometam o estado de utilização. Os critérios e níveis de desempenho para impactos de corpo duro estão descritos na Figura 24.

\subsubsection{Segurança contra incêndio}

A ABNT NBR 15.575 define critérios que dificultam o início do incêndio e a propagação do fogo e o Tempo Requerido de Resistência ao Fogo (TRRF), o que permite possibilidade de fuga. Além da ABNT NBR 15.575, as necessidades de segurança contra incêndio devem ser atendidas pelas exigências previstas na ABNT NBR 14.432 (ABNT, 2000) (Figura 25). 


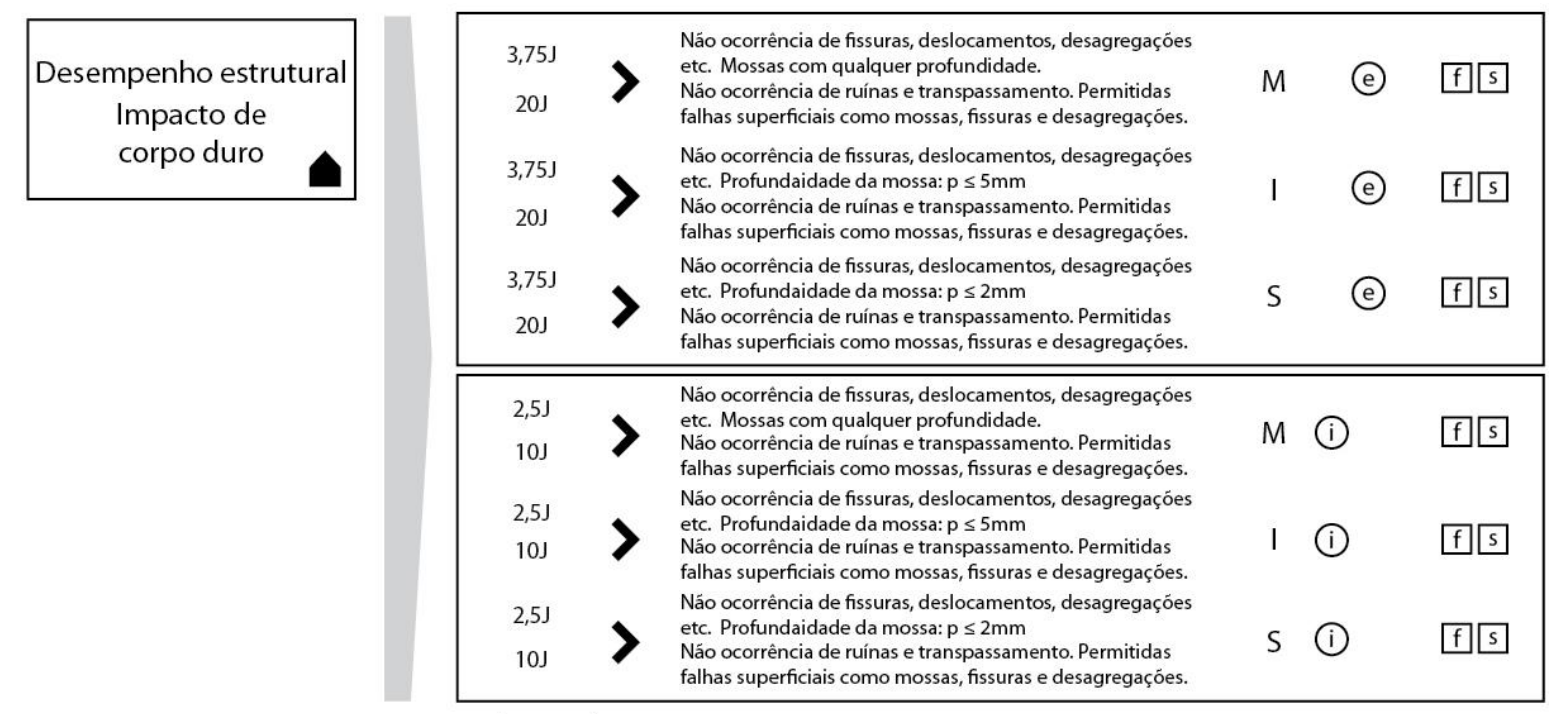

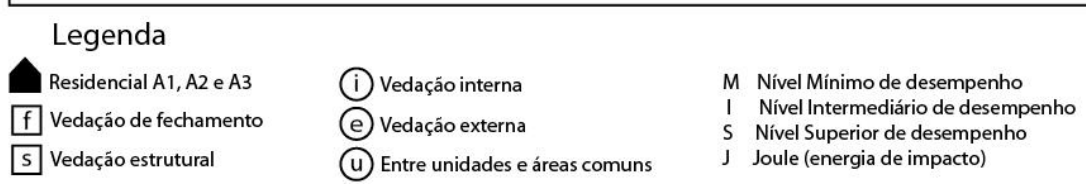

Figura 24: Requisitos para impactos de corpo duro nas faces internas e externas das vedações verticais.

Fonte: do autor, baseado em ABNT (2013).

\begin{tabular}{|c|c|c|c|c|c|}
\hline \multirow{3}{*}{$\begin{array}{l}\text { Resistência } \\
\text { ao fogo }\end{array}$} & \multicolumn{2}{|l|}{ NBR 14.432} & \multicolumn{3}{|c|}{ NBR 15.575} \\
\hline & $h_{s}>10 m>90 m i n$ & (i)(e(4) $f \mathrm{~s}$ & 5 pavimentos & $>30 \mathrm{~min}$ (i) & (4) 5 \\
\hline & $>60(30) \mathrm{min}$ & (i)(e) f요 & $\begin{array}{l}\text { casas térreas } \\
\text { e sobrados }\end{array}$ & $30 \mathrm{~min}$ & (4) $f$ s \\
\hline & $>30 \mathrm{~min}$ & (i)(e(4) $f \mathrm{~s}$ & \multirow{2}{*}{$\begin{array}{l}\text { unifamiliar isolada } \\
\text { até } 2 \text { pavimentos } \\
\text { (áreas de cozinha e } \\
\text { ambientes fechados com } \\
\text { equipamentos de gás) }\end{array}$} & \multirow{2}{*}{$30 \mathrm{~min}$ (i)e } & \multirow{2}{*}{ fs } \\
\hline & $6 \mathrm{~m}<\mathrm{h} \leq 12 \mathrm{~m}>30 \mathrm{~min}$ & (i)(e) fs & & & \\
\hline & $12 \mathrm{~m}<\mathrm{h} \leq 23 \mathrm{~m}\rangle \quad 60 \mathrm{~min}$ & (i)(e) fls & \multirow{3}{*}{$\begin{array}{l}\text { Legenda } \\
\text { Residencial A1, A2 e A3 } \\
\text { } 9 \text { Vedaçăo de fechamento } \\
5 \text { Vedaçăo estrutural }\end{array}$} & \multirow{3}{*}{$\begin{array}{l}\text { (i) Vedaçáo interna } \\
\text { (e) Vedaçáo externa } \\
\text { (U) Entre unidades n } \\
\text { eáreas comuns }\end{array}$} & \multirow{3}{*}{$\begin{array}{l}\text { hs Altura subsol } \\
\text { h Altura } \\
\text { min Minutos }\end{array}$} \\
\hline & $23 \mathrm{~m}<\mathrm{h} \leq 30 \mathrm{~m}\rangle 90 \mathrm{~min}$ & (i)(e) f(1) & & & \\
\hline & $>120 \mathrm{~min}$ & (i)(e) fs & & & \\
\hline
\end{tabular}

Figura 25: Requisitos TRRF sistematizados. Fonte: do autor, baseados em ABNT (2013b) e ABNT (2000).

Quanto à resistência ao fogo, os critérios são estanqueidade, isolamento térmico e estabilidade. De acordo com esses critérios os elementos construtivos são classificados em estável ao fogo (atendem ao primeiro critério), párachamas (atendem ao segundo) e isolamento térmico e corta-fogo (atendem a todos). Sendo assim, os TRRFs descritos na Figura 25 são classificados como isolamento térmico e corta-fogo (ABNT, 2013b). A norma traz as exigências para dificultar a inflamação generalizada e limitação da fumaça, controlando a incombustabilidade, propagação superficial e geração de fumaça (CBIC, 2013) (Figura 26). 


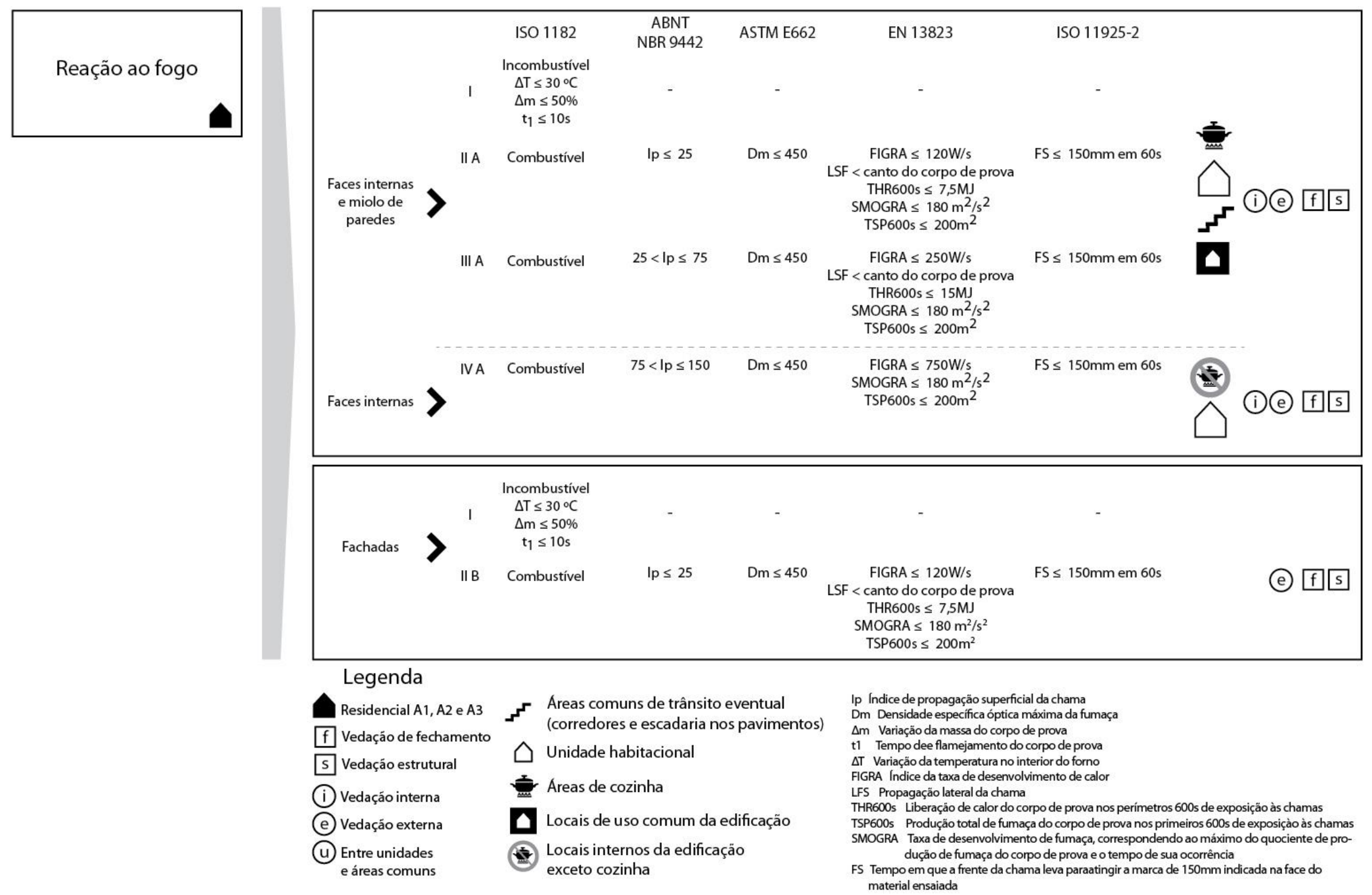

Figura 26: Requisitos de reação ao fogo para faces internas das vedações e fachadas. Fonte: do autor, baseado em ABNT (2013b) 


\subsubsection{Desempenho Térmico}

Segundo ABNT (2013b), o desempenho térmico dependerá das características do local da obra, como topografia, umidade do ar e direção dos ventos, e da edificação em si, como materiais constituintes, orientação das fachadas e pé direito. $O$ desempenho térmico está estreitamente relacionada com a ventilação dos ambientes, influenciada pelo posicionamento e dimensões das aberturas, sendo assim essa sensação está relacionada diretamente com o SVVIE das habitações.

Devido à extensão territorial brasileira, a ABNT NBR 15.220-3 divide o país em oito regiões climáticas (veja Anexo 1), definindo um dia típico de inverno e verão com base na temperatura do ar, umidade relativa, velocidade do vento e radiação solar incidente para o dia mais frio e mais quente (ABNT, 2003).

De acordo com a ABNT NBR 15.575 (ABNT, 2013a) a avaliação térmica pode ser feita com três procedimentos: simplificado (normativo), simulação computacional (normativo) ou medição in loco (informativo).

A avaliação simplificada considera as propriedades térmicas das fachadas e coberturas, por meio do atendimento aos requisitos e critérios para envelopamento da obra com base na transmitância térmica (U) e capacidade térmica (CT). A avaliação feita por simulação computacional contabiliza os elementos e fenômenos simultaneamente e os resultados são globais. E a medição in loco é feita em edificações existentes ou protótipos.

Os dados apresentados na Figura 27 foram determinados pelo procedimento simplificado e referem-se somente as características das SVVE.

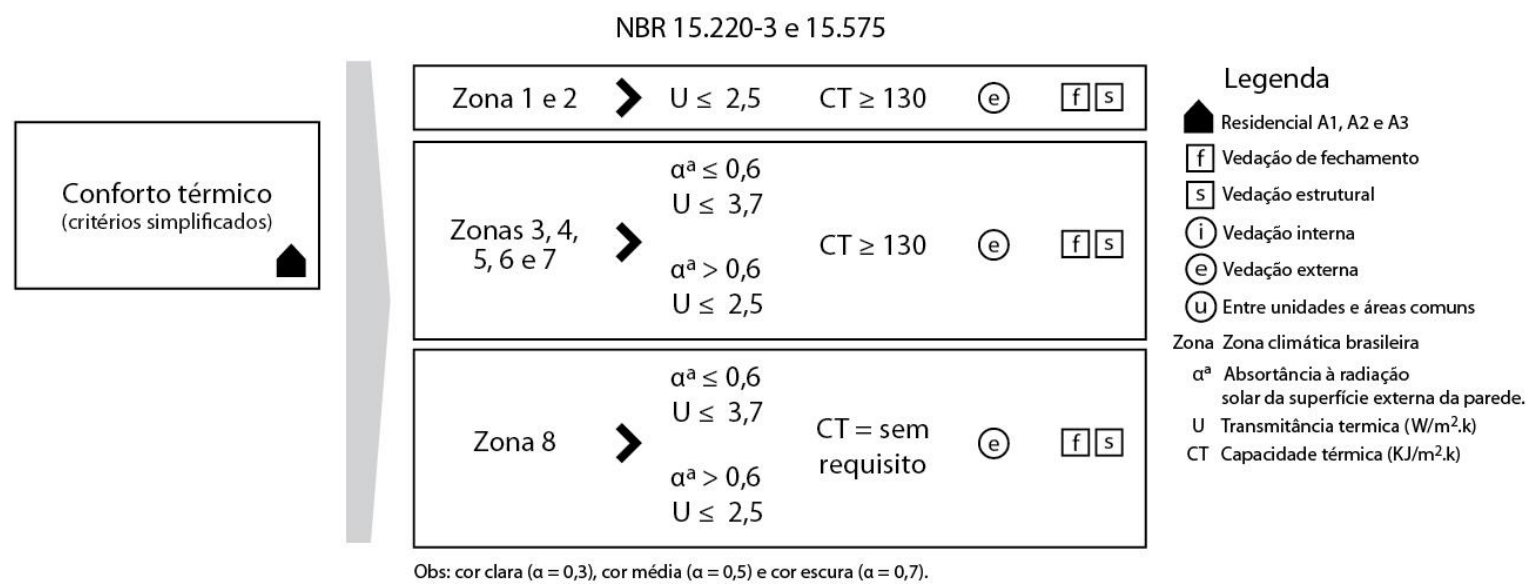

Figura 27: Critérios mínimos de desempenho térmico por Zona Bioclimática de acordo com procedimento simplificado de avaliação de avaliação térmica. Fonte: do autor, baseado em ABNT (2013b). 


\subsubsection{Estanqueidade}

A estanqueidade é um fator de influência na durabilidade das edificações e para a saúde humana, devido à ocorrência de doenças respiratórias associadas à formação de micro-organismos em áreas úmidas. Segundo a ABNT NBR 15.575 (ABNT, 2013b) os requisitos englobam umidade ascendente do solo, percolação de umidade entre ambientes internos e infiltrações.

A ABNT (2013a) estabelece que os projetos devem conter sistemas de prevenção de infiltração da água da chuva e umidade do solo por meio da implantação de drenagem adequada; sistemas que não permitam a penetração de água ou umidade em porões e subsolos; e sistemas que impedem a entrada de umidade para o interior da habitação. Além disso, não devem ocorrer infiltrações pelos elementos, encontro entre paredes e estrutura, entre telhado e paredes ou entre corpo principal e pisos ou calçadas. Os requisitos de desempenho das vedações verticais internas e externas estão descritos na Figura 28.

Com relação ao SVVIE, a estanqueidade à água é definida em função dos índices pluviométricos do local da obra e velocidade e direção do vento, que são estabelecidos para cada uma das cinco regiões brasileiras (veja Anexo 2).

NBR 15.575

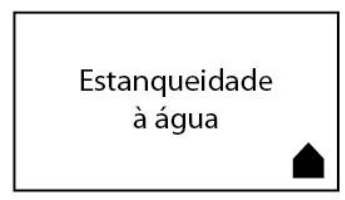

Definição de percentual máximo da soma das áreas das manchas de umidade da face oposta à incidência da água em relação à área total do corpo de prova submetido à aspersão de água no fim do ensaio de $7 \mathrm{~h}$

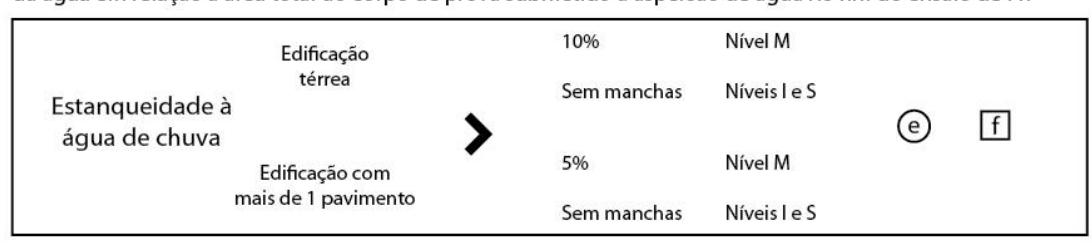

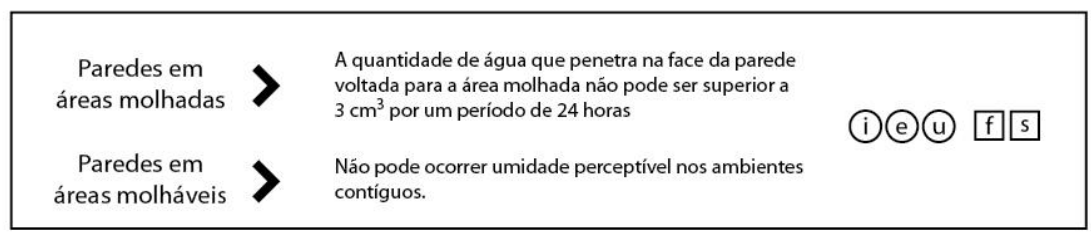

\footnotetext{
Legenda

Residencial A1, A2 e A3
$\mathrm{f}$ Vedaçáo de fechamento
$\mathrm{s}$ Vedaçáo estrutural
}

(i) Vedaçáo interna
(e) Vedaçáo externa
(u) Entre unidades
e áreas comuns

M Nível Mínimo de desempenho

I Nivel Intermediário de desempenho

S Nivel Superior de desempenho

Figura 28: Requisitos de estanqueidade a água para SVVIE. Fonte: do autor, baseado em ABNt (2013b)

\subsubsection{Desempenho Acústico}

A ABNT NBR 15.575 traz critérios de isolamento ao som aéreo e para ruídos transmitidos por impactos, mas os fenômenos difração, ressonância, reverbera- 
ção e absorção não são tratados individualmente. Para as vedações verticais, a norma estipula critérios de atenuação acústica ao som aéreo do envelope da construção. Considera a necessidade do isolamento acústico nas vedações geminadas, divisórias e entre áreas privativas e áreas comuns nas edificações multifamiliares, mas não traz requisitos mínimos para o isolamento entre cômodos da habitação.

Complementar a essa norma, a ABNT NBR 10.152 traz os níveis de máxima intensidade sonora admitida nos casos de dormitórios e sala de estar. Os limites da NBR 15.575 estão definidos pela intensidade de ruídos identificados em áreas residenciais ou pequenos centros comerciais, que são de 55 a 60 dB (ABNT, 2013a).

Segundo CBIC (2013) para a avaliação acústica dos sistemas construtivos os critérios devem ser verificados com ensaios de campo. No caso das vedações verticais, a isolação sonora das vedações entre ambientes pode ser feita por verificação em campo por Método de Engenharia (diferença padronizada de nível ponderado - DnT,w) ou por Método Simplificado (Diferença padronizada de nível ponderada a 2m - D2w, nT, w) ou ensaio de laboratório por Método de Precisão (Índice de redução sonora ponderado - $\mathrm{Rw}$ ). Os valores de referência limite dos desempenhos acústicos estão na Figura 29.

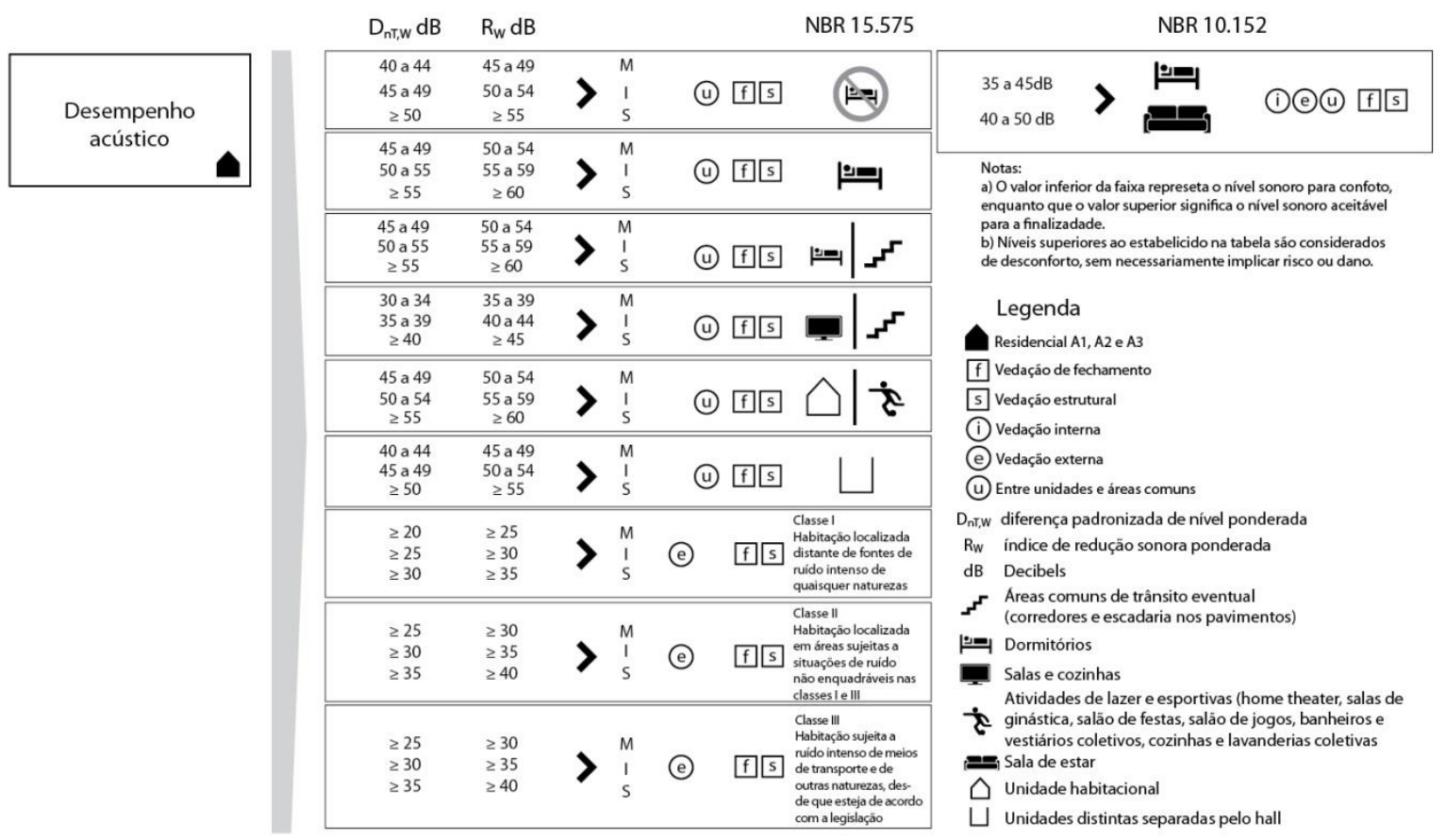

Figura 29: Critérios de desempenho acústico sistematizados considerando CBIC (2013) e ABNT (1987). 
2.2.5. Durabilidade e manutenibilidade

A ABNT NBR 15.575 define requisitos de manutenção e Vida Útil de Projeto (VUP) para diversos elementos e componentes da construção, além de sugerir prazos de garantia. A Vida Útil da edificação é uma composição do valor teórico da VUP com a influência positiva ou negativa da manutenção e fatores externos, como mudanças do clima, alterações no entorno etc. (ABNT, 2013a).

Segundo CBIC (2013) quanto maior a durabilidade de um produto, menor é o consumo de recursos naturais, água e energia e a geração de resíduos e poluentes. A norma ainda estipula prazos de VUP em níveis mínimo, intermediário e superior, sendo que as classificações "intermediário" e "superior" não são obrigatórias, mas se justificam como balizadores do que é possível ser obtido, para justificar que os custos podem ser diluídos ao longo do tempo com um VUP maior e para induzir o mercado para a busca de soluções com o custo-benefício que atendam a padrões mais altos de VUP.

Com relação ao SVVIE a norma traz os prazos estipulados na Figura 30. Os prazos iniciam-se na data de conclusão da edificação, que na norma é definida como a data de expedição do Auto de Conclusão da Edificação.

Quanto à durabilidade das fachadas externas, a norma destaca a ação do calor e choque térmico em vedações externas, que devem cumprir os requisitos de deslocamento horizontal instantâneo, no plano perpendicular ao corpo de prova, superior a h/300; e ocorrência de falhas que comprometam a sua durabilidade.

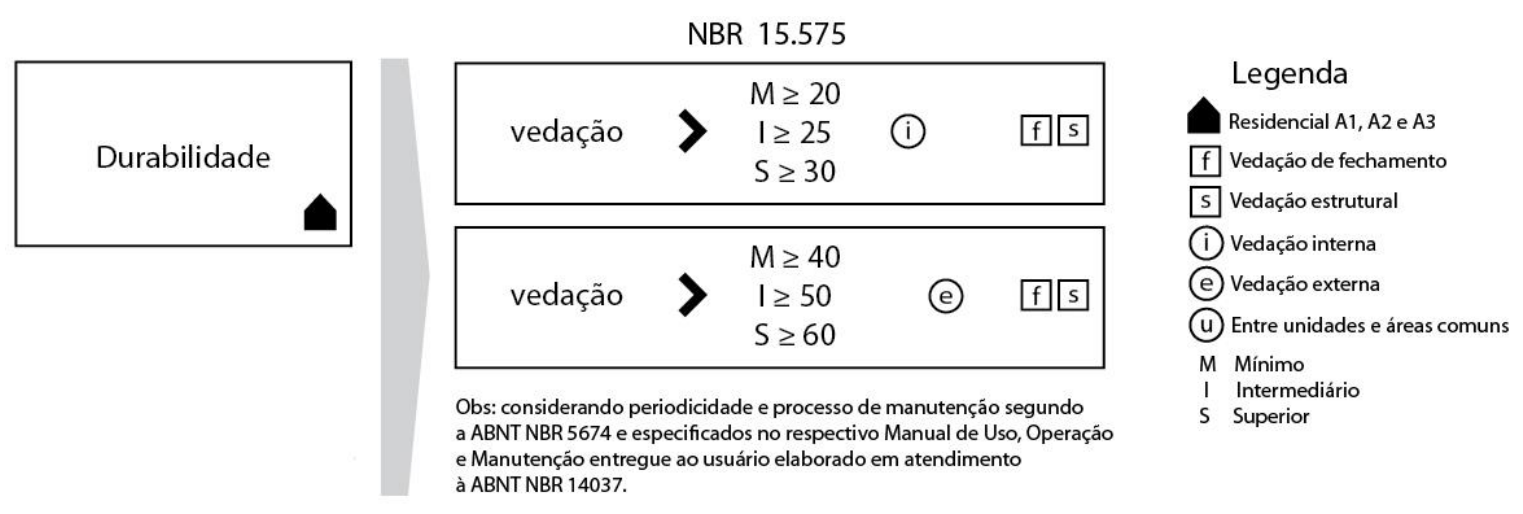

Figura 30: Vida Útil de Projeto para SVVIE. Fonte: do autor, baseado em ABNT (2013a) 


\subsection{Requisitos de desempenho no Reino Unido}

No Reino Unido, existem regulações para edificações que contém regras para novas e existentes edificações tornando-as mais seguras, acessíveis e eficientes. Além disso, edificações com menores taxas de geração de resíduos e impactos ambientais (UK GOVERNMENT, 2014).

O Ministério das Comunidades e do Poder Local publicou documentos orientativos que atendem a essas regulações. Esses documentos contêm recomendações gerais sobre o desempenho, o cumprimento das regulações pelas edificações e alguns exemplos e soluções considerando as edificações mais comuns.

Existem catorze documentos que cobrem toda a edificação: (A) estrutura; (B) segurança contra incêndio; (C) resistência a contaminantes e umidade; (D) substâncias tóxicas; $(E)$ resistência ao som; $(F)$ ventilação; $(G)$ saneamento básico, segurança para água quente e eficiência do uso da água; $(H)$ drenagem e disposição de resíduos; (I) aparelhos a combustão e sistema de armazenamento de combustível; (J) proteção contra queda; (L) conservação do combustível e energia; (M) acesso e uso das edificações; $(\mathrm{N})$ segurança elétrica; e (O) materiais e mão-de-obra.

Os documentos mais importantes para esta pesquisa são E: Resistência ao som e L: Conservação do combustível e da energia, pois essas informações também são utilizadas na pesquisa desenvolvida no Brasil para a definição da função e da unidade funcional da vedação vertical externa.

Requisitos de desempenho são usados na BRE para a definição da unidade funcional, que é de $0.3 \mathrm{~W} / \mathrm{m}^{2} \mathrm{~K}$ para as vedações externas. Valores que são muito inferiores aos requisitos mínimos das vedações brasileiras, visto que o clima e as baixas temperaturas exigem o uso de materiais com velocidade menor de troca de calor. Essa informação é apresentada nas publicações dos protótipos de edificações, por exemplo, a Casa do Príncipe possui U-value para paredes, vidros e telhado $(0.20,0.75$ e 0.11 , respectivamente).

\subsubsection{E: Resistência ao som}

Esse documento contém requisitos para casas, apartamentos ou cômodos para propósitos residenciais, incluindo alojamentos e quartos de hotel. Cômodos podem ser projetados e construídos fornecendo satisfatórias resistências ao som de outras partes da mesma edificação; de edificações geminadas; para paredes inter- 
nas entre dormitórios ou um cômodo que contenha instalações sanitárias; e para pavimentos internos (HM GOVERNMENT, 2010a) (

Quadro 3).

Este documento contém exemplos de vedações que podem cumprir os requisitos de desempenho definidos: vedação, vedação com cavidade entre as camadas, vedação entre painéis independentes e framed wall com material absorvente. Contém ainda uma descrição prática do que deve ser feito e do que não pode ser feito para o cumprimento da norma, além do detalhamento de que tipologias atendem aos requisitos acústicos.

Quadro 3: Requisitos acústicos

\begin{tabular}{|c|c|c|c|c|}
\hline & \multicolumn{2}{|c|}{$\begin{array}{c}\text { Casas e apartamentos (veda- } \\
\text { ções internas, andares e esca- } \\
\text { das que têm função de separa- } \\
\text { ção) }\end{array}$} & \multicolumn{2}{|c|}{$\begin{array}{l}\text { Cômodos para propósitos resi- } \\
\text { denciais (vedações internas, anda- } \\
\text { res e escadas que têm função de } \\
\text { separação) }\end{array}$} \\
\hline & $\begin{array}{c}\text { Isolamento } \\
\text { do ruído aé- } \\
\text { reo }^{11} \\
\text { Isolamento } \\
\text { do som } \\
\mathrm{D}_{\mathrm{nT}, \mathrm{w}}+\mathrm{C}_{\mathrm{tr}} \mathrm{dB}^{12} \\
\text { (valores mí- } \\
\text { nimos) }\end{array}$ & $\begin{array}{c}\text { Isolamento do } \\
\text { impacto sono- } \\
\text { ro } \\
\text { L'nT,w dB } \\
\text { (valores máxi- } \\
\text { mos) }\end{array}$ & $\begin{array}{c}\text { Isolamento do ru- } \\
\text { ído aéreo } \\
\text { Isolamento do } \\
\text { som } \\
\mathrm{D}_{\mathrm{nT}, \mathrm{w}}+\mathrm{C}_{\mathrm{tr}} \mathrm{dB} \\
\text { (valores mínimos) }\end{array}$ & $\begin{array}{l}\text { Isolamento } \\
\text { do impacto } \\
\text { sonoro } \\
\text { L'nT,w dB } \\
\text { (valores má- } \\
\text { ximos) }\end{array}$ \\
\hline \multicolumn{5}{|c|}{ Casas e apartamentos construídos propositalmente } \\
\hline Vedações & 45 & - & 43 & - \\
\hline $\begin{array}{l}\text { Andares e esca- } \\
\text { das }\end{array}$ & 45 & 62 & 45 & 62 \\
\hline \multicolumn{5}{|c|}{ Casas e apartamentos que tiveram o uso alterado } \\
\hline Vedações & 43 & - & 43 & - \\
\hline $\begin{array}{l}\text { Andares e esca- } \\
\text { das }\end{array}$ & 43 & 64 & 43 & 64 \\
\hline
\end{tabular}

Quadro 4: Requisitos acústicos considerando valores obtidos em laboratório

Valores obtidos em laboratório para novas paredes internas e andares dentro de casas, apartamentos e cômodos com propósito residencial, se construído propositalmente ou que tenha o uso alterado

Isolamento do ruído aéreo - $\mathrm{R}_{\mathrm{w}} \mathrm{dB}^{13}$ (valores mínimos)

\footnotetext{
Vedações verticais, andares 40

11 Isolamento do som que reduz a transmissão do som aéreo entre edicações ou partes da edificação.

12 Um número único que caracteriza o isolamento do som aéreo usando ruído espectro nำ2.

${ }^{13}$ Um número único que caracteriza o isolamento do som aéreo para um material ou elemento da edificação obtido no laboratório.
} 


\subsubsection{L: Conservação do combustível e da energia}

Essa regulação define os requisitos de eficiência energética para edificações e é dividida em quatro partes e trata da conservação do combustível e energia em novas habitações, em habitações existentes, em edificações não residenciais e em edificações não residenciais existentes. Essa regulação apresenta estratégias usadas para economizar combustível e energia, como a limitação do ganho e da perda de calor, por meio de elementos térmicos, e o fornecimento de serviços de manutenção, como a eficiência energética e o controle efetivo regulados por testes e ajustes necessários (HM GOVERNMENT, 2010b).

Os requisitos de eficiência energética podem ser comprovados com cinco critérios:

- Emissões de $\mathrm{CO}_{2}$ das habitações (Dwelling $\mathrm{CO}_{2}$ emission - DER) não podem ser maiores que a meta da taxa de emissão de $\mathrm{CO}_{2}\left(\right.$ Target $\mathrm{CO}_{2}$ emission rate - TER);

- A eficiência energética da envoltória da habitação (Dwelling fabric energy efficiency - DFEE) não pode ser maior que a meta da eficiência energética da envoltória (Target fabric energy efficient - TFEE);

- A performance da envoltória e dos serviços de manutenção podem alcançar razoáveis padrões de eficiência energética;

- A habitação precisa ter uma limitação da medição de controle de passivos dos ganhos de calor para temperaturas de ambientes internos no verão;

- A performance da habitação poderá ser consistente com as taxas de DER e DFEE; e

- A eficiência energética da operação poderá ser ajustada.

Nessa regulação, os U-values são usados como parâmetros para a limitação do desempenho da envoltória, conforme Quadro 5.

Quadro 5: Parâmetros limites para envoltória

\begin{tabular}{ll}
\hline Elemento & U-value \\
& $\mathbf{W} / \mathbf{m}^{2} \cdot \mathbf{K}$ \\
\hline Telhado & 0,20 \\
\hline Parede & 0,30 \\
\hline
\end{tabular}




\begin{tabular}{ll}
\hline Piso & 0,25 \\
\hline Paredes geminadas & 0,20 \\
\hline Área da piscina & 0,25 \\
\hline Janelas, janelas de telhado, telhados de vidro, fachada e portas de vidro & 2,00 \\
\hline
\end{tabular}

Fonte: HM Government, 2010b.

Além disso, essa regulação provê um resumo das especificações da edificação ideais, o que é mostrado no Quadro 6.

Quadro 6: Resumo das especificações da habitação ideal, considerando requisitos térmicos para alguns elementos e sistemas

\begin{tabular}{ll}
\hline Elemento ou sistema & Valores \\
\hline $\begin{array}{l}\text { Vedações externas (incluindo elementos opacos e fa- } \\
\text { chadas) }\end{array}$ & $0.18 \mathrm{~W} /\left(\mathrm{m}^{2} . \mathrm{K}\right)$ \\
\hline Paredes geminadas & $0.0 \mathrm{~W} /\left(\mathrm{m}^{2} . \mathrm{K}\right)$ \\
\hline Piso & $0.13 \mathrm{~W} /\left(\mathrm{m}^{2} . \mathrm{K}\right)$ \\
\hline Telhado & $0.13 \mathrm{~W} /\left(\mathrm{m}^{2} . \mathrm{K}\right)$ \\
\hline $\begin{array}{l}\text { Janelas, janelas de telhado, telhados de vidro e portas } \\
\text { de vidro }\end{array}$ & $\begin{array}{l}1.4 \mathrm{~W} /\left(\mathrm{m}^{2} . \mathrm{K}\right) \text { (valor para a janela } \\
\text { como um todo })\end{array}$ \\
\hline Portas envidraçadas & $1.0 \mathrm{~W} /\left(\mathrm{m}^{2} . \mathrm{K}\right)$ \\
\hline Portas parcialmente envidraçadas & $1.2 \mathrm{~W} /\left(\mathrm{m}^{2} \cdot \mathrm{K}\right)$ \\
\hline Ventilação & $5.0 \mathrm{~m}^{3} /\left(\mathrm{h}^{2} \mathrm{~m}^{2}\right)$ \\
\hline Fonte: HM Government, 2010b.
\end{tabular}

\subsubsection{Código para casas sustentáveis}

O Código para casas sustentáveis foi desenvolvido pelo Governo Britânico, Building Research Establishment (BRE) e Associação de Informação e Pesquisa da Indústria da Construção (CIRIA) e pretende ser um padrão único nacional para apoiar a indústria da construção no desenvolvimento e construção de casas sustentáveis. Esse código possui conexão com a Building Regulations, pois os padrões mínimos da edificação foram definidos considerando esse conjunto de regulações. Nesse código, existem nove categorias de projeto (DEPARTMENT FOR COMMUNITIES AND LOCAL GOVERNMENT, 2006):

i. Energia/ $\mathrm{CO}_{2}$ : essa categoria é classificada considerando a porcentagem de crescimento da meta de emissão (TER) como determinado pela legislação de regulação de edificações, considerando envoltória e iluminação interna, espaços secos, selos ambientais, iluminação externa, tecnologias elétricas de baixo ou zero carbono, ciclos de armazenamento e escritório em casa; 
ii. Poluição: essa categoria avalia substâncias perigosas, que aumentem o potencial de aquecimento global, o potencial de destruição da camada de ozônio e as emissões de óxidos nítricos (NOx);

iii. Água: essa categoria avalia a potabilidade da água consumida medida em litros por pessoa por dia (1/p/d) e sistemas de coleta de água da chuva para irrigação externa;

iv. Materiais: essa categoria considera impactos ambientais em materiais aplicados em casas avaliadas. Os elementos-chave de uma edificação são telhado e acabamentos, vedações externas, piso superior, paredes internas e janelas e portas. Ao menos três desses cinco elementos-chave devem ser especificados de acordo com o BRE Green Guide to Specification 2006 com classificação D (ANDERSON et al, 2008). Além disso, essa categoria avalia a responsabilidade da cadeia de fornecedores dos materiais;

v. Escoamento da água de superfície: essa categoria garante que as taxas de escoamento de pico e volumes anuais de escoamento não sejam maiores que condições anteriores;

vi. Resíduos: essa categoria garante a existência de um local para operação do plano de gerenciamento de resíduos e adequado espaço para o armazenamento dos resíduos, além de instalações para compostagem dos resíduos gerados na fase de construção;

vii. Saúde e bem-estar: essa categoria avalia a entrada da luz do dia nos cômodos da casa, isolamento do som, espaço privado e vida útil da casa;

viii. Gerenciamento: essa categoria considera o guia de uso da casa, esquema do construtor, impactos da obra e segurança;

ix. Ecologia: esse impacto considera o valor ecológico do terreno, valorização ecológica, preservação das características ecológicas, mudança do valor ecológico e pegada da edificação.

O sistema de classificação do código foi elaborado com estrelas (de uma a seis) que são atribuídas considerando o desempenho ambiental da habitação.

\subsection{A utilização da classificação e requisitos das vedações verticais}

A definição da classificação proposta e os requisitos mínimos das vedações verticais, por meio da ABNT NBR 15.575, permite a elaboração de uma unidade funcional precisa que atenda a requisitos pré-determinados, possibilite o uso de ma- 
teriais diferentes para uma mesma função no contexto da construção e permita comparar duas vedações funcionalmente equivalentes.

Ao invés da unidade funcional da vedação ser somente $1 \mathrm{~m}^{2}$ de vedação vertical, a unidade funcional estabelecida a partir dos requisitos da ABNT NBR 15.575 e normas específicas permite especificar, como por exemplo, uma vedação externa, com função estrutural, que tenha um desempenho térmico para a Zona 8, resistência ao fogo mínima de 30 minutos, desempenho acústico de $20 \mathrm{~dB}$, entre outras características.

Com base nesse contexto, serão definidos no Capítulo 3 os requisitos que deverão ser atendidos, com base em dados secundários disponíveis, e as características das vedações que cumprirão a esses requisitos, como a espessura da parede, a espessura e características da argamassa, características do bloco, espessura da fiada horizontal e vertical, entre outros.

\subsection{Definição dos elementos e componentes do SVVIE}

O segundo recorte feito nesta pesquisa é a definição do elemento e componentes considerados no estudo. Os pré-requisitos para a definição do elemento foi a importância no contexto da Construção, a utilização desse elemento, possibilidade de aplicação do modelo e dados disponíveis sobre o seu desempenho.

Com auxílio da classificação da Vedação Vertical elaborada nesta pesquisa e esquematizada na Figura 20, optou-se pelo elemento Vedação Vertical para o objeto de estudo desta pesquisa. Esse tipo de vedação é amplamente utilizada no Brasil e Reino Unido, principalmente em edificações tradicionais e residenciais. A vedação de alvenaria é um sistema construtivo consolidado, que possui informações relacionadas com o desempenho das paredes construídas, o que ainda não é encontrado com facilidade no caso de sistemas construtivos inovadores no Brasil.

Dentro das tipologias de Vedações de Alvenaria são estudadas aquelas constituídas por blocos cerâmicos, que são os tipos de blocos mais utilizados. Levantamento feito pelo IBGE (2011) demonstrou que 90,68\% dos domicílios particulares permanentes possuem as vedações externas construídas com alvenaria ${ }^{14}$.

\footnotetext{
${ }^{14} \mathrm{O}$ dado do IBGE busca avaliar a salubridade das habitações brasileiras, por isso são consideradas neste estudo domicílios com as vedações externas constituídas por alvenaria, madeira, taipa, palha, outro material e sem vedação vertical. No entanto, por falta de dados do número de habitações brasileiras de alvenaria foi utilizado esse dado para demonstrar sua importância na Construção no Brasil. Existe o senso comum de que a alvenaria é o sistema mais utilizado nas habitações, mas não foi possível tornar essa informação menos subjetiva.
} 
No Reino Unido, mais de $84 \%$ das residências são construídas com blocos ou tijolos, o que define o estilo tradicional das casas no Reino Unido, considerando que $93 \%$ da população querem viver em casas construídas de blocos ou tijolos (BRICK DEVELOPMENT ASSOCIATION, 2014).

\subsection{Caracterização das Cadeias Produtivas dos componentes das ve- dações de blocos cerâmicos}

\subsubsection{Vedação de Bloco Cerâmico no Brasil}

A Vedação de Bloco Cerâmico pode ser constituída por blocos com função estrutural ou de vedação, que possuem características diferentes e são regulados pelas normas ABNT NBR 15.270 (ABNT, 2005a; ABNT, 2005b; ABNT, 2005c).

\subsubsection{Extração da matéria-prima, fabricação e transporte}

A cadeia produtiva do bloco cerâmico é descrita com base em materiais de referência e visita técnica ${ }^{15}$. O bloco cerâmico deve ser fabricado por conformação plástica de matéria-prima argilosa, contendo ou não aditivos, e queimado em elevadas temperaturas (ABNT, 2005a).

As matérias-primas utilizadas são argila e água, sendo a argila é extraída de uma jazida por meio de retroescavadeiras movidas a diesel e levada para as fábricas por caminhões. Na fábrica esse material é movimentado por meio de escavadeiras até o desintegrador, que é um equipamento de vibração constante que desintegra grandes porções de argila endurecida e mistura tipos de argilas diferentes quando existe a necessidade de corrigir a granulometria ${ }^{16}$ (Figura 31).

As propriedades mais importantes das argilas para a cerâmica são a plasticidade, que é a atração entre as partículas; e a retração, como consequência da evaporação da água que compõem o bloco, que pode se deformar pela evaporação não absolutamente uniforme (BAUER, 2000).

A argila passa pelo desintegrador, misturador e laminador, por meio de esteiras movidas a energia elétrica. Ao entrar na extrusora, são modelados e cortados os blocos que passam a se movimentar pela fábrica por carrinhos em trilhos movi-

\footnotetext{
${ }^{15}$ A fábrica visitada é a Cerâmica União localizada em Anápolis-GO.

${ }^{16}$ O processo produtivo do bloco cerâmico foi montado por meio de visita técnica a Cerâmica União localizada em Anápolis, em maio/2013.
} 
dos por motores elétricos, manualmente, esteiras etc. Os blocos passam por vários tipos de processos de secagem, dependendo na planta industrial da fábrica, podendo ser na estufa com o ar quente vindo do forno, com ventiladores que auxiliam na evaporação da água, ao ar livre e na estufa elétrica que aquece e seca os blocos, ou ainda uma combinação desses processos.

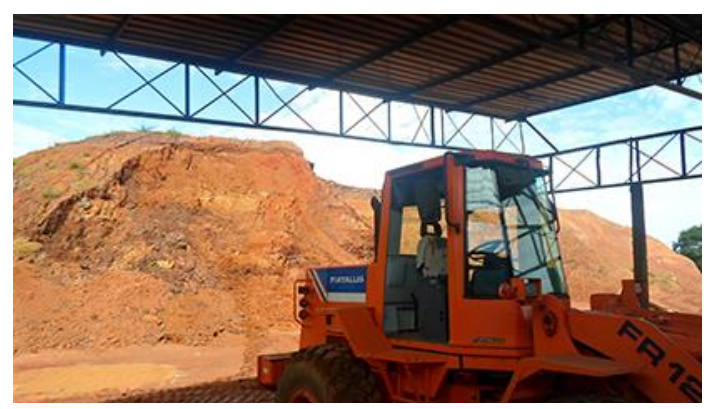

A. Movimentação da argila com escavadeira.

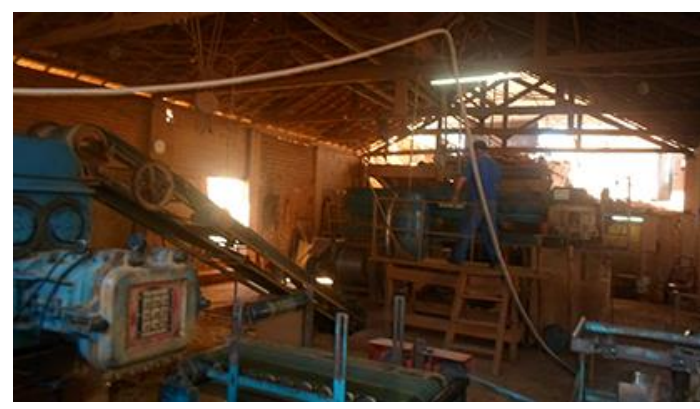

C. Laminação da argila.

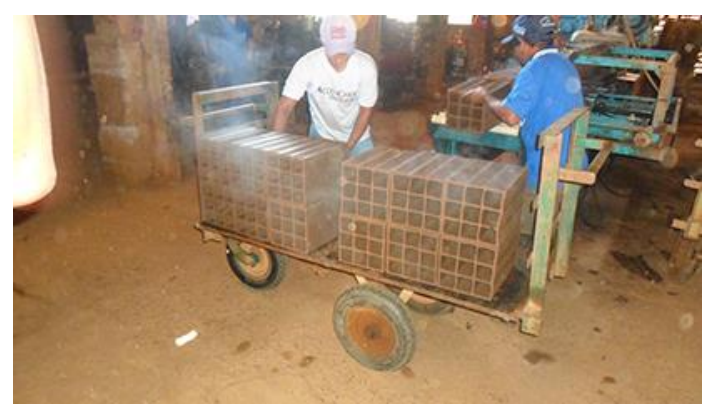

E. Movimentação dos blocos modelados.

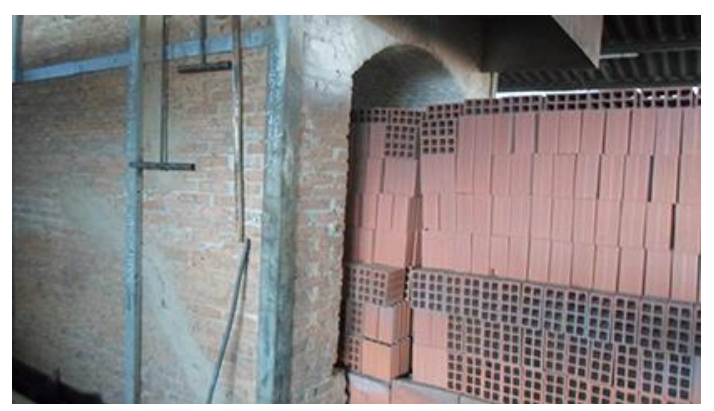

G. Blocos saindo da queima,

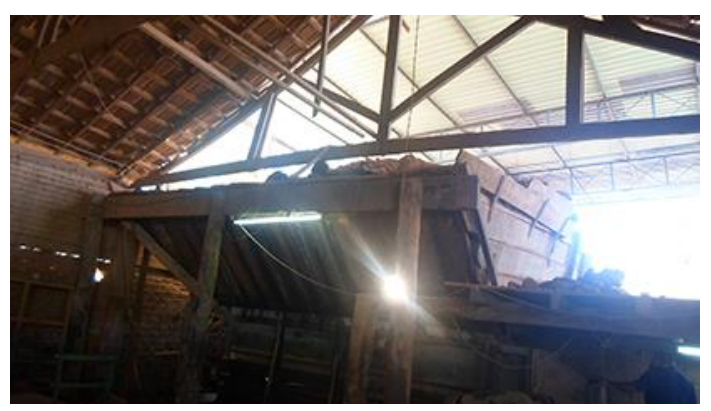

B. Desintegração dos torrões de argila.

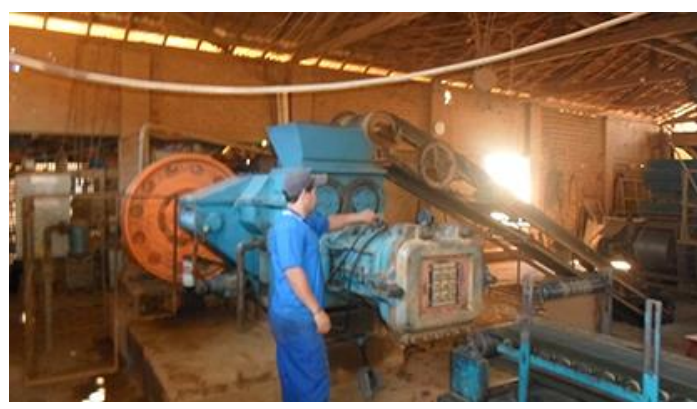

D. Extrusora.

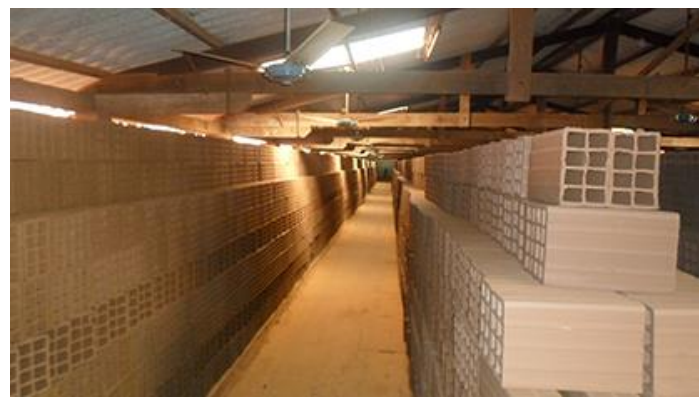

F. Secagem dos blocos.

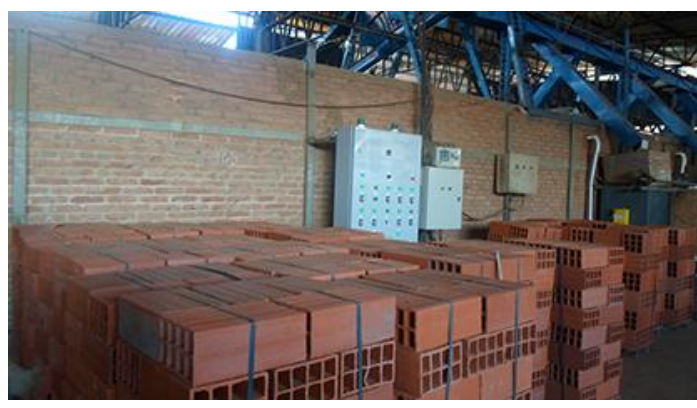

H. Blocos paletizados.

Figura 31: Processo produtivo do bloco cerâmico. 
O cozimento é feito em um forno intermitente, que é carregado em lotes de blocos, acionado, arrefecido e descarregado; e fornos contínuos. onde o processo de queima é ativo e o fogo é gradualmente transferidos em torno de uma série de câmaras de interligação, geralmente, para produção em larga escala são utilizados o forno de túnel contínuo ou o forno Hoffman (MENDES et al, 2012).

Os fornos podem ser alimentados por diferentes combustíveis, tais como poliestireno, madeira, óleo diesel, gás natural e biomassa ${ }^{17}$ (CAMPIOLLI et al, 2011). Após o cozimento e esfriamento, os blocos são paletizados e empacotados. A partir desse momento o transporte dentro da fábrica é feito por uma empilhadeira movida a gás liquefeito de petróleo (GLP). Os blocos são vendidos para as construtoras e entregues nos canteiros de obras, onde permanecem acondicionados até a utilização para a construção da vedação.

\subsubsection{Bloco Cerâmico}

O Bloco Cerâmico pode ser estrutural ou de vedação, onde ambos possuem furos prismáticos perpendiculares às faces que os contém, porém o primeiro deve ser produzido para assentamento com furos da vertical e o segundo pode ser assentado na vertical ou horizontal (ABNT, 2005b) (Figura 32 e Figura 33). O Bloco Cerâmico de Vedação constitui a alvenaria externa ou interna da edificação que não tem como função resistir a outras cargas verticais, além do peso da própria alvenaria que faz parte (ABNT, 2005a).

Bloco cerâmico estrutural de vedações vazadas

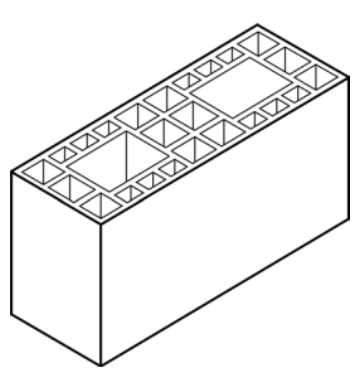

Bloco cerâmico estrutural com vedações maciças (vedações internas

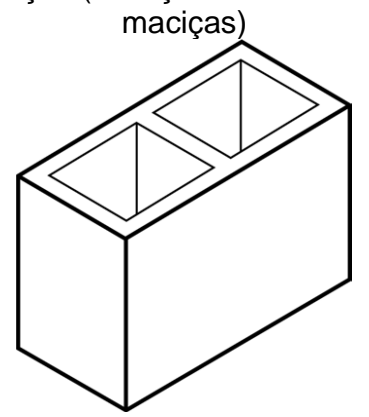

Bloco cerâmico estrutural com vedações maciças (vedações internas vazadas)

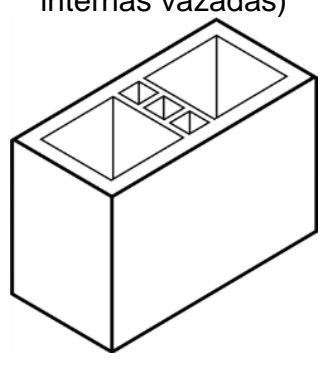

Bloco cerâmico estrutural perfurado

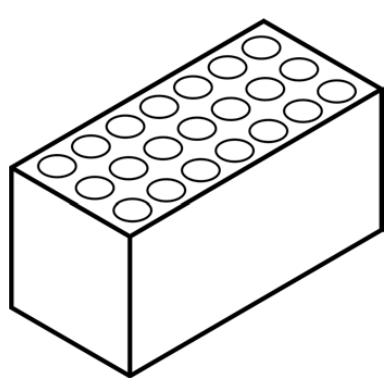

Figura 32: Tipos de blocos cerâmicos estruturais (ABNT, 2005b).

\footnotetext{
${ }^{17} \mathrm{Na}$ fábrica visitada são utilizados cavacos de eucalipto.
} 

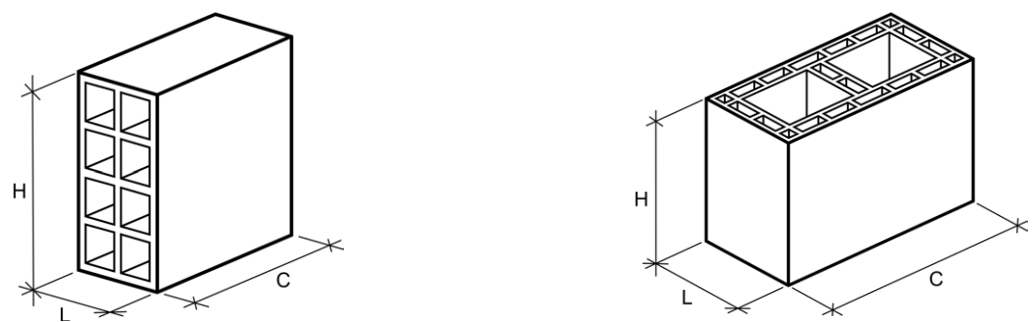

Figura 33: Blocos cerâmicos de vedação (ABNT, 2005a).

Quanto às características técnicas, os blocos cerâmicos estruturais possuem uma resistência à compressão (f $f_{b k}$ ) de, no mínimo, 3,0 MPA; as tolerâncias dimensionais individuais são de mais ou menos $5 \mathrm{~mm}$ e, em média, $3 \mathrm{~mm}$; devem ser isentos de defeitos sistemáticos que não permitam o seu emprego na função especificada; a absorção de água pode variar entre 8 e 22\%; o desvio do esquadro deve ser inferior a 3mm; e a flecha máxima deve ser de 3mm (PINI, 2008a).

Dentre as características técnicas dos blocos cerâmicos de vedação, previstas na ABNT NBR 15.270-1 (ABNT, 2005d) tem-se: resistência à compressão (fb) de 1,5 MPa para blocos com furos na horizontal e de 3,0 MPa para os com furos na vertical; isentos de defeitos sistemáticos; absorção de água (AA) entre 8 e $22 \%$; o desvio em relação ao esquadro menor igual e a flecha máxima menor ou igual a 3 $\mathrm{mm}$; com tolerâncias dimensionais de mais ou menos $5 \mathrm{~mm}$ (individuais) e $3 \mathrm{~mm}$ (média); e espessura dos septos de 7 mm, no mínimo 6 (PINI, 2008a).

\subsubsection{Construção da Vedação de blocos cerâmicos}

As vedações construídas com blocos cerâmicos estruturais e de vedação possuem características diferentes. Por isso, serão abordadas separadamente.

As vedações de blocos cerâmicos estruturais são compostas por blocos, argamassa de assentamento, barras de aço e graute (PINI, 2008a). Apesar disso, nesta pesquisa serão considerados apenas os componentes blocos, argamassa de assentamento e emboço em ambas as faces, visto que a falta do emboço pode comprometer o desempenho térmico das vedações e foi feita uma simplificação dos componentes para facilitar a análise.

O consumo de material para a construção da vedação definido nas Tabelas de Composição de preços para Orçamento (TCPO) apresenta valores distintos conforme o assentamento das peças (PINI, 2008b) (Tabela 1). 
Tabela 1: Consumo de materiais das vedações de blocos cerâmicos estruturais (PINI, 2008b).

\begin{tabular}{|c|c|c|c|}
\hline \multirow{3}{*}{$\begin{array}{l}\text { Espessura da } \\
\text { vedação*** }\end{array}$} & \multirow{3}{*}{$\begin{array}{l}\text { Consumo de blo- } \\
\cos \left(\mathrm{un} / \mathrm{m}^{2}\right)\end{array}$} & \multirow{3}{*}{$\begin{array}{l}\text { Consumo de argamas- } \\
\qquad \mathrm{sa}^{*}\left(\mathrm{~m}^{3} / \mathrm{m}^{2}\right)\end{array}$} & Variação da perda** \\
\hline & & & Blocos cerâmicos $\left(\% / m^{2}\right)$ \\
\hline & & & Med. \\
\hline 14 & 14 & 0,0106 & 3 \\
\hline 19 & 14 & 0,0143 & 3 \\
\hline \multicolumn{4}{|c|}{$\begin{array}{l}{ }^{* *} \text { A variação de perda do material vai depender do nível de racionalização da obra. } \\
{ }^{* * \star} \text { A altura do bloco é de } 19 \mathrm{~cm} \text { e o comprimento de } 39 \mathrm{~cm} \text {. }\end{array}$} \\
\hline
\end{tabular}

Segundo PINI (2008a) um projeto de alvenaria estrutural deve conter: (i) plantas de locação da primeira e segunda fiadas com definição dos locais de grauteamento; (ii) elevação das vedações com blocos (inteiros, meios-blocos e blocos para amarração "T" e "L"), singularidades, instalações, vãos, aberturas, grauteamentos, cintas de amarração, vergas e contra-vergas; (iii) características das juntas entre os blocos; (iv) detalhes do graute vertical, cintas, vergas e contra-vergas; (v) juntas de controle e movimentação; e (vi) especificações do bloco, argamassa e graute.

Para a construção das vedações com blocos cerâmicos de vedação são necessários blocos, argamassa de assentamento e telas metálicas de ligação ou ferros-cabelo (PINI, 2008a). Assim como nas vedações de blocos cerâmicos estruturais, serão considerados apenas os componentes blocos, argamassa de assentamento e emboço em ambas as faces.

O consumo de material para a construção da vedação definido nas TCPO apresenta valores distintos conforme o assentamento das peças (PINI, 2008b) (Tabela 2).

Tabela 2: Consumo de materiais nasvedações de blocos cerâmicos de vedação (PINI, 2008b).

\begin{tabular}{|c|c|c|c|c|c|c|c|c|}
\hline \multicolumn{9}{|c|}{ Blocos cerâmicos com furos na horizontal } \\
\hline \multirow{3}{*}{$\begin{array}{l}\text { Espessura } \\
\text { da vedação }\end{array}$} & \multirow{3}{*}{$\begin{array}{l}\text { Consumo } \\
\text { de blocos } \\
\left(u n / m^{2}\right)\end{array}$} & \multirow{3}{*}{$\begin{array}{l}\text { Consumo de } \\
\text { argamassa* } \\
\qquad\left(\mathrm{m}^{3} / \mathrm{m}^{2}\right)\end{array}$} & \multicolumn{6}{|c|}{ Variação da perda** } \\
\hline & & & \multicolumn{3}{|c|}{ Blocos cerâmicos $\left(\% / \mathrm{m}^{2}\right)$} & \multicolumn{3}{|c|}{ Argamassa $\left(\% / m^{2}\right)$} \\
\hline & & & Min. & Med. & Max. & Min. & Med. & Max. \\
\hline 9 & 27 & 0,0120 & \multirow{2}{*}{3} & \multirow{2}{*}{11} & \multirow{2}{*}{25} & \multirow{2}{*}{5,3} & \multirow{2}{*}{13,8} & \multirow{2}{*}{43,5} \\
\hline 19 & 54 & 0,0340 & & & & & & \\
\hline
\end{tabular}

\begin{tabular}{|c|c|c|c|c|c|c|c|c|}
\hline \multicolumn{9}{|c|}{ Blocos cerâmicos com furos na vertical } \\
\hline \multirow{3}{*}{$\begin{array}{l}\text { Espessura } \\
\text { da veda- } \\
\text { ção*** }\end{array}$} & \multirow{3}{*}{$\begin{array}{l}\text { Consumo } \\
\text { de blocos } \\
\left(\mathrm{un} / \mathrm{m}^{2}\right)\end{array}$} & \multirow{3}{*}{$\begin{array}{l}\text { Consumo de } \\
\text { argamassa } \\
\qquad\left(\mathrm{m}^{3} / \mathrm{m}^{2}\right)\end{array}$} & \multicolumn{6}{|c|}{ Variação da perda** } \\
\hline & & & \multicolumn{3}{|c|}{ Blocos cerâmicos $\left(\% / \mathrm{m}^{2}\right)$} & \multicolumn{3}{|c|}{ Argamassa $\left(\% / \mathrm{m}^{2}\right)$} \\
\hline & & & Min. & Med. & Max. & Min. & Med. & Max. \\
\hline 9 & 13 & 0,0081 & 1 & 3 & 15 & 5,3 & 14,7 & 37,9 \\
\hline
\end{tabular}




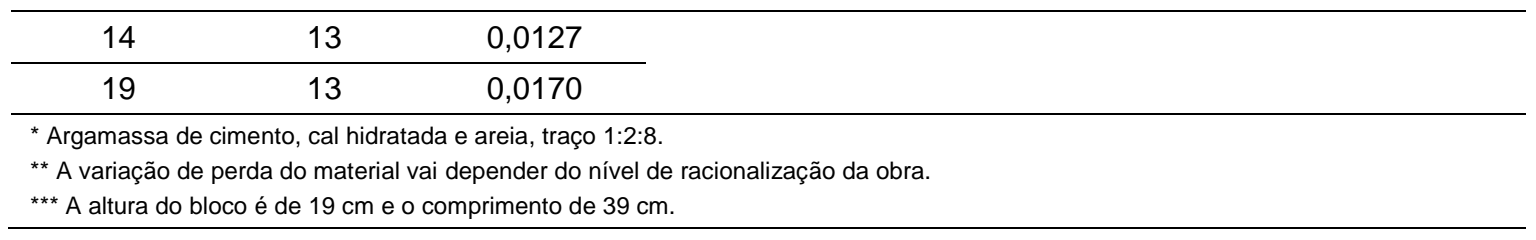

O projeto de alvenaria sem função estrutural contempla itens próximos da alvenaria estrutural (PINI, 2008a), porém como não é necessário o grauteamento, essas informações não são necessárias.

A juntas horizontais e verticais entre os blocos possuem, geralmente, $1 \mathrm{~cm}$ de espessura para as vedações com e sem função estrutural e a espessura da argamassa de emboço vai variar conforme a tipologia da vedação especificada.

\subsubsection{Argamassa Industrializada e tradicional}

A argamassa é uma mistura homogênea de agregado miúdo, aglomerante e água, que pode conter aditivos, e que tem propriedades de aderência e endurecimento (ABNT, 2005d). São materiais bastante empregados na construção, como no assentamento de alvenaria e nas etapas de revestimento, como emboço, reboco ou revestimento em camada única (CARASEK, 2010).

Usada em construções, a argamassa pode ser classificada, quanto ao local de produção, como argamassa tradicional, que é dosada e misturada no canteiro de obras, e industrializada, dosada e misturada na fábrica e comercializada em forma de pó, requerendo apenas adição de água, ou em pasta, já pronta para uso.

Segundo Carasek (2010), as argamassas podem ser classificadas com relação a vários critérios, nesta pesquisa optou-se por classificar a argamassa segundo a sua função na construção (Quadro 7).

Quadro 7: Classificação das argamassas segundo sua função na construção

\begin{tabular}{ll}
\hline Função & Tipos \\
\hline Para construção de alvenarias & Argamassa de assentamento (elevação da alvenaria) \\
\cline { 2 - 2 } & Argamassa de fixação (ou encunhamento) \\
\hline Para revestimento de vedações & Argamassa de chapisco \\
\cline { 2 - 2 } verticais e horizontais & Argamassa de emboço \\
\cline { 2 - 2 } & Argamassa de reboco \\
\cline { 2 - 2 } & Argamassa de camada única \\
\cline { 2 - 2 } & Argamassa para revestimento decorativo monocamada \\
\hline Para revestimento de pisos & Argamassa de contrapiso \\
\cline { 2 - 2 } & Argamassa de alta resistência para piso \\
\hline
\end{tabular}




\begin{tabular}{ll}
\hline & Argamassa para assentamento de peças cerâmicas (colante) \\
\cline { 2 - 2 } & Argamassa de rejuntamento \\
\hline Para recuperação de estruturas & Argamassa de reparo \\
\hline Fonte: Carasek 2010
\end{tabular}

Fonte: Carasek, 2010.

As argamassas, geralmente, são compostas por cimento Portland, água, agregados miúdos, cal virgem ou hidratada e aditivos. O cimento Portland é composto de clínquer Portland moído acrescido de sulfato de cálcio, podendo ser adicionado materiais pozolânicos, escórias granuladas de alto-forno ou materiais carbonáticos. No caso das argamassas deve ser utilizado o CP II-Z (cimento Portland composto com pozolana).

A água deve ser limpa, isenta de componentes que comprometa a qualidade da argamassa. Os agregados miúdos são compostos de grãos minerais duros, compactos, estáveis, duráveis e limpos, sendo de origem natural (areia lavada ou areia de rio), ou artificial (britagem de rochas) (ABNT, 2009).

A cal virgem é a calcinação de carbonatos de cálcio e, ou magnésio, constituído de óxido de cálcio e óxido de magnésio, ou de óxido de cálcio, óxido de magnésio e hidróxido de cálcio. A cal hidratada é o pó da hidratação da cal virgem, constituído de hidróxido de cálcio e hidróxido de magnésio ou de hidróxido de cálcio, hidróxido de magnésio e óxido de magnésio. Os aditivos auxiliam na incorporação de ar trazendo trabalhidade, adesão, diminuição da massa específica, retenção de água e viscosidade (ABNT, 2011).

Devido ao recorte dado, nesta pesquisa serão consideradas apenas as argamassas de assentamento de alvenaria e as argamassas de revestimento para chapisco e emboço.

A argamassa de assentamento possui a função de unir as unidades formando um elemento monolítico, distribuir as cargas atuantes na vedação de forma uniforme, selar as juntas e garantir a estanqueidade à água e absorver as deformações naturais, sejam elas térmicas ou higroscópicas. As argamassas de revestimento são utilizadas para revestir as vedações verticais e horizontais e podem receber outros tipos de acabamentos. O chapisco é uma camada de preparo da base com a finalidade de uniformizar a superfície quanto a absorção e a aderência do revestimento. E o emboço é uma camada para cobrir irregularidades de forma a per- 
mitir o recebimento de outra camada de revestimento, seja reboco ou revestimento decorativo (CARASEK, 2010).

2.6.1.5. Extração da matéria-prima, fabricação e transporte das argamassas

A cadeia produtiva da argamassa industrializada e tradicional foi descrita com base em materiais de referência. Essa cadeia é dividida em extração e beneficiamento da matéria-prima, fabricação e transporte.

\section{i. Argamassa industrializada}

A extração e beneficiamento das matérias-primas da argamassa industrializada utiliza: cimento Portland, água, cal virgem ou hidratada e agregados miúdos, que são transportadas por caminhões até a fábrica, onde é fabricada a argamassa industrializada. O processo de fabricação da argamassa industrializada envolve as etapas: (i) secagem, moagem, classificação e ensilagem de agregados; (ii) recepção e ensilagem de outras matérias-primas; (iii) dosagem e mistura; (iv) ensacagem, paletização e plastificação dos pallets; recebimento no canteiro de obras e estocagem; (v) pesagem da massa de água; (vi) preparo da argamassa (FURTADO et al, 2013).

O transporte da argamassa industrializada é feito por caminhões até o canteiro de obras, onde a argamassa é preparada conforme orientações do fabricante.

\section{ii. Argamassa tradicional (MOV - massa virada em obra)}

A extração e beneficiamento das matérias-primas da argamassa tradicional envolve as mesmas matérias-primas: cimento Portland, agregado miúdo areia e cal hidratada. As matérias-primas são transportadas por caminhões até o canteiro de obras, onde é fabricada a argamassa tradicional. O processo de fabricação da argamassa tradicional envolve as etapas: (i) recebimento e armazenamento dos materiais; (ii) peneiramento; (iii) medição e mistura da argamassa intermediária; (iv) estocagem; (v) mistura final (FURTADO et al, 2013).

O transporte da argamassa no canteiro de obras é feito, geralmente, por carrinhos de mão e, ou elevadores de transporte de cargas utilizados nas obras. Observa-se que o tipo de equipamento utilizado dependerá do nível de industrialização da obra, podendo ir desde o manual (carrinhos de mão, mistura manual da argamassa) até níveis mais automatizados (argamassadeiras, elevadores de carga). 


\subsubsection{Vedações de Bloco Cerâmico no Reino Unido}

Para o Reino Unido, foram consideradas as tipologias de vedação vertical externa dos protótipos do Parque Tecnológico de Inovação da BRE, visto que essa tipologia de vedação foi estudada no período do Doutorado Sanduíche e a coleta de dados precisava cumprir o cronograma estabelecido no Plano de Trabalho, o que limitava uma pesquisa mais exploratória como foi feito no Brasil.

\subsubsection{Seleção da vedação britânica}

Neste Parque Tecnológico de Inovação existem dez protótipos que poderiam ser usados para este estudo. Por isso, optou-se por elaborar uma matriz comparativa com seis categorias: tipologia da vedação externa, disponibilidade dos dados, localização dos fornecedores, características gerais, foco da inovação e função.

Essas categorias foram classificadas de 1 a 3 , conforme sua comparabilidade com a tipologia estudada no Brasil. No final, fez-se uma média simples com os valores atribuídos para a obtenção dos resultados finais, conforme Quadro 8. Os resultados demonstram que a melhor opção é a tipologia de vedação vertical externa da Casa do Príncipe, por ser construída de blocos cerâmicos e ter como principal inovação o fato de ser uma casa tradicional de rápida execução e menor custo.

\subsubsection{A Casa do Príncipe}

Construída em 2010, essa casa foi projetada pela Prince's Foundation for Building Community para ser uma casa tradicional construída com materiais naturais, de fácil execução, de baixo custo e com baixo consumo de energia e geração de $\mathrm{CO}_{2}$ (PRINCE'S FOUNDATION, 2010).

Para a coleta dos dados sobre a vedação externa da Casa do Príncipe foi feita uma visita técnica ao Parque de Inovação da $B R E^{18}$ e foram usados materiais de referência que detalhavam aspectos técnicos da vedação (PRINCE'S FOUNDATION, 2012; BRE, 2012).

O desempenho térmico dessa vedação é de $0,20 \mathrm{~W} / \mathrm{m}^{2} \mathrm{~K}$, que está de acordo com as normas inglesas para desempenho térmico. Apesar do desempenho acústico também ser um dos focos desta pesquisa, os dados não estão disponíveis.

\footnotetext{
18 Visita técnica realizada em 09/10/2014 no Parque de Inovação da BRE tendo como recursos os materiais expositivos e o guia impresso dos protótipos.
} 
Quadro 8: Matriz de comparação das tipoligias das vedações dos protótipos do Parque de Inovação da BRE

\begin{tabular}{|c|c|c|c|c|c|c|c|c|c|c|c|c|c|}
\hline Protótipo & $\begin{array}{l}\text { A - Materiais } \\
\text { usados nas } \\
\text { vedações ex- } \\
\text { ternas }\end{array}$ & $\begin{array}{l}\stackrel{0}{c} \\
\stackrel{0}{0}\end{array}$ & $\begin{array}{l}\text { B - Exis- } \\
\text { tem dados } \\
\text { disponíveis }\end{array}$ & $\begin{array}{l}\stackrel{0}{c} \\
\text { 옴 }\end{array}$ & $\begin{array}{l}\text { C - Localização do } \\
\text { fornecedor/parceiro }\end{array}$ & 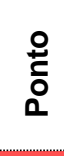 & $\begin{array}{c}\text { D - Características ge- } \\
\text { rais }\end{array}$ & $\stackrel{\stackrel{0}{\check{0}}}{\stackrel{0}{0}}$ & $\begin{array}{l}\text { E - Foco da } \\
\text { inovação }\end{array}$ & $\begin{array}{l}\stackrel{0}{\check{1}} \\
\stackrel{0}{0}\end{array}$ & F - Função & $\begin{array}{l}\stackrel{0}{c} \\
\stackrel{0}{0}\end{array}$ & Total \\
\hline $\begin{array}{l}\text { Osborne } \\
\text { House }\end{array}$ & $\begin{array}{l}\text { Sistema de } \\
\text { painel estrutu- } \\
\text { ral com isola- } \\
\text { mento térmico }\end{array}$ & 1 & Sim & 3 & 50 fornecedores & 1 & $\begin{array}{l}\text { Utiliza painel estrutural } \\
\text { com isolamento. } \\
\text { Telhado e piso erguidos } \\
\text { em } 1,5 \text { dias }\end{array}$ & 1 & $\begin{array}{l}\text { Construção } \\
\text { mais rápida }\end{array}$ & 2 & Residencial & 3 & 1.8 \\
\hline $\begin{array}{l}\text { Willmott Di- } \\
\text { xon Heal- } \\
\text { thcare } \\
\text { Campus }\end{array}$ & $\begin{array}{l}\text { Sistema de } \\
\text { painel de ma- } \\
\text { deira }\end{array}$ & 1 & Sim & 3 & 49 fornecedores & 1 & $\begin{array}{l}\text { Sistema de coleta de } \\
\text { energia desenvolvido por } \\
\text { The Facility, baixo con- } \\
\text { sumo de energia, ventila- } \\
\text { ção natural }\end{array}$ & 1 & Retrofit & 1 & Hospital & 1 & 1.3 \\
\hline $\begin{array}{l}\text { Hanson } \\
\text { EcoHouse }\end{array}$ & $\begin{array}{l}\text { Vedação ex- } \\
\text { terna de bloco } \\
\text { cerâmico pré- } \\
\text { fabricada }\end{array}$ & 2 & Sim & 3 & $\begin{array}{l}\text { Hanson (Stewartby, } \\
\text { Bedford, MK43 9LZ) }\end{array}$ & 3 & $\begin{array}{l}\text { A primeira casa de alve- } \\
\text { naria projetado com nível } \\
4 \text { do Código de Casas } \\
\text { Sustentáveis }\end{array}$ & 2 & $\begin{array}{l}\text { Paineis de } \\
\text { alvenaria } \\
\text { muito efici- } \\
\text { entes }\end{array}$ & 2 & Residencial & 3 & 2.5 \\
\hline $\begin{array}{l}\text { Sigma- } \\
\text { Rexel Home }\end{array}$ & $\begin{array}{l}\text { Estruturas pré- } \\
\text { fabricadas }\end{array}$ & 1 & Sim & 3 & $\begin{array}{l}\text { Stewart Milne Group } \\
\text { (Scotland) } \\
\text { Rexel Energy Solu- } \\
\text { tions (Rainham } \\
\text { Road, South Dagen- } \\
\text { ham, Essex, RM10 } \\
\text { 8SX) }\end{array}$ & 2 & $\begin{array}{l}\text { Sistema de fundação mo- } \\
\text { dular usando estruturas } \\
\text { pré-fabricadas, alto índice } \\
\text { de isolamento feito com } \\
\text { vedações de paineis de } \\
\text { madeira; } 3 \text { diferentes ti- } \\
\text { pos de madeira pré- } \\
\text { fabricada; and pre- } \\
\text { insulated roof cassettes. } \\
\text { Elementos do banheiro } \\
\text { pré-fabricados }\end{array}$ & 1 & $\begin{array}{l}\text { Altos índices } \\
\text { de isolamen- } \\
\text { to, energia } \\
\text { renovável, } \\
\text { métodos } \\
\text { modernos } \\
\text { de constru- } \\
\text { ção }\end{array}$ & 1 & Residencial & 3 & 1.8 \\
\hline $\begin{array}{l}\text { Barratt } \\
\text { Green Hou- } \\
\text { se }\end{array}$ & $\begin{array}{l}180 \mathrm{~mm} \text { de } \\
\text { camada de iso- } \\
\text { lamento de alta } \\
\text { performance } \\
\text { envolvendo as } \\
\text { vedações da } \\
\text { casa para } \\
\text { manter o calor } \\
\text { dentro da habi- } \\
\text { tação }\end{array}$ & 1 & Sim & 3 & $\begin{array}{l}\text { Barratt Development } \\
\text { PLC (Fitzrovia, Lon- } \\
\text { don W1W 8AJ, } \\
\text { Coalville Leicester- } \\
\text { shire LE67 1UF) }\end{array}$ & 2 & $\begin{array}{l}\text { Altos níveis de redução } \\
\text { de troca térmica, o que } \\
\text { reduz a necessidade de } \\
\text { refrigeração durante o ve- } \\
\text { rão e aquecimento no in- } \\
\text { verno }\end{array}$ & 1 & $\begin{array}{l}\text { Casa zero } \\
\text { carbono }\end{array}$ & 1 & Residencial & 3 & 1.8 \\
\hline
\end{tabular}




\begin{tabular}{|c|c|c|c|c|c|c|c|c|c|c|c|c|c|}
\hline $\begin{array}{l}\text { Renewable } \\
\text { House }\end{array}$ & $\begin{array}{l}\text { Frame de ma- } \\
\text { deira e } \\
\text { Hemcrete } \AA \\
\text { com emboço } \\
\text { externo de cal }\end{array}$ & 1 & Sim & 3 & 5 fornecedores & 2 & $\begin{array}{l}\text { Construída com materiais } \\
\text { energia renovável, mate- } \\
\text { riais de baixo carbon, in- } \\
\text { cluindo madeira }\end{array}$ & 1 & $\begin{array}{l}\text { Totalmente } \\
\text { de materias } \\
\text { renováveis }\end{array}$ & 2 & Residencial & 3 & 2.0 \\
\hline Cub House & $\begin{array}{l}\text { Frame modular } \\
\text { de aço } 65-90 \% \\
\text { reciclado }\end{array}$ & 1 & Sim & 3 & 50 fornecedores & 1 & $\begin{array}{l}\text { Fabricada com no mínimo } \\
65 \% \text { de aço recicladol } \\
\text { Resistente ao fogo e à } \\
\text { enchentes }\end{array}$ & 1 & $\begin{array}{l}\text { Materiais } \\
\text { recicláveis } \\
\text { de baixo } \\
\text { custo }\end{array}$ & 1 & Residencial & 3 & 1.7 \\
\hline $\begin{array}{l}\text { Victorian } \\
\text { Terrace }\end{array}$ & Blocos sólidos & 1 & Sim & 3 & $\begin{array}{l}\text { Micronol } \\
\text { Wallite } \\
\text { Velux }\end{array}$ & 2 & $\begin{array}{l}\text { Aerogels, Grey EPS, iso- } \\
\text { lamento Thermafleece, } \\
\text { isolamento Spray foam, } \\
\text { janelas e portas com vi- } \\
\text { dros triplos }\end{array}$ & 1 & Retrofit & 1 & Laboratórios & 1 & 1.5 \\
\hline $\begin{array}{l}\text { Prince's Na- } \\
\text { tural House }\end{array}$ & $\begin{array}{l}\text { Blocos cerâmi- } \\
\text { cos e arga- } \\
\text { massa de cal }\end{array}$ & 3 & Sim & 3 & NBT & 3 & $\begin{array}{l}\text { Construída com materiais } \\
\text { naturais, construção sim- } \\
\text { ples, habilidades conven- } \\
\text { cionais, mais rápida que o } \\
\text { bloco tradicional e com } \\
\text { estratégias de baixo car- } \\
\text { bono }\end{array}$ & 3 & $\begin{array}{l}\text { Construir } \\
\text { algo sim- } \\
\text { ples, tradici- } \\
\text { onal e sus- } \\
\text { tentável }\end{array}$ & 3 & Residencial & 3 & 3.0 \\
\hline $\begin{array}{l}\text { Smart Ho- } \\
\text { me }\end{array}$ & Timber SIPs & 1 & Sim & 3 & $\begin{array}{l}\text { Informação não dis- } \\
\text { ponível nos docu- } \\
\text { mentos avaliados }\end{array}$ & 1 & $\begin{array}{l}\text { Seleção de materiais sus- } \\
\text { tentáveis para envoltória, } \\
\text { baixa energia incorpora- } \\
\text { da, longo ciclo de vida e } \\
\text { baixa manutenção }\end{array}$ & 2 & $\begin{array}{l}\text { Baixo car- } \\
\text { bon, casa } \\
\text { eco-eficiente }\end{array}$ & 1 & Residencial & 3 & 1.8 \\
\hline
\end{tabular}




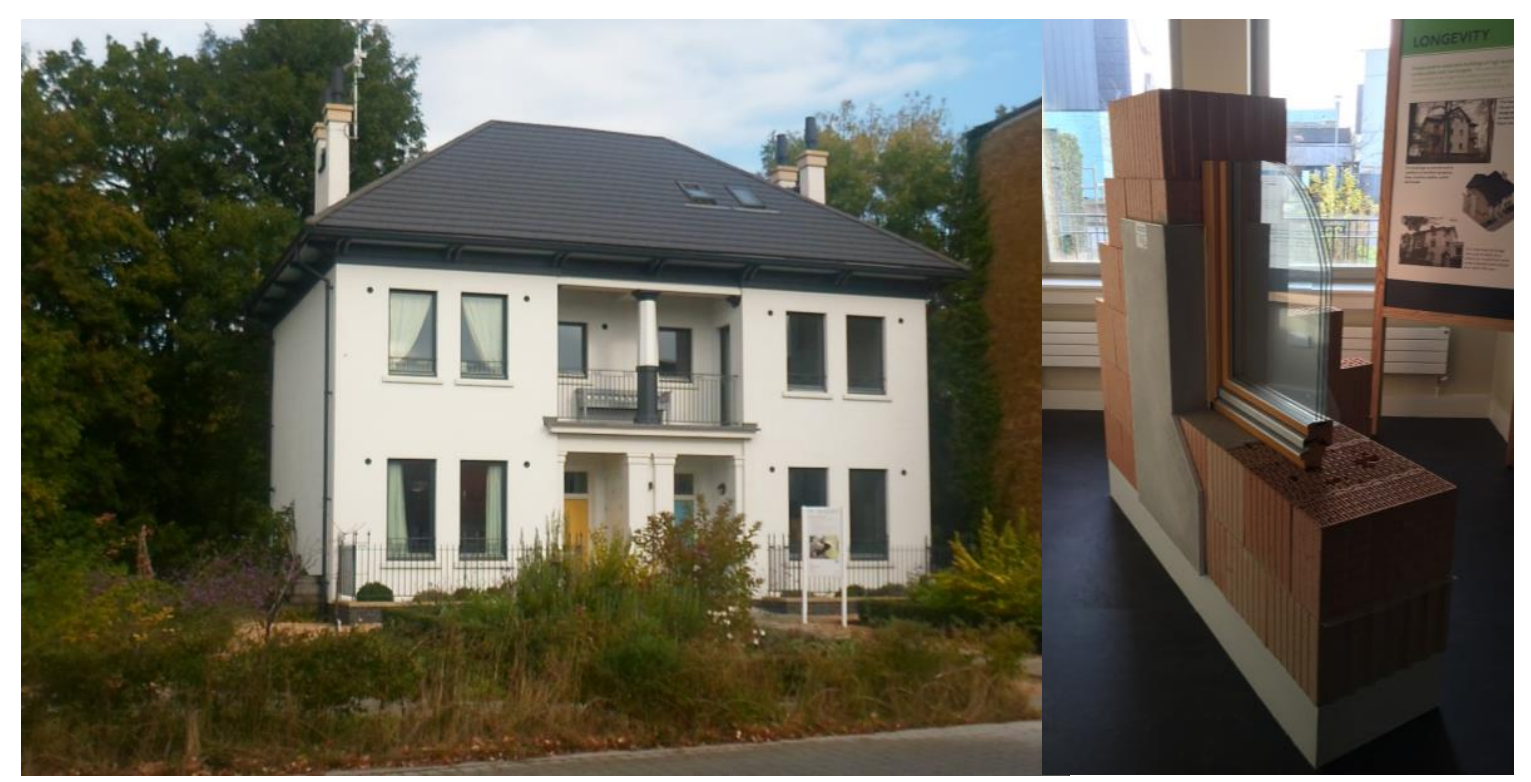

Figura 34: Casa do Príncipe e sistema construtivo da vedação. Fonte: do autor.

\subsubsection{Sistema Construtivo da Casa do Príncipe}

A vedação vertical é constituída por blocos cerâmicos porosos no formato 425x248x249mm (LxAxC) assentada sobre membrana a prova de umidade com fiada vertical seca e $1 \mathrm{~mm}$ de fiada horizontal de argamassa industrializada, utilizando para isso um rolo que reduz o desperdício e permite uma cobertura adequada. A primeira fileira de blocos é assentada com o auxílio da linha e nível e, por se tratar de uma vedação vertical externa autoportante, cada bloco é assentado utilizando o encaixe do bloco para manter a união, estabilidade e alinhamento do conjunto (NBT, 2013).

Internamente, a vedação recebe duas camadas de acabamento, sendo $12 \mathrm{~mm}$ de argamassa industrializada e $3 \mathrm{~mm}$ de acabamento e, externamente, $15 \mathrm{~mm}$ de argamassa e $3 \mathrm{~mm}$ de acabamento, o que totaliza uma vedação de 458mm. As argamassas são aplicadas utilizando um misturador vaporizador, que não só espalha a argamassa na superfície da vedação, como também adiciona água e mistura a argamassa (WIENERBERGER, 2014). A Figura 35 mostra o processo de construção da vedação utilizando o sistema construtivo da Casa do Príncipe.

No entanto, assim como os acabamentos não foram considerados na tipologia brasileira, foram retiradas da análise as camadas externa e interna de acabamento da vedação. Também não foram considerados os elementos de fixação da vedação e estrutura e os materiais de embalagem. 

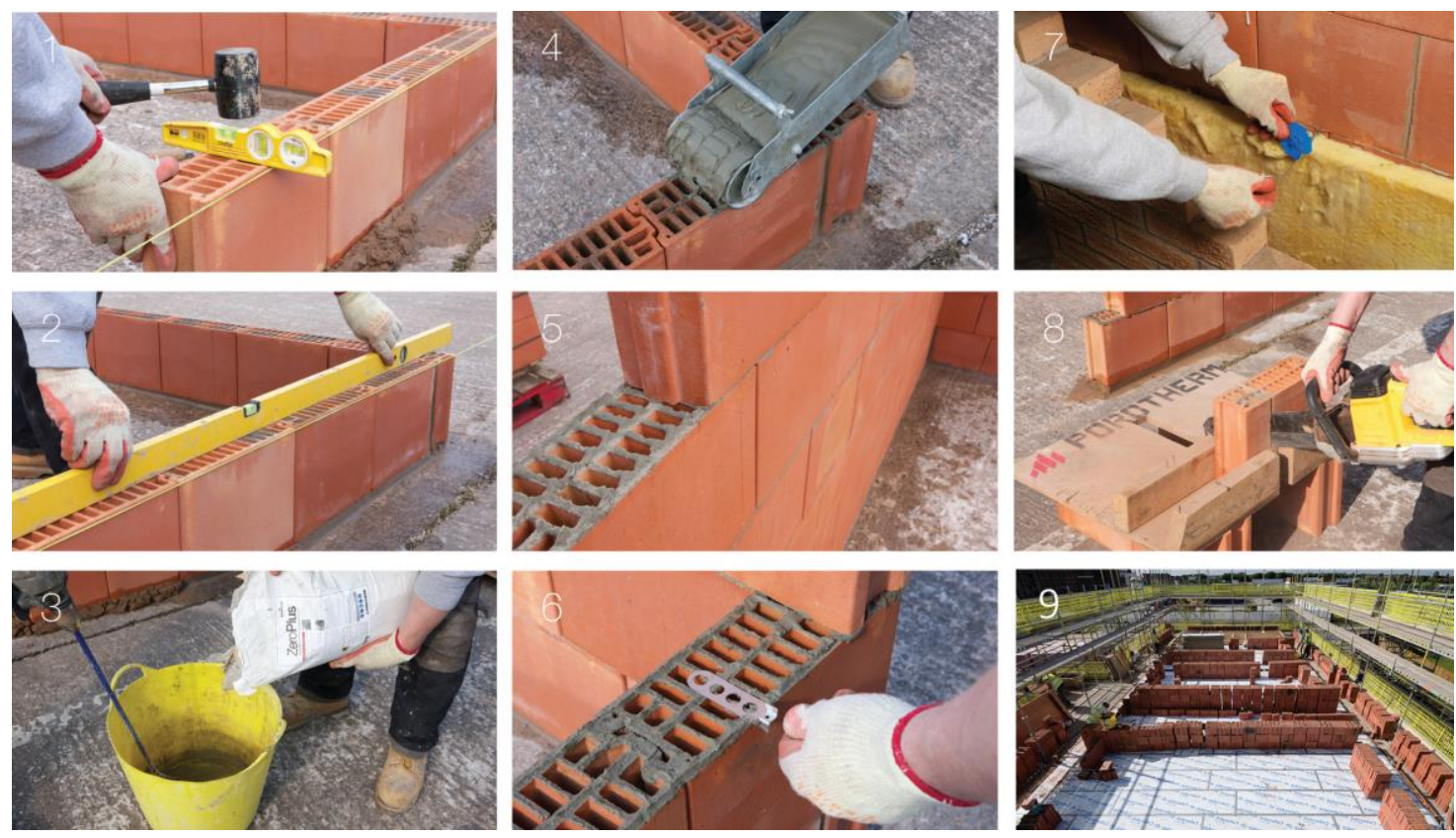

Figura 35: Processo de construção da vedação de bloco cerâmico. Fonte: Wienerberger, 2014

\subsection{Fim da vida e benefícios da vedação de blocos cerâmicos}

Para as etapas de fim da vida e benefícios da vedação foi considerado o modelo adotado pela BRE para o desenvolvimento dos cenários de descarte e reaproveitamento (BRE, 2014). Após a demolição da vedação, os resíduos da demolição podem ser reutilizados na própria obra ou levados a áreas de transbordo onde parte do resíduo é reciclado e o restante é descartado como resíduo inerte.

No Reino Unido, considera-se que $90 \%$ do resíduo da construção e demolição é reciclado e transformado em agregado miúdo que pode ser empregado para a fabricação de blocos, argamassas, sub-base de pavimentação, terraplanagem, aterramento e outros usos. Os demais $10 \%$ são descartados em aterros sanitários como material inerte (BRE, 2014).

Os dados da reciclagem de materiais da construção no Brasil ainda não foram contabilizados de forma a se ter um dado que defina qual é a porcentagem de reciclagem. Por isso, adotou-se o percentual de reciclagem de $2 \%$ para os resíduos, que segundo Abrelpe (2013) é a taxa média de reciclagem dos resíduos sólidos urbanos nos municípios brasileiros. Sendo assim, 98\% dos resíduos são depositados em aterros sanitários como material inerte. 


\subsection{Recorte da pesquisa}

Considerando as possibilidades de combinações existentes entre os blocos apresentados, a argamassa de assentamento, o tipo de chapisco e o emboço, foram necessários alguns recortes na pesquisa (Quadro 9):

Quadro 9: Recortes da tipologia considerada para este estudo.

\begin{tabular}{ll}
\hline Recorte & Justificativa \\
\hline $\begin{array}{l}\text { Tipologias para vedações } \\
\text { externas }\end{array}$ & $\begin{array}{l}\text { Os requisitos de Desempenho Térmico são aplicados somente às vedações } \\
\text { externas da habitação }\end{array}$ \\
\hline $\begin{array}{l}\text { Vedação sem função es- } \\
\text { trutural }\end{array}$ & $\begin{array}{l}\text { Os requisitos de Desempenho Estrutural não foram considerados devido à } \\
\text { complexidade que essa variável insere na análise da tipologia }\end{array}$ \\
\hline Blocos Inteiros & $\begin{array}{l}\text { Para reduzir a complexidade do cálculo e da análise foram considerados } \\
\text { para } 1 \text { m² }^{2} \text { de vedação apenas os blocos inteiros da família de blocos. Sendo } \\
\text { assim, foram descartados os meio-blocos, as canaletas e as meia canaletas }\end{array}$ \\
\hline Sem rasgos & $\begin{array}{l}\text { Os rasgos na vedação podem aumentar a taxa de perda dos blocos, depen- } \\
\text { dendo da técnica empregada para a execução }\end{array}$ \\
\hline Sem aberturas & $\begin{array}{l}\text { As aberturas podem ser descontadas do total de metros quadrados de ve- } \\
\text { dação que serão construídos na habitação, ao analisar-se a edificação co- } \\
\text { mo um todo }\end{array}$ \\
\hline Elementos de ligação en- & $\begin{array}{l}\text { Para reduzir a complexidade de matérias-primas e processos utilizados na } \\
\text { execução da vedação, foram desconsiderados os elementos de ligação }\end{array}$ \\
\hline tre a vedação e a estrutura & $\begin{array}{l}\text { Também não foram considerados os componentes para acabamento, como } \\
\text { tintas, impermeabilizantes, revestimentos, etc. }\end{array}$ \\
\hline Acabamento &
\end{tabular}

\section{Síntese analítica do Capítulo 3}

Considerando a edificação como um sistema, o subsistema Vedação Vertical é um importante fator no desempenho térmico, acústico e de estanqueidade da edificação, além de abrir frente para a execução de outros subsistemas e empregar um grande volume de materiais que, muitas vezes, possuem altas taxas de desperdício.

Dentre os tipos de Vedações Verticais, a mais utilizada no Brasil é a de blocos, o que permite uma maior quantidade de dados e estudos referentes ao desempenho desse tipo de vedação, além de permitir trabalhar com um tema que pode ser aplicado à realidade da construção no Brasil.

A utilização dos requisitos de desempenho das vedações verticais pode permite uma maior precisão na caracterização do escopo da ACV, considerando o papel da vedação e não os materiais utilizados para a sua construção. A tipologia da vedação torna-se coadjuvante frente a função desempenhada 
desviando o foco dos materiais empregados para a execução da vedação. Sendo assim, esses dados serão utilizados no Capítulo 4, onde será definida a função e unidade funcional.

Considerando-se o recorte feito, as vedações desta pesquisa são constituídas de blocos cerâmicos vazados, argamassa de assentamento e as argamassas de revestimento para chapisco e emboço. Para as vedações do Reino Unido e do Brasil foram descritas as fases do ciclo de vida de extração da matéria-prima, fabricação dos componentes, transporte dos componentes, construção da vedação, disposição final dos resíduos e benefícios resultantes da reciclagem, reuso ou reaproveitamento.

Os blocos cerâmicos vazados podem ter função estrutural ou de fechamento e são fabricados por meio da mistura de argilas, água e, ou agregados, extrudidos, secos e cozidos em fornos de diferentes níveis tecnológicos e com diferentes tipos de combustíveis, sendo a biomassa o combustível mais usado no Brasil e o gás natural no Reino Unido.

As vedações são construídas com o assentamento manual dos blocos e com aplicação manual ou projetada mecanicamente as argamassas de assentamento e de revestimento. $O$ transporte das matérias-primas e dos componentes é feito por meio de caminhões a diesel, assim como o transporte dos resíduos da construção durante a fase de construção e de demolição.

No Brasil, optou-se por estudar a vedação de forma mais ampla abrangendo diferentes níveis tecnológicos da cadeia produtiva. Porém, devido ao tempo restrito para o desenvolvimento da pesquisa no Reino Unido, optou-se por estudar uma vedação de um protótipo do Parque de Inovações da BRE, o que facilitou a coleta de dados primários e o uso de dados secundários já disponíveis no banco de dados de ACV da BRE.

A vedação dos protótipos que mais se assemelha à vedação estudada no Brasil foi a vedação externa da Casa do Príncipe composta por blocos cerâmicos porosos, argamassa de assentamento com tela fixadora e argamassa de emboço, que posteriormente era coberta por uma camada de acabamento. 


\section{Capítulo 3: Modelagem - Objetivo e escopo}

Neste capítulo são definidos elementos básicos para o início de um estudo de ACV: objetivo e escopo. Essas informações fornecem subsídios para a modelagem e os resultados apresentados nos Capítulo 4 e 5.

Como visto no Capítulo 1, no objetivo da ACV são caracterizados os elementos obrigatórios qual é a aplicação prevista deste estudo, quais são as limitações identificadas, contexto decisório, quais comparações podem ser feitas, atores envolvidos, situação econômica de aplicação e a relação de documentos de referência utilizados para o desenvolvimento do estudo.

No escopo são definidos as regras para o tratamento das inconsistências; a função e unidade funcional do produto; as regras para informações confidenciais; o tipo de resultados esperado; o fluxo de referência; as fronteiras do sistema; a listagem de exclusões; os critérios de corte da avaliação; as categorias de impacto consideradas, bem como o método de AICV aplicado; os métodos de normalização e ponderação; a representatividade tecnológica, geográfica e temporal; quais são as fontes de dados e se existem dados primários; os requisitos de qualidade mínimos; como será o cálculo de incertezas, de completude e de sensibilidade; e quais são as comparações, os cenários e as alternativas de análise.

\subsection{Objetivo}

\subsubsection{Aplicação, limitações e contexto decisório}

O objetivo é quantificar os potenciais impactos ambientais relacionados à produção de vedações de bloco cerâmico que atendam aos requisitos de desempenho térmico e acústico do Brasil e do Reino Unido, tendo em vista a construção de um modelo que, por meio de parâmetros, possa gerar resultados comparativos ou demonstrativos para diferentes tipologias de vedação.

Quanto às limitações, foram analisados os impactos obrigatórios da EN 15.804, que define como devem ser feitas as declarações ambientais de produtos tipo III na Europa. Quanto às premissas, deverá ser considerada a variabili- 
dade nos tipos de processos produtivos da cadeia produtiva da vedação de bloco cerâmico. Nesta pesquisa foram adotadas as seguintes premissas:

- O solo usado não precisa de correção da sua granulometria;

- As distâncias percorridas pelos caminhões foram fixadas em 100 km para facilitar os cálculos e permitir a multiplicação dos valores em casos de distâncias maiores;

- Os caminhões usados foram o modelo Truck com capacidade de carga de 12t (modelo disponível no banco de dados do GaBi 6);

- Quanto ao contexto decisório, foi utilizada a modelagem atribucional, analisando a sensibilidade por meio de variáveis.

\subsubsection{Públicos-alvo}

Os públicos-alvo são a comunidade acadêmica, o setor privado, os consumidores e o Governo. A comunidade acadêmica tem na pesquisa uma fonte de informações, além da geração de dados no estudo do bloco cerâmico. No setor privado, tem-se como públicos as indústrias produtoras das matériasprimas, os fabricantes, as construtoras e as instituições representantes do setor. Como exemplo, citam-se a Associação Nacional da Indústria Cerâmica (ANICER), que elaborou uma ACV média para os produtos cerâmicos, comparando-os aos produtos em cimento Portland equivalentes.

Por meio do demonstrativo das vantagens e desvantagens dos produtos comparados, os consumidores têm mais informação e poderão tomar decisões de forma mais consciente, incluindo particularmente especificadores de materiais, como engenheiros, arquitetos e projetistas. Para o Governo, a análise fortalecerá o PBACV, uma vez que foi construído com base na plataforma internacional de dados de ACV: o ILCD.

3.1.3. Comparações, atores envolvidos, situação e documentos de referência

Nesta pesquisa, foram comparadas duas tipologias de vedação vertical brasileiras que atendam aos mesmos requisitos de desempenho térmico e acústico, mas construídas com materiais diferentes; e uma tipologia de vedação vertical britânica aplicada hipoteticamente em habitações no Brasil e de fato em habitações no Reino Unido considerando os requisitos de desempenho 
de cada país. Os atores envolvidos nesta pesquisa são a Universidade de Brasília e a Building Research Establishment (BRE).

Quanto a situação, o ILCD classifica os níveis de decisão de uma ACV como micro (situação $A$ ), médio/macro (situação $B$ ) e contábeis com inclusão de interações com outros sistemas e sem interações com outros sistemas (situações C1 e C2). A avaliação desta pesquisa está classificada na situação $A$, que considera o produto em si, mas fabricado por diferentes níveis tecnológicos de fabricantes e sistemas construtivos (JRC, 2010). Além do ILCD e das normas já mencionadas, o modelo foi construído tendo como base o Product $\mathrm{Ca}$ tegory Rule (PCR) utilizado na BRE (BRE, 2014).

\subsection{Escopo}

Além das recomendações e obrigatoriedades estabelecidas pelo manual ILCD (JRC, 2010) detalhadas no Capítulo 1, outras informações e passos foram inseridos no escopo a medida que se percebeu que as etapas previstas pelo ILCD não eram suficientes para o desenho de um modelo parametrizado que fosse o mais genérico possível, sem perder as características fundamentais, e que pudesse receber mais dados e fases do ciclo de vida do produto em trabalhos futuros. Ao final do processo de desenvolvimento do modelo será apresentado uma esquematização com as etapas do ILCD acrescidos dos passos complementares e essenciais inseridos ao longo desta pesquisa.

\subsubsection{Inconsistências, confidencialidades e resultados esperados}

Definiu-se que as inconsistências deveriam ser revistas e corrigidas, dentro do possível, por meio de revisões críticas feitas em três rodadas ao longo do processo de modelagem, tanto nos métodos utilizados, quanto nas premissas e dados coletados. As informações confidenciais foram agregadas e os valores divulgados foram médias dos dados fornecidos pelos produtores.

Com essa ACV obteve-se um MTP para vedações verticais elaborado e testado, considerando vedações de bloco cerâmico. Obteve-se ainda a quantificação dos impactos ambientais de pontos médios para as categorias de impacto obrigatórias para a emissão de uma DAP, segundo a EN 15.804 (BSI, 2014). Além disso, foram obtidos dados do consumo de energia e matérias- 
primas dos processos analisados, bem como as causas para os processos mais impactantes.

\subsubsection{Função e unidade funcional}

Para a definição desses dois critérios, utilizaram-se os requisitos de desempenho térmico e acústico das vedações do Brasil e do Reino Unido. Para isso, esses requisitos foram comparados com as tipologias que os cumpre.

3.2.2.1. Os requisitos de desempenho térmico e acústico e a caracterização das tipologias da vedação de bloco cerâmico no Brasil e no Reino Unido

O Guia Orientativo para atendimento à Norma ABNT NBR 15.575 (CBIC, 2013) traz uma tabela com tipologias de vedações e os valores indicativos do índice de redução sonora ponderado. Dessa tabela foram extraídos os dados referentes às tipologias de vedação de blocos (Quadro 10).

A análise feita quanto ao cumprimento dos requisitos da norma ABNT NBR 10.152 não foi considerada no Quadro 10, pois a faixa de limite de isolamento acústico se refere ao ruído que pode ver percebido no interior dos cômodos e, por isso, o nível de isolamento indicado em cada tipologia não é suficiente para afirmar que somente esse nível de ruído será audível no cômodo.

Quadro 10: Índice de redução sonora ponderado para vedações. Fonte: do autor, baseado em IPT (2011) apud CBIC (2013)

\begin{tabular}{|c|c|c|c|}
\hline Descrição da vedação & $\begin{array}{l}\text { Massa } \\
\text { aproxima- } \\
\text { da }\end{array}$ & $\begin{array}{c}\mathbf{R}_{\mathbf{w}} \\
(\mathrm{dBA})\end{array}$ & Desempenho Acústico (NBR 15.575) \\
\hline $\begin{array}{l}\text { Blocos vazados de concre- } \\
\text { to, } 9 \mathrm{~cm}(\mathrm{~L}) \text {, argamassa } 1,5 \\
\mathrm{~cm} \text { em cada face }\end{array}$ & $180 \mathrm{~kg} / \mathrm{m}^{2}$ & 41 & $\begin{array}{l}\text { Salas, cozinhas e áreas comuns entre unidades } \\
\text { (I); e Classes I, II e III de vedações externas (S) }\end{array}$ \\
\hline $\begin{array}{l}\text { Blocos vazados de concre- } \\
\text { to, } 11,5 \mathrm{~cm}(\mathrm{~L}) \text {, argamassa } \\
1,5 \mathrm{~cm} \text { em cada face }\end{array}$ & $210 \mathrm{~kg} / \mathrm{m}^{2}$ & 42 & $\begin{array}{l}\text { Salas, cozinhas e áreas comuns entre unidades } \\
\text { (I); e Classes I, II e III de vedações externas (S) }\end{array}$ \\
\hline $\begin{array}{l}\text { Blocos vazados de concre- } \\
\text { to, } 14,0 \mathrm{~cm}(\mathrm{~L}) \text {, argamassa } \\
1,5 \mathrm{~cm} \text { em cada face }\end{array}$ & $230 \mathrm{~kg} / \mathrm{m}^{2}$ & 45 & $\begin{array}{c}\text { Todos os cômodos menos dormitório entre uni- } \\
\text { dades (M); salas, cozinhas e áreas comuns en- } \\
\text { tre unidades (S); unidades distintas separadas } \\
\text { pelo hall (M); e Classes I, II e III de vedações } \\
\text { externas (S) }\end{array}$ \\
\hline $\begin{array}{l}\text { Blocos vazados cerâmi- } \\
\cos ^{19}, 9 \mathrm{~cm}(L), \text { argamassa } \\
1,5 \mathrm{~cm} \text { em cada face }\end{array}$ & 120 kg/m² & 38 & $\begin{array}{l}\text { Salas, cozinhas e áreas comuns entre unidades } \\
\text { (M); classe I de vedações externas (S); e clas- } \\
\text { ses II e III de vedações externas (I) }\end{array}$ \\
\hline
\end{tabular}

\footnotetext{
${ }^{19}$ Os valores das alvenarias referem-se a ensaios realizados com juntas horizontais e juntas verticais totalmente preenchidas. Para blocos cerâmicos vazados pode haver variações significativas em função da geometria e direção dos furos (CBIC, 2013).
} 


\begin{tabular}{|c|c|c|c|}
\hline $\begin{array}{l}\text { Blocos vazados cerâmicos, } \\
11,5 \mathrm{~cm}(\mathrm{~L}) \text {, argamassa } 1,5 \\
\mathrm{~cm} \text { em cada face }\end{array}$ & $150 \mathrm{~kg} / \mathrm{m}^{2}$ & 40 & $\begin{array}{l}\text { Salas, cozinhas e áreas comuns entre unidades } \\
\text { (I); e Classes I, II e III de vedações externas (S) }\end{array}$ \\
\hline $\begin{array}{l}\text { Blocos vazados cerâmicos, } \\
14 \mathrm{~cm}(\mathrm{~L}), \text { argamassa } 1,5 \\
\mathrm{~cm} \text { em cada face }\end{array}$ & $180 \mathrm{~kg} / \mathrm{m}^{2}$ & 42 & $\begin{array}{l}\text { Salas, cozinhas e áreas comuns entre unidades } \\
\text { (I); e Classes I, II e III de vedações externas (S) }\end{array}$ \\
\hline \multicolumn{4}{|l|}{ Legenda } \\
\hline \multicolumn{4}{|c|}{ Tipologia que atende aos requisitos de } \\
\hline \multicolumn{4}{|c|}{ Em áreas específicas da edificação; } \\
\hline \multicolumn{4}{|c|}{ Tipologia que atende aos requisitos de desempenho acústico; } \\
\hline \multicolumn{4}{|c|}{ Tipologia que não atende aos requisitos de desempenho acústico. } \\
\hline
\end{tabular}

A isolação acústica das vedações maciças é regida pela Lei das Massas, sendo assim, quanto mais pesada uma vedação, maior será o seu isolamento acústico. Para massas a partir de $120 \mathrm{~kg} / \mathrm{m}^{2}$, ao se dobrar a massa da vedação ocorre um maior isolamento acústico de $6 \mathrm{~dB}$.

Segundo CBIC (2013), o isolamento acústico pode ser estimado por meio de fórmulas. No entanto, o uso de fórmulas não é viável para o presente estudo, visto que as vedações constituídas por blocos vazados possuem uma série de fatores que influenciam na isolação acústica, tais como geometria e massa, disposição e formato dos furos, rugosidade superficial do material, etc. Além disso, a presença de frestas nas vedações externas pode reduzir em até $30 \%$ a isolamento acústico da envoltória do edifício e a adoção de junta seca nas alvenarias também pode comprometer o isolamento acústico (CBIC, 2013).

Para o desempenho térmico, a sua definição vai depender de vários fatores como a aberturas para ventilação, o zoneamento bioclimático onde se localiza a edificação, estratégias bioclimáticas adotadas, as características da cobertura e das vedações externas, etc.

Apesar da importância da combinação desses fatores para o desempenho da edificação, esta pesquisa se concentra nas características que a vedação externa necessita para cumprir os requisitos de desempenho térmico de cada zoneamento bioclimático no Brasil.

A Norma ABNT NBR 15.220-3 Anexo D (ABNT, 2003) traz uma listagem de tipologias de vedações verticais e os dados de transmitância térmica $(U)$, capacidade térmica $\left(\mathrm{C}_{\mathrm{T}}\right)$ e atraso térmico $(\varphi)$. Outro material de referência utilizado é o Selo Azul da Caixa (JOHN et al, 2010), que complementa as tipologias descritas na ABNT NBR 15.220-3 (ABNT, 2003). 


\section{Com base nas listagens das duas publicações elaborou-se o Quadro}

\section{1, que é uma compilação das tipologias apresentadas nas publicações com os}

resultados do desempenho térmico exigido pelas normas.

Quadro 11: Tipologias de vedação e dados de transmitância térmica, capacidade térmica e atraso térmico. Fonte: do autor, baseado em ABNT (2003) e John et al (2010)

\begin{tabular}{|c|c|c|c|c|}
\hline Vedação & Descrição & $\underset{[W /(m}{U}$ & $\begin{array}{c}\mathbf{C}_{\mathrm{T}} \\
{\left[\mathrm{kJ} /\left(\mathrm{m}^{2} \cdot \mathrm{K}\right)\right.} \\
]\end{array}$ & Desempenho Térmico \\
\hline & $\begin{array}{l}\text { Bloco } 6 \text { furos quadrados }(9,0 \times \\
14,0 \times 19,0 \mathrm{~cm}) \\
\text { Argamassa interna e externa: } \\
2,5 \mathrm{~cm}\end{array}$ & 2,48 & 159 & Para qualquer zona. \\
\hline & $\begin{array}{l}\text { Tijolo } 8 \text { furos quadrados }(9,0 \times \\
19,0 \times 19,0 \mathrm{~cm}) \\
\text { Argamassa interna e externa: } \\
2,5 \mathrm{~cm}\end{array}$ & 2,49 & 158 & Para qualquer zona. \\
\hline & $\begin{array}{l}\text { Tijolos } 6 \text { furos quadrados }(9,0 \\
\text { x14,0 x } 19,0 \mathrm{~cm}) \\
\text { Argamassa interna e externa: } \\
2,5 \mathrm{~cm}\end{array}$ & 2,02 & 192 & Para qualquer zona. \\
\hline & $\begin{array}{l}\text { Tijolos } 8 \text { furos quadrados }(9,0 \\
\times 19,0 \times 19,0 \mathrm{~cm}) \\
\text { Argamassa interna e externa: } \\
2,5 \mathrm{~cm}\end{array}$ & 1,80 & 231 & Para qualquer zona. \\
\hline & $\begin{array}{l}\text { Bloco de concreto }(9,0 \times 19,0 \times \\
39,0 \mathrm{~cm}) \\
\text { Argamassa interne e externa } \\
(2,5 \mathrm{~cm})\end{array}$ & 2,86 & 203 & $\begin{array}{l}\text { Pode ser usada nas zonas } 3,4 \\
\quad 5,6,7 \text { e } 8 \text { com } \alpha^{a} \leq 0,6\end{array}$ \\
\hline & $\begin{array}{l}\text { Gesso interno }(2,0 \mathrm{~cm}) \\
\text { Bloco de concreto }(9,0 \times 19,0 \times \\
39,0 \mathrm{~cm}) \\
\text { Argamassa externa }(2,5 \mathrm{~cm})\end{array}$ & 2,80 & 174 & $\begin{array}{l}\text { Pode ser usada nas zonas } 3,4 \\
5,6,7 \text { e } 8 \text { com } \alpha^{a} \leq 0,6\end{array}$ \\
\hline & $\begin{array}{l}\text { Sem revestimento interno } \\
\text { Bloco de concreto }(9,0 \times 19,0 \times \\
39,0 \mathrm{~cm}) \\
\text { Argamassa externa }(2,5 \mathrm{~cm})\end{array}$ & 3,09 & 157 & $\begin{array}{l}\text { Pode ser usada nas zonas } 3,4 \\
\quad 5,6,7 \text { e } 8 \text { com } \alpha^{a} \leq 0,6\end{array}$ \\
\hline & $\begin{array}{l}\text { Bloco de concreto }(14,0 \times 19,0 \\
\text { x } 39,0 \mathrm{~cm}) \\
\text { Argamassa interne e externa } \\
(2,5 \mathrm{~cm})\end{array}$ & 2,76 & 265 & $\begin{array}{l}\text { Pode ser usada nas zonas } 3,4 \\
\quad 5,6,7 \text { e } 8 \text { com } \alpha^{a} \leq 0,6\end{array}$ \\
\hline & $\begin{array}{l}\text { Gesso interno }(2,0 \mathrm{~cm}) \\
\text { Bloco de concreto }(14,0 \times 19,0 \\
\text { x } 39,0 \mathrm{~cm}) \\
\text { Argamassa externa }(2,5 \mathrm{~cm})\end{array}$ & 2,70 & 235 & $\begin{array}{l}\text { Pode ser usada nas zonas } 3,4 \\
5,6,7 \text { e } 8 \text { com } \alpha^{a} \leq 0,6\end{array}$ \\
\hline
\end{tabular}




\begin{tabular}{|c|c|c|c|c|c|}
\hline & & $\begin{array}{l}\text { Sem revestimento interno } \\
\text { Bloco de concreto }(14,0 \times 19,0 \\
\text { x } 39,0 \mathrm{~cm}) \\
\text { Argamassa externa }(2,5 \mathrm{~cm}) \\
\text { Pintura externa }(\alpha)\end{array}$ & 2,95 & 214 & $\begin{array}{l}\text { Pode ser usada nas zonas } 3,4 \text {, } \\
5,6,7 \text { e } 8 \text { com } \alpha^{a} \leq 0,6\end{array}$ \\
\hline & & $\begin{array}{l}\text { Bloco cerâmico }(9,0 \times 14,0 \times \\
24,0 \mathrm{~cm}) \\
\text { Argamassa interna e externa } \\
(2,5 \mathrm{~cm})\end{array}$ & 2,59 & 145 & $\begin{array}{l}\text { Pode ser usada nas zonas } 3,4 \text {, } \\
\qquad 5,6,7 \text { e } 8 \text { com } \alpha^{a} \leq 0,6\end{array}$ \\
\hline & & $\begin{array}{l}\text { Gesso interno }(2,0 \mathrm{~cm}) \\
\text { Bloco cerâmico }(9,0 \times 14,0 \times \\
24,0 \mathrm{~cm}) \\
\text { Argamassa externa }(2,5 \mathrm{~cm})\end{array}$ & 2,55 & 115 & Somente zona 8 com $\alpha^{a} \leq 0,6$ \\
\hline & & $\begin{array}{l}\text { Sem revestimento interno } \\
\text { Bloco cerâmico }(9,0 \text { x } 9,0 \times \\
24,0 \mathrm{~cm}) \\
\text { Argamassa externa }(2,5 \mathrm{~cm})\end{array}$ & 2,86 & 100 & Somente zona 8 com $\alpha^{a} \leq 0,6$ \\
\hline & & $\begin{array}{l}\text { Sem revestimento interno } \\
\text { Bloco cerâmico }(9,0 \times 9,0 \times \\
24,0 \mathrm{~cm}) \\
\text { Sem revestimento externo }\end{array}$ & 3,12 & 41 & Somente zona 8 com $\alpha^{a} \leq 0,6$ \\
\hline & & $\begin{array}{l}\text { Argamassa interna e externa } \\
(2,5 \mathrm{~cm}) \text {; } \\
\text { Bloco cerâmico }(14,0 \times 19,0 x \\
29,0 \mathrm{~cm})\end{array}$ & 1,98 & 156 & Para qualquer zona. \\
\hline & & $\begin{array}{l}\text { Gesso interno }(2,0 \mathrm{~cm}) \\
\text { Bloco cerâmico }(14,0 \times 19,0 \times \\
29,0 \mathrm{~cm}) \\
\text { Argamassa externa }(2,5 \mathrm{~cm})\end{array}$ & 1,89 & 122 & $\begin{array}{c}\text { Somente zona } 8 \text { sem restrição } \\
\text { de } \alpha^{a}\end{array}$ \\
\hline \multicolumn{6}{|l|}{ Legenda } \\
\hline & & $\begin{array}{l}\text { gia que atende aos requisitos de } \\
\text { eas específicas da edificação; } \\
\text { gia que atende aos requisitos de } \\
\text { gia que não atende aos requisitos }\end{array}$ & $\begin{array}{l}\text { sempe } \\
\text { sempe } \\
\text { e dese }\end{array}$ & $\begin{array}{l}\text { érmicc } \\
\text { érmicc } \\
\text { nho té }\end{array}$ & forma parcial ou somente \\
\hline
\end{tabular}

No contexto do Reino Unido o levantamento feito como no Brasil não foi necessário, visto que as vedações devem obedecer ao critério de 0,3 $\mathrm{W} / \mathrm{m}^{2}$.K para o desempenho térmico, ou seja, nenhum material que não atenda a esse requisito pode ser comercializado no mercado. Os requisitos acústicos são de $45 \mathrm{~dB}$ para as vedações verticais de casas ou apartamentos, porém para as vedações externas o requisito acústico não é obrigatório.

Considerando os dados levantados, a unidade funcional foi definida como $1 \mathrm{~m}^{2}$ de vedação vertical externa que atenda aos requisitos térmicos 
da Zona 6 e desempenho acústico maior ou igual a $41 \mathrm{~dB}$ para o caso das vedações brasileiras, considerando um ciclo de vida de 40 anos $^{20}$. Para $O$ Reino Unido, considerou-se $1 \mathrm{~m}^{2}$ de vedação vertical externa que atenda aos requisitos térmicos e um ciclo de vida de $\mathbf{4 0}$ anos $^{21}$.

Sendo assim, a vedação considerada neste estudo, para o contexto brasileiro, é externa, composta por blocos cerâmicos sem função estrutural e inteiros (14x19x29cm - LxAxC), argamassa de assentamento com $12 \mathrm{~mm}$ de espessura, chapisco e emboço com $2,5 \mathrm{~cm}^{22}$ de espessura de cada lado. Essa vedação possui: (i) U: $1,98 \mathrm{~W} / \mathrm{m}^{2}$.K; (ii) $\mathrm{CT}$ : $156 \mathrm{~kJ} / \mathrm{m}^{2} . \mathrm{K}$; e (iii) $\mathrm{Rw}$ : $42 \mathrm{~dB}{ }^{23}$. Para o Reino Unido considera-se como objeto de estudo a vedação da Casa do Príncipe que é externa, autoportante, composta por blocos cerâmicos porosos $(42,5 \times 24,8 \times 24,9 \mathrm{~cm}$ - LXAxC), $1 \mathrm{~mm}$ de fiada horizontal de argamassa de assentamento com tela de fibra, $12 \mathrm{~mm}$ de argamassa interna e $15 \mathrm{~mm}$ de argamassa externa. Essa vedação possui: (i) U: $0,20 \mathrm{~W} / \mathrm{m}^{2} . \mathrm{K}$.

\subsubsection{Limites do sistema}

Em uma ACV podem ser adotados diferentes limites, como ilustrado na Figura 36.

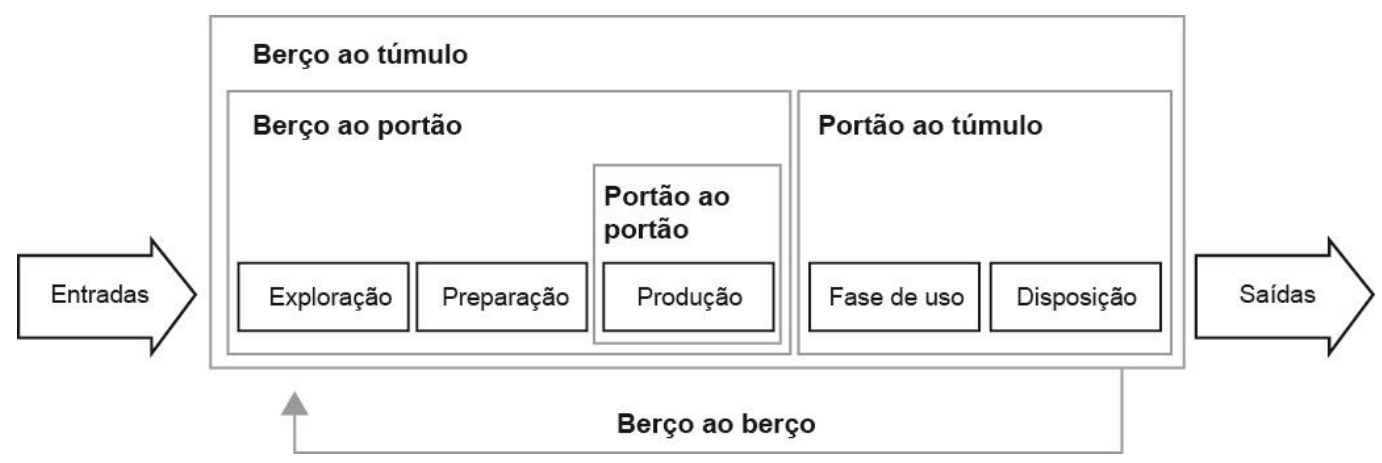

Figura 36: Limites de um modelo tecnológico de ACV. Fonte: PE International, 2011.

\footnotetext{
${ }^{20}$ Segundo a NBR 15.575 (ABNT, 2013), o ciclo de vida mínimo para uma vedação vertical externa são 40 anos.

${ }^{21}$ Para as vedações verticais externas utilizadas no Reino Unido, a BRE não considera o requisito acústico como relevante, visto que a espessura das vedações que cumprem ao requisito térmico estabelecido também possuem um isolamento acústico suficiente. O desempenho acústico é um requisito das vedações verticais internas, por exemplo.

${ }_{22}$ A espessura da argamassa usada no Quadro 10 é de $1,5 \mathrm{~cm}$ em cada face e o exemplo considerada uma espessura maior, $2,5 \mathrm{~cm}$ em cada face, o que demonstra que o desempenho acústico do exemplo citado é pelo menos tão eficiente quanto àquele de menor espessura. Sendo assim, a informação do Quadro 10 é válida para o exemplo descrito.

${ }^{23}$ Segundo método Ensaio de Laboratório do desempenho acústico (CBIC, 2013).
} 
A norma EN 15.804 (BSI, 2014) e a ISO 21.930 (BSI, 2007) estabelece que os estágios do ciclo de vida mínimos para uma DAP, no caso dos materiais da construção, são do "berço ao portão" mais a construção ou instalação do produto/material no canteiro de obras (Figura 37 ).

\begin{tabular}{|c|c|c|c|c|c|c|c|c|c|c|c|c|c|c|c|c|}
\hline \multicolumn{3}{|c|}{$\begin{array}{l}\text { Fase de Produ- } \\
\text { ção }\end{array}$} & \multicolumn{2}{|c|}{$\begin{array}{c}\text { Fase de } \\
\text { Construção }\end{array}$} & \multicolumn{7}{|c|}{ Fase de Uso } & \multicolumn{4}{|c|}{ Fase de fim da vida } & \multirow{2}{*}{$\begin{array}{c}\text { Benefícios } \\
\text { e cargas } \\
\text { além das } \\
\text { fronteiras } \\
\text { do sistema } \\
\text { D }\end{array}$} \\
\hline A1 & A2 & $\mathrm{A} 3$ & A4 & A5 & B1 & B2 & B3 & B4 & B5 & B6 & B7 & $\mathrm{C} 1$ & $\mathrm{C} 2$ & $\mathrm{C} 3$ & C4 & \\
\hline 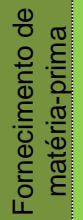 & $\begin{array}{l}\stackrel{0}{t} \\
\frac{0}{0} \\
\frac{0}{0} \\
\stackrel{0}{\pi} \\
\stackrel{0}{\models}\end{array}$ & 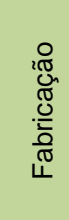 & 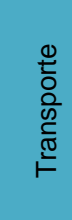 & 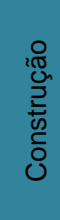 & $\stackrel{\wp}{\mathscr{D}}$ & 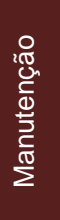 & $\begin{array}{l}\frac{0}{\pi} \\
\frac{0}{0} \\
\frac{0}{0}\end{array}$ & 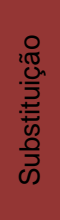 & 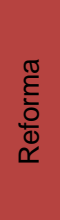 & 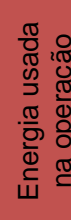 & 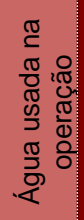 & 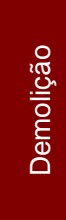 & 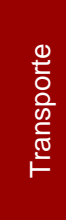 & 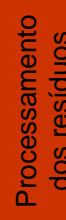 & 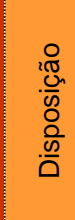 & 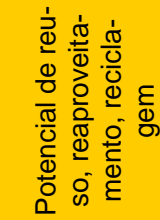 \\
\hline
\end{tabular}

Figura 37: Estágios do ciclo de vida de um produto da construção. Fonte: BSI, 2014.

Para essa modelagem, adotou-se como limites do sistema os estágios de fabricação e construção (A1 a A5), de fim da vida (C2 a C4) e de benefícios (D). Os estágios de fim da vida e de benefícios foram inseridos após a elaboração do modelo intermediário, o que implicou na revisão do escopo. Esse procedimento não compromete os resultados desta pesquisa, visto que a ACV prevê ciclos iterativos no desenvolvimento do modelo (JRC, 2010).

\subsubsection{Elaboração de modelos concretos}

Com a caracterização da cadeia é possível elaborar os modelos concretos da pesquisa baseados em objetos reais, que são o subsídio para a elaboração do objeto modelo, que por sua vez será utilizado para a construção do MTP. Com base na descrição da vedação, apresentada no Capítulo 2, elaboraram-se modelos concretos esquemáticos e reduzidos dessa cadeia, que combinam algumas possibilidades de produção do bloco cerâmico, argamassa de assentamento, chapisco e emboço. É possível ainda fazer outras combinações, totalizando mais de 960 combinações $^{24}$, por isso ilustram-se essa possibilidades com quatro objetos concretos (Figura 38).

\footnotetext{
${ }^{24}$ Combinação das variáveis: (a) três tipos de fornos (intermitente, semicontínuo e túnel); (b) quatro tipos de combustíveis: cavaco, serragem, lenha e retalho de móveis; (c) cinco tipos de secagem: natural e artificial com ou sem aproveitamento do calor dos fornos; (d) dois traços de chapisco; (e) dois traços de argamassa de assentamento; (f) dois traços de argamassa de revestimento; $(\mathrm{g})$ equipamento utilizado para o preparo das argamassas: manualmente ou com o auxílio de uma betoneira; (h) um modelo de bloco cerâmico; e (i) constantes as espessuras das argamassas.
} 

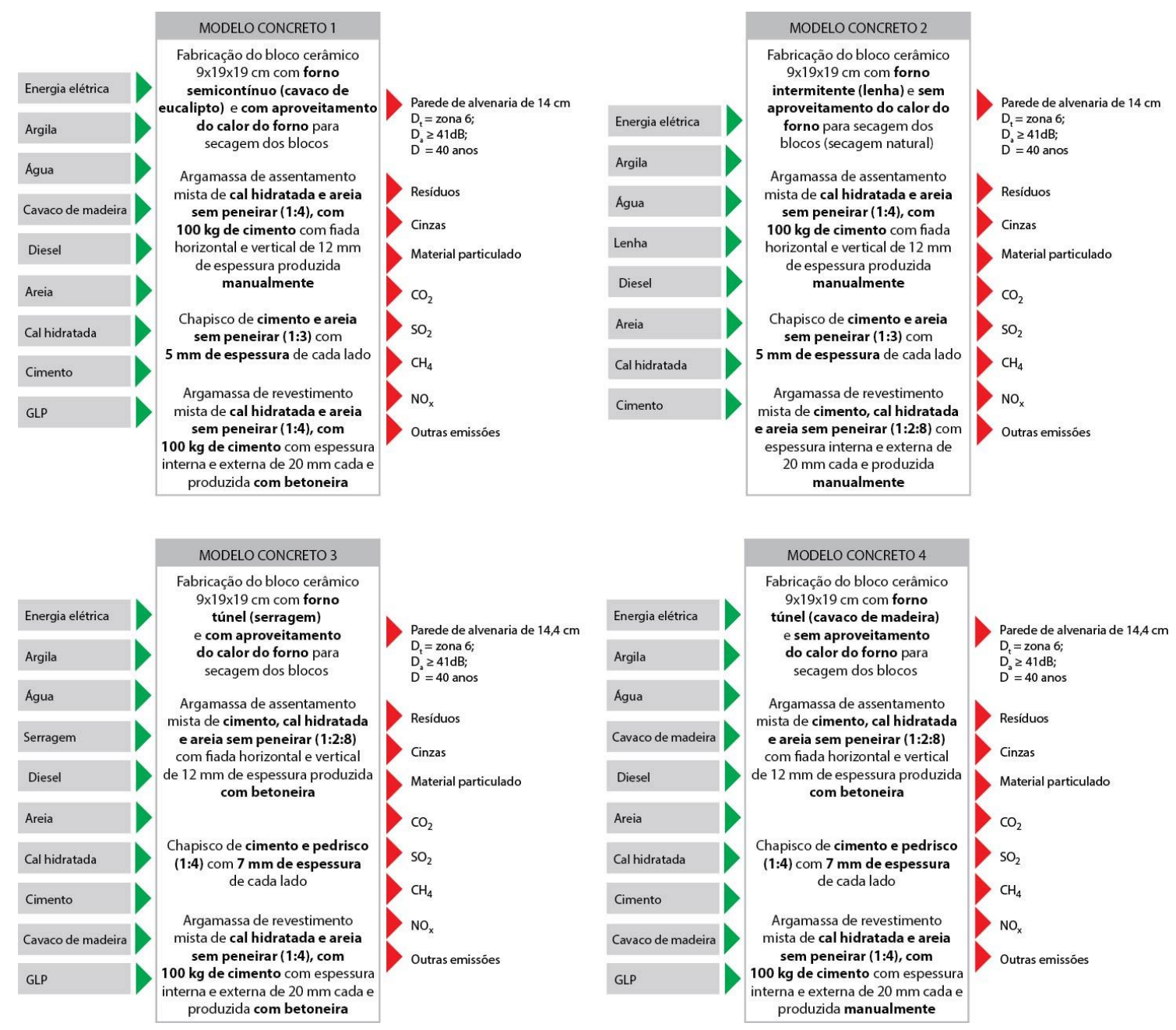

Figura 38: Modelos Concretos da Vedação de bloco cerâmico. Fonte: do autor.

3.2.1. Elaboração do objeto modelo (fluxograma da cadeia)

Com os modelos concretos elaborados e a descrição da cadeia produtiva, foi construído um objeto modelo que contém etapas, processos produtivos, possibilidades, entradas, saídas, equipamentos e limites do sistema, considerando seu caráter esquemático e reducionista e que existem outros tipos de fornos, combustíveis e traços. O objetivo desse objeto modelo é tornar a cadeia a mais genérica possível para atender às diversas tipologias de vedações de bloco cerâmico, mas sem perder as características fundamentais (Figura 39). 


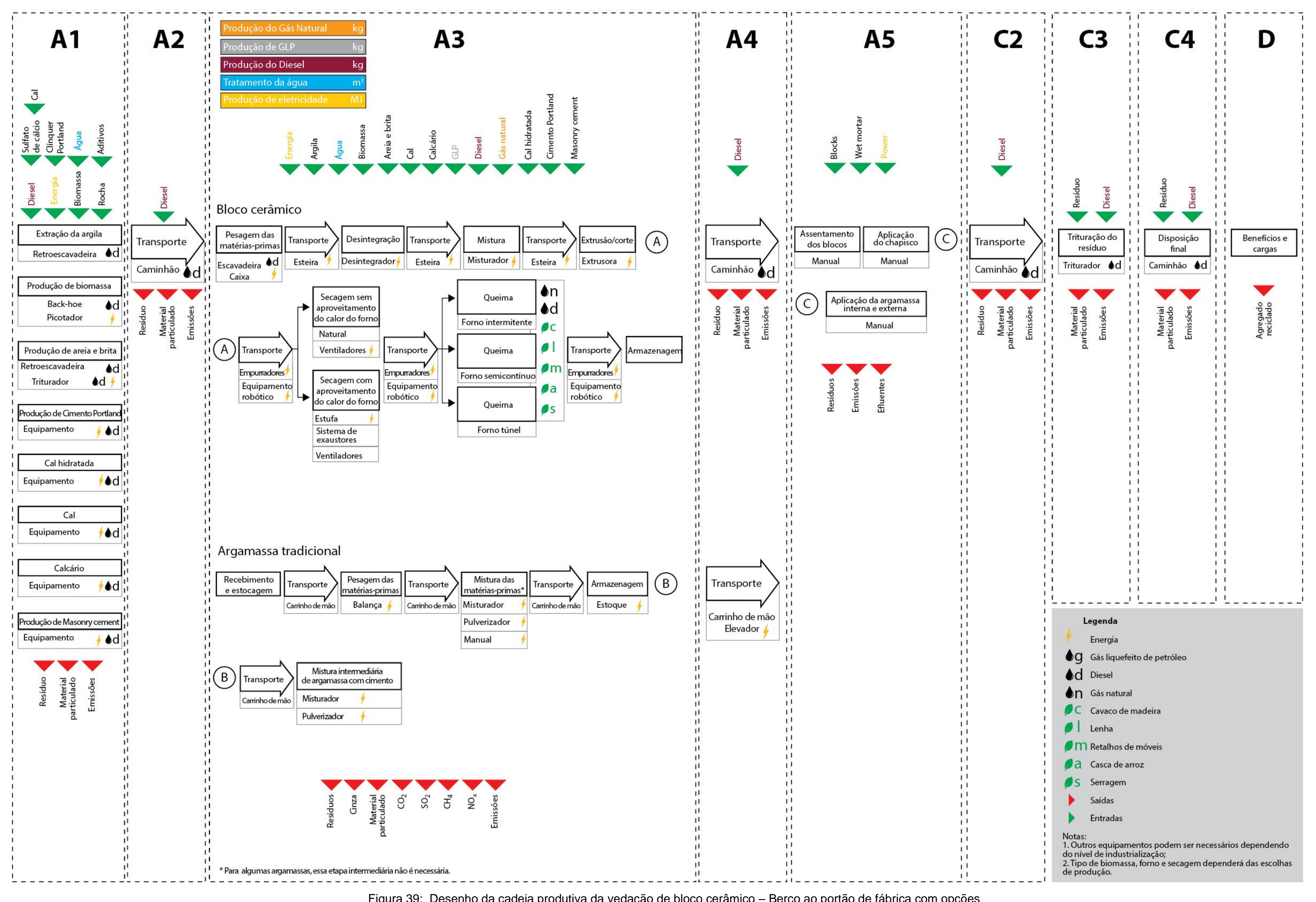




\subsubsection{Listagem de exclusões e critérios de corte}

Neste estudo foram desconsideradas as entradas com valores inferiores a $1 \%$ da massa total do produto analisado, como materiais usados para a limpeza e lubrificação dos equipamentos e embalagem dos blocos cerâmicos. Também foram desconsiderados nas análises do Brasil e do Reino Unido componentes de fixação, elementos estruturais e acabamentos devido ao corte que foi feito na pesquisa e a falta desses dados no contexto brasileiro.

O valor do critério de corte adotado é de $1 \%$ em massa e em relação à massa total do fluxo de referência e, no máximo $5 \%$ da massa de fluxos por módulo de ACV (BRE, 2014). Vigon et al (1995) afirma que os equipamentos e emissões pessoais, geralmente não são considerados por resultarem em cargas ambientais baixas. Além disso, a água e energia consideradas no processo produtivo correspondem ao consumo total da fábrica, no caso da fabricação dos blocos cerâmicos.

\subsubsection{Categorias de impacto}

Segundo Ferreira (2004) as categorias de impacto selecionadas na análise devem permitir uma avaliação abrangente, ter o mínimo de sobreposição, ser internacionalmente aceitas e o número de categorias não deve ser demasiadamente elevado.

As categorias normalmente utilizadas em estudos de ACV foram classificadas em três áreas de proteção: recurso, saúde humana e saúde do ecossistema, conforme Erro! Fonte de referência não encontrada.. O manual do ILCD (JRC, 2010) recomenda que as categorias selecionadas devam abranger essas três áreas.

Para a definição das categorias de impacto desta ACV foi feito um levantamento das categorias utilizadas nos sistemas de emissão nacionais de DAP do Reino Unido, Alemanha, França, Holanda, Espanha, Noruega e Suécia e nas ACVs conduzidas em produções técnico-científicas brasileiras ${ }^{25}$. Além disso, foram consideradas as categorias de impacto obrigatórias da EN 15.804 (BSI, 2014). Considerando-se as categorias de maior ocorrência e a viabilidade de aplicação, foram consideradas nesta avaliação as seguintes categorias:

\footnotetext{
${ }^{25}$ Esse levantamento encontra-se no Apêndice $\mathrm{C}$ deste trabalho.
} 
i. Potencial de Mudanças Climáticas (GWP): é causado pelo efeito estufa que é induzido pela emissão de gases como $\mathrm{CO}_{2}$ e $\mathrm{CH}_{4}$ para a atmosfera. As consequências dessas mudanças são as alterações na intensidade das chuvas e frequência de inundações, por exemplo (JRC, 2011). A unidade de medida dessa categoria de impacto é kg equivalente de $\mathrm{CO}_{2}$;

ii. Potencial de Destruição da Camada de Ozônio (ODP): acontece devido à emissão de compostos químicos como o triclorofluormetano (R-11 ou CFC-11) ou clorodifluormetano (R-22). A mudança integrada no total de ozônio estratosférico por unidade de massa de emissão de um composto específico, relativamente à mudança integrada no total de ozônio por unidade de massa de emissão de um composto de referência (ex. CFC11) (JRC, 2010). A unidade de medida dessa categoria de impacto é $\mathrm{kg}$ equivalente de R11;

iii. Potencial de Acidificação (AP): é calculado sobre as emissões de substâncias ácidas nos ecossistemas naturais por meio da ação do homem. As principais fontes de emissões dessas substâncias são a agricultura, por meio dos fertilizantes, e a queima de combustíveis fósseis utilizados principalmente no transporte e na produção de eletricidade. Exemplos dessas substâncias são: Dióxido de Enxofre $\left(\mathrm{SO}_{2}\right)$, Óxidos de Nitrogênio ( $\left.\mathrm{NO}_{x}\right)$ e Amônia $\left(\mathrm{NH}_{3}\right)$ (JRC, 2011). A unidade de medida dessa categoria de impacto é $\mathrm{kg}$ equivalente de $\mathrm{SO}_{2}$;

iv. Potencial de Eutrofização (EP): é calculado sobre o aumento de nitrogênio e fósforo em ambientes aquáticos ou terrestres. $O$ aumento desses nutrientes na água causa um crescimento acelerado de algas impedindo que a luz do Sol chegue a profundidades mais baixas, o que reduz a fotossíntese, aumenta a quantidade de material orgânico na água e, consequentemente, reduz a disponibilidade de oxigênio levando ao desequilíbrio do ecossistema aquático. No ambiente terrestre, o aumento da acidificação do solo torna as plantas mais suscetíveis a pragas, além do excesso dessas substâncias que pode ser depositado na água potável (JRC, 2010). A unidade de medida dessa categoria é kg equivalente de $\mathrm{PO}_{4}^{3-;}$ 
v. Potencial de Formação de Ozônio Fotoquímico (POCP): é calculado sobre as emissões de óxidos de nitrogênio $\left(\mathrm{NO}_{\mathrm{x}}\right)$ e compostos orgânicos voláteis (VOCs). Na presença do Sol, o ozônio pode ser criado baixa atmosfera o que pode resultar em doenças respiratórias (JRC, 2010). A unidade de medida desse impacto é kg equivalente de $\mathrm{C}_{2} \mathrm{H}_{4}$;

vi. Potencial de depleção de Recursos Abióticos fósseis e não fósseis (ADP): é a redução da disponibilidade de recursos em virtude da atividade humana comprometendo a oportunidade das gerações futuras em ter acesso a tal recurso e a capacidade de prosseguir com atividades que dependem desse recurso e acarretando em pressão aos substitutos (FERREIRA, 2004). É calculado sobre o potencial de redução dos recursos abióticos (recursos não vivos e não renováveis presentes na natureza, tais como rochas, areia, água, etc) e fósseis (JRC, 2010).

As categorias selecionadas abrangem as três áreas de proteção e as macrocategorias Impacto Ambiental Globais, indicadores de uso de recursos, indicadores de fluxo de saída e indicadores de categorias de resíduo definidas pela EN 15.804 (BSI, 2014).

\subsubsection{Método de AICV, normalização e ponderação}

O método de AICV utilizado é o CML 2001, versão de novembro de 2010, assim como para a normalização, considerando os dados para o mundo, e a ponderação, desenvolvida pela PE-International em 2012 considerando o contexto mundial para as metodologias CML, ReCiPe e Traci.

Foram adotadas uma normalização e uma ponderação de abrangência mundial, visto que o Brasil ou os países da América Latina não possuem regras para normalização ou ponderação estabelecidos para as suas realidades. Como o objetivo era comparar os resultados finais das tipologias do Reino Unido e do Brasil, e para manter a consistência da comparação, utilizou-se a normalização e ponderação de abrangência mundial para todos os contextos analisados nesta pesquisa.

Os fatores da normalização da metodologia CML 2010 (novembro de 2010) para o mundo estão no Quadro 12. E os pesos da ponderação criada pela PE-International estão no Quadro 13. 
Quadro 12: Fatores de normalização da metodologia CML 2010

\begin{tabular}{lll}
\hline Categoria & Unidade & $\begin{array}{l}\text { Fator de nor- } \\
\text { malização }\end{array}$ \\
\hline Depleção Abiótica (ADP) & $\mathrm{Kg} \mathrm{Sb}-\mathrm{eq}$ & $6.39 \mathrm{E}-012$ \\
\hline Potencial de Acidificação (AP) & $\mathrm{Kg} \mathrm{SO}$-eq & $3.34 \mathrm{E}-012$ \\
\hline Potencial de Eutrofização (EP) & $\mathrm{Kg} \mathrm{Phosphate-eq}$ & $7.74 \mathrm{E}-012$ \\
\hline Potencial de Mudança Climática (GWP) & $\mathrm{Kg} \mathrm{CO}$-eq & $2.25 \mathrm{E}-014$ \\
\hline Potencial de Depleção da Camada de Ozônio (ODP) & $\mathrm{R} 11$-eq & $1.94 \mathrm{E}-009$ \\
\hline Potencial de formação de Ozônio Fotoquímico (POCP) & $\mathrm{Kg}$ ethane-eq & $2.2 \mathrm{E}-011$ \\
\hline Fonte: GaBi, 2013 & &
\end{tabular}

Quadro 13: Pesos das categorias

\begin{tabular}{lll}
\hline Categoria & Unidade & $\begin{array}{l}\text { Fator de pon- } \\
\text { deração }\end{array}$ \\
\hline Depleção Abiótica (ADP elements) & $\mathrm{Kg} \mathrm{Sb}-\mathrm{eq}$ & 6.4 \\
\hline Depleção Abiótica (ADP fossil) & $\mathrm{MJ}$ & 7 \\
\hline Potencial de Acidificação (AP) & $\mathrm{Kg} \mathrm{SO}$-eq & 6.1 \\
\hline Potencial de Eutrofização (EP) & $\mathrm{Kg} \mathrm{Phosphate-eq}$ & 6.6 \\
\hline Potencial de Mudança Climática (GWP) & $\mathrm{Kg} \mathrm{CO}$-eq & 9.3 \\
\hline Potencial de Depleção da Camada de Ozônio (ODP) & $\mathrm{R} 11$-eq & 6.2 \\
\hline Potencial de formação de Ozônio Fotoquímico (POCP) & $\mathrm{Kg}$ ethane-eq & 6.5 \\
\hline Fonte: GaBi, 2013 & &
\end{tabular}

\subsubsection{Representatividades tecnológica, geográfica e temporal}

A representatividade tecnológica define os limites tecnológicos que serão considerados na análise, sendo assim é preciso diferenciar métodos artesanais de métodos industriais de produção. No caso de ACVs comparativas esse fator é de grande relevância, uma vez que a diferenciação no nível de tecnologia empregado na cadeia produtiva pode ser grande entre empresas ou entre processos produtivos. Desta forma, para o Brasil, foram definidos diferentes índices de consumo de matérias-primas de acordo com os recursos utilizados nas fábricas de bloco cerâmico, como por exemplo os processos de secagem, os tipos de fornos e o uso de equipamentos na preparação das argamassas. Para o Reino Unido, foram usados dados para fábricas de alta tecnologia, onde são utilizados equipamentos eletrônicos e robotizado.

Para a representatividade temporal, é indicado que a escala temporal seja de um ano. Porém, para o Brasil utilizou-se os dados coletados por Manfredini et al (2005) para um período de seis meses. Para o Reino Unido, foram utilizados dados consolidados pela BRE do seu banco de dados, que além de seguirem o padrão de 1 ano de coleta, já foram verificados por terceiros, conforme determina a ISO 14.040 (BSI, 2006a). 
O manual ILCD recomenda que o alcance geográfico da análise seja definido e que pode ser tanto de uma fábrica quanto para um país. Para esta pesquisa, utilizou-se como escala geográfica dados coletados no Rio Grande do Sul, que considerou diferentes níveis tecnológicos das fábricas de bloco cerâmico. E no caso do Reino Unido, os dados têm representatividade nacional.

3.2.6. Fontes de dados, requisitos de qualidade e completude

As principais fontes de dados desta pesquisa são trabalhos acadêmicos sobre bloco cerâmico, a TCPO (PINI, 2008), o banco de dados da BRE, o banco de dados do GaBi 6, normas de materiais de construção do Brasil e do Reino Unido e normas de desempenho das edificações.

Os dados devem ser coletados junto aos produtores ou, no caso de dados secundários, verificados e analisados quanto a sua representatividade e devem ser eliminados dados que estejam fora da curva.

O nível de completude é de $99 \%$, considerando que a massas das embalagens utilizadas e os materiais para limpeza e lubrificação dos equipamentos corresponde a menos de $1 \%$ do valor total da massa do fluxo de referência e que os processos das demais matérias-primas são do banco de dados do GaBi. Quanto a completude dos dados, $14 \%$ dos dados brasileiros foram estimados enquanto que para o Reino Unido todos os dados estavam disponíveis e, por isso, não precisaram de ser estimados. Ressalta-se ainda que os dados brasileiros mais significativos não foram estimados, mas sim calculados ou coletados, tais como energia consumida no processo, massa das matériasprimas, resíduos gerados e etc.

\subsubsection{Comparações, cenários e alternativas}

Os cenários de fim da vida foram selecionados considerando que o resíduo é transportado para aterro sanitário, parte é reciclada e transformada em agregado reciclado, que poderá substituir agregado virgem em outras cadeias produtivas. Para o Brasil não foram encontrados dados na literatura sobre existe o percentual de resíduos da Construção que são reciclados, por isso foi con- 
siderado que apenas $2 \%$ será reciclado, enquanto que no Reino Unido $90 \%$ desses resíduos são reciclados (BRACELPE, 2013; BRE, 2008) ${ }^{26}$.

Para o desenvolvimento de uma ACV podem ser adotadas alternativas dentro do sistema produtivo do produto, material ou serviço, possibilitando comparações e identificando pontos de maior sensibilidade e melhorias. As alternativas de análise de sensibilidade, considerando o modelo elaborado nesta pesquisa, são:

- Uso dos fornos intermitente, semicontínuo e túnel;

- Uso dos combustíveis lenha, retalho de móveis, serragem e cavaco de madeira;

- Uso de secagem natural e artificial com e sem uso do calor do forno;

- Uso de dois diferentes traços de argamassa para assentamento, chapisco e emboço interno e externo;

- Uso de diferentes espessuras de emboço e modelo de blocos.

Para a análise desenvolvida no Reino Unido, foi selecionada uma tipologia de vedação utilizada na Casa do Príncipe e que já possuía dados consolidados e revisados pela equipe da BRE. Por isso, para o Reino Unido não são apresentadas alternativas, conforme detalhado no Capítulo 4.

As comparações feitas neste estudo, bem como os cenários considerados e as alternativas estão detalhados no Quadro 14.

26 Segundo a Bracelpe (2013) 2\% de todo o resíduo gerado no Brasil é reciclado. Apesar do resíduo da Construção ser um resíduo específico, foi considerado esse valor também para resíduos da Construção. 
Quadro 14: Quadro de suposições adotadas nas comparações desta pesquisa

\begin{tabular}{|c|c|c|c|c|c|c|c|c|c|c|c|c|}
\hline \multirow{2}{*}{\multicolumn{2}{|c|}{ Módulos }} & $A 1$ & A2 & A3 & A4 & A5 & $B$ & C1 & $\mathrm{C} 2$ & C3 & C4 & $\mathrm{D}$ \\
\hline & & 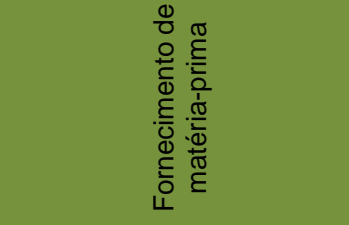 & 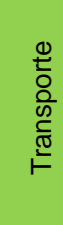 & 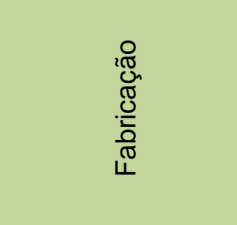 & $\begin{array}{l}\frac{0}{5} \\
\frac{0}{0} \\
\frac{0}{0} \\
\frac{0}{0} \\
\stackrel{0}{\models}\end{array}$ & 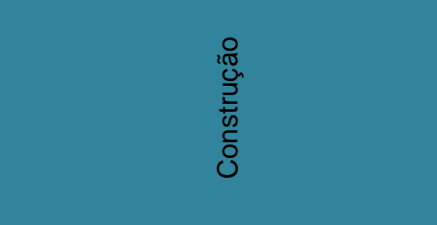 & 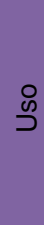 & 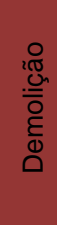 & 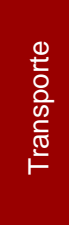 & 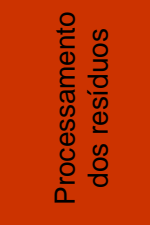 & $\begin{array}{l}\frac{0}{10} \\
\frac{.0}{0} \\
00 \\
\frac{0}{01} \\
\frac{0}{0}\end{array}$ & 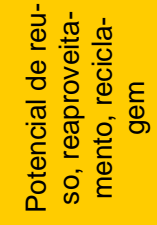 \\
\hline \multicolumn{2}{|c|}{$\begin{array}{l}\text { Quais fases foram } \\
\text { consideradas }\end{array}$} & $x$ & $x$ & $\mathrm{x}$ & $x$ & $x$ & - & - & $\mathrm{x}$ & $x$ & $x$ & $x$ \\
\hline 1 & $\begin{array}{c}\text { Tipologia } 1 \\
\text { Brasil } \\
\mathbf{X} \\
\begin{array}{c}\text { Tipologia } 2 \\
\text { Brasil }\end{array}\end{array}$ & $\begin{array}{c}\text { Extração da argila } \\
\text { Produção de cavaco de } \\
\text { madeira } \\
\text { Produção de eletricidade } \\
\text { Aggua tratada } \\
\text { Produção do diesel } \\
\text { Produção de GLP } \\
\text { Produção e cimento Por- } \\
\text { tland } \\
\text { Extração da areia } \\
\text { Produção da cal hidratada } \\
\text { Produção do pedrisco }\end{array}$ & $\begin{array}{l}100 \\
\mathrm{~km}\end{array}$ & $\begin{array}{c}\text { Produção do blo- } \\
\text { co cerâmico bra- } \\
\text { sileiro com seca- } \\
\text { gem natu- } \\
\text { ral/artificial e sem } \\
\text { reaproveitamento } \\
\text { do calor do forno } \\
\text { intermitente (re- } \\
\text { talhos de mó- } \\
\text { veis) } \\
\text { X } \\
\text { Produção de blo- } \\
\text { co cerâmico bra- } \\
\text { sileiro com seca- } \\
\text { gem natural e- } \\
\text { forno túnel (le- } \\
\text { nha) }\end{array}$ & $\begin{array}{l}100 \\
\mathrm{~km}\end{array}$ & $\begin{array}{c}\text { Bloco: } \\
\text { Bloco cerâmico 140x190x290mm } \\
\text { Argamassa de assentamento: } \\
1: 4 \text { (cal hidratada, areia) } \\
\text { 1cm de espessura } \\
\text { Argamassa para chapisco: } \\
\text { 1:4 (cimento Portland, pedrisco) - } \\
0,5 \mathrm{~cm} \text { de espessura em ambos os } \\
\text { lados } \\
\text { Emboço externo: } \\
\text { 1:2:6 (cimento Portland, cal hidra- } \\
\text { tada, areia) } \\
2 \text { cm de espessura } \\
\text { Emboço interno: } \\
\text { 1:3 (cimento Portland, areia) } \\
2 \text { cm de espessura } \\
\text { X } \\
\text { Bloco: } \\
\text { Bloco cerâmico 140x190x290mm } \\
\text { Argamassa de assentamento: } \\
\text { 1:2:8 (cimento Portland, cal hidra- } \\
\text { tada, areia) } \\
10 \text { mm de espessura } \\
\text { Argamassa para chapisco: } \\
\text { 1:3 (cimento Portland, areia) - } 7 \\
\text { m de espessura em ambos os } \\
\text { lados } \\
\text { Emboço externo: } \\
\text { 1:2:6 (cimento Portland, cal hidra- } \\
\text { tada, areia) } \\
2 \text { cm de espessura }\end{array}$ & - & - & $\begin{array}{l}100 \\
\mathrm{~km}\end{array}$ & $\begin{array}{l}\text { Trituração } \\
(2,0 \% \text { da } \\
\text { massa de } \\
\text { resíduos) }\end{array}$ & $\begin{array}{l}\text { Material iner- } \\
\text { te para aterro } \\
\text { sanitário } \\
\text { ( } 98,0 \% \text { da } \\
\text { massa de } \\
\text { resíduos) }\end{array}$ & $\begin{array}{l}\text { Agregado } \\
\text { reciclado } \\
\text {-3,64 kg de } \\
\text { agregado } \\
\text { triturado } \\
\text { X } \\
\text {-3,66 kg de } \\
\text { agregado } \\
\text { triturado }\end{array}$ \\
\hline
\end{tabular}




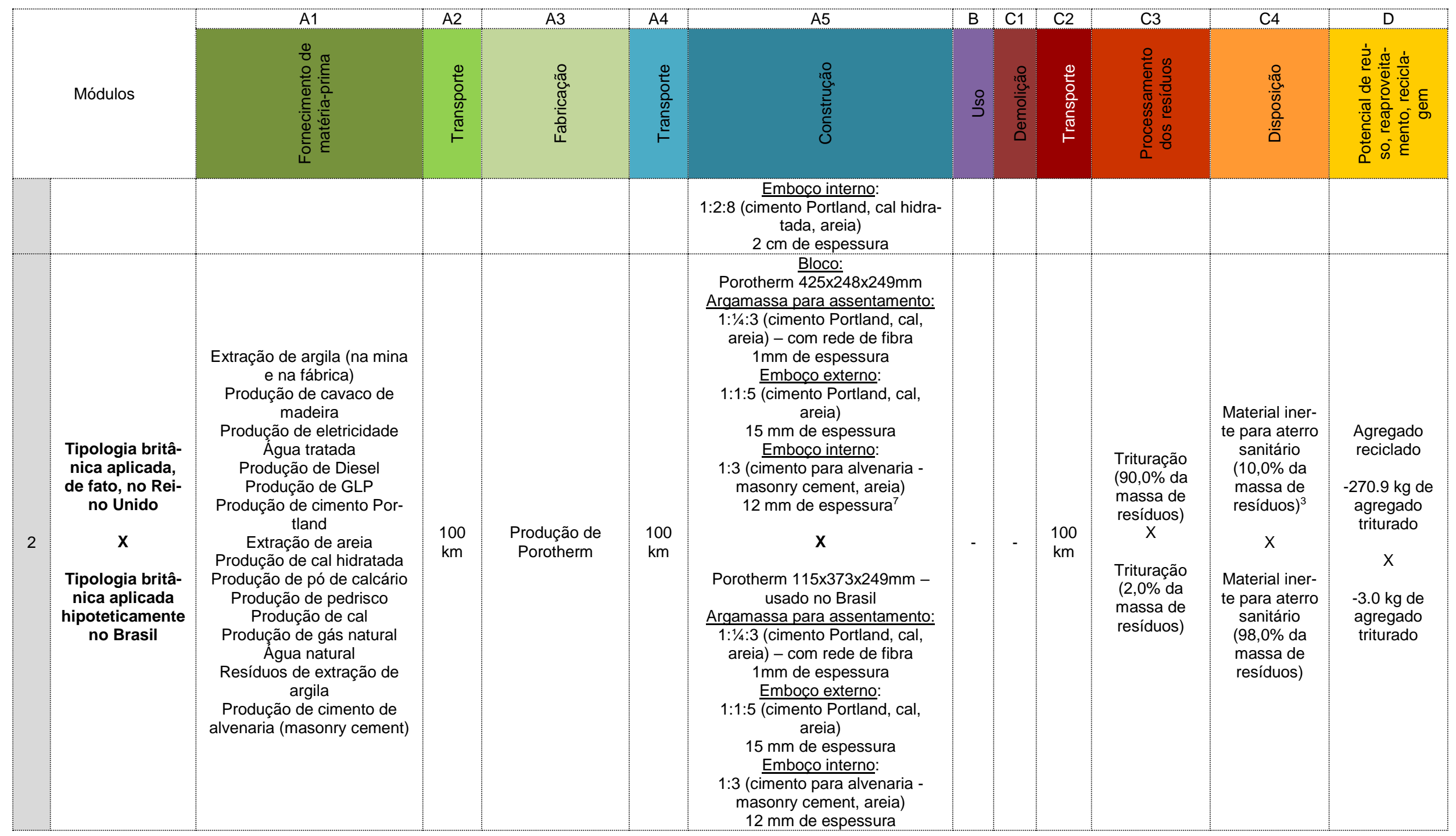




\subsubsection{Fluxo de referência}

O fluxo de referência é a massa de matérias-primas necessárias para a produção da unidade funcional da ACV (JRC, 2010). Considerando-se as premissas estabelecidas e as compraçãoes estabelecidas neste estudo, o Quadro 15 mostra os fluxos de referência em quilogramas de massa de entrada e saída das vedações.

Quadro 15: Fluxos de referência para as comparações desta ACV

\begin{tabular}{|c|c|c|c|}
\hline \multicolumn{2}{|c|}{ Comparação 1} & \multicolumn{2}{|c|}{ Comparação 2} \\
\hline Tipologia 1 & Tipologia 2 & Aplicada ao Brasil & $\begin{array}{c}\text { Aplicado ao Reino } \\
\text { Unido }\end{array}$ \\
\hline $\begin{array}{l}81,3 \mathrm{~kg} \text { de bloco } \\
\text { cerâmico }\end{array}$ & $\begin{array}{l}81,3 \mathrm{~kg} \text { de bloco } \\
\text { cerâmico }\end{array}$ & $\begin{array}{l}127 \text { kg de bloco cerâ- } \\
\text { mico }\end{array}$ & $\begin{array}{c}280 \text { kg de bloco cerâ- } \\
\text { mico }\end{array}$ \\
\hline $\begin{array}{l}37,6 \mathrm{~kg} \text { de arga- } \\
\text { massa de assen- } \\
\text { tamento }\end{array}$ & $\begin{array}{l}41,6 \mathrm{~kg} \text { de arga- } \\
\text { massa de assen- } \\
\text { tamento }\end{array}$ & $\begin{array}{c}0,195 \mathrm{~kg} \text { de argamas- } \\
\text { sa de assentamento }\end{array}$ & $\begin{array}{c}\text { 2,46 kg de argamassa } \\
\text { de assentamento }\end{array}$ \\
\hline $\begin{array}{c}13,9 \text { kg de arga- } \\
\text { massa de chapisco }\end{array}$ & $\begin{array}{c}14,5 \text { kg de arga- } \\
\text { massa de chapisco }\end{array}$ & $\begin{array}{c}0 \mathrm{~kg} \text { de argamassa de } \\
\text { chapisco }\end{array}$ & $\begin{array}{c}0 \mathrm{~kg} \text { de argamassa de } \\
\text { chapisco }\end{array}$ \\
\hline $\begin{array}{l}54,7 \text { kg de arga- } \\
\text { massa de emboço } \\
\text { interno }\end{array}$ & $\begin{array}{l}52,3 \mathrm{~kg} \text { de arga- } \\
\text { massa de emboço } \\
\text { interno }\end{array}$ & $\begin{array}{c}15,6 \mathrm{~kg} \text { de argamassa } \\
\text { de emboço interno }\end{array}$ & $\begin{array}{c}15,6 \mathrm{~kg} \text { de argamassa } \\
\text { de emboço interno }\end{array}$ \\
\hline $\begin{array}{l}68,9 \text { kg de arga- } \\
\text { massa de emboço } \\
\text { externo }\end{array}$ & $\begin{array}{c}68,9 \text { kg de arga- } \\
\text { massa de emboço } \\
\text { externo }\end{array}$ & $\begin{array}{c}13,5 \mathrm{~kg} \text { de argamassa } \\
\text { de emboço externo }\end{array}$ & $\begin{array}{c}13,5 \mathrm{~kg} \text { de argamassa } \\
\text { de emboço externo }\end{array}$ \\
\hline
\end{tabular}

\section{Síntese Analítica do Capítulo 3}

Neste capítulo foram apresentadas a definição do objetivo e do escopo da ACV, considerando cada uma das etapas de elaboração e os contextos de análise, bem como as ferramentas que deram subsídio a elaboração do MTP.

Considerando a definição do objetivo e do escopo para a elaboração da ACV e, consequentemente do MTP, novos passos complementares e essenciais foram inseridos às etapas definidas pelo ILCD.

Para a elaboração de um modelo abrangente e genérico o suficiente para não perder as características fundamentais, foi necessária uma análise da cadeia produtiva da vedação de bloco cerâmico, dividindo-a em fases comuns com características específicas de acordo com o nível tecnológico do fabricante 
de bloco, dos traços e matérias-primas das argamassas selecionadas, dos cenários de fim da vida.

Os módulos do ciclo de vida não obrigatórios para uma DAP sem dados e informações foram excluídos da análise, como as fases de uso (B1 a B7) e demolição da vedação (C1).

O Reino Unido possui médias de consumo de energia e água de acordo com a tipologia e função da edificação e esses dados são utilizados para a estimativa de consumo ao longo do ciclo de vida da vedação vertical. Porém, o Brasil está iniciando a elaboração de benchmark para edifícios públicos e ainda não possui esses dados consolidados, sobretudo para as edificações residenciais, que não são o foco desse levantamento. Sendo assim, não foi considerado nesta pesquisa a fase de uso da edificação considerando a falta de dados.

Para as fases de objetivo e escopo, os passos e informações obrigatórias do manual do ILCD foram respondidas e, para as fases de ICV, AICV e Interpretação, essas informações serão apresentadas nos Capítulos 4 e 5. 


\section{Capítulo 4: Modelagem - ICV e AICV}

Neste capítulo é apresentada duas fases da ACV: o Inventário do Ciclo de Vida (ICV) e a Avaliação do Impacto do Ciclo de Vida (AICV).

No ICV tem-se a coleta de dados e a modelagem do Modelo Tecnológico Parametrizado. O MTP foi modelado em etapas iterativas, nas quais cada versão do modelo é revisada e avaliada de forma crítica e as inconsistências analisadas para que possam ser corrigidas. Este capítulo contém as três versões dos MTP, bem como a listagem de parâmetros criados em cada versão. No final é apresentado o resultado de ICV considerando os diferentes contextos de análise das tipologias avaliadas e uma interpretação desses dados.

A AICV contém os resultados dos potenciais impactos calculados, a ponderação e a normalização apresentados em dois dashboards que permitem uma visão geral dos impactos. No capítulo 5 esses dados serão interpretados na fase de Intepretação da ACV.

\subsection{Inventário do Ciclo de Vida}

\subsubsection{Identificação dos processos}

Como a modelagem utilizada nesta pesquisa é atribucional, segundo JRC (2010), os processos devem ser descritos e classificados em níveis para que se definam os dados que deverão ser coletados e os dados que poderão ser genéricos. Os processos podem ser classificados em nível 0, 1, 2 e 3 ou mais de acordo com a proximidade com o processo principal (

Quadro 16).

Quadro 16: Descrição dos processos e classificação em níveis de proximidade com o processo núcleo

\begin{tabular}{lclc}
\hline Processo & Nível & Descrição & Tipo de dado \\
\hline & & $\begin{array}{l}\text { Construção da vedação de blocos cerâmicos vaza- } \\
\text { dos produzidos no Brasil e porosos produzidos no }\end{array}$ & $\begin{array}{l}\text { Dados primários } \\
\text { ou secundários } \\
\text { Reino Unido com assentamento manual com arga- }\end{array}$ \\
$\begin{array}{l}\text { Construção da ve- } \\
\text { dação }\end{array}$ & $0 \quad \begin{array}{l}\text { massa tradicional e revestimento das vedações } \\
\text { manual ou com uso de equipamentos elétricos. As } \\
\text { argamassas foram preparadas no canteiro de obras } \\
\text { utilizando equipamentos elétricos. }\end{array}$ \\
\hline $\begin{array}{l}\text { Fabricação dos } \\
\text { blocos cerâmicos }\end{array}$ & 1 & $\begin{array}{l}\text { Fabricação de blocos compostos de argila, água e, } \\
\text { ou outras matérias-primas, como calcário e agrega- }\end{array}$ & $\begin{array}{l}\text { Dados primários } \\
\text { ou secundários }\end{array}$ \\
\hline
\end{tabular}




\begin{tabular}{|c|c|c|c|}
\hline & & $\begin{array}{l}\text { dos, moldados por extrusão, queimados em fornos } \\
\text { e secos natural ou artificialmente. }\end{array}$ & específicos \\
\hline & & $\begin{array}{l}\text { Para esse processo foram considerados diferentes } \\
\text { níveis tecnológicos de fornos e processo de seca- } \\
\text { gem, além de diferentes combustíveis. Essas op- } \\
\text { ções foram parametrizadas e serão apresentadas } \\
\text { na seção sobre a definição de parâmetros. }\end{array}$ & \\
\hline $\begin{array}{l}\text { Fabrica- } \\
\text { ção/preparação das } \\
\text { argamassas }\end{array}$ & 1 & $\begin{array}{l}\text { Fabricação de argamassas tradicionais utilizando } \\
\text { argamassadeira ou betoneira a partir de traços a } \\
\text { serem definidos. }\end{array}$ & $\begin{array}{l}\text { Dados primários } \\
\text { ou secundários } \\
\text { específicos }\end{array}$ \\
\hline $\begin{array}{l}\text { Fabricação e extra- } \\
\text { ção das matérias- } \\
\text { primas }\end{array}$ & 2 & $\begin{array}{l}\text { Contém todos os processos necessários para a ex- } \\
\text { tração e, ou beneficiamento das matérias-primas. }\end{array}$ & $\begin{array}{l}\text { Dados genéricos } \\
\text { (banco de dados) }\end{array}$ \\
\hline $\begin{array}{l}\text { Produção de Die- } \\
\text { sel, GLP e gás na- } \\
\text { tural }\end{array}$ & 3 & $\begin{array}{l}\text { Inclui os processos para a produção de combustí- } \\
\text { veis fósseis que, nesta pesquisa, são utilizados no } \\
\text { maquinário e nos caminhões }\end{array}$ & $\begin{array}{l}\text { Dados genéricos } \\
\text { (banco de dados) }\end{array}$ \\
\hline $\begin{array}{l}\text { Transformação da } \\
\text { Energia }\end{array}$ & 3 & $\begin{array}{l}\text { O processo de transformação da energia é baseado } \\
\text { no mix elétrico do país de acordo com as porcenta- } \\
\text { gens dos tipos de fontes de energia utilizadas para } \\
\text { a produção de energia elétrica. }\end{array}$ & $\begin{array}{l}\text { Dados genéricos } \\
\text { (banco de dados) }\end{array}$ \\
\hline $\begin{array}{l}\text { Produ- } \\
\text { ção/processamento } \\
\text { de biomassa }\end{array}$ & 3 & $\begin{array}{l}\text { Inclui extração e beneficiamento da biomassa que, } \\
\text { para este estudo, foram consideradas lenha, cava- } \\
\text { co de madeira, serragem e retalho de móveis. }\end{array}$ & $\begin{array}{l}\text { Dados genéricos } \\
\text { (banco de dados) }\end{array}$ \\
\hline $\begin{array}{l}\text { Tratamento de } \\
\text { água }\end{array}$ & 3 & $\begin{array}{l}\text { Inclui os processos para o tratamento da água, tor- } \\
\text { nando a água própria para o consumo. }\end{array}$ & $\begin{array}{l}\text { Dados genéricos } \\
\text { (banco de dados) }\end{array}$ \\
\hline $\begin{array}{l}\text { Tratamento dos } \\
\text { resíduos sólidos da } \\
\text { construção }\end{array}$ & 3 & $\begin{array}{l}\text { Os resíduos sólidos da construção, que não são } \\
\text { reciclados ou reutilizados, são enviados para ater- } \\
\text { ros sanitários. }\end{array}$ & $\begin{array}{l}\text { Dados genéricos } \\
\text { (banco de dados) }\end{array}$ \\
\hline $\begin{array}{l}\text { Reciclagem de re- } \\
\text { síduos sólidos da } \\
\text { construção }\end{array}$ & 3 & $\begin{array}{l}\text { Trituração dos resíduos sólidos para a produção de } \\
\text { agregado reciclado a ser usado em outras cadeias } \\
\text { produtivas, visto que nem a produção de blocos ce- } \\
\text { râmicos e nem a preparação das argamassas pre- } \\
\text { veem o uso desse tipo de agregado. }\end{array}$ & $\begin{array}{l}\text { Dados genéricos } \\
\text { (banco de dados) }\end{array}$ \\
\hline Transporte & 3 & $\begin{array}{l}\text { Contém os processos e os impactos da queima do } \\
\text { combustível para o transporte das matérias-primas } \\
\text { e produtos necessários para a construção da veda- } \\
\text { ção. }\end{array}$ & $\begin{array}{l}\text { Dados genéricos } \\
\text { (banco de dados) }\end{array}$ \\
\hline
\end{tabular}

\subsubsection{Planejamento da obtenção dos dados}

A definição dos dados a serem coletados foi feita com base na análise de outras ACVs feitas para materiais da construção. JRC (2010) recomenda que sejam identificados os processos unitários específicos e definidos os dados que serão primários ou secundários específicos, além da elaboração de um diagrama que mostre a cadeia produtiva do produto analisado. Porém, julgou-se necessária a elaboração de um fluxo diagrama da cadeia produtiva ainda na fase de escopo, que foi apresentado no capítulo anterior.

Os principais itens que compõem o inventário do ciclo de vida do modelo tecnológico para vedações verticais são: 
i. Consumo de água: relativa ao consumo de água dos processos produtivos do material analisado. Essa matéria-prima pode ser quantificada por meio de leitura direta das médias das contas de água do último ano, por estimativa ou por medição aproximada (SOARES et al, 2002);

ii. Consumo de energia: os dados sobre o consumo de energia de um processo são obtidos pela análise das faturas, contratos com concessionárias de energia, contratos com fornecedoras de gás, medição do consumo de combustível, etc. Segundo Soares et al (2002), se possível, o consumo de energia deve ser quantificado para cada um dos processos produtivos do material. Esse levantamento também pode ser feito com uma estimativa do consumo dos equipamentos por meio da ponderação da potência dos motores e o tempo de uso das máquinas;

iii. Matérias-primas: devem ser quantificadas as matérias-primas utilizadas na fabricação do material construtivo. Para isso, podem ser usados os recursos: documentos de aquisição e sua periodicidade, fichas ou manuais técnico-informativos sobre as características da matéria-prima, como a toxidade e a composição e entrevistas com os fabricantes;

iv. Emissões gasosas: as emissões gasosas devem ser conhecidas e quantificadas. Nos processos já existentes em um banco de dados de um software, essas emissões são quantificadas e identificadas pelo próprio software. Já nos processos que precisam ser construídos essas emissões são quantificadas e identificadas com base na literatura ou com medições. Entretanto, a falta de dados é uma dificuldade observada na maior parte dos estudos em ACV no Brasil, conforme abordado;

v. Resíduos: devem ser identificados os principais resíduos relacionados ao processo produtivo do material, contendo as seguintes informações: composição, destinação, forma de estocagem, etc;

vi. Efluentes líquidos: esses dados dependem dos efluentes produzidos, tratados, reciclados ou descartados (SOARES et al, 2002). Na visita técnica, observou-se que os efluentes líquidos são descartados na rede pública de esgoto. Como acontece com as emissões gasosas, a falta de dados dos potenciais impactos negativos desses efluentes no ambiente é uma dificuldade observada nos estudos em ACV, conforme abordado; 
vii. Desperdícios energéticos: depende do rendimento das máquinas utilizadas e do nível de entropia do sistema, sendo de 30\%, em média, para motores à combustão e $95 \%$ para máquinas elétricas (VIANNA, 2011).

No levantamento, os dados usados são primários, coletados junto à fábrica de bloco cerâmico, e secundários, provenientes de revisão bibliográfica de produções técnico-científicas, do banco de dados do software $\mathrm{GaBi}, \mathrm{TCPO}$ 2008 (PINI, 2008b), do banco de dados da BRE e visita técnica ao protótipo da habitação estudada na própria BRE.

Alguns dados como as emissões e os efluentes líquidos não puderam ser coletados nas visitas técnicas e, por isso, foram usadas as conversões do software $\mathrm{GaBi}$. As informações precisaram ser estimadas ou suprimidas na análise. O plano de obtenção de dados está apresentado junto com os valores dos dados e as fontes no Quadro 17, na seção de coleta dos dados.

O questionário para a coleta de dados foi desenvolvido para a fabricação do bloco cerâmico brasileiro, visto que para as argamassas e a construção os dados já haviam sido consolidados pela TCPO 2008 (PINI, 2008b) e os dados da vedação do Reino Unido já haviam sido coletados e consolidados pela BRE em seu banco de dados. O questionário desenvolvido encontra-se no Apêndice $E$ desta pesquisa.

\subsubsection{Coleta dos dados primários e secundários ${ }^{27}$}

Para a coleta de dados, aplicou-se o questionário desenvolvido em visita técnica feita em uma fábrica de blocos cerâmicos de Anápolis, que fornece blocos para o Distrito Federal. Porém, a coleta de dados só seria válida e abrangente o suficiente se fosse aplicada a várias fábricas, o que inviabilizava a pesquisa devido ao tempo necessário para essa coleta.

Como a coleta de dados não era o foco desta pesquisa, foi feito um levantamento bibliográfico com base nas publicações técnico-científicas identificadas no Capítulo 2. Esse levantamento resultou na coleta de dados secundários sobre a cadeia produtiva do bloco cerâmico resultantes do trabalho de Manfredini et al (2005). No entanto, os dados encontrados eram de vinte fábricas de pequeno, médio e grande porte do Rio Grande do Sul para 2003, o que

\footnotetext{
${ }^{27}$ A memória de cálculo dos dados está disponível no Apêndice C.
} 
comprometia a representatividade temporal e geográfica dos dados coletados em 2010 em Anápolis. Por isso, descartaram-se os dados coletados em Anápolis para o cálculo das médias dos insumos necessários à produção dos blocos e consideraram-se apenas os dados secundários de Manfredini et al (2005).

No contexto brasileiro, os dados referentes às argamassas são extraídos da Tabela de Composição de Preços para Orçamentos (TCPO) 2008 (PINI, 2008b) e os dados dos processos do Reino Unido, provenientes do levantamento de dados feito pela BRE em 2008 e disponibilizados em seu banco de dados. Devido a grande quantidade de dados coletados e o tamanho excessivo da tabela, esses dados foram organizados no Apêndice $\mathrm{H}$ em dados gerais $\mathrm{e}$ dados para cada componentes da vedação. Esse apêndice contém todos os dados coletados, com os seguintes itens:

i. Nomenclatura do dado;

ii. Classificação do dado: os dados coletados foram classificados conforme o tipo de dado: dado médio $(M)$ ou específico $(E)$; conforme a brangência: genérico $(G)$, coletado $(C)$ ou estimado $(E)$; e conforme a origem primário $(P)$ ou secundário $(S)$;

iii. Valor do dado considerando a unidade funcional de $1 \mathrm{~m}^{2}$ de vedação;

iv. Unidade, que segue o Sistema Internacional de Unidades;

v. Fonte do dado;

vi. Nacionalidade.

Quadro 17: Exemplo dos dados coletados e disponíveis no Apêndice H

\begin{tabular}{|c|c|c|c|c|c|c|c|}
\hline \multirow[b]{2}{*}{ Dados } & \multicolumn{3}{|c|}{ Tipo de dado } & \multirow[b]{2}{*}{ Valor } & \multirow[b]{2}{*}{ Unidade } & \multirow[b]{2}{*}{ Fonte } & \multirow[b]{2}{*}{$\begin{array}{l}\text { Nacionali- } \\
\text { dade }\end{array}$} \\
\hline & $\begin{array}{c}\text { Média } \\
\text { Específico }\end{array}$ & $\begin{array}{l}\text { Genérico } \\
\text { Coletado } \\
\text { Estimado }\end{array}$ & $\begin{array}{c}\text { Primário } \\
\text { Secundário }\end{array}$ & & & & \\
\hline \multicolumn{8}{|l|}{ DADOS GERAIS } \\
\hline $\begin{array}{l}\text { Densidade apa- } \\
\text { rente areia }\end{array}$ & M & $\mathrm{G}$ & $S$ & 1640 & $\mathrm{~kg} / \mathrm{m}^{3}$ & $\begin{array}{l}\text { Serna et al, } \\
2009\end{array}$ & $\mathrm{BR}$ \\
\hline
\end{tabular}

É importante ressaltar que a planilha original dos dados foi mantida com os valores coletados e só então foram parametrizados para a unidade funcional definida, conforme recomenda JRC (2010). 
4.1.3.1. Agregação e controle de qualidade dos dados

Visando garantir a confidencialidade dos dados coletados por Manfredini et al (2005), os dados dos fabricantes de blocos cerâmicos foram agregados e as médias calculadas por tipo de forno e combustível, por tipo de secagem utilizada e média geral de consumo de insumos. Além disso, para garantir a qualidade, foram descartados dados que estavam fora da curva de consumo de insumos por porte da fábrica. Das vinte empresas com dados coletados por Manfredini et al (2005) duas fábricas foram descartadas, pois possuíam os dados de consumo de energia e de combustível muito abaixo das demais empresas com o mesmo porte.

\subsubsection{Seleção dos processos e planos}

Para o desenho do modelo tecnológico parametrizado foram utilizados os processos do banco de dados do Software $\mathrm{GaBi}$, desenvolvido pela empresa PE International, do banco de dados da BRE ou criados. Os processos listados no Quadro 18 foram extraídos do banco de dados da BRE e do GaBi e criados conforme demanda identificada e estão descritos no Apêndice I.

Quadro 18: Lista de processos utilizados na ACV da vedação de bloco cerâmico

\section{Processos}

DE: Cal Hidratada $\left(\mathrm{Ca}(\mathrm{OH})_{2}\right.$; seca; slaked lime) PE

RER: Areia Média 0/2 PE

RER: Cimento Portland (CEM I) ELCD/CEMBUREAU

RER: Areia Grossa 2/32 PE

BR: Mix de Energia Elétrica PE

GB: Mix de Energia Elétrica PE

Porotherm process

Masonry cement

Calcário moído $\left(\mathrm{CaCO}_{3}\right.$; seco)

$\mathrm{DE}$ : Cal (CaO; quicklime irregular) PE

Fibra de vidro

Transporte

BR: Mix de Diesel na Refinaria PE

GB: Mix de Diesel na Refinaria PE

Processo de vapor de gás natural $90 \%$

Caminhão (Euro 5, payload 12t)

Transporte, combinação de caminhões, combustível diesel 


\section{Processos}

Diesel, queimado em equipamento industrial (saída em MJ)

BR: LPG, queimado em equipamento industrial (saída em MJ)

Argila da mina/CH U

BR: Água tratada

GB: Água tratada

BR: Escavadeira

US: Resíduo de Madeira, não especificado, queimado em indústrias

BR: Fabricação do bloco cerâmico

GLO: Aterro sanitário para produtos inertes (Glass)

BR: Mortar mix 1:4 (hydrated lime:sand) - thin bed

BR: Mortar mix 1:2:8 (cement:hydrated lime:sand)

BR: Mortar mix 1:4 (cement:gravel)

BR: Mortar mix 1:2:6 (cement:hydrated lime:sand)

BR: Mortar mix 1:3 (cement:sand)

GB: Mortar mix 1:3 (masonry cement:sand) - int. wall

GB: Mortar mix 1:1/4:3 (Cement:lime:sand) - wet mortar - thin bed

GB: Mortar mix 1:1:5 (cement:lime:sand)

UK: Mortar waste disposal

GLO: Clay Brick Typology_new

GLO: Brick waste processing_new

GLO: Crushed recycled aggregate

Brick waste disposal

GLO: Agregado reciclado

\subsubsection{Migração dos dados}

Após a seleção dos processos, foi necessária a migração dos dados do software de ACV Simapro 8 para o software GaBi 6, visto que a BRE utiliza o Simapro e o modelo havia sido construído no GaBi 6.

Para a transferência dos dados foram estabelecidos critérios de migração para que todos os dados fossem migrados da mesma forma: (i) atenção se o fluxo inserido no novo processo é de entrada ou saída; (ii) atenção se a emissão é para a terra, água ou ar conforme processo original; (iii) as entradas ou saídas iguais foram somadas, pois o GaBi não permite a inserção de fluxos em duplicidade; e (iv) o Simapro permite o cálculo médio de fluxos de entrada que se referem a um mesmo dado, por exemplo consumos de energia de vá- 
rios fabricantes podem ser inseridos no Simapro e o software calcula a média, por isso optou-se por calcular a média e inserir o valor no processo.

Para a migração dos dados foram feitas as seguintes experiências:

i. Migração do valor final das categorias: nessa experiência, as categorias de impacto e seus valores associado ao bloco cerâmico poroso são inseridos em um novo processo como fluxos de saída. No entanto, a leitura dos resultados finais mostraria apenas os dados agregados por módulo ou estágio da Declaração Ambiental de Produto (DAP) e o dado seria tratado como "caixa preta";

ii. Cópia do inventário do bloco cerâmico poroso: nessa experiência, gera-se o inventário do bloco cerâmico que é copiado para uma planiIha e depois copiado novamente para um novo processo no GaBi. Foram copiados e reconectados em torno de 300 fluxos de entrada e 500 fluxos de saída;

iii. Cópia dos processos e montagem dos planos: nessa experiência, o processo do bloco é copiado para uma planilha, bem como os processos associados a ele. Esse procedimento é mais trabalhoso que a experiência anterior, mas permite manter todos os dados associados aos módulos da DAP, o que não era possível com os procedimentos anteriores, visto que os módulos A1, A2 e A3 ficariam com seus valores agregados.

A EN 15804 (ISO, 2014) permite a apresentação dos dados agregados, porém para a vedação vertical externa brasileira esses módulos estariam desagregados, o que tornava a modelagem e a apresentação dos dados incoerentes.

Alguns processos associados ao bloco cerâmico poroso foram substituídos por processos similares do banco de dados do GaBi. Para comparar a precisão dos dois procedimentos de migração, foi feita a comparação dos resultados finais de AICV do modelo utilizando o processo montado a partir do inventário (experiência ii) e com os processos montados um a um (experiência iii). Os resultados de AICV para as duas experiências mostraram-se equivalentes. Desse modo, optou-se por adotar o procedimento da experiência iii que mantém os processos 
montados individualmente e que permite a leitura dos dados dos módulos da DAP.

\subsubsection{Criação de planos, processos e fluxos}

Além dos processos e planos selecionados no banco de dados do $\mathrm{GaBi}$ 6 e da BRE, alguns planos, processos e fluxos precisaram ser criados para a elaboração do MTP. Como não havia recomendações para a criação desses itens no manual do ILCD (JRC, 2010), esta parte da pesquisa foi feita de maneira iterativa com melhorias inseridas conforme a observação das limitações da modelagem anterior e da observação da inserção desses itens nos bancos de dados usados como referências.

Observou-se que tanto os planos quanto os processos podem ser meIhor aproveitados em outros modelos se fossem parametrizados para a saída de 1 unidade de produto ( $1 \mathrm{~kg}, 1$ tonelada, $1 \mathrm{~m}^{3}$ etc).

É importante a documentação desses processos e planos, por meio do preenchimento das informações nas fichas fornecidas pelo software de ACV utilizado. Quanto maior a quantidade de informações preenchidas, melhor será a utilização desses itens em trabalhos futuros, pois o usuário saberá, por exemplo, qual é o limite considerado, quais processos produtivos foram considerados, etc. Além disso, para a criação desses itens, devem ser consideradas as nomenclaturas definidas por JRC (2010) em manual específico.

Além das observações feitas anteriormente, para a criação dos fluxos deve-se observar a correta classificação da natureza do fluxo: recurso, saída do sistema, saída que necessita de tratamento, etc. Essa classificação exigirá ou não a inserção de processos conectados anteriormente às entradas ou posteriormente às saídas.

\subsubsection{Variáveis e parâmetros}

Parâmetros são as bases para a modelagem de cenários na ACV e são utilizados para variar múltiplos aspectos de um processo. O objetivo dessa variação nos parâmetros é dar um melhor entendimento da relação de causa e consequência entre mudanças no processo e o resultado na análise dos impactos ambientais (PE-INTERNATIONAL, 2014). 
Os parâmetros do modelo foram definidos com base na pesquisa de campo e bibliográfica da cadeia produtiva da vedação de bloco cerâmico, bem como no levantamento dos dados dos processos dessa cadeia. Os parâmetros serão apresentados conforme a evolução de cada uma das versões do MTP: inicial, intermediário e final.

\subsubsection{Controle de qualidade dos dados e alocação}

O controle de qualidade foi feito por meio da revisão dos dados coletados, filtragem de dados que estavam fora da curva ao serem comparados a dados similares, uso de dados compilados da bibliografia de referência e dados de banco de dados já avaliados por terceiros.

Apenas um dos dados precisou ser estimado com base em dados empíricos, conforme demonstrado no Quadro 17. Esse dado é a quantidade de água para a preparação das argamassas tradicionais brasileiras, que foi estimado em torno de $15 \%$ da massa da mistura seca. O tratamento da água usada é um dos menores impactos observados em argamassas compostas por cimento Portland ou por cal hidratada, além de ser a menor quantidade de matéria-prima da mistura.

Para esta pesquisa, optou-se por adotar os procedimentos de alocação por massa. No entanto, nenhum dos processos ou dos planos inseridos nesse projeto precisaram de alocação.

\subsubsection{Modelagem e testes do modelo}

Com os dados da vedação vertical brasileira e com as definições de escopo e objetivo, iniciou-se a etapa de modelagem. Essa etapa consiste em arranjar os dados por meio de parâmetros fixos e variáveis, conectar processos e planos e inserir as variáveis que formarão os contextos de análise.

\subsubsection{Modelo Inicial}

\section{A) Modelagem}

Considerando os passos descritos nos tópicos anteriores e seguidos para a elaboração do MTP ao iniciar a modelagem foram seguidas as seguintes etapas: 
i. Criação dos processos e planos necessários, que ainda não foram criados e que não são do banco de dados do GaBi 6;

ii. Busca no banco de dados pelos processo e planos e inserção deles em um plano geral;

iii. Documentação do plano geral com o preenchimento do objetivo e escopo no formulário disponibilizado pelo software de ACV;

iv. Inserção dos parâmetros fixos e livres nos processos e planos;

v. Conexão dos processos e planos;

vi. Inserção dos parâmetros livres (variáveis) no Plano Geral vinculados aos parâmetros fixos que estão nos processos e planos específicos que foram inseridos no Plano Geral.

O modelo inicial elaborado está ilustrado na Figura 40 , onde se vê as caixas dos processos e dos planos específicos, as conexões entre os objetos e uma separação preliminar das etapas da ACV, por meio da diagramação em colunas dentro do Plano Geral. Na tentativa de tornar a informação visualmente mais clara, as setas que conectam os processos e planos específicos foram coloridas conforme o fluxo da informação. Porém, a quantidade de caixas dos processos e planos específicos e de setas tornava a compreensão do modelo bastante difícil para que fosse manipulado.

Esse MTP inicial é composto por 177 parâmetros ${ }^{28}$ divididos entre os processos e planos, compostos sobretudo de valores específicos, como a eficiência do consumo de água do fabricante M1 para a fabricação do bloco cerâmico; fórmulas matemáticas, como o cálculo da massa de areia usada nas argamassas a partir do volume e da densidade aparente do material; ou fórmulas condicionais que caracterizavam a vedação e o bloco brasileiro. O Quadro 19 apresenta apenas um exemplo dos parâmetros livres e fixos que foram desenvolvidos para este MTP, por que a tabela completa se mostrou um elemento massivo e que interrompiaa fluidez da leitura deste capítulo. O quadro completo de parâmetros do Modelo Inicial está disponível no Apêndice J.

\footnotetext{
${ }^{28}$ Nessa contagem constam apenas os parâmetros dos processos e planos criados neste estudos e apenas dois parâmetros dos processo já existentes: partículas por enxofre e distância, que foram alterados conforme a necessidade.
} 
Esse apêndice contém o quadro geral de parâmetros do MTP Inicial dividido entre parâmetros livres e fixos e detalhado o nome do processo ou plano, o código do parâmetro, a fórmula, o valor atribuído e comentário.

Quadro 19: Exemplo de parâmetro livre do total de parâmetros criados para o MTP inicial

\begin{tabular}{|c|c|c|c|c|}
\hline $\begin{array}{c}\text { Nome } \\
\text { do Pro- } \\
\text { cesso } \\
\text { ou Plano }\end{array}$ & Código & Fórmula & Valor & Comentário \\
\hline \multicolumn{5}{|c|}{ Parâmetros fixos } \\
\hline $\begin{array}{l}\text { BR: Ar- } \\
\text { gamassa } \\
\text { Assen- } \\
\text { tamento }\end{array}$ & energia & 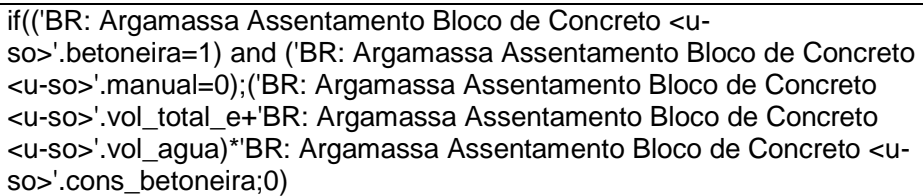 & 0 & $\begin{array}{l}\text { MJ (calclu- } \\
\text { lado) }\end{array}$ \\
\hline
\end{tabular}

B) Análise crítica dos resultados e revisão das inconsistências

Foi feito o primeiro balanço do modelo inicial, que gerou alguns problemas, mas que foram corrigidos com ajustes nos parâmetros e com a correta inter-relação entre os parâmetros fixos e livres. No entanto, foram identificados outros problemas que não tinham conexão direta com o balanço, tais como: problemas nas dimensões do bloco cerâmico, aplicação equivocada do traço da argamassa do emboço interno, etc. As inconsistências identificadas e as soluções propostas foram:

i. Padronização das saídas dos processos para $1 \mathrm{~kg}$ de produto de referência: observando os processos do banco de dados da BRE inseridos no Simapro, foi possível identificar que todos os processos possuíam saídas padronizadas para 1 quilo ou para 1 tonelada de produto. Por isso, a saída dos processos de argamassas e bloco, criados no Brasil, foram alterados para o mesmo padrão, assim esses processos podem ser usados em outros planos além da vedação estudada, visto que esses processos estavam anteriormente padronizados para a saída de $1 \mathrm{~m}^{2}$;

ii. Mudança do bloco do Brasil: o bloco cerâmico brasileiro utilizado era o de $9 \mathrm{~cm}$ de largura, porém esse bloco não pode ser utilizado em vedações externas e não cumpre com os requisitos térmicos mínimos para as vedações externas utilizadas na Zona 1, 2 e 3, áreas de onde provém os dados utilizados no modelo e coletados por Manfredini et al (2005). Sendo assim, o bloco foi substituído por 
um modelo de $14 \mathrm{~cm}$ de largura, que, utilizado junto às argamassas interna e externa, cumpre os requisitos térmicos para todas as zonas bioclimáticas do Brasil e os requisitos acústicos para habitações classes I, II e III, segundo a NBR 15.575 e NBR 10.152 (ABNT, 2013b; ABNT, 1987);

iii. Alteração do traço das argamassas do Brasil: dois traços aplicados precisaram ser alterados, pois um dos traços de argamassa de emboço interno havia sido erroneamente aplicado no lado externo da vedação. O outro traço de argamassa alterado foi o que seria aplicado no assentamento dos blocos cerâmicos, pois esse traço misturava medidas em volume e em massa dificultando o cálculo, o que poderia tornar os dados imprecisos. O traço novo inserido usava como referência de medida apenas dados em massa;

iv. Inserção de parâmetros para calcular as médias de consumo de energia e de combustível: os processos do banco de dados da BRE foram construídos considerando o cálculo da média de consumo de energia por fabricante. Por isso, foram inseridos parâmetros para cada um dos fabricantes pesquisados e parâmetros médios que permitem utilizar valores médios para qualquer forno e combustível, valor médio para cada tipo de forno e tipo de combustível ou valores específicos dos fabricantes. Sendo assim, utilizando os processos e os parâmetros é possível criar DAPs médias ou específicas por meio do modelo elaborado;

v. Fluxos de correção dos balanços: os processos do banco de dados da BRE possuem fluxos sem impacto que auxiliam na correção nos balanços de massa dos processos e planos, assim os balanços ficam corretos, mas sem aumentar o impacto de nenhum deles. Essa medida foi adotada nos processos criados. 


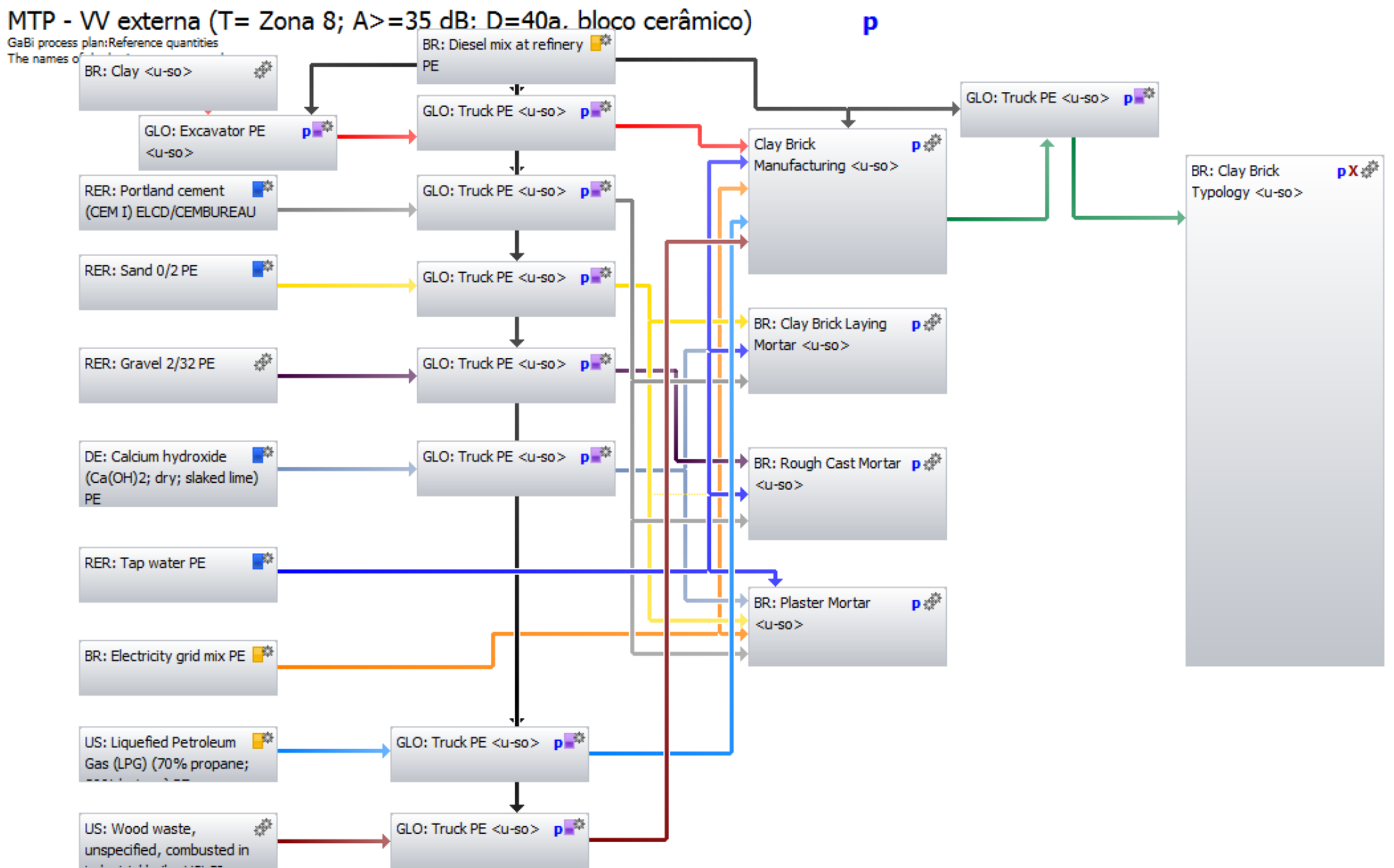

Figura 40: Primeira versão do MTP. 


\subsubsection{Modelo Intermediário}

A) Modelagem:

Além das alterações descritas na revisão das inconsistências do modelo inicial, para o modelo intermediário foram inseridos os processos e planos da vedação de bloco cerâmico do Reino Unido.

No MTP intermediário, os processos foram normalizados para $1 \mathrm{~kg}$ de produto, o que eliminou os parâmetros associados aos fluxos de entrada e saída, o que era feito até o MTP inicial. Por exemplo, no MTP inicial havia um processo para cada componente da vedação. A Figura 41 mostra o processo do componente chapisco, que continha todas as possibilidades de traços considerados na pesquisa. Sendo assim, qualquer inserção de novo traço de chapisco demandava a alteração do processo do componente.

No MTP intermediário, as argamassas passaram a ter processos separados para cada traço considerado na pesquisa, independente da função desta argamassa na edificação. Assim, a inserção de novos traços depende apenas da criação de um novo processo, o que não altera os processos originais do modelo e reduz a possibilidade de erros ao manipular o MTP e a complexidade na inserção de novos parâmetros.

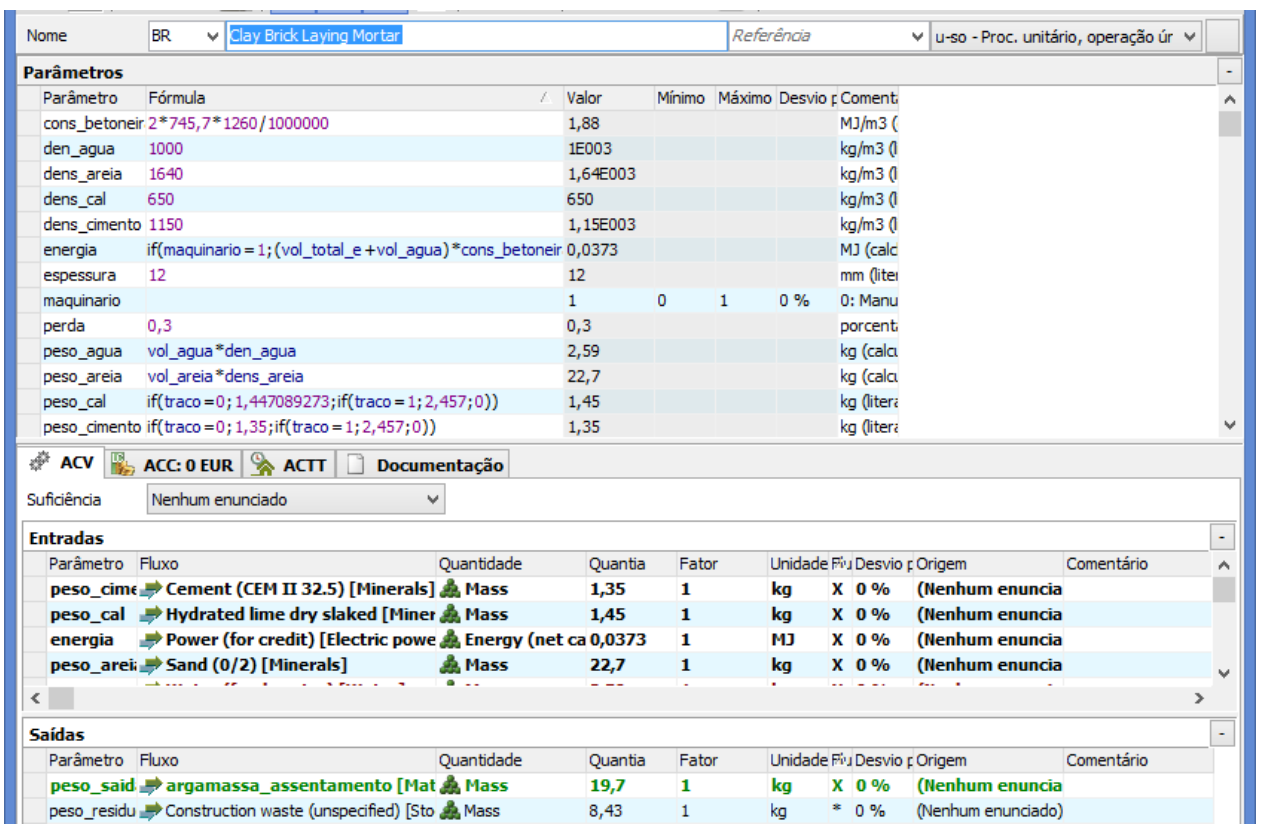

Figura 41: Processo de argamassa de chapisco do MTP inicial 
A Figura 42 possui os valores de entradas e saídas fixados para $1 \mathrm{~kg}$ de saída de produto. Essa estratégia de montagem do processo foi feita a partir da observação do banco de dados da BRE. Sendo assim, a inserção de parâmetros ficou restrita onde eles eram fundamentais para o desenho e na consistência do MTP.

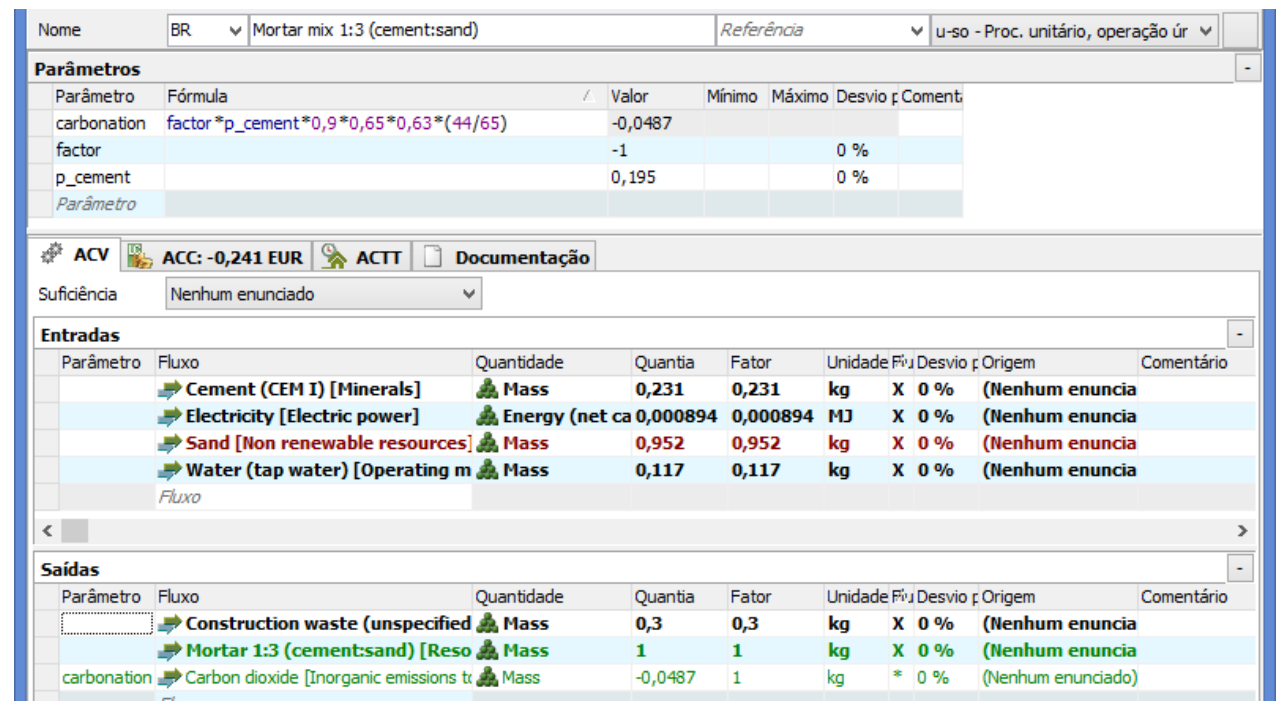

Figura 42: Processo da argamassa 1:3 (cimento Portland e areia)

Devido aos ajustes feitos, o MTP intermediário passou a ter 154 parâmetros nos processos e planos criados, além dos parâmetros dos processos já existentes (Apêndice K:).

Observa-se que, apesar do aumento do número de processos e planos com a inserção dos dados da vedação vertical dos Reino Unido, houve uma redução do número de parâmetros em relação ao MTP inicial. Isso reforça a simplicidade da abordagem de modelagem intermediária em relação à inicial, conceito defendido por autores como Mueller et al (2004) e Hens et al (2009).

Os parâmetros do MTP intermediário estão listados no Apêndice $\mathrm{K}$ devido a massividade da informação e a quebra da fluidez do texto. Além do quadro geral de parâmetros, o Apêndice $\mathrm{K}$ também traz a lista de parâmetros excluídos nessa etapa de desenvolvimento. 
Foram seguidas as seguintes etapas (Figura 43):

i. Migração dos processos do banco de dados da BRE para o software GaBi 6;

ii. Substituição de alguns processos do banco de dados da BRE para processos do banco de dados do $\mathrm{GaBi}$, tais como cimento Portland, cal hidratada, diesel, tratamento de água etc, visto que eram processos similares aos do banco de dados da BRE e que já estavam sendo usados para a vedação externa brasileira;

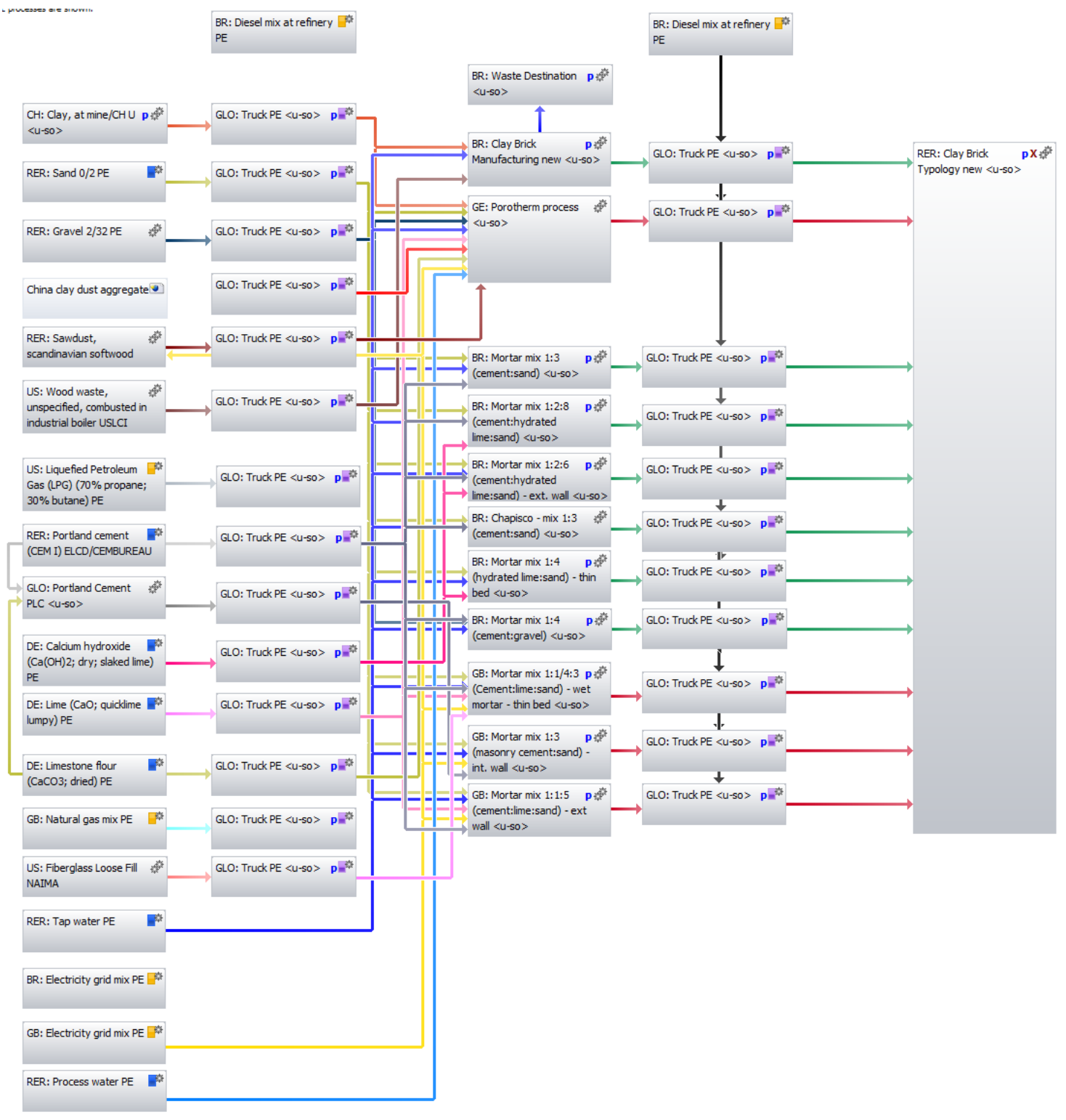

Figura 43: Versão intermediária do MTP com os dados do Brasil e do Reino Unido.

iii. Busca no software e inserção das caixas dos processos e planos específicos no Plano Geral; 
iv. Conexão dos objetos inseridos;

v. Revisão dos parâmetros livres (variáveis) no Plano Geral vinculados aos parâmetros fixos, visto que novos processos e planos haviam sido inseridos;

vi. Definição das características dos componentes, processos e planos que, no caso do software GaBi 6, é feito da ferramenta GaBi Analyst. Dentro dessa ferramenta são elaborados os contextos de análise que serão considerados por meio dos parâmetros livres selecionados. Como apresentado no objetivo e no escopo, os contextos de análise desta pesquisa são: (i) comparação entre duas tipologias brasileiras; e (ii) comparação da aplicação de uma tipologia do Reino Unidos nos contextos no Reino Unido e, hipoteticamente, no Brasil.

B) Análise crítica dos resultados e revisão das inconsistências

Além das inconsistências e soluções identificadas, nessa etapa foram revisados os valores atribuídos aos dados, os processos e planos inseridos; e os valores dos parâmetros fixos e variáveis.

i. Classificação dos processos e planos: Foi mantida a separação em colunas de etapas do ciclo de vida e as setas coloridas, porém a medida que novos objetos foram inseridos ao Plano Geral, a compreensão do modelo e, bem como a sua alteração, se tornaram ainda mais complexas e difíceis de serem apreendidas.

Sendo assim, optou-se por classificar os objetos do plano geral por módulo de uma DAP, o que permite gerar os resultados do balanço por módulo, além de colorir os objetos e tornar a compreensão do modelo mais fácil. Essa classificação permite cumprir aos requisitos estabelecidos da EN 15.804 (ISO, 2014) com a separação dos processos por tipo (A1 a D). O Quadro 20 mostra as características consideradas em cada um dos módulos de ACV;

ii. Inserção de cenários de fim da vida: a concepção inicial do modelo considerava um sistema 'do berço ao canteiro de obras, com opções', ou seja, apenas os estágios de produção e construção do 
produto. Porém, com a evolução do modelo, foi sugerido que outros módulos fossem inseridos no processo produtivo do produto analisado. Com isso, foram inseridos os módulos C2, C3, C4 e D, que analisam a disposição final do resíduo, processamento e potenciais benefícios de reciclagem, reuso ou reaproveitamento;

Quadro 20: Módulos de ACV e os itens considerados

\begin{tabular}{|c|c|}
\hline $\begin{array}{c}\text { Está- } \\
\text { gio }\end{array}$ & Itens considerados em cada módulo \\
\hline 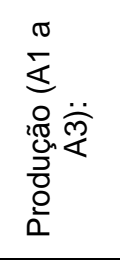 & $\begin{array}{l}\text { Extração e produção da matéria-prima e o processamento de entradas de materiais reciclados } \\
\text { (A1); transporte das matérias-primas (A2); e produção e empacotamento dos produtos (A3). } \\
\text { Esse estágio inclui o fornecimento das matérias-primas, produtos e energia, assim como o } \\
\text { processamento dos resíduos e a disposição final. A energia consumida nas fábricas e nos es- } \\
\text { critórios são inseridas na contagem, porém é excluído o consumo dos escritórios centrais e } \\
\text { pontos de venda. Outros itens excluídos são a manutenção dos equipamentos e os itens con- } \\
\text { sumidos com massa inferior a } 1 \% \text { e que não possuam impacto relevante. }\end{array}$ \\
\hline 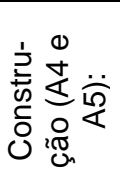 & $\begin{array}{l}\text { Transporte do produto desde a fábrica até a obra (A4); e instalação do produto na obra, bem } \\
\text { como desperdícios da instalação (A5). São inseridas nessa fase o processamento dos resí- } \\
\text { duos gerados e a energia consumida (se estiver disponível). Para as avaliações que conside- } \\
\text { ram a edificação como um todo, devem ser inseridos os produtos auxiliares, a energia e a } \\
\text { água consumida para instalação e operação da obra para a construção do produto. }\end{array}$ \\
\hline 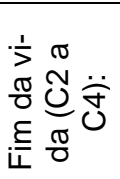 & $\begin{array}{l}\text { Substituição, demolição ou desconstrução do produto na edificação e que não terá qualquer } \\
\text { outra funcionalidade, o que pode acontecer nos estágios de construção e de uso. Esse estágio } \\
\text { incluiu transporte dos resíduos (C2); processamento dos resíduos para reuso, reciclagem ou } \\
\text { aproveitamento da energia (C3); e disposição final (C4), bem como processos associados; }\end{array}$ \\
\hline
\end{tabular}

Benefícios e cargas do reuso ou reciclagem dos produtos ou o reaproveitamento da energia

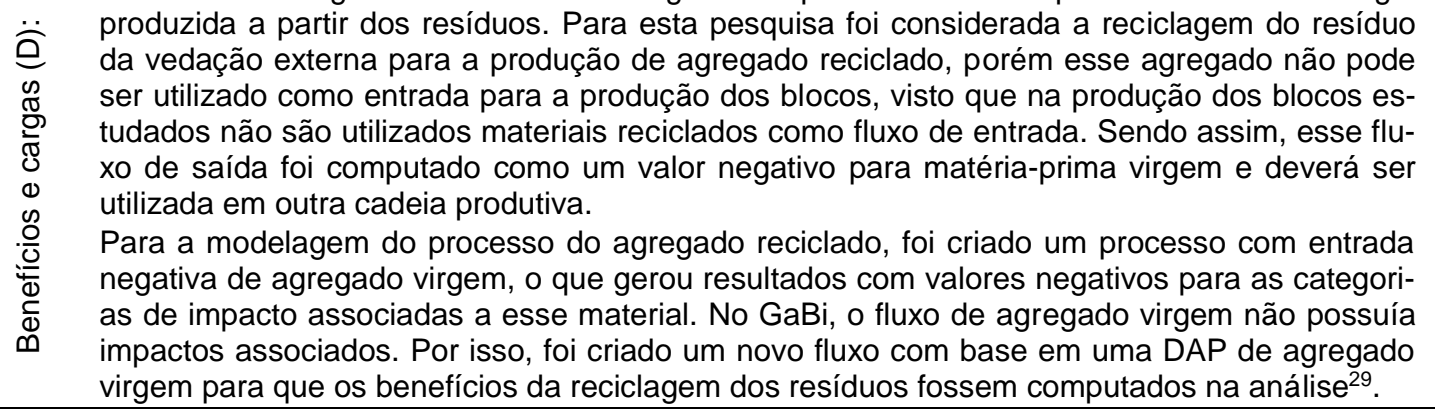
Fonte: BRE, 2014.

iii. Erro de conversão da unidade: os dados iniciais do processo do bloco cerâmico foram inseridos no Gabi em quilogramas, e, posteriormente, os dados tomados do processo do bloco cerâmico do Reino Unido foram inseridos em toneladas. Esse erro só foi percebido devido aos altíssimos valores gerados em algumas categorias de impactos relacionadas à queima de combustível, que levou ao rastreamento da origem dos dados.

\footnotetext{
${ }^{29}$ O DAP utilizado como referência para a criação do fluxo é de Holcim (2014).
} 
Outro erro observado aconteceu na conversão de MJ para quilos de combustível, visto que o processo de transporte do GaBi permite o transporte de quilos de combustível, enquanto que o processo do Ecoinvent permite o transporte de MJ de combustível. Sendo assim, os processos do Ecoinvent que foram usados precisaram ser convertidos de MJ para quilos de combustível, por meio da inserção de parâmetros fixos de conversão dos valores;

iv. Duplicação na contagem da queima de combustível: no plano de fabricação do bloco cerâmico brasileiro, a biomassa estava duplicada com a inserção da queima da biomassa no processo do bloco e com a conexão de biomassa já queimada;

v. Altos valores do Potencial de Acidificação: foi observado que o Potencial de Acidificação era o impacto mais importante nas avaliações do bloco britânico. Geralmente, o impacto mais relevante das ACVs é o Potencial de Mudança Climática. Por isso, os resultados obtidos com o modelo foram comparados aos resultados do bloco britânico gerados pelo Simapro. Os resultados estavam muito próximos e, também no processo do Simapro, o potencial de Acidificação era o impacto mais relevante;

vi. Comparação dos resultados do modelo: o plano do bloco cerâmico inglês foi criado inserindo cada um dos processos e a partir do inventário. Os resultados desses dois tipos de modelagem foram comparados e foram bastante similares.

O modelo final, elaborado após as correções e alterações está ilustrado na Figura 44. Na última versão do MTP existem 195 parâmetros e os parâmetros inseridos nesta etapa foram detalhados no Apêndice L. A alteração na abordagem que foi feito do MTP intermediário pata o MTP final está na inserção do parâmetro nacionalidade, que unificou processos como a destinação final dos resíduos, mas que demandou a inserção de parâmetros associados. Além disso, inseriu-se os módulos de ACV de C2 a D, que demandaram a elaboração de outros processos e planos. Essa abordagem ainda demandou a retirada de alguns parâmetros que estão detalhados no Apêndice L. 

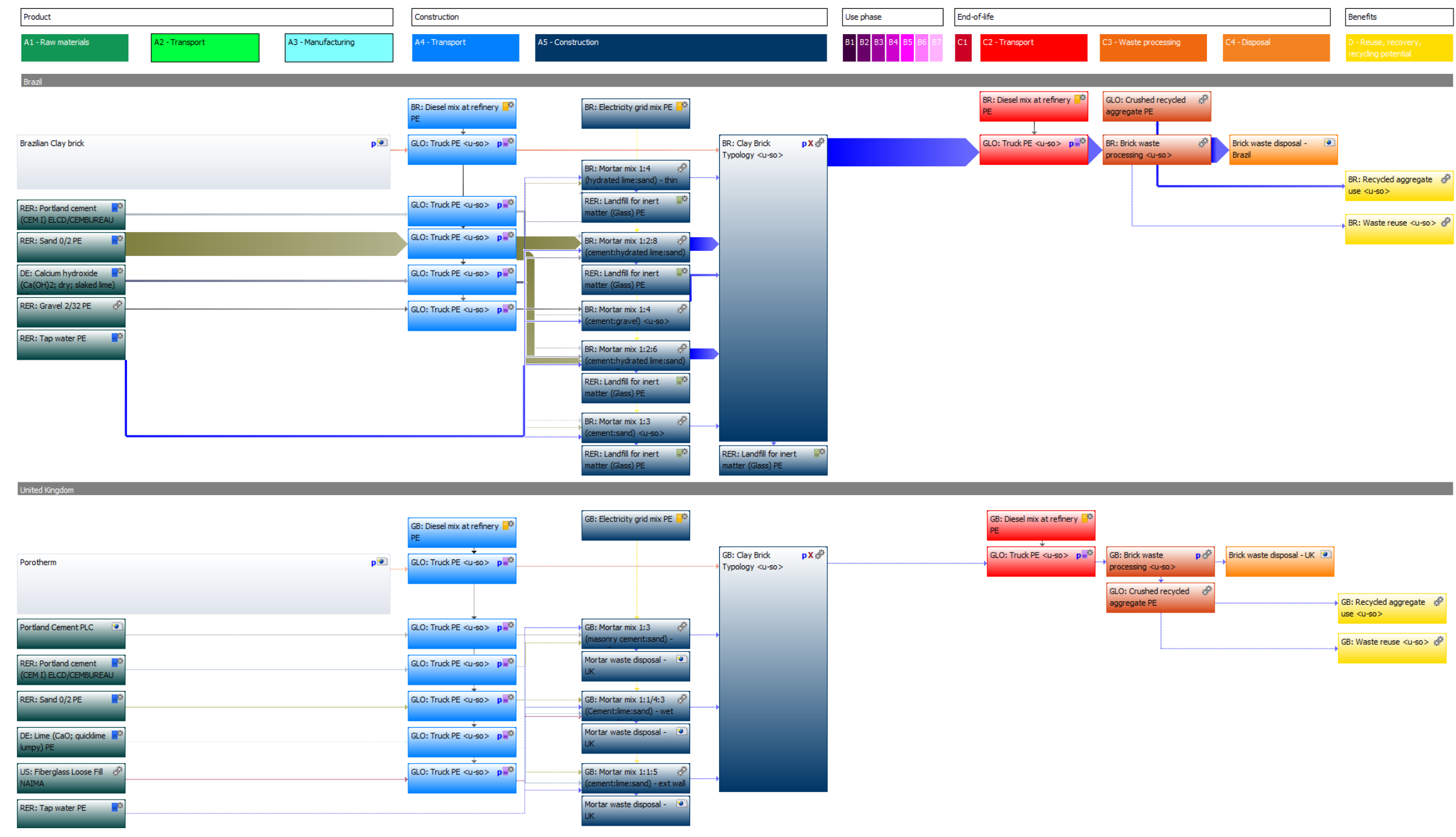

Figura 44: Modelo Tecnológico Parametrizado final. Fonte: dos autores 


\subsubsection{Ajustes no modelo final}

O objetivo dessa modelagem é criar um modelo o mais genérico possível, sem perder suas características fundamentais e que possa receber uma grande quantidade de dados e parâmetros.

Com isso, criou-se o parâmetro "nacionalidade" que define, além da origem geográfica, uma série de características relacionadas. Foram atreladas à nacionalidade as porcentagens de resíduos reciclados, as porcentagens de resíduos encaminhados ao aterro sanitário e o tipo de tratamento, o diesel, as partículas por milhão de Enxofre (ppm), as taxas de perda de bloco na construção da vedação e os pesos dos blocos (Figura 45).

O último ajuste feito foi a inserção das equações de carbonatação, que é o processo de captura do $\mathrm{CO}_{2}$ da atmosfera por produtos que contenham cimento ou cal devido à reação do óxido de cálcio ou hidróxido de cálcio contidos nos produtos de concreto. Essas equações são inseridas nos produtos onde 0 saldo negativo de $\mathrm{CO}_{2}$ deve ser incorporado ao módulo $\mathrm{B} 1$ e, para as argamassas, o saldo negativo deve ser incorporado ao módulo A5. Segundo BRE (2014a) o raciocínio utilizado para o cálculo é:

Carbonatação $\left(\mathrm{kg} / \mathrm{m}^{3}\right)=0,63 \times \mathrm{McaO} \times \mathrm{m} \cdot \mathrm{mco} 2 / \mathrm{m} . \mathrm{mcaO} \quad$ Eqn. 1
Onde $\quad 0,63=$ quantidade de $\mathrm{CaO}$ que sofrerá o processo de carbonatação
$\mathrm{m} \cdot \mathrm{m}_{\mathrm{co} 2}=$ massa molecular do $\mathrm{CO}_{2}(44)$
$\mathrm{m} \cdot \mathrm{m}_{\mathrm{CaO}}=$ massa molecular do $\mathrm{CaO}(56)$
$\mathrm{M}$ caO $=$ massa de $\mathrm{CaO}$ no produto de concreto $\left(\mathrm{kg} / \mathrm{m}^{3}\right)$, obtido como mostrado abaixo:

Massa de $\mathrm{CaO}, \mathrm{McaO}=\mathrm{Qcem}_{\mathrm{c}} \times \mathrm{Ccem} \times \% \mathrm{CaOc}$

Eqn. 2

Onde $\quad$ Qcem $=$ quantidade de cimento no concreto $\left(\mathrm{kg} / \mathrm{m}^{3}\right)$

$\% \mathrm{C}_{\mathrm{Cem}}=$ porcentagem de clinquer no cimento (80\% para misturas prontas, $90 \%$ para pré-prepadas e $80 \%$ para pavimentação)

$\% \mathrm{CaO} c=$ porcentagem de $\mathrm{CaO}$ no clinquer $(65 \%)$

Por substituição, Eqn. 1 torna-se

Carbonatação $\left(\mathrm{kg} / \mathrm{m}^{3}\right)=0,63 \times$ Qcem $\times \% C_{\text {cem }} \times 0,65 \times 44 / 56 \quad$ Eqn. 3

Se $(0,63 \times 0,65 \times 44 / 56)$ for substituído por ' $z$ ' na Eqn. 3, então tem-se:

Carbonatação $\left(\mathrm{kg} / \mathrm{m}^{3}\right)=\mathrm{z} \times$ Qcem $\times \% C$ cem Eqn. 4

Por exemplo, se o produto possui $16 \%$ de cimento, a equação será:

$-1^{*} 0.16^{*} 0.9^{*} 0.65^{*} 0.63^{*}(44 / 56)=-0,0463$ 


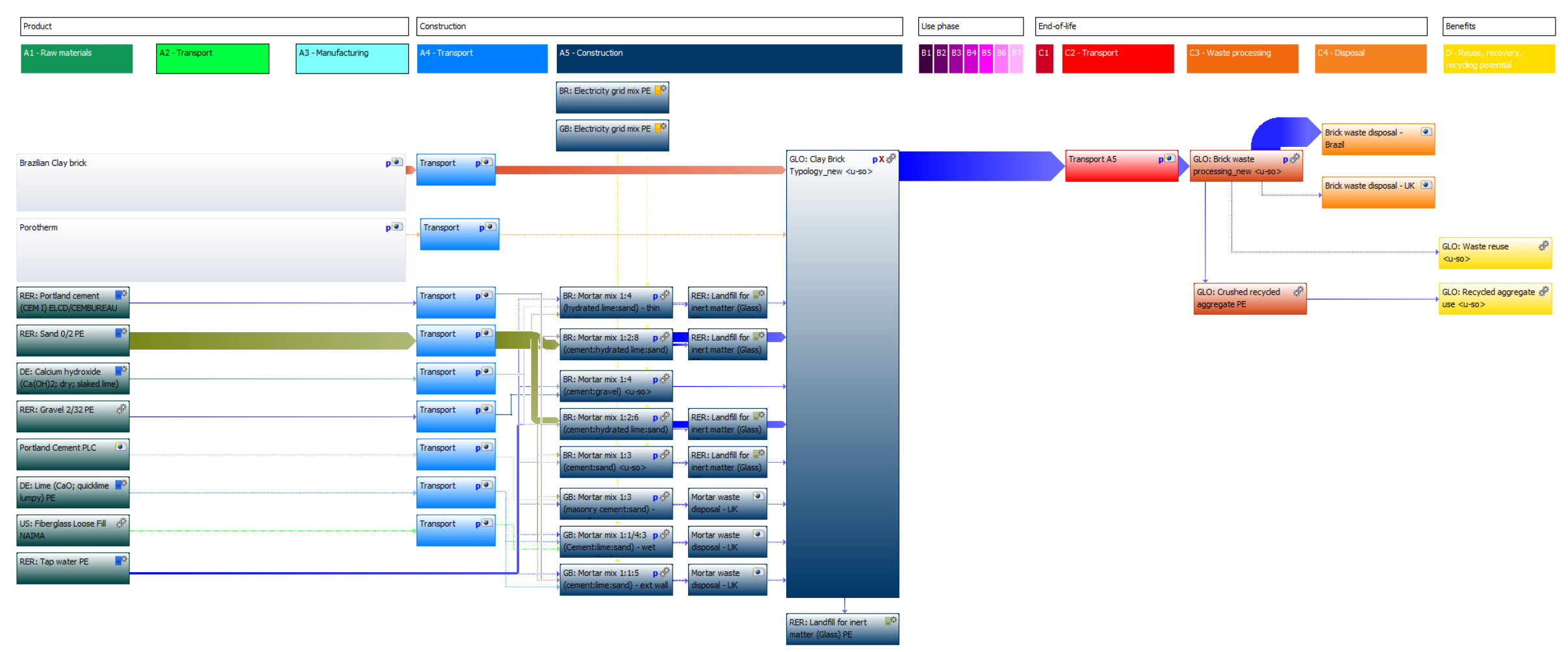

Figura 45: Ajustes no MTP final. Fonte: dos autores

Os contextos de análises elaborados para esta pesquisa seguem o exposto no Quadro 21 e seguem os parâmetros livres definidos e que caracterizam o processo produtivo de acordo com as escolhas de projeto do produto. Nesse quadro é possível ver os arranjos das comparações entre os contextos de análise e o que cada valor de parâmetros assumido significa. 


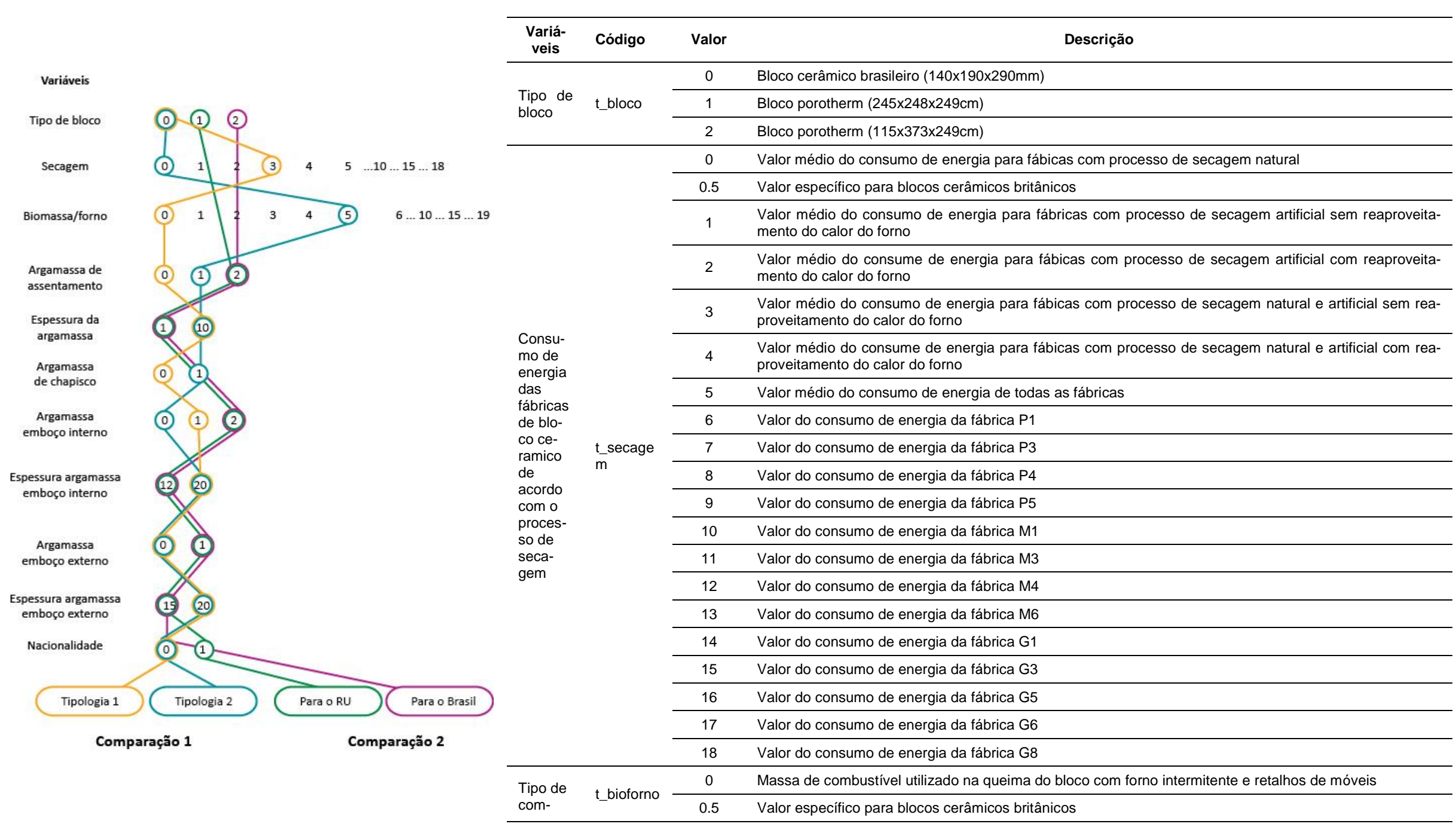




\begin{tabular}{|c|c|c|c|}
\hline \multirow{19}{*}{$\begin{array}{l}\text { bustível } \\
\text { e forno }\end{array}$} & & 1 & Massa de combustível utilizado na queima do bloco com forno intermitente e lenha \\
\hline & & 2 & Massa de combustível utilizado na queima do bloco com forno intermitente e serragem \\
\hline & & 3 & Massa de combustível utilizado na queima do bloco com forno semicontínuo e lenha \\
\hline & & 4 & Massa de combustível utilizado na queima do bloco com forno túnel e cavaco de madeira \\
\hline & & 5 & Massa de combustível utilizado na queima do bloco com forno túnel e lenha \\
\hline & & 6 & Valor médio do consumo de combustível para todas as fábricas \\
\hline & & 7 & Valor do consumo de combustível da fábrica P1 \\
\hline & & 8 & Valor do consumo de combustível da fábrica P3 \\
\hline & & 9 & Valor do consumo de combustível da fábrica P4 \\
\hline & & 10 & Valor do consume de combustível da fábrica P5 \\
\hline & & 11 & Valor do consumo de combustível da fábrica M1 \\
\hline & & 12 & Valor do consumo de combustível da fábrica M3 \\
\hline & & 13 & Valor do consumo de combustível da fábrica M4 \\
\hline & & 14 & Valor do consumo de combustível da fábrica M6 \\
\hline & & 15 & Valor do consumo de combustível da fábrica G1 \\
\hline & & 16 & Valor do consumo de combustível da fábrica G3 \\
\hline & & 17 & Valor do consumo de combustível da fábrica G5 \\
\hline & & 18 & Valor do consumo de combustível da fábrica G6 \\
\hline & & 19 & Valor do consumo de combustível da fábrica G8 \\
\hline \multirow{3}{*}{$\begin{array}{l}\text { Chapis- } \\
\text { co }\end{array}$} & \multirow{3}{*}{ t_cha } & 0 & Traço de cimento Portland e pedrisco (1:4) \\
\hline & & 0.5 & Sem chapisco \\
\hline & & 1 & Traço de cimento Portland e areia (1:3) \\
\hline \multirow{3}{*}{$\begin{array}{l}\text { Arga- } \\
\text { massa } \\
\text { de as- } \\
\text { senta- } \\
\text { mento }\end{array}$} & \multirow{3}{*}{ t_ass } & 0 & Traço de cal hidratada e areia (1:4) \\
\hline & & 1 & Traço de cimento Portland, cal hidratada e areia (1:2:8) \\
\hline & & 2 & Traço de cimento Portland, cal e areia $(1: 1 / 4: 3)$ \\
\hline \multirow{2}{*}{$\begin{array}{l}\text { Arga- } \\
\text { massa } \\
\text { de em- } \\
\text { boço } \\
\text { externa }\end{array}$} & \multirow[b]{2}{*}{$t^{t \text { temb_ex }}$} & 0 & Traço de cimento Portland, cal hidratada e areia (1:2:6) \\
\hline & & 1 & Traço de cimento Portland, cal e areia (1:1:5) \\
\hline \multirow{2}{*}{$\begin{array}{l}\text { Arga- } \\
\text { massa }\end{array}$} & \multirow{2}{*}{ t_emb_int } & 0 & Traço de cimento Portland, cal hidratada e areia (1:2:8) \\
\hline & & 1 & Traço de cimento Portland e areia (1:3) \\
\hline
\end{tabular}




\begin{tabular}{|c|c|c|c|}
\hline $\begin{array}{l}\text { de em- } \\
\text { boço } \\
\text { interna }\end{array}$ & & 2 & Traço de masonry cement e areia $(1: 3)$ \\
\hline \multirow{6}{*}{$\begin{array}{l}\text { Nacio- } \\
\text { nalida- } \\
\text { de }\end{array}$} & \multirow{6}{*}{ brazil_uk } & \multirow[b]{3}{*}{0} & Brasil \\
\hline & & & $\underline{\text { Valores ou processos associados }}$ \\
\hline & & & $\begin{array}{l}2 \% \text { de resíduos para reaproveitamento no estágio de fim da vida; } 98 \% \text { de resíduo para aterro sanitário; } \\
\text { Disposição de resíduos no Brasil; Diesel brasileiro; } 1800 \text { ppm de enxofre; } 5 \% \text { de perda de blocos cerâmi- } \\
\text { cos no canteiro de obras; e Bloco cerâmico brasileiro; }\end{array}$ \\
\hline & & \multirow[b]{3}{*}{1} & Reino Unido \\
\hline & & & Valores ou processos associados \\
\hline & & & $\begin{array}{l}90 \% \text { de resíduos para reaproveitamento no estágio de fim da vida; } 10 \% \text { de resíduo para aterro sanitário; } \\
\text { Disposição de resíduos no Reino Unido; Diesel britânico; } 10 \mathrm{ppm} \text { de enxofre; } 3 \% \text { de perda de blocos ce- } \\
\text { râmicos no canteiro de obras; e bloco poroso cerâmico britânico }\end{array}$ \\
\hline
\end{tabular}

\subsubsection{Resultados de ICV}

Para a análise dos resultados do ICV das vedações comparadas nos contextos de análise, utilizaram-se as informações disponibilizadas no balanço de massa, que foi classificado de acordo com o módulo de ACV. A Tabela 3 contém os dados dos fluxos mássicos dos recursos, resíduos depositados e emissões para a comparação 1, que trata das duas tipologias brasileiras e a Tabela 4 contém os dados da comparação 2, que trata da aplicação da tipologia inglesa no Reino Unido e, de uma aplicação hipotética no Brasil. As tabelas completas do ICV dos dois contextos de análises estão disponíveis no Apêndice M.

Tabela 3: Tabela do Inventário do Ciclo de Vida do contexto de análise 1 por fluxo e por módulo de ACV

\begin{tabular}{|c|c|c|c|c|c|c|c|c|c|c|}
\hline \multicolumn{11}{|c|}{ Tipologia 1} \\
\hline & Total & A1 & A2 & A3 & A4 & A5 & C2 & C3 & C4 & D \\
\hline Fluxos & $7,24 \mathrm{E}+03$ & $5,48 \mathrm{E}+03$ & $2,27 \mathrm{E}+01$ & $1,31 \mathrm{E}+01$ & $1,18 \mathrm{E}+02$ & $1,50 \mathrm{E}+03$ & $1,05 \mathrm{E}+02$ & $-6,70 \mathrm{E}+01$ & $6,09 \mathrm{E}+01$ & $4,59 \mathrm{E}+00$ \\
\hline Recursos & $3,75 \mathrm{E}+03$ & $2,89 \mathrm{E}+03$ & $1,13 \mathrm{E}+01$ & $-4,09 \mathrm{E}+01$ & $5,84 \mathrm{E}+01$ & $9,06 \mathrm{E}+02$ & $5,17 \mathrm{E}+01$ & $-1,60 \mathrm{E}+02$ & $3,06 \mathrm{E}+01$ & $4,59 \mathrm{E}+00$ \\
\hline Resíduos depositados & $1,30 \mathrm{E}+02$ & $6,92 \mathrm{E}+01$ & 3,17E-03 & $4,19 \mathrm{E}+00$ & 2,77E-02 & $5,57 \mathrm{E}+01$ & $2,45 \mathrm{E}-02$ & $1,08 \mathrm{E}+00$ & $8,20 \mathrm{E}-03$ & 0 \\
\hline Emissões para o ar & $2,26 \mathrm{E}+02$ & $1,17 \mathrm{E}+02$ & $7,54 \mathrm{E}+00$ & $1,21 \mathrm{E}+01$ & $3,55 \mathrm{E}+01$ & $4,73 \mathrm{E}+00$ & $3,14 \mathrm{E}+01$ & $1,06 \mathrm{E}+00$ & $1,67 \mathrm{E}+01$ & 0 \\
\hline
\end{tabular}




\begin{tabular}{|c|c|c|c|c|c|c|c|c|c|c|}
\hline Emissões para a água potável & $3,13 \mathrm{E}+03$ & $2,40 \mathrm{E}+03$ & $3,81 \mathrm{E}+00$ & $3,77 \mathrm{E}+01$ & $2,32 \mathrm{E}+01$ & $5,36 \mathrm{E}+02$ & $2,05 \mathrm{E}+01$ & $9,11 \mathrm{E}+01$ & $1,35 \mathrm{E}+01$ & $\underline{0}$ \\
\hline Emissões para o mar & $2,83 \mathrm{E}+00$ & $5,98 \mathrm{E}-01$ & $4,68 \mathrm{E}-02$ & $1,21 \mathrm{E}-02$ & $1,01 \mathrm{E}+00$ & $1,60 \mathrm{E}-01$ & $8,91 \mathrm{E}-01$ & $4,54 \mathrm{E}-03$ & 1,12E-01 & 0 \\
\hline Emissões para o solo agrícola & 2,92E-06 & $2,40 \mathrm{E}-06$ & $-2,07 \mathrm{E}-07$ & $1,36 \mathrm{E}-07$ & $-5,53 \mathrm{E}-07$ & $1,81 \mathrm{E}-06$ & $-4,90 \mathrm{E}-07$ & 2,97E-07 & $-4,69 \mathrm{E}-07$ & 0 \\
\hline Emissões para o solo industrial & 1,81E-02 & 1,79E-02 & $6,43 \mathrm{E}-07$ & 1,53E-05 & $3,11 \mathrm{E}-06$ & 1,91E-04 & $2,75 \mathrm{E}-06$ & $7,88 \mathrm{E}-07$ & 1,47E-06 & 0 \\
\hline \multicolumn{11}{|c|}{ Tipologia 2} \\
\hline & Total & A1 & A2 & A3 & A4 & A5 & C2 & C3 & C4 & D \\
\hline Fluxos & $7,02 \mathrm{E}+03$ & $5,37 \mathrm{E}+03$ & $2,15 \mathrm{E}+01$ & $9,90 \mathrm{E}+00$ & $1,16 \mathrm{E}+02$ & $1,41 \mathrm{E}+03$ & $1,05 \mathrm{E}+02$ & $-6,73 E+01$ & $6,12 \mathrm{E}+01$ & $7,02 \mathrm{E}+03$ \\
\hline Recursos & $3,65 \mathrm{E}+03$ & $2,83 \mathrm{E}+03$ & $1,07 \mathrm{E}+01$ & $-4,09 \mathrm{E}+01$ & $5,75 \mathrm{E}+01$ & $8,60 \mathrm{E}+02$ & $5,19 \mathrm{E}+01$ & $-1,61 \mathrm{E}+02$ & $3,07 \mathrm{E}+01$ & $3,65 \mathrm{E}+03$ \\
\hline Resíduos depositados & $1,26 \mathrm{E}+02$ & $7,03 E+01$ & $3,01 \mathrm{E}-03$ & $4,19 \mathrm{E}+00$ & $2,73 \mathrm{E}-02$ & $5,08 \mathrm{E}+01$ & $2,46 \mathrm{E}-02$ & $1,08 \mathrm{E}+00$ & 8,23E-03 & $1,26 \mathrm{E}+02$ \\
\hline Emissões para o ar & $2,14 \mathrm{E}+02$ & $1,10 \mathrm{E}+02$ & $7,16 \mathrm{E}+00$ & $8,88 \mathrm{E}+00$ & $3,49 \mathrm{E}+01$ & $3,59 \mathrm{E}+00$ & $3,15 \mathrm{E}+01$ & $1,06 \mathrm{E}+00$ & $1,68 \mathrm{E}+01$ & $2,14 \mathrm{E}+02$ \\
\hline Emissões para a água potável & $3,03 E+03$ & $2,35 E+03$ & $3,62 \mathrm{E}+00$ & $3,77 \mathrm{E}+01$ & $2,28 \mathrm{E}+01$ & $4,92 \mathrm{E}+02$ & $2,06 \mathrm{E}+01$ & $9,15 \mathrm{E}+01$ & $1,36 \mathrm{E}+01$ & $3,03 E+03$ \\
\hline Emissões para o mar & $2,90 \mathrm{E}+00$ & $6,99 \mathrm{E}-01$ & $4,45 \mathrm{E}-02$ & $1,21 \mathrm{E}-02$ & $9,91 \mathrm{E}-01$ & $1,46 \mathrm{E}-01$ & $8,94 \mathrm{E}-01$ & 4,56E-03 & 1,13E-01 & $2,90 \mathrm{E}+00$ \\
\hline Emissões para o solo agrícola & 3,38E-06 & $3,00 \mathrm{E}-06$ & $-1,97 \mathrm{E}-07$ & 1,36E-07 & $-5,45 \mathrm{E}-07$ & 1,65E-06 & $-4,92 \mathrm{E}-07$ & 2,98E-07 & $-4,71 \mathrm{E}-07$ & 3,38E-06 \\
\hline Emissões para o solo industrial & 1,77E-02 & $1,75 \mathrm{E}-02$ & $6,11 \mathrm{E}-07$ & 1,49E-05 & $3,06 \mathrm{E}-06$ & 1,74E-04 & $2,76 \mathrm{E}-06$ & 7,91E-07 & 1,47E-06 & 1,77E-02 \\
\hline
\end{tabular}

Tabela 4: Tabela do Inventário do Ciclo de Vida do contexto de análise 2 por fluxo e por módulo de ACV

\begin{tabular}{|c|c|c|c|c|c|c|c|c|c|c|}
\hline \multicolumn{11}{|c|}{ Tipologia inglesa aplicada ao Reino Unido } \\
\hline & Total & A1 & A2 & A3 & A4 & A5 & C2 & C3 & C4 & D \\
\hline Fluxos & $1,85 \mathrm{E}+04$ & $7,68 \mathrm{E}+03$ & $3,12 \mathrm{E}+01$ & $-1,72 E+02$ & $1,26 \mathrm{E}+02$ & $7,49 \mathrm{E}+02$ & $1,24 \mathrm{E}+02$ & $9,67 \mathrm{E}+03$ & $9,80 \mathrm{E}-01$ & $2,46 \mathrm{E}+02$ \\
\hline Recursos & $9,50 \mathrm{E}+03$ & $3,96 \mathrm{E}+03$ & $1,49 \mathrm{E}+01$ & $-1,79 \mathrm{E}+02$ & $6,25 \mathrm{E}+01$ & $6,64 \mathrm{E}+02$ & $6,16 \mathrm{E}+01$ & $4,67 \mathrm{E}+03$ & 4,98E-01 & $2,46 \mathrm{E}+02$ \\
\hline Resíduos depositados & $1,11 \mathrm{E}+02$ & $4,43 \mathrm{E}+01$ & $2,75 \mathrm{E}-02$ & $1,28 \mathrm{E}-01$ & $2,96 \mathrm{E}-02$ & $8,42 \mathrm{E}+00$ & 2,92E-02 & $5,76 \mathrm{E}+01$ & 1,13E-03 & 0 \\
\hline Emissões para o ar & $3,73 \mathrm{E}+02$ & $2,36 \mathrm{E}+02$ & $2,56 \mathrm{E}+00$ & $2,51 \mathrm{E}+00$ & $3,80 \mathrm{E}+01$ & $1,10 \mathrm{E}-01$ & $3,74 \mathrm{E}+01$ & $5,67 \mathrm{E}+01$ & $2,06 \mathrm{E}-02$ & 0 \\
\hline Emissões para a água potável & $8,46 \mathrm{E}+03$ & $3,44 \mathrm{E}+03$ & $1,21 \mathrm{E}+01$ & $4,29 \mathrm{E}+00$ & $2,48 \mathrm{E}+01$ & $7,70 \mathrm{E}+01$ & $2,44 \mathrm{E}+01$ & $4,88 \mathrm{E}+03$ & 4,09E-01 & 0 \\
\hline Emissões para o mar & $7,01 \mathrm{E}+00$ & $2,90 \mathrm{E}+00$ & $1,64 \mathrm{E}+00$ & $1,52 \mathrm{E}-03$ & $1,08 \mathrm{E}+00$ & $3,30 \mathrm{E}-02$ & $1,06 \mathrm{E}+00$ & $2,43 \mathrm{E}-01$ & $5,09 \mathrm{E}-02$ & 0 \\
\hline Emissões para o solo agrícola & $3,26 \mathrm{E}-04$ & $3,10 \mathrm{E}-04$ & $8,04 \mathrm{E}-07$ & $8,45 \mathrm{E}-09$ & $-5,92 \mathrm{E}-07$ & $6,08 \mathrm{E}-07$ & $-5,83 E-07$ & $1,59 \mathrm{E}-05$ & $3,45 \mathrm{E}-08$ & 0 \\
\hline Emissões para o solo industrial & 1,17E-02 & $1,10 \mathrm{E}-02$ & $3,88 \mathrm{E}-07$ & $6,26 \mathrm{E}-04$ & 3,33E-06 & $2,90 \mathrm{E}-05$ & $3,28 \mathrm{E}-06$ & 4,22E-05 & $1,65 \mathrm{E}-08$ & 0 \\
\hline \multicolumn{11}{|c|}{ Tipologia inglesa aplicada ao Brasil } \\
\hline
\end{tabular}




\begin{tabular}{|c|c|c|c|c|c|c|c|c|c|c|}
\hline & Total & A1 & A2 & A3 & A4 & A5 & $\mathrm{C} 2$ & C3 & C4 & D \\
\hline Fluxos & $4,14 \mathrm{E}+03$ & $3,68 \mathrm{E}+03$ & $1,41 \mathrm{E}+01$ & $-7,78 \mathrm{E}+01$ & $6,31 \mathrm{E}+01$ & $4,02 \mathrm{E}+02$ & $6,20 \mathrm{E}+01$ & $-3,98 \mathrm{E}+01$ & $3,62 E+01$ & $2,72 E+00$ \\
\hline Recursos & $2,15 \mathrm{E}+03$ & $1,90 \mathrm{E}+03$ & $6,74 \mathrm{E}+00$ & $-8,10 E+01$ & $3,12 \mathrm{E}+01$ & $3,39 E+02$ & $3,07 \mathrm{E}+01$ & $-9,51 E+01$ & $1,81 E+01$ & $2,72 \mathrm{E}+00$ \\
\hline Resíduos depositados & $3,23 \mathrm{E}+01$ & $2,53 \mathrm{E}+01$ & $1,25 \mathrm{E}-02$ & 5,81E-02 & $1,48 \mathrm{E}-02$ & $6,24 \mathrm{E}+00$ & $1,45 \mathrm{E}-02$ & $6,38 \mathrm{E}-01$ & 4,87E-03 & 0 \\
\hline Emissões para o ar & $1,62 \mathrm{E}+02$ & $1,12 \mathrm{E}+02$ & $1,16 \mathrm{E}+00$ & $1,14 \mathrm{E}+00$ & $1,89 \mathrm{E}+01$ & $-3,37 \mathrm{E}-01$ & $1,86 \mathrm{E}+01$ & $6,29 \mathrm{E}-01$ & $9,93 \mathrm{E}+00$ & 0 \\
\hline Emissões para a água potável & $1,79 \mathrm{E}+03$ & $1,64 \mathrm{E}+03$ & $5,49 \mathrm{E}+00$ & $1,95 \mathrm{E}+00$ & $1,24 \mathrm{E}+01$ & $5,74 \mathrm{E}+01$ & $1,22 \mathrm{E}+01$ & $5,41 \mathrm{E}+01$ & $8,01 \mathrm{E}+00$ & $\underline{0}$ \\
\hline Emissões para o mar & $3,26 \mathrm{E}+00$ & $1,35 \mathrm{E}+00$ & 7,45E-01 & $6,91 \mathrm{E}-04$ & $5,37 \mathrm{E}-01$ & $2,68 \mathrm{E}-02$ & $5,29 \mathrm{E}-01$ & 2,69E-03 & $6,65 \mathrm{E}-02$ & 0 \\
\hline Emissões para o solo agrícola & $1,41 E-04$ & $1,40 \mathrm{E}-04$ & 3,65E-07 & 3,83E-09 & $-2,96 \mathrm{E}-07$ & $5,37 \mathrm{E}-07$ & $-2,91 \mathrm{E}-07$ & $1,76 \mathrm{E}-07$ & $-2,78 \mathrm{E}-07$ & 0 \\
\hline
\end{tabular}




\subsubsection{Interpretação dos resultados do ICV}

No contexto de análise 1 os parâmetros foram alterados para os supostamente melhores e piores cenários das tipologias de vedações verticais brasileiras, por exemplo: a mudança do parâmetro da secagem onde na tipologia 1 considera-se uma secagem natural e artificial sem aproveitamento do calor do forno (valor 3 atribuído ao parâmetro secagem) e, para a tipologia 2, considerase uma secagem natural na qual não é demandado consumo de energia (valor 3 atribuído ao parâmetro secagem); ou ainda no consumo de cimento Portland, que é maior para o traço da argamassa de emboço interno da tipologia 1 (valor 1 do parâmetro Argamassa emboço interno) e que influirá no valor final da geração de impactos. A relação entre os parâmetros e os contextos de análise está disponível no Quadro 24.

Nessa análise, o módulo A1 concentra os maiores valores em massa dos fluxos tanto de recursos, quanto de resíduos depositados e emissões. A tipologia 1 possui valores maiores, em massa, para todos os fluxos considerados, o que demonstra que além consumir mais recursos, a tipologia 1 possui um maior volume de resíduos e emissões associado à sua produção. Se algum dos parâmetros de secagem ou de energia demandada fosse alterado para um cenário de menor consumo, como o valor 0 para secagem e valor 5 para energia demandada, os impactos poderiam ser reduzidos.

A mesma estratégia poderia ser usada para os demais fluxos do sistema. Considerando o fluxo Energia, que compõe o fluxo Recursos, observa-se que a demanda por fontes de energia não renováveis são muito maiores que as fontes renováveis, visto que a quantidade de combustível fóssil utilizado no transporte e no maquinário, tanto do beneficiamento das matérias-primas quanto na fabricação dos blocos e no processamento dos resíduos é superior à demanda de energia elétrica necessárias para a fábrica de blocos, a preparação e a aplicação das argamassas e da disposição final dos resíduos.

Das emissões atmosféricas, as emissões atmosféricas inorgânicas são as mais importantes, enquanto que as menos significativas são as partículas lançadas para o ar e as emissões radioativas, que apesar de possuírem um potencial de impacto que deve ser considerado, possuem valores muito pequenos na análise. As emissões para a água e para o mar concentram-se na categoria 
"outras emissões", o que demonstra que os valores de metais pesados, emissões orgânicas e inorgânicas e as partículas lançados para a água são valores pequenos. Por fim, as emissões para o solo agrícola e para o solo industrial são muito pequenas, em massa.

No contexto de análise 2, que compara uma vedação vertical inglesa aplicada no Reino Unido e, hipoteticamente, aplicada no Brasil o fluxo de massa da aplicação no Reino Unido é maior que o do Brasil, visto que é necessária mais massa de vedação por metro quadrado.

Apesar da taxa de reciclagem do resíduo da construção no Reino Unido, adotada nos processos elaborados pela BRE, ser de $90 \%$, ou seja, 45 vezes maior que a taxa de reciclagem dos resíduos no Brasil, a geração de resíduos no Reino Unido ainda é pouco mais de 3 vezes maior. Se no Brasil fossem necessárias de vedações verticais com maior espessura, devido aos requisitos de desempenho térmico como no Reino Unido, a geração de resíduos e o fluxo de massa da vedação seria muito maior, o que aumentaria o potencial de gerar impactos.

Considerando as emissões atmosféricas, observam-se tanto emissões orgânicas, que apresentam os valores mais expressivos, quanto emissões inorgânicas, que apesar de terem valores menores possuem um grande potencial de impacto ambiental. Além disso, observa-se a emissão de radiação para 0 ar em ambos os processos em quantidades pequenas, mas que podem ser um risco para a saúde humana e para o ecossistema.

As emissões para a água potável e para o mar também se concentram na categoria "outras emissões" demonstrando que os valores de metais pesados, de emissões orgânicas, de emissões inorgânicas e de partículas lançadas para a água são valores pequenos. Para as emissões para o solo agrícola e para o solo industrial observam-se o mesmo comportamento e valores muito pequenos, em massa.

Os valores apresentados nas Tabela 3 e 6 são dados em quilos de recursos, resíduos depositados e emissões e precisam ser classificados, caracterizados, normalizados e ponderados para serem interpretados de acordo com o potencial impacto associado à produção das tipologias analisadas. Essas etapas foram feitas e descritas na AICV, que foi abordada no item 6.2. 


\subsection{Avaliação do Impacto do Ciclo de Vida}

\subsubsection{Classificação e Metodologia de conversão}

A classificação tem como objetivo alocar cada substância do inventário nas categorias de impacto. Para a escolha da metodologia de conversão usada na classificação compararam-se as metodologias disponíveis e as categorias de impactos considerados como resultados intermediários (midpoints), segundo a JRC (2010) em cada uma dessas metodologias (Quadro 22).

Quadro 22: Metodologias de ACV e os midpoints dos indicadores considerados na pesquisa.

\begin{tabular}{|c|c|c|c|c|c|c|c|c|c|c|}
\hline \multicolumn{11}{|c|}{ Metodologias de Avaliação de Impacto } \\
\hline $\begin{array}{l}\text { Categorias } \\
\text { (midpoints) }\end{array}$ & $\begin{array}{l}\text { CML } \\
2001\end{array}$ & $\begin{array}{c}\text { Eco- } \\
\text { indi- } \\
\text { cator } \\
99\end{array}$ & $\begin{array}{c}\text { EDIP } \\
97 / 20 \\
03\end{array}$ & $\begin{array}{l}\text { EPS } \\
2000\end{array}$ & $\begin{array}{c}\text { Im- } \\
\text { pacto } \\
2002 \\
+\end{array}$ & LIME & $\begin{array}{l}\text { LU- } \\
\text { CAS }\end{array}$ & $\begin{array}{l}\text { Re- } \\
\mathrm{CiPe}\end{array}$ & $\begin{array}{l}\text { TRA- } \\
\mathrm{Cl}\end{array}$ & $\begin{array}{l}\text { MEE } \\
\text { UP }\end{array}$ \\
\hline GWP & $\mathrm{S}$ & $\mathrm{N}$ & $\mathrm{N}$ & $\mathrm{N}$ & $\mathrm{N}$ & $\mathrm{N}$ & $\mathrm{N}$ & $\mathrm{S}$ & $\mathrm{N}$ & $\mathrm{N}$ \\
\hline ODP & $\mathrm{S}$ & $\mathrm{N}$ & $\mathrm{S}$ & $\mathrm{N}$ & $\mathrm{N}$ & $\mathrm{N}$ & $\mathrm{N}$ & $\mathrm{N}$ & $\mathrm{N}$ & $\mathrm{N}$ \\
\hline AP & $\mathrm{S}$ & $\mathrm{N}$ & S & $\mathrm{N}$ & $\mathrm{S}$ & S & $\mathrm{N}$ & S & $\mathrm{S}$ & S \\
\hline EP & $\mathrm{S}$ & $\mathrm{N}$ & $\mathrm{S}$ & $\mathrm{N}$ & $\mathrm{N}$ & $\mathrm{N}$ & $\mathrm{N}$ & $\mathrm{N}$ & $S$ & $S$ \\
\hline РОCP & $S$ & $\mathrm{~N}$ & $S$ & $\mathrm{~N}$ & $\mathrm{~N}$ & $S$ & $\mathrm{~N}$ & $S$ & $S$ & $S$ \\
\hline ADP & $S$ & $\mathrm{~N}$ & $S$ & $\mathrm{~N}$ & $S$ & $\mathrm{~N}$ & $\mathrm{~N}$ & $\mathrm{~N}$ & $\mathrm{~N}$ & $\mathrm{~N}$ \\
\hline $\begin{array}{l}\mathrm{S}=\text { quando exi } \\
\mathrm{N}=\text { não existe }\end{array}$ & $\begin{array}{l}\text { Mid } \\
\text { point }\end{array}$ & nt pa & $\begin{array}{l}\text { a categ } \\
\text { egoria. }\end{array}$ & & & & & & & \\
\hline
\end{tabular}

Com base no Quadro 22, observa-se que a metodologia CML 2001 abrange todas as categorias de impacto consideradas nesta ACV e, por isso, foi adotada nesta pesquisa.

A metodologia CML 2001 está disponível em versões para software de ACV GaBi, usado para assistir à modelagem do ciclo de vida da cadeia produtiva e a contabilização dos impactos. Segundo análise de Caldeira-Pires (2011) esse software de ACV é o único do mercado mundial que possui a base de dados de inventários do ciclo de vida ELCD, da Plataforma Internacional do Ciclo de Vida-ILCD, da qual o Brasil é signatário através do lbict e do MCTI.

Além disso, esse software é o líder do mercado mundial em ferramentas computacionais para ACV e sua base de dados é reconhecida pela qualidade e volume de informação que contem (CALDEIRA-PIRES, 2011). Além disso, possui uma versão educacional gratuita e disponível para download e a base de dados estendida foi recentemente adquirida pelo Laboratório de Ener- 
gia e Ambiente (LEA) da UnB, o que facilita o acesso às informações e, por esses motivos, foi adotado nesta pesquisa para auxiliar na avaliação feita. Ressalta-se ainda que a etapa de classificação do inventário é feita automaticamente pelo software GaBi e a metodologia CML.

\subsubsection{Caracterização, Normalização e Ponderação}

Essa etapa envolve a conversão dos resultados do inventário para a mesma unidade e a agregação de resultados é convertida dentro da mesma categoria de impacto, sendo que o resultado desse cálculo é um valor numérico do indicador (ABNT, 2009b).

Para a caracterização são aplicados fatores que mostram a contribuição relativa de uma substância do inventário para cada categoria de impacto utilizando uma tabela de equivalência de substâncias (FERREIRA, 2004).

Nesta pesquisa consideraram-se os fatores de caracterização contidos no método CML 2001, visto que esse método abrange todas as categorias de impacto analisadas nesta avaliação. O método CML faz uma abordagem orientada ao problema, por meio de pontos intermediários. O cálculo do impacto ambiental é feito somando-se a multiplicação da massa de cada substância equivalente pelo seu fator de caracterização (GUINEÉ et al, 2001).

De acordo com o que foi apresentado no escopo, normalização utilizada nesta pesquisa foi da metodologia CML 2001 com abrangência global. A ponderação utilizada foi baseada na pesquisa feita pela PE Internacional intitulada PE LCIA Survey 2012 (Global; CML, ReCiPe, Traci), que poderia ser utilizado tanto nas vedações brasileiras quanto na vedação inglesa ${ }^{30}$.

\subsubsection{Resultados dos contextos de análise}

Com a elaboração do MTP no Brasil, sua complementação com a coleta de dados na BRE e os parâmetros livres inseridos no Plano deste estudo, que permitem fazer testes com escolhas de projeto diferentes, criaram-se dois contextos de análise, já apresentados no objetivo e detalhados no escopo e no Quadro 21. Compararam-se duas tipologias brasileiras com características diferentes para a produção dos blocos cerâmicos e traços diferentes para as argamassas de assentamento, chapisco e emboços externo e interno, ou seja,

\footnotetext{
${ }^{30}$ Os fatores de normalização e ponderação utilizados foram apresentados nos Quadro 12 e Quadro 13.
} 
duas tipologias de vedação vertical externa que atendam aos mesmos requisitos de desempenho térmico e acústico, mas que consideram valores diferentes para os parâmetros e, por isso, possuem diferentes desempenhos ambientais que podem ser comparados ainda na fase de projeto da vedação vertical.

A segunda comparação foi feita alterando-se apenas 2 parâmetros: 0 tipo de bloco e a nacionalidade, que possui uma série de características associadas ao país, como demonstrado no Quadro 21. A alteração de menos parâmetros reforça ainda mais a importância da parametrização do inventário e dos parâmetros de projeto. Nessa comparação a mesma tipologia atende aos requisitos térmicos e acústicos do Reino Unido e do Brasil, sendo uma tipologia de vedação vertical externa de bloco cerâmico utilizada no Reino Unido e, hipoteticamente, aplicada no Brasil.

O modelo construído está preparado para ser submetido a outras análises, por meio da alteração dos parâmetros listados no Quadro 21, como a comparação dos potenciais impactos ambientais por fabricante de bloco cerâmico, outras combinações de insumos que resultem em vedações com outros requisitos de desempenho térmico e acústico, por exemplo. Os resultados nãoponderados e não-normalizados estão apresentados nos dashboards das páginas 174 e 175, conforme recomenda a EN 15804 (BSI, 2014).

Para a análise dos resultados do Contexto de Análise 1, os valores dos parâmetros inseridos no software de ACV estão apresentados no dashboard da página 174, onde também são apresentadas as suposições consideradas por módulo de ACV das tipologias brasileiras comparadas.

Os valores não normalizados e não ponderados dos potenciais impactos ambientais estão disponíveis no dashboard, onde são comparados o valor total do impacto ambiental potencial das tipologias brasileiras comparadas. Contexto de Análise 1, onde é possível comparar as duas tipologias brasileiras.

O mesmo é feito para o Contexto de Análise 2, onde são apresentados os valores dos parâmetros, as suposições, os valores não normalizados e não ponderados dos potenciais impactos ambientais no dashboard da página 175. 
DASHBOARD - CONTEXTO DE ANÁLISE 1 (Valores não-normalizados e não-ponderados da comparação)

\section{TIPOLOGIA 1}

\begin{tabular}{|c|c|c|c|c|c|c|c|c|c|c|c|c|c|c|}
\hline \multirow{2}{*}{\multicolumn{3}{|c|}{ Módulos }} & A1 & A2 & A3 & A1-A3 & A4 & A5 & B & C1 & $\mathrm{C} 2$ & $\mathrm{C} 3$ & $\mathrm{C} 4$ & D \\
\hline & & & 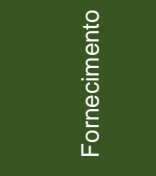 & 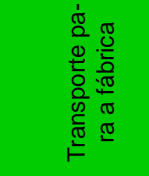 & 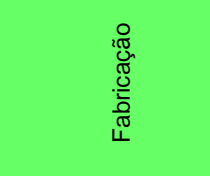 & 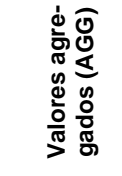 & 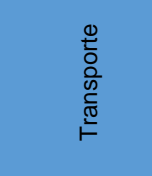 & 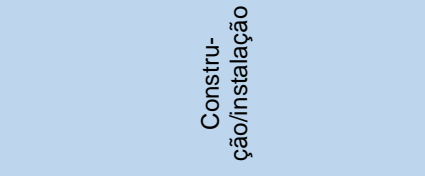 & $\stackrel{\circ}{9}$ & 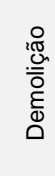 & 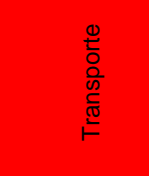 & 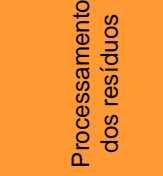 & 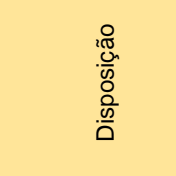 & 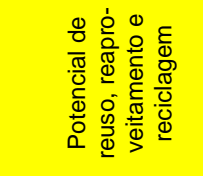 \\
\hline \multicolumn{3}{|c|}{$\begin{array}{l}\text { Valores dos parâmetros } \\
\text { de projeto da tipologia } 1\end{array}$} & - & - & $\begin{array}{l}\text { Secagem: } 3 \\
\text { Forno e combus- } \\
\text { tível: } 0\end{array}$ & - & - & $\begin{array}{l}\frac{\text { Bloco: } 0}{\text { Assentamento: } 0} \\
\text { Emboço interno: } 1 \\
\text { Emboço externo: } 0 \\
\text { Ehapisco: } 0\end{array}$ & & & - & - & - & $\underline{\text { Nacionalidade: } 0}$ \\
\hline \multicolumn{3}{|c|}{ Suposições } & $\begin{array}{l}\text { Produção e } \\
\text { extração de: } \\
\text { argila, cava- } \\
\text { co de madei- } \\
\text { ra, eletrici- } \\
\text { dade, água } \\
\text { potável, } \\
\text { diesel, } \\
\text { GLP, cimen- } \\
\text { to Portland, } \\
\text { areia, cal } \\
\text { hidratada, } \\
\text { pedrisco, }\end{array}$ & $100 \mathrm{~km}$ & $\begin{array}{l}\text { Produção do blo- } \\
\text { co cerâmico bra- } \\
\text { sileiro com seca- } \\
\text { gem natu- } \\
\text { ral/artificial sem } \\
\text { aproveitamento } \\
\text { do calor do forno } \\
\text { intermitente (reta- } \\
\text { Ihos de móveis) }\end{array}$ & - & $100 \mathrm{~km}$ & 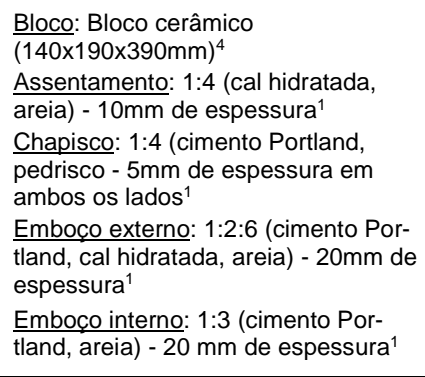 & & & $100 \mathrm{~km}$ & $\begin{array}{l}\text { Processo de } \\
\text { trituragem } \\
(2 \% \text { da } \\
\text { massa de } \\
\text { resíduos da } \\
\text { construção })^{5}\end{array}$ & $\begin{array}{l}\text { Material inerte } \\
\text { para o aterro } \\
\text { sanitário (98\% } \\
\text { da massa de } \\
\text { resíduos da } \\
\text { construção) }\end{array}$ & $\begin{array}{l}2 \% \text { de reaprovei- } \\
\text { tamento com } \\
100 \% \text { de eficiên- } \\
\text { cia } \\
3,64 \mathrm{~kg} \text { de agre- } \\
\text { gado reciclado }\end{array}$ \\
\hline \multirow{8}{*}{$\begin{array}{l}\text { o. } \\
\text { o } \\
\text { o } \\
\underline{\underline{E}}\end{array}$} & Indicador & Unidade & \multicolumn{12}{|c|}{ Valores dos impactos } \\
\hline & GWP & $\mathrm{kg} \mathrm{CO}_{2}$ eq. & 33.331284 & 0.2357995 & 8.7580627 & $4.23 \mathrm{E}+01$ & 2.1227665 & -6.7515152 & \multicolumn{2}{|c|}{ INA } & 1.8793662 & 0.0489862 & 0.0587369 & -0.0142292 \\
\hline & ODP & $\mathrm{kg}$ CFC 11 eq. & $1.04 \mathrm{E}-06$ & $6.07 E-12$ & $4.35 \mathrm{E}-11$ & $1.04 \mathrm{E}-06$ & $3.02 E-11$ & $5.80 \mathrm{E}-10$ & \multicolumn{2}{|c|}{ INA } & 2.67E-11 & $2.12 \mathrm{E}-11$ & $1.39 \mathrm{E}-11$ & $-2.31 \mathrm{E}-12$ \\
\hline & AP & $\mathrm{kg} \mathrm{SO}_{2}$ eq. & 0.0638125 & 0.0008636 & 0.0041579 & $6.88 \mathrm{E}-02$ & 0.0048394 & 0.0046289 & \multicolumn{2}{|c|}{ INA } & 0.0042845 & 0.0001717 & 0.0004743 & -0.0001987 \\
\hline & EP & $\mathrm{kg}\left(\mathrm{PO}_{4}\right)^{3}$ eq. & 0.0079021 & 0.0001323 & 0.0009098 & $8.94 \mathrm{E}-03$ & 0.0010848 & 0.0006311 & \multicolumn{2}{|c|}{ INA } & 0.0009604 & $3.53 \mathrm{E}-05$ & $7.34 \mathrm{E}-05$ & $-1.68 \mathrm{E}-05$ \\
\hline & РОCP & $\mathrm{kg} \mathrm{C}_{2} \mathrm{H}_{4}$ eq. & 0.0071419 & -0.000147 & 0.0004079 & 7.40E-03 & -0.0014933 & 0.0004833 & \multicolumn{2}{|c|}{ INA } & -0.0013221 & $1.89 \mathrm{E}-05$ & 7.14E-05 & -0.0003048 \\
\hline & ADPE & $\mathrm{kg}$ Sb eq. & 3.47E-05 & $7.61 \mathrm{E}-09$ & 2.04E-08 & 3.48E-05 & 4.77E-08 & $2.75 \mathrm{E}-07$ & \multicolumn{2}{|c|}{ INA } & $4.22 \mathrm{E}-08$ & $6.52 \mathrm{E}-09$ & $1.87 \mathrm{E}-08$ & $-9.69 \mathrm{E}-10$ \\
\hline & ADPF & MJ eq. & 156.04483 & 3.278543 & 0.7935392 & $1.60 \mathrm{E}+02$ & 28.935489 & 10.586856 & \multicolumn{2}{|c|}{ INA } & 25.617693 & 0.6761519 & 7.8474695 & -0.0183143 \\
\hline
\end{tabular}

\section{TIPOLOGIA 2}

\begin{tabular}{|c|c|c|c|c|c|c|c|c|c|c|c|c|c|c|}
\hline \multirow{2}{*}{\multicolumn{3}{|c|}{ Módulos }} & $\mathrm{A} 1$ & A2 & A3 & A1-A3 & A4 & A5 & B & C1 & $\mathrm{C} 2$ & C3 & C4 & $\mathrm{D}$ \\
\hline & & & 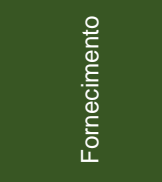 & 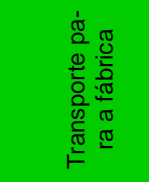 & 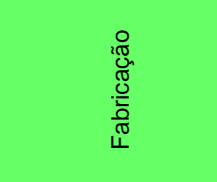 & 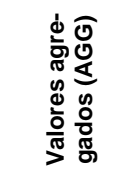 & 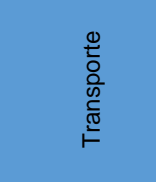 & 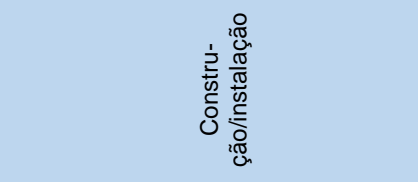 & $\stackrel{\circ}{3}$ & 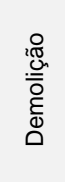 & 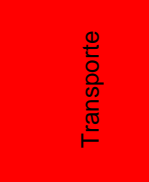 & 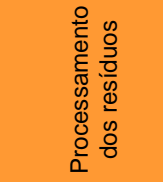 & 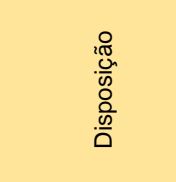 & 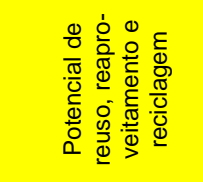 \\
\hline \multicolumn{3}{|c|}{$\begin{array}{l}\text { Valores dos parâmetros } \\
\text { de projeto da tipologia } 2\end{array}$} & - & - & $\begin{array}{l}\text { Secagem: } 0 \\
\text { Forno e combus- } \\
\underline{\text { tivel: } 5}\end{array}$ & - & - & $\begin{array}{l}\text { Bloco: } 0 \\
\text { Assentamento: } 1 \\
\text { Emboco interno: } 0 \\
\text { Emboço externo: } 0 \\
\text { Chapisco: } 1\end{array}$ & & & - & - & - & $\underline{\text { Nacionalidade: } 0}$ \\
\hline \multicolumn{3}{|c|}{ Suposições } & $\begin{array}{l}\text { Produção e } \\
\text { extração de: } \\
\text { argila, cava- } \\
\text { co de madei- } \\
\text { ra, eletrici- } \\
\text { dade, água } \\
\text { potável, } \\
\text { diesel, } \\
\text { GL, cimen- } \\
\text { to Portland, } \\
\text { areia, cal } \\
\text { hidratada, } \\
\text { pedrisco } 0^{4,2}\end{array}$ & $100 \mathrm{~km}$ & $\begin{array}{l}\text { Produção do blo- } \\
\text { co cerâmico bra- } \\
\text { sileiro com seca- } \\
\text { gem natural e } \\
\text { forno túnel (le- } \\
\text { nha) }\end{array}$ & - & $100 \mathrm{~km}$ & 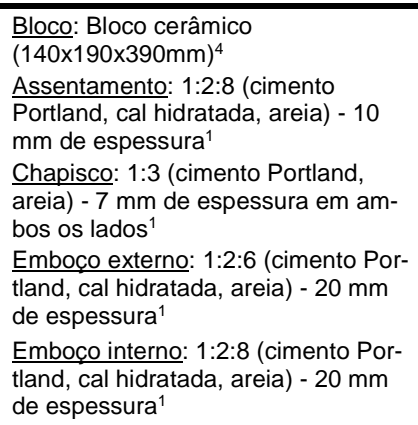 & & & $100 \mathrm{~km}$ & $\begin{array}{l}\text { Processo de } \\
\text { trituragem } \\
(2 \% \text { da } \\
\text { massa de } \\
\text { resíduos da } \\
\text { construção })^{5}\end{array}$ & $\begin{array}{l}\text { Material inerte } \\
\text { para o a aerro } \\
\text { sanitário }(98 \% \\
\text { da massa de } \\
\text { resíduos da } \\
\text { construção) }\end{array}$ & $\begin{array}{l}2 \% \text { de reaprovei- } \\
\text { tamento com } \\
100 \% \text { de eficiên- } \\
\text { cia } \\
3,64 \mathrm{~kg} \text { de agre- } \\
\text { gado reciclado }\end{array}$ \\
\hline \multirow{8}{*}{$\begin{array}{l}\stackrel{0}{0} \\
\stackrel{0}{0} \\
\underline{0} \\
\underline{\underline{E}}\end{array}$} & Indicador & Unidade & \multicolumn{12}{|c|}{ Valores dos impactos } \\
\hline & GWP & $\mathrm{kg} \mathrm{CO}_{2}$ eq. & 32.85064 & 0.2239433 & 5.5187048 & $3.86 \mathrm{E}+01$ & 2.0906611 & -6.9510203 & \multicolumn{2}{|c|}{ INA } & 1.8870264 & 0.0491859 & 0.0589763 & -0.0142872 \\
\hline & ODP & $\mathrm{kg}$ CFC 11 eq. & $8.13 \mathrm{E}-07$ & $5.76 \mathrm{E}-12$ & $4.35 \mathrm{E}-11$ & $8.13 \mathrm{E}-07$ & $2.97 \mathrm{E}-11$ & $5.28 \mathrm{E}-10$ & \multicolumn{2}{|c|}{ INA } & $2.68 \mathrm{E}-11$ & $2.12 \mathrm{E}-11$ & $1.40 \mathrm{E}-11$ & $-2.32 \mathrm{E}-12$ \\
\hline & AP & $\mathrm{kg} \mathrm{SO}_{2}$ eq. & 0.0522865 & 0.0008201 & 0.0036286 & $5.67 \mathrm{E}-02$ & 0.0047662 & 0.0042224 & \multicolumn{2}{|c|}{ INA } & 0.004302 & 0.0001724 & 0.0004762 & -0.0001996 \\
\hline & EP & $\mathrm{kg}\left(\mathrm{PO}_{4}\right)^{3}$ eq. & 0.0065128 & 0.0001256 & 0.0008151 & $7.45 E-03$ & 0.0010684 & 0.0005754 & \multicolumn{2}{|c|}{ INA } & 0.0009643 & $3.55 \mathrm{E}-05$ & $7.37 \mathrm{E}-05$ & $-1.69 \mathrm{E}-05$ \\
\hline & POCP & $\mathrm{kg} \mathrm{C}_{2} \mathrm{H}_{4}$ eq. & 0.0058863 & -0.00014 & 0.0003452 & $6.09 \mathrm{E}-03$ & -0.0014707 & 0.0004408 & \multicolumn{2}{|c|}{ INA } & -0.0013274 & $1.89 \mathrm{E}-05$ & 7.17E-05 & -0.000306 \\
\hline & ADPE & $\mathrm{kg}$ Sb eq. & $2.73 \mathrm{E}-05$ & $7.22 \mathrm{E}-09$ & $2.04 \mathrm{E}-08$ & $2.74 \mathrm{E}-05$ & $4.70 \mathrm{E}-08$ & $2.51 \mathrm{E}-07$ & \multicolumn{2}{|c|}{ INA } & $4.24 \mathrm{E}-08$ & $6.55 \mathrm{E}-09$ & $1.88 \mathrm{E}-08$ & $-9.72 \mathrm{E}-10$ \\
\hline & ADPF & MJ eq. & $1.53 \mathrm{E}+02$ & $3.11 \mathrm{E}+00$ & $7.94 \mathrm{E}-01$ & $1.57 \mathrm{E}+02$ & $2.85 \mathrm{E}+01$ & $9.65 \mathrm{E}+00$ & \multicolumn{2}{|c|}{ INA } & $2.57 \mathrm{E}+01$ & $6.79 \mathrm{E}-01$ & $7.88 \mathrm{E}+00$ & $-1.84 \mathrm{E}-02$ \\
\hline
\end{tabular}

(INA = Indicator não avaliado, $A G G=$ Agredado, $N A=$ Não aplicável)

GWP = Potencial de Mudança Climática; ODP = Potencial de destruição da camada de ozônio; AP = Potencial de Acidificação do solo e da água; EP = Potencial de Eutrofização; POCP = Potencial de formação de ozônio fotoquímico; ADPE = Potencial de depleção dos recursos abióticos Fonte: dos autores.

Gráficos dos valores não normalizados e não ponderados dos potenciais impactos ambientais do contexto de análise 1

Potencial de depleção de recurso abiótico (ADP elementos) kg Sb-Eq

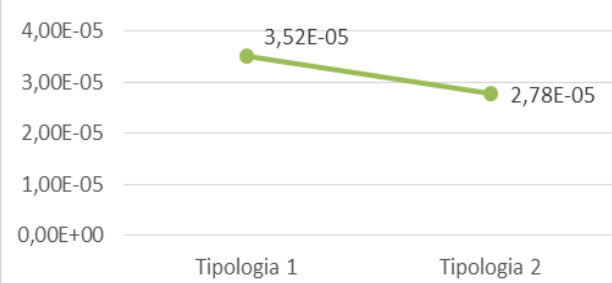

Potencial de depleção de recurso abiótico (ADP fóssil) MJ

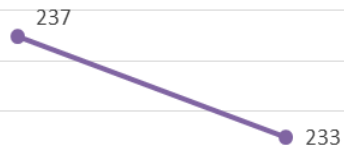

Tipologia 1

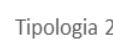

Potencial de Eutrofização (EP) kg Fosfato-Eq.

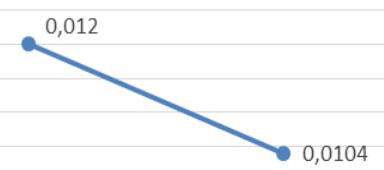

Potencial de Mudança climática (GWP 100 anos) kg CO2-Eq.

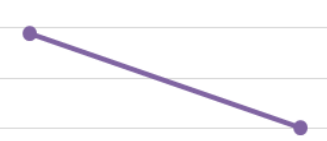

Tipologia 1

Tipologia 2

Potencial de criação de ozônio fotoquímico (POCP) kg Eteno-Eq.

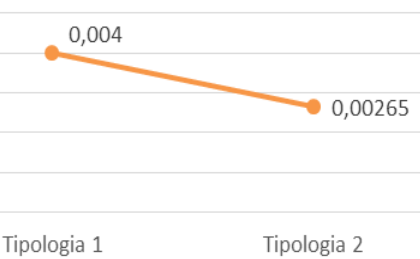

Potencial de Acidificação (AP) kg SO2Eq

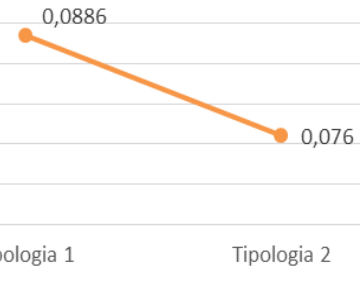

Potencial de destruição da camada de ozônio (ODP) kg R11-Eq

$$
1,04 \mathrm{E}-06
$$


DASHBOARD - CONTEXTO DE ANÁLISE 2 (Valores não-normalizados e não-ponderados da comparação)

\section{APLICADA AO REINO UNIDO 1}

\begin{tabular}{|c|c|c|c|c|c|c|c|c|c|c|c|c|c|c|}
\hline & & & A1 & A2 & A3 & A1-A3 & A4 & A5 & B & $\mathrm{C} 1$ & $\mathrm{C} 2$ & $\mathrm{C} 3$ & $\mathrm{C} 4$ & $\mathrm{D}$ \\
\hline & Módu & & 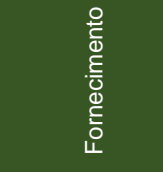 & 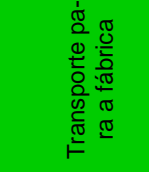 & 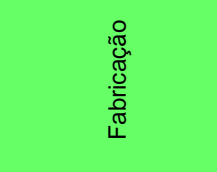 & 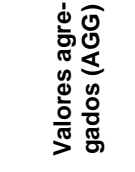 & 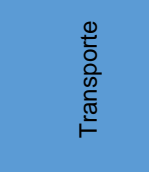 & 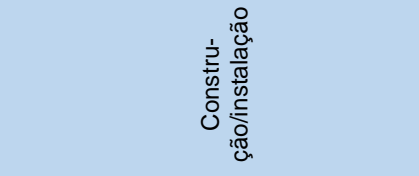 & $\stackrel{\circ}{3}$ & 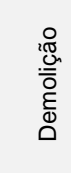 & 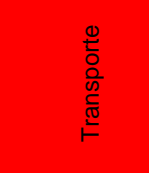 & 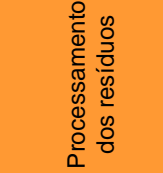 & 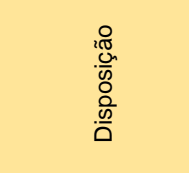 & 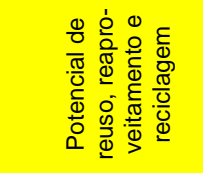 \\
\hline & $\begin{array}{l}\text { Valores dos } F \\
\text { de projeto da }\end{array}$ & $\begin{array}{l}\text { arâmetros } \\
\text { ipologia } 1\end{array}$ & - & - & $\begin{array}{l}\text { Secagem: } 0,5 \\
\text { Forno e combus- } \\
\text { tível: } 0,5\end{array}$ & - & - & $\begin{array}{l}\text { Bloco: } 1 \\
\text { Assentamento: } 2 \\
\text { Emboco interno: } 2 \\
\text { Emboço externo: } 1 \\
\text { Chapisco: } 0,5\end{array}$ & - & - & - & - & - & Nacionalidade: 1 \\
\hline & Suposi & & $\begin{array}{l}\text { Argila, cavaco } \\
\text { de madeira, } \\
\text { eletricidade, } \\
\text { água potável, } \\
\text { Diesel, GLP, } \\
\text { cimento } \\
\text { Portland, areia, } \\
\text { cal hidratada, } \\
\text { calcário, pe- } \\
\text { drisco, cal, gás } \\
\text { natural, água, } \\
\text { agregado }\end{array}$ & $100 \mathrm{~km}$ & $\begin{array}{l}\text { Produção de } \\
\text { Porotherm } \\
\text { (dados específi- } \\
\text { cos da fábrica) }\end{array}$ & - & $100 \mathrm{~km}$ & $\begin{array}{l}\text { Bloco: Porotherm ( } 115 \times 373 \times 249 \mathrm{~mm} \text { ) } \\
\text { - usado no Brasil } \\
\text { Assentamento: 1:1/4:3 (cimento Por- } \\
\text { tland, cal, areia) - com malha de } \\
\text { fibra - } 1 \mathrm{~mm} \text { de espessura } \\
\text { Emboco externo: } 1: 1: 5 \text { (cimento Por- } \\
\text { tland, cal, areia) - } 15 \mathrm{~mm} \text { de espes- } \\
\text { sura } \\
\text { Emboço interno: } 1: 3 \text { (masonry ce- } \\
\text { ment, areia) - } 12 \text { de espessura }\end{array}$ & & & $100 \mathrm{~km}$ & $\begin{array}{l}\text { Trituração } \\
\text { dos resíduos } \\
\text { (90\% da } \\
\text { massa de } \\
\text { resíduos) }\end{array}$ & $\begin{array}{l}\text { Material inerte } \\
\text { para aterro } \\
\text { sanitário } \\
\text { (10\% da mas- } \\
\text { sa de resíduos) }\end{array}$ & $\begin{array}{l}90 \% \text { recovery of } \\
\text { material } \\
100 \% \text { efficiency } \\
270.9 \mathrm{~kg} \text { of } \\
\text { crushed } \\
\text { aggregate }\end{array}$ \\
\hline & Indicador & Unidade & & & & & & Valores dos impactos & & & & & & \\
\hline & GWP & $\mathrm{kg} \mathrm{CO}_{2}$ eq. & 16.247011 & 0.9878376 & 0.3622732 & $1.76 \mathrm{E}+01$ & 1.13383211 & -1.6296821 & & JA & 1.1154016 & 0.0290732 & 0.0348603 & -0.008445 \\
\hline & ODP & $\mathrm{kg}$ CFC 11 eq. & $2.15 \mathrm{E}-07$ & $2.43 \mathrm{E}-12$ & $1.75 \mathrm{E}-12$ & $2.15 \mathrm{E}-07$ & $1.61 \mathrm{E}-11$ & $6.56 \mathrm{E}-11$ & & JA & $1.58 \mathrm{E}-11$ & $1.26 \mathrm{E}-11$ & $8.28 \mathrm{E}-12$ & $-1.37 E-12$ \\
\hline$\frac{8}{8}$ & AP & $\mathrm{kg} \mathrm{SO}_{2}$ eq. & 0.0366891 & 0.0020795 & 0.4057996 & $4.45 \mathrm{E}-01$ & 0.00258488 & 0.0005448 & & JA & 0.0025429 & 0.0001019 & 0.0002815 & -0.000118 \\
\hline & EP & $\mathrm{kg}\left(\mathrm{PO}_{4}\right)^{3}$ eq. & 0.0037115 & 0.0004552 & 0.0017799 & $5.95 \mathrm{E}-03$ & 0.00057942 & $7.29 \mathrm{E}-05$ & & JA & 0.00057 & $2.10 \mathrm{E}-05$ & $4.36 \mathrm{E}-05$ & $-1.00 \mathrm{E}-05$ \\
\hline & POCP & $\mathrm{kg} \mathrm{C}_{2} \mathrm{H}_{4}$ eq. & 0.0033166 & -0.000724 & 0.0275641 & $3.02 \mathrm{E}-02$ & -0.0007976 & $5.61 \mathrm{E}-05$ & & JA & -0.0007846 & $1.12 \mathrm{E}-05$ & $4.24 \mathrm{E}-05$ & -0.0001809 \\
\hline & ADPE & $\mathrm{kg} \mathrm{Sb}$ eq. & $1.03 \mathrm{E}-05$ & $1.23 \mathrm{E}-08$ & $7.28 \mathrm{E}-10$ & $1.04 \mathrm{E}-05$ & $2.55 \mathrm{E}-08$ & $3.07 \mathrm{E}-08$ & & JA & $2.51 \mathrm{E}-08$ & 3.87E-09 & $1.11 \mathrm{E}-08$ & $-5.75 \mathrm{E}-10$ \\
\hline & ADPF & MJ eq. & 207.32709 & 13.189002 & 0.0557461 & $2.21 \mathrm{E}+02$ & 15.4552969 & 1.438373 & & JA & 15.20407 & 0.4012954 & 4.6574637 & -0.0108695 \\
\hline
\end{tabular}

\section{APLICADA AO BRASIL}

\begin{tabular}{|c|c|c|c|c|c|c|c|c|c|c|c|c|c|c|}
\hline & & & $\mathrm{A} 1$ & A2 & A3 & A1-A3 & A4 & A5 & B & $\mathrm{C} 1$ & C2 & C3 & C4 & $\mathrm{D}$ \\
\hline \multicolumn{3}{|c|}{ Módulos } & 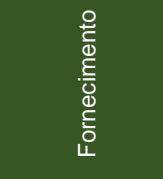 & 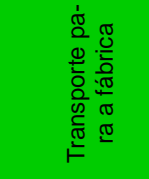 & 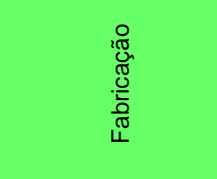 & 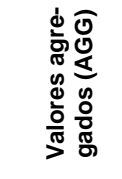 & 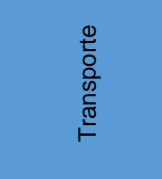 & 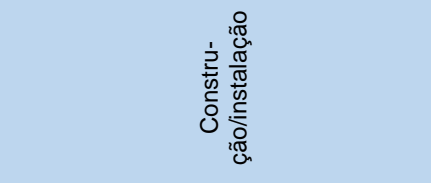 & $\stackrel{\circ}{9}$ & 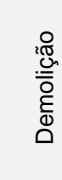 & 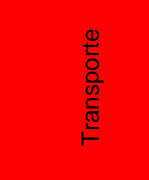 & 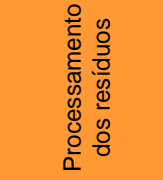 & $\begin{array}{l}\frac{10}{10} \\
\frac{10}{0} \\
\frac{0}{00} \\
\frac{0}{0} \\
\frac{0}{10}\end{array}$ & 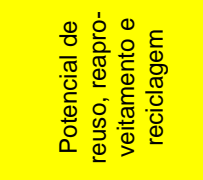 \\
\hline \multicolumn{3}{|c|}{$\begin{array}{l}\text { Valores dos parâmetros } \\
\text { de projeto da tipologia } 2\end{array}$} & - & - & $\begin{array}{l}\text { Secagem: } 0,5 \\
\text { Forno e combus- } \\
\text { tível: } 0,5\end{array}$ & - & - & $\begin{array}{l}\text { Bloco: } 2 \\
\text { Assentamento: } 2 \\
\text { Emboço interno: } 2 \\
\text { Emboço externo: } 1 \\
\text { Chapisco: } 0,5\end{array}$ & - & - & - & - & - & Nacionalidade: 0 \\
\hline \multicolumn{3}{|c|}{ Suposições } & $\begin{array}{l}\text { Argila, cavaco } \\
\text { de madeira, } \\
\text { eletricidade, } \\
\text { água potável, } \\
\text { Diesel, GLP, } \\
\text { cimento } \\
\text { Portland, areia, } \\
\text { cal hidratada, } \\
\text { calcáro, pe- } \\
\text { drisco, cal, gás } \\
\text { natural, gaua, } \\
\text { agregado } \\
\end{array}$ & $100 \mathrm{~km}$ & $\begin{array}{l}\text { Produção de } \\
\text { Porotherm } \\
\text { (dados específi- } \\
\text { cos da fábrica) }\end{array}$ & - & $100 \mathrm{~km}$ & 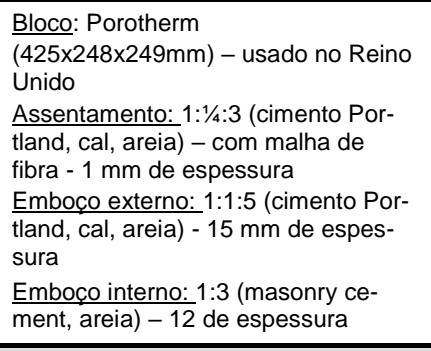 & & & $100 \mathrm{~km}$ & $\begin{array}{l}\text { Trituração } \\
\text { dos resíduos } \\
\text { (2\% da } \\
\text { massa de } \\
\text { resíduos) }\end{array}$ & $\begin{array}{l}\text { Material inerte } \\
\text { para aterro } \\
\text { sanitário } \\
\text { (98\% da mas- } \\
\text { sa de resíduos) }\end{array}$ & $\begin{array}{l}2 \% \text { recovery of } \\
\text { material } \\
100 \% \text { efficiency } \\
3.0 \mathrm{~kg} \text { of crushed } \\
\text { aggregate }\end{array}$ \\
\hline \multirow{8}{*}{ 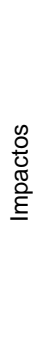 } & Indicador & Unidade & \multicolumn{12}{|c|}{ Valores dos impactos } \\
\hline & GWP & $\mathrm{kg} \mathrm{CO}_{2}$ eq. & 16.247011 & 0.9878376 & 0.3622732 & $1.76 \mathrm{E}+01$ & 1.13383211 & -1.6296821 & \multicolumn{2}{|c|}{ INA } & 1.1154016 & 0.0290732 & 0.0348603 & -0.008445 \\
\hline & ODP & $\mathrm{kg}$ CFC 11 eq. & $2.15 \mathrm{E}-07$ & $2.43 \mathrm{E}-12$ & $1.75 \mathrm{E}-12$ & $2.15 \mathrm{E}-07$ & $1.61 \mathrm{E}-11$ & $6.56 \mathrm{E}-11$ & \multicolumn{2}{|c|}{ INA } & $1.58 \mathrm{E}-11$ & $1.26 \mathrm{E}-11$ & $8.28 \mathrm{E}-12$ & $-1.37 \mathrm{E}-12$ \\
\hline & $\mathrm{AP}$ & $\mathrm{kg} \mathrm{SO}_{2}$ eq. & 0.0366891 & 0.0020795 & 0.4057996 & $4.45 \mathrm{E}-01$ & 0.00258488 & 0.0005448 & \multicolumn{2}{|c|}{ INA } & 0.0025429 & 0.0001019 & 0.0002815 & -0.000118 \\
\hline & EP & $\mathrm{kg}\left(\mathrm{PO}_{4}\right)^{33}$ eq. & 0.0037115 & 0.0004552 & 0.0017799 & $5.95 \mathrm{E}-03$ & 0.00057942 & $7.29 \mathrm{E}-05$ & \multicolumn{2}{|c|}{ INA } & 0.00057 & $2.10 \mathrm{E}-05$ & $4.36 \mathrm{E}-05$ & $-1.00 E-05$ \\
\hline & POCP & $\mathrm{kg} \mathrm{C}_{2} \mathrm{H}_{4}$ eq. & 0.0033166 & -0.000724 & 0.0275641 & $3.02 \mathrm{E}-02$ & -0.0007976 & $5.61 \mathrm{E}-05$ & \multicolumn{2}{|c|}{ INA } & -0.0007846 & $1.12 \mathrm{E}-05$ & 4.24E-05 & -0.0001809 \\
\hline & ADPE & $\mathrm{kg} \mathrm{Sb}$ eq. & $1.03 \mathrm{E}-05$ & $1.23 \mathrm{E}-08$ & $7.28 \mathrm{E}-10$ & $1.04 \mathrm{E}-05$ & $2.55 \mathrm{E}-08$ & $3.07 \mathrm{E}-08$ & \multicolumn{2}{|c|}{ INA } & $2.51 \mathrm{E}-08$ & 3.87E-09 & $1.11 \mathrm{E}-08$ & $-5.75 \mathrm{E}-10$ \\
\hline & ADPF & MJ eq. & 207.32709 & 13.189002 & 0.0557461 & $2.21 \mathrm{E}+02$ & 15.4552969 & 1.438373 & \multicolumn{2}{|c|}{ INA } & 15.20407 & 0.4012954 & 4.6574637 & -0.0108695 \\
\hline
\end{tabular}

(INA = Indicator não avaliado, $A G G=$ Agredado, $N A=$ Não aplicável)

GWP $=$ Potencial de Mudança Climática; $\mathrm{ODP}=$ Potencial de destruição da
Elementos; $A D P F=$ Potencial de depleção dos recursos abióticos - Fósseis.

Fonte: dos autores.

Gráficos dos valores não normalizados e não ponderados dos potenciais impactos ambientais do contexto de análise 2

Potencial de Acidificação (AP) kg SO2-Equiv.

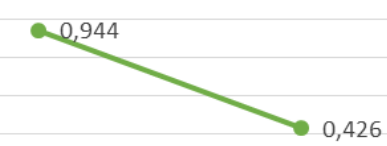

Potencial de depleção de recurso abiótico (ADP elementos) kg Sb-

$$
\text { Equiv. }
$$

2,00E-05

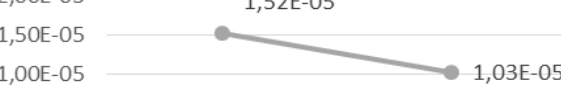

$0,00 \mathrm{E}+00$

Potencial de Eutrofização (EP) kg Phosphate-Equiv.

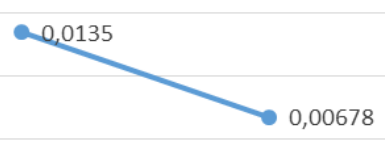

Potencial de depleção de recurso abiótico (ADP fóssil) M

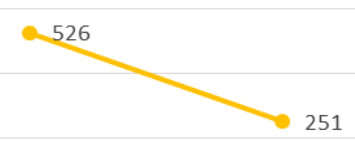

UK

BR

Potencial de criação de ozônio fotoquímico (POCP) kg EtheneEquiv.

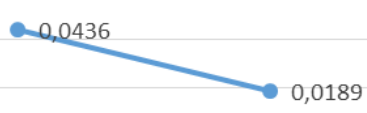

Potencial de Mudança climática (GWP 100 anos) kg CO2-Equiv.

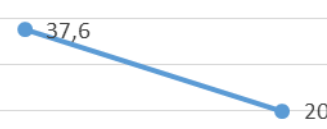

uK

Potencial de destruição da camada de ozônio (ODP) kg R11-Equiv.

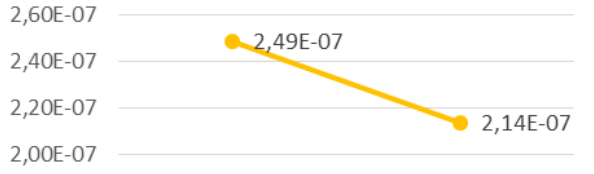




\section{Capítulo 5: Modelagem - Interpretação}

Este capítulo contém a fase final da metodologia de ACV: a Interpretação. É nessa fase que são identificados os problemas mais significantes do processo e são feitas as avaliações e checagens de completude, consistência e sensibilidade, podendo haver ciclos iterativos para a adequação do escopo ou do objetivo.

Após a Interpretação é preparado o relatório, é feita a revisão crítica por terceiros e os resultados de ACV são publicados ou aplicados a uma cadeia produtiva, produto, processo ou serviço.

Este capítulo ainda apresenta um fluxograma da metodologia do ILCD (JRC, 2010) com as etapas e passos inseridos ao longo do processo de elaboração do Modelo Tecnológico Parametrizado.

\subsection{Identificação de problemas significativos e avaliação dos resultados}

5.1.1. Comparação 1: parâmetros das tipologias brasileiras 1 e 2 de vedação externa

Como explicado anteriormente, no contexto de comparação 1 foram assumidos valores de parâmetros de projeto supostamente para o pior e o meIhor caso de análise, considerando as tipologias brasileiras. Sendo assim, a alteração dos valores dos parâmetros de projeto auxilia na avaliação das melhores e piores escolhas para o ciclo de vida da vedação vertical.

Comparando-se os gráficos da Figura 46, observa-se que estão apresentados os valores relativos e absolutos normalizados e ponderados do impacto global das tipologias brasileiras 1 e 2 . Observando os gráficos, conclui-se que a tipologia 1 possui um desempenho ambiental pior que a tipologia 2 para todas as categorias de impacto consideradas na análise, ou seja, para cumprir a mesma função a tipologia 1 apresentou valores maiores de potencial de impacto ambiental. 


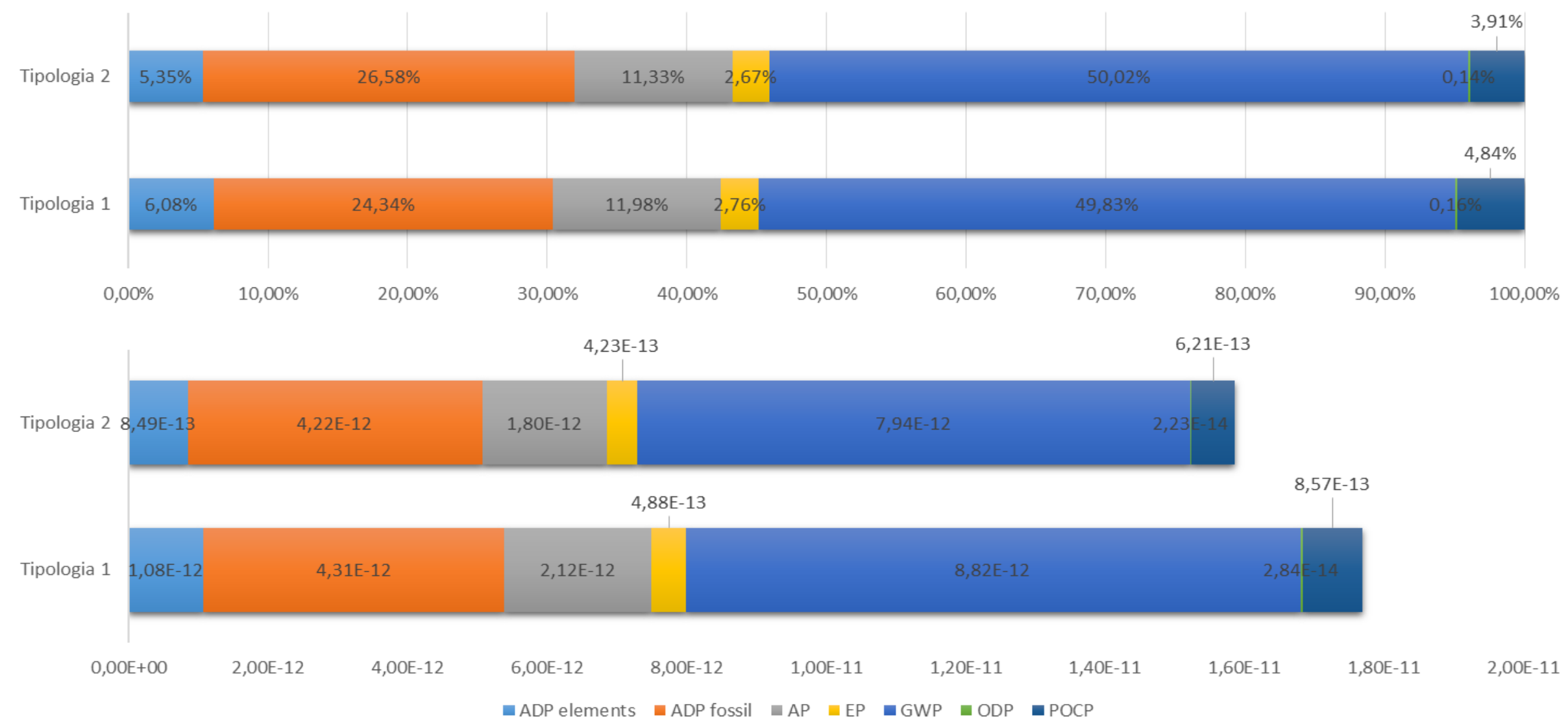

Figura 46: Valores relativos e absolutos das contribuições dos potenciais dos impactos ambientais totais do Contexto de Análise 1 
Isso se dá sobretudo porque o processo produtivo da tipologia 1 consome mais energia na queima e secagem dos blocos cerâmicos, porque a tecnologia utilizada no forno é mais antiga e o processo de secagem não aproveita o calor do forno para acelerar a secagem dos blocos, o que demanda mais energia e torna o processo mais entrópico. Além disso, a tipologia 1 demanda mais cimento Portland na produção das argamassas, o que contribui para os altos níveis de impacto dessa tipologia.

Os valores totais normalizados e ponderados do impacto potencial da tipologia 1 é de $8,13 \times 10^{-11}$ e da tipologia 2 é de $6,78 \times 10^{-11}$, ou seja, a tipologia 2 é $18 \%$ menos impactante. Esses valores podem parecer pequenos ao serem comparados, porém vale lembrar que a unidade funcional deste estudo é de apenas $1 \mathrm{~m}^{2}$. Somente para comparação, uma casa popular de $50 \mathrm{~m}^{2}$ de área construída possui aproximadamente $41 \mathrm{~m}^{2}$ de vedação externa, desconsiderando-se as aberturas e um pé direito de 2,75m (valor mínimo padrão).

Considerando cada categoria de impacto, em valores absolutos, a categoria Mudanças Climáticas (GWP) é a que possui maior diferença entre as tipologias analisadas e isso acontece porque na tipologia 2 é usada menos biomassa e energia elétrica, além de consumir menor quantidade de cimento Portland. Como pode ser observado na Figura 47, o processo produtivo do $\mathrm{Ci}$ mento Portland da tipologia 2 é menor que na tipologia 1, devido a menor quantidade em massa demandada.

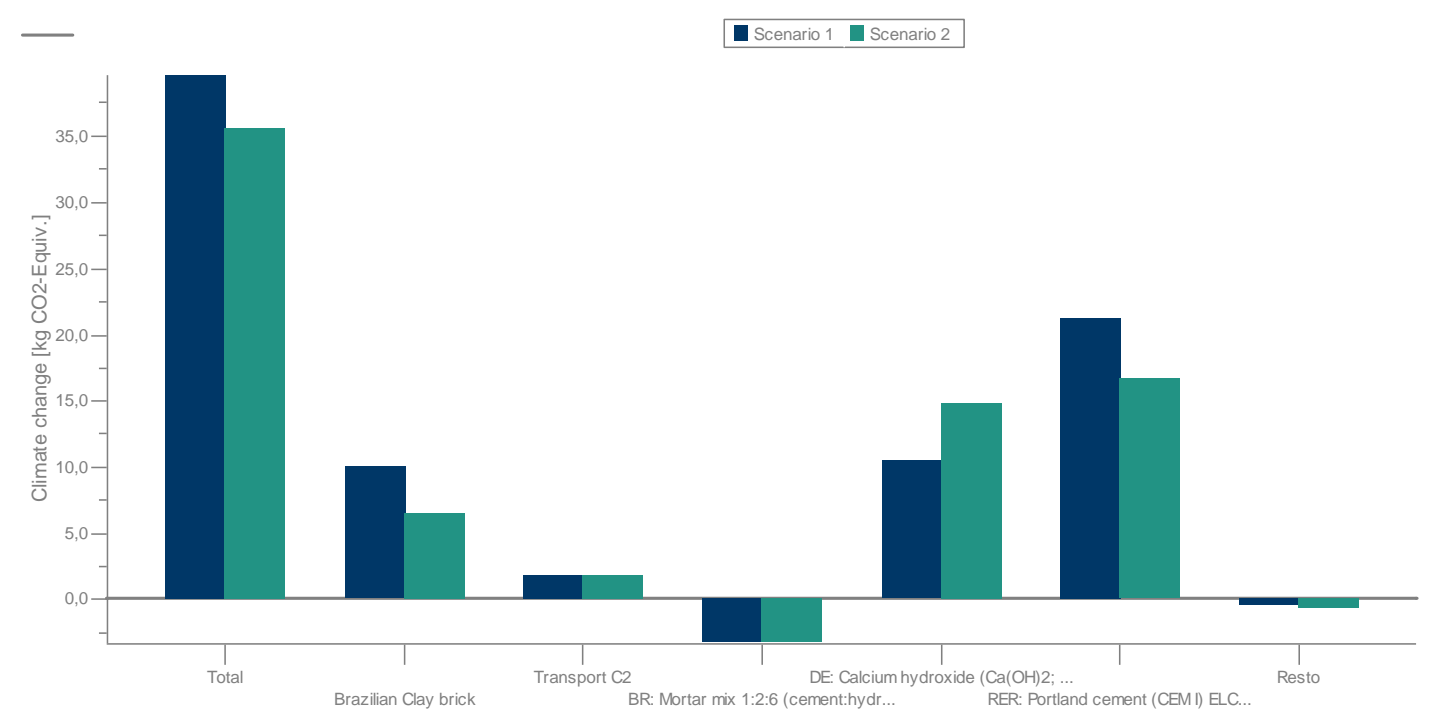

Figura 47: Comparação dos impacto potenciais dos processos das tipologias 1 e 2 quanto à categoria de impacto GWP 
Em alguns traços de argamassas usadas na tipologia 2, o cimento Portland foi substituído parcial ou totalmente por cal hidratada (calcium hydroxide). Apesar da cal hidratada mostrar maior impacto GWP na tipologia 2, o impacto do cimento Portland é maior significativo. Sendo assim, o somatório do impacto GWP desses materiais é maior na tipologia 1 que na tipologia 2.

Em termos relativos, a maior diferença entre os valores concentra-se na categoria de impacto Criação de Ozônio Fotoquímico (POCP), que é calculado sobre as emissões de óxidos de nitrogênio e compostos voláteis. Esses compostos são emitidos sobretudo pela queima de combustíveis fósseis pela indústria e pelos veículos. Na Figura 48, observa-se que os impactos potenciais POCP da tipologia 1 (colunas amarelas) são maiores em quase todos os processos, destacando-se a produção de cimento Portland, que mais uma vez reforça a afirmativa que a escolha por tipologias com argamassas com alto teores de cimento é potencialmente mais impactante.

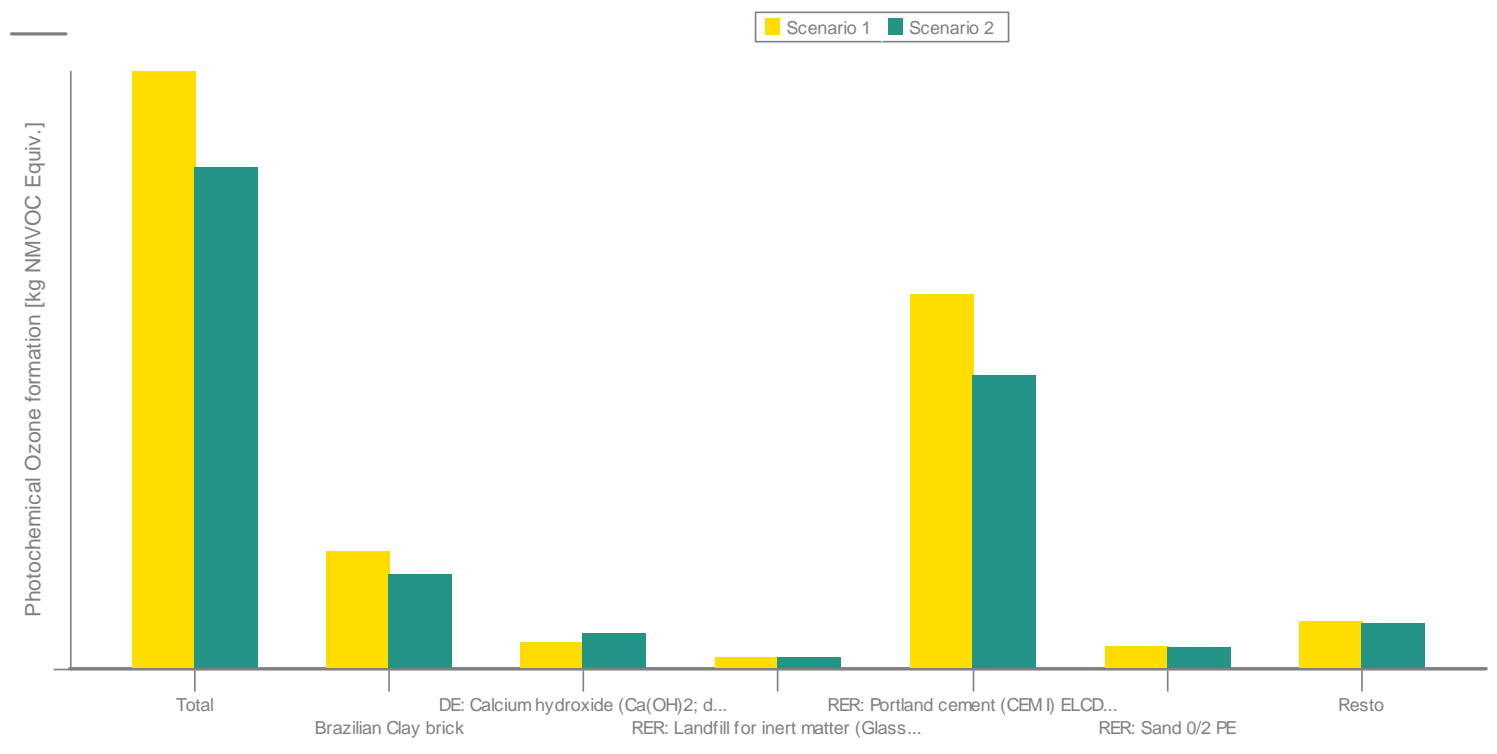

Figura 48: Comparação dos impacto potenciais dos processos das tipologias 1 e 2 quanto à categoria de impacto POCP

A Figura 49 mostra os valores absolutos e relativos das diferenças entre os impactos potenciais de cada categoria de impacto, sendo as linhas tracejadas a diferença do impacto global das tipologias 1 e 2 . A dispersão dos valores mostra que as categorias de impacto GWP e POCP são aquelas mais distantes da média do impacto global. Enquanto que a categoria de impacto Po- 
tencial de Acidificação (AP) e Depleção de Recurso Abiótico (ADP-elements) encontram-se mais próximas da média global.

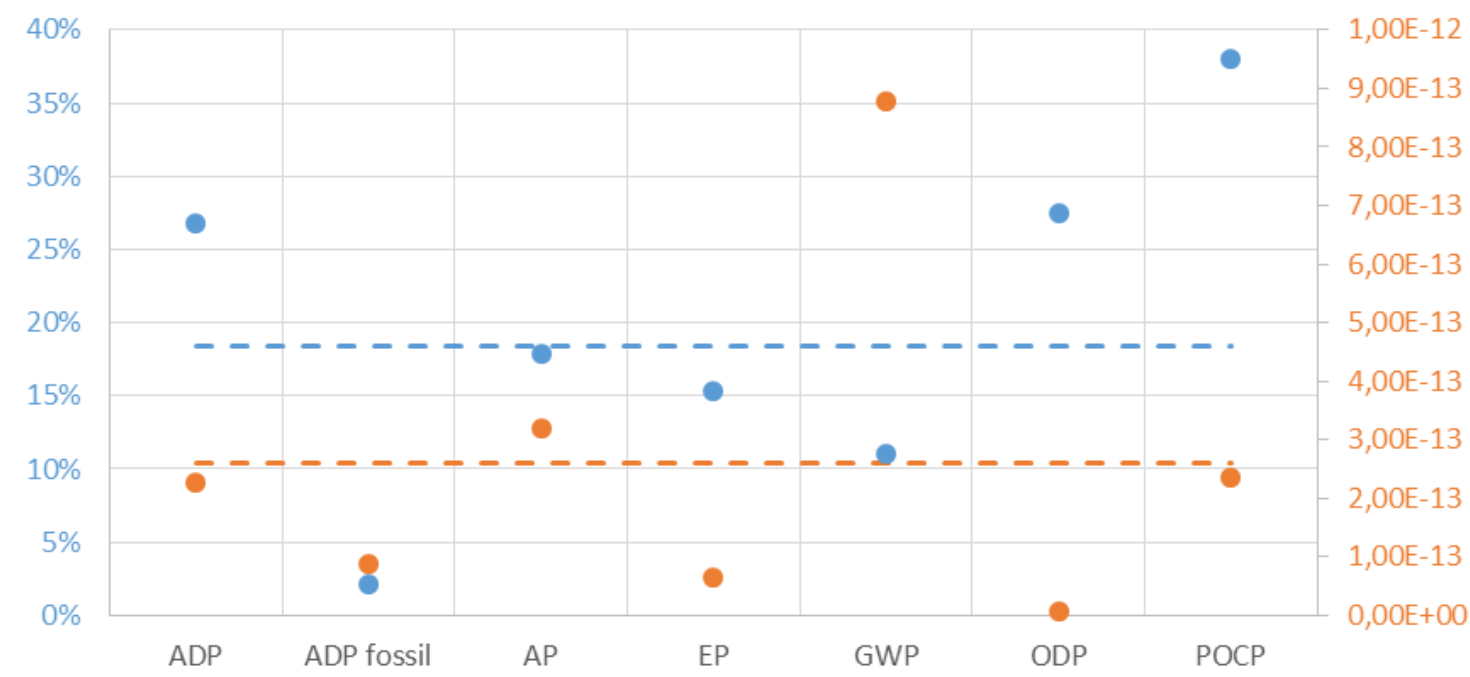

Figura 49: Diferença relativa e absoluta entre os impactos potenciais de cada categoria de impacto para o Contexto de Análise 1

No Contexto de Análise 1 e Tipologia 1, a maior parte dos impactos de todas as categorias concentra-se no Fornecimento das matérias-primas (módulo A1), por que nessa fase concentram-se todos os processos associados à extração e produção da matéria-prima, que demandam grande quantidade de recursos naturais e insumos.

A 


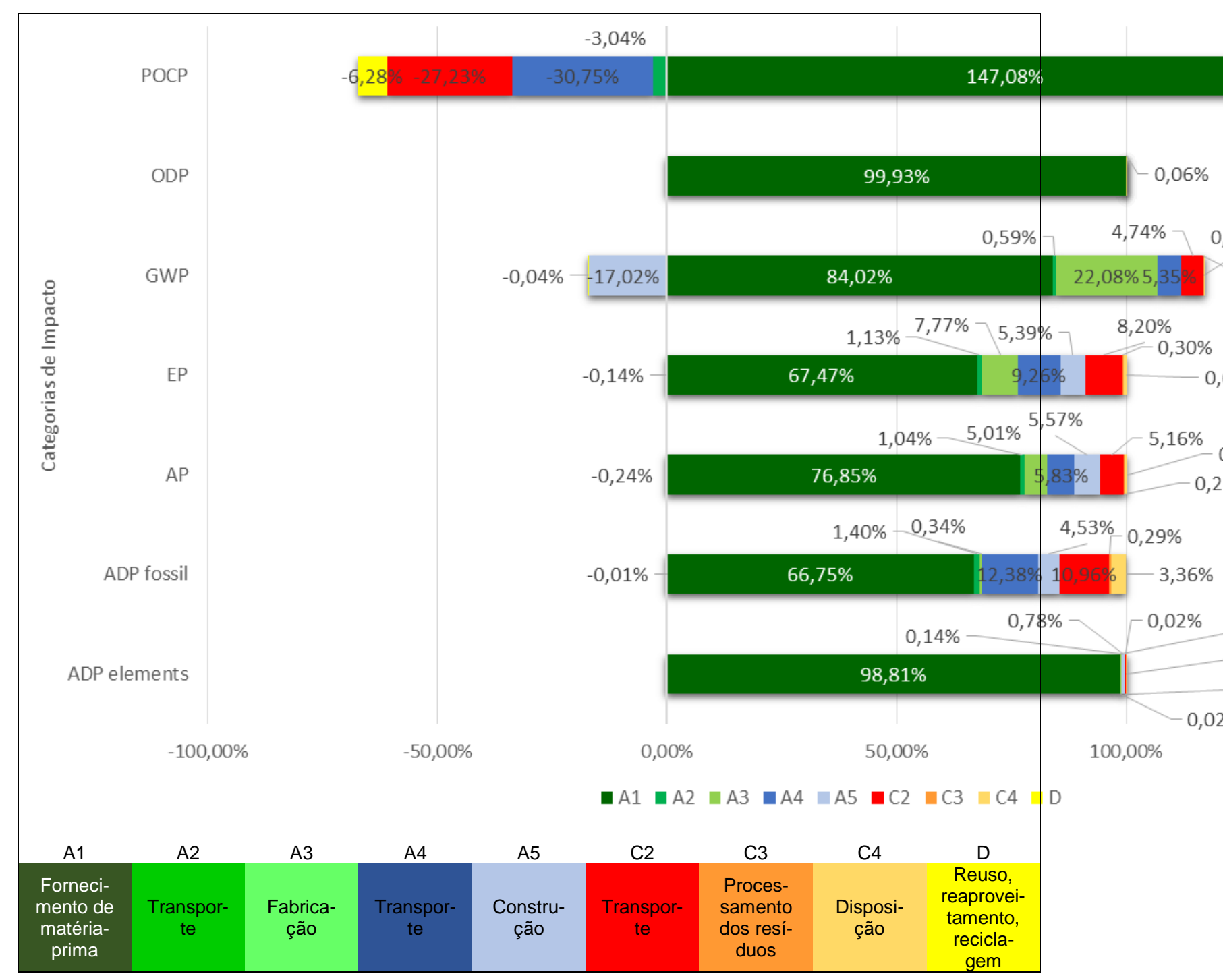

Figura 50 mostra que na categoria de impacto ADP elements, o módulo A1 corresponde a $98,81 \%$ do impacto, ou seja, é nesse módulo que a maior parte dos recursos abióticos são consumidos. Ao considerar-se a categoria ADP fóssil, que considera a depleção de recursos abióticos de fonte fóssil, o módulo A1 é responsável por $66,75 \%$ dos impactos. Isso demonstra que o Fornecimento das matérias-primas é um módulo que comtribui de forma significativa para o consumo de combustíveis fósseis, mas que outros módulos também podem contribuir como os módulos de transporte (A2, A4 e C2).

Outro fato que vale ser ressaltado na análise da 


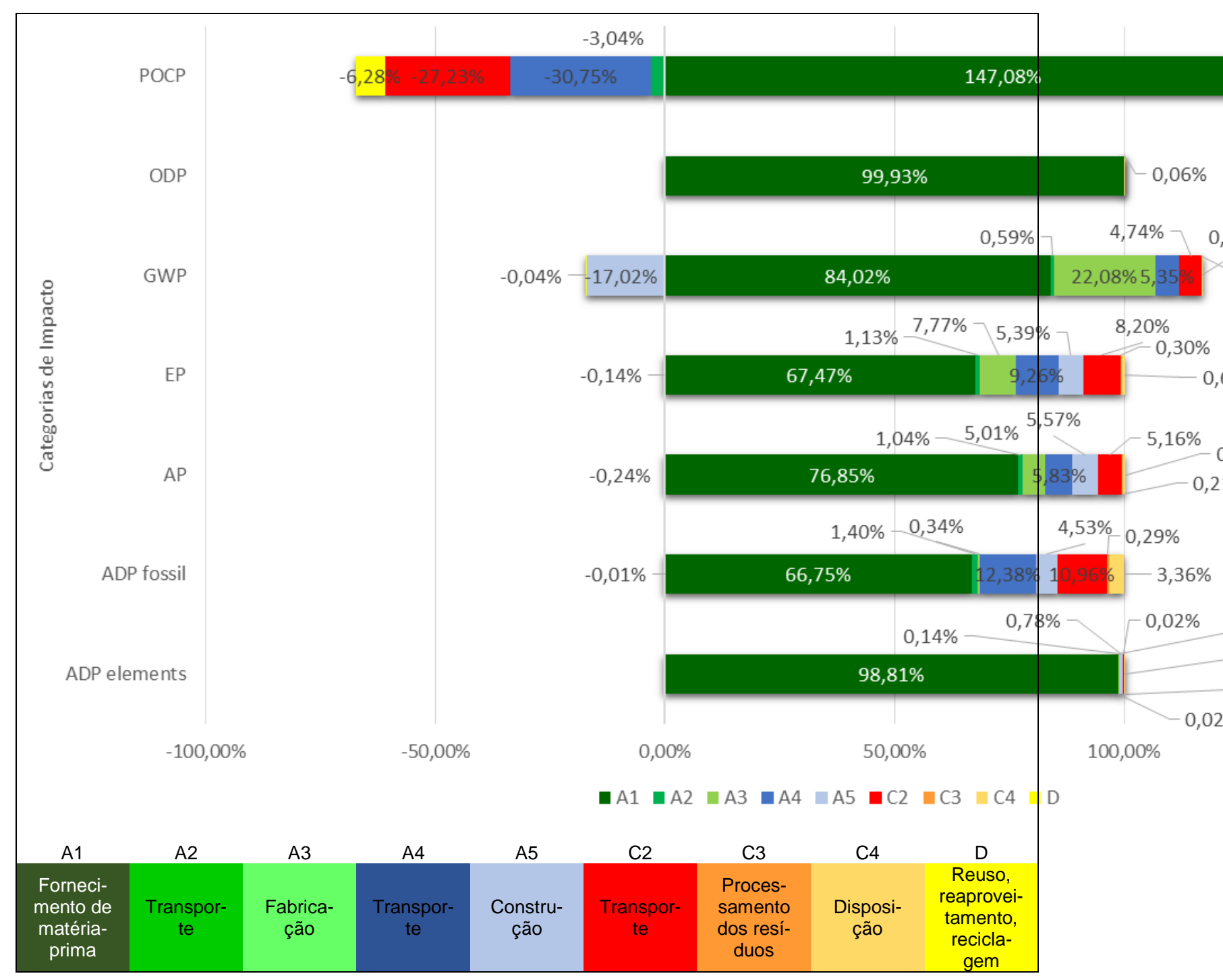

Figura 50 é que a categoria de impacto GWP, que costuma ser positiva na maior parte dos processos, é negativa para o módulo $A 5$, ou seja, nesse módulo há um "consumo de $\mathrm{CO}_{2} \mathrm{eq}$ ". Isso se dá devido à composição dos produtos, que contém cal e cimento Portland que absorvem $\mathrm{CO}_{2}$ assim que instalados (processo de carbonatação). 


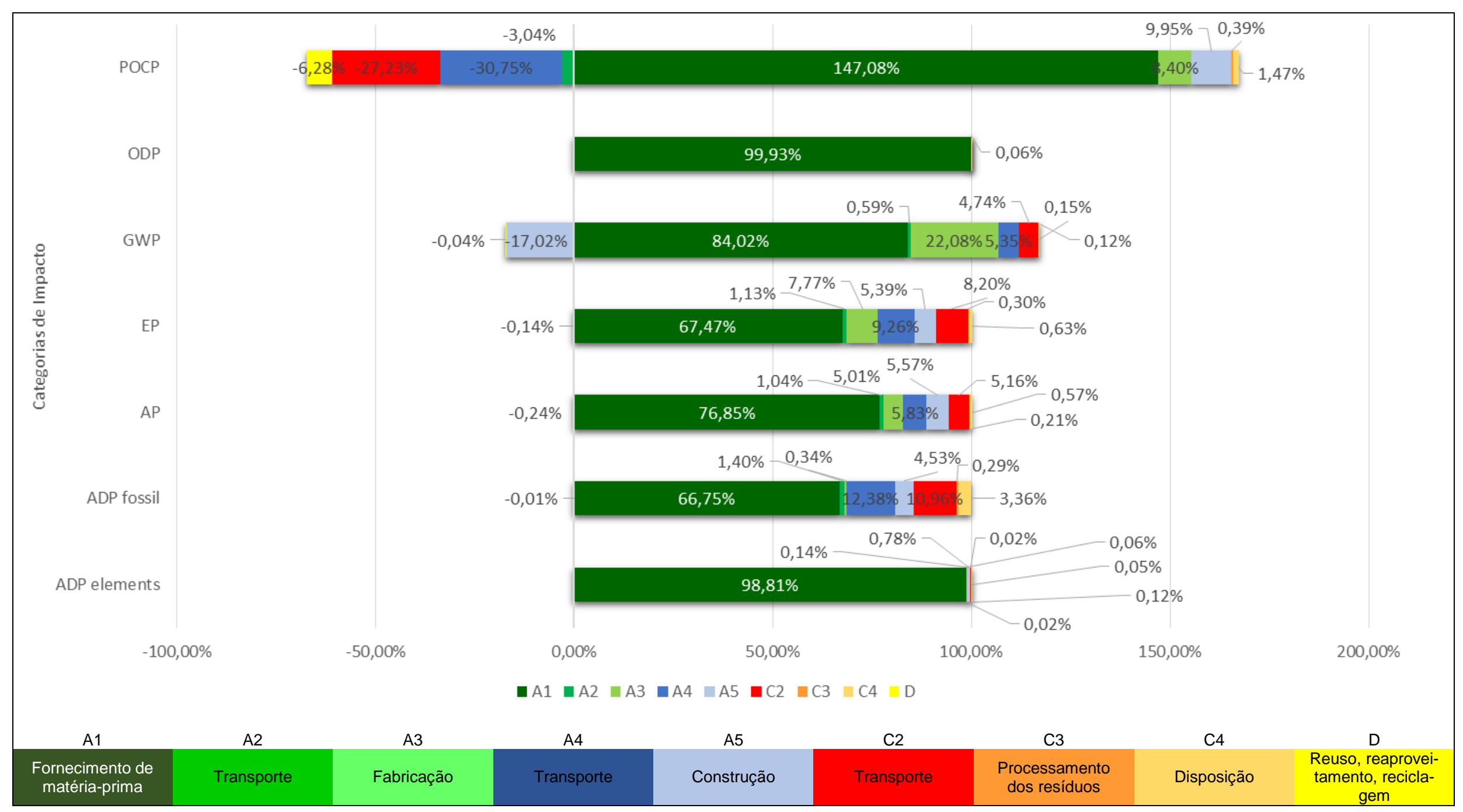

Figura 50: Valores relativos da contribuição de cada módulo de ACV para as categorias de impacto do Contexto de Análise 1 e Tipologia 1 


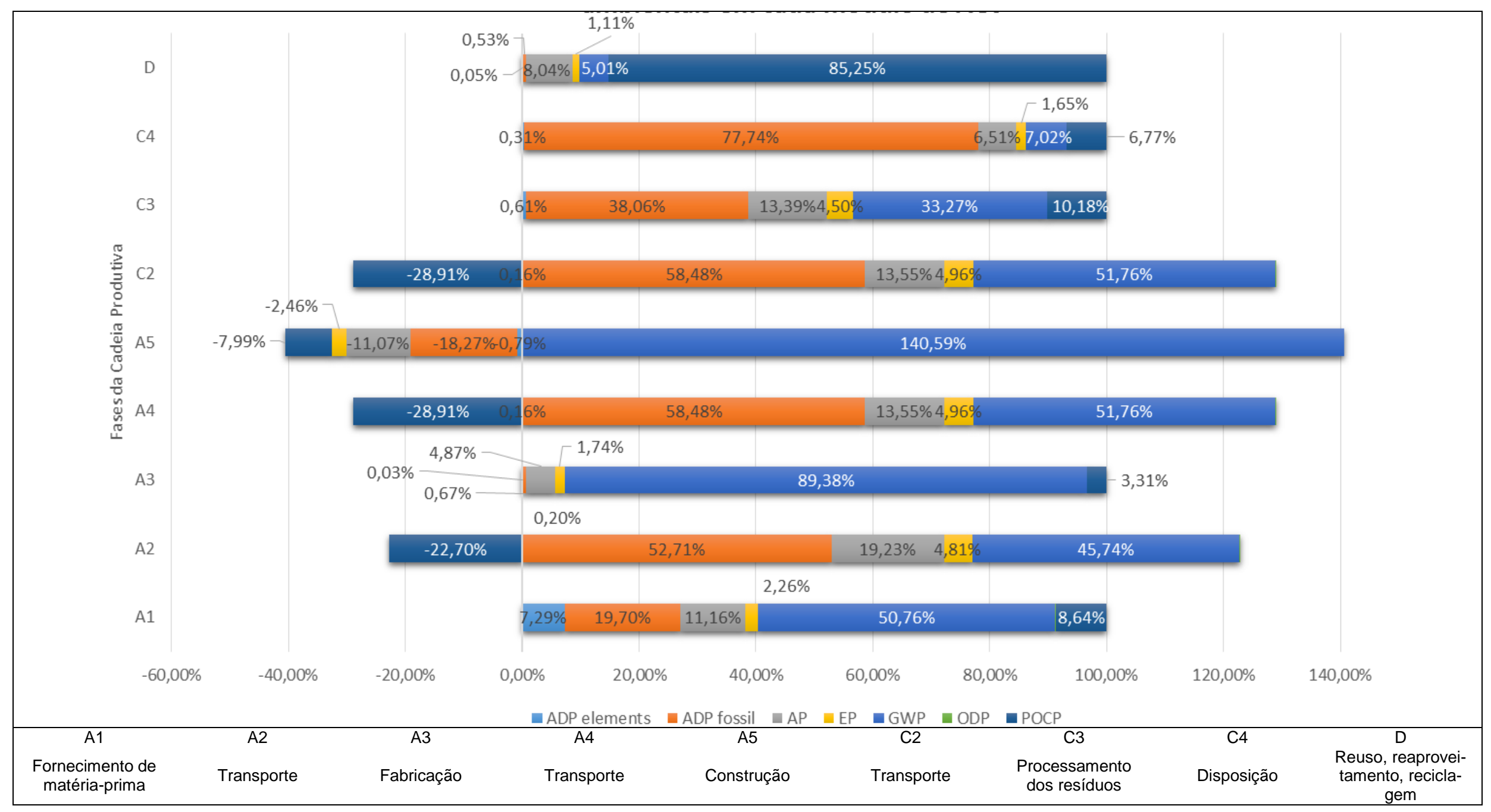

Figura 51: Valores relativos dos potenciais impactos ambientais do Contexto de Análise 1 e Tipolgia 
No estágio de produção, os processos com maior probabilidade de causar impactos ambientais negativos são da queima da biomassa no forno para a produção dos blocos e a produção de cimento Portland e cal hidratada, materiais utilizados na produção das argamassas. Entretanto,

Outros módulos que "consomem" ao invés de emitir são os módulos A2, A4 e C2, que são módulos de transporte. Os processos de queima de diesel e do caminhão desenvolvidos pelo $\mathrm{GaBi} 6$ absorvem $\mathrm{C}_{2} \mathrm{H}_{4}$ eq. Fato que não acontece com outras metodologias de cálculo como a do banco de dados do Simapro, que pode ser analisado durante o período de estágio no exteior.

No estágio de fim da vida (C2 a C4), os impactos ambientais resultam do resíduo enviado para o aterro sanitário ou estação de processamento e a trituração deste resíduo. Os impactos desses processos são associados à depleção de recursos abióticos (combustíveis fósseis) do uso de diesel no maquinário do aterro sanitário ou estação de processamento.

Existem benefícios no estágio de benefícios e encargos (módulo $\mathrm{D}$ ) associados à reciclagem do resíduo das vedações externas como agregado reciclado, que poderá ser utilizado em outra cadeia produtiva, considerando que nestas análises materiais secundários não estão sendo utilizados para a fabricação dos blocos cerâmicos e nem para a produção das argamassas. Porém, destaca-se que a porcentagem de reciclagem de resíduos no Brasil é de apenas $2 \%$ e, por isso, o módulo $D$ possui um baixo valor relativo de nãoimpacto.

Os valores apresentados na 


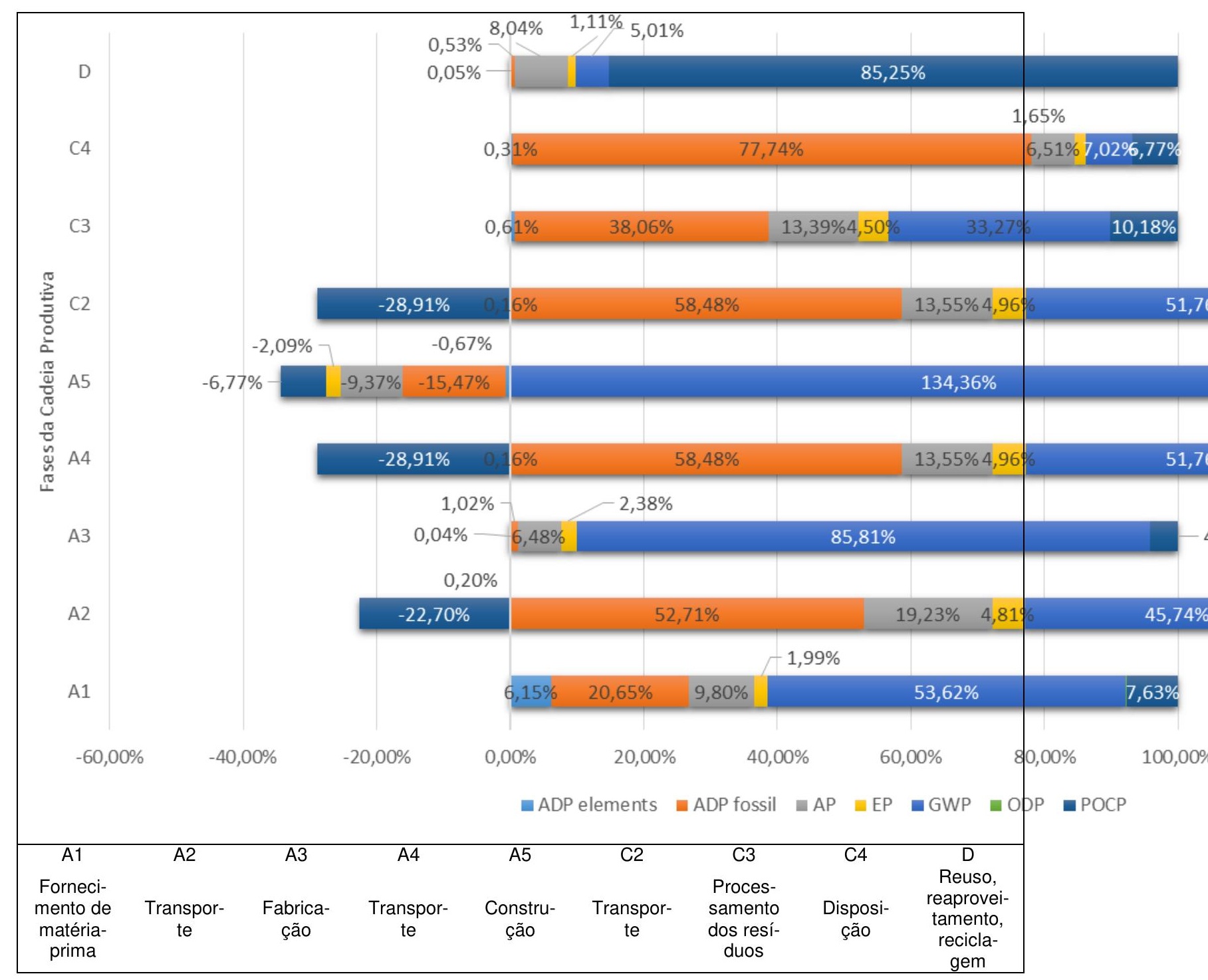

Figura 52 e 


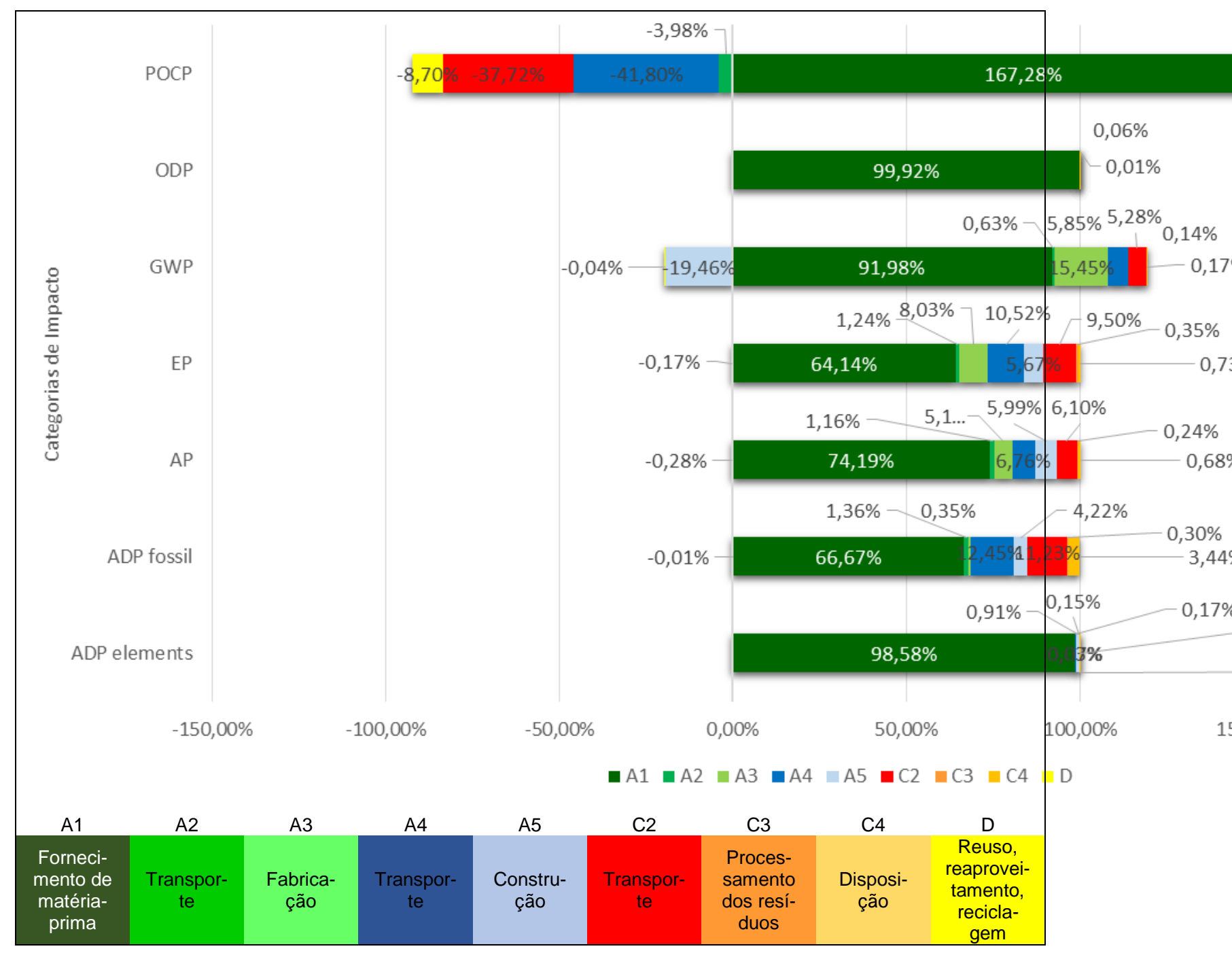

Figura 53, que apresentam os valores relativos dos impactos da Tipologia 2 sob dois pontos de vista da ACV, são próximos dos valores analisados da Tipologia 1. Os valores dos módulos A2, A4 e C4 são os mesmos vistos que as distâncias consideradas foram iguais e que a massa de matéria-prima é bem próxima entre as duas tipologias. As diferenças concentram-se nos módulos $A 1, A 3$ e $A 5$, pois diferem os processos produtivos da produção do bloco e os traços das argamassas utilizadas. 


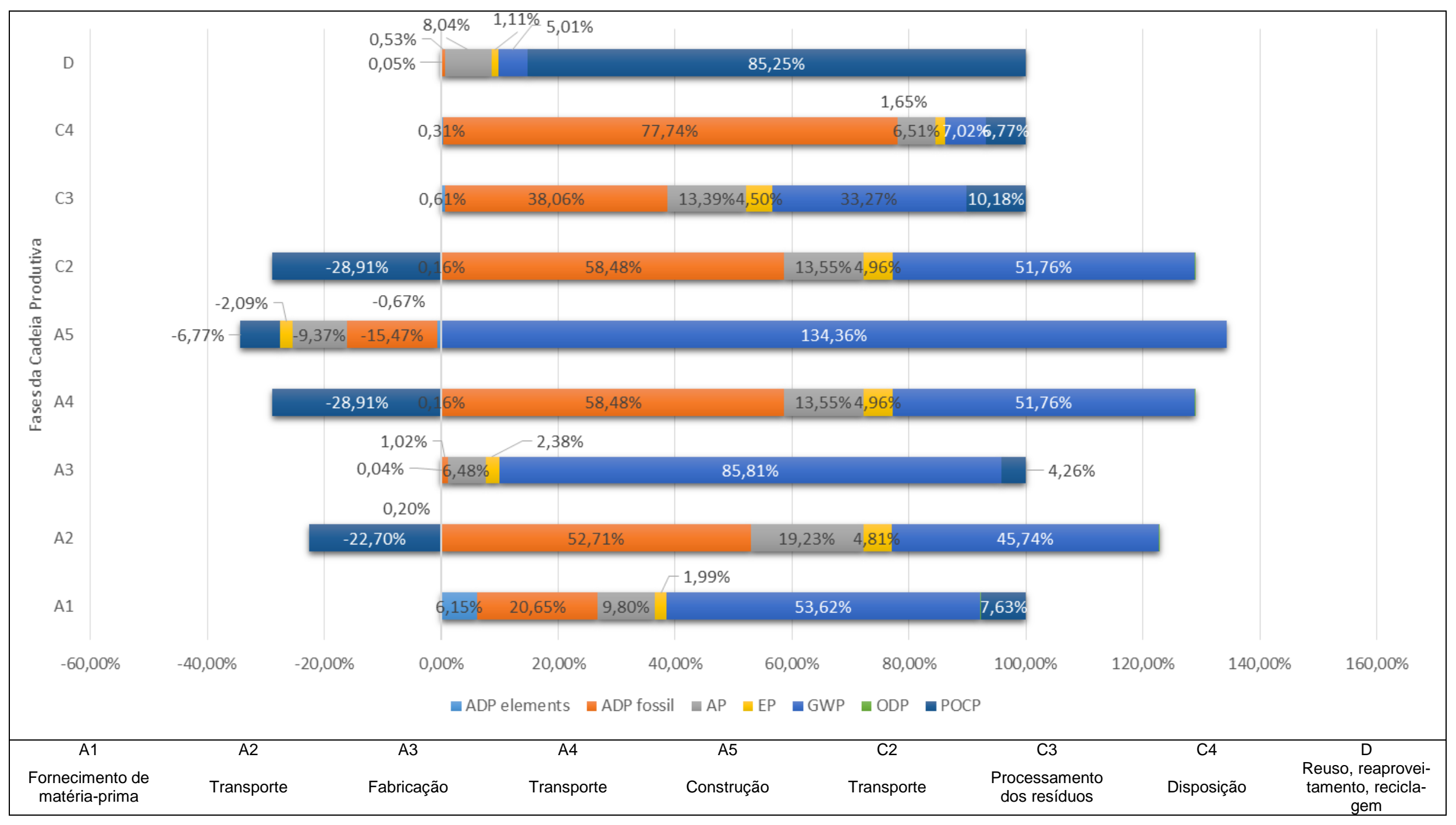

Figura 52: Valores relativos dos potenciais impactos ambientais do Contexto de Análise 1 e Tipolgia 2 


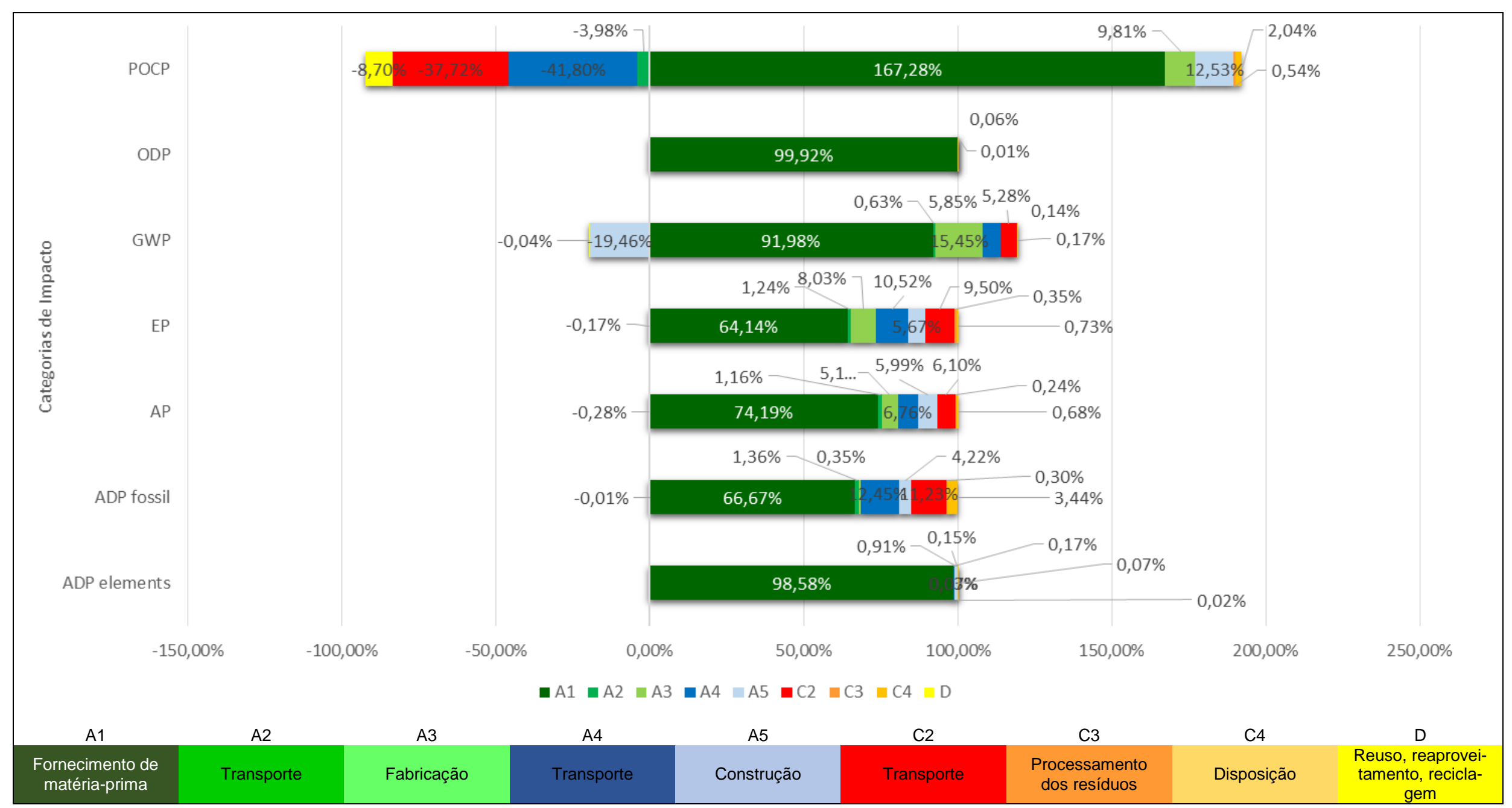

Figura 53: Valores relativos da contribuição de cada módulo de ACV para o potencial de impacto ambiental do Contexto de Análise 1 e Tipologia 2 
No processamento dos resíduos (módulo A3), na disposição dos resíduos (módulo C4) e os benefícios (D) apresentam valores bastante semelhantes entre as tipologias comparadas, visto que a taxa de reciclagem (2\%) é a mesma, a massa de vedação de $1 \mathrm{~m}^{2}$ das duas tipologias $(258,6$ e $256,4 \mathrm{~kg})$ são próximas e que é dado o mesmo tratamento, diposição final e reaproveitamento para ambas. Na tipologia 1 apenas $5,17 \mathrm{~kg}$ é reciclado e transformado em agregado e, na tipologia 2, 5,13kg de resíduo da construção e demolição é reciclado, ou seja, para cada metro quadrado de vedação demolida, as tipologias apresentam uma diferença de apenas $400 \mathrm{~g}$.

Apenas a critério de curiosidade, a tipologia britânica, que será avaliada no Contexto de Análise 2, aplicada ao Brasil possui um impacto potencial global de $5,82 \times 10^{-11}$, ou seja, é $33 \%$ menor que o impacto da tipologia brasileira 2 avaliada neste contexto de análise. A tipologia 2 foi a que apresentou o meIhor desempenho ambiental na primeira análise e esse cenário poderia ficar ainda melhor se a tipologia britânica fosse aplicada para o Brasil, considerando a mesma função, unidade funcional e requisitos de desempenho.

Apesar da tipologia britânica utilizar blocos cerâmicos que consomem maior quantidade de combustível fóssil (gás natural), as taxas de eficiência do uso do material - como o uso de menores espessuras de argamassa para revestir as vedações e assentar os blocos e menor taxa de desperdício de materiais tanto na fabricação do bloco, quanto na produção da vedação - ao longo do ciclo de vida da vedação compensam esse consumo maior inicial.

5.1.2. Comparação 2: Tipologia britânica de vedação vertical externa aplicada ao Reino Unido e ao Brasil

Como explicado anteriormente, nesse contexto de comparação foram alterados somente dois valores de parâmetros: o tipo de bloco e a nacionalidade, que embutia características específicas para cada país. Sendo assim, a alteração desses valores releva o quanto sensível é determinado parâmetro de projeto para a vedação vertical aplicada no Reino Unido e no Brasil.

A vedação aplicada ao Reino Unido possui um impacto potencial global três vezes maior que a vedação aplicada ao Brasil, como pode ser observado na Figura 54. 


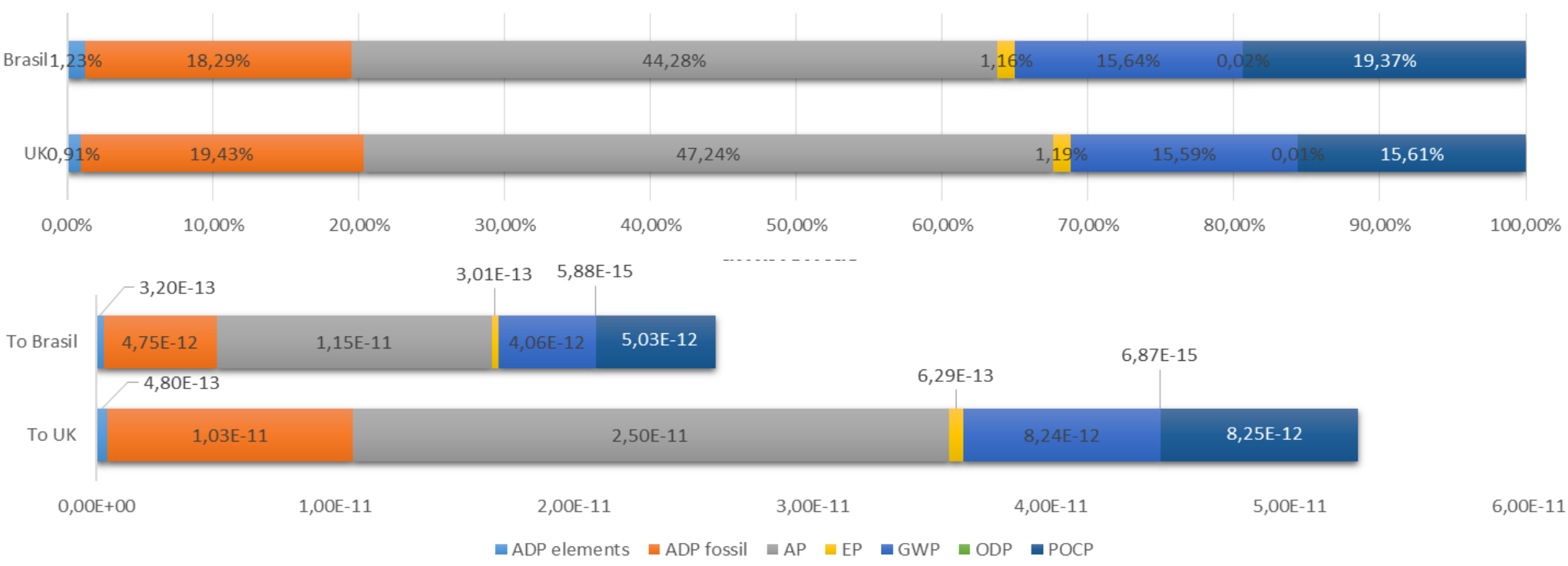

Figura 54:Valores relativos e absolutos das contribuições dos potenciais dos impactos ambientais totais do Contexto de Análise 2 
Isso se dá, basicamente, pela quantidade de massa de componentes necessária para a instalação da vedação, visto que a vedação britânica aplicada ao Reino Unido necessita de um bloco de $425 \mathrm{~mm}$ de largura para cumprir com os requisitos térmicos mínimos, enquanto que a mesma vedação aplicada ao Brasil pode usar um bloco de $115 \mathrm{~mm}$ de largura, além de demandar menor quantidade de argamassa para assentar os blocos.

A outra diferença está na disposição final dos resíduos de demolição e construção da vedação, dos quais $90 \%$ é reciclado no Reino Unido e apenas $2 \%$ é reciclado no Brasil, transformando-se em matéria-prima para outras cadeias produtivas. Mesmo a taxa de reciclagem no Brasil sendo tão inferior, os impactos potenciais da vedação aplicado ao Reino Unido foram bastante significativos.

Observa-se também que, se no Brasil, os resíduos fossem reciclados ao invés de depositados em aterros sanitários como material inerte, o impacto global potencial global seria maior $\left(6,2 \times 10^{-11}\right)$, visto que seria necessário o processo de trituração dos resíduos. No entanto, ao aproveitar um resíduos, reduz-se a demanda por matéria-prima virgem e a pressão sobre os aterros sanitários e seus impactos relacionados.

A Figura 54 mostra os valores relativos e absolutos dos impactos potenciais totais da tipologia britânica aplicada ao Reino Unido e ao Brasil. Observa-se que o impacto mais relevante é o Potencial de Acidificação. Isso não é um resultado comum na ACV, visto que, na maioria dos casos, o Potencial de Mudança Climática é o impacto mais significante.

Esse impacto está fortemente presente na produção do bloco cerâmico britânico, como pode ser visto na Figura 55. Isso se dá, principalmente, pelo uso do gás natural no processo produtivo dos blocos, sobretudo para a sua queima, e também no uso desse combustível e de energia térmica para a extração da argila chinesa que é matéria-prima na produção do bloco. Na Figura 55, o Potencial de Acidificação também está presente na matriz energética do Reino Unido, na produção da argila chinesa e na queima de combustíveis, mas a produção do bloco é disparado o maior impacto. 
O Potencial de Acidificação é predominantemente influenciado pela produção de óxidos de nitrogênio $\left(\mathrm{NO}_{\mathrm{x}}\right)$ e óxidos de enxofre $\left(\mathrm{SO}_{\mathrm{x}}\right)$ gerados pela combustão dos combustíveis fósseis no forno, no maquinário e no transporte.

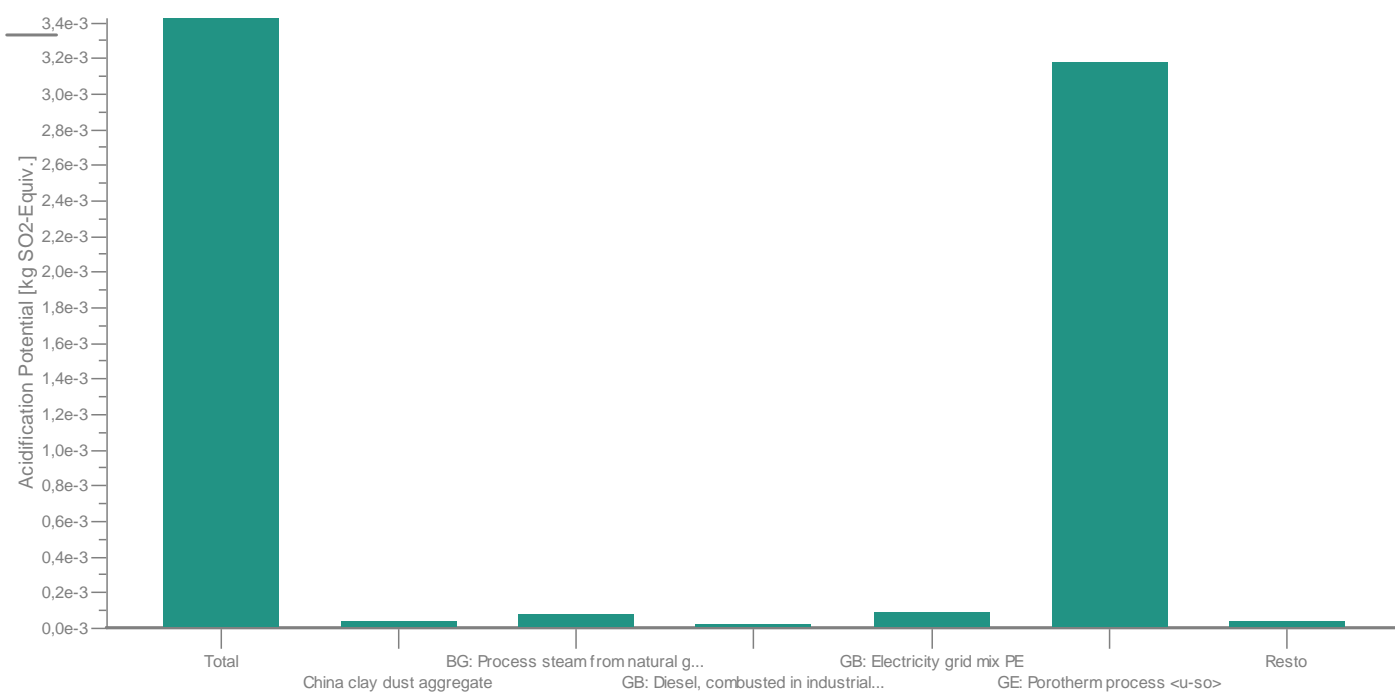

Figura 55: Potencial de Acidificação na produção de $1 \mathrm{~kg}$ do bloco cerâmico poroso do Reino Unido

Outros impactos significativos são POCP, GWP e ADP fóssil. O Potencial de Formação de Ozônio Fotoquímico (POCP) é calculado sobre as emissões de óxidos de nitrogênio e compostos voláteis, que são emitidos na queima de combustíveis fósseis. Ou seja, também para essa categoria de impacto, a produção do bloco é o maior responsável por essa emissão (Figura 55).

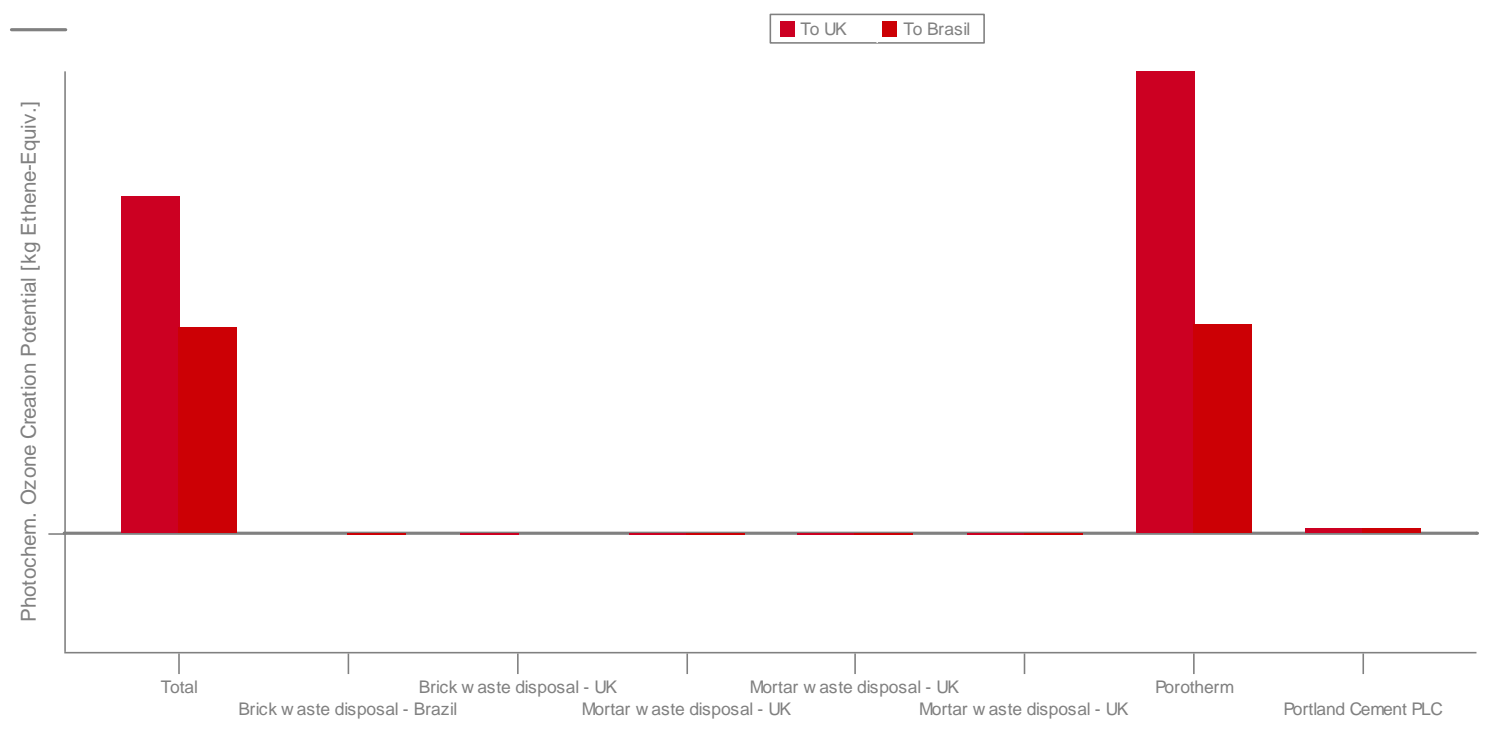

Figura 56: Categoria de impacto POCP por processo da tipologia britânica

O Potencial de Mudança Climática (GWP) e a Depleção de recursos abióticos (ADP fóssil) são contabilizadas em $\mathrm{CO}_{2}$ eq e $\mathrm{MJ}$, sendo o consumo e 
queima de combustível fósseis o principal fator de emissão. Também para esses impactos, o processo de produção do bloco cerâmico é o mais significante (Figura 57 e Figura 58).

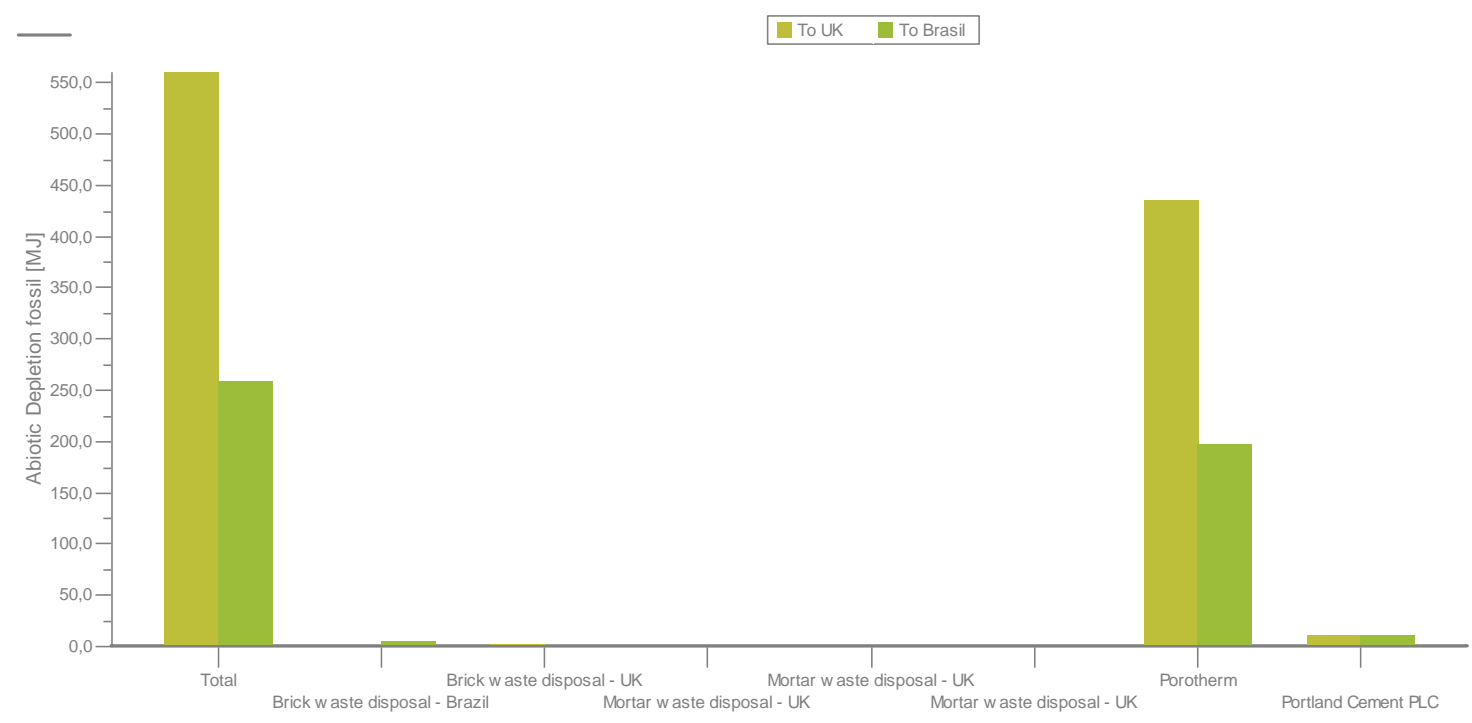

Figura 57: Potencial de Depleção de recurso abiótico(fóssil) e a produção da tipologia britânica

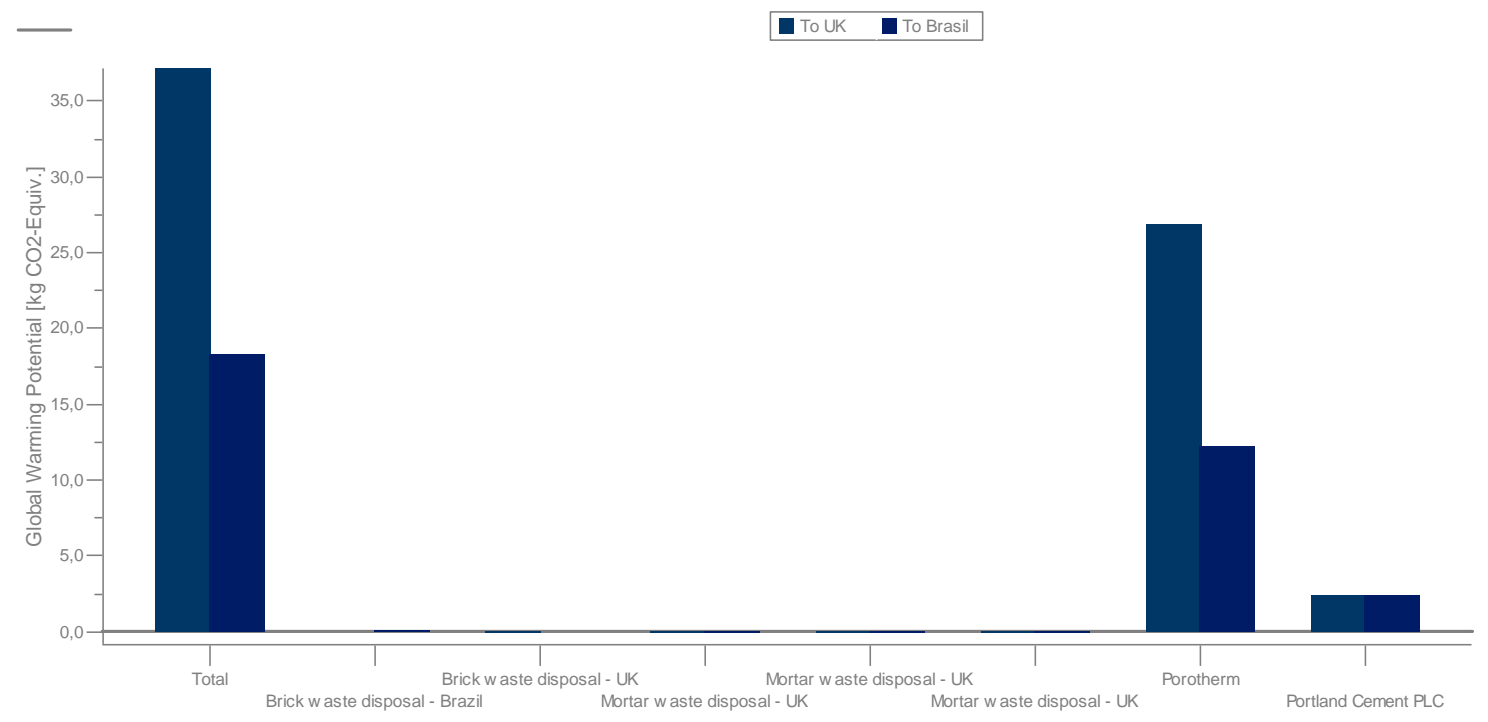

Figura 58: Potencial de Mudança Climática e a tipologia britânica

O destaque dado ao processo de produção do bloco cerâmico poroso britânico se deve também ao reduzido emprego de argamassas na produção da vedação, que além de serem empregadas em menor quantidade que nas vedações do Brasil, ainda possuem taxas de desperdício inferiores. No Brasil, aplica-se uma argamassa externa e interna de $25 \mathrm{~mm}$ de espessura para cada lado da vedação, além do assentamento do bloco que é feito com $10 \mathrm{~mm}$ de ar- 
gamassa entre os blocos. No Reino Unido, a espessura de argamassa interna é de $12 \mathrm{~mm}$, o externo é de $15 \mathrm{~mm}$ e o assentamento é feito com apenas $1 \mathrm{~mm}$ de espessura. Ou seja, com a mesma quantidade de argamassa aplicada em $1 \mathrm{~m}^{2}$ das vedações brasileiras, dá para revestir $1,85 \mathrm{~m}^{2}$ de vedação britânica. Isso sem contar o desperdício de material que, no Brasil, é de $30 \%$ e, no Reino Unido, é de $15 \%$. Contando os desperdícios de ambos, seria possível revestir $2,09 \mathrm{~m}^{2}$ de vedação britânica.

Avaliando-se a tipologia britânica aplicada ao Reino Unido e ao Brasil de forma separada, tem-se que os impactos mais significativos são diferentes de acordo com o módulo de ACV avaliado, mas que os impactos relativos da vedação aplicada ao Brasil e ao Reino Unido são bastante parecidos (

Figura $59 \mathrm{e}$

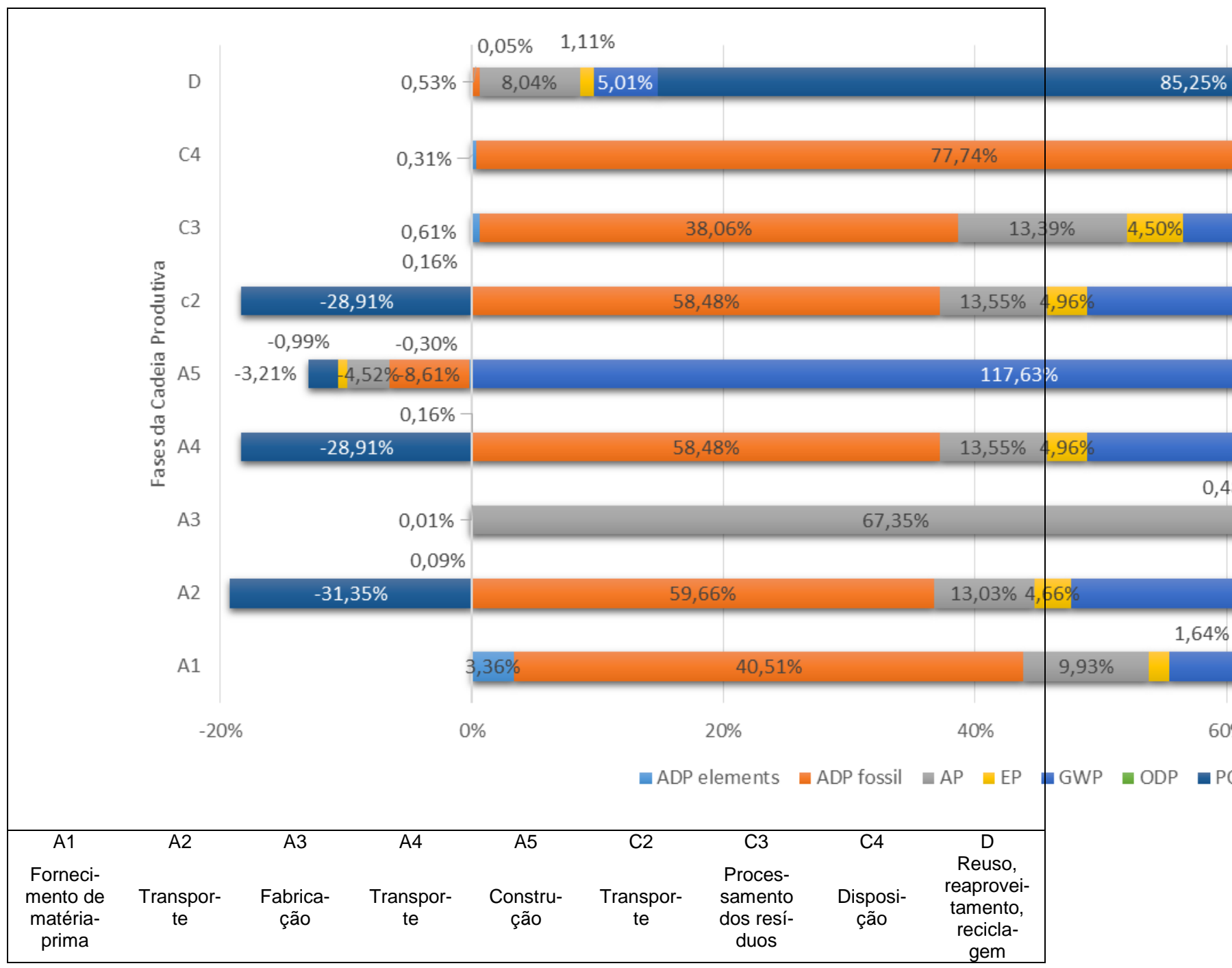

Figura 60). 
Esses gráficos estão apresentados com os valores relativos e sendo os processos produtivos semelhantes, alterando-se somente as massas de componentes e destinação final, as diferenças entre esses gráficos encontram-se no módulo $A 1$ devido à quantidade de matéria-prima demandada por cada componente, no módulo $A 5$ devido à massa de cada componente aplicada e no módulo C4, onde diferentes quantidades de resíduos são dispostas no aterro sanitário. Por isso, ao analisar-se esses gráficos os valores dos impactos são muito próximos em valores percentuais.

Nos módulos A1, A2, A4 e C2 o maior impacto é o ADP fóssil, principalmente devido ao uso de combustíveis fósseis para a extração e produção das matérias-primas, sobretudo o cimento Portland e a cal, e no transporte das matérias-primas. No módulo $A 3$, observa-se que o maior impacto é do Potencial de Acidificação devido à queima do gás natural na produção dos blocos e na extração da argila.

O Módulo A5 apresenta valores negativos para GWP e ADP fóssil por causa do processo de carbonatação que acontece nessa fase. O módulo C3 utiliza diesel para a trituração dos resíduos e produção do agregado reciclado, o que gera um maior impacto das categorias ADP fóssil e GWP. E o módulo $D$ possui um impacto significativo da categoria POCP pelo uso de combustíveis fósseis na produção de agregado reciclado natural, que foi o fluxo utilizado nessa fase para representar o agregado reciclado. 


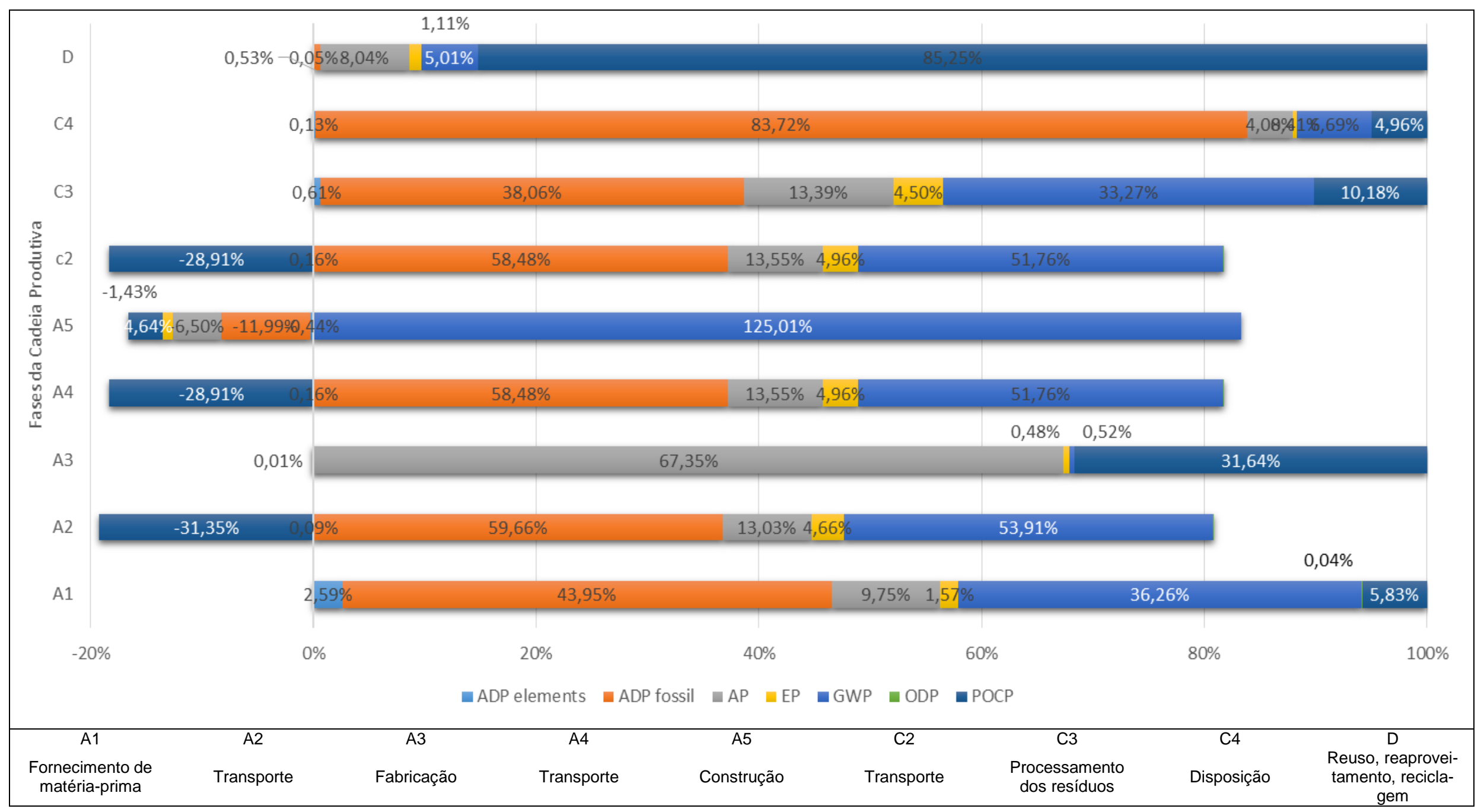

Figura 59: Valores relativos dos potenciais impactos ambientais do Contexto de Análise 2 e Tipolgia aplicada ao Reino Unido 


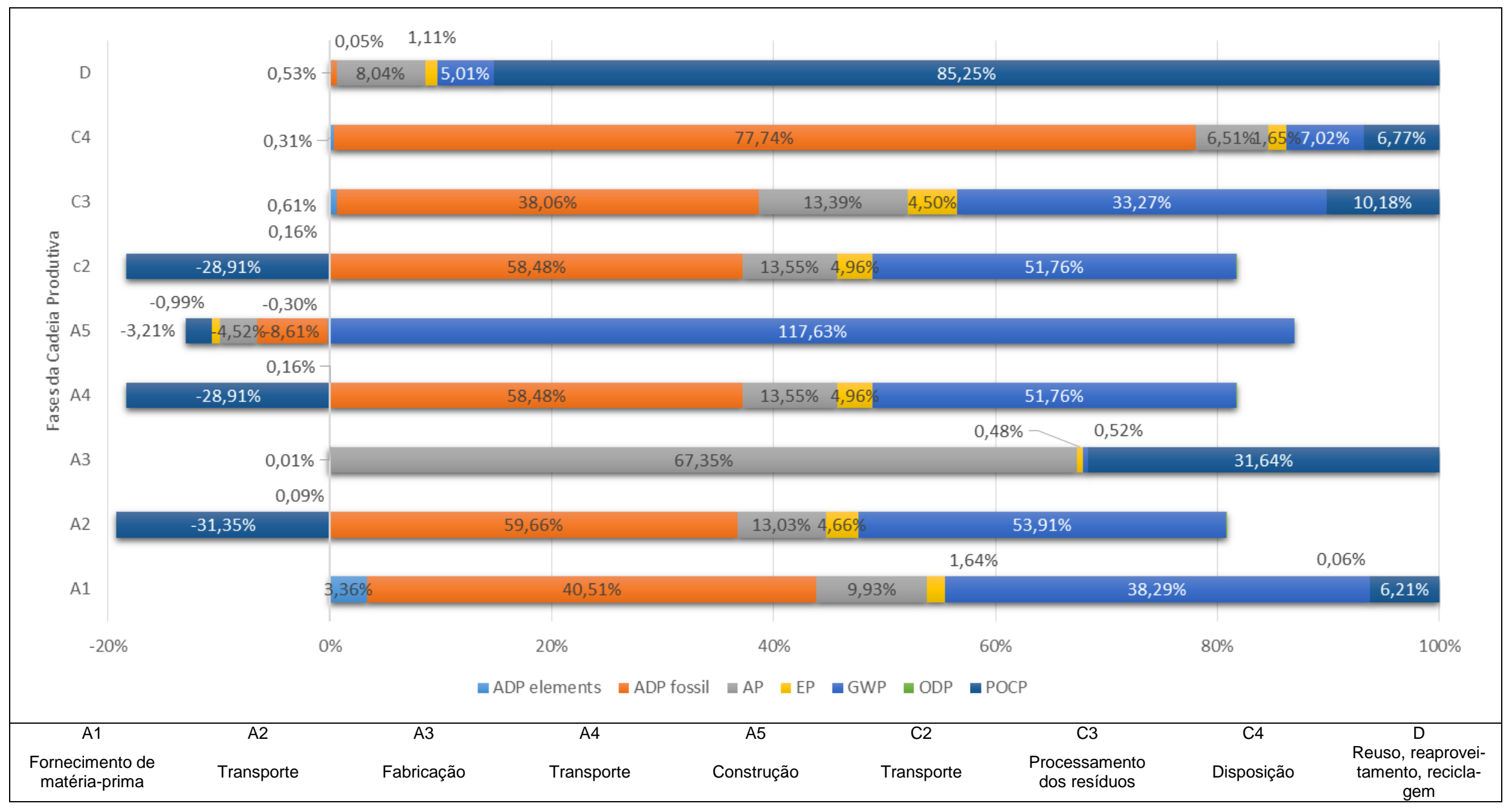

Figura 60: Valores relativos dos potenciais impactos ambientais do Contexto de Análise 2 e Tipolgia aplicada ao Brasil 
Os impactos ambientais também podem ser avaliados pela contribuição de cada módulo de ACV para a tipologia britânica (Figura 61 e

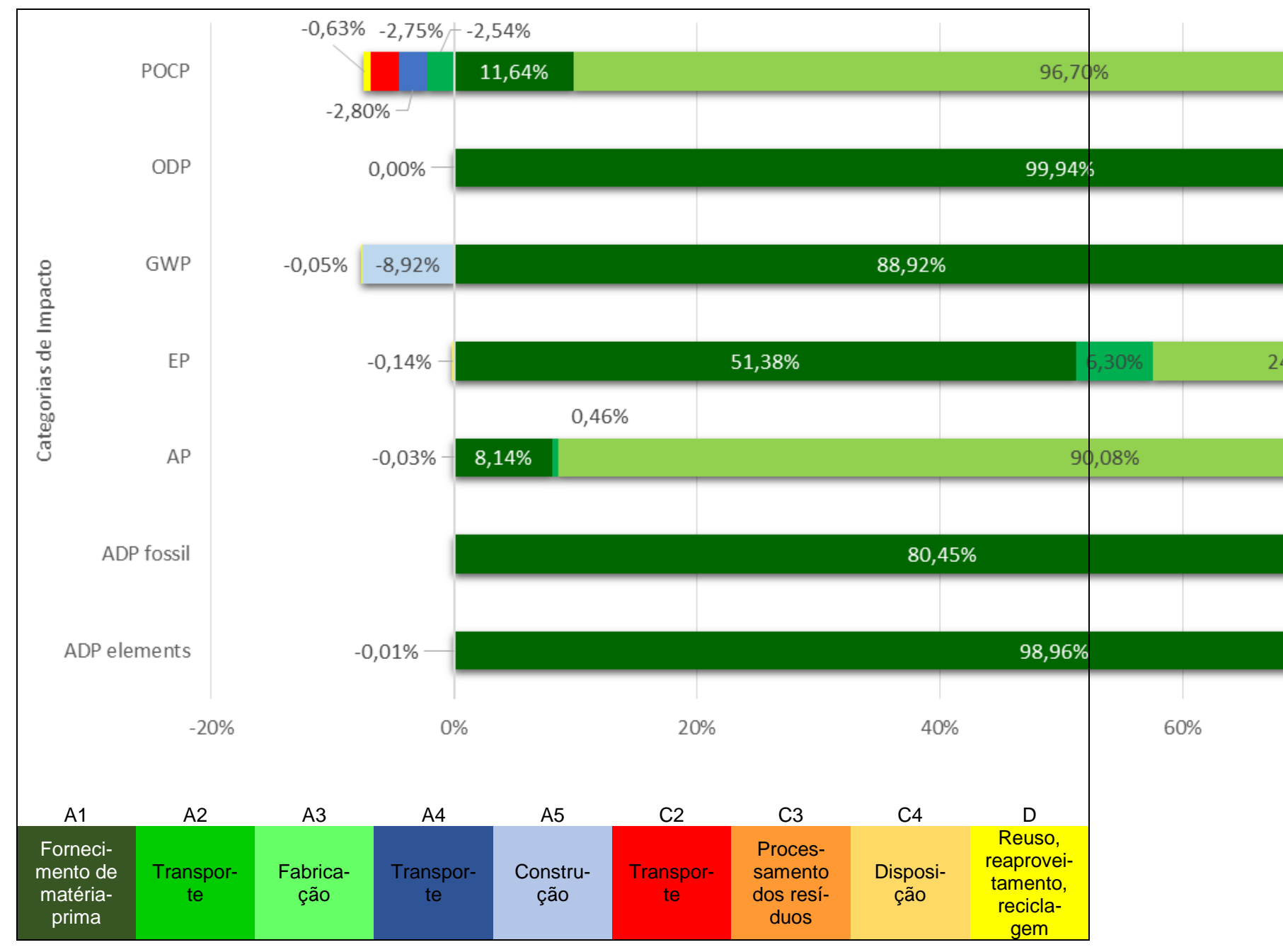

Figura 62). Para a categoria Depleção de Recuros abiótico (ADP elements), como era o esperado, o maior impacto provem do módulo $A 1$, onde grande quantidade de matéria-prima é empregada para a produção dos componentes.

Na categoria Potencial de Mudança Climática (GWP), a fase A5 possui no Brasil um valor percentual negativo maior que na vedação aplicada ao Reino Unido, isso por que a razão bloco/argamassa (cal e cimento Portland) é menor, ou seja, o processo de carbonatação será praticamente o mesmo na vedação aplicada nos dois países, porém se o dado é tratado de forma relativa, onde a razão bloco/argamassa é maior no Reino Unido, o valor percentual será menor onde a argamassa for menos representativa na composição da vedação. 
$\mathrm{Na}$ categoria Potencial de Eutrofização (EP), Potencial de Mudança Climática (GWP) e Depleção de recursos abiótico (ADP fóssil), o módulo C3 apresenta valores maiores na vedação aplicada ao Reino Unido que ao Brasil. Isso acontece porque para o contexto do Reino Unido, as taxas de reciclagem dos resíduos são muito maiores e, por isso, demanda-se nesse módulo maior quantidade de processamento industrial. Na mesma forma, os benefícios do módulo D são maiores na Figura 61, que mostra os resultados da tipologia aplicada ao Reino Unido, visto que as taxas de reciclagem são de $90 \%$ e, por isso, é possível compensar os impactos ao longo da cadeia produtiva.

O módulo A3, relativamente, é significante para as categorias Potencial de Acidificação (AP) e Formação de ozônio fotoquímico (POCP). A grande demanda por calor proveniente da queima do gás natural na produção dos blocos libera gases que aumentam esses impactos. 


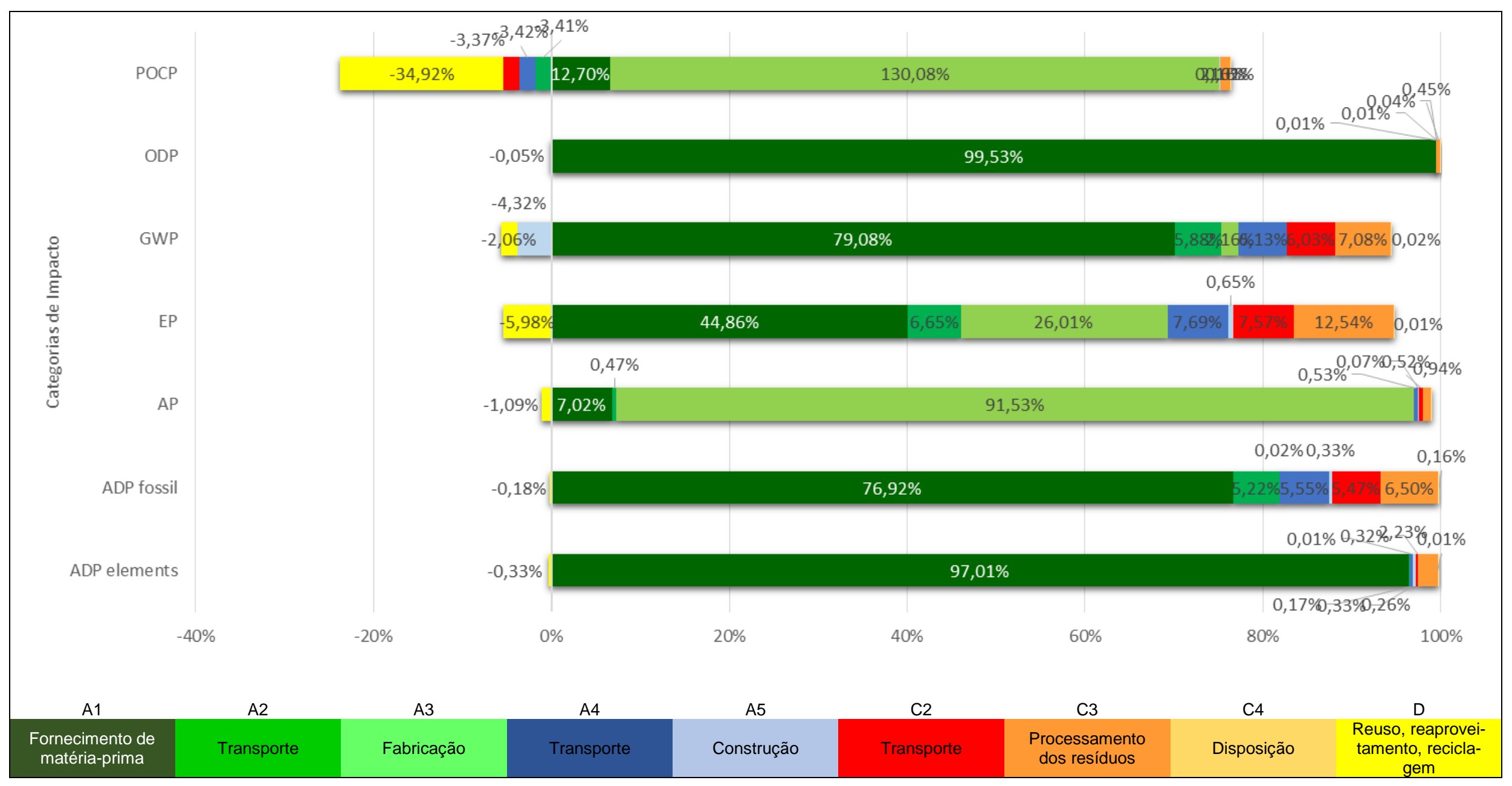

Figura 61: Valores relativos da contribuição de cada módulo de ACV para o potencial de impacto ambiental do Contexto de Análise 2 e Tipologia aplicada ao Reino Unido 


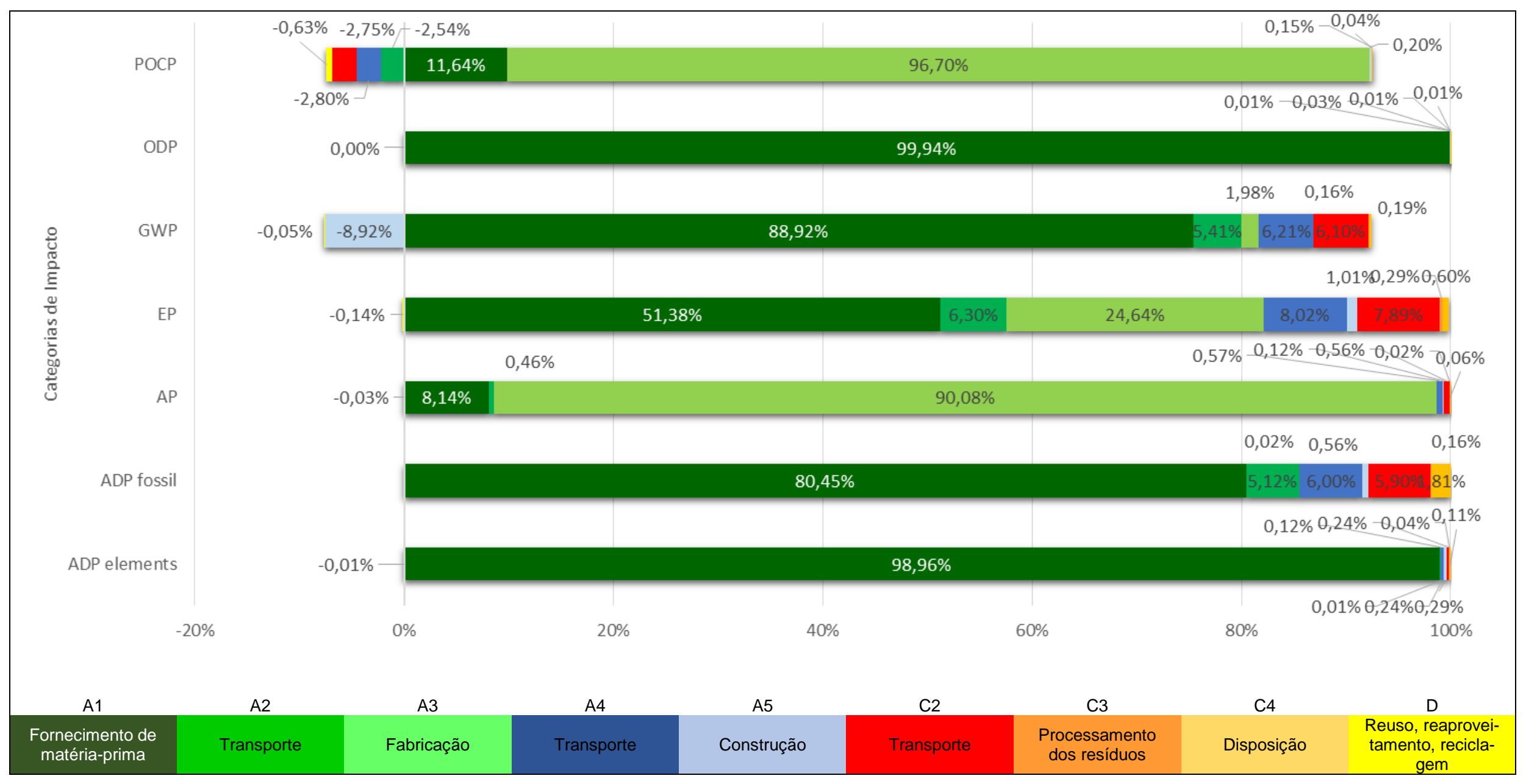

Figura 62: Valores relativos da contribuição de cada módulo de ACV para o potencial de impacto ambiental do Contexto de Análise 2 e Tipologia aplicada ao Brasil 


\subsection{Checagem de completude, consistência e sensibilidade}

5.2.1. Checagem de completude e de consistência

A checagem de completude e consistência foi feita por meio do software de ACV GaBi, que está sendo usado nesta pesquisa para os cálculos dos impactos.

Para a checagem da consistência, fez-se o balanço de massa de todos os processos inseridos no Plano Geral. Dos processos criados para esse plano, tem-se que os processos de reuso e de uso do material reciclado, que estão conectados ao fim da vida da vedação, aparecem com valores de massa maiores que $10 \%$, pois não estão conectados a processos externos. Sendo assim, para equilibrar o balanço de massa esses processos precisam ser conectados a outros planos de uso dos resíduos da vedação.

Os demais processos criados obedeceram ao limite de valores inferiores aos $10 \%$ de diferença de massa entre as entradas e as saídas.

Dos processos prontos utilizados do $\mathrm{GaBi}$, os processos de queima de combustível, tratamento da água e produção de resíduos de madeira apresentaram valores maiores que o limite de $10 \%$ de massa. Isso se deve à diferença entre entrada em massa e saída em Megajoules de energia e a processos que contabilizam somente fluxos individuais ou que não possuem informações de completude declarados.

Dos 48 processos inseridos no Plano Geral, somente onze apresentaram problemas de consistência do dado, sendo que esses processos não estão nos níveis zero e 1 da análise. Além disso, dos 48 processos 9 não possuem informações quanto à sua completude ou possuem processos que contabilizam informações individuais de fluxos contabilizadas. O Quadro 23 apresenta os processos, valores de entrada, valores de saída, a diferença entre a entrada e a saída e a completude do dado. Os valores em negrito são os que apresentaram problemas.

Quadro 23: Checagem de completude e de consistência

\begin{tabular}{lllll}
\hline Processo & Entrada & Saída & Diferença & Completude \\
\hline BR: diesel at refenery PE & 170 & 170 & 0 & ARFR \\
\hline US: transport, combination truck, & 0,0228 & 0,806 & $\mathbf{- 0 , 0 5 7 8}$ & NE \\
\hline
\end{tabular}




\begin{tabular}{|c|c|c|c|c|}
\hline \multicolumn{5}{|l|}{ diesel powered } \\
\hline $\begin{array}{l}\text { BR: diesel, combusted in industrial } \\
\text { equipment }\end{array}$ & 0,838 & 2,77 & $-1,93$ & $\mathrm{NE}$ \\
\hline US: liquefied petroleum (LGP) & 100 & 101 & 1 & ARFR \\
\hline Clay at mine & 1,04 & 1 & $-0,04$ & ARFR \\
\hline $\begin{array}{l}\text { US:softwood logs with back, har- } \\
\text { vested at medium intensity site, at } \\
\text { mill }\end{array}$ & 0,0399 & 450 & 450 & IFR \\
\hline BR: Electricitu grid mix & 2,78 & 0 & $-2,78$ & ARFR \\
\hline RER: Tap water PE & 1,34 & 1,32 & $-0,02$ & ARFR \\
\hline GLO: truck & 1 & 1,01 & 0,01 & ARFR \\
\hline $\begin{array}{l}\text { BR: LGP, combusted in industrial } \\
\text { equipment }\end{array}$ & 0,838 & 2,77 & 1,93 & $\mathrm{NE}$ \\
\hline RER: landfill for inert matter & 10,9 & 10,5 & $-0,4$ & ARFR \\
\hline BR: waste destination & 0,0319 & 0,0319 & 0 & ARFR \\
\hline GB: diesel mix at refinery & 23,4 & 24 & 0,2 & ARFR \\
\hline $\begin{array}{l}\text { US: transport, combination truck, } \\
\text { diesel powered }\end{array}$ & 0,00238 & 0,0806 & 0,0578 & NE \\
\hline $\begin{array}{l}\text { GB: diesel, combusted in industrial } \\
\text { equipment }\end{array}$ & 0,838 & 2,77 & 1,93 & $\mathrm{NE}$ \\
\hline Sand & 4,57 & 4,56 & $-0,01$ & ARFR \\
\hline Gravel & 4,58 & 4,57 & $-0,01$ & ARFR \\
\hline US: Wood waste & 1,04 & 1,89 & 0,85 & NE \\
\hline DE: limestone flour & 37,9 & 37,9 & 0 & ARFR \\
\hline DE: lime & 50,5 & 51,5 & 1 & ARFR \\
\hline $\begin{array}{l}\text { BG: process steam from natural gas } \\
90 \%\end{array}$ & 1,43 & 1,76 & 0,33 & ARFR \\
\hline Process water & 9,47 & 9,38 & $-0,09$ & ARFR \\
\hline GB: Electricity grid mix & 95,5 & 95,5 & 0 & ARFR \\
\hline GB: Porotherm process & 1,1 & 1,01 & $-0,09$ & ARFR \\
\hline $\begin{array}{l}\text { EU-27: Waste water treatment (con- } \\
\text { tains organic load) }\end{array}$ & 2,25 & 1,19 & $-1,06$ & ARFR \\
\hline $\begin{array}{l}\text { EU-27: Landfill of municipal solid } \\
\text { waste }\end{array}$ & 29,9 & 30,2 & 0,3 & ARFR \\
\hline RER: Portland cement (CEM I) & $2,68 \mathrm{E} 003$ & $2,78 \mathrm{E} 003$ & 100 & ARFR \\
\hline $\begin{array}{l}\text { DE: Calcium hydroxide }(\mathrm{Ca}(\mathrm{OH}) 2 ; \\
\text { dry; slaked lime) }\end{array}$ & 42,9 & 43,7 & 0,8 & ARFR \\
\hline GLO: Portland Cement PLC & 1 & 1 & 0 & ARFR \\
\hline US: Fiberglass Loose Fill & 31,2 & 27,3 & $-3,9$ & ARFR \\
\hline $\begin{array}{l}\text { BR: Mortar mix 1:4 (hydrated } \\
\text { lime:sand) - thin bed }\end{array}$ & 1,32 & 1,3 & $-0,02$ & ARFR \\
\hline $\begin{array}{l}\text { BR: Mortar mix 1:2:8 (ce- } \\
\text { ment:hydrated lime:sand) }\end{array}$ & 1,3 & 1,26 & $-0,04$ & ARFR \\
\hline BR: Mortar mix 1:4 (cement:gravel) & 0,999 & 0,951 & $-0,048$ & ARFR \\
\hline $\begin{array}{l}\text { BR: Mortar mix 1:2:6 (ce- } \\
\text { ment:hydrated lime:sand) - ext. wall }\end{array}$ & 1,25 & 1,2 & $-0,05$ & ARFR \\
\hline BR: Mortar mix 1:3 (cement:sand) & 1,3 & 1,25 & $-0,05$ & ARFR \\
\hline
\end{tabular}




\begin{tabular}{|c|c|c|c|c|}
\hline $\begin{array}{l}\text { GB: Mortar mix 1:3 (masonry ce- } \\
\text { ment:sand) - int. wall }\end{array}$ & 1,15 & 1,09 & $-0,06$ & ARFR \\
\hline $\begin{array}{l}\text { GB: Mortar mix 1:1/4:3 (Ce- } \\
\text { ment:lime:sand) - wet mortar }- \text { thin } \\
\text { bed }\end{array}$ & 1,16 & 1,08 & $-0,08$ & ARFR \\
\hline $\begin{array}{l}\text { GB: Mortar mix 1:1:5 (ce- } \\
\text { ment:lime:sand) - ext wall }\end{array}$ & 1,15 & 1,09 & $-0,06$ & ARFR \\
\hline GB: Mortar waste disposal & 1 & 1 & 0 & ARFR \\
\hline GB: Light fuel oil at refinery & 24,9 & 25 & 0,1 & ARFR \\
\hline $\begin{array}{l}\mathrm{CH} \text { : Process-specific burdens, inert } \\
\text { material landfill }\end{array}$ & 1 & 1 & 0 & ARFR \\
\hline GLO: Clay Brick Typology_new & 10,1 & 10,1 & 0 & ARFR \\
\hline GB: Brick waste processing_new & 1 & 1 & 0 & ARFR \\
\hline GLO: Crushed recycled aggregate & 21,3 & 21,3 & 0 & ARFR \\
\hline GLO: Waste reuse & 1 & 0 & -1 & IFR \\
\hline GLO: Recycled aggregate use & 1 & -1 & -2 & IFR \\
\hline
\end{tabular}

Considerando os valores expostos e as conclusões obtidas sobre essas informações, conclui-se que o Plano Geral possui boa completude e que a consistência dos dados é de qualidade. Sendo assim, novas revisões no Plano Geral não foram necessárias.

\subsubsection{Análise de sensibilidade}

A análise de sensibilidade usa como critério de avaliação os diferentes consumos de energia dos fornecedores de blocos cerâmicos do Brasil. Considerando que esses dados foram coletados por Manfredini et al (2005), avaliouse que esses dados precisavam ser checados e comparados.

Sendo assim, foram gerados gráficos comparativos entre os fornecedores de blocos cerâmicos e os demais parâmetros do Plano Geral foram mantidos para que a comparação pudesse ser o mais fiel possível. Ressalta-se que o GaBi 6 possui apenas o processo de biomassa de cavaco de madeira, o que pode prejudicar a análise. Os fornecedores analisados utilizam cavaco de madeira, serragem, retalhos de móveis e lenha e os poderes caloríferos de cada material foi respeitado nas conversões de energia, porém os impactos considerados para cada biomassa partiram de um único processo.

Considerando as limitações expostas, os impactos normalizados e ponderados estão apresentados na Figura 63. 


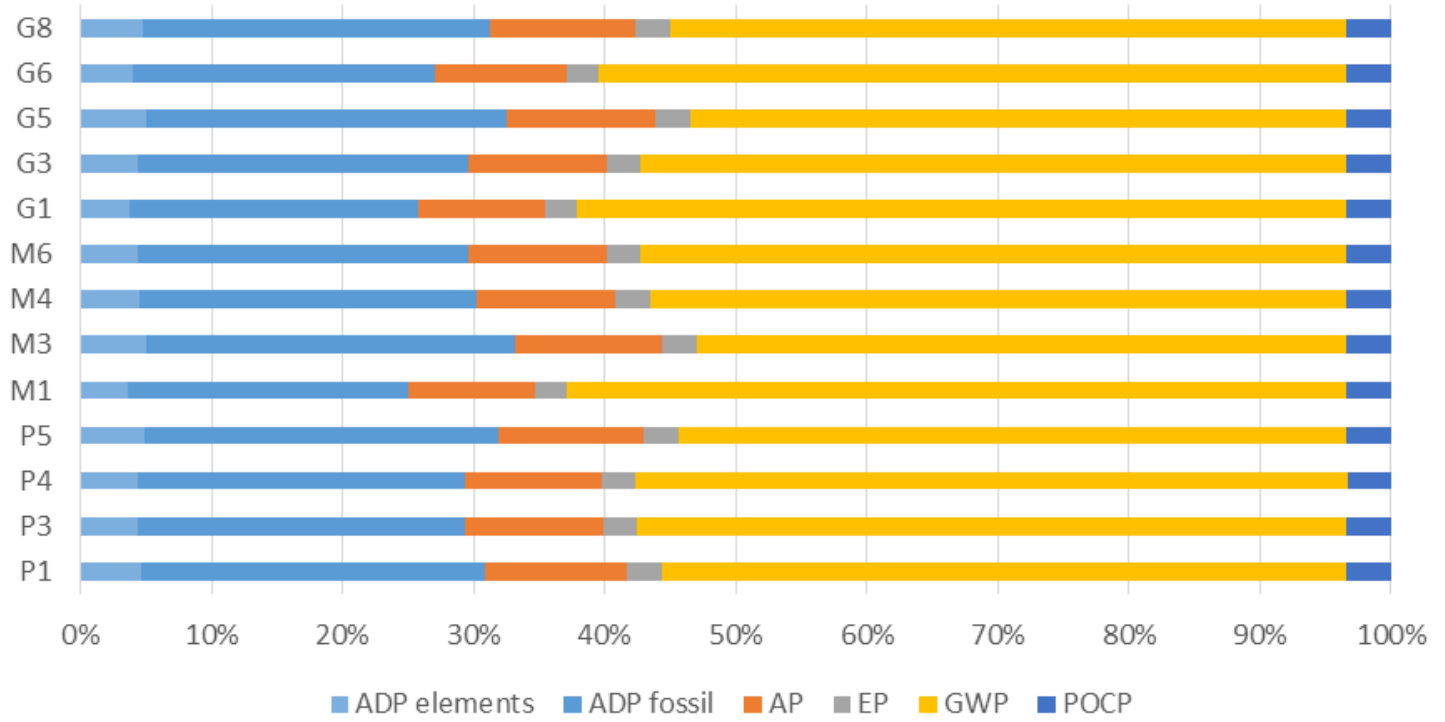

Figura 63: Contribuição percentual de cada categoria de impacto no impacto potencial provocado pela cadeia produtiva do bloco cerâmico de cada fabricante

Considerando as categorias de impacto potenciais, tem-se que os impactos relativos à categoria Mudança Climática GWP são os mais significativos para todos os fornecedores. Sendo assim, optou-se por detalhar os valores absolutos na Figura 64 para que possa ser avaliado o impacto potencial de cada fornecedor. Os fornecedores M1, G1 e M6 possuem os maiores impactos potenciais de Mudança Climática, enquanto que os fornecedores P5, M3 e G5 possuem os menores impactos potenciais.

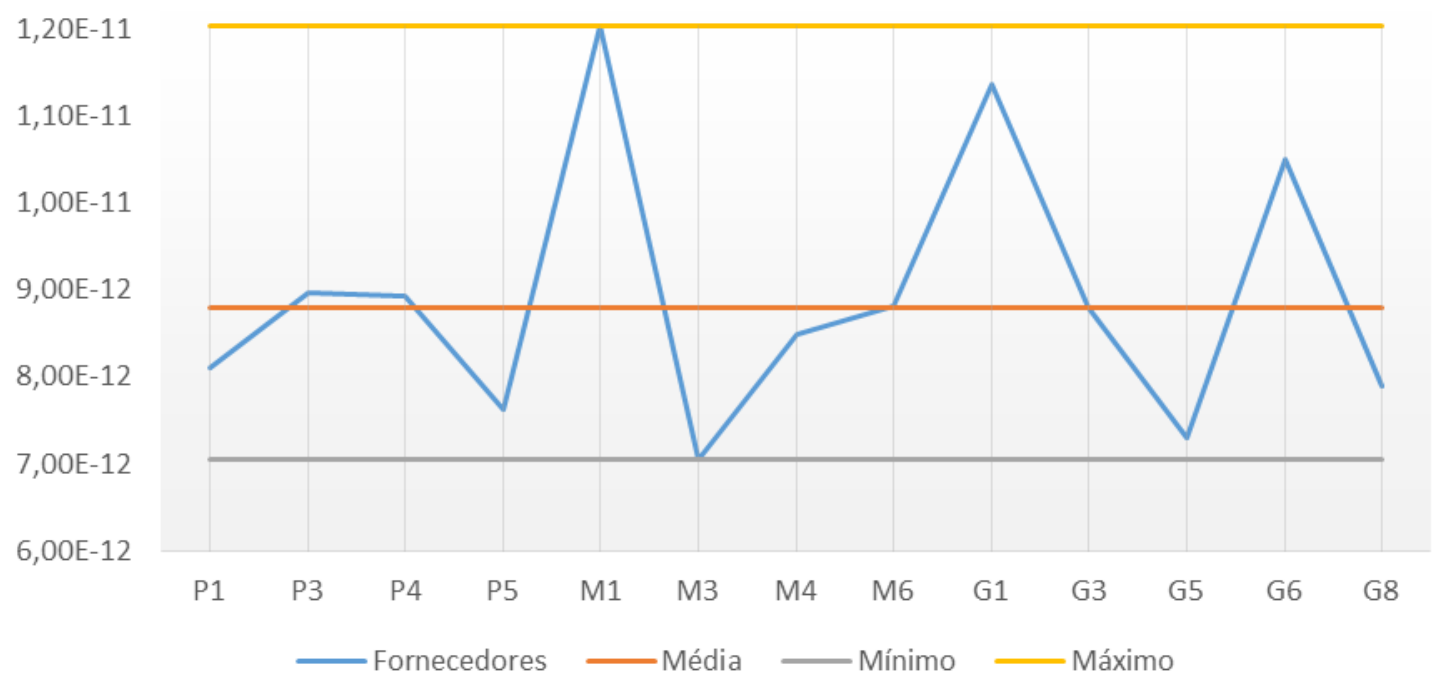

Figura 64: Impactos absolutos para cada fabricante considerando o Potencial de Mudança Climática 
Considerando as características de cada processo produtivo apresentadas no Quadro 24, observa-se que o impacto ambiental potencial está diretamente relacionado ao poder calorífero e à massa de biomassa necessária para a queima dos blocos. Visto que, quanto maior o poder calorífero da biomassa, menor será a massa necessária para a queima.

Isso se dá devido ao uso de um único processo de queima de biomassa disponível no GaBi 6, ou seja, para qualificar essa informação e torná-la mais fiel aos impactos, é necessário o desenvolvimento de processos específicos para cada biomassa considerando os respectivos impactos ambientais associados.

Mesmo considerando que os fornos intermitentes e semicontínuos possuem um rendimento menor que o forno túnel e que a secagem artificial demandaria maior consumo de energia, esses fatores não influenciaram de forma direta o impacto ambiental potencial associado com cada processo produtivo.

Quadro 24: Características do processo produtivo de cada fornecedor

\begin{tabular}{cccc}
\hline Fornecedor & Tipo de secagem & Tipo de biomassa & Tipo de forno \\
\hline M1 & Natural e artificial & Serragem & Intermitente \\
\hline G1 & Natural e artificial & Cavaco & Túnel \\
\hline G6 & Artificial & Serragem & Túnel \\
\hline P5 & Natural & Lenha & Semicontínuo \\
\hline M3 & Natural & Lenha & Intermitente \\
\hline G5 & Artificial & Lenha & Túnel \\
\hline
\end{tabular}

A análise de sensibilidade demonstrou que a diferença entre o maior e 0 menor impaco ambiental é de 6,8E-12, que é aproximadamente o menor valor de impacto, ou seja, a o maior valor é quase o dobro do menor valor. Por isso, observa-se uma expressiva diferença entre os valores de impacto ambiental potencial assocido a cada uma das cadeias produtivas consideradas. Além disso, essa análise evidenciou a falta de dados dos processos de combustão com diferentes tipos de biomassa. 


\subsection{Relatório, revisão crítica, publicação e, ou aplicação}

Após as quatro etapas da $A C V$, é elaborado o relatório, feita a revisão crítica, a publicação e, ou a aplicação da ACV elaborada.

Por se tratar de um exercício para a aplicação do modelo elaborado, as ACVs desta pesquisa passaram por revisão crítica de terceiros, sendo revisada apenas pelo discente, orientador e co-orientadores. Finalmente, a publicação se dá no momento da defesa e disponibilização desta tese.

\subsection{Contribuições para a metodologia de elaboração de um MTP}

Após a elaboração do modelo e sua aplicação nos contextos de análise, verificou-se que outras etapas e passos metodológicos foram inseridos à metodologia do ILCD (JRC, 2010), visto que apenas com as etapas descritas e com seu detalhamento quanto à obrigatoriedades, recomendações e sugestões não foram suficientes.

Essas etapas e passos inseridos ao longo do processo foram esquematizados sobre a metodologia do ILCD, previamente apresentada no Capítulo 5. Essa esquematização das novas etapas e passos estão detalhados em verde na Figura 65.

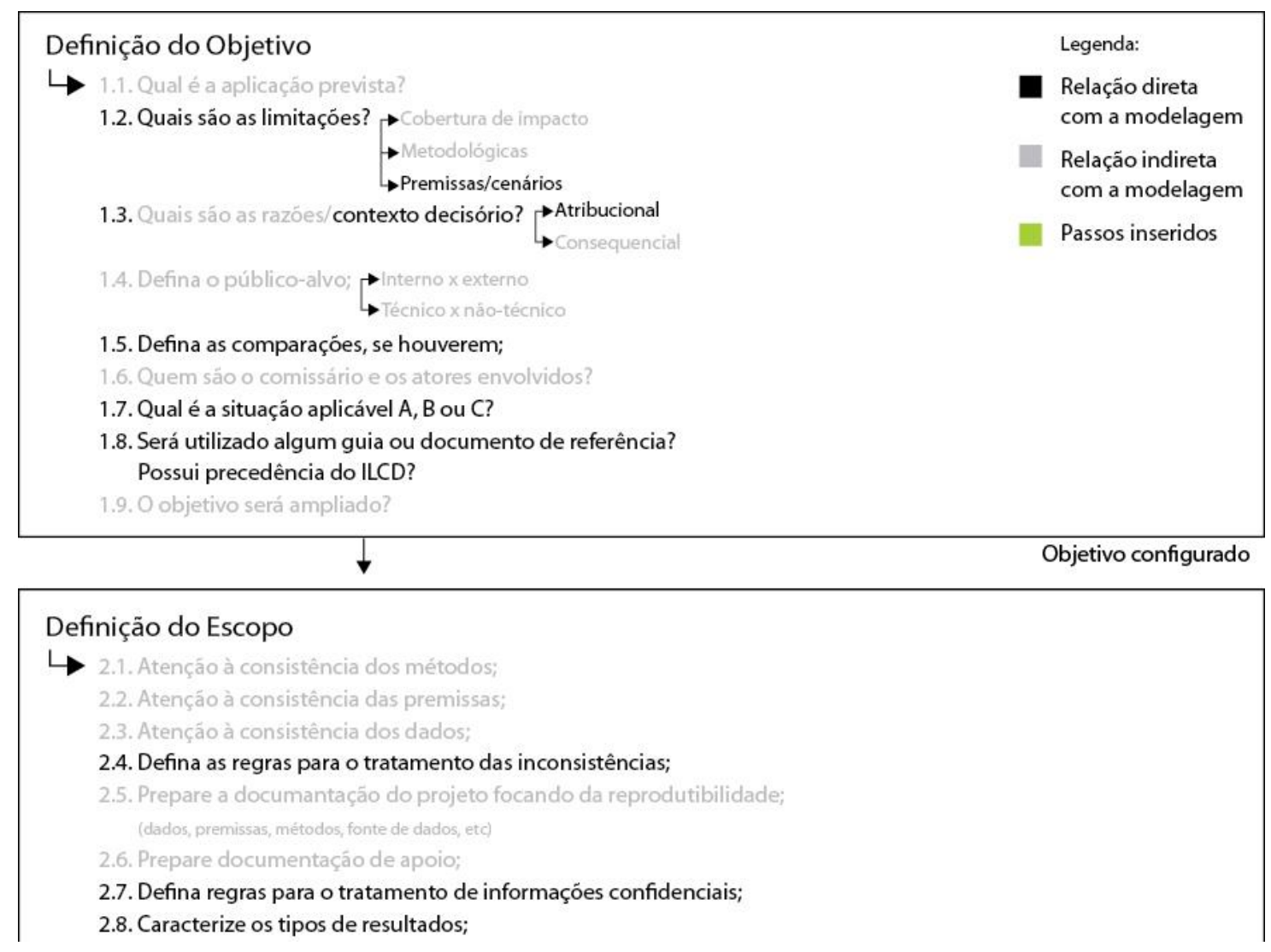


Resultados de categorias de impacto por estágio do ciclo de vida da edificaçáo (A, B, C e D)

2.9. Identifique sistemas e processos (fotos, especificaçóes etc);

2.10. Defina funçáo e unidade funcional com foco na funçáo e náo nos materiais

(deve responder: o que? quanto? por quanto tempo? de que maneira);

Definiçáo de quais requisitos de desempenho sáo relevantes ou possuem dados disponíveis
Levantamento dos requisitos de desempenho e das tipologias do produto da Construçáo
Defuzamentçáo dos produtos que entrarăo na análise
Definiçáo do fluxo de referência

2.11. Defina propriedades obrigató rias e de posicionamento:

2.12. Defina os métodos de mediçáo:

2.13. Existem alternativas e complementos à unidade funcional?

Análise da cadeia produtiva do produto (extraçáo dos insumos < produto construído/instalado > descarte final)

Seleçáo dos processos e características específicas de cada fabricante/sistema

Construçáo de objetos modelo (diagramas) que retratem o processo produtivo específico $\downarrow$

Identificaçáo de pontos-chave, simplificaçáo e generalizaçáo da cadeia $\downarrow$

Construçáo de objeto modelo que simplifique e generalize a cadeia produtiva

2.14. Seráo feitos estudos comparativos?

Definiçáo das comparaçóes

2.15. A modelagem será? $\longrightarrow$ Quanto à situação? A, B ou C?

$\rightarrow$ Quanto à estrutura de modelagem? Atribucional ou consequencial?

$\rightarrow$ Quanto às abordagens metodolóqicas? Alocação ou substituição?

2.16. Quais sáo as fronteiras do sistema?

Fronteiras definidas de acordo com os estágios do ciclo de vida (A, B, C e D)

2.17. Prepare um diagrama das fronteiras so sistema;

2.18. Prepare uma lista de exclusóes;

2.19. Considere as relaçóes entre parte e sistema e entre sistemas;

2.20. Defina os critérios de corte;

2.21. Defina as categorias de impacto (em conformidade com o objetivo)

2.22. Defina o método de AICV

(avalie se as categorias de impacto definidas e pontos finais ou médios estáo de acordo com o método de AICV):

2.23. Haverá exclusáo ou adiçáo de categorias?

2.24. Existem impactos relevantes fora do escopo?

2.25. A ponderaçá̃o e a normalizaçáo influenciam os critérios de corte?

2.26. Haverá normalizaçáo e ponderaçăo?

2.27. Documente as decisóes de métodos de AICV, categorias de impacto, normalizaçáo e ponderaçáo;

2.28. Qual é a representatividade tecnológica? $\rightarrow$ É um processo específico?

$\rightarrow$ Existem diferentes tecnologias de acordo com a modelagem?

2.29. Qual é a representatividade geográfica?

2.30. Qual é a representatividade temporal? $\longrightarrow$ Situaçăo sazonal ou específica?

$\rightarrow$ Considera processos futuros?

2.31. Crie uma visáo geral das principais fontes de dados;

2.32. Quais sáo os requisitos gerais de qualidade dos dados e conjunto de dados?

2.33. Existem comparaçóes? $\rightarrow$ Assertivas ou não-assertivas

$\rightarrow$ Observe a consistência na modelagem de ICV, premissas e qualidade dos dados

2.34. Faça o cálculo de exatidáo ou incerteza;

2.35. Teste de completude (corte);

2.36. Exclua partes idênticas

2.37. Existe equivalência funcional na comparação?

2.38. Selecione as alternativas a serem comparadas; 
2.39. Selecione cenários de produçáo, operação e uso (incluindo cenários hipóteticos, se aplicável);

2.40. Existe a necessidade de revisáo crítica?

2.41. Defina a estrutura do relatório.

Escopo configurado

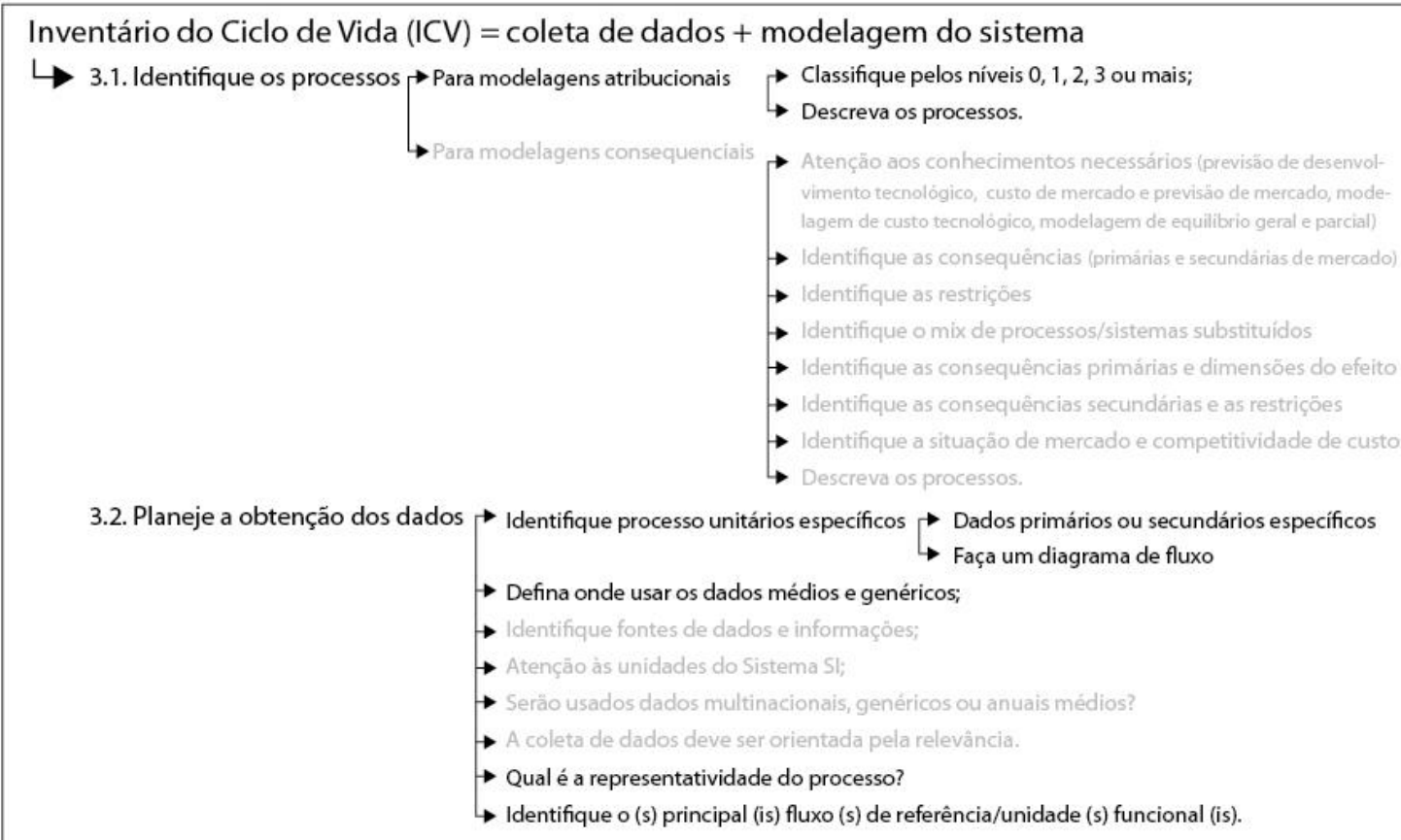

Desenvolva questionário para coleta de dados primários

3.3. Colete os dados primários e secundários;

Aplique o questionário para coleta de dados primários (nível 0 e, ou 1 )

Busque material de regerência com dados (associaçóes) e dados na bibliografia disponível (nível 0 e , ou 1)

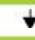

Selecione e avalie processos e planos em um banco de dados (niveis 2, 3 ou mais)

$\downarrow$ E preciso migrar os dados entre banco de dados e, ou softwares?

Migre os dados entre bancos de dadose, ou softwares $\rightarrow$ Migraçăo por dados do inventário:

- Migração por impactos;

$\rightarrow$ Migração por processos e planos;

$\rightarrow$ Migração por exportação.

3.3. Caracterize o processo unitário

3.4. Defina o valor de 1 unidade de referência para o fluxo de referência relacionando dados e o processo unitário; Prepare uma planilha de dados de acordo com o fluxo de referência/unidade funcional

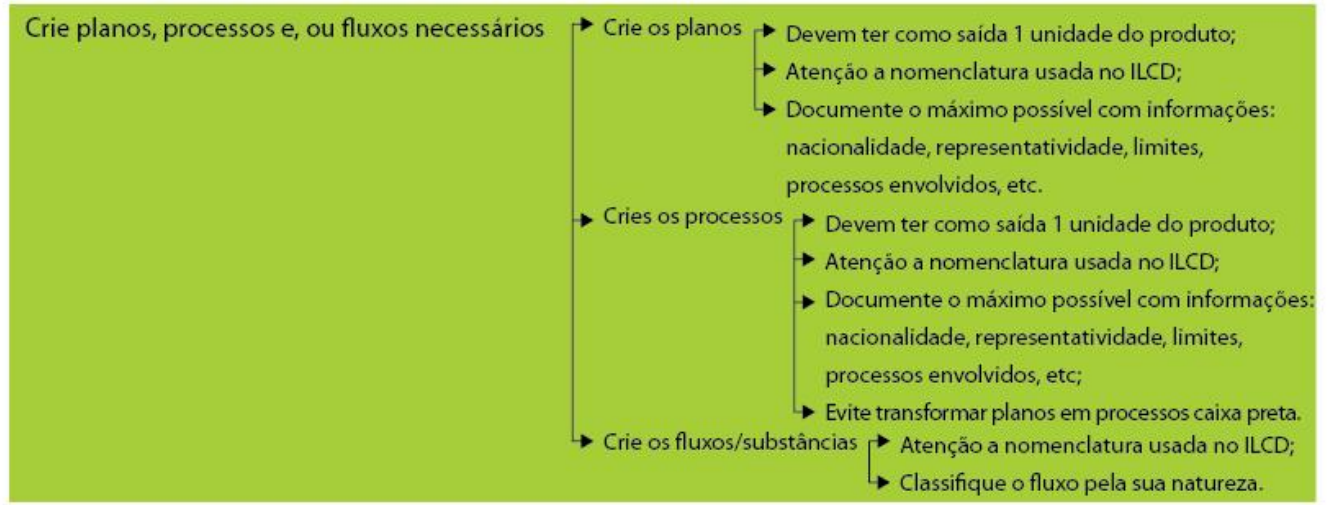

3.5. Documente o valor absoluto do processo central;

3.6. Os dados do inventário devem representar um ciclo completo $\rightarrow 1$ ano completo de dados;

Defina e liste as variáveis do modelo (parâmetros livres) $\rightarrow$ Quais caracteristicas do produto serão as variáveis? $\rightarrow$ que o difere um produto do outro? 
3.7. Parametrize os dados;

Defina os parâmetros fixos (dados e fórmulas de cálculo) $\rightarrow$ O que quero calcular? Que valores são necessários?
$\longrightarrow$ Que dados, fórmulas e funçōes são necessárias?

3.8. Verifique limites legais

3.9. Dimensione os dados para a unidade funcional definida;

3.10. Agregue os dados para manter a confidencialidade;

3.11. Verifique a validade dos dados coletados;

3.12. Faça controle da qualidade dos dados $\longrightarrow$ Todos os dados relevantes estão na análise?

$\rightarrow$ Há proporcionalidade?

$\rightarrow$ Faça uma avaliaçăo intermediária de impactos;

- Avalie a consistência no método;

$\rightarrow$ Avalie as discrepâncias;

$\rightarrow$ Avalie dados ausentes e lacunas: pode ser estimado?

3.13. Seráo inseridos processos e fluxos elementares futuros?

3.14. Insira fluxos de lembrete, se necessários;

3.15. Modele o tratamento do resíduo $\rightarrow$ Modele inteiramente a gestão dos resíduos;

$\rightarrow$ Modele o descarte de bens na natureza;

$\rightarrow$ Modele os resíduos como saída.

3.16. Avalie os dados secundários $\rightarrow$ São consistentes?

$\rightarrow$ Foram construídos com base na qualidade?

$\rightarrow$ São dados pré-verificados?

$\rightarrow$ Estäo bem documentados?

3.17. Modele o sistema $\rightarrow$ Dimensione corretamente o inventário

- Modelo o sistema completo;

- Defina valores de parâmetro;

- Aplique outra rodada de controle de qualidade

$\rightarrow$ Use dados consistentes e, ou com qualidade suficiente

3.18. Defina procedimentos de alocação $\rightarrow$ Por subdivisão:

$\rightarrow$ Por divisão parcial;

Por divisão virtual;

- Por preço de mercado;

$\rightarrow$ Por massa.

Modele o modelo inicial

Teste o modelo inicial

Por exemplo, módulos de ACV dos estágios de ciclo de vida do produto

$\begin{aligned} \text { Faça uma análise crítica dos resultados de ICV e AICV } & \rightarrow \text { Os resultados de AICV sáo coerentes? } \\ & \rightarrow \text { Os resultados estáo dentro do esperado? Sem sim, avaliar. } \\ & \text { Se náo, porque? } \\ & \rightarrow \text { Existe algum benchmarketing? }\end{aligned}$

Faça uma revisáo das inconsistências

\begin{tabular}{|c|c|}
\hline Faça uma revisão da modelagem, dados, processos e parâmetros & $\begin{array}{l}\rightarrow \text { Revise valores inseridos para os dados; } \\
\rightarrow \text { Revise fórmulas e funçóes; } \\
\rightarrow \text { Troque os valores das variáveis para testar } \\
\text { como o modelo se comporta; } \\
\rightarrow \text { Revise os processos e planos. }\end{array}$ \\
\hline \multicolumn{2}{|r|}{$\mathrm{s}^{2}$} \\
\hline \multicolumn{2}{|l|}{ Avalie o modelo intermediário } \\
\hline \multicolumn{2}{|l|}{$\downarrow$} \\
\hline \multicolumn{2}{|c|}{ Escolha as propriedades dos componentes, processos e planos (valores para os parâmetros livres/variáveis) } \\
\hline \multicolumn{2}{|c|}{$\downarrow$} \\
\hline \multicolumn{2}{|c|}{ Monte as análises e as comparaçóes de acordo com objetivo e escopo? (Gabi Analyst) } \\
\hline \multicolumn{2}{|l|}{$\downarrow$} \\
\hline \multicolumn{2}{|l|}{ Teste o modelo intermediário } \\
\hline \multicolumn{2}{|l|}{$\downarrow$} \\
\hline \multicolumn{2}{|l|}{ Repita a análise crítica dos resultados de ICV e AICV } \\
\hline \multicolumn{2}{|l|}{$\downarrow$} \\
\hline \multicolumn{2}{|l|}{ Faça uma revisão das inconsistências } \\
\hline \multicolumn{2}{|l|}{$\downarrow$} \\
\hline Faça nova revisáo do modelo, dados, processos e parâmetros & \\
\hline
\end{tabular}

$\downarrow$ É possivel generalizar e, ou simplificar o sistema? 
Generalize e, ou simplifique o modelo o quanto possivel sem que perca suas características principais

Versão final do modelo testada e ajustada

3.19. Calcule os resultados de ICV $\longrightarrow$ Use os mesmos procedimentos de cálculo;

$\rightarrow$ Calcule e agregue os dados do inventário.

$\downarrow$ Dados coletados e modelagem feita

\section{Avaliação do Impacto do Ciclo de Vida}

$\longrightarrow$ 4.1. Calcule os resultados $\rightarrow$ Classifique os fluxos elementares

Revisáo

$\rightarrow$ Caracterize os fluxos elementare

$\rightarrow$ Calcule os resultados de AICV por categoria de impacto

$\rightarrow$ Calcule os resultados para emissōes de longo prazo

$\rightarrow$ Calcule separadamente resultados de AICV näo-genéricos

4.2. Normalize $\rightarrow$ Para dar suporte à interpretaçăc;

$\rightarrow$ Como quantificaçäo do corte

4.3. Pondere $\rightarrow$ Para dar suporte à interpretaçăo;

$\rightarrow$ Como quantificação do corte

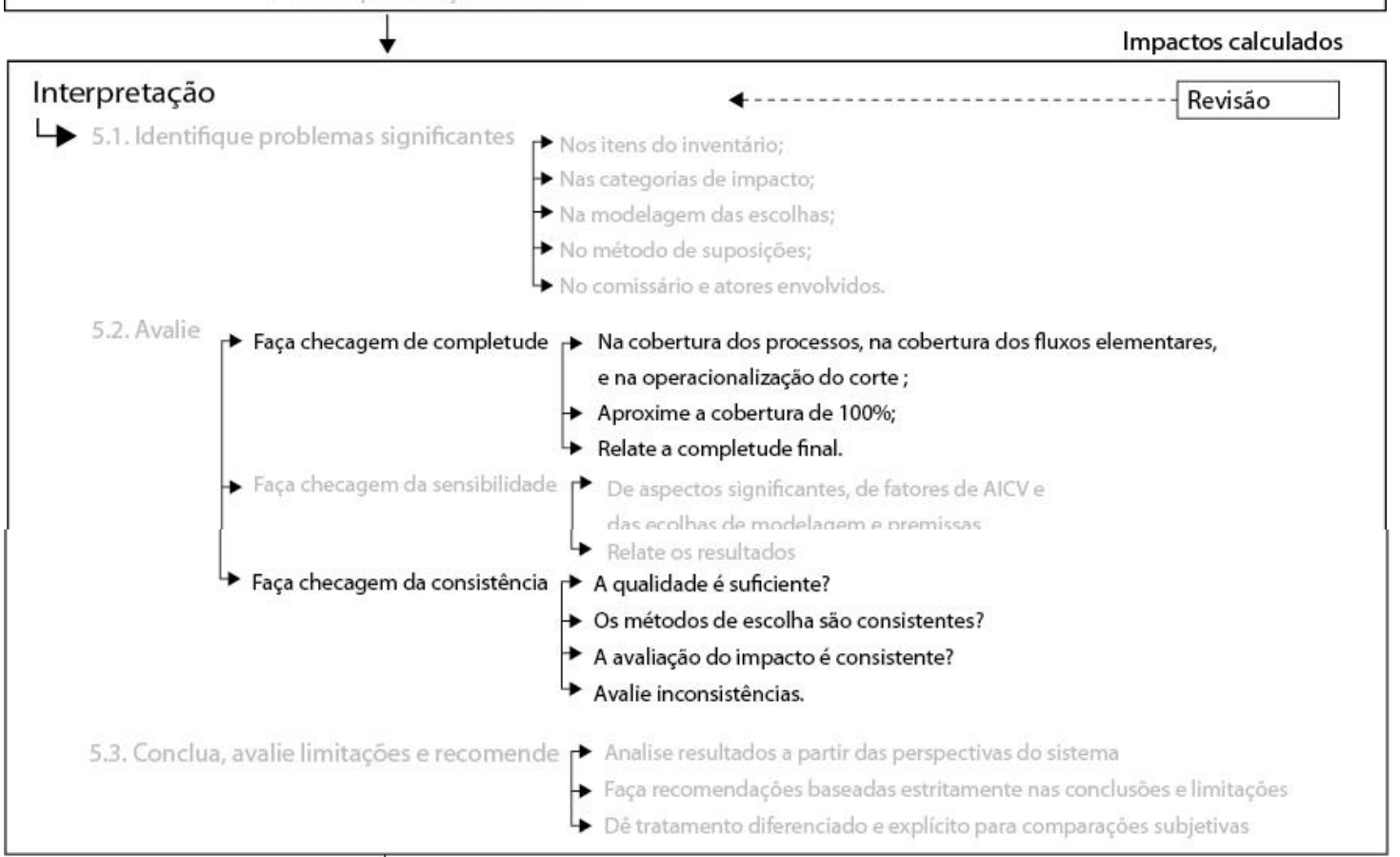

$\downarrow$ Resultados interpretados

\begin{tabular}{|l|l|l|}
\hline Relatório & \multicolumn{1}{|c|}{ Relatório montado } \\
\hline Revisão crítica & $\checkmark$ \\
\hline
\end{tabular}

Resultados publicados e, ou aplicados

Figura 65: Esquematização das novas etapas e passos metodológicos para a elaboração de MTPs. 


\section{Conclusão}

O MTP desenvolvido nesta pesquisa pode ser expandido e aplicado a outras tipologias de vedação vertical externa, a outros subsistemas da edificação e a edificação como um todo, por meio da inserção de novos parâmetros no inventário, mantendo tanto os dados do ICV parametrizados, quanto os parâmetros de projeto (livres) que permitem o desenho de contextos de análise.

Esse desenvolvimento e aplicação de MTPs permite produzir elementos que se conectam entre si, tendo em vista avaliar o impacto do ciclo de vida de toda a edificação. O MTP também pode ser expandido para outras fases do ciclo de vida da edificação, como a fase de uso da construção, que é uma das fases com significativo impacto ambiental, uma vez que o ciclo de vida das habitações brasileiras é de 50 anos e que os sistemas da edificação interagem nessa fase, podendo causar outros tipos de impacto não identificados nas fases iniciais.

Importante ressaltar que as escolhas de projeto para as tipologias da vedação vertical externa são decisivas para a redução do consumo de energia e para o conforto térmico da habitação, além dos impactos ambientais associados a essas escolhas e que podem ser testados ainda na fase de projeto pelos parâmetros desenhados no MTP.

Embora o modelo tenha sido construído considerando-se edificações domésticas, os mesmos princípios de elaboração podem ser utilizados para edificações com outras funções, tais como hospitais, escolas, usos comerciais, prédios públicos, entre outros.

A utilização dos requisitos de desempenho das vedações verticais permite uma maior acuidade na definição da Função e Unidade Funcional do MTP, considerando o papel da vedação e não os materiais utilizados para a sua construção. Sendo assim, a tipologia da vedação torna-se informação coadjuvante frente a função desempenhada, desviando o foco dos materiais empregados para a execução da vedação.

O desenvolvimento e a aplicação de um MTP nas ACVs permitem a elaboração de várias avaliações com base em uma origem comum, que consi- 
dera os mesmos dados e os mesmos princípios de modelagem, tornando o processo mais rápido e padronizado, permitindo a sistematização de uma metodologia de elaboração de MTP e a inserção de etapas e passos complementando a metodologia de ACV descrita no ILCD.

No entanto, somente com as informações contidas nesse manual não foi possível o desenvolvimento do modelo desta pesquisa, sendo necessário a inserção de novas etapas de desenvolvimento e definição de instruções mais detalhadas para que o MPT fosse elaborado e testado.

Dentre os ganhos para esta tese destacam-se o acesso a um banco de dados de ACV com dados consolidados, além da análise de como é feita a estruturação dessas informações. Foi possível ter acesso a regulações sobre DAPs que permitiram que o MTP fosse estruturado de forma a ser entendido, modificado e atualizado por outros profissionais de ACV utilizando uma linguagem comum a outras ACVs. Sendo assim, o MTP passou de uma série de caixas de processos e planos que só faziam sentido para quem elaborou o processo, para um modelo coerente onde as fases e módulos de uma DAP podem ser claramente observados.

Verificou-se ainda a ampliação da visão de aplicação da ACV para além da avaliação em si por meio da utilização das informações de ACV em diferentes certificações e avaliações e como integrá-las com outras ferramentas e metodologias no contexto da Construção.

A ACV encontra-se mais disseminada nos países desenvolvidos por possuirem bancos de dados de ACV já desenvolvidos e recursos disponíveis para serem aplicados à pesquisa, ao desenvolvimento e à inovação.

No Brasil, a ACV é ainda pouco utilizada devido à vários fatores: (i) falta de um banco de dados nacional; (ii) sua aplicação encontra-se em um estágio inicial, visto que a maior parte dos estudos concentra-se em materiais e componentes, etapa anterior e essencial para a realização de ACV de edificações e infraestruturas, uma vez que irá alimentar de dados as análises e compor os inventários do ciclo de vida; e (iii) sua aplicação na construção enfrenta dificuldades devido às características da cadeia produtiva da indústria da construção, como o grande número de agentes, atores, materiais e serviços; o longo ciclo de vida das edificações; a complexidade da relação entre insumos, componen- 
tes e elementos na edificação; entre outros motivos que tornam a aplicação da ACV nessa cadeia ainda mais complexa.

Mais trabalhos em ACV precisam ser elaborados para que se expanda a aplicação da metodologia no Brasil e avaliações de impactos ambientais negativos de produtos da construção possam ser realizados, bem como a emissão de DAPs com base em ACV, considerando como exemplo o que é feito em outros países.

No Reino Unido, além das declarações individuais de produtos emitidas para cada fabricante, ainda existem DAPs com dados médios, que abrangem uma cadeia produtiva, e o catálogo Green Guide. Esse catálogo possui os impactos ambientais negativos de elementos da edificação quantificados e classificados, o que auxilia arquitetos, projetistas e engenheiros na escolha por materiais menos agressivos ao meio ambiente e que incentiva a cadeia produtiva a desenvolverem produtos que possam ser classificados como $A$ e $A+$, segundo a metodologia de classificação do catálogo.

Espera-se que esse trabalho possa contribuir para a sustentabilidade da cadeia produtiva da construção de forma a tornar a previsão dos impactos ambientais negativos menos subjetiva e dimensionar o quanto ainda é preciso ser feito para tornar o mundo um lugar melhor para se viver, pelo menos sob o ponto de vista ambiental.

\section{Trabalhos futuros}

Como trabalhos futuros pode-se destacar a necessidade da elaboração de MTPs aplicados a outros tipos de vedações verticais e a mais etapas do ciclo de vida desse subsistema, bem como a outros subsistemas da edificação, que possam se integrar e formar um modelo parametrizado aplicado à edificação como um todo desde a fase de extração e beneficiamento da matériaprima até o descarte final dos resíduos e possíveis benefícios da reinserção desses resíduos, seja na forma de reciclagem, reuso ou reaproveitamento.

Existe a necessidade de elaborar inventários do ciclo de vida de materiais da construção no contexto brasileiro, que sigam uma mesma metodologia de coleta de dados e desenvolvimento e que estejam disponíveis em um banco de dados comum, além da adequação das fórmulas de cálculo de processos 
básicos para o desenvolvimento de qualquer ACV, como os processos de energia, combustíveis, transporte, etc. $O$ desenvolvimento de mais trabalhos de ACV, principalmente de ICVs, auxilia na formação de um banco de dados nacional para que novos estudos possam ser conduzidos com menor demanda de recursos à medida em que o banco de dados se torne mais robusto.

Também faltam dados das vedações verticais e de seus cumprimentos dos requisitos de desempenho para além do térmico e do acústico, o que qualifica melhor a função e a unidade funcional do elemento da construção estudado e que permite comparar de forma mais adequada as inúmeras possibilidades de combinação existentes entre esses elementos, pois muitas vezes são comparadas, por exemplo, vedações formadas insumos diferentes, mas que não podem ser comparadas quanto às suas funções e desempenhos.

É preciso também trabalhar na definição de parâmetros médios para as condições da Construção no Brasil, como as taxas de desperdício de materiais, a eficiência em água ou em energia, a porcentagem de material que é reciclado ou reaproveitado, etc. Sem deixar de atualizar esses parâmetros periodicamente e à medida que as cadeias produtivas de materiais e da construção evoluam para uma maior eficiência.

Apesar do manual ILCD ser mais um passo em direção da tangibilidade da aplicação da ACV, é preciso elaborar para o Brasil documentos que guiem a elaboração de $A C V s$ de forma mais precisa e adequada à realidade do país, como as categorias de regra de produto (product categories rules - PCR) usadas durante o período do doutorado no exterior na Inglaterra. 


\section{Referências Bibliográficas}

ABNT. ABNT NBR 10152. Níveis de ruído para conforto acústico. 1987.

ABNT. ABNT NBR 14432. Exigências de resistência ao fogo de elementos construtivos de edificações - Procedimento. 2000.

ABNT. ABNT NBR 15220-3. Desempenho térmico de edificações - Parte 3: Zoneamento bioclimático brasileiro e diretrizes construtivas para habitações unifamiliares de interesse social. 2003.

ABNT. ABNT NBR 15270-1. Componentes cerâmicos Parte 1: Blocos cerâmicos para alvenaria de vedação - Terminologia e requisitos. 2005a.

ABNT. ABNT NBR 15270-2. Componentes cerâmicos Parte 2: Blocos cerâmicos para alvenaria estrutural - Terminologia e requisitos. 2005b.

ABNT. ABNT NBR 15270-3. Componentes cerâmicos Parte 3: Blocos cerâmicos para alvenaria de vedação e estrutural - Métodos de ensaio. 2005c.

ABNT. ABNT NBR 13281:2005. Argamassa para assentamento e revestimento de paredes e tetos - Requisitos. 2005d.

ABNT. NBR ISO 14.040. Gestão Ambiental: Avaliação do Ciclo de Vida Princípios e estrutura. 2009.

ABNT. ABNT NBR 15575-1_2013 Edificações Habitacionais - Desempenho Parte 1: Requisitos gerais. 2013a.

ABNT. ABNT NBR 15575-4_2013 Edificações habitacionais - Desempenho Parte 4: Sistemas de vedações verticais internas e externas - SVVIE. $2013 \mathrm{~b}$.

ABRELPE. Panorama dos Resíduos Sólidos no Brasil 2012: Edição Especial 10 anos. São Paulo: ABRELPE, 2013.

ALMEIDA, M.; DIAS, A. C.; ARROJA, L. M. A Declaração ambiental de produto para materiais de construção. Centro tecnológico de Cerâmica de Vidro. Portugal. 2011.

ANDERSON, J; SHIERS, D; STEELE, K. The Green Guide to Specification. IHS BRE Press: Watford, 2008.

ANDRADE. Pedrisco Limpo. Disponível em: < http://www.andradeareiaepedra. com.br/index.php/pedrisco-limpo>. Acessado em: 17 nov. 2013.

ASSIS, R. L. Traços de argamassa e de Concreto. Instituto Federal Goiano: Goiânia, 2012.

ATHENA SUSTAINABLE MATERIALS INSTITUTE. Building as Products: Issues and Challenges for LCA. International Conference on Life Cycle Assessment: Tools for Sustainability. Arlington, Virginia, 2000. 
AYRES, R. U.; AYRES, L. W. A Handbook of Industrial Ecology. Cheltenham: Edward Elgar Publishing Limited, 2002.

BARBOZA, A. S. R.; BARBIRATO, J. C. C.; SILVA, M. M. C. P. Avaliação do uso de bambu como material alternativo para a execução de habitação de interesse social. In: Ambiente Construído, Porto Alegre, v. 8, n. 1, p. 115-129, 2008.

BARROS, M. M. B.; SABBATINI, F. H.; FRANCO, L. S. Tecnologia de vedações Verticais. 2007. Disponível em: <http://pcc2435.pcc.usp.br/>. Acessado em: 20 jun. 2012.

BAUER, L. A. F. Materiais de Construção. 5. ed. Rio de Janeiro: LTC, 2000.

BAUMIT. Product Data Sheet - Baumit FL 68. Baumit: Bad Hindelang, 2005.

Technisches Merkblatt Stand 03-08/05 - ZiegelPlan ZP 99. Baumit: Bad Hindelang, 2012.

BERBERICH, M. Life Cycle Assessment of Connectors: Accuracy Analysis of a Parameterised Model, SENCE Project 1 2013. Disponível em: https://www.hs-rottenburg.net/zielgruppen/studieninteressierte/studienangebote/ msc-sustainable-energy-competence-sence/. Acessado em: 05 set. 2015.

BLANC, I. Parameterized models \& reduced parameterized models with Global Sensitivity Analysis. In: Doctoral d'Excellence CDE1 - Advanced LCA Methodologies and Tools: Uncertainties \& Impact Assessment, Paris: 2014.

BLUMENSCHEIN, R. N. A Sustentabilidade na Cadeia Produtiva da Indústria da Construção. 2004. 264f. Tese (Doutorado em Política e Gestão Ambiental). Centro de Desenvolvimento Sustentável da Universidade de Brasília. Brasília, 2004.

BRASIL. MINISTÉRIO DE MINAS E ENERGIA. Balanço Energético Nacional. Brasília, 2000.

BRE. BRE Global Methodology for Environmnetal Profiles of Construction Products. BRE: Watford, 2008.

Green Book Live. Disponível em: <http://www.greenbooklive. $\overline{\mathrm{com}} /$ search/companysearch.jsp? sectionid $=0 \&$ partid $=10000 \& \mathrm{id}=217 \&$ company $\mathrm{N}$ ame $=\&$ product $\mathrm{Type}=\&$ productName $=\&$ certNo $=\&$ countryld $=0$. Acessado em: 04 mar. 2012.

BRE Global Product Category Rules for Type III - Environmental product declaration of construction products to EN 15804:2012 + A1:2013. PN 514. BRE Global: Watford, 2014.

BRIBIÁN, I. Z.; USÓN, A. A.; SCARPELLINI, S. Life cycle assessment in buildings: State-of-the-art and simplified LCA methodology as a complement for building certification. Building and Environment, vol. 44, pp. 2510-2520. 2009. 
BRICK DEVELOPMENT ASSOCIATION. Brick: Building a sustainable resource for the future. Disponível em: <http://www.brick.org.uk/sustainability thefacts/>. Acessado em: 16 out. 2014.

BRICK INDUSTRY. Dimensioning and Estimating Brick Masonry. Disponível em: < http://www.gobrick.com/portals/25/docs/technical\%20notes/tn10.pdf> . Acessado: 13 nov. 2014.

BSI. BS EN ISO 14.040. Environmental management - Life cycle assessment Principles and framework. 2006a.

. BS EN ISO 14.044. Environmental management - Life cycle assessment - Requirements and guidelines. 2006b.

BS EN ISO 14.025. Environmental labels and declarations - Type III environmental declarations - Principles and procedures. 2006c.

BS ISO 21930. Sustainability in building construction - Environmental declaration of building products. 2007.

BS EN 15804:2012+A1:2013. Sustainability of construction works Environmental product declarations - Core rules for the product category of construction products. 2014.

BUILDING ECOLOGY. Life Cycle Assessment Software, Tools and Databases. Disponível em: < http://www.buildingecology.com/sustainability/lifecycle-assessment/life-cycle-assessment-software>. Acessado em: 10 jan. 2012.

BUNGE, M. Teoria e realidade. São Paulo: Perspectiva, 1974.

CALDEIRA-PIRES, A.; PAULA, M. C. S.; VILLAS-BOAS, R. C. Avaliação de Ciclo de Vida: A ISO 14.040 na América Latina. Brasília: ABIPTI, 2005.

CALDEIRA-PIRES, A. Introdução a Ecologia Industrial. 27 abr. 2011. Notas de aula.

CAMPIOLLI, A.; LAVAGNA, M. Misurare la sostenibilità: il laterizio. In: Costruire in Laterizio, 143, p. 65-71, 2011.

CARASEK, H. Argamassas. In: ISAIA, G. C. (Org.). Materiais de Construção Civil e Princípios de Ciência e Engenharia de Materiais. V. 2. São Paulo: Ibracon, 2010. p. 863-904

CARDOSO, F.; SABBATINI, F.; FRANCO, L. S.; BARROS, M. M. Vedações Verticais: Conceitos Básicos. Disponível em: http://pcc2435.pcc.usp.br/ Aulas\%20em\%20pdf-2006-2007/4-\%20Veda\%C3\%A7\%C3\%B5es\%20 Verticais/aula \%2018\%20veda\%C3\%A7\%C3\%B5es-v1.pdf. Acessado em: 24 nov. 2012.

CARVALHO, J. Análise de Ciclo de Vida Ambiental aplicada à Construção Civil - Estudo de caso: Comparação entre cimento Portland com adição de resíduos. Dissertação (Mestrado em Engenharia Civil). Curso de Engenharia Civil, Universidade de São Paulo. 2002. 
CAVAlCANTI, E. Programa Brasileiro de Avaliação do Ciclo de Vida. Workshop Mercosul. Brasília, 2009. Disponível em: <http://www.mdic.gov.br/ arquivos/dwnl_1283451608.pdf>. Acessado em: 20 fev. 2012.

CBCS. Plataforma Global de Avaliação do Ciclo de Vida Simplificada para a Construção Sustentável. Disponível em: http://www.cbcs.org.br/ userfiles/download/CBCS_Rio+20_PlataformaGlobaldeACVsparaConstrucaoSustent avel.pdf?. Acessado em: 01 mai. 2012.

CBIC. Desenvolvimento com Sustentabilidade: Construção Sustentável. Disponível em: < http://www.cbic.org.br/sites/default/files/ProgramaConstrucao-Sustentavel.pdf>. Acessado em: 28 set. 2011 (a).

. Informativo Econômico: Construção civil desempenho e perspectivas. Brasília, 2011(b).

Desempenho de edificações habitacionais: Guia orientativo para atendimento à norma ABNT NBR 15575/2013. Câmara Brasileira da Indústria da Construção: Fortaleza, 2013.

. Banco de dados. Disponível em: < http://www.cbicdados.com.br/home/>. Acessado em: 12 mar. 2015.

CONMETRO. Resolução no 4, de 15 de dezembro de 2010. Dispões sobre a aprovação do Programa Brasileiro de Avaliação do Ciclo de Vida e dá outras providências. Diário Oficial da União, ano CXLVIII, № 2, Seção 1, Brasília.

DEPARTMENT FOR COMMUNITIES AND LOCAL GOVERNMENT. Code for Sustainable Homes: A step-change in sustainable home building practice. London: Communities and Local Government Publications, 2006.

EDWARDS, B. O Guia Básico para a Sustentabilidade. Barcelona: GG, 2005.

EGAS, L. Análise pluridimensional da sustentabilidade do ciclo de vida de um sistema estrutural de cobertura em madeira de pinus. Caso assentamento rural Pirituba II. Dissertação de mestrado. Escola de Engenharia de São Carlos, Universidade de São Paulo, São Carlos, 2008.

FERREIRA, C. M. Combustíveis industriais. In: IBP - Instituto Brasileiro de Petróleo. Apostilas do Curso de Informação sobre Combustíveis e Combustão. Rio de Janeiro: IBP, 1977.

FERREIRA, J. V. R. Gestão Ambiental: Análise do Ciclo de Vida dos Produtos. Instituto Politécnico de Viseu, 2004.

FOUREZ, G. A. A construção das ciências: introdução a filosofia e à ética das ciências. São Paulo: Unesp, 1998.

FREITAS JR, J. A. Materiais de Construção III: Impacto Ambiental dos Materiais de Construção e emissão de $\mathrm{CO}_{2}$. Notas de Aula. 2011.

FURTADO, L. M. S.; MILLER, K. B.; DUARTE, M. V. F. Desempenho ambiental de argamassas para assentamento de blocos cerâmicos em paredes 
de alvenaria. In: IV Congresso Brasileiro sobre Gestão pelo Ciclo de Vida. São Bernardo do Campo: 2014.

GABI. Coordenação da PE International. Desenvolvido PE International. Disponível em: < http://www.gabi-software.com/>. Version 6. 2014.

GARCIA, D. B, RODRIGUES, F. C, AGUILAR, M. T. P. Avaliação de ciclo de vida de um elemento estrutural pilar em Aço x Pilar em concreto armado. 2o Congresso Brasileiro em Gestão de Ciclo de Vida de produtos e Serviços. Florianópolis, 2010. Disponível em: < http://www.ciclodevida.ufsc.br/ congresso/images/acv-2010.pdf>. Acesso: 17 de mai. 2011.

GOLEMAN, D. Inteligência Ecológica: $O$ impacto do que consumimos e as mudanças que podem melhorar o planeta. Tradução de Ana Beatriz Rodrigues. Rio de Janeiro: Elsevier, 2009. Título original: Ecological Intelligencce. 245 p.

GOVERNO ALEMÃO. Okobau.dat: Informationsportal Nachhaltiges Bauen. Disponível em: <http://www.nachhaltigesbauen.de/oekobaudat/. Acessado em: 20 jun. 2012.

GRIGOLETTI, G. C. Caracterização de impactos ambientais de Indústrias de Cerâmica Vermelha do Estado do Rio Grande do Sul. 2001. 168 f. Dissertação (Mestrado em Engenharia Civil). Escola de Engenharia, Universidade Federal do Rio Grande do Sul. 2001.

$\mathrm{HACHICH}$, V. F. Desafios de Seleção de materiais e fornecedores. 2009. Disponível em: < http://www.cbcs.org.br/sushi/images/see_pdf/Vera\%20 Hachihe\%20Sem.\%20CBCS-CDHU\%2005-11-09.pdf>. Acessado em: 30 abr. 2012.

HECK, T.; BAUER, C.; DONES, R. Technical paper $n^{\circ} 4.1$ - RS la "Development of parameterisation methods to derive transferable life cycle inventories": Technical guideline on parameterisation of life cycle inventory data. 2009. Disponível em: <http://www.openlca.org/documentation/index.php/Adv anced_functions>. Acessado em: 06 set. 2015.

HENDRIKS, C. F; PIETERSEN, H. S. Report 22: Sustainable raw materials :onstruction and demolition waste. RILEM Publications, 2000.

HM GOVERNMENT. The Building Regulations 2010: Resistance to the passage of sound E. 2010(a). 2010(b).

The Building Regulations 2010: Conversation of fuel and power L1A.

IBGE. Em 2011, PIB cresce 2,7\% e totaliza R \$ 4,143 trilhões. Disponível em: http://www.ibge.gov.br/home/presidencia/noticias/noticia_visualiza.php?id noticia=2093. Acessado em: 14 jun. 2012.

Indicadores IBGE: Pesquisa mensal de emprego - Janeiro 2015. IBGE: Rio de Janeiro, 2015. 
JOHN, V. M. Reciclagem de Resíduos na Construção Civil: contribuição para metodologia de pesquisa e desenvolvimento. 2000. $113 \mathrm{f}$. Tese (Livre Docência) - Escola Politécnica, Universidade de São Paulo, São Paulo, 2000.

. Quase insustentável [set. 2010]. São Paulo: Revista Téchne. Entrevista concedida a Luciana Tamaki. 2010.

JOHN, V. M.; OLIVEIRA, D. P.; AGOPYAN, V. Critérios de sustentabilidade para seleção de materiais e componentes: uma perspectiva de sustentabilidade para países em desenvolvimento. Journal of Building Environment, 2006.

JOHN, V. M.; OLIVEIRA, D. P.; LIMA, J. A. R. Levantamento do Estado da arte: Seleção de materiais. FINEP: São Paulo, 2007.

JOHN, V. M. PRADO, R. T. A. Selo Casa Azul: Boas práticas para habitação mais sustentável. São Paulo: Páginas \& Letras - Editora e Gráfica, 2010.

JRC. Institute for Environmental and Sustainability (ILCD) Handbook. Publications Office of the European Union: Luxemburgo, 2010.

KEELER, M. BURKE, B. Fundamentos de projetos de Edificações Sustentáveis. Porto Alegre: Bookman, 2010.

KEOLEIAN, G.A.; MENEREY, D. Sustainable development by design: Review of life cycle design and related approaches. In: Air and Waste, 44, 645-668, 1994.

LINKED IN. Life Cycle Assessment. Disponível em: <http://www.linkedin. com/groupltem?view=\&gid=1686017\&type=member\&item $=66671554 \&$ commen $\mathrm{tID}=-1$ \&qid=15cf404d-b776-4a5f-a69d-1fe2b126d89d\&goback=\%2Egmp_16 86017\#lastComment>. Acessado em: 10 jan. 2012.

LIME TECHNOLOGY. Baumit RK 38 Lime Plaster. Lime technology: Abingdon, 2011.

MANFREDINI, C. Impactos Ambientais causados pela Indústria de Cerâmica Vermelha no Rio Grande do Sul. 2003. Dissertação (Mestrado em Engenharia Civil). Escola de Engenharia, Universidade Federal do Rio Grande do Sul, Santa Catarina. 2003.

MANFREDINI, C. SATTLER, M. A. Estimativa da energia incorporada a materiais de cerâmica vermelha no Rio Grande do Sul. Ambiente Construído, Porto Alegre, v.5, n.1, p. 23-37, jan./mar. 2005.

MASTELLA. D. V. Comparação entre os processos de produção de Blocos Cerâmicos e de Concreto para alvenaria estrutural, através da Análise do Ciclo de Vida. 2002. 107 f. Dissertação (Mestrado em Engenharia Civil). Curso de Engenharia Civil, Universidade de Santa Catarina, Florianópolis. 2002.

MDIC. Fórum de Competitividade: diálogo para o desenvolvimento. Relatório de resultados: cadeia produtiva da indústria da construção. 2002. 29p. Brasília.

MENDES, H.; CARVALHO, K. M. B.; BORGES, T. E. Tijolos e Alvenaria: no âmbito da Construção Civil. Faculdade de Tecnologia e Ciência: Itabuna, 2012. 
MILLER. K.B.; BLUMENSCHEIN, R. N.; CALDEIRA-PIRES, A. A.; FONSECA JÚNIOR, J. M. M. Comparison between European EPD issuing Systems and lessons learned to Latin American Countries. In: Cilca 2013. Mendonza. 2013a.

MILLER. K.B.; BLUMENSCHEIN, R. N.; CALDEIRA-PIRES, A. A.; TOMÉ, M. V. F. D. The State of art the LCA in PCCI. In: Vth International Conference on Life Cycle Assessment, CILCA 2013. Mendoza: Facultad Regional Mendoza, Universidad Tecnológica Nacional, $2013 \mathrm{~b}$.

MTE. Nível de Emprego Formal Celetista: Cadastro Geral de Empregados e Desempregados (CAGED) - Resultado de Junho de 2014 e do Primeiro Semestre 2014. Disponível em: http://portal.mte.gov.br/data/files/FF80808 147277624014745BBC673365F/CAGED\%20Apresenta\%C3\%A7\%C3\%A30\%2 0junho_2014.pdf. Acessado em: 12. mar. 2015.

MUELLER, K. G.; LAMPÉRTH, M. U.; KIMURA, F. Parameterised Inventories for Life Cycle Assessment: Systematically Relating Design Parameters to the Life Cycle Inventory. In: Life Cycle Assessment Journal, 9, 227-235, 2004.

MUELLER, K. G.; BESANT, C. Streamlining life cycle analysis: A method. In: Proceedings of EcoDesign '99, pp. 114-121, 1999.

NBT. Thermoplan Masonry System ZV09. NBT publication, 2013.

OLIVEIRA, A. S. Análise Ambiental da Viabilidade de Seleção de produtos da Construção Civil através da ACV e do Software Bees 3.0. Dissertação (Mestrado em Engenharia). 2007. Curso de Engenharia Civil, Universidade Federal do Rio Grande do Sul. 2007.

ONU. A ONU e o desenvolvimento. Disponível em: < http://unic.un.org/ imu$\mathrm{cms} /$ rio-de-janeiro/64/38/a-onu-e-o-desenvolvimento. aspx>. Acessado em: 14 jun. 2012.

em:

Population, Development and the Environment 2013. Disponível

http://www.un.org/en/development/desa/population/publications/pdf/develop ment/pde_wallchart_2013.pdf>. Acesso em: 08 jan. 2014.

PARLIAMENTARY OFFICE OF SCIENCE AND TECHNOLOGY. Post Note: carbon footprint of electricity generation. 2006. Disponível em: http://www.parliament.uk/post. Acessado em: 25 abr. 2012.

PE-INTERNATIONAL. Handbook for Life Cycle Assessment (LCA): Using The GaBi Education Software Package. Leinfelden-Echterdingen, 2009.

Parameters. GaBi Education, Stuttgart: 2014. 1 video (7 min), disponível na internet, son., color.

PEREIRA, S. W. Análise ambiental do processo produtivo de pisos cerâmicos. Aplicação de avaliação de ciclo de vida. Dissertação de Mestrado. Universidade de Santa Catarina, Florianópolis, 2004. 
PEREIRA, J. C. D.; STURION, J. A.; HIGA, A. R.; HIGA, R. C. V.; SHIMIZU, J. $Y$. Características da madeira de algumas espécies de eucalipto plantadas no Brasil. Colombo: Embrapa Florestas, 2000.

PIGOSSO, D. C. A.; GUELERE FILHO, A.; ROZENFELD, H. Melhoria do Desempenho Ambiental de Produtos através da Integração de Métodos do Ecodesign ao Processo de Desenvolvimento Produtos. In: 1st International Workshop Advances in Cleaner Production, 2007, São Paulo. 1st International Workshop Advances in Cleaner Production, 2007.

PINI. Alternativas Tecnológicas para Edificação. Volume 1. São Paulo: PINI, 2008a.

Tabelas de Composições de Preços para Orçamentos. 13. ed. São Paulo: PINI, 2008b.

PRINCE'S FOUNDATION. The Natural House. Prince's Foundation for the Building Environmental: Londres, 2010.

The Prince's Natural House. Prince's Foundation for the Building Environmental: Londres, 2012.

REDENERGIA. Apresenta informações sobre poderes caloríficos de insumos energéticos. Disponível em: < http://www.redenergia.com.br/>. Acesso em: 5 dez. 2013.

SABBATINI, F. H.; FRANCO, L. S.; BARROS, M. M. B. Visão Sistêmica e conceito de desempenho. 2005. Disponível em: <http://pcc5303.pcc.usp.br/ Aulas/aula3\%20-\%202005\%20-v2.PDF>. Acessado em: 20 jun. 2012a.

SABBATINI, F. H.; FRANCO, L. S.; BARROS, M. M. B; ARAÚJO, L. O. C. Vedações verticais internas com painéis de gesso acartonado. 2005. Disponível em: <http://pcc2435.pcc.usp.br/>. Acessado em: 30 jun. 2012b.

SERRA, G. G.; Pesquisa em Arquitetura e Urbanismo. São Paulo: Mandarim, 2006.

SILVA, V. G. SILVA, M. G. AGOPYAN, V. Avaliação de Edifícios no Brasil: da avaliação ambiental para a avaliação da sustentabilidade. Ambiente Construído, Porto Alegre, v. 3, n. 3, p. 7-18, jul./set. 2003.

SILVEIRA, E. J. T. Balanço Energético Consolidado do Estado do Rio Grande do Sul 1999-2000. Porto Alegre: Secretaria de Energia, Minas e Comunicações, 2002.

SIMETRIC. Density Meters. Disponível em: < http://www.simetric.co.uk/ si_materials.htm >. Acessado em: 06 dez. 2014.

SINDUSCON-SP. Construção Civil: Desempenho em 2011 e perspectivas para 2012. 2011. Disponível em: < http://www.sindusconsp.com.br/downloads/ imprensa/2011/ coletiva.pdf>. Acessado em: 14 jun. 2012. 
SOARES, S. R.; PEREIRA, S. W.; BREITENBACH, F. E. Análise do Ciclo de Vida de Produtos Cerâmicos da Indústria de Construção Civil. XXVIII Congreso Interamericano de Ingeniería Sanitaria y Ambiental, Cancún, 2002.

SOARES, S. R.; PEREIRA, S. W. Inventário da produção de pisos e tijolos cerâmicos no contexto da análise do ciclo de vida. Ambiente Construído, Porto Alegre, v. 4, n. 2, p. 83-94, abr./jun. 2004.

TECMIX. Tecmix TMX Pro 1250 Hand-Held 1600W Mixer Drill 230V. Disponível em: < http://www.screwfix.com/p/tecmix-tmx-pro-1250-hand-held$1600 \mathrm{w}$-mixer-drill-230v/18173?kpid=18173\&cm_mmc=Google-_-Product\%20

Listing\%20Ads-_-Sales\%20Tracking-_-sales\% 20tracking\%20 url\&kpid $=18173 \& \mathrm{~cm} \_\mathrm{mmc}=$ Google-_-Shopping\%20-\%20Power\%20Tools-_-Shopping \%20-\%20Power\% 20Tools\&gclid=CjwKEAjw8O 2hBRDKur2lse LW6C8SJACr1J3U-3-cUth7gug-LVEyq-rfelcfTirjiV2vmEQV8X0OhoCJPnw_wcB\#product _additional_details_container>. Acessado em: 07 dez, 2014.

TORGAL, F. P.; JALALI, S. A Sustentabilidade dos materiais da construção. 1.ed. Portugal: TecMinho, 2010.

UNEP. Buildings and Climate Change. Status, Challenges and Opportunities. Paris: United Nations Environment Programme, 2007.

UNITED KINGDOM. Building and buildings, England and Wales - The Building Regulations 2010. 2010.

VIANNA, J. N. Energia e Desenvolvimento Sustentável. Notas de aula. Universidade de Brasília: Brasília, 2011.

VIGON, B. W. et al. Life Cycle Assessment: Inventory Guidelines and Principles. Cincinnati: U. S. Government Printing Office, 1995.

WIEBERNERGER. Porotherm: Wall solutions. Weibernerger. Birmingham: 2014.

ZANINI, L. F. P. Potencial mineral para não metálicos da Região Metropolitana de Porto Alegre, RS. Porto Alegre: CPRM/METROPLAN, 1998. 
Anexos 


\section{Anexo 1: Zoneamento Bioclimático Brasileiro}

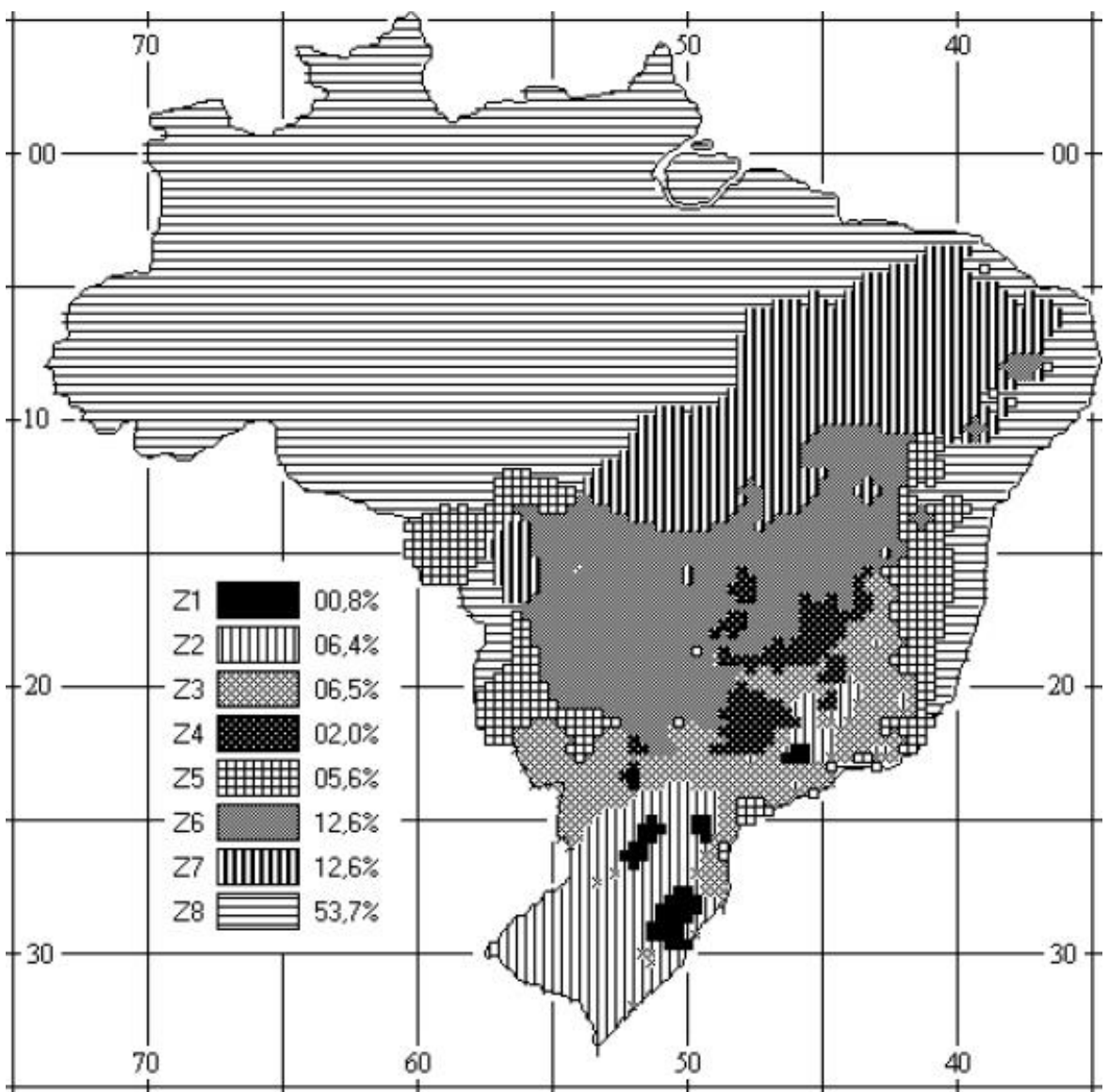

Fonte: ABNT (2003). 
Anexo 2: Regiões brasileiras para efeito de estanqueidade à água

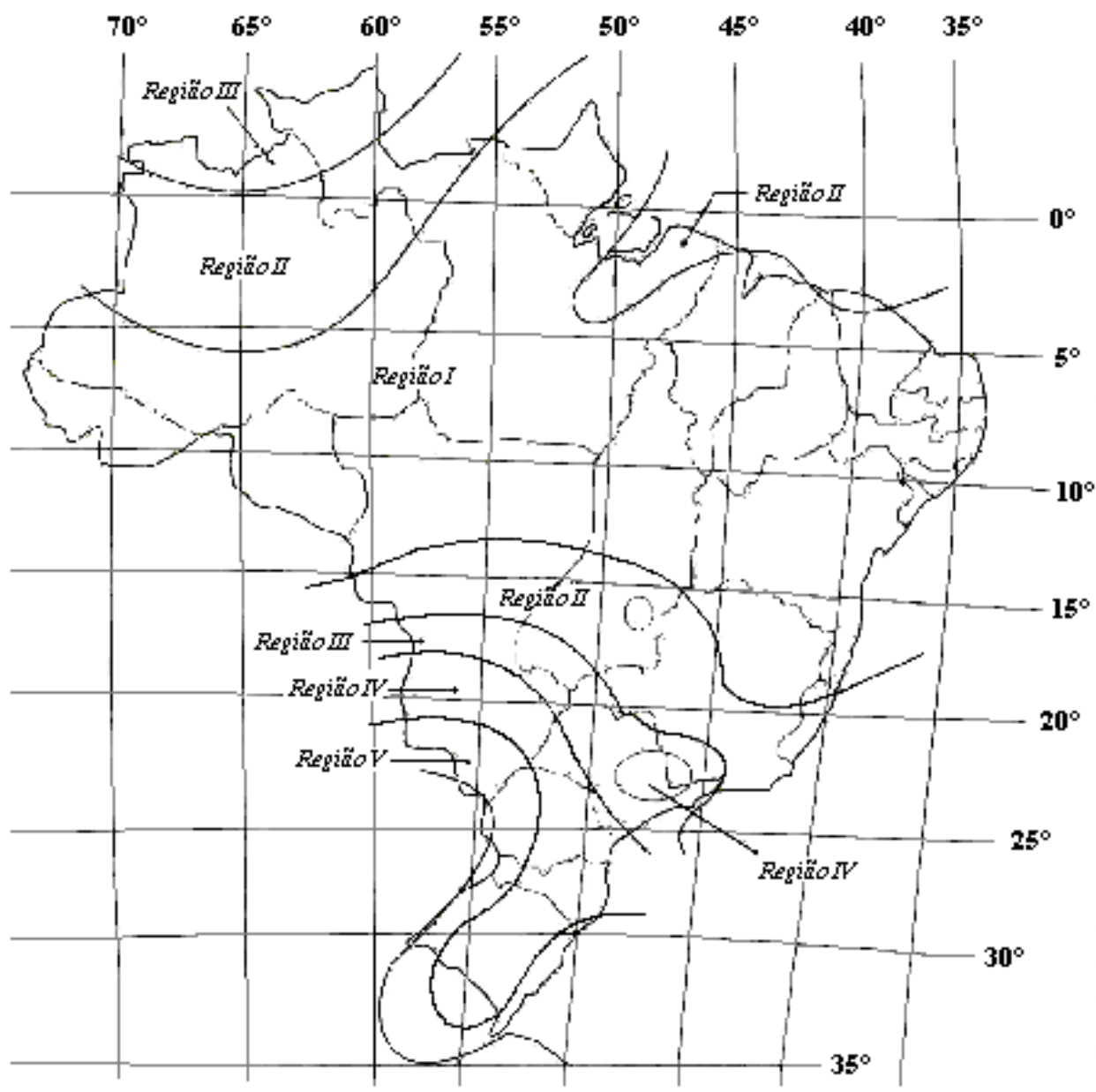

Fonte: ABNT (2013b). 


\section{Apêndices}




\section{Apêndice A: Levantamento de metodologias, bancos de dados e softwares de ACV usados na Construção no mundo ${ }^{31}$}

\begin{tabular}{|c|c|c|c|c|c|}
\hline $\begin{array}{l}\text { Programa/ Banco de da- } \\
\text { dos }\end{array}$ & $\begin{array}{l}\text { Local/Instituição } \\
\text { responsável }\end{array}$ & O que é? & $\begin{array}{l}\text { Vantagens/ desvan- } \\
\text { tagens }\end{array}$ & $\begin{array}{l}\text { Número de } \\
\text { indicações }\end{array}$ & Site \\
\hline $\begin{array}{l}\text { TRACI/Database and } \\
\text { software }\end{array}$ & USA/EPA Software & $\begin{array}{l}\text { TRACI permite examinar os impactos potenciais associados com o } \\
\text { uso de matérias-primas e emissões químicas resultantes dos pro- } \\
\text { cessos produtivos de um produto. } \\
\text { Considera os indicadores: Depleção do ozônio, mudança climática, } \\
\text { acidificação, substâncias cancerígenas e não cancerígenas, eutrofi- } \\
\text { zação, formação de smog, ecotoxidade uso de combustíveis fósseis } \\
\text { e uso da terra e água. }\end{array}$ & $\begin{array}{l}\text { Não é uma metodo- } \\
\text { logia que vem em- } \\
\text { butida no software } \\
\text { GaBi. }\end{array}$ & 1 & $\begin{array}{l}\text { http://www.ep } \\
\text { a.gov/nrmrl/st } \\
\text { d/sab/traci/ }\end{array}$ \\
\hline $\begin{array}{l}\text { APME/ Database } \\
\text { The Association of } \\
\text { Plastics Manufacturers } \\
\text { in Europe }\end{array}$ & UE & $\begin{array}{l}\text { APME publica dados anuais sobre o consume e recuperação de } \\
\text { plásticos usados no setor de embalagens, construção, setor auto- } \\
\text { motive, elétrico e eletrônico. }\end{array}$ & Não identificado. & 2 & $\begin{array}{l}\text { http://www.pla } \\
\text { sticseurope.or } \\
\text { g/plastics- } \\
\text { sustainabil- } \\
\text { ity/life-cycle- } \\
\text { thinking.aspx }\end{array}$ \\
\hline $\begin{array}{l}\text { The Environmental Im- } \\
\text { pact Estimator/ Soft- } \\
\text { ware }\end{array}$ & $\begin{array}{l}\text { ATHENA Sustaina- } \\
\text { ble Materials Institu- } \\
\text { te }\end{array}$ & $\begin{array}{l}\text { The Estimator permite avaliar implicações ambientais de designs } \\
\text { industriais, institucionais, de escritórios e residenciais. Quando é } \\
\text { relevante também permite distinguir entre unidades ocupadas pelo } \\
\text { dono e por aluguel. The Estimator coloca o meio ambiente em pé } \\
\text { de igualdade com outros critérios mais tradicionais de design duran- } \\
\text { te a fase conceitual da construção, incorpora os bancos de dados } \\
\text { do inventário do ciclo de vida do instituto, cobrindo mais de } 90 \text { ma- } \\
\text { teriais estruturais e de envoltório e } 1000 \text { diferentes combinações de } \\
\text { uso. Os indicadores considerados: consume de combustíveis fós- } \\
\text { seis, potencial de aquecimento global, potencial de acidificação, po- } \\
\text { tencial de efeitos sobre a saúde respiratória humana, potencial de } \\
\text { depleção do ozônio, potencial de formação de smog, potencial de } \\
\text { eutrofização e uso de recurso natural. }\end{array}$ & $\begin{array}{l}\text { Possui versão de } \\
\text { teste } \\
\text { Versão atualizada } \\
\text { em } 2011\end{array}$ & 5 & $\begin{array}{l}\text { http://www.at } \\
\text { he- } \\
\text { nasmi.org/tool } \\
\text { s/impactEstim } \\
\text { ator/pressRel } \\
\text { ease_201109 } \\
\text {.html }\end{array}$ \\
\hline BEES 3.0/Software & $\begin{array}{l}\text { National Institute for } \\
\text { Standards and } \\
\text { Technology (NIST) } \\
\text { Building and Fire }\end{array}$ & $\begin{array}{l}\text { O software BEES (Building for Environmental and Economic Sus- } \\
\text { tainability) pode ser usado para equilibrar os desempenhos ambien- } \\
\text { tal e econômico de produtos da construção. A versão } 3.0 \text {, com pú- } \\
\text { blico alvo de designers, construtores e produtores industriais, inclui }\end{array}$ & $\begin{array}{l}\text { Gratuito } \\
\text { Funciona online }\end{array}$ & 5 & $\begin{array}{l}\text { http://www.nis } \\
\text { t.gov/el/econo } \\
\text { mics/BEESSo } \\
\text { ftware.cfm }\end{array}$ \\
\hline
\end{tabular}

${ }^{31}$ Dados coletados nas fontes Linked in, Building Ecology e U.S. Environmental Protection Agency. 


\begin{tabular}{|c|c|c|c|c|c|}
\hline & $\begin{array}{l}\text { Research Laborato- } \\
\text { ry }\end{array}$ & $\begin{array}{l}\text { dados atualizados de desempenho ambiental e econômico de } 65 \\
\text { produtos. }\end{array}$ & & & \\
\hline $\begin{array}{l}\text { The Boustead Model } \\
5.0 / \text { Software }\end{array}$ & $\begin{array}{l}\text { Boustead Consult- } \\
\text { ing } \\
\text { (Reino Unido) }\end{array}$ & $\begin{array}{l}\text { O Boustead Model é um banco de dados extensivo, no qual dados } \\
\text { como combustíveis e uso energético, requisitos de matéria prima, } \\
\text { emissões sólidas, líquidas e gasosas são armazenados. Também } \\
\text { inclui software que permite ao usuário manipular dados no banco e } \\
\text { selecionar um método de apresentação adequada dos dados de } \\
\text { uma gama de opções. Considera os indicadores: produção de com- } \\
\text { bustível, processamento de materiais, emissões para o ar e água, } \\
\text { resíduos sólidos, matérias-primas, combustíveis e funções. }\end{array}$ & $\begin{array}{l}\text { Disponível em ver- } \\
\text { são } 5.0 \text { em agosto } \\
\text { de } 2011 \\
\text { Download via CD }\end{array}$ & 2 & \\
\hline CMLCA/Software & $\begin{array}{l}\text { Centre of Environ- } \\
\text { mental Science } \\
(\mathrm{CML}) \text { - Leiden Uni- } \\
\text { versity }\end{array}$ & $\begin{array}{l}\text { Chain Management by Life Cycle Assessment (CMLCA) é uma fer- } \\
\text { ramenta de software cujo propósito é auxiliar as etapas técnicas do } \\
\text { procedimento de Avaliação do Ciclo de Vida. O modo avançado é } \\
\text { híbrido entre LCA, LCC e análise de eco-eficiência. } \\
\text { Não possui suporte ao usuário, dados (precisam ser comprados ou } \\
\text { baixados) e nem interface gráfica para construir fluxos e diagramas. }\end{array}$ & $\begin{array}{l}\text { Livre, não precisa } \\
\text { ser instalado, flexí- } \\
\text { vel, compatível com } \\
\text { a ISO } 14.040 \text {, além } \\
\text { de ser adequado } \\
\text { para uso em sala } \\
\text { de aula e por cien- } \\
\text { tistas. }\end{array}$ & 2 & $\begin{array}{l}\text { http://www.cm } \\
\text { lca.eu/ }\end{array}$ \\
\hline $\begin{array}{l}\text { Eco-Indicator 99/ Data- } \\
\text { base }\end{array}$ & PRé Consultants & $\begin{array}{l}\text { O Eco-Indicator } 99 \text { é um método de avaliação de impacto "orientado } \\
\text { a danos" com etapas claramente detalhadas como análise de fatali- } \\
\text { dade, exposição, efeito e dano. Considera as categorias: danos à } \\
\text { saúde humana, à qualidade dos ecossistemas e recursos naturais. }\end{array}$ & Não identificado. & 2 & $\begin{array}{l}\text { http://www.pr } \\
\text { e.nl/content/e } \\
\text { co-indicator- } \\
99 /\end{array}$ \\
\hline $\begin{array}{l}\text { The ecoinvent Cen- } \\
\text { tre/database }\end{array}$ & Suíça & $\begin{array}{l}\text { O Centro Suíço para Inventários de Ciclo de Vida, o banco de da- } \\
\text { dos central de Inventário de Ciclo de Vida dados dos métodos de } \\
\text { Análise de Impacto do Ciclo de Vida. }\end{array}$ & Não identificado. & 3 & $\begin{array}{l}\text { http://www.ec } \\
\text { oinvent.com/ }\end{array}$ \\
\hline ECO-it 1.3/software & PRé Consultants & $\begin{array}{l}\text { ECO-it vem com mais de } 200 \text { avaliações do eco-indicator } 99 \text { de ma- } \\
\text { teriais comumente utilizados como metais, plásticos, papel e vidro, } \\
\text { bem como os processos de produção, transporte, energia e trata- } \\
\text { mento de resíduos. Calcula o custo ambiental de um produto e exi- } \\
\text { be que partes do produto mais contribuem para esse impacto. }\end{array}$ & $\begin{array}{l}\text { Possui versão de } \\
\text { demonstração. }\end{array}$ & 2 & $\begin{array}{l}\text { http://www.ep } \\
\text { a.gov }\end{array}$ \\
\hline EcoScan 3.0 & $\begin{array}{l}\text { TNO Industrial } \\
\text { Technology }\end{array}$ & $\begin{array}{l}\text { O Ecoscan } 3.0 \text { analisa o custo e os impactos ambientais de produ- } \\
\text { tos. A ferramenta de software pode ser utilizada por gerentes e en- } \\
\text { genheiros que implementam EcoDesign no desenvolvimento de } \\
\text { produtos. }\end{array}$ & $\begin{array}{l}\text { Possui versão de } \\
\text { demonstração, en- } \\
\text { tretanto o site não } \\
\text { funciona. }\end{array}$ & 2 & $\begin{array}{l}\text { http://www.ind } \\
\text {.tno.nl/en/pro } \\
\text { duct/ecoscan/ }\end{array}$ \\
\hline $\begin{array}{l}\text { Economic Input-Output } \\
\text { Life Cycle Assessment }\end{array}$ & $\begin{array}{l}\text { Green Design Initia- } \\
\text { tive of Carnegie } \\
\text { Mellon }\end{array}$ & $\begin{array}{l}\text { Permite estimar impactos ambientais da produção de uma quanti- } \\
\text { dade em dólares de uma commodity ou serviço qualquer nos EUA } \\
\text { de uma lista de } 500 \text {. Fornece uma orientaça aproximada nos im- } \\
\text { pactos relativos de diferentes tipos de produtos, materiais, serviços }\end{array}$ & Funciona online. & 2 & $\begin{array}{l}\text { http://www.eio } \\
\text { lca.net/ }\end{array}$ \\
\hline
\end{tabular}




\begin{tabular}{|c|c|c|c|c|c|}
\hline & & ou indústrias em relação ao uso de recursos e emissões. & & & \\
\hline EDIP PC-tool & Danish EPA & $\begin{array}{l}\text { A ferramenta EDIP PC possui banco de dados que suporta o pro- } \\
\text { cesso de ACV de acordo com o método EDIP. Para executar uma } \\
\text { ACV, informações detalhadas sobre todos os processos e materiais } \\
\text { incluídos no ciclo de vida do produto são necessárias. A ferramenta } \\
\text { foi equipada com um bando de dados relacional. }\end{array}$ & $\begin{array}{l}\text { Sem sucesso para } \\
\text { download. }\end{array}$ & 1 & $\begin{array}{l}\text { http://www.ms } \\
\text { t.dk/English/ }\end{array}$ \\
\hline $\begin{array}{l}\text { EPS } 2000 \text { Design Sys- } \\
\text { tem/software }\end{array}$ & $\begin{array}{l}\text { Assess Ecostrategy } \\
\text { Scandinavia } A B\end{array}$ & $\begin{array}{l}\text { EPS (Environmental Priority Strategies) é um software de análise de } \\
\text { impacto do ciclo de vida para desenvolvimento de produtos susten- } \\
\text { táveis. }\end{array}$ & $\begin{array}{l}\text { Possui versão de } \\
\text { demonstração. }\end{array}$ & 2 & $\begin{array}{l}\text { http://www.as } \\
\text { sess.se/ }\end{array}$ \\
\hline $\begin{array}{l}\text { GaBi } 4 \text { Software Sys- } \\
\text { tem and Databases } \\
\text { GaBi Build-it }\end{array}$ & $\begin{array}{l}\text { PE Europe GmbH } \\
\text { and IKP University } \\
\text { of Stuttgart }\end{array}$ & $\begin{array}{l}\text { Diferentes versões estão disponíveis, desde educacionais a profis- } \\
\text { sionais, para uso da ACV para avaliar o desempenho ambiental, } \\
\text { econômico e social de produtos, processos e tecnologias. Contem } \\
\text { bancos de dados abrangentes do GaBi com cobertura de dados } \\
\text { mundial, bem como dados do Ecoinvent. }\end{array}$ & $\begin{array}{l}\text { Versão demo com } 1 \\
\text { ano de licença }\end{array}$ & 5 & $\begin{array}{l}\text { www.gabi- } \\
\text { software.com }\end{array}$ \\
\hline $\begin{array}{l}\text { GEMIS (Global Emis- } \\
\text { sion Model for Inte- } \\
\text { grated Systems) }\end{array}$ & Öko-Institut & $\begin{array}{l}\text { GEMIS é um programa de ACV e um banco de dados para siste- } \\
\text { mas de transporte, de energia e materiais. O banco de dados GE- } \\
\text { MIS oferece informação sobre combustíveis fósseis, renováveis, } \\
\text { processos para geração de energia elétrica e calor, matérias-primas } \\
\text { e transportes. }\end{array}$ & Gratuito. & 2 & $\begin{array}{l}\text { http://www.oe } \\
\text { ko.de/service/ } \\
\text { gemis/en/inde } \\
\text { x.htm }\end{array}$ \\
\hline GREET Model/software & $\begin{array}{l}\text { U.S. Department of } \\
\text { Energy's Office of } \\
\text { Transportation } \\
\text { Technologies }\end{array}$ & $\begin{array}{l}\text { Permite a pesquisadores avaliar várias combinações de motores e } \\
\text { combustíveis numa base consistente de ciclo de combustíveis. }\end{array}$ & $\begin{array}{l}\text { Gratuito. } \\
\text { Calcula apenas de } \\
\text { transporte. }\end{array}$ & 2 & $\begin{array}{l}\text { http://greet.es } \\
\text {.anl.gov/main }\end{array}$ \\
\hline $\begin{array}{l}\text { IDEMAT } \\
\text { 2005aq/software }\end{array}$ & $\begin{array}{l}\text { Delft University of } \\
\text { Technology }\end{array}$ & $\begin{array}{l}\text { IDEMAT é uma ferramenta para seleções de materiais no processo } \\
\text { de design. Fornece um banco de dados com informações técnicas } \\
\text { sobre materiais processos e componentes e permite que o usuário } \\
\text { compare as informações. }\end{array}$ & $\begin{array}{l}\text { Possui versão de } \\
\text { demonstração. }\end{array}$ & 2 & \\
\hline $\begin{array}{l}\text { IVAM LCA Data } \\
\text { 4.0/database }\end{array}$ & IVAM & $\begin{array}{l}\text { Consiste de cerca de } 1000 \text { processos, que levam a cerca de } 300 \\
\text { materiais. Os dados podem ser usados para aplicações de ACV em } \\
\text { vários setores. }\end{array}$ & & 3 & $\begin{array}{l}\text { http://www.iva } \\
\text { m.uva.nl }\end{array}$ \\
\hline Ecoquantum/software & IVAM & $\begin{array}{l}\text { O desempenho ambiental de uma construção é determinado por } \\
\text { vários fatores, como o consumo de água, energia e matérias- } \\
\text { primas, climatização e localização da construção. Com o programa } \\
\text { EcoQuantum (baseado em cálculos de ACV), o desempenho ambi- } \\
\text { ental de uma construção pode ser expresso em um ou mais núme- } \\
\text { ros. }\end{array}$ & Para construções. & 2 & $\begin{array}{l}\text { http://www.iva } \\
\text { m.uva.nl/inde } \\
\text { x.php?id=pro } \\
\text { ducten_en_di } \\
\text { en- } \\
\text { sten\&L=1\#c1 } \\
874\end{array}$ \\
\hline
\end{tabular}




\begin{tabular}{|c|c|c|c|c|c|}
\hline KCL-ECO 4.0/software & $\mathrm{KCL}$ & $\begin{array}{l}\text { Inclui funcionalidades de alocação, análise de impacto (caracteriza- } \\
\text { ção, normalização e distribuição ponderada) e produção de gráfi- } \\
\text { cos. }\end{array}$ & $\begin{array}{l}\text { Possui versão de } \\
\text { demonstração, en- } \\
\text { tretanto a página } \\
\text { não carrega. }\end{array}$ & 1 & $\begin{array}{l}\text { http://www1.k } \\
\text { cl.fi/eco/softw. } \\
\text { html }\end{array}$ \\
\hline LCAiT 4/software & CIT Ekologik & $\begin{array}{l}\text { LCAit tem sido usado para análise ambiental de produtos e proces- } \\
\text { sos. Inclui um banco de dados de análise de impactos, incluindo } \\
\text { fatores de caracterização e de distribuição ponderada. }\end{array}$ & $\begin{array}{l}\text { Possui versão de } \\
\text { demonstração. }\end{array}$ & 2 & $\begin{array}{l}\text { http://www.lca } \\
\text { it.com/ }\end{array}$ \\
\hline LCAPIX/software & KM Limited & $\begin{array}{l}\text { O software LCAPIX combina ACV e Activity Based Costing (ABC, } \\
\text { Custo baseado em atividade) para auxiliar a indústria a garantir } \\
\text { conformidade ambiental e rentabilidade. Permite produzir medições } \\
\text { quantitativas que podem indicar o impacto ambiental de um produ- } \\
\text { to. }\end{array}$ & $\begin{array}{l}\text { Possui versão de } \\
\text { demonstração. }\end{array}$ & 2 & $\begin{array}{l}\text { Não identifi- } \\
\text { cado. }\end{array}$ \\
\hline $\begin{array}{l}\text { Life-Cycle Inventory } \\
\text { Database }\end{array}$ & $\begin{array}{l}\text { National Renewable } \\
\text { Energy Laboratory }\end{array}$ & $\begin{array}{l}\text { O Banco de Dados do Inventário do Ciclo de Vida está disponível } \\
\text { ao público em geral e contém módulos de dados para materiais e } \\
\text { processos comumente usados, como produção e combustão de } \\
\text { combustíveis primários, geração de eletricidade e processos de } \\
\text { transformação. }\end{array}$ & Não identificado. & 1 & $\begin{array}{l}\text { Não identifi- } \\
\text { cado. }\end{array}$ \\
\hline $\begin{array}{l}\text { MIET } 3.0- \\
\text { ventory } \\
\text { Tool }\end{array}$ & $\begin{array}{lr}\text { Centre of } & \text { Environ- } \\
\text { mental } & \text { Science } \\
(\mathrm{CML}) & \end{array}$ & $\begin{array}{l}\text { O MIET é uma planilha do Microsoft Excel que permite estimar o } \\
\text { Inventário de Ciclo de Vida de fluxos ausentes que foram truncados. } \\
\text { O MIET é baseado nos dados mais atualizados dos EUA de tabela } \\
\text { de input-output e dados ambientais. O MIET cobre cerca de } 1200 \\
\text { diferentes intervenções ambientais incluindo emissões para o ar, } \\
\text { água, da indústria e para o solo agrícola e uso de recursos por vá- } \\
\text { rios setores industriais. }\end{array}$ & $\begin{array}{l}\text { É uma tabela excel. } \\
\text { Download gratuito. }\end{array}$ & 2 & $\begin{array}{l}\text { http://cml.leid } \\
\text { en.edu/softwa } \\
\text { re/ }\end{array}$ \\
\hline SimaPro 7/software & PRé Consultants & $\begin{array}{l}\text { SimaPro é uma ferramenta de software de ACV profissional, que } \\
\text { contém vários métodos de avaliação de impactos e vários bancos } \\
\text { de dados de inventário, que podem ser editados e expandidos sem } \\
\text { limitação. Permite comparar e analisar produtos complexos com } \\
\text { ciclos de vida complexos. }\end{array}$ & $\begin{array}{l}\text { Possui versão de- } \\
\text { mo. Entretanto, es- } \\
\text { sa versão possibilita } \\
\text { apenas fazer um } \\
\text { exemplo. }\end{array}$ & 3 & $\begin{array}{l}\text { http://www.pr } \\
\text { e.nl/content/si } \\
\text { mapro-lca- } \\
\text { software/ }\end{array}$ \\
\hline SPINE@CPM/database & CPM & $\begin{array}{l}\text { Esse banco de dados contém informação detalhada sobre todos os } \\
\text { tipos de transportes de cargas, produção energética, produção de } \\
\text { materiais selecionados e alternativas de gerência de resíduos sóli- } \\
\text { dos. }\end{array}$ & $\begin{array}{l}\text { Download gratuito } \\
\text { no site. }\end{array}$ & 2 & $\begin{array}{l}\text { http://www.ep } \\
\text { a.gov/ }\end{array}$ \\
\hline $\begin{array}{l}\text { SPOLD Data Ex- } \\
\text { change/Software }\end{array}$ & $\begin{array}{l}\text { The Society for } \\
\text { Promotion of Life- } \\
\text { cycle Assessment }\end{array}$ & $\begin{array}{l}\text { Esse software é usado para criar, editar e exportar dados no forma- } \\
\text { to SPOLD } 99 .\end{array}$ & $\begin{array}{l}\text { Não exporta no } \\
\text { format ILCD adota- } \\
\text { do pelo Brasil. }\end{array}$ & 2 & $\begin{array}{l}\text { Não identifi- } \\
\text { cado. }\end{array}$ \\
\hline TEAM/Software & Pricewaterhouse & TEAMTM é uma ferramenta profissional para avaliar o desempenho & Possui versão de & 2 & https://www.e \\
\hline
\end{tabular}




\begin{tabular}{|c|c|c|c|c|c|}
\hline & $\begin{array}{l}\text { Coopers Ecobilan } \\
\text { Group }\end{array}$ & $\begin{array}{l}\text { ambiental e econômico do ciclo de vida de produtos e tecnologias. } \\
\text { Contém um banco de dados abrangente com mais de } 600 \text { módulos } \\
\text { com cobertura mundial. }\end{array}$ & demonstração. & & $\begin{array}{l}\text { cobi- } \\
\text { lan.com/uk_te } \\
\text { am.php }\end{array}$ \\
\hline Umberto/Software & $\begin{array}{l}\text { Institute for Envi- } \\
\text { ronmental Informat- } \\
\text { ics, Hamburg }\end{array}$ & $\begin{array}{l}\text { Umberto é uma ferramenta que fornece funcionalidades para visua- } \\
\text { lizar sistemas de fluxos de materiais e energia. Dados são extraídos } \\
\text { de sistemas de informação externos ou são modelados e calcula- } \\
\text { dos pelo usuário da ferramenta. }\end{array}$ & $\begin{array}{l}\text { Possui versão de } \\
\text { demonstração. }\end{array}$ & 3 & $\begin{array}{l}\text { http://www.u } \\
\text { mberto.de/en/ }\end{array}$ \\
\hline BRE & Reino Unido & $\begin{array}{l}\text { BREEAM avaliação ambiental de construções. } \\
\text { Desenvolveu uma tabela comparativa entre vários materiais que } \\
\text { podem ser usados na construção. É um passo posterior à ACV e de } \\
\text { divulgação dos resultados para o Mercado. }\end{array}$ & $\begin{array}{l}\text { Possui dados e ver- } \\
\text { são online. }\end{array}$ & 1 & $\begin{array}{l}\text { http://www.br } \\
\text { e.co.uk/ }\end{array}$ \\
\hline Eco-bat & $\begin{array}{l}\text { Laboratory of Solar } \\
\text { Energetics and } \\
\text { Building Physics in } \\
\text { the School of Busi- } \\
\text { ness and Engineer- } \\
\text { ing Vaud (HEIG-VD } \\
\text { of the University of } \\
\text { Applied Science of } \\
\text { Western Switzer- } \\
\text { land) }\end{array}$ & $\begin{array}{l}\text { Calcula o impacto da parte material (fabricação, reposição e elimi- } \\
\text { nação), a instalação técnica e a demanda energética por aqueci- } \\
\text { mento, refrigeração, aquecimento de água e eletricidade. A parte } \\
\text { material é baseada nas diferentes camadas de cada element (fa- } \\
\text { chada, telhado, laje,elementos internos, etc). A demanda energética } \\
\text { pode ser inserida manualmente ou automaticamente de acordo com } \\
\text { um design feito a priori. Os bancos de dados usados são o Swiss } \\
\text { KBOB list e o Ecoinvent. }\end{array}$ & Não identificado. & 2 & $\begin{array}{l}\text { www.eco- } \\
\text { bat.ch }\end{array}$ \\
\hline Open LCA & & $\begin{array}{l}\text { Um software livre, para modelagem e avaliação de Ciclo de Vida, } \\
\text { com várias opções para importar e exportar dados. Possui um fra- } \\
\text { mework básico para cálculos da avaliação do ciclo de vida (ACV) e } \\
\text { dois plugins, um conversor de formatos e um módulo de incertezas. } \\
\text { O conversor de formatos converte formatos de dados relevantes de } \\
\text { ACV de um para o outro, sem perdas de informação. O módulo de } \\
\text { incertezas auxilia a especificar, calcular, visualizar e interpretar in- } \\
\text { certezas em sistemas produtivos. }\end{array}$ & $\begin{array}{l}\text { Gratuito e com ver- } \\
\text { sões para Mac, Li- } \\
\text { nux e Windowns. } \\
\text { Lançou apenas a } \\
\text { versão beta }\end{array}$ & 1 & $\begin{array}{l}\text { http://www.op } \\
\text { enlca.org }\end{array}$ \\
\hline
\end{tabular}




\section{Apêndice C: Memória de cálculo}

\begin{tabular}{|c|c|c|c|c|c|c|c|c|c|c|c|c|c|c|c|c|c|}
\hline & Un & $\begin{array}{c}\text { Indústria } \\
\text { P1 }\end{array}$ & $\begin{array}{c}\text { Indústria } \\
\text { P2 }\end{array}$ & $\begin{array}{c}\text { Indústria } \\
\text { P3 }\end{array}$ & $\begin{array}{c}\text { Indústria } \\
\text { P4 }\end{array}$ & $\begin{array}{c}\text { Indústria } \\
\text { P5 }\end{array}$ & $\begin{array}{c}\text { Indústria } \\
\text { M1 }\end{array}$ & $\begin{array}{c}\text { Indústria } \\
\text { M2 }\end{array}$ & $\begin{array}{c}\text { Indústria } \\
\text { M3 }\end{array}$ & $\begin{array}{c}\text { Indústria } \\
\text { M4 }\end{array}$ & $\begin{array}{c}\text { Indústria } \\
\text { M5 }\end{array}$ & $\begin{array}{c}\text { Indústria } \\
M 6\end{array}$ & $\begin{array}{c}\text { Indústria } \\
\text { G1 }\end{array}$ & $\begin{array}{c}\text { Indústria } \\
\text { G3 }\end{array}$ & $\begin{array}{c}\text { Indústria } \\
\text { G5 }\end{array}$ & $\begin{array}{c}\text { Indústria } \\
\mathrm{G} 6\end{array}$ & $\begin{array}{c}\text { Indústria } \\
\text { G8 }\end{array}$ \\
\hline $\begin{array}{l}\text { Tipo de pro- } \\
\text { duto }\end{array}$ & Tipo & $\begin{array}{l}\text { Tijolos } \\
\text { maciços }\end{array}$ & $\begin{array}{l}\text { Tijolos } \\
\text { maciços }\end{array}$ & $\begin{array}{l}\text { Tijolos } \\
\text { maciços, } \\
\text { blocos de } \\
4,6 \mathrm{e} 8 \\
\text { furos }\end{array}$ & $\begin{array}{c}\text { Tijolos } \\
\text { maciços e } \\
\text { blocos de } \\
6 \text { furos }\end{array}$ & $\begin{array}{l}\text { Tijolos } \\
\text { maciços e } \\
\text { blocos de } \\
6 \text { furos }\end{array}$ & $\begin{array}{c}\text { Blocos de } \\
6 \\
\text { furos, } \\
\text { telhas e } \\
\text { cumeei- } \\
\text { ras }\end{array}$ & $\begin{array}{c}\text { Tijolos de } \\
3 \\
\text { furos }\end{array}$ & $\begin{array}{l}\text { Blocos de } \\
6 \text { furos }\end{array}$ & $\begin{array}{l}\text { Tijolos } \\
\text { maciocos e } \\
\text { blocos de } \\
6 \mathrm{e} 13 \\
\text { furos }\end{array}$ & $\begin{array}{c}\text { Tijolos } \\
\text { maciços }\end{array}$ & $\begin{array}{c}\text { Blocos de } \\
6 \text { e } 8 \\
\text { furos }\end{array}$ & $\begin{array}{l}\text { Blocos de } \\
6 \text { furos }\end{array}$ & $\begin{array}{c}\text { Blocos de } \\
6 \text { e } 11 \\
\text { furos }\end{array}$ & $\begin{array}{c}\text { Blocos de } \\
6 \text { furos }\end{array}$ & $\begin{array}{c}\text { Blocos } \\
\text { variados }\end{array}$ & $\begin{array}{l}\text { Tijolos, } \\
\text { blocos } \\
\text { de veda- } \\
\text { ção e } \\
\text { estrutu- } \\
\text { rais }\end{array}$ \\
\hline Produção & $\begin{array}{c}\text { pe- } \\
\text { ças/mê } \\
s\end{array}$ & 40.000 & 50.000 & 60.000 & 80.000 & 100.000 & 130.000 & 150.000 & 174.000 & 250.000 & 250.000 & 290.000 & 320.000 & 500.000 & 600.000 & 1.200 .000 & 1.400 .000 \\
\hline $\begin{array}{l}\text { Massa de } \\
\text { argila (entra- } \\
\text { da) }\end{array}$ & $\mathrm{kg} / \mathrm{mês}$ & 104.000 & 112.500 & 126.000 & 192.000 & 219.500 & 274.000 & 255.000 & 469.800 & 538.500 & 550.000 & 667.000 & 790.000 & 1.000 .000 & 1.500 .000 & 3.469 .000 & 3.000 .000 \\
\hline $\begin{array}{l}\text { Tipo de se- } \\
\text { cagem }\end{array}$ & - & Natural & Natural & Natural & Natural & Natural & $\begin{array}{c}\text { Natural e } \\
\text { artificial }\end{array}$ & Natural & Natural & $\begin{array}{c}\text { Natural e } \\
\text { artificial }\end{array}$ & $\begin{array}{c}\text { Natural e } \\
\text { artificial }\end{array}$ & $\begin{array}{c}\text { Natural e } \\
\text { artificial }\end{array}$ & & Natural & Artificial & Artificial & Artificial \\
\hline $\begin{array}{l}\text { Aproveita- } \\
\text { mento }\end{array}$ & - & a & Não & Não & Não & Não & Sim & Não & Ião & Não & Sim & Não & Sim & Não & Sim & Não & Sim \\
\hline $\begin{array}{l}\text { Energia elé- } \\
\text { trica }\end{array}$ & kWh & 1.750 & 161 & 3.000 & 1.070 & 4.550 & 9.315 & $800^{32}$ & 3.000 & 8.000 & 2700 & 14.000 & 12.800 & 17.000 & 40.535 & 126.000 & 77.329 \\
\hline $\begin{array}{l}\text { Consumo de } \\
\text { energia elé- } \\
\text { trica/kg de } \\
\text { argila }\end{array}$ & MJ & $\begin{array}{c}0,060576 \\
923\end{array}$ & 0,005152 & 0,085714 & 0,020063 & 0,074624 & 0,122387 & $\begin{array}{c}0,011294 \\
118\end{array}$ & 0,022989 & 0,053482 & $\begin{array}{c}0,017672 \\
727\end{array}$ & 0,075562 & 0,058329 & 0,061200 & 0,097284 & 0,130758 & 0,092795 \\
\hline $\begin{array}{l}\text { Tipo de For- } \\
\text { no }\end{array}$ & - & $\begin{array}{l}\text { Intermi- } \\
\text { tente }\end{array}$ & $\begin{array}{l}\text { Intermi- } \\
\text { tente }\end{array}$ & $\begin{array}{l}\text { Semicon- } \\
\text { tínuo }\end{array}$ & $\begin{array}{l}\text { Intermi- } \\
\text { tente }\end{array}$ & $\begin{array}{l}\text { Semicon- } \\
\text { tínuo }\end{array}$ & $\begin{array}{l}\text { Intermi- } \\
\text { tente }\end{array}$ & $\begin{array}{l}\text { Intermi- } \\
\text { tente }\end{array}$ & $\begin{array}{l}\text { Intermi- } \\
\text { tente }\end{array}$ & $\begin{array}{l}\text { Intermi- } \\
\text { tente }\end{array}$ & $\begin{array}{l}\text { Semicon- } \\
\text { tínuo }\end{array}$ & $\begin{array}{c}\text { Semicon- } \\
\text { tínuo }\end{array}$ & Túnel & Túnel & Túnel & Túnel & Túnel \\
\hline $\begin{array}{l}\text { Combustível } \\
\text { forno }\end{array}$ & Tipo & $\begin{array}{c}\text { Retalhos } \\
\text { de mó- } \\
\text { veis }\end{array}$ & $\begin{array}{c}\text { Retalhos } \\
\text { de mó- } \\
\text { veis }\end{array}$ & Lenha & Lenha & Lenha & Serragem & $\begin{array}{c}\text { Retalhos } \\
\text { de mó- } \\
\text { veis }\end{array}$ & Lenha & $\begin{array}{c}\text { Retalhos } \\
\text { de mó- } \\
\text { veis }\end{array}$ & Lenha & Lenha & Cavaco & Serragem & Lenha & $\begin{array}{l}\text { Cavaco e } \\
\text { serragem }\end{array}$ & Lenha \\
\hline \multirow{3}{*}{$\begin{array}{l}\text { Consumo do } \\
\text { forno }\end{array}$} & kWh & 57.613 & 84.819 & 102.843 & 158.672 & 88.151 & 404.453 & 111.734 & 108.720 & 363.135 & 264.453 & 514.214 & 1.040 .231 & 640.142 & 440.755 & 3.720 .825 & 1.439 .798 \\
\hline & MJ & 207406,8 & 305348,4 & 370.235 & 571.219 & 317.344 & 1.4 & 242 & 392 & 1.307 .286 & 952.031 & 1.851 .170 & 3.744 .832 & 2.304 .511 & 1.586 .718 & $\begin{array}{c}13.394 .97 \\
0\end{array}$ & 5.183 .273 \\
\hline & $\mathrm{Kg}$ & 16555,5 & 24373,3 & 29.553 & 45.595 & 25.331 & 139.467 & .529 & .241 & 104.349 & 5.992 & 147.763 & 8.700 & 20.739 & 126.654 & 1.283 .043 & 413.735 \\
\hline $\begin{array}{l}\text { Consumo de } \\
\text { biomassa/kg } \\
\text { de argila }\end{array}$ & $\mathrm{Kg}$ & 59187 & 0,216651 & 0,234544 & 0,237476 & 0,115402 & 0,509002 & 0,151094 & 0,066499 & 0,193777 & 0,138168 & 0,221533 & 0,454051 & 0,220739 & 0,084436 & 0,369860 & 0,137912 \\
\hline
\end{tabular}

32 Os dados marcados em vermelho foram desconsiderados no cálculo da média dos valores, visto que distoavam dos valores das demais empresas com níveis de industrialização similares. 


\begin{tabular}{|c|c|c|c|c|c|c|c|c|c|c|c|c|c|c|c|c|c|}
\hline Transporte & kWh & 739 & 2.132 & 1.456 & 7.106 & 853 & 11.797 & $\begin{array}{c}13.645 \\
\text { (transpor- } \\
\text { te e ex- } \\
\text { tração) }\end{array}$ & 2.234 & 6.460 & 967 & 8.034 & $\begin{array}{c}10571 \\
\text { (transpor- } \\
\text { te e ex- } \\
\text { tração) }\end{array}$ & 19.988 & 26.650 & 171.123 & $\begin{array}{c}111991 \\
\text { (transpor- } \\
\text { te e gera- } \\
\text { dor) }\end{array}$ \\
\hline Fonte & & $\begin{array}{l}\text { MAN- } \\
\text { FREDINI } \\
\text { et al, } \\
2005\end{array}$ & $\begin{array}{l}\text { MAN- } \\
\text { FREDINI } \\
\text { et } \quad \text { al, } \\
2005\end{array}$ & $\begin{array}{l}\text { MAN- } \\
\text { FREDINI } \\
\text { et } \quad \text { al, } \\
2005\end{array}$ & $\begin{array}{l}\text { MAN- } \\
\text { FREDINI } \\
\text { et } \quad \text { al, } \\
2005\end{array}$ & $\begin{array}{l}\text { MAN- } \\
\text { FREDINI } \\
\text { et al, } \\
2005\end{array}$ & $\begin{array}{l}\text { MAN- } \\
\text { FREDINI } \\
\text { et } \quad \text { al, } \\
2005\end{array}$ & $\begin{array}{l}\text { MAN- } \\
\text { FREDINI } \\
\text { et } \quad \text { al, } \\
2005\end{array}$ & $\begin{array}{l}\text { MAN- } \\
\text { FREDINI } \\
\text { et } \quad \text { al, } \\
2005\end{array}$ & $\begin{array}{l}\text { MAN- } \\
\text { FREDINI } \\
\text { et } \quad \text { al, } \\
2005\end{array}$ & $\begin{array}{l}\text { MAN- } \\
\text { FREDINI } \\
\text { et al, } \\
2005 \quad\end{array}$ & $\begin{array}{l}\text { MAN- } \\
\text { FREDINI } \\
\text { et } \quad \text { al, } \\
2005\end{array}$ & $\begin{array}{l}\text { MAN- } \\
\text { FREDINI } \\
\text { et al, } \\
2005 \text {, }\end{array}$ & $\begin{array}{l}\text { MAN- } \\
\text { FREDINI } \\
\text { et } \quad \text { al, } \\
2005\end{array}$ & $\begin{array}{l}\text { MAN- } \\
\text { FREDINI } \\
\text { et al, } \\
2005\end{array}$ & $\begin{array}{l}\text { MAN- } \\
\text { FREDINI } \\
\text { et } \quad \text { al, } \\
2005\end{array}$ & $\begin{array}{l}\text { MAN- } \\
\text { FREDINI } \\
\text { et al, } \\
2005\end{array}$ \\
\hline
\end{tabular}

\begin{tabular}{|c|c|c|c|c|c|c|c|}
\hline \multirow{3}{*}{$\begin{array}{l}\text { Conclusão } \\
\text { Forno } \\
\text { Tipo de biomassa }\end{array}$} & \multicolumn{7}{|l|}{ Un } \\
\hline & \multicolumn{2}{|l|}{-} & \multicolumn{2}{|c|}{ Intermitente } & \multirow{2}{*}{$\begin{array}{c}\text { Semicontínuo } \\
\text { Lenha }\end{array}$} & \multicolumn{2}{|c|}{ Túnel } \\
\hline & - & Retalho de móveis & Lenha & Serragem & & Cavaco & Lenha \\
\hline Consumo de biomassa/kg de argila & kg & 0,180177 & 0,237476 & 0,509002 & 0,177412 & 0,348216 & 0,111174 \\
\hline
\end{tabular}

Consumo de energia elétrica para secagem natural

MJ

0,0541944

Consumo de energia elétrica secagem artificial com aproveitamento

MJ

0,095039

Consumo de energia elétrica secagem artifi-

cial sem aproveitamento

MJ

0,130758

Consumo de energia elétrica com secagem

natural e artificial com aproveitamento

0,058329

Consumo de energia elétrica com secagem

natural e artificial sem aproveitamento

0,064522 
Apêndice D: Matriz de ocorrência das categorias de impacto por sistemas de EPD de materiais de construção na Europa, EN 15.804 e produções técnico-científicas brasileiras

\begin{tabular}{|c|c|c|c|c|c|c|c|c|c|}
\hline Metodologias & IBU & BRE & FDES & MRPI & EN 15.804 & SEMC & CAATEEB & Noruega & ACV Brasil \\
\hline \multicolumn{10}{|c|}{ Indicadores Globais de impacto ambiental } \\
\hline Mudanças climáticas (GWP) & $\mathrm{X}$ & $\mathrm{X}$ & $\mathrm{x}$ & $\mathrm{X}$ & $\mathrm{X}$ & $\mathrm{X}$ & $\mathrm{X}$ & $\mathrm{X}$ & $\mathrm{X}$ \\
\hline Potencial de destruição da camada de ozônio (ODP) & $\mathrm{X}$ & $\mathrm{X}$ & $\mathrm{X}$ & $\mathrm{X}$ & $\mathrm{X}$ & $\mathrm{X}$ & - & $\mathrm{X}$ & - \\
\hline Potencial de Acidificação (AP) & $\mathrm{x}$ & $\mathrm{X}$ & $\mathrm{x}$ & $x$ & $\mathrm{X}$ & $\mathrm{X}$ & - & $\mathrm{X}$ & $\mathrm{X}$ \\
\hline Potencial de eutrofização (EP) & $\mathrm{x}$ & $x$ & $\mathrm{x}$ & $\mathrm{x}$ & $x$ & $x$ & - & $\mathrm{x}$ & - \\
\hline Potencial de formação de ozônio estratosférerico (POCP) & $\mathrm{x}$ & $\mathrm{x}$ & $\mathrm{x}$ & $\mathrm{x}$ & $\mathrm{x}$ & $\mathrm{x}$ & - & $\mathrm{x}$ & - \\
\hline $\begin{array}{l}\text { Potencial de depleção de recursos abióticos não fósseis e } \\
\text { fósseis (ADP) }\end{array}$ & $x$ & $x$ & $x$ & $x$ & - & - & - & $\mathrm{x}$ & $x$ \\
\hline \multicolumn{10}{|c|}{ Indicadores de recursos usados } \\
\hline Total de energia primária renovável consumida & $\mathrm{x}$ & - & $\mathrm{x}$ & $\mathrm{x}$ & - & $\mathrm{X}$ & $\mathrm{X}$ & $\mathrm{X}$ & - \\
\hline Total de energia não-renovável consumida & $\mathrm{X}$ & - & $\mathrm{x}$ & $\mathrm{X}$ & - & $\mathrm{X}$ & $\mathrm{X}$ & $\mathrm{x}$ & - \\
\hline Material secundário & - & - & - & - & - & - & - & - & - \\
\hline Combustíveis secundários renováveis e não renováveis & - & - & - & - & - & - & - & - & - \\
\hline Consumo de água & $\mathrm{x}$ & $\mathrm{X}$ & $\mathrm{x}$ & - & - & - & $\mathrm{X}$ & - & $\mathrm{X}$ \\
\hline \multicolumn{10}{|c|}{ Indicadores de fluxos de saída } \\
\hline Componentes reutilizáveis & - & $\mathrm{X}$ & - & - & - & - & - & - & - \\
\hline Materiais recicláveis & - & $\mathrm{X}$ & - & - & - & - & - & - & - \\
\hline Energia recuperada & - & - & - & - & - & - & - & - & - \\
\hline Energia exportada & - & - & - & - & - & - & - & - & - \\
\hline \multicolumn{10}{|c|}{ Indicadores de categorias de resíduos } \\
\hline Disposição de resíduo perigoso & - & $\mathrm{x}$ & - & - & - & - & - & - & - \\
\hline Disposição de resíduo não perigoso & - & $\mathrm{X}$ & - & - & - & - & - & - & - \\
\hline Disposição de resíduo radioativo & $x$ & $\mathrm{X}$ & - & - & - & - & - & - & - \\
\hline Resíduos sólidos & $\mathrm{x}$ & $\mathrm{x}$ & $x$ & $x$ & $x$ & - & $x$ & - & - \\
\hline \multicolumn{10}{|c|}{ Outros indicadores } \\
\hline Ecotoxidade & $\mathrm{X}$ & $\mathrm{X}$ & $\mathrm{X}$ & $\mathrm{X}$ & - & - & - & - & - \\
\hline Toxidade humana & $x$ & $x$ & $x$ & $x$ & - & - & - & - & $x$ \\
\hline
\end{tabular}




\section{Apêndice E: Questionário desenvolvido para coleta de dados junto aos fabricantes de bloco cerâmico}

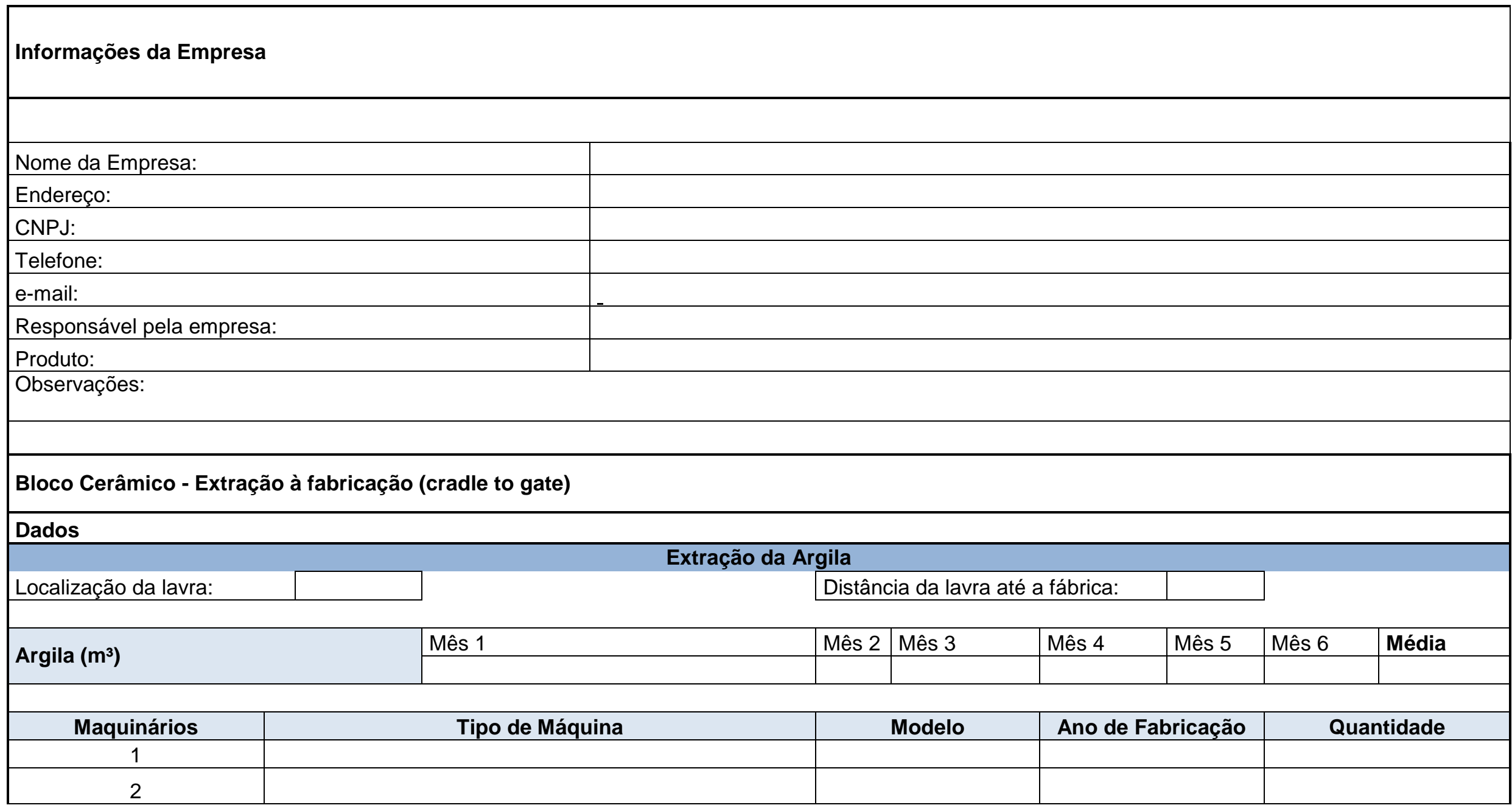




\begin{tabular}{|c|c|c|c|c|}
\hline \multicolumn{5}{|c|}{ Consumo do maquinário } \\
\hline \multirow{2}{*}{ Óleo Diesel } & Litros/mês: & Litros/mês: & Litros/mês: & Litros/mês: \\
\hline & & Rendimento: & & \\
\hline
\end{tabular}

\begin{tabular}{|l|l|l|l|l|l|}
\hline \multicolumn{2}{|c|}{ Fabricação } & & \\
\hline $\begin{array}{l}\text { A argila precisa ser corrigi- } \\
\text { da? }\end{array}$ & $\left(\right.$ Sim $\left(\begin{array}{c}\text { Não. Com qual mate- } \\
\text { rial? }\end{array}\right.$ & & \\
\hline
\end{tabular}

\section{Materiais para correção}

\section{Material 1:}

Localização da lavra:

Material $1\left(\mathrm{~m}^{3}\right)$

(2)

\begin{tabular}{|l|l|l|l} 
& Mês \\
\cline { 2 - 3 } &
\end{tabular}

\begin{tabular}{|c|c|}
\hline Maquinários & Tipo de Máquina \\
\hline 1 & \\
\hline 2 & \\
\hline
\end{tabular}

\section{Consumo do maquinário}

\begin{tabular}{l|l|} 
Óleo Diesel & \multicolumn{1}{c}{ Escavadeira } \\
\cline { 2 - 2 } & Litros/mês: \\
\cline { 2 - 2 } & \\
\cline { 2 - 2 }
\end{tabular}

\begin{tabular}{|c|c|c|c|c|c|c|}
\hline \multicolumn{3}{|c|}{ Distância da lavra até a fábrica: } & \multirow[b]{2}{*}{ Mês 4} & \multirow[b]{2}{*}{ Mês 5} & \multirow[b]{2}{*}{ Mês 6} & \multirow[b]{2}{*}{ Média } \\
\hline Mês 1 & Mês 2 & Mês 3 & & & & \\
\hline Tipo de Máquina & \multicolumn{2}{|r|}{ Modelo } & \multicolumn{2}{|c|}{ Ano de Fabricação } & \multicolumn{2}{|c|}{ Quantidade } \\
\hline \multirow[t]{2}{*}{ Escavadeira } & \multicolumn{2}{|c|}{ Caminhão } & \multicolumn{2}{|c|}{ Maquinário 3} & \multicolumn{2}{|c|}{ Maquinário 4} \\
\hline & \multicolumn{2}{|c|}{ Litros/mês: } & \multicolumn{2}{|c|}{ Litros/mês: } & \multicolumn{2}{|c|}{ Litros/mês: } \\
\hline \multirow[t]{2}{*}{ (trabalhadas) } & \multicolumn{2}{|c|}{$\begin{array}{l}\text { Hora/mês (trabalha- } \\
\text { das) }\end{array}$} & \multicolumn{2}{|c|}{$\begin{array}{l}\text { Hora/mês (trabalha- } \\
\text { das) }\end{array}$} & \multicolumn{2}{|c|}{ Hora/mês (trabalhadas) } \\
\hline & \multicolumn{2}{|c|}{ Rendimento: } & & & & \\
\hline
\end{tabular}

\section{Material 2:}

Localização da lavra:

Ano de Fabricação $\quad$ Quantidade

\begin{tabular}{|c|c|c|c|c|c|c|}
\hline \multicolumn{3}{|c|}{ Distância da lavra até a fábrica: } & \multirow[b]{2}{*}{ Mês 4} & \multirow[b]{2}{*}{ Mês 5} & \multirow[b]{2}{*}{ Mês 6} & \multirow[b]{2}{*}{ Média } \\
\hline Mês 1 & Mês 2 & Mês 3 & & & & \\
\hline Tipo de Máquina & \multicolumn{2}{|r|}{ Modelo } & \multicolumn{2}{|c|}{ Ano de Fabricação } & \multicolumn{2}{|c|}{ Quantidade } \\
\hline \multirow[t]{2}{*}{ Escavadeira } & \multicolumn{2}{|c|}{ Caminhão } & \multicolumn{2}{|c|}{ Maquinário 3} & \multicolumn{2}{|c|}{ Maquinário 4} \\
\hline & \multicolumn{2}{|c|}{ Litros/mês: } & \multicolumn{2}{|c|}{ Litros/mês: } & \multicolumn{2}{|c|}{ Litros/mês: } \\
\hline \multirow[t]{2}{*}{ (trabalhadas) } & \multicolumn{2}{|c|}{$\begin{array}{l}\text { Hora/mês (trabalha- } \\
\text { das) }\end{array}$} & \multicolumn{2}{|c|}{$\begin{array}{l}\text { Hora/mês (trabalha- } \\
\text { das) }\end{array}$} & \multicolumn{2}{|c|}{ Hora/mês (trabalhadas) } \\
\hline & \multicolumn{2}{|c|}{ Rendimento: } & & & & \\
\hline
\end{tabular}

\begin{tabular}{|c|c|c|c|c|c|c|}
\hline \multicolumn{3}{|c|}{ Distância da lavra até a fábrica: } & \multirow[b]{2}{*}{ Mês 4} & \multirow[b]{2}{*}{ Mês 5} & \multirow[b]{2}{*}{ Mês 6} & \multirow[b]{2}{*}{ Média } \\
\hline Mês 1 & Mês 2 & Mês 3 & & & & \\
\hline Tipo de Máquina & \multicolumn{2}{|r|}{ Modelo } & \multicolumn{2}{|c|}{ Ano de Fabricação } & \multicolumn{2}{|c|}{ Quantidade } \\
\hline \multirow[t]{2}{*}{ Escavadeira } & \multicolumn{2}{|c|}{ Caminhão } & \multicolumn{2}{|c|}{ Maquinário 3} & \multicolumn{2}{|c|}{ Maquinário 4} \\
\hline & \multicolumn{2}{|c|}{ Litros/mês: } & \multicolumn{2}{|c|}{ Litros/mês: } & \multicolumn{2}{|c|}{ Litros/mês: } \\
\hline \multirow[t]{2}{*}{ (trabalhadas) } & \multicolumn{2}{|c|}{$\begin{array}{l}\text { Hora/mês (trabalha- } \\
\text { das) }\end{array}$} & \multicolumn{2}{|c|}{$\begin{array}{l}\text { Hora/mês (trabalha- } \\
\text { das) }\end{array}$} & \multicolumn{2}{|c|}{ Hora/mês (trabalhadas) } \\
\hline & \multicolumn{2}{|c|}{ Rendimento: } & & & & \\
\hline
\end{tabular}

\begin{tabular}{|c|c|c|c|c|c|c|}
\hline \multicolumn{3}{|c|}{ Distância da lavra até a fábrica: } & \multirow[b]{2}{*}{ Mês 4} & \multirow[b]{2}{*}{ Mês 5} & \multirow[b]{2}{*}{ Mês 6} & \multirow[b]{2}{*}{ Média } \\
\hline Mês 1 & Mês 2 & Mês 3 & & & & \\
\hline Tipo de Máquina & \multicolumn{2}{|r|}{ Modelo } & \multicolumn{2}{|c|}{ Ano de Fabricação } & \multicolumn{2}{|c|}{ Quantidade } \\
\hline \multirow[t]{2}{*}{ Escavadeira } & \multicolumn{2}{|c|}{ Caminhão } & \multicolumn{2}{|c|}{ Maquinário 3} & \multicolumn{2}{|c|}{ Maquinário 4} \\
\hline & \multicolumn{2}{|c|}{ Litros/mês: } & \multicolumn{2}{|c|}{ Litros/mês: } & \multicolumn{2}{|c|}{ Litros/mês: } \\
\hline \multirow[t]{2}{*}{ (trabalhadas) } & \multicolumn{2}{|c|}{$\begin{array}{l}\text { Hora/mês (trabalha- } \\
\text { das) }\end{array}$} & \multicolumn{2}{|c|}{$\begin{array}{l}\text { Hora/mês (trabalha- } \\
\text { das) }\end{array}$} & \multicolumn{2}{|c|}{ Hora/mês (trabalhadas) } \\
\hline & \multicolumn{2}{|c|}{ Rendimento: } & & & & \\
\hline
\end{tabular}

\begin{tabular}{|c|}
\hline Distância da lavra até a fábrica: \\
\hline
\end{tabular}




\begin{tabular}{|c|c|c|c|c|c|c|c|c|}
\hline \multicolumn{2}{|l|}{ Material $2\left(\mathrm{~m}^{3}\right)$} & Mês 1 & Mês 2 & Mês 3 & Mês 4 & Mês 5 & Mês 6 & Média \\
\hline Maquinários & & Tipo de Máquina & \multicolumn{2}{|r|}{ Modelo } & \multicolumn{2}{|c|}{ Ano de Fabricação } & \multicolumn{2}{|c|}{ Quantidade } \\
\hline \multicolumn{9}{|l|}{2} \\
\hline \multicolumn{9}{|c|}{ Consumo do maquinário } \\
\hline \multirow{2}{*}{ Óleo Diesel } & \multicolumn{2}{|r|}{ Escavadeira } & \multicolumn{2}{|c|}{ Caminhão } & \multicolumn{2}{|c|}{ Maquinário 3} & \multicolumn{2}{|c|}{ Maquinário 4} \\
\hline & & & \multicolumn{2}{|c|}{ Rendimento: } & & & & \\
\hline Tipo de bloco & $\begin{array}{c}\text { Dimensões } \\
(\mathrm{m})\end{array}$ & \multicolumn{2}{|l|}{ Traço } & Resistência & Volume & Peso & Estrutural & Preço \\
\hline \multicolumn{9}{|l|}{ Bloco 1} \\
\hline \multicolumn{9}{|l|}{ Bloco 2} \\
\hline \multirow{7}{*}{\multicolumn{2}{|c|}{ Produção de blocos (mil) }} & \multicolumn{7}{|c|}{ Bloco 1} \\
\hline & & Mês 1 & Mês 2 & Mês 3 & Mês 4 & Mês 5 & Mês 6 & Média \\
\hline & & \multicolumn{7}{|c|}{ Bloco 2} \\
\hline & & Mês 1 & Mês 2 & Mês 3 & Mês 4 & Mês 5 & Mês 6 & Média \\
\hline & & & & & & & & \\
\hline & & \multicolumn{7}{|c|}{ Bloco 3} \\
\hline & & Mês 1 & Mês 2 & Mês 3 & Mês 4 & Mês 5 & Mês 6 & Média \\
\hline
\end{tabular}




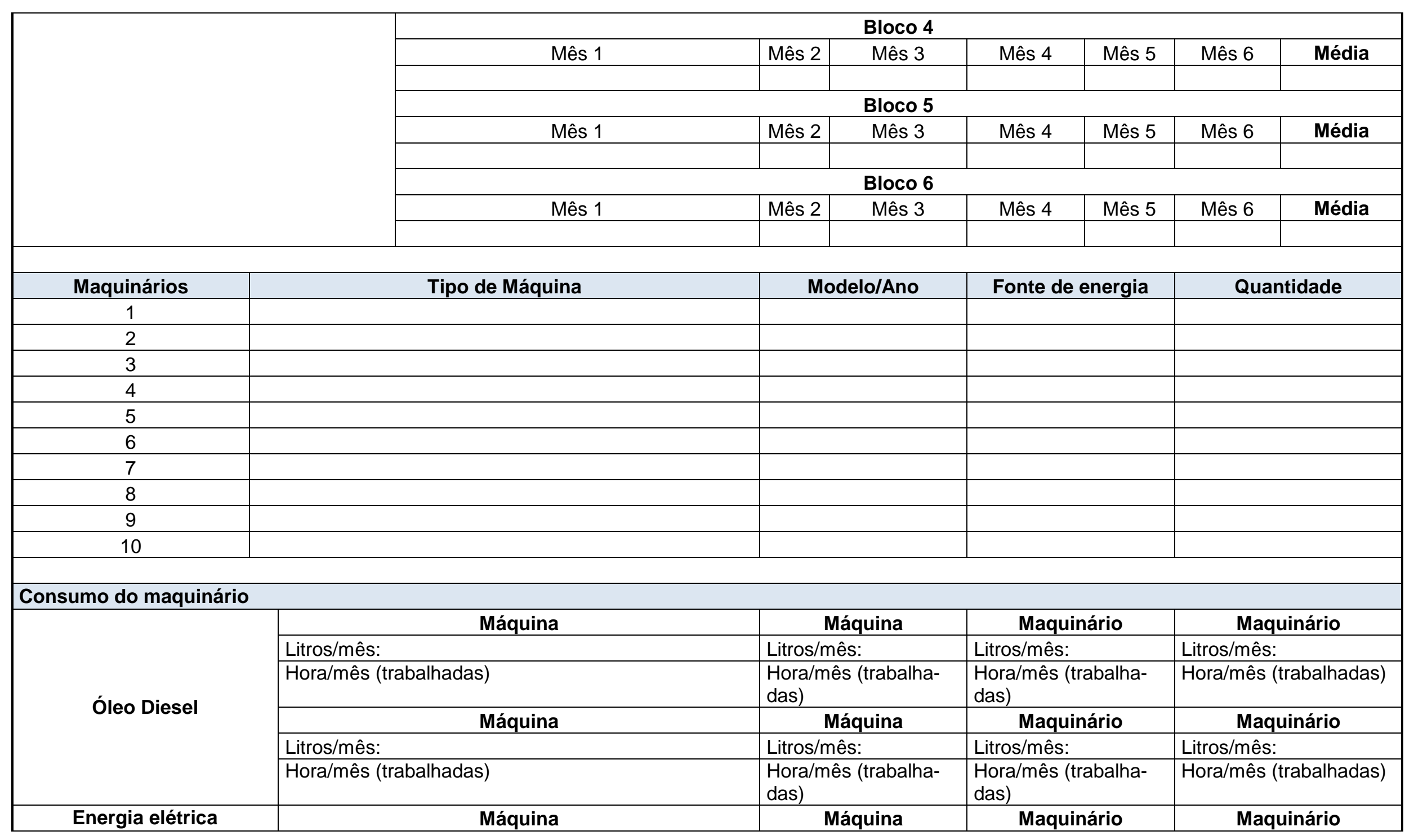




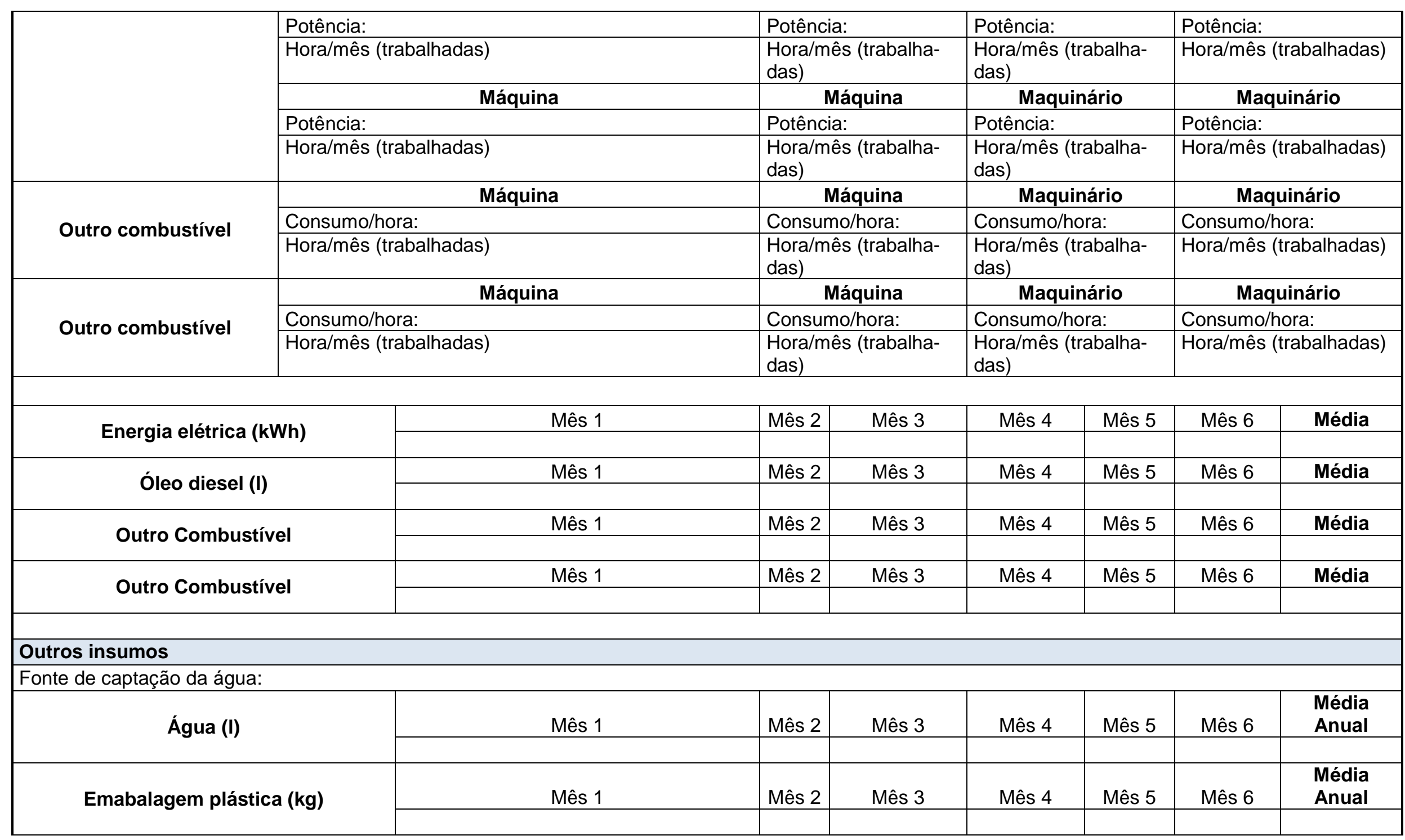




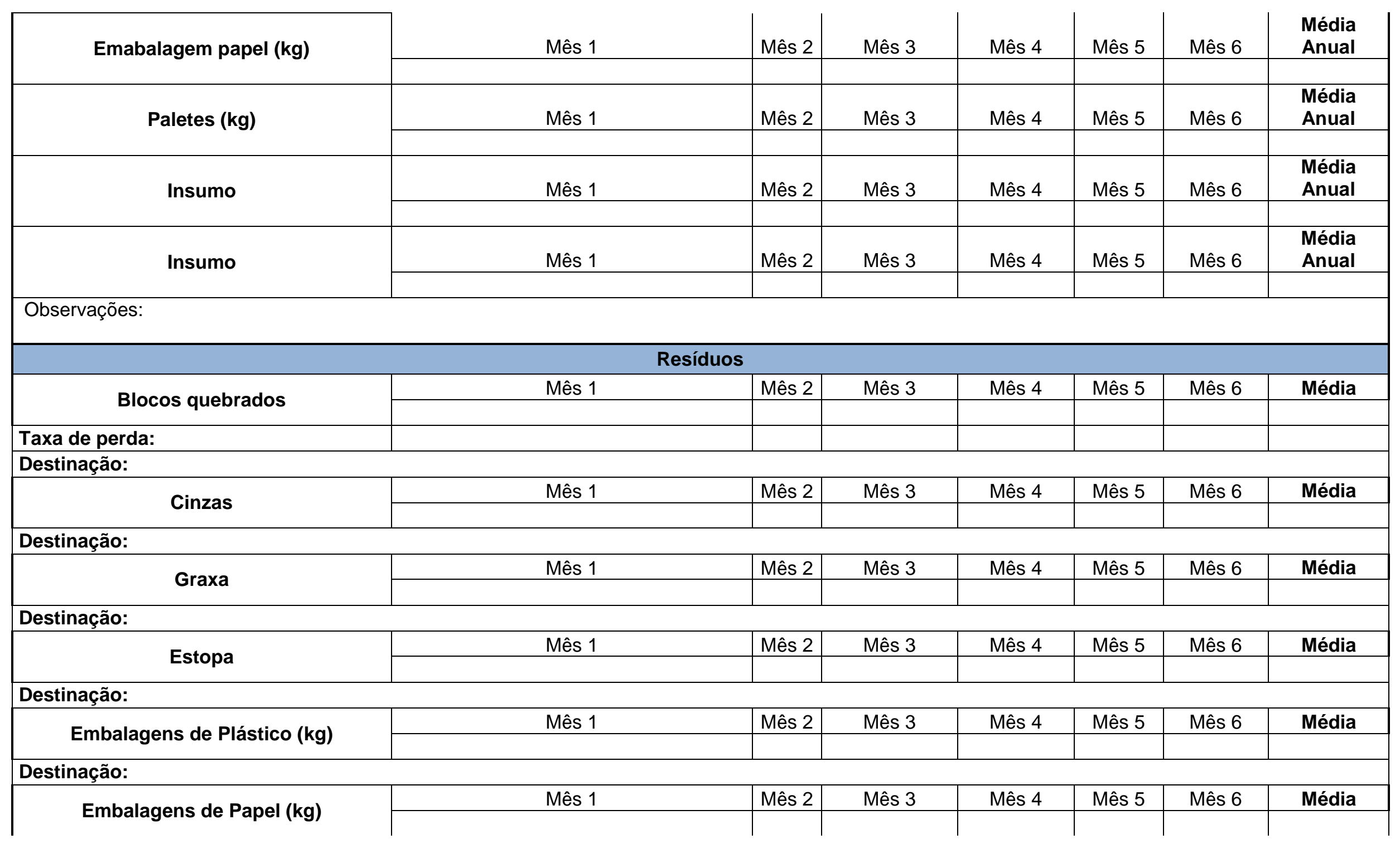




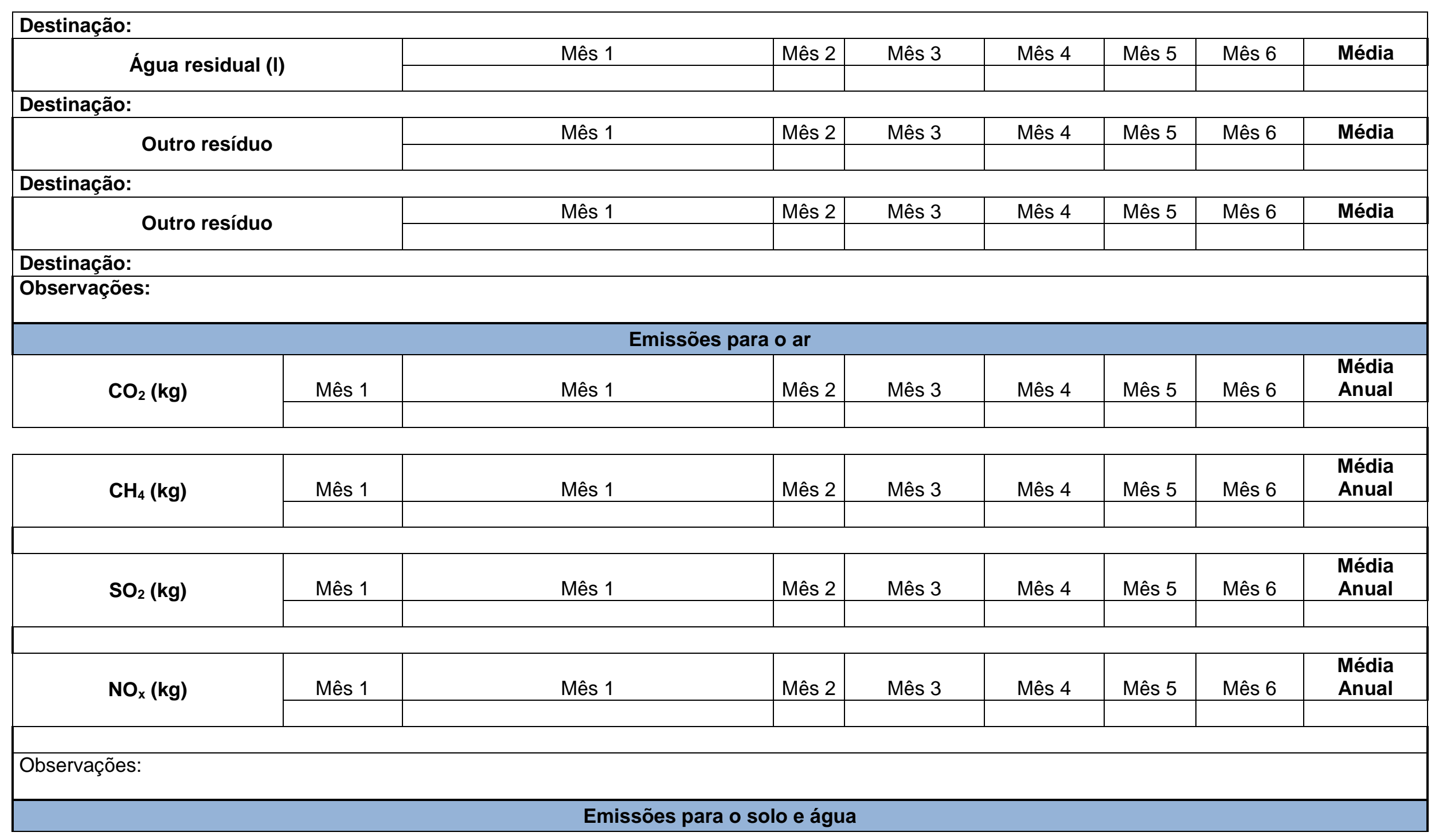




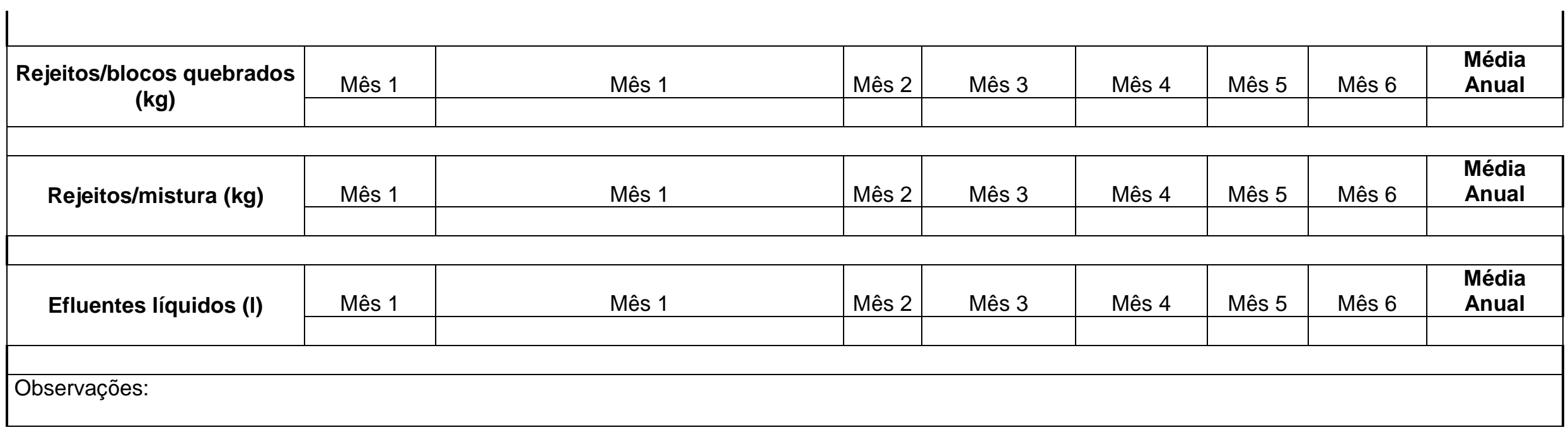




\section{Apêndice F: Síntese dos trabalhos acadêmicos identificados no currículo dos doutores da Plataforma Lattes do CNPq}

\begin{tabular}{|c|c|c|c|c|}
\hline $\begin{array}{l}\text { Tipo de } \\
\text { produção }\end{array}$ & Título da produção & Objetivo & Metodologia & Resultado \\
\hline Dissertação & $\begin{array}{l}\text { Análise ambiental da } \\
\text { viabilidade de seleção de } \\
\text { produtos da construção civil } \\
\text { através da ACV e do } \\
\text { software Bees } 3.0\end{array}$ & $\begin{array}{l}\text { Testar a viabilidade da utilização do } \\
\text { software de ACV desenvolvido pelo } \\
\text { NIST nos Estados Unidos e a } \\
\text { veracidade dos dados obtidos nos } \\
\text { cálculos para a realidade brasileira } \\
\text { (OLIVEIRA, 2007); }\end{array}$ & $\begin{array}{l}\text { Cálculo dos impactos gerados com dados nacionais, } \\
\text { extraídos de trabalhos acadêmicos e bibliografia da } \\
\text { área, e comparação com os dados obtidos no } \\
\text { software (OLIVEIRA, 2007); }\end{array}$ & $\begin{array}{l}\text { Conclui-se que o uso do software facilita a } \\
\text { quantificação e proporciona maior confiabilidade } \\
\text { dos resultados. Entretanto realizar os } \\
\text { procedimentos sem ter um banco de dados } \\
\text { brasileiro pode distorcer os dados (OLIVEIRA, } \\
\text { 2007); }\end{array}$ \\
\hline Dissertação & $\begin{array}{l}\text { Análise pluridimensional da } \\
\text { sustentabilidade do ciclo de } \\
\text { vida de um sistema } \\
\text { estrutural de cobertura em } \\
\text { madeira de pinus: caso } \\
\text { assen-tamento rural Pirituba } \\
\text { II }\end{array}$ & $\begin{array}{l}\text { Elaborar metodologia para a análise } \\
\text { da sustentabilidade de um sistema } \\
\text { estrutural de cobertura de pinus } \\
\text { (EGAS, 2008). }\end{array}$ & $\begin{array}{l}\text { Aplicação da ACV para a cobertura de pinus no } \\
\text { âmbito social, ambiental, cultural, político e } \\
\text { econômico. Adaptação do método de ACV de } \\
\text { edificações associado aos indicadores de } \\
\text { sustentabilidade o que culminou na elaboração de } \\
\text { um método denominado Análise Pluridimensional do } \\
\text { Ciclo de Vida (EGAS, 2008). }\end{array}$ & $\begin{array}{l}\text { Conclui-se que a utilização desse material pode } \\
\text { ter menor impacto em relação a outros materiais } \\
\text { uma vez que a madeira é um material renovável e } \\
\text { captura } \mathrm{CO}_{2} \text { da atmosfera (EGAS, 2008). }\end{array}$ \\
\hline Dissertação & $\begin{array}{l}\text { Análise ambiental do } \\
\text { processo produtivo de pisos } \\
\text { cerâmicos: Aplicação de } \\
\text { avaliação de ciclo de vida }\end{array}$ & $\begin{array}{l}\text { Aplicar a avaliação de ciclo de vida } \\
\text { comparando-se a produção de dois } \\
\text { pisos cerâmicos (PEREIRA, 2004); }\end{array}$ & $\begin{array}{l}\text { Inventário e análise ambiental dos dois produtos por } \\
\text { meio da metodologia de ACV apontando as } \\
\text { medições dos impactos e uma postura voltada para } \\
\text { o meio ambiente pelos fabricantes dos materiais. As } \\
\text { categorias de análise usadas foram consumo de } \\
\text { matéria-prima, uso de água, esgotamento das } \\
\text { reservas de combustíveis fósseis, degradação de } \\
\text { áreas pela disposição de resíduos, aquecimento } \\
\text { global, acidificação prejuízo à saúde huma-na. As } \\
\text { metodologias usadas foram TRACl e IPCC } \\
\text { (PEREIRA, 2004); }\end{array}$ & $\begin{array}{l}\text { Identificou-se uma problemática na aplicação de } \\
\text { bancos de dados estrangeiros dos programas de } \\
\text { ACV para a quantificação no Brasil (PEREIRA, } \\
\text { 2004); }\end{array}$ \\
\hline Dissertação & $\begin{array}{l}\text { Comparação entre } \\
\text { processos de produção de } \\
\text { blocos cerâmicos e de } \\
\text { concreto para alvenaria } \\
\text { estrutural, através da } \\
\text { análise de ciclo de vida }\end{array}$ & $\begin{array}{l}\text { Comparar dois produtos a fim de } \\
\text { subsidiar as escolhas por materiais } \\
\text { mais compatíveis com o meio } \\
\text { ambiente (MASTELLA, 2002). }\end{array}$ & $\begin{array}{l}\text { Aplicação da ACV considerando-se as categorias de } \\
\text { análises: eficiência energética, perdas de matérias- } \\
\text { primas, potencial ecotóxico de efluentes líquidos e } \\
\text { gasosos, dejetos emitidos e potencial ecotóxico dos } \\
\text { lixiviantes (MASTELLA, 2002). }\end{array}$ & $\begin{array}{l}\text { Conclui-se que o concreto possui maior } \\
\text { compatibilidade com } 0 \text { meio ambiente } \\
\text { (MASTELLA, 2002). }\end{array}$ \\
\hline Artigo & $\begin{array}{l}\text { Inventário da Produção de } \\
\text { pisos e tijolos cerâmicos no } \\
\text { contexto da análise do ciclo } \\
\text { de vida. }\end{array}$ & $\begin{array}{l}\text { Realizar inventário de ACV da } \\
\text { produção de pisos e tijolos cerâmicos } \\
\text { (SOARES et al, 2004). }\end{array}$ & $\begin{array}{l}\text { Inventário da produção de pisos e tijolos cerâmicos } \\
\text { utilizando a ACV. Esse artigo foi uma etapa da } \\
\text { dissertação "Análise ambiental do processo } \\
\text { produtivo de pisos cerâmicos: aplicação de } \\
\text { avaliação de ciclo de vida" já contabilizado neste } \\
\text { quadro. }\end{array}$ & $\begin{array}{l}\text { Inventário de ACV da produção de pisos e tijolos } \\
\text { cerâmicos. }\end{array}$ \\
\hline
\end{tabular}




\begin{tabular}{|c|c|c|c|c|}
\hline Artigo & $\begin{array}{l}\text { Estimativa de energia } \\
\text { incorporada a materiais de } \\
\text { cerâmica vermelha no Rio } \\
\text { Grande do Sul }\end{array}$ & $\begin{array}{l}\text { Estimar energia incorporada em } \\
\text { materiais de cerâmica vermelha no } \\
\text { Rio Grande do Sul (MANFREDINI et } \\
\text { al, 2005). }\end{array}$ & $\begin{array}{l}\text { Aplicação de questionários nas empresas } \\
\text { pesquisadas para o levantamento de dados, mas } \\
\text { devido à dificuldade na obtenção das informações } \\
\text { só foi possível identificar os dados em } 20 \text { das } 40 \\
\text { empresas pesquisadas. Esse artigo é parte das } \\
\text { quantificações realizadas para as dissertações } \\
\text { "Caracterização de impactos ambientais de } \\
\text { indústrias de cerâmica vermelha do Estado do RS" e } \\
\text { "Impactos Ambientais Causados pelas Indústrias de } \\
\text { Cerâmica Vermelha no Rio Grande do Sul" ambas } \\
\text { vinculadas ao Núcleo Orientado para a Inovação da } \\
\text { Edificação (NORIE). }\end{array}$ & $\begin{array}{l}\text { Apresentação dos impactos ambientais causados } \\
\text { pelo processo produtivo de indústrias produtoras } \\
\text { de cerâmica vermelha de portes variados } \\
\text { abordando aspectos qualitativos e quantitativos } \\
\text { relacionados ao consumo de fontes energéticas } \\
\text { (MANFREDINI et al 2005). }\end{array}$ \\
\hline Artigo & $\begin{array}{l}\text { Avaliação de } \text { Edifícios no } \\
\text { Brasil: da avaliação } \\
\text { ambiental para a avaliação } \\
\text { da sustentabilidade }\end{array}$ & $\begin{array}{l}\text { Comparar os principais sistemas de } \\
\text { avaliação ambiental de edifícios } \\
\text { usados no mundo. }\end{array}$ & $\begin{array}{l}\text { Apresentação e comparação dos principais sistemas } \\
\text { de avaliação ambiental de edifícios no mundo: } \\
\text { Method (BREEAM) e o Leadership in Energy and } \\
\text { Environmental Design (LEED). }\end{array}$ & $\begin{array}{l}\text { Evidencia a impossibilidade de mera importação } \\
\text { de métodos existentes com base no sucesso } \\
\text { alcançado em países com condições sociais, } \\
\text { econômicas e ambientais diferentes das do Brasil } \\
\text { (SILVA et al, 2003); }\end{array}$ \\
\hline Artigo & $\begin{array}{l}\text { Avaliação do uso de bambu } \\
\text { como material alternativo } \\
\text { para a execução de } \\
\text { habitação de interesse } \\
\text { social. }\end{array}$ & $\begin{array}{l}\text { Identificar os impactos positivos e } \\
\text { negativos na utilização do bambu para } \\
\text { cobertura e vedação das casas } \\
\text { (BARBOZA et al 2008). }\end{array}$ & $\begin{array}{l}\text { Identificação dos impactos positivos e negativos da } \\
\text { utilização do bambu, por meio de dados da } \\
\text { bibliografia e entrevistas com a população. }\end{array}$ & $\begin{array}{l}\text { Conclui-se que o material é uma alternativa viáve } \\
\text { para a habitação de interesse social no Brasil e os } \\
\text { problemas identificados estavam relacionados ao } \\
\text { projeto e não com o material em si. }\end{array}$ \\
\hline Dissertação & $\begin{array}{l}\text { Análise de Ciclo de Vida } \\
\text { Ambiental aplicada à } \\
\text { Construção Civil - Estudo de } \\
\text { Caso: Comparação entre } \\
\text { Cimentos Portland com } \\
\text { adição de Resíduos }\end{array}$ & $\begin{array}{l}\text { Quantificar os impactos ambientais } \\
\text { por meio da aplicação de ACV (ISO } \\
14040 \text { ) ao cimento Portland com } \\
\text { adição de resíduos }\end{array}$ & $\begin{array}{l}\text { Aplicação de ACV (ISO 14040) ao cimento Portland } \\
\text { com adição de resíduos. }\end{array}$ & $\begin{array}{l}\text { Conclui-se que a adição de resíduos da } \\
\text { construção civil ao cimento traz benefícios quanto } \\
\text { à resistência do produto e quanto à deposição de } \\
\text { resíduos (CARVALHO, 2002). }\end{array}$ \\
\hline Dissertação & $\begin{array}{l}\text { Caracterização de impactos } \\
\text { ambientais de indústrias de } \\
\text { cerâmica vermelha do RS }\end{array}$ & $\begin{array}{l}\text { Caracterizar os principais impactos } \\
\text { sociais econômicos e ambientais na } \\
\text { produção de tijolos, blocos e telhas } \\
\text { cerâmicas através da ACV. }\end{array}$ & $\begin{array}{l}\text { Aplicação da ACV. Os dados foram obtidos junto ao } \\
\text { Sindicato das Indústrias de Olaria e de Cerâmica } \\
\text { para a Construção no Estado do Rio Grande do Sul } \\
\text { e Associação Nacional da Indústria da Cerâmica. }\end{array}$ & $\begin{array}{l}\text { Conclui-se que as empresas pesquisadas } \\
\text { possuem iniciativas de baixo impacto ambiental, } \\
\text { mas há a necessidade de reduzir as perdas no } \\
\text { processo de produção e melhoria nas condições } \\
\text { de trabalho (GRIGOLETTI, 2001). }\end{array}$ \\
\hline Dissertação & $\begin{array}{l}\text { Impactos Ambientais } \\
\text { causados pela Indústria de } \\
\text { Cerâmica Vermelha do Rio } \\
\text { Grande do Sul }\end{array}$ & $\begin{array}{l}\text { Analisar os impactos ambientais } \\
\text { causados pela Indústria de Cerâmica } \\
\text { Vermelha do Rio Grande do Sul } \\
\text { (MANFREDINI, 2003). }\end{array}$ & $\begin{array}{l}\text { Análise dos dados coletados em pesquisa realizada } \\
\text { em } 40 \text { indústrias de cerâmica vermelha de } \\
\text { diferentes escalas (MANFREDINI, 2003). }\end{array}$ & $\begin{array}{l}\text { Identificou-se impactos do uso de recursos } \\
\text { naturais, fontes energéticas, geração de resíduos } \\
\text { sólidos e emissões gasosas, relacionados a cada } \\
\text { fase do processo produtivo (MANFREDINI, 2003). }\end{array}$ \\
\hline Artigo & $\begin{array}{l}\text { Análise do ciclo de vida de } \\
\text { produtos cerâmicos da } \\
\text { Indústria de Construção Civil }\end{array}$ & $\begin{array}{l}\text { Analisar os impactos gerados no ciclo } \\
\text { de vida de produtos cerâmicos da } \\
\text { Indústria de Construção Civil }\end{array}$ & $\begin{array}{l}\text { Aplicação da ACV. Esse artigo foi uma etapa da } \\
\text { dissertação "Análise Ambiental do processo } \\
\text { produtivo de pisos cerâmicos. Aplicação de } \\
\text { avaliação de ciclo de vida" contida neste quadro. }\end{array}$ & $\begin{array}{l}\text { Identificou-se uma problemática na aplicação de } \\
\text { bancos de dados estrangeiros dos programas de } \\
\text { ACV para a quantificação no Brasil. }\end{array}$ \\
\hline Artigo & $\begin{array}{l}\text { Avaliação de Ciclo de Vida } \\
\text { de um elemento estrutural }\end{array}$ & $\begin{array}{l}\text { Avaliar as vantagens e desvantagens } \\
\text { ambientais do elemento estrutural aço }\end{array}$ & $\begin{array}{l}\text { Aplicação da metodologia de ACV associada ao } \\
\text { programa Simapro para testar a confiabilidade do }\end{array}$ & $\begin{array}{l}\text { Conclui-se que o pilar de concreto possui } \\
\text { melhores resultados ambientais que } 0 \text { pilar de }\end{array}$ \\
\hline
\end{tabular}




\begin{tabular}{|c|c|c|c|c|}
\hline & $\begin{array}{l}\text { pilar em Aço X pilar em } \\
\text { Concreto Armado }\end{array}$ & X pilar de concreto armado. & método aplicado à construção civil. & $\begin{array}{l}\text { aço. Ressaltou-se a falta de precisão das } \\
\text { quantificações no Brasil com base em banco de } \\
\text { dados estrangeiros (GARCIA et al, 2010). }\end{array}$ \\
\hline Artigo & $\begin{array}{l}\text { A life cycle energy analysis } \\
\text { of social housing in Brazil: } \\
\text { Case study for the program } \\
\text { "MY HOUSE MY LIFE" }\end{array}$ & $\begin{array}{l}\text { Visualizar a energia utilizada } \\
\text { (incorporada e operacional) durante o } \\
\text { ciclo de vida de uma habitação do } \\
\text { Programa Minha Casa Minha Vida. }\end{array}$ & $\begin{array}{l}\text { Estudo de caso de uma habitação com a } \\
\text { quantificação da energia operacional e incorporada. }\end{array}$ & $\begin{array}{l}\text { A maior redução da energia incorporada está } \\
\text { conectada às paredes ao escolher materiais e } \\
\text { sistemas com menor energia incorporada e maior } \\
\text { durabilidade reduzindo a demanda por } \\
\text { manutenção e substituição de materiais }\end{array}$ \\
\hline Dissertação & 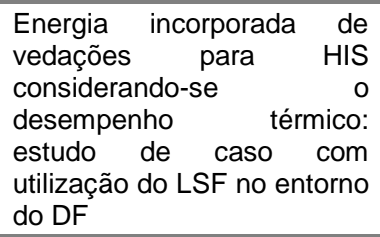 & $\begin{array}{l}\text { Levantar e analisar a Energia } \\
\text { Incorporada (EI) da fase de pré-uso } \\
\text { (extração, fabricação dos materiais e } \\
\text { transporte ao canteiro) do Light Steel } \\
\text { Frame }\end{array}$ & $\begin{array}{l}\text { Estudo de caso de um projeto de HIS do entorno do } \\
\text { DF, uso de dados secundários e coleta de } \\
\text { informações e cálculos }\end{array}$ & $\begin{array}{l}\text { O Light Steel Frame possui a massa } 60 \% \text { menor e } \\
30 \% \text { menos Energia Incorporada que as vedações } \\
\text { convencionais. }\end{array}$ \\
\hline Dissertação & $\begin{array}{l}\text { Energia incorporada } \mathrm{e} \\
\text { emissões de } \mathrm{CO}_{2} \text { de } \\
\text { fachadas: estudo de caso do } \\
\text { steel frame para utilização } \\
\text { em Brasília }\end{array}$ & $\begin{array}{l}\text { Analisar a energia incorporada e } \\
\text { emissões de } \mathrm{CO}_{2} \text { de um modelo de } \\
\text { fachada em steel frame compara- } \\
\text { tivamente com um modelo de fachada } \\
\text { convencional. }\end{array}$ & $\begin{array}{l}\text { Estudo de caso, dados secundários e levantamento } \\
\text { de dados junto com fabricantes e empresas } \\
\text { especializadas. }\end{array}$ & $\begin{array}{l}\text { Mostrar as dificuldades ao comparar alternativas } \\
\text { construtivas sob a ótica da sustentabilidade. } \\
\text { Incrementa o banco nacional de dados de energia } \\
\text { incorporada e emissões de } \mathrm{CO}_{2} \text {. }\end{array}$ \\
\hline
\end{tabular}




\section{Apêndice G: Resultados de ACV obtidos em busca com os melhores fornecedores da Construção no Brasil}

\begin{tabular}{|c|c|c|c|}
\hline Categoria & Empresa & Aplicação da ACV & Fonte \\
\hline \multirow{2}{*}{$\begin{array}{l}\text { Aquecedor domés- } \\
\text { tico }\end{array}$} & Soletrol & $\begin{array}{l}\text { O Aquecedor Solar Compacto foi comparado com um aquecedor solar de baixo custo e } \\
\text { composto de embalagens descartáveis em uma dissertação de mestrado. }\end{array}$ & $\begin{array}{l}\text { http://www.webposgrad.propp.ufu.br/p } \\
\text { pg/producao_anexos/009_LarissaOliv } \\
\text { eiraArantes.pdf }\end{array}$ \\
\hline & Bosch & $\begin{array}{l}\text { Possui os dados inventariados: emissão de } \mathrm{CO}_{2} \text {, consumo de energia, emissões e consu- } \\
\text { mos, resíduos, desperdício de água, consumo de água/ano/fábrica. }\end{array}$ & http://www.bosch.com.br/ \\
\hline \multirow{2}{*}{$\begin{array}{l}\text { Caixilho de alumí- } \\
\text { nio }\end{array}$} & YKK & $\begin{array}{l}\text { O grupo realizou ACV da divisão do Japão, entretanto não existe previsão para a aplicação } \\
\text { da metodologia no Brasil. }\end{array}$ & http://www.ykk.com/ \\
\hline & Esquadrimetal & $\begin{array}{l}\text { Inventariaram emissões de } \mathrm{CO}_{2} \text { totalizando } 60 \text { teq } \mathrm{CO}_{2} \text {, considerando deslocamentos, con- } \\
\text { sumo energético, resíduos e logística para entrega do alumínio. }\end{array}$ & http://www.esquadrimetal.com.br \\
\hline $\begin{array}{l}\text { Concreto dosado } \\
\text { em central }\end{array}$ & Polimix & $\begin{array}{l}\text { Inventariou as emissões de GEE tendo como base } 2010 \text {. Foram inventariadas a Matriz, as } \\
\text { plantas brasileiras e seus respectivos equipamentos. }\end{array}$ & http://www.polimixambiental.com.br/ \\
\hline \multirow{2}{*}{$\begin{array}{l}\text { Disjuntor/ interrup- } \\
\text { tor/tomada }\end{array}$} & Siemens & A empresa cita investimentos em ACV, entretanto sem detalhamento no site. & http://www.siemens.com.br/ \\
\hline & Bticino & Realiza ACV em seus produtos e substitui substâncias impactantes. & http://www.bticino.com.br/ \\
\hline \multirow{2}{*}{$\begin{array}{l}\text { Elevador, escada e } \\
\text { esteira rolante }\end{array}$} & $\begin{array}{l}\text { Atlas Schin- } \\
\quad \text { dler }\end{array}$ & $\begin{array}{l}\text { Desenvolveu ferramenta que avalia o consumo de energia e matéria-prima e permite com- } \\
\text { parar desempenhos e reduzir impactos para projetos futuros. }\end{array}$ & http://www.atlas.schindler.com/ \\
\hline & ThyssenKrupp & $\begin{array}{l}\text { A divisão dos EUA fez ACV gerando DAPs, considerando as categorias: energia primária, } \\
\text { aquecimento global, eutrofização, acidificação e formação de Smog. }\end{array}$ & $\begin{array}{l}\text { http://www.thyssenkruppelevadores.c } \\
\text { om.br }\end{array}$ \\
\hline Impermeabilização & Viapol & $\begin{array}{l}\text { Tem consciência da importância da ACV dos produtos fabricados pela empresa, mas ad- } \\
\text { mite que muito ainda precisa ser feito para o uso dessa metodologia. }\end{array}$ & http://www.viapol.com.br \\
\hline Metais Sanitários & Docol & $\begin{array}{l}\text { Colaborou com estudo sobre materiais a partir de seus ciclos de vida (trabalho acadêmico } \\
\text { Roberta Helena dos Santos Tonicelo da UDESC). }\end{array}$ & http://www.docol.com.br/ \\
\hline \multirow{2}{*}{$\begin{array}{l}\text { Tubo e conexão } \\
\text { para água fria e } \\
\text { quente }\end{array}$} & Tigre & $\begin{array}{l}\text { Por meio de ACV decidiu substituir os estabilizantes a base de chumbo por estabilizantes a } \\
\text { base de cálcio e zinco. }\end{array}$ & www.tigre.com.br \\
\hline & Amanco & Substituição dos estabilizantes a base de chumbo por de cálcio e zinco. & http://www.amanco.com.br \\
\hline \multirow[b]{2}{*}{ Vergalhão } & Arcelor Mittal & Análise para peças automotivas de uma nova categoria de fabricação da empresa & http://www.arcelormittal.com \\
\hline & Votoraço & $\begin{array}{l}\text { Análise o consumo de energia e água, geração de resíduos sólidos e líquidos, emissões } \\
\text { atmosféricas e matéria-prima utilizada na fabricação do aço. }\end{array}$ & www.votoraco.com \\
\hline
\end{tabular}


Apêndice H: Tabela de dados coletados com as classificações, valores, unidades de medida e fonte do dado

\begin{tabular}{|c|c|c|c|c|c|c|c|}
\hline \multirow[b]{2}{*}{ Dados } & \multicolumn{3}{|c|}{ Tipo de dado } & \multirow[b]{2}{*}{ Valor } & \multirow[b]{2}{*}{ Unidade } & \multirow[b]{2}{*}{ Fonte } & \multirow[b]{2}{*}{ Nacionalidade } \\
\hline & $\begin{array}{c}\text { Média } \\
\text { Específico }\end{array}$ & $\begin{array}{l}\text { Genérico } \\
\text { Coletado } \\
\text { Estimado }\end{array}$ & $\begin{array}{c}\text { Primário } \\
\text { Secundário }\end{array}$ & & & & \\
\hline \multicolumn{8}{|l|}{ DADOS GERAIS } \\
\hline Densidade aparente areia & M & $\mathrm{G}$ & $\mathrm{S}$ & 1640 & $\mathrm{~kg} / \mathrm{m}^{3}$ & Serna et al, 2009 & BR \\
\hline Densidade aparente do cimento Portland & M & $\mathrm{G}$ & $\mathrm{S}$ & 1150 & $\mathrm{~kg} / \mathrm{m}^{3}$ & Calculado & BR \\
\hline Densidade cal hidratada & M & $\mathrm{G}$ & $\mathrm{S}$ & 650 & $\mathrm{~kg} / \mathrm{m}^{3}$ & Calculado & BR \\
\hline Densidade aparente pedrisco & $\mathrm{M}$ & $\mathrm{G}$ & $\mathrm{S}$ & 1400 & $\mathrm{~kg} / \mathrm{m}^{3}$ & Andrade, 2013 & BR \\
\hline Densidade relativa bloco cerâmico brasileiro & $E$ & C & $\mathrm{P}$ & 0,00068 & $\mathrm{~kg} / \mathrm{cm}^{3}$ & Calculado & BR \\
\hline Densidade relativa do bloco inglês (modelo 1) & M & $\mathrm{G}$ & $\mathrm{S}$ & 650 & $\mathrm{Kg} / \mathrm{m}^{3}$ & NBT, 2013 & UK \\
\hline Densidade relativa do bloco inglês (modelo 2) & M & $\mathrm{G}$ & $\mathrm{S}$ & 1200 & $\mathrm{Kg} / \mathrm{m}^{3}$ & NBT, 2013 & UK \\
\hline $\begin{array}{l}\text { Densidade relativa do chapisco (1) (traço } 1: 4 \text { - ci- } \\
\text { mento Portland e pedrisco) }\end{array}$ & $E$ & $\mathrm{C}$ & $P$ & 1992,857 & $\mathrm{~kg} / \mathrm{m}^{3}$ & Calculado & $\mathrm{BR}$ \\
\hline $\begin{array}{l}\text { Densidade relativa do chapisco (0) (traço } 1: 3 \text { - ci- } \\
\text { mento Portland e areia) }\end{array}$ & $E$ & $\mathrm{C}$ & $P$ & 1990 & $\mathrm{~kg} / \mathrm{m}^{3}$ & Calculado & $\mathrm{BR}$ \\
\hline $1 \mathrm{HP}$ & $\mathrm{E}$ & $\mathrm{G}$ & $\mathrm{S}$ & 745,7 & W & Calculado & BR \\
\hline Potência Betoneira & $M$ & $\mathrm{G}$ & $\mathrm{S}$ & 2 & $\mathrm{HP}$ & PINI, 2008b & BR \\
\hline Capacidade Betoneira & $M$ & $\mathrm{G}$ & $\mathrm{S}$ & 400 & I & PINI, 2008b & BR \\
\hline Tempo para $0,02 \mathrm{~m}^{3}$ & M & $\mathrm{G}$ & $\mathrm{S}$ & 0,007 & $\mathrm{~h}$ & PINI, 2008b & BR \\
\hline Tempo por $\mathrm{m}^{3}$ & $M$ & $G$ & $\mathrm{~S}$ & 0,35 & $\mathrm{~h}$ & Calculado & BR \\
\hline Energia por $\mathrm{m}^{3}$ & M & $G$ & $\mathrm{~S}$ & 1,879164 & MJ & Calculado & BR \\
\hline Porcentagem de Água na argamassa & $M$ & $\mathrm{E}$ & $\mathrm{S}$ & 15 & $\%$ & Assis, 2012 & BR \\
\hline $1 \mathrm{~m}^{3}$ de argila & M & $\mathrm{G}$ & $\mathrm{S}$ & 1700 & $\mathrm{~kg}$ & Zanini, 1998 & BR \\
\hline $1 \mathrm{kcal}$ & $M$ & $\mathrm{G}$ & $S$ & 4180 & $\mathrm{~kJ}$ & - & GLO \\
\hline $1 \mathrm{kcal}$ & $M$ & $\mathrm{G}$ & $\mathrm{S}$ & 0,00116 & kWh & - & GLO \\
\hline $1 \mathrm{kWh}$ & $\mathrm{M}$ & $\mathrm{G}$ & $\mathrm{S}$ & 3,6 & MJ & - & GLO \\
\hline Poder calorífico - Óleo diesel & $M$ & $G$ & $\mathrm{~S}$ & 9159 & $\mathrm{kcal} / \mathrm{l}$ & Brasil, 2000; Silveira, 2002 & BR \\
\hline Poder calorífico - Lenha & $M$ & $G$ & $\mathrm{~S}$ & 3000 & $\mathrm{kcal} / \mathrm{kg}$ & Silveira, 2002 & BR \\
\hline Poder calorífico - Lenha de eucalipto & $M$ & $\mathrm{G}$ & $\mathrm{S}$ & 4166 & $\mathrm{kcal} / \mathrm{kg}$ & Pereira et al, 2000 & BR \\
\hline
\end{tabular}




\begin{tabular}{|c|c|c|c|c|c|c|c|}
\hline \multirow[b]{2}{*}{ Dados } & \multicolumn{3}{|c|}{ Tipo de dado } & \multirow[b]{2}{*}{ Valor } & \multirow[b]{2}{*}{ Unidade } & \multirow[b]{2}{*}{ Fonte } & \multirow[b]{2}{*}{ Nacionalidade } \\
\hline & $\begin{array}{c}\text { Média } \\
\text { Específico }\end{array}$ & $\begin{array}{l}\text { Genérico } \\
\text { Coletado } \\
\text { Estimado }\end{array}$ & $\begin{array}{c}\text { Primário } \\
\text { Secundário }\end{array}$ & & & & \\
\hline Poder calorífico - Serragem & $\mathrm{M}$ & $\mathrm{G}$ & $\mathrm{S}$ & 2500 & $\mathrm{kcal} / \mathrm{kg}$ & Ferreira, 1977; Redenergia, 2002 & $\mathrm{BR}$ \\
\hline Poder calorífico - Cavacos & $\mathrm{M}$ & $\mathrm{G}$ & $\mathrm{S}$ & 2500 & $\mathrm{kcal} / \mathrm{kg}$ & Ferreira, 1977; Redenergia, 2002 & $\mathrm{BR}$ \\
\hline Poder calorífico - Sabugo de milho & $M$ & $\mathrm{G}$ & $\mathrm{S}$ & 2900 & $\mathrm{kcal} / \mathrm{kg}$ & Redenergia, 2002 & BR \\
\hline $1 \mathrm{~m}^{3}$ de óleo BPF & $\mathrm{M}$ & $\mathrm{G}$ & $\mathrm{S}$ & 1024 & $\mathrm{Kg}$ & PETROBRAS, 2014 & $\mathrm{BR}$ \\
\hline $1 \mathrm{~m}^{3} \mathrm{de}$ óleo diesel & $\mathrm{M}$ & $\mathrm{G}$ & $\mathrm{S}$ & 852 & $\mathrm{Kg}$ & Brasil, 2000 & $\mathrm{BR}$ \\
\hline $1 \mathrm{~m}^{3}$ de lenha comercial & M & $G$ & $S$ & 400 & $\mathrm{Kg}$ & Silveira, 2002 & BR \\
\hline $1 \mathrm{~m}^{3}$ de lenha de eucalipto & $M$ & $\mathrm{G}$ & $\mathrm{S}$ & 303 & $\mathrm{Kg}$ & Pereira et al., 2000 & $\mathrm{BR}$ \\
\hline $1 \mathrm{~m}^{3}$ de retalhos de móveis & $\mathrm{M}$ & $\mathrm{G}$ & $\mathrm{S}$ & 550 & $\mathrm{Kg}$ & Indústrias visitadas & $\mathrm{BR}$ \\
\hline $1 \mathrm{~m}^{3}$ de cavaco ou serragem & $\mathrm{M}$ & $\mathrm{G}$ & $\mathrm{S}$ & 550 & $\mathrm{Kg}$ & Indústrias visitadas & $\mathrm{BR}$ \\
\hline $1 \mathrm{~m}^{3} \mathrm{de}$ argila & $M$ & $\mathrm{G}$ & $S$ & 1700 & $\mathrm{Kg}$ & Zanini, 1998 & $\mathrm{BR}$ \\
\hline Potência do misturador & $\mathrm{M}$ & $\mathrm{G}$ & $\mathrm{S}$ & 1600 & W & Tecmix, 2014 & UK \\
\hline Densidade da cal, triturada, fina & $M$ & $G$ & $S$ & 1201 & $\mathrm{Kg} / \mathrm{m}^{3}$ & Simetric, 2014 & UK \\
\hline Densidade da areia seca & $M$ & $\mathrm{G}$ & $\mathrm{S}$ & 1602 & $\mathrm{Kg} / \mathrm{m}^{3}$ & Simetric, 2014 & UK \\
\hline Densidade da cal hidratada & $\mathrm{M}$ & $\mathrm{G}$ & $\mathrm{S}$ & 481 & $\mathrm{Kg} / \mathrm{m}^{3}$ & Simetric, 2014 & UK \\
\hline Densidade do cimento Portland & $M$ & $G$ & $\mathrm{~S}$ & 1506 & $\mathrm{Kg} / \mathrm{m}^{3}$ & Simetric, 2014 & UK \\
\hline Densidade do calcário pulverizado & $M$ & $\mathrm{G}$ & $\mathrm{S}$ & 1394 & $\mathrm{Kg} / \mathrm{m}^{3}$ & Simetric, 2014 & UK \\
\hline Densidade do masonry cement & M & $\mathrm{G}$ & $\mathrm{S}$ & 1360,38 & $\mathrm{Kg} / \mathrm{m}^{3}$ & Calculado & UK \\
\hline Densidade da argamassa de assentamento & $\mathrm{M}$ & $\mathrm{G}$ & $\mathrm{S}$ & 1842,11 & $\mathrm{Kg} / \mathrm{m}^{3}$ & Calculado & UK \\
\hline Densidade da tela de fibra & $M$ & $\mathrm{G}$ & $\mathrm{S}$ & 0,058 & $\mathrm{Kg} / \mathrm{m}^{3}$ & Kobau, 2014 & UK \\
\hline \multicolumn{8}{|l|}{ DADOS BLOCO CERÂMICO } \\
\hline Blocos/metro quadrado (bloco brasileiro) & M & $\mathrm{G}$ & $\mathrm{S}$ & 12,9 & peças $/ \mathrm{m}^{2}$ & PINI, 2008b & BR \\
\hline Blocos/metro quadrado (bloco inglês, modelo 1) & $\mathrm{M}$ & $\mathrm{G}$ & $\mathrm{S}$ & 16 & peças $/ \mathrm{m}^{2}$ & NBT, 2013 & UK \\
\hline Blocos/metro quadrado (bloco inglês, modelo 2) & M & $\mathrm{G}$ & $\mathrm{S}$ & 10,7 & peças $/ \mathrm{m}^{2}$ & NBT, 2013 & UK \\
\hline Dimensões (bloco brasileiro) & $E$ & $\mathrm{G}$ & $\mathrm{S}$ & $140 \times 190 \times 390$ & $\mathrm{~mm}$ & PINI, 2008b & BR \\
\hline Dimensões (bloco inglês, modelo 1) & $E$ & $\mathrm{G}$ & $\mathrm{S}$ & $425 \times 248 \times 249$ & $\mathrm{~mm}$ & NBT, 2013 & UK \\
\hline Dimensões (bloco inglês, modelo 2) & $E$ & $\mathrm{G}$ & $\mathrm{S}$ & $115 \times 373 \times 249$ & $\mathrm{~mm}$ & NBT, 2013 & UK \\
\hline Peso de saída (bloco brasileiro) & $\mathrm{M}$ & $\mathrm{C}$ & $P$ & 6 & $\mathrm{~kg}$ & Calculado & $\mathrm{BR}$ \\
\hline Peso de saída (bloco inglês, modelo 1) & $M$ & $\mathrm{C}$ & $\mathrm{S}$ & 17 & $\mathrm{Kg}$ & NBT, 2013 & UK \\
\hline
\end{tabular}




\begin{tabular}{|c|c|c|c|c|c|c|c|}
\hline \multirow[b]{2}{*}{ Dados } & \multicolumn{3}{|c|}{ Tipo de dado } & \multirow[b]{2}{*}{ Valor } & \multirow[b]{2}{*}{ Unidade } & \multirow[b]{2}{*}{ Fonte } & \multirow[b]{2}{*}{ Nacionalidade } \\
\hline & $\begin{array}{c}\text { Média } \\
\text { Específico }\end{array}$ & $\begin{array}{l}\text { Genérico } \\
\text { Coletado } \\
\text { Estimado }\end{array}$ & $\begin{array}{c}\text { Primário } \\
\text { Secundário }\end{array}$ & & & & \\
\hline Peso de saída (bloco inglês, modelo 2) & $\mathrm{M}$ & $\mathrm{C}$ & $\mathrm{S}$ & 11,3 & $\mathrm{Kg}$ & NBT, 2013 & UK \\
\hline Desempenho térmico (vedação brasileira) & $E$ & $\mathrm{G}$ & $\mathrm{S}$ & 1,98 & $\mathrm{~W} / \mathrm{m}^{2} \mathrm{~K}$ & ABNT, 2013 & $\mathrm{BR}$ \\
\hline Desempenho térmico (vedação externa inglesa) & $\mathrm{E}$ & $\mathrm{G}$ & $\mathrm{S}$ & 0,2 & $\mathrm{~W} / \mathrm{m}^{2} \mathrm{~K}$ & Visita técnica & UK \\
\hline Desempenho térmico (vedação interna inglesa) & $\mathrm{E}$ & $\mathrm{G}$ & $\mathrm{S}$ & 1,98 & $\mathrm{~W} / \mathrm{m}^{2} \mathrm{~K}$ & Visita técnica & UK \\
\hline Desempenho Acústico & $E$ & $\mathrm{G}$ & $\mathrm{S}$ & $\geq 35$ & $\mathrm{~dB}$ & ABNT, 2013 & BR \\
\hline Porcentagem de argila & M & $\mathrm{C}$ & $\mathrm{S}$ & $80 \%$ & $\%$ & MASTELLA, 2002 & BR \\
\hline Porcentagem de água & $\mathrm{M}$ & $\mathrm{C}$ & $\mathrm{S}$ & $20 \%$ & $\%$ & MASTELLA, 2002 & $\mathrm{BR}$ \\
\hline Porcentagem de água que fica no bloco & M & $\mathrm{C}$ & $\mathrm{S}$ & $13,4 \%$ & $\%$ & MASTELLA, 2002 & $\mathrm{BR}$ \\
\hline Porcentagem de água que evapora & $\mathrm{M}$ & $\mathrm{C}$ & $\mathrm{S}$ & $6,59 \%$ & $\%$ & MASTELLA, 2002 & $\mathrm{BR}$ \\
\hline Massa de argila extraída da mina (bloco brasileiro) & $\mathrm{M}$ & $\mathrm{C}$ & $\mathrm{P}$ & 5,04 & $\mathrm{~kg}$ & Calculado & $\mathrm{BR}$ \\
\hline Massa de argila extraída da mina (bloco inglês) & $\mathrm{M}$ & $\mathrm{C}$ & $\mathrm{S}$ & 0,336 & $\mathrm{~kg}$ & BRE Database, 2008 & UK \\
\hline Massa de argila extraída na fábrica (bloco inglês) & M & $\mathrm{C}$ & $\mathrm{S}$ & 0,0752 & $\mathrm{~kg}$ & BRE Database, 2008 & UK \\
\hline Massa de água & $\mathrm{M}$ & $\mathrm{C}$ & $\mathrm{P}$ & 0,463845533 & $\mathrm{~kg}$ & Calculado & $\mathrm{BR}$ \\
\hline Massa de água & $\mathrm{M}$ & $\mathrm{C}$ & $\mathrm{S}$ & 0,013 & $\mathrm{~kg}$ & BRE Database, 2008 & UK \\
\hline Massa de água potável & $\mathrm{M}$ & $\mathrm{C}$ & $\mathrm{S}$ & 0,0299 & $\mathrm{~kg}$ & BRE Database, 2008 & UK \\
\hline Massa de areia 1 & $\mathrm{M}$ & $\mathrm{C}$ & $\mathrm{S}$ & 0,246 & $\mathrm{~kg}$ & BRE Database, 2008 & UK \\
\hline Massa de areia 2 & $\mathrm{M}$ & $\mathrm{C}$ & $\mathrm{S}$ & 0,0484 & $\mathrm{~kg}$ & BRE Database, 2008 & UK \\
\hline Massa de cal & $\mathrm{M}$ & $\mathrm{C}$ & $\mathrm{S}$ & 0,000465 & $\mathrm{~kg}$ & BRE Database, 2008 & UK \\
\hline Massa de calcário & $\mathrm{M}$ & $\mathrm{C}$ & $\mathrm{S}$ & 0,003179 & $\mathrm{~kg}$ & BRE Database, 2008 & UK \\
\hline Massa de agregado & $\mathrm{M}$ & $\mathrm{C}$ & $\mathrm{S}$ & 0,346 & $\mathrm{~kg}$ & BRE Database, 2008 & UK \\
\hline Massa total de entrada (bloco brasileiro) & $\mathrm{M}$ & $\mathrm{C}$ & $\mathrm{P}$ & 2,311845533 & $\mathrm{~kg}$ & Calculado & $\mathrm{BR}$ \\
\hline Taxa de resíduo (fábrica brasileira) & $\mathrm{M}$ & $\mathrm{C}$ & $\mathrm{P}$ & 5 & $\%$ & Coletado (Visita técnica) & $\mathrm{BR}$ \\
\hline Taxa de resíduo (fábrica inglesa) & M & $\mathrm{C}$ & $\mathrm{S}$ & 5 & $\%$ & Brick Industry, 2014 & UK \\
\hline Massa de água que evapora & M & $\mathrm{C}$ & S & 0,15 & $\mathrm{~kg}$ & $\begin{array}{l}\text { Calculado com base em Mas- } \\
\text { tella, } 2002\end{array}$ & $\mathrm{BR}$ \\
\hline Massa de água que fica no bloco & M & $\mathrm{C}$ & $\mathrm{S}$ & 0,31 & $\mathrm{Kg}$ & $\begin{array}{l}\text { Calculado com base em Mas- } \\
\text { tella, } 2002\end{array}$ & $\mathrm{BR}$ \\
\hline Consumo de energia elétrica para secagem natural & M & $\mathrm{C}$ & $\mathrm{S} / \mathrm{P}$ & 0,054194393 & $\mathrm{MJ} / \mathrm{kg}$ argila & $\begin{array}{l}\text { Calculado com base em Man- } \\
\text { fredini, } 2005\end{array}$ & $\mathrm{BR}$ \\
\hline
\end{tabular}




\begin{tabular}{|c|c|c|c|c|c|c|c|}
\hline \multirow[b]{2}{*}{ Dados } & \multicolumn{3}{|c|}{ Tipo de dado } & \multirow[b]{2}{*}{ Valor } & \multirow[b]{2}{*}{ Unidade } & \multirow[b]{2}{*}{ Fonte } & \multirow[b]{2}{*}{ Nacionalidade } \\
\hline & $\begin{array}{c}\text { Média } \\
\text { Específico }\end{array}$ & $\begin{array}{l}\text { Genérico } \\
\text { Coletado } \\
\text { Estimado }\end{array}$ & $\begin{array}{l}\text { Primário } \\
\text { Secundário }\end{array}$ & & & & \\
\hline $\begin{array}{l}\text { Consumo de energia elétrica secagem artificial com } \\
\text { aproveitamento do calor do forno }\end{array}$ & M & C & $\mathrm{S} / \mathrm{P}$ & 0,0950394 & $\mathrm{MJ} / \mathrm{kg}$ argila & $\begin{array}{l}\text { Calculado com base em Man- } \\
\text { fredini, } 2005\end{array}$ & $\mathrm{BR}$ \\
\hline $\begin{array}{l}\text { Consumo de energia elétrica secagem artificial sem } \\
\text { aproveitamento }\end{array}$ & M & C & $\mathrm{S} / \mathrm{P}$ & 0,130758144 & $\mathrm{MJ} / \mathrm{kg}$ argila & $\begin{array}{l}\text { Calculado com base em Man- } \\
\text { fredini, } 2005\end{array}$ & $\mathrm{BR}$ \\
\hline $\begin{array}{l}\text { Consumo de energia elétrica com secagem natural e } \\
\text { artificial com aproveitamento }\end{array}$ & M & C & $\mathrm{S} / \mathrm{P}$ & 0,058329114 & $\mathrm{MJ} / \mathrm{kg}$ argila & $\begin{array}{l}\text { Calculado com base em Man- } \\
\text { fredini, } 2005\end{array}$ & $\mathrm{BR}$ \\
\hline $\begin{array}{l}\text { Consumo de energia elétrica com secagem natural e } \\
\text { artificial sem aproveitamento }\end{array}$ & M & $\mathrm{C}$ & $\mathrm{S} / \mathrm{P}$ & 0,064522057 & $\mathrm{MJ} / \mathrm{kg}$ argila & $\begin{array}{l}\text { Calculado com base em Man- } \\
\text { fredini, } 2005\end{array}$ & $\mathrm{BR}$ \\
\hline Consumo de energia elétrica médio (fábrica inglesa) & M & $\mathrm{C}$ & S & 45,3 & $\mathrm{KWh}$ & BRE database, 2008 & UK \\
\hline Consumo GLP (fábrica brasileira) & M & C & $\mathrm{S} / \mathrm{P}$ & 0,00025836 & $\mathrm{~kg} / \mathrm{kg}$ argila & $\begin{array}{l}\text { Calculado com base em Man- } \\
\text { fredini, } 2005\end{array}$ & $\mathrm{BR}$ \\
\hline Consumo diesel (escavadeira do Brasil) & M & C & $\mathrm{S} / \mathrm{P}$ & 0,000808372 & $\mathrm{l} / \mathrm{kg}$ argila & $\begin{array}{l}\text { Calculado com base em Man- } \\
\text { fredini, } 2005\end{array}$ & $\mathrm{BR}$ \\
\hline Consumo diesel (fábrica inglesa) & $\mathrm{M}$ & $\mathrm{C}$ & $\mathrm{S}$ & 0,0246 & MJ & BRE Database, 2008 & UK \\
\hline Gás natural (fábrica inglesa) & $\mathrm{M}$ & $\mathrm{C}$ & $\mathrm{S}$ & 0,706 & MJ & BRE Database, 2008 & UK \\
\hline Massa de retalho de móveis - forno Intermitente & M & C & $\mathrm{S} / \mathrm{P}$ & 0,180177463 & $\mathrm{~kg} / \mathrm{kg}$ argila & $\begin{array}{l}\text { Calculado com base em Man- } \\
\text { fredini, } 2005\end{array}$ & $\mathrm{BR}$ \\
\hline Massa de lenha - forno Intermitente & M & C & $\mathrm{S} / \mathrm{P}$ & 0,237476054 & $\mathrm{~kg} / \mathrm{kg}$ argila & $\begin{array}{l}\text { Calculado com base em Man- } \\
\text { fredini, } 2005\end{array}$ & $\mathrm{BR}$ \\
\hline Massa de serragem - forno Intermitente & M & C & $\mathrm{S} / \mathrm{P}$ & 0,509002014 & $\mathrm{~kg} / \mathrm{kg}$ argila & $\begin{array}{l}\text { Calculado com base em Man- } \\
\text { fredini, } 2005\end{array}$ & $\mathrm{BR}$ \\
\hline Massa de lenha - forno semicontínuo & M & C & $\mathrm{S} / \mathrm{P}$ & 0,177411821 & $\mathrm{~kg} / \mathrm{kg}$ argila & $\begin{array}{l}\text { Calculado com base em Man- } \\
\text { fredini, } 2005\end{array}$ & $\mathrm{BR}$ \\
\hline Massa de cavaco - forno túnel & M & C & $\mathrm{S} / \mathrm{P}$ & 0,348216 & $\mathrm{~kg} / \mathrm{kg}$ argila & $\begin{array}{l}\text { Calculado com base em Man- } \\
\text { fredini, } 2005\end{array}$ & $\mathrm{BR}$ \\
\hline Massa de lenha - forno túnel & M & C & $\mathrm{S} / \mathrm{P}$ & 0,111173755 & $\mathrm{~kg} / \mathrm{kg}$ argila & $\begin{array}{l}\text { Calculado com base em Man- } \\
\text { fredini, } 2005\end{array}$ & $\mathrm{BR}$ \\
\hline Massa de biomassa (fábrica inglesa) & $\mathrm{M}$ & $\mathrm{C}$ & $\mathrm{S}$ & 0079 & $\mathrm{~m}^{3} / \mathrm{m}^{2}$ & BRE Database, 2008 & UK \\
\hline Taxa de perda no canteiro de obras & $\mathrm{M}$ & $\mathrm{G}$ & $\mathrm{S}$ & 5 & $\%$ & PINI, 2008b & $\mathrm{BR}$ \\
\hline
\end{tabular}




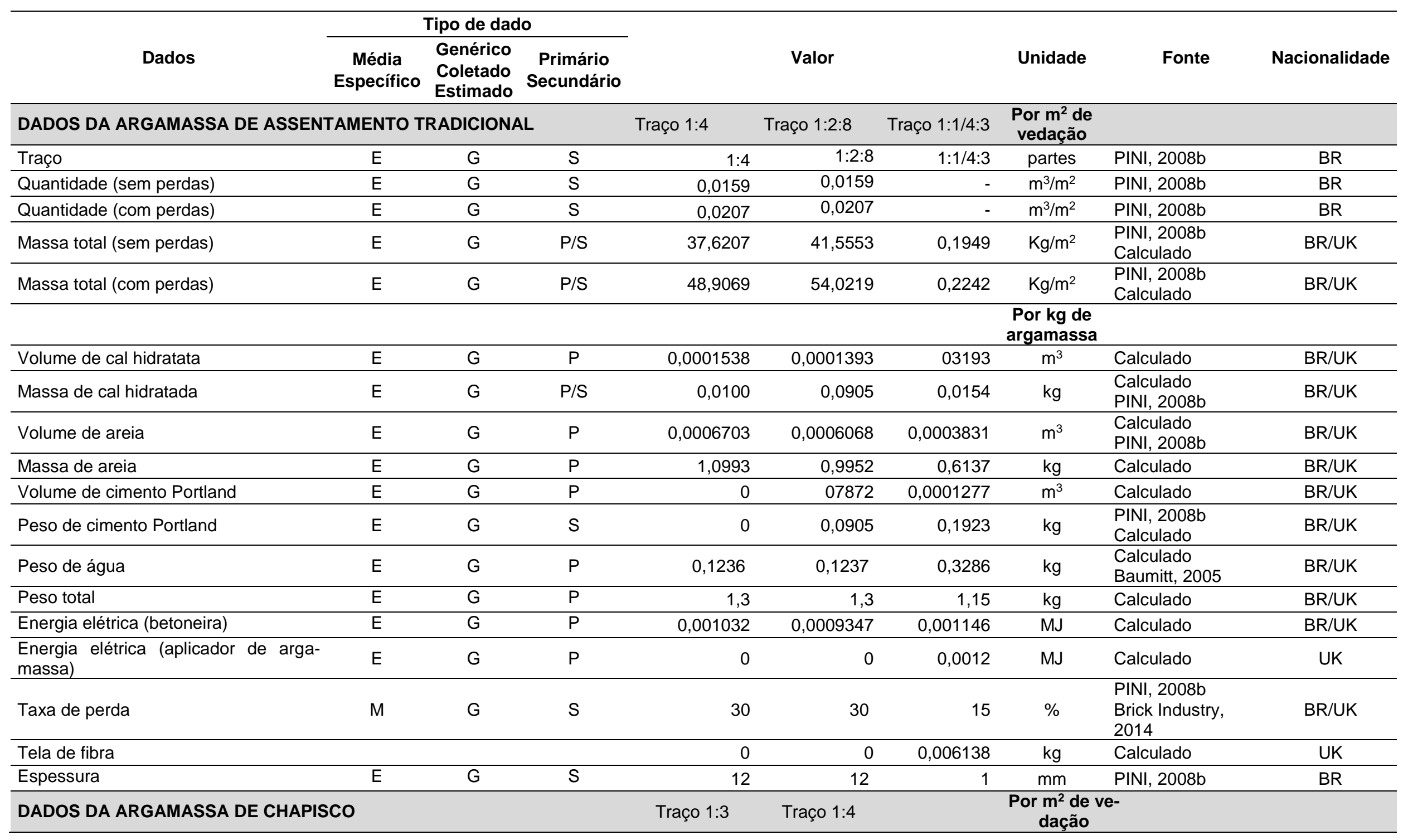




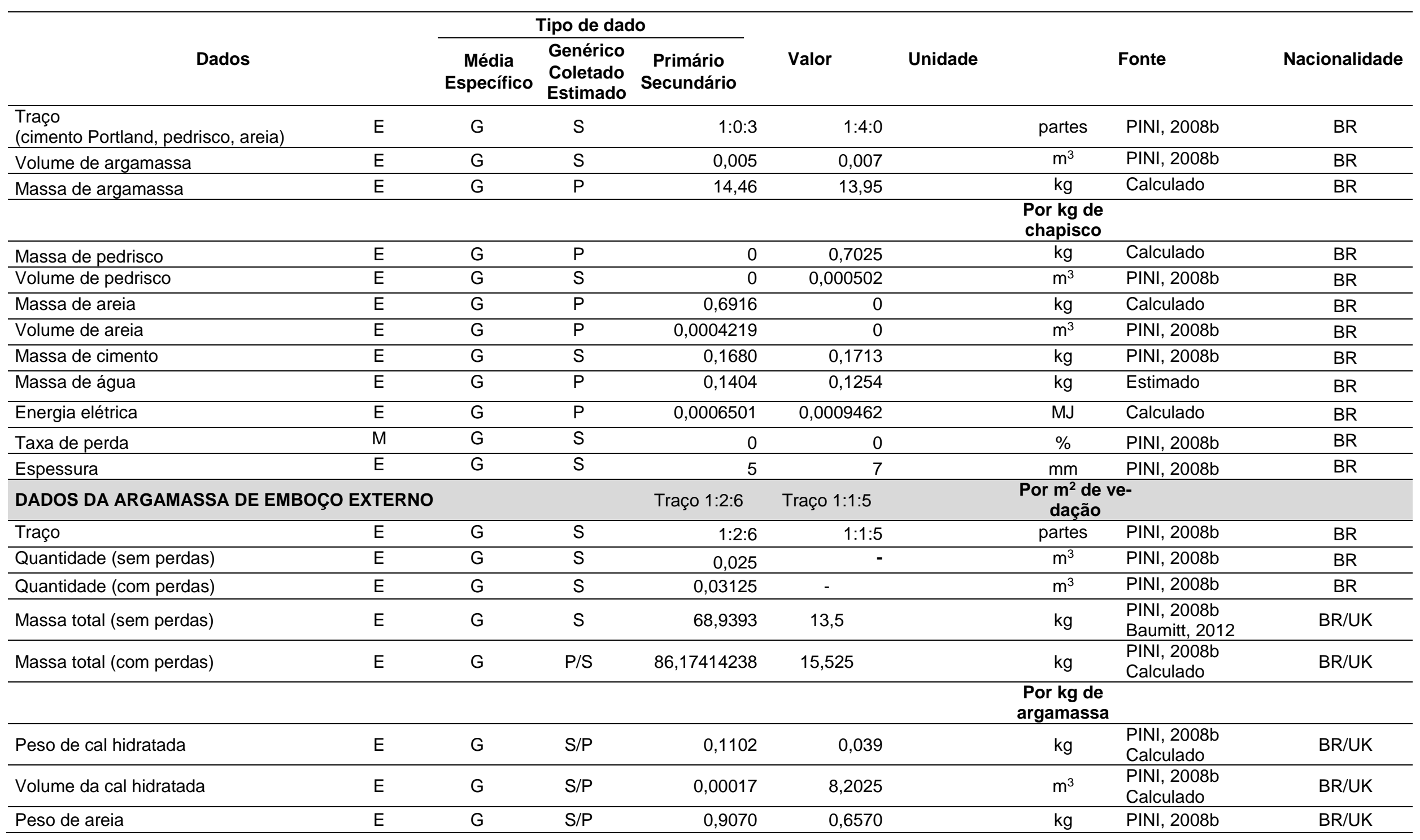




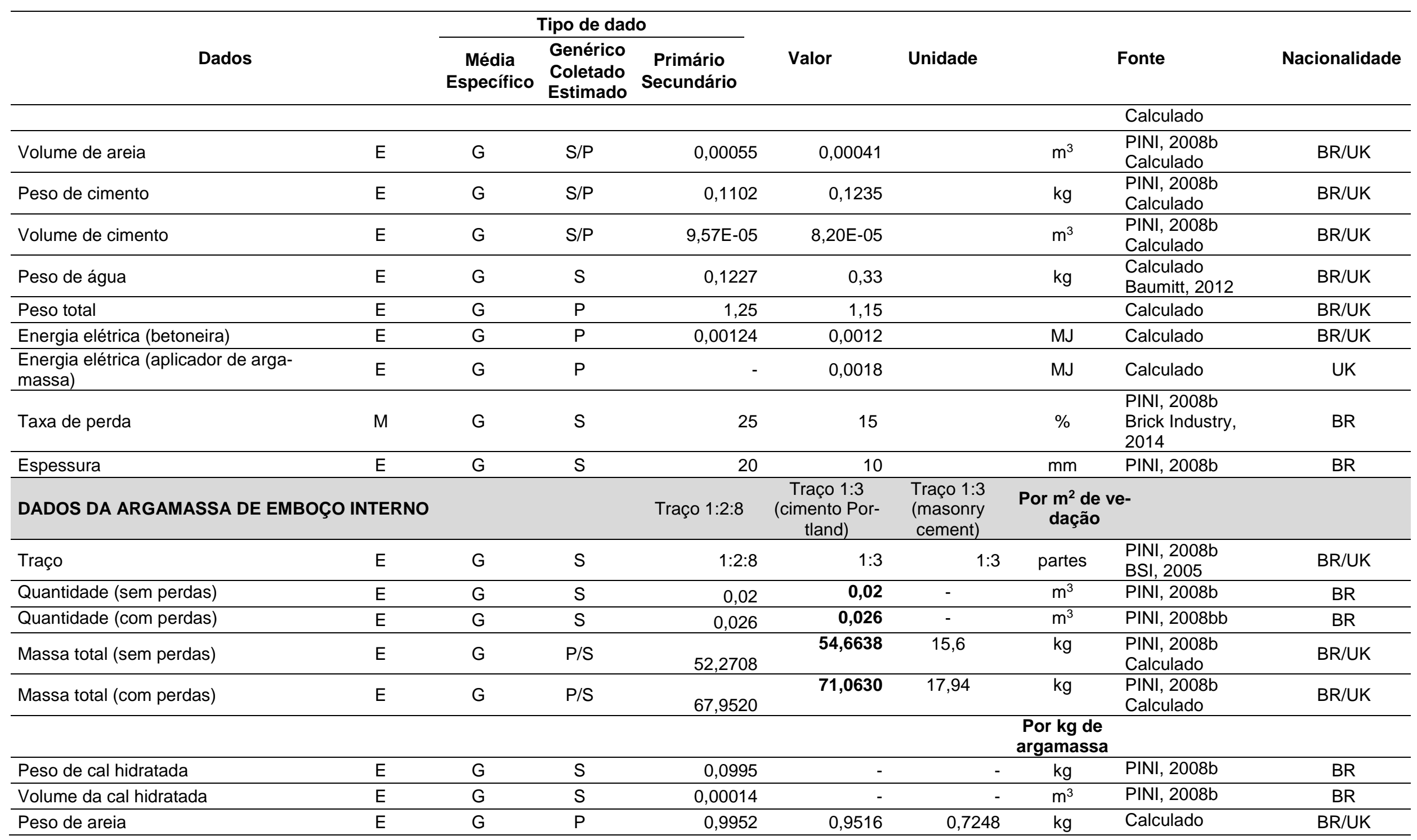




\begin{tabular}{|c|c|c|c|c|c|c|c|c|c|}
\hline \multirow[b]{2}{*}{ Dados } & & \multicolumn{3}{|c|}{ Tipo de dado } & \multirow[b]{2}{*}{ Valor } & \multirow[b]{2}{*}{ Unidade } & & \multirow[b]{2}{*}{ Fonte } & \multirow[b]{2}{*}{ Nacionalidade } \\
\hline & & $\begin{array}{c}\text { Média } \\
\text { Específico }\end{array}$ & $\begin{array}{l}\text { Genérico } \\
\text { Coletado } \\
\text { Estimado }\end{array}$ & $\begin{array}{l}\text { Primário } \\
\text { Secundário }\end{array}$ & & & & & \\
\hline Volume de areia & $E$ & G & $P$ & 0,00060 & 0,00058 & 0,00045 & $\mathrm{~m}^{3}$ & $\begin{array}{l}\text { PINI, 2008b } \\
\text { Calculado }\end{array}$ & BR/UK \\
\hline Peso de cimento Portland & $E$ & $\mathrm{G}$ & $S$ & 0,0905 & 0,2311 & - & $\mathrm{kg}$ & PINI, 2008b & $\mathrm{BR}$ \\
\hline Volume de cimento Portland & $E$ & $G$ & $P$ & 7,87E-05 & 0,00020 & - & $\mathrm{m}^{3}$ & Calculado & BR \\
\hline Peso de masonry cement & $E$ & $\mathrm{G}$ & $\mathrm{P}$ & - & - & 0,2051 & $\mathrm{~kg}$ & Calculado & UK \\
\hline Volume de masonry cement & $E$ & $\mathrm{G}$ & $\mathrm{P}$ & - & - & 0,00015 & $\mathrm{~m}^{3}$ & Calculado & UK \\
\hline Peso de água & $E$ & G & $\mathrm{P} / \mathrm{S}$ & 0,1237 & 0,1172 & 0,22 & $\mathrm{~kg}$ & $\begin{array}{l}\text { Calculado } \\
\text { Lime Technology, } \\
2014\end{array}$ & BR/UK \\
\hline Peso total & & & & 1,3 & 1,3 & 1,15 & $\mathrm{~kg}$ & Calculado & BR/UK \\
\hline Energia elétrica (betoneira) & $E$ & $\mathrm{G}$ & $\mathrm{P}$ & 0,00093 & 0,00089 & 0,0010 & $\mathrm{MJ}$ & Calculado & BR/UK \\
\hline $\begin{array}{l}\text { Energia elétrica (aplicador de arga- } \\
\text { massa) }\end{array}$ & $E$ & G & $\mathrm{P}$ & - & - & 0,0016 & MJ & Calculado & BR/UK \\
\hline Taxa de perda & M & $\mathrm{G}$ & $\mathrm{S}$ & 30 & 30 & 15 & $\%$ & $\begin{array}{l}\text { PINI, 2008b } \\
\text { Brick Industry, } \\
2014\end{array}$ & BR/UK \\
\hline Espessura & $E$ & G & $\mathrm{S} / \mathrm{P}$ & 20 & 20 & 12 & $\mathrm{~mm}$ & $\begin{array}{l}\text { PINI, 2008b } \\
\text { Visita técnica }\end{array}$ & BR/UK \\
\hline
\end{tabular}




\section{Apêndice I: Lista de processos utilizados na ACV da vedação de bloco cerâmico}

\section{Processos}

DE: Cal Hidratada $\left(\mathrm{Ca}(\mathrm{OH})_{2}\right.$; seca; slaked lime) PE

RER: Areia Média 0/2 PE

\section{Descrição}

Processo de fabricação da cal hidratada considerando desde a extração das matérias-primas até o produto fabricado. Apesar de o processo produtivo ser para a Alemanha, as características descritas se assemelham ao processo produtivo no Brasil.

Os dados deste processo são do "berço ao portão" abrangendo a extração da pedra calcária, a limpeza, as etapas de trituração, moagem e crivagem. A cobertura é de pelo menos $95 \%$ de massa e energia da entrada e saída de fluxos, e $98 \%$ de sua relevância ambiental (de acordo com a opinião de peritos). Considerando que a área do DF e entorno é uma área de nascentes, a extração da areia se dá, sobretudo por britagem da areia e não por dragagem de rios, por isso adotou-se nesta avaliação o processo produtivo da areia britada.

RER: Cimento Portland (CEM I) ELCD/CEMBUREAU

São considerados neste processo: extração de matéria-prima, produção do clinker e moagem do cimento, ou seja, do "berço ao portão". Cobertura de pelo menos 95\% de massa e energia da entrada e saída de fluxos, e 98\% de sua relevância ambiental (de acordo com a opinião de peritos).

RER: Pedrisco 2/32 PE

Processo de extração das pedras e preparação do pedrisco

BR: Mix de Energia Elétrica PE

Neste processo foi considerada a matriz energética brasileira com a composição de $79,7 \%$ hidrelétricas, $6,3 \%$ gás natural, 4,3\% biomassa, 3,8\% petróleo, 3,0\% nuclear, 1,4\% carvão mineral, 1,2\% carvão, 0,2\% de eólica e $0,1 \%$ de solar. Inclui produção, transporte, conversão e transmissão até o usuário final, além da energia que é importada.

GB: Mix de Energia Elétrica PE

Neste processo foi considerada a matriz energética do Reino Unido com a composição de 43,29 eólica, 27,36\% resíduos, 18.08\% nuclear, $2,43 \%$ gás natural, $2,34 \%$ hidrelétrica, $1,73 \%$ fotovoltáico, $1,46 \%$ lignite, $1,14 \%$ óleo pesado, $0,92 \%$ biomassa e $0,37 \%$ carvão. Inclui produção, transporte, conversão e transmissão até o usuário final, além da energia que é importada.

Porotherm process

Processo de fabricação do bloco poroso cerâmico a partir de argila retirada da mina, argila retirada na fábrica, areia, calcário e cal. O bloco é moldado por extrusão, queimado em forno utilizando gás natural e biomassa e seco. Abrange desde a entrada das matérias-primas na fábrica até o produto pronto para ser entregue

Masonry cement

Cimento que contém maior quantidade de cal que o cimento Portland. Esse plano é constituído por cimento Portland PLC e cimento Portland (CEM I)

Calcário moído $\left(\mathrm{CaCO}_{3} ;\right.$ seco $)$

O conjunto de dados abrange todas as etapas/tecnologias relevantes do processo ao longo da cadeia produtiva do berço ao portão. O inventário é baseado principalmente em dados da indústria e é completado, quando necessário, por dados secundários. A moagem de calcário é feita num processo de múltiplos passos, usando moinhos de rolagem. A eletricidade usada é modelada de acordo com a situação específica de cada país. As diferentes técnicas de mineração e exploração (emissões e eficiências) nos diferentes países de exploração são contabilizadas de acordo com o conhecimento atual e as informações de engenharia. Todos os processos relevantes e conhecidos de transporte utilizados estão incluídos.

$\mathrm{DE}$ : $\mathrm{Cal}\left(\mathrm{CaO}\right.$; quicklime irregular) PE $\quad \mathrm{A}$ cal viva $(\mathrm{CaO})$ é fabricada tecnicamente por desacidificação de pedra calcária $(\mathrm{CaCO} 3)$ a temperaturas superiores a $900{ }^{\circ} \mathrm{C}$. Isto 
Processos

Fibra de vidro

\section{Descrição}

conduz, em média, para a produção de $7,58 \mathrm{~kg}$ de $\mathrm{CO}_{2} / \mathrm{t}$ de Cal. Estas emissões são fisicamente determinada e eles dominam o balanço de CO2 do processo de queima de cal. Diferentes tipos de fornos verticais são considerados. Os combustíveis que são adicionados ao calcário são carvão mineral ou combustíveis como o gás natural ou o óleo de aquecimento, que são colocadas em estufa. A eletricidade usada é modelada de acordo com a situação específica de cada país. As diferentes técnicas de mineração e exploração (emissões e eficiências) nos diferentes países de exploração são contabilizadas de acordo com o conhecimento atual e as informações de engenharia. Todos os processos relevantes e conhecidos de transporte estão incluídos.

Os limites do sistema compreendem o berço ao ciclo de vida do portão deste produto de isolamento de fibra de vidro. Os dados refletem a tecnologia utilizada na indústria da América do Norte em 2007. Nos casos em que não há dados primários estavam disponíveis, foram utilizados tanto estimativas fornecidas pelas empresas envolvidas ou dados calculados. Embalagens também estão incluídas. A eletricidade usada no processo é modelada de acordo com a situação específica de cada país. As diferentes técnicas de mineração e exploração (emissões e eficiências) de cada país são contabilizadas de acordo com o conhecimento atual e as informações de engenharia.

Transporte

Esse plano é constituído pelos processos Mix de Diesel na Refinaria PE e Caminhão (Euro 5, payload 12t), além de um processo que define qual é a nacionalidade do diesel

BR: Mix de Diesel na Refinaria PE

O diesel é obtido pelo refino do petróleo, processos de destilação atmosférica, craqueamento catalítico fluido e craqueamento retardado. Para a remoção das impurezas do diesel, os gasóleos são tratados quimicamente com hidrogênio, nafta e querosene. Os dados deste processo contêm os subprocessos de geração de eletricidade, energia térmica, transporte dos materiais e fabricação dos produtos na refinaria. Cobertura de pelo menos $95 \%$ de massa e energia da entrada e saída de fluxos, e $98 \%$ de sua relevância ambiental (de acordo com a opinião de peritos). O processo adotado é específico para o diesel brasileiro.

GB: Mix de Diesel na Refinaria PE

O conjunto de dados abrange toda a cadeia produtiva de produtos da refinaria de petróleo. Isso inclui perfuração de poços, a produção e processamento de petróleo bruto, bem como transporte de petróleo por oleoduto e navio para a refinaria. Principais tecnologias como produção convencional (primário, secundário, terciário) e não-convencional (areias betuminosas, in-situ), incluindo em ambas os parâmetros como o consumo de energia, as distâncias de transporte e tecnologias de processamento de petróleo bruto. Também são consideradas propriedades de matéria-prima (petróleo bruto) e produto (óleo diesel, etc.), como teores de enxofre. Os componentes biogênicos misturados ao combustível fóssil também são modelados individualmente. O inventário é baseado principalmente em dados da indústria e é completado, quando necessário, por dados secundários.

Processo de vapor de gás natural $90 \%$

O conjunto de dados abrange todas as etapas relevantes do processo e tecnologias ao longo da cadeia produtiva. A mistura nacional de energia é utilizada para o processo de produção de vapor. Um modelo detalhado usina de energia elétrica é usado, que combina medidas (por exemplo NOx) com valores de emissão calculados (por exemplo, metais pesados). Em geral, as eficiências de processo de vapor são: $85 \%, 90 \%$ e $95 \%$. O inventário é baseado em dados da indústria primária e em dados da literatura secundárias.

Caminhão (Euro 5, payload 12t)

O caminhão adotado na análise possui a capacidade de 11,4 t e padrão Euro 5 de emissões. As distâncias percorridas variam conforme médias calculadas com base no levantamento da localização dos fornecedores.

As partículas de enxofre por milhão foram alteradas para 1800 ppm. 


\begin{tabular}{|c|c|}
\hline Processos & Descrição \\
\hline $\begin{array}{l}\text { Transporte, combinação de caminhões, } \\
\text { combustível diesel }\end{array}$ & Processo de transporte que combina diferentes tipos de caminhões para o uso de um caminhão médios modais \\
\hline $\begin{array}{l}\text { Diesel, queimado em equipamento in- } \\
\text { dustrial (saída em MJ) }\end{array}$ & $\begin{array}{l}\text { Esses processos tiveram a saída adaptada para MJ para possibilitar a conexão no software, visto que o mesmo fluxo deve ser co- } \\
\text { nectado de um processo para o outro }\end{array}$ \\
\hline $\begin{array}{l}\text { BR: LPG, queimado em equipamento } \\
\text { industrial (saída em MJ) }\end{array}$ & $\begin{array}{l}\text { Esses processos tiveram a saída adaptada para MJ para possibilitar a conexão no software, visto que o mesmo fluxo deve ser co- } \\
\text { nectado de um processo para o outro }\end{array}$ \\
\hline Argila da mina/CH U & Argila extraída na mina e levada para a fábrica. Cobre todos os processos relevantes para a extração da argila. \\
\hline \multirow{3}{*}{$\begin{array}{l}\text { BR: Água tratada } \\
\text { GB: Água tratada }\end{array}$} & O conjunto de dados deste processo abrange todas as etapas e tecnologias relevantes da cadeia do "berço ao portão". O inventá- \\
\hline & $\begin{array}{l}\text { rio baseou-se em dados da indústria e, quando necessário, em dados secundários. O termo "Tratamento de água" abrange todos } \\
\text { os tipos de aplicações de água industrial. }\end{array}$ \\
\hline & $\begin{array}{l}\text { Essa tecnologia considera o tratamento da água e as etapas de filtragem, sedimentação, descarbonização, desinfecção e filtra- } \\
\text { gem. }\end{array}$ \\
\hline \multirow[t]{2}{*}{ BR: Escavadeira } & $\begin{array}{l}\text { Os dados deste processo foram construídos com base na literatura e em planilhas dos fabricantes das máquinas. Possui a cober- } \\
\text { tura de pelo menos } 95 \% \text { de massa e energia da entrada e saída de fluxos, e } 98 \% \text { de sua relevância ambiental. }\end{array}$ \\
\hline & $\begin{array}{l}\text { A máquina escavadora deste processo é usada em processos do setor da construção. O sistema limita-se a fase de operação da } \\
\text { máquina utilizando as entradas do material escavado e combustível e as saídas emissões de combustão. }\end{array}$ \\
\hline $\begin{array}{l}\text { US: Resíduo de Madeira, não especifi- } \\
\text { cado, queimado em indústrias }\end{array}$ & Dados do inventário US LCI para produção de biomassa, do berço ao portão, para utilização como combustível. \\
\hline BR: Fabricação do bloco cerâmico & $\begin{array}{l}\text { Processo de fabricação do bloco cerâmico considerando todas as matérias primas já dentro da fábrica. O consumo de energia e } \\
\text { combustíveis estão associados ao maquinário envolvido no processo produtivo dos blocos. A energia elétrica está associada ao } \\
\text { processamento de matéria prima, movimentação da matéria prima e dos blocos na fábrica antes da queima, secagem dos blocos } \\
\text { em alguns casos, e demais fontes de consumo de energia da fábrica, como iluminação, equipamentos de escritório, etc. O consu- } \\
\text { mo de GLP está associado às empilhadeiras usadas na movimentação dos blocos já queimados. O consumo de madeira está as- } \\
\text { sociado à queima dos blocos. }\end{array}$ \\
\hline $\begin{array}{l}\text { GLO: Aterro sanitário para produtos iner- } \\
\text { tes (Glass) }\end{array}$ & $\begin{array}{l}\text { O dado cobre todos os processos e tecnologias relevantess para o tratamento dos resíduos no aterro sanitário. O inventário é, } \\
\text { principalmente, baseado nos dados da indústria e é complementado com dados secundários. }\end{array}$ \\
\hline $\begin{array}{l}\text { BR: Mortar mix 1:4 (hydrated lime:sand) } \\
\text { - thin bed }\end{array}$ & $\begin{array}{l}\text { Produção de argamassa traço } 1: 4 \text { de cal hidratada e areia utilizada para o assentamento dos blocos, preparada com betoneira e } \\
\text { aplicada manualmente }\end{array}$ \\
\hline $\begin{array}{l}\text { BR: Mortar mix 1:2:8 (cement:hydrated } \\
\text { lime:sand) }\end{array}$ & $\begin{array}{l}\text { Produção de argamassa traço } 1: 2: 8 \text { de cimento Portland, cal hidratada e areia utilizado para o revestimento interno da vedação } \\
\text { vertical, preparada com betoneira e aplicada manualmente }\end{array}$ \\
\hline
\end{tabular}




\begin{tabular}{|c|c|}
\hline Processos & Descrição \\
\hline BR: Mortar mix 1:4 (cement:gravel) & $\begin{array}{l}\text { Produção de argamassa traço } 1: 4 \text { de cimento Portland e pedrisco, utilizada para o chapisco, preparada com betoneira e aplicada } \\
\text { manualmente }\end{array}$ \\
\hline $\begin{array}{l}\text { BR: Mortar mix 1:2:6 (cement:hydrated } \\
\text { lime:sand) }\end{array}$ & $\begin{array}{l}\text { Produção de argamassa traço } 1: 2: 6 \text { de cimento Portland, cal hidratada e areia, utilizada para o revestimento externo, preparada } \\
\text { com betoneira e aplicada manualmente }\end{array}$ \\
\hline BR: Mortar mix 1:3 (cement:sand) & $\begin{array}{l}\text { Produção de argamassa traço } 1: 3 \text { de cimento Portland e areia, utilizada para chapisco, preparada com betoneira e aplicada manu- } \\
\text { almente }\end{array}$ \\
\hline $\begin{array}{l}\text { GB: Mortar mix 1:3 (masonry ce- } \\
\text { ment:sand) - int. wall }\end{array}$ & $\begin{array}{l}\text { Produção de argamassa traço } 1: 3 \text { de masonry cement e areia, utilizada para o revestimento interno, preparada com misturador } \\
\text { manual e aplicada com spray elétrico de aplicação de argamassa }\end{array}$ \\
\hline $\begin{array}{l}\text { GB: Mortar mix 1:1/4:3 (Ce- } \\
\text { ment:lime:sand) - wet mortar - thin bed }\end{array}$ & $\begin{array}{l}\text { Produção de argamassa traço } 1: 1 / 4: 3 \text { de cimento Portland, cal e areia, utilizada para o assentamento de blocos, preparada com } \\
\text { misturador manual e aplicada com maquinário não elétrico }\end{array}$ \\
\hline GB: Mortar mix 1:1:5 (cement:lime:sand) & $\begin{array}{l}\text { Produção de argamassa traço } 1: 1: 5 \text { de cimento Portland, cal e areia, utilizada para o revestimento externo, preparada com mistu- } \\
\text { rador manual e aplicada com spray elétrico de aplicação de argamassa }\end{array}$ \\
\hline UK: Mortar waste disposal & Os resíduos de argamassa são enviados ao aterro sanitário para tratamento do resíduo e descarte final \\
\hline GLO: Clay Brick Typology_new & Processo que contém todos os blocos e argamassas utilizados e parametrizado conforme plano geral \\
\hline GLO: Brick waste processing_new & $\begin{array}{l}\text { Os resíduos do bloco são enviados ao aterro sanitário para tratamento do resíduo e descarte final, sem do destinado para reuso, } \\
\text { reciclagem ou envio para disposição final }\end{array}$ \\
\hline GLO: Crushed recycled aggregate & $\begin{array}{l}\text { Os resíduos que são reciclados são triturados e transformados em agregado reciclado. Esse processo foi construído com base no } \\
\text { processo de produção do calcário triturado }\end{array}$ \\
\hline Brick waste disposal & Contém os processos e as demandas de energia para a disposição final dos resíduos que não são reciclados ou reaproveitados \\
\hline GLO: Agregado reciclado & vo para a saída de agregado virgem como forma de reaproveitar os resíduos gerados pela vedação vertical \\
\hline
\end{tabular}




\section{Apêndice J: Parâmetros livres e fixos inseridos no MTP inicial}

\begin{tabular}{|c|c|c|c|c|}
\hline $\begin{array}{l}\text { Nome do Pro- } \\
\text { cesso ou Plano }\end{array}$ & Código & Fórmula & Valor & Comentário \\
\hline \multicolumn{5}{|c|}{ Parâmetros livres } \\
\hline $\begin{array}{l}\text { MTP - VV ex- } \\
\text { terna }\end{array}$ & t_bio_forno & - & 1 & \\
\hline \multirow{3}{*}{$\begin{array}{l}\text { BR: Argamassa } \\
\text { Assentamento }\end{array}$} & $\begin{array}{l}\text { A_CiCaAr_1_0 } \\
\text { 5_8 }\end{array}$ & - & 1 & Valor verdadeiro_falso \\
\hline & betoneira & - & 0 & Valor verdadeiro falso \\
\hline & manual & - & 1 & Valor verdadeiro_falso \\
\hline \multirow{8}{*}{ BR: b_ceramico } & $\mathrm{a}$ & - & 19 & $\mathrm{~cm}$ (altura) \\
\hline & c & - & 19 & cm (comprimento) \\
\hline & 1 & - & 9 & $\mathrm{~cm}$ (largura) \\
\hline & perc_clay & - & 0,58 & percentual \\
\hline & perc_evapora & - & 0,0659 & \\
\hline & perc_water & - & 0,18 & percentual \\
\hline & perda & - & 0,05 & percentual \\
\hline & porc_cinza & - & 0,15 & Depende do tipo de madeira \\
\hline \multirow[b]{2}{*}{$\begin{array}{l}\text { BR: Clay Brick } \\
\text { Laying Mortar }\end{array}$} & maquinario & - & 1 & 0: Manual; 1: Betoneira \\
\hline & traco & - & 1 & $\begin{array}{l}\text { 0: CalcárioAreiaCimento(1:4 com } 100 \\
\mathrm{~kg} \text { de cimento); } 1 \text { : CimentoAreiaCalcário } \\
(1: 2: 8)\end{array}$ \\
\hline \multirow{6}{*}{$\begin{array}{l}\text { BR: Tipolo- } \\
\text { gia_bloco }\end{array}$} & peso_1_2_6 & - & 0 & \\
\hline & peso_1_2_8 & - & 0 & \\
\hline & peso_1_3_c_s & - & 0 & \\
\hline & peso_1_4_c_g & - & 0 & \\
\hline & peso_1_4_I_s & - & 0 & \\
\hline & peso_bloco & - & 6 & \\
\hline BR: Plaster Mor- & maquinario & - & 1 & 0: Manual; 1 : Betoneira \\
\hline
\end{tabular}




\begin{tabular}{|c|c|c|c|c|}
\hline tar & traco & - & 1 & $\begin{array}{l}\text { 0: CalcárioAreiaCimento(1:4 com 100 } \\
\text { kg de cimento); 1: CimentoAreiaCalcário } \\
(1: 2: 8)\end{array}$ \\
\hline \multirow[b]{2}{*}{$\begin{array}{l}\text { BR: Rough Cast } \\
\text { Mortar }\end{array}$} & maquinario & - & 1 & 0: Manual; 1: Betoneira \\
\hline & traco & - & 1 & $\begin{array}{l}\text { 0: traco 1:3 (cimento; areia média) } 1 \text { de } \\
\text { água; } 1 \text { : traco 1:4 (cimento; pedrisco) } 1 \\
\text { de água (literatur }\end{array}$ \\
\hline \multirow{2}{*}{ GLO: Truck PE } & distance & - & 100 & $\begin{array}{l}{[\mathrm{km}] \text { distance start - end, default }=100} \\
\mathrm{~km}\end{array}$ \\
\hline & ppm_sulfur & - & 10 & $\begin{array}{l}\text { [ppm] sulphur content in diesel, default } \\
\text { Europe }=10 \text { ppm }\end{array}$ \\
\hline \multicolumn{5}{|c|}{ Parâmetros fixos } \\
\hline \multirow[t]{15}{*}{$\begin{array}{l}\text { BR: Argamassa } \\
\text { Assentamento }\end{array}$} & cons_betoneira & $2^{\star} 745,7^{*} 1260 / 1000000$ & 1,879164 & $\begin{array}{l}\text { MJ/m3 (conversao de HP para W*tempo } \\
\text { de betoneira por m3/conversão para } \\
\text { MJ) }\end{array}$ \\
\hline & den_agua & 1000 & 1000 & $\mathrm{~kg} / \mathrm{m} 3$ (literatura) \\
\hline & dens_areia & 1640 & 1640 & kg/m3 (literatura) \\
\hline & dens_cimento & 1150 & 1150 & kg/m3 (literatura) \\
\hline & energia & $\begin{array}{l}\text { if(('BR: Argamassa Assentamento Bloco de Concreto <u-sos'.betoneira=1) and ('BR: Argamassa Assen- } \\
\text { tamento Bloco de Concreto <u-so>'.manual=0);('BR: Argamassa Assentamento Bloco de Concreto <u- } \\
\text { sos'.vol_total_e+'BR: Argamassa Assentamento Bloco de Concreto <u-so>'.vol_agua) }{ }^{\star \prime} B R \text { : Argamassa } \\
\text { Assentamento Bloco de Concreto <u-so>'.cons_betoneira;0) }\end{array}$ & 0 & MJ (calclulado) \\
\hline & espessura & 10 & 10 & $\mathrm{~mm}$ (literatura) \\
\hline & perda & 0,3 & 0,3 & porcentagem (literatura) \\
\hline & peso_agua & $\begin{array}{l}\text { 'BR: Argamassa Assentamento Bloco de Concreto <u-so>'.vol_agua*'BR: Argamassa Assentamento Blo- } \\
\text { co de Concreto <u-so>'.den_agua }\end{array}$ & 2,412169 & $\mathrm{~kg}$ (calculado) \\
\hline & peso_areia & $\begin{array}{l}\text { 'BR: Argamassa Assentamento Bloco de Concreto <u-so>'.vol_areia*'BR: Argamassa Assentamento Blo- } \\
\text { co de Concreto <u-so>'.dens_areia }\end{array}$ & 22,20888 & $\mathrm{~kg}$ (calculado) \\
\hline & peso_cal & if('BR: Argamassa Assentamento Bloco de Concreto <u-so>'.A_CiCaAr_1_05_8=1;0,5106;0) & 0,5106 & kg (literatura) \\
\hline & peso_cimento & if('BR: Argamassa Assentamento Bloco de Concreto <u-so>'.A_CiCaAr_1_05_8=1;2,0202;0) & 2,0202 & kg (literatura) \\
\hline & peso_residuo & $\begin{array}{l}\text { 'BR: Argamassa Assentamento Bloco de Concreto <u-so>'.peso_total'BR: Argamassa Assentamento } \\
\text { Bloco de Concreto <u-so>'.perda }\end{array}$ & 8,145555 & $\mathrm{~kg}$ (calculado) \\
\hline & peso_total & $\begin{array}{l}\text { 'BR: Argamassa Assentamento Bloco de Concreto <u-so>'.peso_cal+'BR: Argamassa Assentamento Blo- } \\
\text { co de Concreto <u-so>'.peso_areia+'BR: Argamassa Assentamento Bloco de Concreto <u- } \\
\text { so>'.peso_cimento+'BR: Argamassa Assentamento Bloco de Concreto <u-so>'.peso_agua }\end{array}$ & 27,15185 & kg (calculado) \\
\hline & vol_agua & 0,15*'BR: Argamassa Assentamento Bloco de Concreto <u-so>'.vol_total_e & 0,002412 & m3 (literatura) \\
\hline & vol_areia & if('BR: Argamassa Assentamento Bloco de Concreto <u-so>'.A_CiCaAr_1_05_8=1;0,013542;0) & 0,013542 & m3 (literatura) \\
\hline
\end{tabular}




\begin{tabular}{|c|c|c|c|c|}
\hline & vol_total_e & $\begin{array}{l}\text { if('BR: Argamassa Assentamento Bloco de Concreto <u-so>'.A_CiCaAr_1_05_8=1;9,5/8*'BR: Argamassa } \\
\text { Assentamento Bloco de Concreto <u-so>'.vol_areia;0) }\end{array}$ & 0,016081 & m3 (calculado) \\
\hline & vol_total_s & 0,0111 & 0,0111 & m3 (literatura) \\
\hline \multirow[t]{14}{*}{ BR: b_ceramico } & biomassa & $\begin{array}{l}\text { 'BR: b_ceramico_natural_tunel_lenha <u-so>'.peso_clay*'BR: b_ceramico_natural_tunel_lenha }<\text { u- } \\
\text { so }>\text { '.le tunel }\end{array}$ & 0,149582 & de acordo com a biomassa e o forno \\
\hline & cinza & $\begin{array}{l}\text { 'BR: b_ceramico_natural_tunel_lenha <u-so>'.biomassa'BR: b_ceramico_natural_tunel_lenha }<\text { u- } \\
\text { so>'.porc_cinza }\end{array}$ & 0,022437 & \\
\hline & con_diesel & 0,000808372*'BR: b_ceramico_natural_tunel_lenha <u-so>'.peso_clay & 0,001088 & \\
\hline & con_glp & 0,000258362*'BR: b_ceramico_natural_tunel_lenha <u-so>'.peso_clay & 0,000348 & \\
\hline & d & 0,00068 & 0,00068 & $\mathrm{~kg} / \mathrm{cm} 3$ (densidade) \\
\hline & en_nat & 0,054194393 & 0,054194 & $\begin{array}{l}\mathrm{MJ} / \mathrm{kg} \text { de argila entrada (secagem natu- } \\
\text { ral) }\end{array}$ \\
\hline & energia & $\begin{array}{l}\text { 'BR: b_ceramico_natural_tunel_lenha }<\text { u-so>'.peso_clay*'BR: b_ceramico_natural_tunel_lenha }<\text { u- } \\
\text { so>'.en_nat }\end{array}$ & 0,072917 & de acordo com o tipo de secagem \\
\hline & Ie_tunel & $0,11117 \overline{7755}$ & 0,111174 & kg/kg de argila (lenha para forno túnel) \\
\hline & peso_agua & $\begin{array}{l}\text { 'BR: b_ceramico_natural_tunel_lenha <u-so>'.peso_entrada*'BR: b_ceramico_natural_tunel_lenha <u- } \\
\text { so>'.perc_water }\end{array}$ & 0,417561 & \\
\hline & peso_bloco & 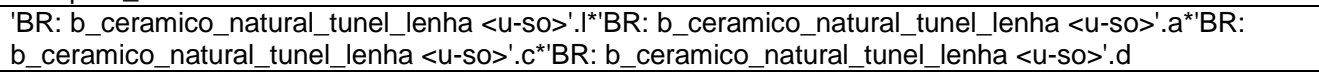 & 2,20932 & $\begin{array}{l}\text { Cálculo do peso com base na densida- } \\
\text { de e volume }\end{array}$ \\
\hline & peso_clay & $\begin{array}{l}\text { 'BR: b_ceramico_natural_tunel_lenha }<\text { u-so>'.peso_entrada*'BR: b_ceramico_natural_tunel_lenha }<\text { u- } \\
\text { so }>\text { '.perc_clay }\end{array}$ & 1,345476 & \\
\hline & peso_entrada & $\begin{array}{l}\text { 'BR: b_ceramico_natural_tunel_lenha <u-so>'.peso_bloco*(1+'BR: b_ceramico_natural_tunel_lenha <u- } \\
\text { so>'.perda) }\end{array}$ & 2,319786 & \\
\hline & peso_evapora & $\begin{array}{l}\text { 'BR: b_ceramico_natural_tunel_lenha <u-so>'.peso_entrada*'BR: b_ceramico_natural_tunel_lenha <u- } \\
\text { so >'.perc_evapora }\end{array}$ & 0,152874 & \\
\hline & peso_perda & $\begin{array}{l}\text { 'BR: b_ceramico_natural_tunel_lenha <u-so>'.peso_bloco*'BR: b_ceramico_natural_tunel_lenha }<\text { u- } \\
\text { sos'.perda }\end{array}$ & 0,110466 & \\
\hline \multirow[t]{7}{*}{$\begin{array}{l}\text { BR: Clay Brick } \\
\text { Laying Mortar }\end{array}$} & cons_betoneira & $2^{*} 745,7^{*} 1260 / 1000000$ & 1,879164 & $\begin{array}{l}\mathrm{MJ} / \mathrm{m} 3 \text { (conversao de HP para } \mathrm{W}^{*} \text { tempo } \\
\text { de betoneira por } \mathrm{m} 3 / \text { conversão para } \\
\mathrm{MJ} \text { ) }\end{array}$ \\
\hline & den_agua & 1000 & 1000 & kg/m3 (literatura) \\
\hline & dens_areia & 1640 & 1640 & kg/m3 (literatura) \\
\hline & dens_cal & 650 & 650 & kg/m3 (literatura) \\
\hline & dens_cimento & 1150 & 1150 & kg/m3 (literatura) \\
\hline & energia & $\begin{array}{l}\text { if('BR: Clay Brick Laying Mortar <u-so>'.maquinario=1;('BR: Clay Brick Laying Mortar <u- } \\
\text { so>'.vol_total_e+'BR: Clay Brick Laying Mortar <u-so>'.vol_agua)*'BR: Clay Brick Laying Mortar <u- } \\
\text { so>'.cons_betoneira;if('BR: Clay Brick Laying Mortar <u-so'.maquinario=0;0;0)) }\end{array}$ & 0,048939 & MJ (calclulado) \\
\hline & espessura & 12 & 12 & mm (literatura) \\
\hline
\end{tabular}




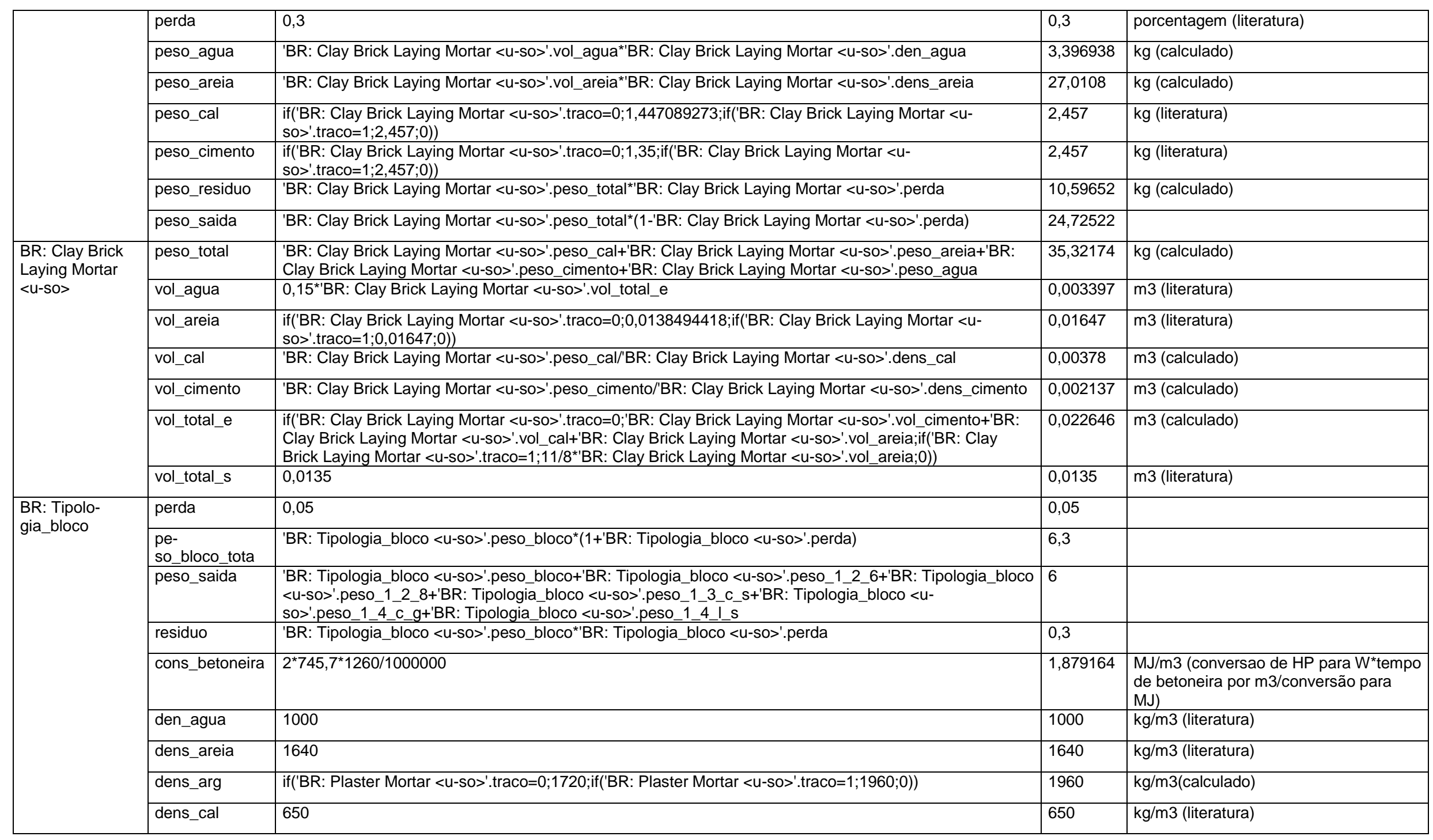




\begin{tabular}{|c|c|c|c|c|}
\hline & dens_cimento & 1150 & 1150 & $\mathrm{~kg} / \mathrm{m} 3$ (literatura) \\
\hline & energia & $\begin{array}{l}\text { if('BR: Plaster Mortar <u-so>'.maquinario=0;0;if('BR: Plaster Mortar <u-so>'.maquinario=1;('BR: Plaster } \\
\text { Mortar <u-so>'.vol_total_e+'BR: Plaster Mortar <u-so>'.vol_agua)"'BR: Plaster Mortar <u- } \\
\text { so>'.cons_betoneira;0)) }\end{array}$ & 0,072503 & MJ (calclulado) \\
\hline & espessura & 20 & 20 & mm (literatura) \\
\hline & perda & 0,25 & 0,25 & porcentagem (literatura) \\
\hline & peso_agua & 'BR: Plaster Mortar <u-so>'.vol_agua*'BR: Plaster Mortar <u-so>'.den_agua & 5,0325 & $\mathrm{~kg}$ (calculado) \\
\hline & peso_areia & 'BR: Plaster Mortar <u-so>'.vol_areia*'BR: Plaster Mortar <u-so>'.dens_areia & 40,016 & $\mathrm{~kg}$ (calculado) \\
\hline & peso_cal & if('BR: Plaster Mortar <u-so>'.traco=0;3,24688;if('BR: Plaster Mortar <u-so>'.traco=1;3,64;0)) & 3,64 & kg (literatura) \\
\hline & peso_cimento & if('BR: Plaster Mortar <u-so>'.traco=0;2,6;f('BR: Plaster Mortar <u-so>'.traco=1;3,64;0)) & 3,64 & kg (literatura) \\
\hline & peso_residuo & 'BR: Plaster Mortar <u-so>'.peso_total*'BR: Plaster Mortar <u-so>'.perda & 13,08213 & $\mathrm{~kg}$ (calculado) \\
\hline & peso_saida & 'BR: Plaster Mortar <u-so>'.peso_total*(1-'BR: Plaster Mortar <u-so>'.perda) & 39,24638 & \\
\hline & peso_total & $\begin{array}{l}\text { 'BR: Plaster Mortar <u-so>'.peso_cal+'BR: Plaster Mortar <u-so>'.peso_areia+'BR: Plaster Mortar <u- } \\
\text { so>'.peso_cimento+'BR: Plaster Mortar <u-so>'.peso_agua }\end{array}$ & 52,3285 & kg (calculado) \\
\hline & vol_agua & 0,15*'BR: Plaster Mortar <u-so>'.vol_total_e & 0,005033 & m3 (literatura) \\
\hline BR: Plaster Mor- & vol_areia & if('BR: Plaster Mortar <u-so>'.traco=0;0,0217648;if('BR: Plaster Mortar <u-so>'.traco=1;0,0244;0)) & 0,0244 & m3 (literatura) \\
\hline & vol_cal & 'BR: Plaster Mortar <u-so>'.peso_cal/'BR: Plaster Mortar <u-so>'.dens_cal & 0,0056 & m3 (calculado) \\
\hline & vol_cimento & 'BR: Plaster Mortar <u-so>'.peso_cimento/'BR: Plaster Mortar <u-so>'.dens_cimento & 0,003165 & m3 (calculado) \\
\hline & vol_total_e & $\begin{array}{l}\text { if('BR: Plaster Mortar <u-so>'.traco=0;'BR: Plaster Mortar <u-so>'.vol_cimento+'BR: Plaster Mortar <u- } \\
\text { so>'.vol_cal+'BR: Plaster Mortar <u-so>'.vol_areia;if('BR: Plaster Mortar <u-so>'.traco=1;11/8*'BR: Plaster } \\
\text { Mortar <u-so>'.vol_areia;0)) }\end{array}$ & 0,03355 & m3 (calculado) \\
\hline & vol_total_s & 0,02 & 0,02 & m3 (literatura) \\
\hline $\begin{array}{l}\text { BR: Rough Cast } \\
\text { Mortar }\end{array}$ & con_chapisco & 0,001 & 0,001 & $\begin{array}{l}\mathrm{m} 3 / 1 \mathrm{~mm}^{*} \mathrm{~m} 2 \text { (volume de chapisco con- } \\
\text { sumido por cada milimetro de espessu- } \\
\text { ra por metro quadrado) }\end{array}$ \\
\hline & cons_betoneira & $2^{*} 745,7^{*} 1260 / 1000000$ & 1,879164 & $\begin{array}{l}\mathrm{MJ} / \mathrm{m3} \text { (conversão de HP para } \mathrm{W}^{\star} \text { tempo } \\
\text { de betoneira por m3/conversão para } \\
\mathrm{MJ} \text { ) }\end{array}$ \\
\hline & den_agua & 1000 & 1000 & $\mathrm{~kg} / \mathrm{m} 3$ (literatura) \\
\hline & den_areia & 1640 & 1640 & kg/m3 (literatura) \\
\hline & den_pedrisco & 1400 & 1400 & kg/m3 (literatura) \\
\hline & energia & $\begin{array}{l}\text { if('BR: Rough Cast Mortar <u-so>'.maquinario=0;0;if('BR: Rough Cast Mortar <u-so>'.maquinario=1;'BR: } \\
\text { Rough Cast Mortar <u-so>'.vol_total"'BR: Rough Cast Mortar <u-so>'.cons_betoneira;0)) }\end{array}$ & 0,013154 & (calculado) \\
\hline
\end{tabular}




\begin{tabular}{|c|c|c|c|}
\hline perda & 0 & 0 & $\begin{array}{l}\text { a massa de perda é tão pequena que } \\
\text { não é considerada como um fator de } \\
\text { perdesdício pela TCPO }\end{array}$ \\
\hline peso_agua & $\begin{array}{l}\text { if('BR: Rough Cast Mortar <u-so>'.traco=0;'BR: Rough Cast Mortar <u-so>'.tra_0_vol_agua*'BR: Rough } \\
\text { Cast Mortar <u-so>'.den_agua;;f('BR: Rough Cast Mortar <u-so>'.traco=1;'BR: Rough Cast Mortar <u- } \\
\text { so>'.tra_1_vol_agua*'BR: Rough Cast Mortar <u-so>'.den_agua;0)) }\end{array}$ & 1,75 & kg (calculado) \\
\hline peso_areia & $\begin{array}{l}\text { if('BR: Rough Cast Mortar <u-so>'.traco=0;'BR: Rough Cast Mortar <u-so>'.den_areia*'BR: Rough Cast } \\
\text { Mortar <u-so>'.tra_0_vol_areia;if('BR: Rough Cast Mortar <u-so>'.traco=1;0;0)) }\end{array}$ & 0 & $\mathrm{~kg}$ (calculado) \\
\hline peso_cimento & if('BR: Rough Cast Mortar <u-so>'.traco=0;2,43;if('BR: Rough Cast Mortar <u-so>'.traco=1;2,394;0)) & 2,394 & $\mathrm{~kg}$ (calculado) \\
\hline peso_pedrisco & $\begin{array}{l}\text { if('BR: Rough Cast Mortar <u-so>'.traco=0;0;if('BR: Rough Cast Mortar <u-so>'.traco=1;'BR: Rough Cast } \\
\text { Mortar <u-so>'.tra_1_vol_ped*'BR: Rough Cast Mortar <u-so>'.den_pedrisco;0)) }\end{array}$ & 9,8 & $\mathrm{~kg}$ (calculado) \\
\hline peso_saida & 'BR: Rough Cast Mortar <u-so>'. peso_total & 13,944 & $\mathrm{~kg}$ \\
\hline peso_total & $\begin{array}{l}\text { 'BR: Rough Cast Mortar <u-so>'.peso_agua+'BR: Rough Cast Mortar <u-so>'.peso_areia+'BR: Rough } \\
\text { Cast Mortar <u-so>'.peso_cimento+'BR: Rough Cast Mortar <u-so>'.peso_pedrisco }\end{array}$ & 13,944 & $\mathrm{~kg}$ \\
\hline $\begin{array}{l}\text { tra_0_espessur } \\
\text { a }\end{array}$ & 5 & 5 & $\mathrm{~mm}$ \\
\hline tra_0_vol_agua & 'BR: Rough Cast Mortar <u-so>'.tra_0_vol_areia/3 & 0,002033 & $\begin{array}{l}\text { (calculado com base no traço do cha } \\
\text { pisco A) }\end{array}$ \\
\hline tra_0_vol_areia & 0,0061 & 0,0061 & m3 (literatura) \\
\hline $\begin{array}{l}\text { tra_1_espessur } \\
\text { a }\end{array}$ & 7 & 7 & $\mathrm{~mm}$ \\
\hline tra_1_vol_agua & 'BR: Rough Cast Mortar <u-so>'.tra_1_vol_ped/4 & 0,00175 & $\begin{array}{l}\text { (calculado com base no traço do cha } \\
\text { pisco B) }\end{array}$ \\
\hline tra_1_vol_ped & 0,007 & 0,007 & m3 (literatura) \\
\hline tra_1_vol_total & 0,007 & 0,007 & m3 (literatura) \\
\hline vol_total & $\begin{array}{l}\text { if('BR: Rough Cast Mortar <u-so>'.traco=0;'BR: Rough Cast Mortar <u-so>'.tra_0_espessura*'BR: Rough } \\
\text { Cast Mortar <u-so>'.con_chapisco;if('BR: Rough Cast Mortar <u-so>'.traco=1;'BR: Rough Cast Mortar <u- } \\
\text { so>'.tra_1_espessura*'BR: Rough Cast Mortar <u-so>'.con_chapisco;0)) }\end{array}$ & 0,007 & (calculado) \\
\hline
\end{tabular}




\section{Apêndice K: Parâmetros livres e fixos inseridos e retirados do MTP intermediário}

\section{Parâmetros inseridos}

\begin{tabular}{|c|c|c|c|c|}
\hline Nome do processo ou plano & Código & Fórmula & Valor & Comentário \\
\hline \multicolumn{5}{|l|}{ Parâmetros livres } \\
\hline \multirow{9}{*}{ BR: Clay Brick Manufacturing new } & t_bio_forno & - & 1 & $\begin{array}{l}0=\text { retalhos/intermitente; } 1=\text { lenha/intermitente;2=serrage } \\
\text { m/intermitente;3=lenha/semicontínuo; } 4=\text { =avaco/t }\end{array}$ \\
\hline & t_secagem & - & 1 & $\begin{array}{l}0=\mathrm{n} ; 1=\mathrm{a} \mathrm{s} / \mathrm{a} ; 2=\mathrm{a} \mathrm{c} / \mathrm{a} ; 3=\mathrm{n} / \mathrm{a} \mathrm{s} / \mathrm{a} ; 4=\mathrm{n} / \mathrm{a} \\
\mathrm{c} / \mathrm{a} ; 5=\mathrm{media} ; 6=\mathrm{p} 1 ; 7=\mathrm{p} 3 ; 8=\mathrm{p} 4 ; 9=\mathrm{p} 5 ; 10=\mathrm{m} 1 ; 11=\mathrm{m} 3 ; 12= \\
\mathrm{m} 4 ; 13=\mathrm{m} 6 ; 14=\mathrm{g} 1 ; 15\end{array}$ \\
\hline & es_chapisco & - & 5 & $\mathrm{~mm}$ \\
\hline & esp_emb_ext & - & 20 & $\mathrm{~mm}$ \\
\hline & esp_emb_int & - & 20 & $\mathrm{~mm}$ \\
\hline & t_bloco & - & 0 & 0: Bloco Ceramico $(l=9, a=19, C=19)$ \\
\hline & traco_arg_ass & - & 0 & \\
\hline & traco_arg_emb & - & 0 & \\
\hline & traco_chap & - & 1 & \\
\hline \multirow{2}{*}{$\mathrm{CH}$ : Clay, at mine/CH U } & clay_mine & - & 0,8484815 & \\
\hline & clay_site & - & 0,18666009 & \\
\hline \multirow{2}{*}{$\begin{array}{l}\text { GB: Mortar mix 1:1/4:3 (Ce- } \\
\text { ment:lime:sand) - wet mortar - thin } \\
\text { bed }\end{array}$} & factor & - & -1 & \\
\hline & p_cement_lime & - & 0,2732 & \\
\hline \multirow{2}{*}{$\begin{array}{l}\text { GB: Mortar mix 1:1:5 (ce- } \\
\text { ment:lime:sand) - ext wall }\end{array}$} & factor & - & -1 & \\
\hline & p_cement_lime & - & 0,2526 & \\
\hline \multirow{2}{*}{$\begin{array}{l}\text { BR: Mortar mix 1:2:6 (ce- } \\
\text { ment:hydrated lime:sand) - ext. wall }\end{array}$} & factor & - & -1 & \\
\hline & p_cement_lime & - & 0,1954 & \\
\hline \multirow{2}{*}{$\begin{array}{l}\text { BR: Mortar mix 1:2:8 (ce- } \\
\text { ment:hydrated lime:sand) }\end{array}$} & factor & - & -1 & \\
\hline & p_cement_lime & - & 0,154 & \\
\hline BR: Mortar mix 1:3 (cement:sand) & factor & - & -1 & \\
\hline
\end{tabular}




\begin{tabular}{|c|c|c|c|c|}
\hline & p_cement & - & 0,1954 & \\
\hline \multirow{2}{*}{$\begin{array}{l}\text { GB: Mortar mix } 1: 3 \text { (masonry ce- } \\
\text { ment:sand) - int. wall }\end{array}$} & factor & - & -1 & \\
\hline & p_cement & - & 0,2206 & \\
\hline \multirow{2}{*}{ BR: Mortar mix 1:4 (cement:gravel) } & factor & - & -1 & \\
\hline & p_cement & - & 0,1955 & \\
\hline \multirow{2}{*}{$\begin{array}{l}\text { BR: Mortar mix } 1: 4 \text { (hydrated } \\
\text { lime:sand) - thin bed }\end{array}$} & factor & - & -1 & \\
\hline & p_cement & - & 0,0834 & \\
\hline \multicolumn{5}{|c|}{ Parâmetros fixos } \\
\hline \multirow[t]{18}{*}{ BR: Clay Brick Manufacturing new } & Ammonia_Inorga & $\begin{array}{l}\text { 8,48043E-08*'BR: Clay Brick Manufacturing new }<\mathrm{u}- \\
\text { so>'.biomassa }\end{array}$ & $1,42 \mathrm{E}-08$ & (kg de nh3/kg de biomassa)*biomassa \\
\hline & Benzene_Group & $\begin{array}{l}\text { 2,80925E-07*'BR: Clay Brick Manufacturing new }<\mathrm{u}- \\
\text { so >'.biomassa }\end{array}$ & $4,71 \mathrm{E}-08$ & (kg de benzeno/kg de biomassa) ${ }^{*}$ biomassa \\
\hline & bi_g1 & 0,381403 & 0,381403 & ( $\mathrm{kg}$ de cavaco/kg bloco) - tunel \\
\hline & bi_g3 & 0,18542 & 0,18542 & (kg de serragem $/ \mathrm{kg}$ bloco) - túnel \\
\hline & bi_g5 & 0,070926 & 0,070926 & (kg de lenha/kg bloco) - túnel \\
\hline & bi_g6 & 0,310682 & 0,310682 & (kg de cavaco serragem/kg bloco) - túnel \\
\hline & bi_g8 & 0,115846 & 0,115846 & (kg de lenha/kg bloco) - túnel \\
\hline & bi_m1 & 0,427562 & 0,427562 & (kg de serragem $/ \mathrm{kg}$ bloco) - intermitente \\
\hline & bi_m3 & 0,055859 & 0,055859 & ( $\mathrm{kg}$ de lenha/kg bloco) - intermitente \\
\hline & bi_m4 & 0,162773 & 0,162773 & ( $\mathrm{kg}$ de retalhos de moveis $/ \mathrm{kg}$ bloco) - intermitente \\
\hline & bi_m6 & 0,186088 & 0,186088 & (kg de lenha/kg bloco) - semicontinuo \\
\hline & bi_medio & 0,18542 & 0,18542 & ( $\mathrm{kg}$ de biomassa/kg bloco) - valor médio \\
\hline & bi_p1 & 0,133717 & 0,133717 & ( $\mathrm{kg}$ de retalhos de moveis $/ \mathrm{kg}$ bloco) - intermitente \\
\hline & bi_p3 & 0,197017 & 0,197017 & (kg de lenha/kg bloco) - semicontínuo \\
\hline & bi_p4 & 0,19948 & 0,19948 & (kg de lenha/kg bloco) - intermitente \\
\hline & bi_p5 & 0,096938 & 0,096938 & (kg de lenha/kg bloco) - semicontinuo \\
\hline & Biological_oxyg & $\begin{array}{l}2,15909 \mathrm{E}-08^{*} \mathrm{BR} \text { : Clay Brick Manufacturing new }<\mathrm{u}- \\
\text { so }>\text { '.biomassa }\end{array}$ & $3,62 \mathrm{E}-09$ & (kg de bod/kg de biomassa)*biomassa \\
\hline & Butane_Group_N & $\begin{array}{l}6,98879 E-07^{* \prime} B R \text { : Clay Brick Manufacturing new }<\mathrm{u}- \\
\text { so>'.biomassa }\end{array}$ & $1,17 \mathrm{E}-07$ & (kg de c4h10/kg de biomassa)*biomassa \\
\hline
\end{tabular}




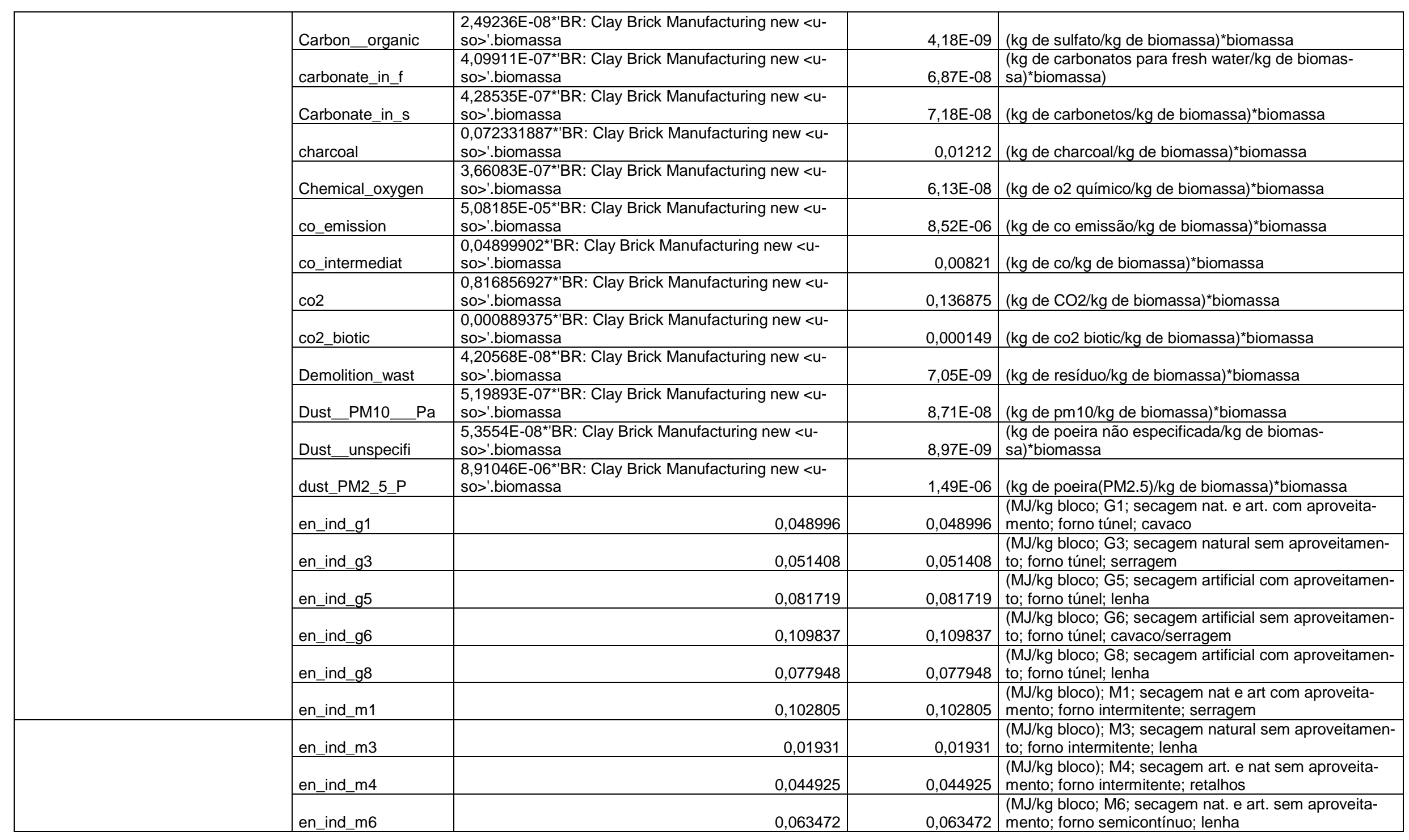




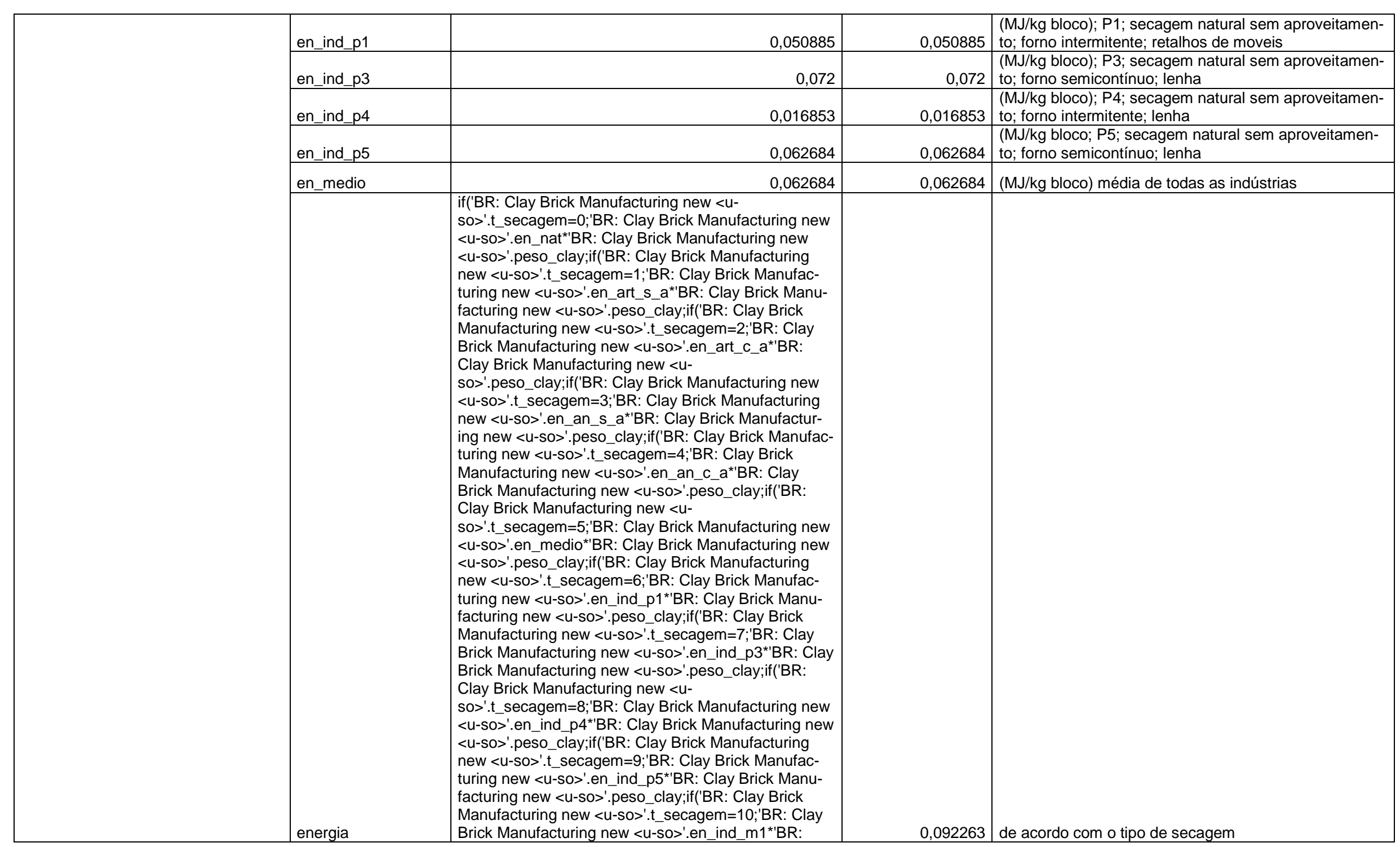




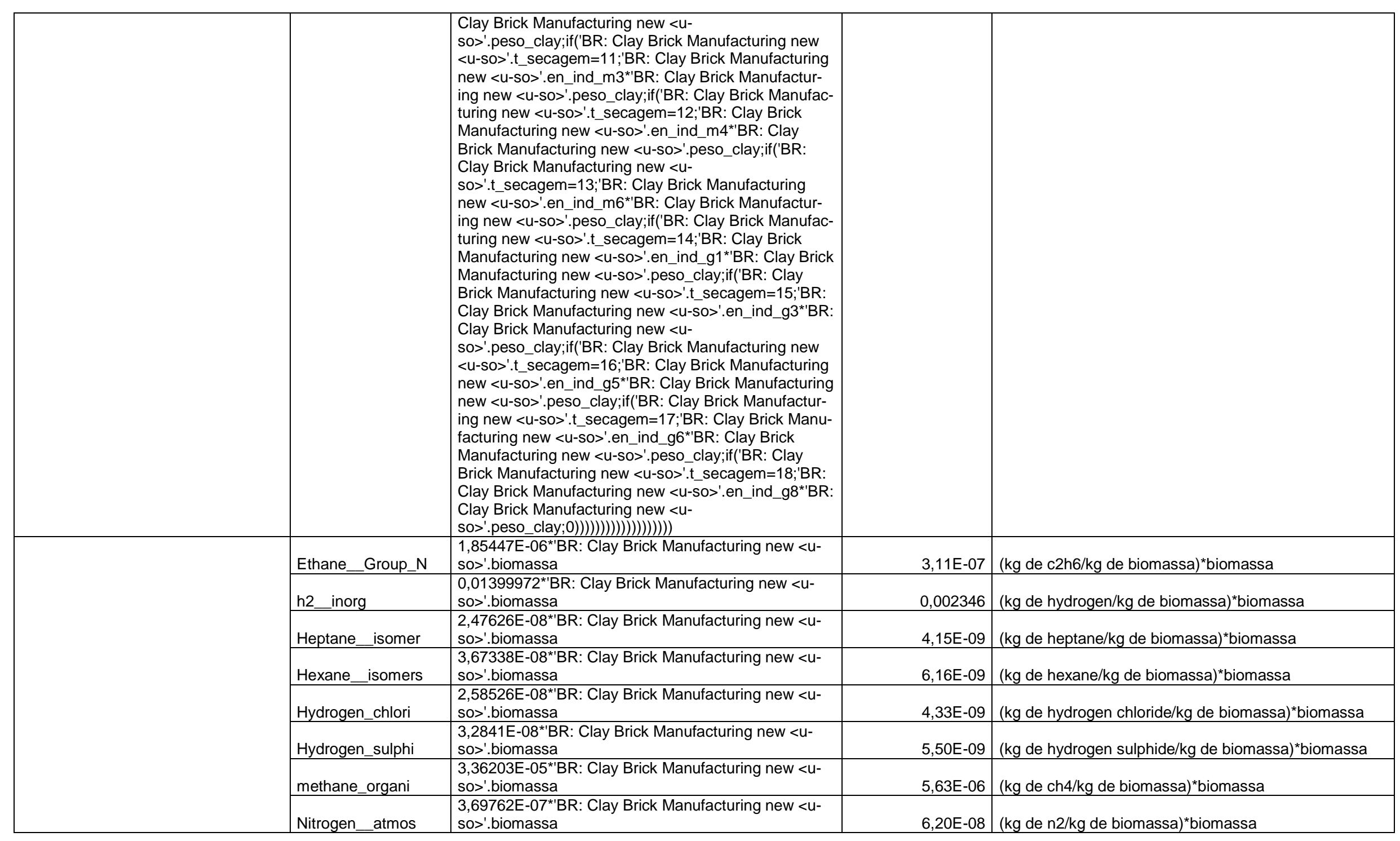




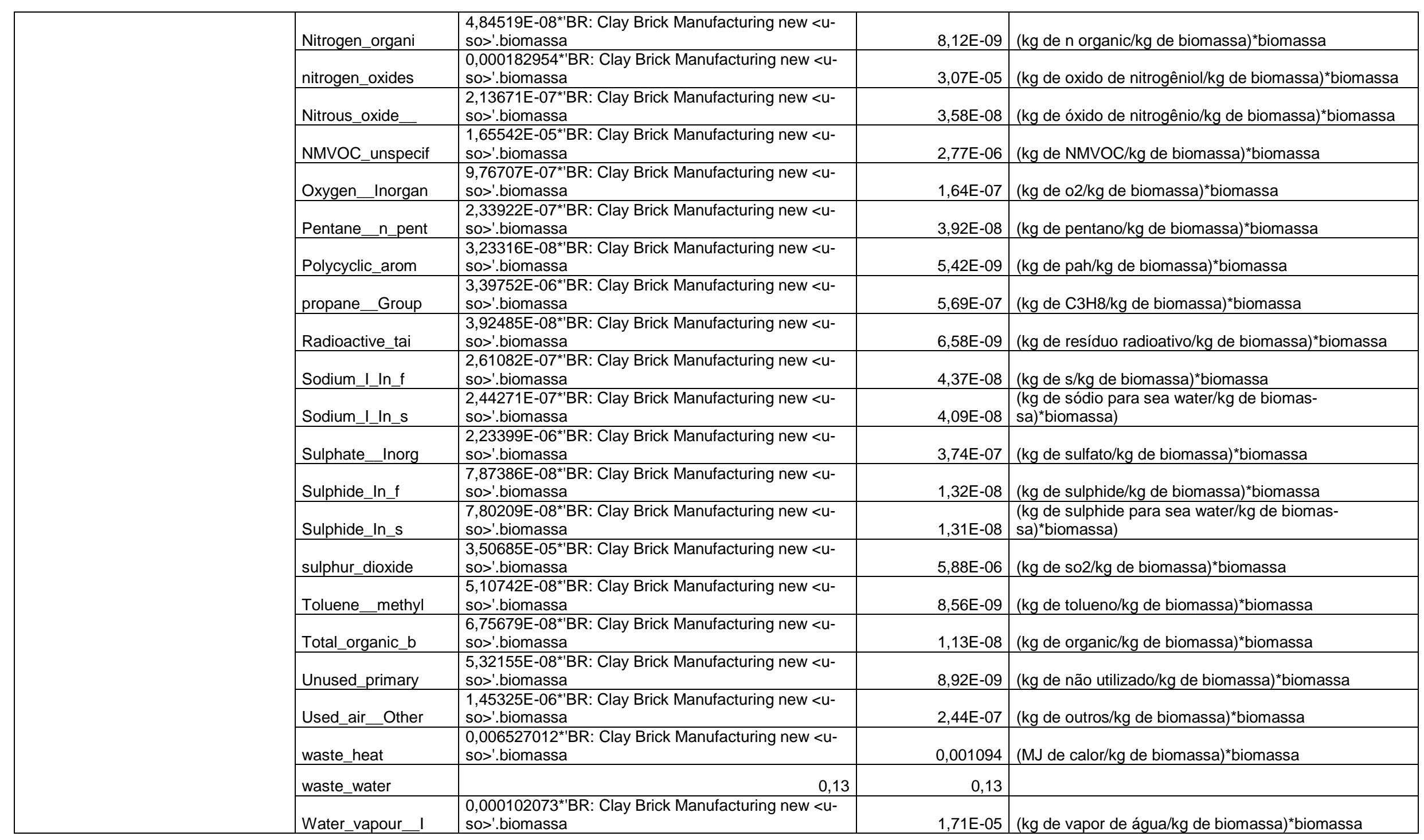




\begin{tabular}{|c|c|c|c|c|}
\hline & Xylene_dimethy & $\begin{array}{l}1,2773 \mathrm{E}-07^{*} \mathrm{BR} \text { : Clay Brick Manufacturing new }<\mathrm{u}- \\
\text { so>'.biomassa }\end{array}$ & $2,14 \mathrm{E}-08$ & (kg de xylene/kg de biomassa)*biomassa \\
\hline \multirow[t]{12}{*}{ RER: Clay Brick Typology new } & area_parede & 1 & 1 & $\mathrm{~m} 2$ \\
\hline & cons_chapisco & 0,001 & 0,001 & volume de chapisco em $\mathrm{m} 3$ por $\mathrm{mm}$ de espessura \\
\hline & dens_arg_emb & $\begin{array}{l}\text { if('RER: Clay Brick Typology new <u- } \\
\text { so>'.traco_arg_emb=0;1720;if('RER: Clay Brick Ty- } \\
\text { pology new <u-so>'.traco_arg_emb=1;1960;0)) }\end{array}$ & 1720 & \\
\hline & esp_asse_cer & 12 & 12 & $\mathrm{~mm}$ \\
\hline & n_blocos & $\begin{array}{l}\text { if('RER: Clay Brick Typology new <u- } \\
\text { so>'.t_bloco }=0 ; 25,7 ; 0)\end{array}$ & 25,7 & \\
\hline & peso_arg_ass & $\begin{array}{l}\text { if('RER: Clay Brick Typology new }<\text { u- } \\
\text { so>'.traco_arg_ass=0;19,7;if('RER: Clay Brick Typol- } \\
\text { ogy new <u-so>'.traco_arg_ass }=1 ; 24,7 ; 0))\end{array}$ & 19,7 & \\
\hline & peso_arg_emb & $\begin{array}{l}\text { 'RER: Clay Brick Typology new <u- } \\
\text { so>'.vol_emboco*'RER: Clay Brick Typology new }<\text { u- } \\
\text { so>'.dens_arg_emb }\end{array}$ & 68,8 & \\
\hline & peso_chap & $\begin{array}{l}\text { if('RER: Clay Brick Typology new <u- } \\
\text { so>'.traco_chap=0;19,9;if('RER: Clay Brick Typology } \\
\text { new <u-so>'.traco_chap=1;27,9;0)) }\end{array}$ & 27,9 & \\
\hline & peso_saida & $\begin{array}{l}\text { 'RER: Clay Brick Typology new <u- } \\
\text { so>'.peso_bloco_tota+'RER: Clay Brick Typology new } \\
<\text { <-so>'.peso_arg_ass+'RER: Clay Brick Typology } \\
\text { new <u-so>'.peso_arg_emb+'RER: Clay Brick Typol- } \\
\text { ogy new <u-so>'.peso_chap }\end{array}$ & 173,197 & \\
\hline & vol_arg_asse & $\begin{array}{l}\text { if('RER: Clay Brick Typology new }<\mathrm{u}- \\
\text { so }>\text { '.t_bloco }=0 ; 0,0135 ; 0)\end{array}$ & 0,0135 & m3 (literatura) \\
\hline & vol_chapisco & $\begin{array}{l}\text { 'RER: Clay Brick Typology new <u- } \\
\text { so>'.cons_chapisco*'RER: Clay Brick Typology new } \\
<\text { <-so>'.es_chapisco*2 }\end{array}$ & 0,01 & m3 (calculado) \\
\hline & vol_emboco & $\begin{array}{l}\text { ('RER: Clay Brick Typology new <u- } \\
\text { so>'.esp_emb_int+'RER: Clay Brick Typology new <u- } \\
\text { so>'.esp_emb_ext) } 0,001\end{array}$ & 0,04 & m3 (literatura) \\
\hline \multirow[t]{2}{*}{$\mathrm{CH}$ : Clay, at mine/CH U } & clay & $\begin{array}{l}\text { 'CH: Clay, at mine/CH U <u-so>'.clay_mine+'CH: } \\
\text { Clay, at mine/CH U }<\text { u-so>'.clay_site }\end{array}$ & 1,035142 & \\
\hline & energy & 'CH: Clay, at mine/CH U <u-so>'.clay_mine*0,0297 & 0,0252 & \\
\hline $\begin{array}{l}\text { GB: Mortar mix 1:1/4:3 (Ce- } \\
\text { ment:lime:sand) - wet mortar - thin } \\
\text { bed }\end{array}$ & carbonation & $\begin{array}{l}\text { 'GB: Mortar mix 1:1/4:3 (Cement:lime:sand) - wet mor- } \\
\text { tar - thin bed <u-so>'.factor*'GB: Mortar mix } 1: 1 / 4: 3 \\
\text { (Cement:lime:sand) - wet mortar - thin bed <u- } \\
\text { so>'.p_cement_lime* } 0,9^{*} 0,65^{\star} 0,63^{\star}(44 / 65)\end{array}$ & $-0,06816$ & \\
\hline $\begin{array}{l}\text { GB: Mortar mix 1:1:5 (ce- } \\
\text { ment:lime:sand) - ext wall }\end{array}$ & carbonation & $\begin{array}{l}\text { 'GB: Mortar mix 1:1:5 (cement:lime:sand) - ext wall } \\
\text { <u-so>'.factor*'GB: Mortar mix 1:1:5 (ce- } \\
\text { ment:lime:sand) - ext wall <u- }\end{array}$ & $-0,06302$ & \\
\hline
\end{tabular}




\begin{tabular}{|c|c|c|c|c|}
\hline & & so>'.p_cement_lime ${ }^{*} 0,9^{*} 0,65^{*} 0,63^{*}(44 / 65)$ & & \\
\hline $\begin{array}{l}\text { BR: Mortar mix 1:2:6 (ce-- } \\
\text { ment:hydrated lime:sand) - ext. wall }\end{array}$ & carbonation & $\begin{array}{l}\text { 'BR: Mortar mix 1:2:6 (cement:hydrated lime:sand) - } \\
\text { ext. wall <u-so>'.factor*'BR: Mortar mix 1:2:6 (ce- } \\
\text { ment:hydrated lime:sand) - ext. wall <u- } \\
\text { so>'.p_cement_lime } 0,9^{\star} 0,65^{\star} 0,63^{\star}(44 / 65)\end{array}$ & $-0,04875$ & \\
\hline $\begin{array}{l}\text { BR: Mortar mix 1:2:8 (ce- } \\
\text { ment:hydrated lime:sand) }\end{array}$ & carbonation & $\begin{array}{l}\text { 'BR: Mortar mix 1:2:8 (cement:hydrated lime:sand) <u- } \\
\text { so>'.factor*'BR: Mortar mix 1:2:8 (cement:hydrated } \\
\text { lime:sand) <u- } \\
\text { so>'.p_cement_lime* } 0,9^{*} 0,65^{*} 0,63^{*}(44 / 65)\end{array}$ & $-0,03842$ & \\
\hline BR: Mortar mix 1:3 (cement:sand) & carbonation & $\begin{array}{l}\text { 'BR: Mortar mix } 1: 3 \text { (cement:sand) <u-so>'.factor*'BR: } \\
\text { Mortar mix } 1: 3(\text { cement:sand) }<u- \\
\text { so }>^{*} \text {.p_cement }{ }^{\star} 0,9^{\star} 0,65^{\star} 0,63^{\star}(44 / 65)\end{array}$ & $-0,04875$ & \\
\hline $\begin{array}{l}\text { GB: Mortar mix 1:3 (masonry ce- } \\
\text { ment:sand) - int. wall }\end{array}$ & carbonation & $\begin{array}{l}\text { 'GB: Mortar mix 1:3 (masonry cement:sand) - int. wall } \\
<u-\text { so>'.factor*'GB: Mortar mix } 1: 3 \text { (masonry ce- } \\
\text { ment:sand) - int. wall }<\text { u- } \\
\text { so>'.p_cement* } 0,9^{*} 0,65^{\star} 0,63^{\star}(44 / 65)\end{array}$ & $-0,05504$ & \\
\hline BR: Mortar mix 1:4 (cement:gravel) & carbonation & $\begin{array}{l}\text { 'BR: Mortar mix 1:4 (cement:gravel) <u- } \\
\text { so>'.factor*'BR: Mortar mix } 1: 4 \text { (cement:gravel) }<\text { u- } \\
\text { so }>\text { '.p cement }{ }^{*} 0,9^{*} 0,65^{\star} 0,63^{*}(44 / 65)\end{array}$ & $-0,04877$ & \\
\hline $\begin{array}{l}\text { BR: Mortar mix 1:4 (hydrated } \\
\text { lime:sand) - thin bed }\end{array}$ & carbonation & $\begin{array}{l}\text { 'BR: Mortar mix 1:4 (hydrated lime:sand) - thin bed } \\
\text { <u-so>'.factor*'BR: Mortar mix 1:4 (hydrated } \\
\text { lime:sand) - thin bed <u- } \\
\text { so>'.p_cement }{ }^{\star} 0,9^{\star} 0,65^{\star} 0,63^{\star}(44 / 65)\end{array}$ & $-0,02081$ & \\
\hline BR: Waste Destination & massa_char & 0,031878 & 0,031878 & \\
\hline
\end{tabular}

\section{Parâmetros retirados}

\begin{tabular}{|c|c|c|c|c|}
\hline $\begin{array}{c}\text { Nome do processo } \\
\text { ou plano }\end{array}$ & Código & Fórmula & Valor & Comentários \\
\hline \multicolumn{5}{|c|}{ Parametros Livres } \\
\hline \multirow{4}{*}{ BR: b_ceramico } & $\mathrm{a}$ & - & 19 & $\mathrm{~cm}$ (altura) \\
\hline & c & - & 19 & cm (comprimento) \\
\hline & 1 & - & 9 & $\mathrm{~cm}$ (largura) \\
\hline & porc_cinza & - & 0,15 & Depende do tipo de madeira \\
\hline \multirow{2}{*}{$\begin{array}{l}\text { BR: Argamassa As- } \\
\text { sentamento }\end{array}$} & A_CiCaAr_1_05_8 & - & 1 & Valor verdadeiro_falso \\
\hline & betoneira & - & 0 & Valor verdadeiro falso \\
\hline BR: Plaster Mortar & maquinario & - & 1 & 0: Manual; 1 : Betoneira \\
\hline
\end{tabular}




\begin{tabular}{|c|c|c|c|c|}
\hline & maquinario & - & 1 & 0: Manual; 1: Betoneira \\
\hline $\begin{array}{l}\text { BR: Argamassa As- } \\
\text { sentamento }\end{array}$ & manual & - & 1 & Valor verdadeiro_falso \\
\hline $\begin{array}{l}\text { BR: Clay Brick Laying } \\
\text { Mortar }\end{array}$ & maquinario & - & 1 & 0: Manual; 1: Betoneira \\
\hline \multirow{6}{*}{ BR: Tipologia_bloco } & peso_1_2_6 & - & 0 & \\
\hline & peso_1_2_8 & - & 0 & \\
\hline & peso_1_3_c_s & - & 0 & \\
\hline & peso_1_4_c_g & - & 0 & \\
\hline & peso_1_4_I_s & - & 0 & \\
\hline & peso_bloco & - & 6 & \\
\hline \multicolumn{5}{|c|}{ Parâmetros fixos } \\
\hline BR: b_ceramico & cinza & $\begin{array}{l}\text { 'BR: b_ceramico_natural_tunel_lenha }<\text { u-so }>\text { '.biomassa*'BR: } \\
\text { b_ceramico_natural_tunel_lenha }<u-\text { so }>\text { '.porc_cinza }\end{array}$ & 0,022437 & \\
\hline $\begin{array}{l}\text { BR: Argamassa As- } \\
\text { sentamento }\end{array}$ & cons_betoneira & $2^{\star} 745,7^{*} 1260 / 1000000$ & 1,879164 & $\begin{array}{l}\mathrm{MJ} / \mathrm{m} 3 \text { (conversao de HP para } W^{*} \text { tempo } \\
\text { de betoneira por } \mathrm{m} 3 / \text { conversão para MJ) }\end{array}$ \\
\hline $\begin{array}{l}\text { BR: Clay Brick Laying } \\
\text { Mortar }\end{array}$ & cons_betoneira & $2^{\star} 745,7^{\star} 1260 / 1000000$ & 1,879164 & $\begin{array}{l}\mathrm{MJ} / \mathrm{m} 3 \text { (conversao de HP para } \mathrm{W}^{\star} \text { tempo } \\
\text { de betoneira por } \mathrm{m} 3 / \text { conversão para } \mathrm{MJ} \text { ) }\end{array}$ \\
\hline BR: Plaster Mortar & cons_betoneira & $2 * 745,7^{*} 1260 / 1000000$ & 1,879164 & $\begin{array}{l}\mathrm{MJ} / \mathrm{m} 3 \text { (conversao de HP para } \mathrm{W}^{\star} \text { tempo } \\
\text { de betoneira por } \mathrm{m} 3 / \text { conversão para } \mathrm{MJ} \text { ) }\end{array}$ \\
\hline $\begin{array}{l}\text { BR: Rough Cast Mor- } \\
\text { tar }\end{array}$ & cons_betoneira & $2 * 745,7^{\star} 1260 / 1000000$ & 1,879164 & $\begin{array}{l}\mathrm{MJ} / \mathrm{m} 3 \text { (conversão de HP para } \mathrm{W}^{*} \text { tempo } \\
\text { de betoneira por } \mathrm{m} 3 / \text { conversão para MJ) }\end{array}$ \\
\hline \multirow{3}{*}{$\begin{array}{l}\text { BR: Argamassa As- } \\
\text { sentamento }\end{array}$} & den_agua & 1000 & 1000 & kg/m3 (literatura) \\
\hline & dens_areia & 1640 & 1640 & kg/m3 (literatura) \\
\hline & dens_cimento & 1150 & 1150 & kg/m3 (literatura) \\
\hline \multirow{4}{*}{$\begin{array}{l}\text { BR: Clay Brick Laying } \\
\text { Mortar }\end{array}$} & den_agua & 1000 & 1000 & kg/m3 (literatura) \\
\hline & dens_areia & 1640 & 1640 & kg/m3 (literatura) \\
\hline & dens_cal & 650 & 650 & kg/m3 (literatura) \\
\hline & dens_cimento & 1150 & 1150 & kg/m3 (literatura) \\
\hline \multirow{3}{*}{ BR: Plaster Mortar } & den_agua & 1000 & 1000 & kg/m3 (literatura) \\
\hline & dens_areia & 1640 & 1640 & kg/m3 (literatura) \\
\hline & dens_cal & 650 & 650 & kg/m3 (literatura) \\
\hline
\end{tabular}




\begin{tabular}{|c|c|c|c|c|}
\hline & dens_cimento & 1150 & 1150 & kg/m3 (literatura) \\
\hline \multirow{3}{*}{$\begin{array}{l}\text { BR: Rough Cast Mor- } \\
\text { tar }\end{array}$} & den_agua & 1000 & 1000 & kg/m3 (literatura) \\
\hline & den_areia & 1640 & 1640 & kg/m3 (literatura) \\
\hline & den_pedrisco & 1400 & 1400 & kg/m3 (literatura) \\
\hline $\begin{array}{l}\text { BR: Argamassa As- } \\
\text { sentamento }\end{array}$ & perda & 0,3 & 0,3 & porcentagem (literatura) \\
\hline $\begin{array}{l}\text { BR: Clay Brick Laying } \\
\text { Mortar }\end{array}$ & perda & 0,3 & 0,3 & porcentagem (literatura) \\
\hline BR: Plaster Mortar & perda & 0,25 & 0,25 & porcentagem (literatura) \\
\hline $\begin{array}{l}\text { BR: Rough Cast Mor- } \\
\text { tar }\end{array}$ & perda & 0 & 0 & $\begin{array}{l}\text { a massa de perda é tão pequena que não } \\
\text { é considerada como um fator de perdes- } \\
\text { dício pela TCPO }\end{array}$ \\
\hline $\begin{array}{l}\text { BR: Argamassa As- } \\
\text { sentamento }\end{array}$ & peso_agua & $\begin{array}{l}\text { 'BR: Argamassa Assentamento Bloco de Concreto <u-so>'.vol_agua*'BR: Argamassa } \\
\text { Assentamento Bloco de Concreto <u-so>'.den_agua }\end{array}$ & 2,412169 & kg (calculado) \\
\hline \multirow{9}{*}{$\begin{array}{l}\text { BR: Argamassa As- } \\
\text { sentamento Bloco de } \\
\text { Concreto }\end{array}$} & peso_areia & $\begin{array}{l}\text { 'BR: Argamassa Assentamento Bloco de Concreto <u-so>'.vol_areia*'BR: Argamassa } \\
\text { Assentamento Bloco de Concreto <u-so>'.dens_areia }\end{array}$ & 22,20888 & kg (calculado) \\
\hline & peso_cal & $\begin{array}{l}\text { if('BR: Argamassa Assentamento Bloco de Concreto }<\mathrm{u}- \\
\text { so>'.A_CiCaAr_1_05_8=1;0,5106;0) }\end{array}$ & 0,5106 & kg (literatura) \\
\hline & peso_cimento & $\begin{array}{l}\text { if('BR: Argamassa Assentamento Bloco de Concreto }<\mathrm{u}- \\
\text { so>'.A_CiCaAr_1_05_8=1;2,0202;0) }\end{array}$ & 2,0202 & kg (literatura) \\
\hline & peso_residuo & $\begin{array}{l}\text { 'BR: Argamassa Assentamento Bloco de Concreto <u-so>'.peso_total'B'BR: Argamassa } \\
\text { Assentamento Bloco de Concreto }<\mathrm{u} \text {-so }>\text { '.perda }\end{array}$ & 8,145555 & kg (calculado) \\
\hline & peso_total & $\begin{array}{l}\text { 'BR: Argamassa Assentamento Bloco de Concreto <u-so>'.peso_cal+'BR: Argamassa } \\
\text { Assentamento Bloco de Concreto <u-so>'.peso_areia+'BR: Argamassa Assentamento } \\
\text { Bloco de Concreto <u-so>'.peso_cimento+'BR: Argamassa Assentamento Bloco de Con- } \\
\text { creto <u-so>'.peso_agua }\end{array}$ & 27,15185 & kg (calculado) \\
\hline & vol_agua & 0,15*'BR: Argamassa Assentamento Bloco de Concreto <u-so>'.vol_total_e & 0,002412 & m3 (literatura) \\
\hline & vol_areia & $\begin{array}{l}\text { if('BR: Argamassa Assentamento Bloco de Concreto <u- } \\
\text { so>'.A_CiCaAr_1_05_8=1;0,013542;0) }\end{array}$ & 0,013542 & m3 (literatura) \\
\hline & vol_total_e & $\begin{array}{l}\text { if('BR: Argamassa Assentamento Bloco de Concreto <u- } \\
\text { sos'.A_CiCaAr_1_05_8=1;9,5/8*'BR: Argamassa Assentamento Bloco de Concreto <u- } \\
\text { so>'.vol_areia;0) }\end{array}$ & 0,016081 & m3 (calculado) \\
\hline & vol_total_s & 0,0111 & 0,0111 & m3 (literatura) \\
\hline \multirow{3}{*}{$\begin{array}{l}\text { BR: Clay Brick Laying } \\
\text { Mortar }\end{array}$} & peso_agua & $\begin{array}{l}\text { 'BR: Clay Brick Laying Mortar <u-so>'.vol_agua*'BR: Clay Brick Laying Mortar <u- } \\
\text { so>'.den_agua }\end{array}$ & 3,396938 & $\mathrm{~kg}$ (calculado) \\
\hline & peso_areia & $\begin{array}{l}\text { 'BR: Clay Brick Laying Mortar <u-so>'.vol_areia*'BR: Clay Brick Laying Mortar <u- } \\
\text { so>'.dens_areia }\end{array}$ & 27,0108 & $\mathrm{~kg}$ (calculado) \\
\hline & peso_cal & $\begin{array}{l}\text { if('BR: Clay Brick Laying Mortar <u-so>'.traco=0;1,447089273;if('BR: Clay Brick Laying } \\
\text { Mortar <u-so>'.traco }=1 ; 2,457 ; 0) \text { ) }\end{array}$ & 2,457 & kg (literatura) \\
\hline
\end{tabular}




\begin{tabular}{|c|c|c|c|c|}
\hline & peso_cimento & $\begin{array}{l}\text { if('BR: Clay Brick Laying Mortar <u-so>'.traco=0;1,35;if('BR: Clay Brick Laying Mortar <u- } \\
\text { so>'.traco }=1 ; 2,457 ; 0) \text { ) }\end{array}$ & 2,457 & kg (literatura) \\
\hline & peso_residuo & $\begin{array}{l}\text { 'BR: Clay Brick Laying Mortar <u-so>'.peso_total'BR: Clay Brick Laying Mortar <u- } \\
\text { so>'.perda }\end{array}$ & 10,59652 & kg (calculado) \\
\hline & peso_saida & $\begin{array}{l}\text { 'BR: Clay Brick Laying Mortar <u-so>'.peso_total*(1-'BR: Clay Brick Laying Mortar <u- } \\
\text { so>'.perda) }\end{array}$ & 24,72522 & \\
\hline & peso_total & $\begin{array}{l}\text { 'BR: Clay Brick Laying Mortar <u-so>'.peso_cal+'BR: Clay Brick Laying Mortar <u- } \\
\text { so>'.peso_areia+'BR: Clay Brick Laying Mortar <u-so>'.peso_cimento+'BR: Clay Brick } \\
\text { Laying Mortar <u-so>'.peso_agua }\end{array}$ & 35,32174 & kg (calculado) \\
\hline & vol_agua & 0,15*'BR: Clay Brick Laying Mortar <u-so>'.vol_total_e & 0,003397 & m3 (literatura) \\
\hline & vol_areia & $\begin{array}{l}\text { if('BR: Clay Brick Laying Mortar <u-so>'.traco=0;0,0138494418;if('BR: Clay Brick Laying } \\
\text { Mortar <u-so>'.traco=1;0,01647;0)) }\end{array}$ & 0,01647 & m3 (literatura) \\
\hline & vol_cal & $\begin{array}{l}\text { 'BR: Clay Brick Laying Mortar <u-so>'.peso_cal/'BR: Clay Brick Laying Mortar <u- } \\
\text { so>'.dens_cal }\end{array}$ & 0,00378 & m3 (calculado) \\
\hline & vol_cimento & $\begin{array}{l}\text { 'BR: Clay Brick Laying Mortar <u-so>'.peso_cimento/'BR: Clay Brick Laying Mortar <u- } \\
\text { so>'.dens_cimento }\end{array}$ & 0,002137 & m3 (calculado) \\
\hline & vol_total_e & $\begin{array}{l}\text { if('BR: Clay Brick Laying Mortar <u-so>'.traco=0;'BR: Clay Brick Laying Mortar <u- } \\
\text { so>'.vol_cimento+'BR: Clay Brick Laying Mortar <u-so>'.vol_cal+'BR: Clay Brick Laying } \\
\text { Mortar <u-so>'.vol_areia;if('BR: Clay Brick Laying Mortar <u-so>'.traco=1;11/8*'BR: Clay } \\
\text { Brick Laying Mortar <u-so>'.vol_areia;0)) }\end{array}$ & 0,022646 & m3 (calculado) \\
\hline & vol_total_s & 0,0135 & 0,0135 & m3 (literatura) \\
\hline \multirow{12}{*}{ BR: Plaster Mortar } & peso_agua & 'BR: Plaster Mortar <u-so>'.vol_agua*'BR: Plaster Mortar <u-so>'.den_agua & 5,0325 & $\mathrm{~kg}$ (calculado) \\
\hline & peso_areia & 'BR: Plaster Mortar <u-so>'.vol_areia*'BR: Plaster Mortar <u-so>'.dens_areia & 40,016 & $\mathrm{~kg}$ (calculado) \\
\hline & peso_cal & $\begin{array}{l}\text { if('BR: Plaster Mortar <u-so>'.traco=0;3,24688;if('BR: Plaster Mortar <u- } \\
\text { so>'.traco=1;3,64;0)) }\end{array}$ & 3,64 & kg (literatura) \\
\hline & peso_cimento & if('BR: Plaster Mortar <u-so>'.traco=0;2,6;ff('BR: Plaster Mortar <u-so>'.traco=1;3,64;0)) & 3,64 & $\mathrm{~kg}$ (literatura) \\
\hline & peso_residuo & 'BR: Plaster Mortar <u-so>'.peso_total*'BR: Plaster Mortar <u-so>'.perda & 13,08213 & $\mathrm{~kg}$ (calculado) \\
\hline & peso_saida & 'BR: Plaster Mortar <u-so>'.peso_total*(1-'BR: Plaster Mortar <u-so>'.perda) & 39,24638 & \\
\hline & peso_total & $\begin{array}{l}\text { 'BR: Plaster Mortar <u-so>'.peso_cal+'BR: Plaster Mortar <u-so>'.peso_areia+'BR: Plas- } \\
\text { ter Mortar <u-so>'.peso_cimento+'BR: Plaster Mortar <u-so>'.peso_agua }\end{array}$ & 52,3285 & kg (calculado) \\
\hline & vol_agua & 0,15*'BR: Plaster Mortar <u-so>'.vol_total_e & 0,005033 & m3 (literatura) \\
\hline & vol_areia & $\begin{array}{l}\text { if('BR: Plaster Mortar <u-so>'.traco=0;0,0217648;if('BR: Plaster Mortar <u- } \\
\text { so>'.traco }=1 ; 0,0244 ; 0))\end{array}$ & 0,0244 & m3 (literatura) \\
\hline & vol_cal & 'BR: Plaster Mortar <u-so>'.peso_cal/'BR: Plaster Mortar <u-so>'.dens_cal & 0,0056 & m3 (calculado) \\
\hline & vol_cimento & 'BR: Plaster Mortar <u-so>'.peso_cimento/'BR: Plaster Mortar <u-so>'.dens_cimento & 0,003165 & m3 (calculado) \\
\hline & vol_total_e & $\begin{array}{l}\text { if('BR: Plaster Mortar <u-so>'.traco=0;'BR: Plaster Mortar <u-so>'.vol_cimento+'BR: Plas- } \\
\text { ter Mortar <u-so>'.vol_cal+'BR: Plaster Mortar <u-so>'.vol_areia;f('BR: Plaster Mortar <u- } \\
\text { so>'.traco=1;11/8*'BR: Plaster Mortar <u-so>'.vol_areia;0)) }\end{array}$ & 0,03355 & m3 (calculado) \\
\hline
\end{tabular}




\begin{tabular}{|c|c|c|c|c|}
\hline & vol_total_s & 0,02 & 0,02 & m3 (literatura) \\
\hline \multirow{14}{*}{$\begin{array}{l}\text { BR: Rough Cast Mor- } \\
\text { tar }\end{array}$} & peso_agua & $\begin{array}{l}\text { if('BR: Rough Cast Mortar <u-so>'.traco=0;'BR: Rough Cast Mortar <u- } \\
\text { so>'.tra_0_vol_agua*'BR: Rough Cast Mortar <u-so>'.den_agua;if('BR: Rough Cast Mor- } \\
\text { tar <u-so>'.traco=1;'BR: Rough Cast Mortar <u-so>'.tra_1_vol_agua*'BR: Rough Cast } \\
\text { Mortar <u-so>'.den_agua;0)) }\end{array}$ & 1,75 & kg (calculado) \\
\hline & peso_areia & $\begin{array}{l}\text { if('BR: Rough Cast Mortar <u-so>'.traco=0;'BR: Rough Cast Mortar <u- } \\
\text { so>'.den_areia*'BR: Rough Cast Mortar <u-so>'.tra_0_vol_areia;if('BR: Rough Cast Mor- } \\
\text { tar <u-so>'.traco=1;0;0)) }\end{array}$ & 0 & kg (calculado) \\
\hline & peso_cimento & $\begin{array}{l}\text { if('BR: Rough Cast Mortar <u-so>'.traco=0;2,43;if('BR: Rough Cast Mortar <u- } \\
\text { so>'.traco=1;2,394;0)) }\end{array}$ & 2,394 & kg (calculado) \\
\hline & peso_pedrisco & $\begin{array}{l}\text { if('BR: Rough Cast Mortar <u-so>'.traco=0;0;if('BR: Rough Cast Mortar <u- } \\
\text { so>'.traco=1;'BR: Rough Cast Mortar <u-so>'.tra_1_vol_ped*'BR: Rough Cast Mortar <u- } \\
\text { so>'.den_pedrisco;0)) }\end{array}$ & 9,8 & kg (calculado) \\
\hline & peso_saida & 'BR: Rough Cast Mortar <u-so>'.peso_total & 13,944 & $\mathrm{~kg}$ \\
\hline & peso_total & $\begin{array}{l}\text { 'BR: Rough Cast Mortar <u-so>'.peso_agua+'BR: Rough Cast Mortar <u- } \\
\text { so>'.peso_areia+'BR: Rough Cast Mortar <u-so>'.peso_cimento+'BR: Rough Cast Mortar } \\
<\mathrm{u} \text {-so>'.peso_pedrisco }\end{array}$ & 13,944 & $\mathrm{~kg}$ \\
\hline & vol_total & $\begin{array}{l}\text { if('BR: Rough Cast Mortar <u-so>'.traco=0;'BR: Rough Cast Mortar <u- } \\
\text { so>'.tra_0_espessura*'BR: Rough Cast Mortar <u-so>'.con_chapisco;if('BR: Rough Cast } \\
\text { Mortar <u-so>'.traco=1;'BR: Rough Cast Mortar <u-so>'.tra_1_espessura*'BR: Rough } \\
\text { Cast Mortar <u-so>'.con_chapisco;0)) }\end{array}$ & 0,007 & (calculado) \\
\hline & tra_0_espessura & 5 & 5 & $\mathrm{~mm}$ \\
\hline & tra_0_vol_agua & 'BR: Rough Cast Mortar <u-so>'.tra_0_vol_areia/3 & 0,002033 & $\begin{array}{l}\text { (calculado com base no traço do chapisco } \\
\text { A) }\end{array}$ \\
\hline & tra_0_vol_areia & 0,0061 & 0,0061 & m3 (literatura) \\
\hline & tra_1_espessura & 7 & 7 & $\mathrm{~mm}$ \\
\hline & tra_1_vol_agua & 'BR: Rough Cast Mortar <u-so>'.tra_1_vol_ped/4 & 0,00175 & $\begin{array}{l}\text { (calculado com base no traço do chapisco } \\
\text { B) }\end{array}$ \\
\hline & tra_1_vol_ped & 0,007 & 0,007 & m3 (literatura) \\
\hline & tra_1_vol_total & 0,007 & 0,007 & m3 (literatura) \\
\hline
\end{tabular}




\section{Apêndice L: Parâmetros livres e fixos inseridos retirados da versão final do MTP}

\section{Parâmetros inseridos}

\begin{tabular}{|c|c|c|c|c|}
\hline $\begin{array}{l}\text { Nome do processo ou } \\
\text { plano }\end{array}$ & Código & Fórmula & Valor & Comentário \\
\hline \multicolumn{5}{|c|}{ Parâmetro livre } \\
\hline \multirow{21}{*}{$\begin{array}{l}\text { Wall - Brazil and UK (EPD } \\
\text { scheme) }\end{array}$} & brazil_uk & - & 0 & 0-> Brazil; 1-> UK \\
\hline & diesel_br & - & 1 & \\
\hline & diesel_uk & - & 1 & \\
\hline & i_m_br & - & 0,9 & \\
\hline & i_m_uk & - & 0,1 & \\
\hline & n_b_115_373_249 & 10,7 & 10,7 & \\
\hline & n_b_14_19_39 & 12,9 & 12,9 & \\
\hline & n_b_425_248_249 & 16 & 16 & \\
\hline & p_b_115_373_249 & 11,3 & 11,3 & \\
\hline & p_b_14_19_39 & 6 & 6 & \\
\hline & p_b_425_248_249 & 17 & 17 & \\
\hline & peso_1_025_3 & if(t_ass=2;0,19494;0) & 0 & \\
\hline & peso_1_1_5 & if(t_emb_ext=1;13,5;0) & 0 & \\
\hline & peso_1_2_6 & if(t_emb_ext=0;68,93931438;0) & 68,93931 & \\
\hline & peso_1_2_8 & if(t_ass=1;if(t_emb_int=0;41,55527217+52,27078261;41,55527217);if(t_emb_int=0;52,27078261;0)) & 93,82605 & \\
\hline & peso_1_3 & if(t_chap=0;if(t_emb_int=1;14,46+54,66382609;14,46);if(t_emb_int=1;54,66382609;0)) & 0 & \\
\hline & peso_1_3_mc_s & if(t_emb_int=2;15,6;0) & 0 & \\
\hline & peso_1_4_c_g & if(t_chap=1;13,949999;0) & 13,95 & \\
\hline & peso_1_4_Is & if(t_ass=0;37,620672;0) & 0 & \\
\hline & peso_bloco_br & if(t_bloco=0;p_b_14_19_39*n_b_14_19_39;0) & 77,4 & \\
\hline & peso_bloco_uk & if(t_bloco=1;p_b_425_248_249*n_b_425_248_249;if(t_bloco=2;p_b_115_373_249*n_b_115_373_249;0)) & 0 & \\
\hline
\end{tabular}




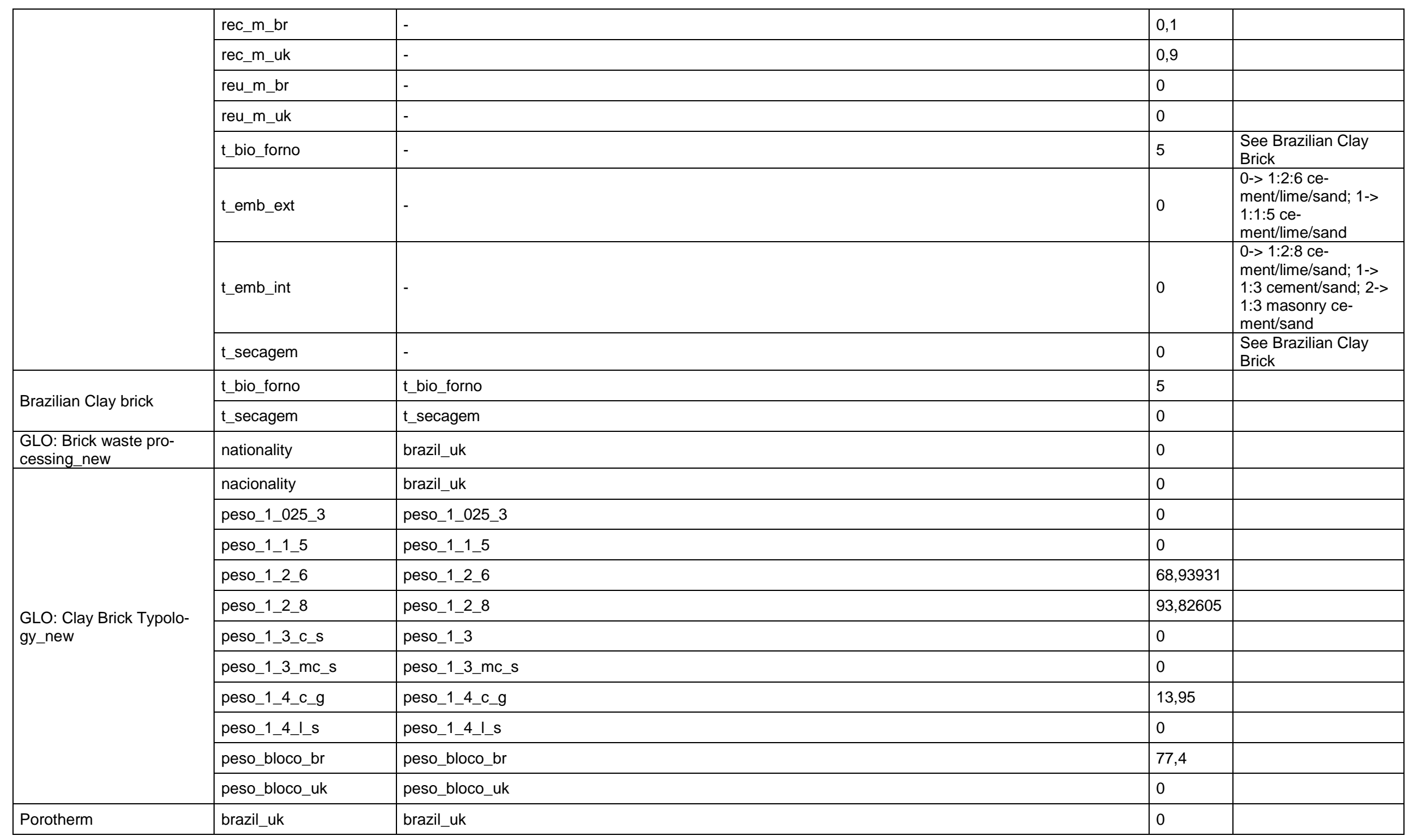




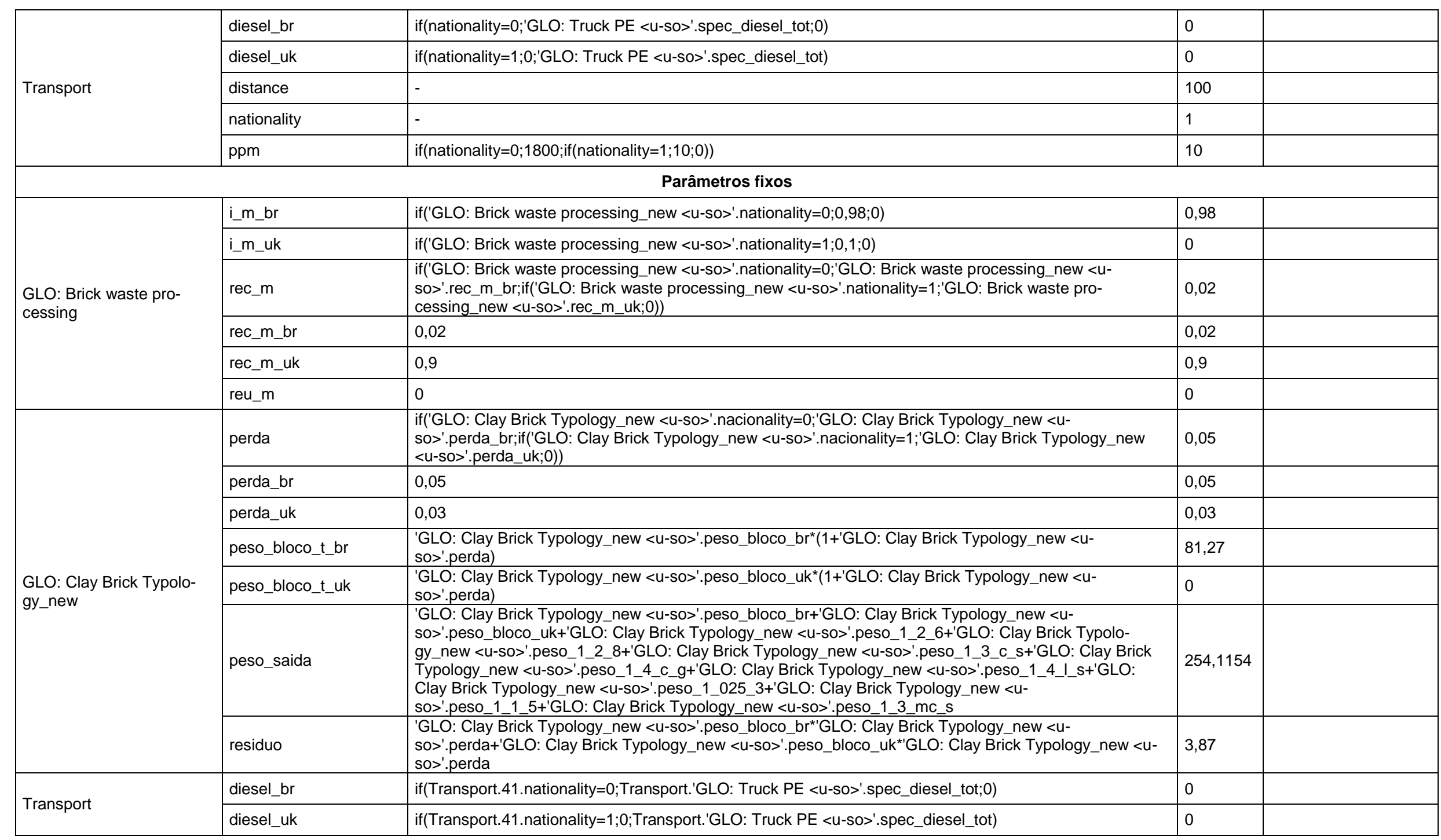




\begin{tabular}{|l|l|l|l|}
\hline & ppm & if(Transport.41.nationality=0;1800;if(Transport.41.nationality=1;10;0)) & 10 \\
\hline BR: Waste Destination & massa_char & 0,031878 & 0,031878 \\
\hline GLO: Diesel nationality & diesel & 'GLO: Diesel nationality <u-so>'.diesel_br+'GLO: Diesel nationality <u-so>'.diesel_uk \\
\hline \multirow{2}{*}{ CH: Clay, at mine/CH U } & clay & 'CH: Clay, at mine/CH U <u-so>'.clay_mine+'CH: Clay, at mine/CH U <u-so>'.clay_site & 2 \\
\cline { 2 - 4 } & energy & 'CH: Clay, at mine/CH U <u-so>'.clay_mine*0,0297 & 1,035142 \\
\hline
\end{tabular}

\section{Parâmetros retirados}

\begin{tabular}{|c|c|c|c|c|}
\hline $\begin{array}{l}\text { Nome do processo ou } \\
\text { plano }\end{array}$ & Código & Fórmula & Valor & Comentário \\
\hline \multicolumn{5}{|c|}{ Parametros Livres } \\
\hline \multirow{3}{*}{$\begin{array}{l}\text { RER: Clay Brick Typology } \\
\text { new }\end{array}$} & es_chapisco & & 5 & $\mathrm{~mm}$ \\
\hline & esp_emb_ext & & 20 & $\mathrm{~mm}$ \\
\hline & esp_emb_int & & 20 & $\mathrm{~mm}$ \\
\hline \multicolumn{5}{|c|}{ Parâmetros fixos } \\
\hline \multirow{10}{*}{$\begin{array}{l}\text { RER: Clay Brick Typology } \\
\text { new }\end{array}$} & area_parede & 1 & 1 & $\mathrm{~m} 2$ \\
\hline & cons_chapisco & 0,001 & 0,001 & $\begin{array}{l}\text { volume de chapisco em } \\
\text { m3 por mm de espessu- } \\
\text { ra }\end{array}$ \\
\hline & dens_arg_emb & $\begin{array}{l}\text { if('RER: Clay Brick Typology new <u-so>'.traco_arg_emb=0;1720;if('RER: Clay Brick Typology new <u- } \\
\text { so>'.traco_arg_emb=1;1960;0)) }\end{array}$ & 1720 & \\
\hline & esp_asse_cer & 12 & 12 & $\mathrm{~mm}$ \\
\hline & n_blocos & if('RER: Clay Brick Typology new <u-so>'.t_bloco=0;25,7;0) & 25,7 & \\
\hline & peso_arg_ass & $\begin{array}{l}\text { if('RER: Clay Brick Typology new <u-so>'.traco_arg_ass=0;19,7;if('RER: Clay Brick Typology new <u- } \\
\text { so>'.traco_arg_ass=1;24,7;0)) }\end{array}$ & 19,7 & \\
\hline & peso_arg_emb & $\begin{array}{l}\text { 'RER: Clay Brick Typology new <u-so>'.vol_emboco*'RER: Clay Brick Typology new <u- } \\
\text { so>'.dens_arg_emb }\end{array}$ & 68,8 & \\
\hline & peso_chap & $\begin{array}{l}\text { if('RER: Clay Brick Typology new <u-so>'.traco_chap=0;19,9;if('RER: Clay Brick Typology new <u- } \\
\text { so>'.traco_chap }=1 ; 27,9 ; 0) \text { ) }\end{array}$ & 27,9 & \\
\hline & peso_saida & $\begin{array}{l}\text { 'RER: Clay Brick Typology new <u-so>'.peso_bloco_tota+'RER: Clay Brick Typology new <u- } \\
\text { so>'.peso_arg_ass+'RER: Clay Brick Typology new <u-so>'.peso_arg_emb+'RER: Clay Brick Typology } \\
\text { new <u-so>'.peso_chap }\end{array}$ & 173,197 & \\
\hline & vol_arg_asse & if('RER: Clay Brick Typology new <u-so>'.t_bloco $=0 ; 0,0135 ; 0)$ & 0,0135 & m3 (literatura) \\
\hline
\end{tabular}




\begin{tabular}{|l|l|l|l|l|}
\hline \multirow{2}{*}{} & vol_chapisco & $\begin{array}{l}\text { 'RER: Clay Brick Typology new <u-so>'.cons_chapisco*'RER: Clay Brick Typology new <u- } \\
\text { so''es_chapisco*2 }\end{array}$ & 0,01 & m3 (calculado) \\
\cline { 2 - 6 } & vol_emboco & $\begin{array}{l}\text { ('RER: Clay Brick Typology new <u-so>'.esp_emb_int+'RER: Clay Brick Typology new <u- } \\
\text { sos'.esp_emb_ext)*0,001 }\end{array}$ & 0,04 & m3 (literatura) \\
\hline
\end{tabular}




\section{Apêndice M: Tabela do Inventário do Ciclo de Vida}

\section{Contexto de análise 1 por fluxo e por módulo de ACV}

\begin{tabular}{|c|c|c|c|c|c|c|c|c|c|c|}
\hline \multicolumn{11}{|c|}{ Tipologia 1} \\
\hline & Total & A1 & A2 & A3 & A4 & A5 & C2 & C3 & C4 & D \\
\hline Fluxos & $7,24 \mathrm{E}+03$ & $5,48 \mathrm{E}+03$ & $2,27 \mathrm{E}+01$ & $1,31 \mathrm{E}+01$ & $1,18 \mathrm{E}+02$ & $1,50 \mathrm{E}+03$ & $1,05 \mathrm{E}+02$ & $-6,70 \mathrm{E}+01$ & $6,09 \mathrm{E}+01$ & $4,59 \mathrm{E}+00$ \\
\hline Recursos & $3,75 E+03$ & $2,89 \mathrm{E}+03$ & $1,13 \mathrm{E}+01$ & $-4,09 \mathrm{E}+01$ & $5,84 \mathrm{E}+01$ & $9,06 \mathrm{E}+02$ & $5,17 \mathrm{E}+01$ & $-1,60 \mathrm{E}+02$ & $3,06 \mathrm{E}+01$ & $4,59 \mathrm{E}+00$ \\
\hline Energia & $6,85 \mathrm{E}+00$ & $4,98 \mathrm{E}+00$ & 7,73E-02 & 2,09E-02 & $6,83 \mathrm{E}-01$ & $2,78 \mathrm{E}-01$ & $6,04 \mathrm{E}-01$ & 2,36E-02 & $1,85 \mathrm{E}-01$ & 0 \\
\hline Recursos não-renováveis & $6,85 \mathrm{E}+00$ & $4,98 \mathrm{E}+00$ & 7,73E-02 & 2,09E-02 & $6,83 \mathrm{E}-01$ & $2,78 \mathrm{E}-01$ & $6,04 \mathrm{E}-01$ & $2,36 \mathrm{E}-02$ & $1,85 \mathrm{E}-01$ & 0 \\
\hline Recursos renováveis & $1,35 \mathrm{E}-03$ & $1,35 \mathrm{E}-03$ & $1,27 \mathrm{E}-18$ & $4,14 \mathrm{E}-16$ & $5,54 \mathrm{E}-16$ & $5,51 \mathrm{E}-15$ & $4,91 \mathrm{E}-16$ & $1,81 \mathrm{E}-13$ & $4,32 \mathrm{E}-18$ & 0 \\
\hline Recursos materiais & $3,75 E+03$ & $2,89 \mathrm{E}+03$ & $1,12 \mathrm{E}+01$ & $-4,09 E+01$ & $5,77 \mathrm{E}+01$ & $9,06 \mathrm{E}+02$ & $5,11 \mathrm{E}+01$ & $-1,60 \mathrm{E}+02$ & $3,04 \mathrm{E}+01$ & $4,59 \mathrm{E}+00$ \\
\hline Resíduos depositados & $1,30 \mathrm{E}+02$ & $6,92 \mathrm{E}+01$ & $3,17 \mathrm{E}-03$ & $4,19 \mathrm{E}+00$ & 2,77E-02 & $5,57 \mathrm{E}+01$ & $2,45 \mathrm{E}-02$ & $1,08 \mathrm{E}+00$ & $8,20 \mathrm{E}-03$ & 0 \\
\hline Stockpile goods & $1,30 \mathrm{E}+02$ & $6,92 \mathrm{E}+01$ & $3,17 \mathrm{E}-03$ & $4,19 \mathrm{E}+00$ & 2,77E-02 & $5,57 \mathrm{E}+01$ & $2,45 \mathrm{E}-02$ & $1,08 \mathrm{E}+00$ & $8,20 \mathrm{E}-03$ & 0 \\
\hline Emissões para o ar & $2,26 \mathrm{E}+02$ & $1,17 \mathrm{E}+02$ & $7,54 \mathrm{E}+00$ & $1,21 \mathrm{E}+01$ & $3,55 \mathrm{E}+01$ & $4,73 \mathrm{E}+00$ & $3,14 \mathrm{E}+01$ & $1,06 \mathrm{E}+00$ & $1,67 \mathrm{E}+01$ & 0 \\
\hline Metais pesados para o ar & $1,84 \mathrm{E}-05$ & $1,52 \mathrm{E}-05$ & $5,48 \mathrm{E}-08$ & $1,45 \mathrm{E}-07$ & $4,50 \mathrm{E}-07$ & $1,94 \mathrm{E}-06$ & $3,99 \mathrm{E}-07$ & $3,60 \mathrm{E}-08$ & $1,32 \mathrm{E}-07$ & 0 \\
\hline Emissões inorgânicas para o ar & $2,16 \mathrm{E}+02$ & $1,13 \mathrm{E}+02$ & $7,53 \mathrm{E}+00$ & $1,17 \mathrm{E}+01$ & $3,54 \mathrm{E}+01$ & $-6,16 \mathrm{E}-01$ & $3,13 \mathrm{E}+01$ & $8,75 \mathrm{E}-01$ & $1,67 \mathrm{E}+01$ & 0 \\
\hline Emissões orgânicas para o ar (grupo VOC) & 4,91E-02 & 4,06E-02 & 3,76E-04 & $8,69 \mathrm{E}-04$ & $2,37 \mathrm{E}-03$ & $1,84 \mathrm{E}-03$ & $2,10 \mathrm{E}-03$ & 8,98E-05 & $8,85 \mathrm{E}-04$ & 0 \\
\hline Outros tipos de emissões & $9,79 \mathrm{E}+00$ & $3,72 \mathrm{E}+00$ & $5,41 \mathrm{E}-03$ & $4,00 \mathrm{E}-01$ & $7,01 \mathrm{E}-02$ & $5,34 \mathrm{E}+00$ & $6,20 \mathrm{E}-02$ & $1,84 \mathrm{E}-01$ & $1,56 \mathrm{E}-02$ & 0 \\
\hline Partículas parao ar & $1,76 \mathrm{E}-02$ & $5,55 \mathrm{E}-03$ & $9,58 \mathrm{E}-06$ & 1,06E-03 & $7,82 \mathrm{E}-05$ & $1,08 \mathrm{E}-02$ & $6,92 \mathrm{E}-05$ & 1,97E-05 & $1,12 \mathrm{E}-05$ & 0 \\
\hline Emissões radioativas para o ar & $1,45 \mathrm{E}-07$ & $1,45 \mathrm{E}-07$ & $1,34 \mathrm{E}-15$ & $2,59 \mathrm{E}-13$ & $7,73 \mathrm{E}-15$ & $3,44 \mathrm{E}-12$ & $6,84 \mathrm{E}-15$ & $8,47 \mathrm{E}-15$ & $3,14 \mathrm{E}-15$ & 0 \\
\hline Emissões para a água potável & $3,13 \mathrm{E}+03$ & $2,40 \mathrm{E}+03$ & $3,81 \mathrm{E}+00$ & $3,77 \mathrm{E}+01$ & $2,32 \mathrm{E}+01$ & $5,36 \mathrm{E}+02$ & $2,05 \mathrm{E}+01$ & $9,11 \mathrm{E}+01$ & $1,35 \mathrm{E}+01$ & 0 \\
\hline Medidas analíticas para a água potável & 2,47E-03 & $2,00 \mathrm{E}-03$ & 4,95E-06 & $3,01 \mathrm{E}-05$ & $3,81 \mathrm{E}-05$ & $3,38 \mathrm{E}-04$ & $3,38 \mathrm{E}-05$ & 9,67E-06 & $1,19 \mathrm{E}-05$ & 0 \\
\hline Metais pesados para a água potável & 5,64E-03 & $5,41 \mathrm{E}-03$ & 1,29E-06 & 1,27E-05 & $6,80 \mathrm{E}-06$ & $1,78 \mathrm{E}-04$ & $6,02 \mathrm{E}-06$ & 2,65E-05 & 4,30E-06 & 0 \\
\hline Emissões inorgânicas para a água potável & $8,11 \mathrm{E}-02$ & $6,29 \mathrm{E}-02$ & $9,22 \mathrm{E}-04$ & 3,27E-04 & $5,50 \mathrm{E}-03$ & $3,94 \mathrm{E}-03$ & 4,87E-03 & $4,21 \mathrm{E}-04$ & $2,19 \mathrm{E}-03$ & 0 \\
\hline Emissões orgânicas para a água potável & $3,15 \mathrm{E}-03$ & $8,69 \mathrm{E}-04$ & $1,81 \mathrm{E}-04$ & 8,79E-06 & $8,26 \mathrm{E}-04$ & $1,14 \mathrm{E}-04$ & 7,31E-04 & 9,07E-06 & $4,11 \mathrm{E}-04$ & 0 \\
\hline Outras emissões para a água potável & $3,13 \mathrm{E}+03$ & $2,40 \mathrm{E}+03$ & $3,81 \mathrm{E}+00$ & $3,77 \mathrm{E}+01$ & $2,31 \mathrm{E}+01$ & $5,36 \mathrm{E}+02$ & $2,05 \mathrm{E}+01$ & $9,11 \mathrm{E}+01$ & $1,35 \mathrm{E}+01$ & 0 \\
\hline Partículas para a água potável & 3,88E-02 & 1,42E-02 & 1,92E-03 & $9,11 \mathrm{E}-05$ & 8,93E-03 & 1,22E-03 & 7,90E-03 & $9,31 \mathrm{E}-05$ & 4,38E-03 & 0 \\
\hline
\end{tabular}




\begin{tabular}{|c|c|c|c|c|c|c|c|c|c|c|}
\hline Emissões radioativas para a água potável & 0 & 0 & 0 & 0 & 0 & 0 & 0 & 0 & 0 & 0 \\
\hline Emissões para o mar & $2,83 \mathrm{E}+00$ & $5,98 \mathrm{E}-01$ & $4,68 \mathrm{E}-02$ & $1,21 \mathrm{E}-02$ & $1,01 \mathrm{E}+00$ & $1,60 \mathrm{E}-01$ & $8,91 \mathrm{E}-01$ & $4,54 \mathrm{E}-03$ & $1,12 \mathrm{E}-01$ & 0 \\
\hline Medidas analíticas para o mar & 1,05E-04 & 2,62E-05 & 1,27E-06 & $4,22 E-06$ & $3,43 E-05$ & 5,82E-06 & 3,04E-05 & $1,55 \mathrm{E}-07$ & $3,03 E-06$ & 0 \\
\hline Metais pesados para o mar & $1,18 \mathrm{E}-05$ & $3,75 \mathrm{E}-06$ & 8,97E-08 & $5,12 \mathrm{E}-08$ & $3,69 \mathrm{E}-06$ & $6,81 \mathrm{E}-07$ & $3,26 \mathrm{E}-06$ & 1,97E-08 & $2,15 \mathrm{E}-07$ & 0 \\
\hline Emissões inorgânicas para o mar & 8,04E-02 & 1,53E-02 & 7,06E-04 & 3,89E-04 & $3,04 \mathrm{E}-02$ & 4,77E-03 & $2,69 \mathrm{E}-02$ & $1,21 \mathrm{E}-04$ & $1,69 \mathrm{E}-03$ & 0 \\
\hline Emissões orgânicas para o mar & 4,76E-05 & $9,06 \mathrm{E}-06$ & 4,19E-07 & 2,13E-07 & $1,80 \mathrm{E}-05$ & 2,83E-06 & $1,60 \mathrm{E}-05$ & 7,17E-08 & $1,00 \mathrm{E}-06$ & 0 \\
\hline Outras emissões para o mar & $2,75 \mathrm{E}+00$ & $5,82 \mathrm{E}-01$ & 4,61E-02 & 1,17E-02 & $9,75 \mathrm{E}-01$ & $1,56 \mathrm{E}-01$ & 8,63E-01 & $4,41 \mathrm{E}-03$ & $1,10 \mathrm{E}-01$ & 0 \\
\hline Partículas para o mar & 1,67E-03 & $7,72 \mathrm{E}-04$ & 3,97E-05 & $6,38 \mathrm{E}-06$ & $3,56 \mathrm{E}-04$ & $8,50 \mathrm{E}-05$ & $3,16 \mathrm{E}-04$ & $2,66 \mathrm{E}-06$ & 9,49E-05 & 0 \\
\hline Medidas analíticas para o mar & 0 & 0 & 0 & 0 & 0 & 0 & 0 & 0 & 0 & 0 \\
\hline Emissões para o solo agrícola & 2,92E-06 & $2,40 \mathrm{E}-06$ & $-2,07 \mathrm{E}-07$ & $1,36 \mathrm{E}-07$ & $-5,53 \mathrm{E}-07$ & $1,81 \mathrm{E}-06$ & $-4,90 \mathrm{E}-07$ & 2,97E-07 & $-4,69 \mathrm{E}-07$ & 0 \\
\hline Metais pesados para o solo agrícola & $2,92 \mathrm{E}-06$ & $2,40 \mathrm{E}-06$ & $-2,07 \mathrm{E}-07$ & $1,36 \mathrm{E}-07$ & $-5,53 E-07$ & $1,81 \mathrm{E}-06$ & $-4,90 \mathrm{E}-07$ & 2,97E-07 & $-4,69 \mathrm{E}-07$ & 0 \\
\hline Emissões para o solo industrial & $1,81 \mathrm{E}-02$ & 1,79E-02 & $6,43 \mathrm{E}-07$ & 1,53E-05 & $3,11 \mathrm{E}-06$ & $1,91 \mathrm{E}-04$ & $2,75 \mathrm{E}-06$ & $7,88 \mathrm{E}-07$ & 1,47E-06 & 0 \\
\hline Metais pesados para o solo insdustrial & 1,51E-05 & $1,51 \mathrm{E}-05$ & $7,20 \mathrm{E}-11$ & 1,25E-09 & $3,67 \mathrm{E}-10$ & $1,66 \mathrm{E}-08$ & $3,25 \mathrm{E}-10$ & $7,37 \mathrm{E}-11$ & $1,67 \mathrm{E}-10$ & 0 \\
\hline Emissões orgânicas para o solo insdustrial & $1,81 \mathrm{E}-02$ & $1,79 \mathrm{E}-02$ & $6,43 \mathrm{E}-07$ & $1,53 \mathrm{E}-05$ & $3,11 \mathrm{E}-06$ & $1,91 \mathrm{E}-04$ & $2,75 \mathrm{E}-06$ & $7,88 \mathrm{E}-07$ & 1,47E-06 & 0 \\
\hline Outras emissões para o solo insdustrial & 1,79E-06 & 1,79E-06 & $1,06 \mathrm{E}-13$ & $1,56 \mathrm{E}-11$ & $7,64 \mathrm{E}-13$ & $2,07 \mathrm{E}-10$ & $6,76 \mathrm{E}-13$ & $4,51 \mathrm{E}-12$ & $2,52 \mathrm{E}-13$ & 0 \\
\hline \multicolumn{11}{|c|}{ Tipologia 2} \\
\hline & Total & A1 & A2 & A3 & A4 & A5 & C2 & C3 & $\mathrm{C4}$ & D \\
\hline Fluxos & $7,02 \mathrm{E}+03$ & $5,37 \mathrm{E}+03$ & $2,15 \mathrm{E}+01$ & $9,90 \mathrm{E}+00$ & $1,16 \mathrm{E}+02$ & $1,41 E+03$ & $1,05 \mathrm{E}+02$ & $-6,73 E+01$ & $6,12 \mathrm{E}+01$ & $7,02 \mathrm{E}+03$ \\
\hline Recursos & $3,65 \mathrm{E}+03$ & $2,83 E+03$ & $1,07 \mathrm{E}+01$ & $-4,09 E+01$ & $5,75 \mathrm{E}+01$ & $8,60 \mathrm{E}+02$ & $5,19 \mathrm{E}+01$ & $-1,61 \mathrm{E}+02$ & $3,07 \mathrm{E}+01$ & $3,65 \mathrm{E}+03$ \\
\hline Energia & $6,71 \mathrm{E}+00$ & $4,87 \mathrm{E}+00$ & 7,34E-02 & 2,09E-02 & $6,72 \mathrm{E}-01$ & $2,54 \mathrm{E}-01$ & 6,07E-01 & 2,37E-02 & $1,86 \mathrm{E}-01$ & $6,71 \mathrm{E}+00$ \\
\hline Recursos não-renováveis & $6,71 \mathrm{E}+00$ & $4,87 \mathrm{E}+00$ & $7,34 \mathrm{E}-02$ & 2,09E-02 & $6,72 \mathrm{E}-01$ & $2,54 \mathrm{E}-01$ & 6,07E-01 & 2,37E-02 & $1,86 \mathrm{E}-01$ & $6,71 \mathrm{E}+00$ \\
\hline Recursos renováveis & $1,06 \mathrm{E}-03$ & 1,06E-03 & $1,21 \mathrm{E}-18$ & $4,14 \mathrm{E}-16$ & $5,46 \mathrm{E}-16$ & $5,03 \mathrm{E}-15$ & 4,93E-16 & $1,81 \mathrm{E}-13$ & $4,34 \mathrm{E}-18$ & 1,06E-03 \\
\hline Recursos materiais & $3,64 \mathrm{E}+03$ & $2,83 \mathrm{E}+03$ & $1,06 \mathrm{E}+01$ & $-4,09 E+01$ & $5,68 \mathrm{E}+01$ & $8,60 \mathrm{E}+02$ & $5,13 \mathrm{E}+01$ & $-1,61 E+02$ & $3,05 \mathrm{E}+01$ & $3,64 \mathrm{E}+03$ \\
\hline Resíduos depositados & $1,26 \mathrm{E}+02$ & $7,03 E+01$ & $3,01 \mathrm{E}-03$ & $4,19 \mathrm{E}+00$ & 2,73E-02 & $5,08 \mathrm{E}+01$ & $2,46 \mathrm{E}-02$ & $1,08 \mathrm{E}+00$ & $8,23 \mathrm{E}-03$ & $1,26 \mathrm{E}+02$ \\
\hline Stockpile goods & $1,26 \mathrm{E}+02$ & $7,03 E+01$ & $3,01 \mathrm{E}-03$ & $4,19 \mathrm{E}+00$ & 2,73E-02 & $5,08 \mathrm{E}+01$ & $2,46 \mathrm{E}-02$ & $1,08 \mathrm{E}+00$ & $8,23 \mathrm{E}-03$ & $1,26 \mathrm{E}+02$ \\
\hline Emissões para o ar & $2,14 \mathrm{E}+02$ & $1,10 \mathrm{E}+02$ & $7,16 \mathrm{E}+00$ & $8,88 \mathrm{E}+00$ & $3,49 \mathrm{E}+01$ & $3,59 \mathrm{E}+00$ & $3,15 \mathrm{E}+01$ & $1,06 \mathrm{E}+00$ & $1,68 \mathrm{E}+01$ & $2,14 \mathrm{E}+02$ \\
\hline Metais pesados para o ar & 1,60E-05 & 1,30E-05 & $5,20 \mathrm{E}-08$ & $1,45 \mathrm{E}-07$ & 4,43E-07 & 1,77E-06 & 4,00E-07 & 3,61E-08 & 1,33E-07 & 1,60E-05 \\
\hline
\end{tabular}




\begin{tabular}{|c|c|c|c|c|c|c|c|c|c|c|}
\hline Emissões inorgânicas para o ar & $2,04 \mathrm{E}+02$ & $1,06 \mathrm{E}+02$ & $7,15 \mathrm{E}+00$ & $8,48 \mathrm{E}+00$ & $3,49 \mathrm{E}+01$ & $-1,29 \mathrm{E}+00$ & $3,15 \mathrm{E}+01$ & $8,78 \mathrm{E}-01$ & $1,68 \mathrm{E}+01$ & $2,04 \mathrm{E}+02$ \\
\hline Emissões orgânicas para o ar (grupo VOC) & 4,64E-02 & 3,83E-02 & 3,57E-04 & $6,43 E-04$ & $2,33 \mathrm{E}-03$ & $1,68 \mathrm{E}-03$ & $2,11 \mathrm{E}-03$ & $9,01 \mathrm{E}-05$ & $8,88 \mathrm{E}-04$ & 4,64E-02 \\
\hline Outros tipos de emissões & $9,54 \mathrm{E}+00$ & $3,93 \mathrm{E}+00$ & $5,14 \mathrm{E}-03$ & 4,00E-01 & $6,90 \mathrm{E}-02$ & $4,87 \mathrm{E}+00$ & $6,23 \mathrm{E}-02$ & 1,85E-01 & 1,57E-02 & $9,54 \mathrm{E}+00$ \\
\hline Partículas para o ar & $1,61 \mathrm{E}-02$ & 5,07E-03 & $9,10 \mathrm{E}-06$ & $1,02 \mathrm{E}-03$ & $7,70 \mathrm{E}-05$ & $9,81 \mathrm{E}-03$ & $6,95 \mathrm{E}-05$ & $1,98 \mathrm{E}-05$ & $1,13 \mathrm{E}-05$ & 1,61E-02 \\
\hline Emissões radioativas para o ar & $1,14 \mathrm{E}-07$ & $1,14 \mathrm{E}-07$ & $1,28 \mathrm{E}-15$ & $2,59 \mathrm{E}-13$ & $7,61 \mathrm{E}-15$ & $3,14 \mathrm{E}-12$ & $6,87 \mathrm{E}-15$ & $8,50 \mathrm{E}-15$ & $3,15 \mathrm{E}-15$ & $1,14 \mathrm{E}-07$ \\
\hline Emissões para a água potável & $3,03 E+03$ & $2,35 \mathrm{E}+03$ & $3,62 \mathrm{E}+00$ & $3,77 \mathrm{E}+01$ & $2,28 \mathrm{E}+01$ & $4,92 \mathrm{E}+02$ & $2,06 \mathrm{E}+01$ & $9,15 \mathrm{E}+01$ & $1,36 \mathrm{E}+01$ & $3,03 \mathrm{E}+03$ \\
\hline Medidas analíticas para a água potável & $2,13 \mathrm{E}-03$ & 1,69E-03 & $4,70 \mathrm{E}-06$ & 2,83E-05 & 3,76E-05 & 3,08E-04 & 3,39E-05 & $9,71 \mathrm{E}-06$ & $1,19 \mathrm{E}-05$ & $2,13 \mathrm{E}-03$ \\
\hline Metais pesados para a água potável & 4,96E-03 & 4,74E-03 & 1,23E-06 & 1,27E-05 & $6,70 \mathrm{E}-06$ & $1,64 \mathrm{E}-04$ & $6,04 \mathrm{E}-06$ & $2,66 \mathrm{E}-05$ & $4,31 \mathrm{E}-06$ & 4,96E-03 \\
\hline Emissões inorgânicas para a água potável & 7,33E-02 & $5,56 \mathrm{E}-02$ & $8,76 \mathrm{E}-04$ & $3,15 \mathrm{E}-04$ & $5,42 \mathrm{E}-03$ & $3,59 \mathrm{E}-03$ & $4,89 \mathrm{E}-03$ & 4,22E-04 & $2,20 \mathrm{E}-03$ & 7,33E-02 \\
\hline Emissões orgânicas para a água potável & $2,98 \mathrm{E}-03$ & $7,30 \mathrm{E}-04$ & $1,72 \mathrm{E}-04$ & $8,69 \mathrm{E}-06$ & $8,13 \mathrm{E}-04$ & $1,04 \mathrm{E}-04$ & 7,34E-04 & $9,10 \mathrm{E}-06$ & $4,12 \mathrm{E}-04$ & $2,98 \mathrm{E}-03$ \\
\hline Outras emissões para a água potável & $3,03 E+03$ & $2,35 \mathrm{E}+03$ & $3,62 \mathrm{E}+00$ & $3,77 \mathrm{E}+01$ & $2,28 \mathrm{E}+01$ & $4,92 \mathrm{E}+02$ & $2,06 \mathrm{E}+01$ & $9,15 \mathrm{E}+01$ & $1,35 \mathrm{E}+01$ & $3,03 E+03$ \\
\hline Partículas para a água potável & $3,70 \mathrm{E}-02$ & $1,27 \mathrm{E}-02$ & $1,83 \mathrm{E}-03$ & $9,11 \mathrm{E}-05$ & 8,79E-03 & $1,11 \mathrm{E}-03$ & 7,93E-03 & 9,35E-05 & 4,39E-03 & 3,70E-02 \\
\hline Emissões radioativas para a água potável & 0 & 0 & 0 & 0 & 0 & 0 & 0 & 0 & 0 & 0 \\
\hline Emissões para o mar & $2,90 \mathrm{E}+00$ & $6,99 \mathrm{E}-01$ & 4,45E-02 & $1,21 \mathrm{E}-02$ & $9,91 \mathrm{E}-01$ & $1,46 \mathrm{E}-01$ & $8,94 \mathrm{E}-01$ & 4,56E-03 & $1,13 \mathrm{E}-01$ & $2,90 \mathrm{E}+00$ \\
\hline Medidas analíticas para o mar & 1,05E-04 & $2,78 \mathrm{E}-05$ & $1,20 \mathrm{E}-06$ & $2,77 \mathrm{E}-06$ & $3,38 \mathrm{E}-05$ & $5,31 \mathrm{E}-06$ & $3,05 \mathrm{E}-05$ & $1,56 \mathrm{E}-07$ & $3,05 \mathrm{E}-06$ & $1,05 \mathrm{E}-04$ \\
\hline Metais pesados para o mar & $1,20 \mathrm{E}-05$ & $4,12 \mathrm{E}-06$ & $8,52 \mathrm{E}-08$ & $5,12 \mathrm{E}-08$ & 3,63E-06 & $6,21 \mathrm{E}-07$ & $3,28 \mathrm{E}-06$ & $1,98 \mathrm{E}-08$ & $2,15 \mathrm{E}-07$ & $1,20 \mathrm{E}-05$ \\
\hline Emissões inorgânicas para o mar & 7,92E-02 & $1,50 \mathrm{E}-02$ & $6,70 \mathrm{E}-04$ & $3,78 \mathrm{E}-04$ & 3,00E-02 & 4,35E-03 & $2,71 \mathrm{E}-02$ & $1,21 \mathrm{E}-04$ & $1,70 \mathrm{E}-03$ & 7,92E-02 \\
\hline Emissões orgânicas para o mar & 4,70E-05 & $8,92 \mathrm{E}-06$ & $3,98 \mathrm{E}-07$ & 2,13E-07 & $1,78 \mathrm{E}-05$ & $2,58 \mathrm{E}-06$ & $1,60 \mathrm{E}-05$ & $7,20 \mathrm{E}-08$ & $1,01 \mathrm{E}-06$ & 4,70E-05 \\
\hline Outras emissões para o mar & $2,82 \mathrm{E}+00$ & $6,83 \mathrm{E}-01$ & 4,38E-02 & 1,17E-02 & $9,61 \mathrm{E}-01$ & $1,42 \mathrm{E}-01$ & 8,67E-01 & 4,43E-03 & $1,11 \mathrm{E}-01$ & $2,82 \mathrm{E}+00$ \\
\hline Partículas para o mar & $1,79 \mathrm{E}-03$ & $9,01 \mathrm{E}-04$ & 3,77E-05 & $6,38 \mathrm{E}-06$ & 3,51E-04 & 7,75E-05 & 3,17E-04 & 2,67E-06 & $9,53 \mathrm{E}-05$ & $1,79 \mathrm{E}-03$ \\
\hline Medidas analíticas para o mar & 0 & 0 & 0 & 0 & 0 & 0 & 0 & 0 & 0 & 0 \\
\hline Emissões para o solo agrícola & $3,38 \mathrm{E}-06$ & $3,00 \mathrm{E}-06$ & $-1,97 \mathrm{E}-07$ & $1,36 \mathrm{E}-07$ & $-5,45 \mathrm{E}-07$ & $1,65 \mathrm{E}-06$ & $-4,92 \mathrm{E}-07$ & $2,98 \mathrm{E}-07$ & $-4,71 \mathrm{E}-07$ & 3,38E-06 \\
\hline Metais pesados para o solo agrícola & $3,38 \mathrm{E}-06$ & 3,00E-06 & $-1,97 \mathrm{E}-07$ & $1,36 \mathrm{E}-07$ & $-5,45 \mathrm{E}-07$ & $1,65 \mathrm{E}-06$ & $-4,92 \mathrm{E}-07$ & $2,98 \mathrm{E}-07$ & $-4,71 \mathrm{E}-07$ & $3,38 \mathrm{E}-06$ \\
\hline Emissões para o solo industrial & 1,77E-02 & $1,75 \mathrm{E}-02$ & $6,11 \mathrm{E}-07$ & $1,49 \mathrm{E}-05$ & $3,06 \mathrm{E}-06$ & $1,74 \mathrm{E}-04$ & $2,76 \mathrm{E}-06$ & 7,91E-07 & 1,47E-06 & $1,77 \mathrm{E}-02$ \\
\hline Metais pesados para o solo insdustrial & $1,21 \mathrm{E}-05$ & $1,21 \mathrm{E}-05$ & $6,84 \mathrm{E}-11$ & $1,25 \mathrm{E}-09$ & $3,61 \mathrm{E}-10$ & $1,52 \mathrm{E}-08$ & $3,26 \mathrm{E}-10$ & $7,40 \mathrm{E}-11$ & $1,67 \mathrm{E}-10$ & 1,21E-05 \\
\hline Emissões orgânicas para o solo insdustrial & $1,76 \mathrm{E}-02$ & $1,75 \mathrm{E}-02$ & $6,11 \mathrm{E}-07$ & $1,49 \mathrm{E}-05$ & $3,06 \mathrm{E}-06$ & $1,74 \mathrm{E}-04$ & $2,76 \mathrm{E}-06$ & $7,91 \mathrm{E}-07$ & 1,47E-06 & $1,76 \mathrm{E}-02$ \\
\hline Outras emissões para o solo insdustrial & $1,41 \mathrm{E}-06$ & $1,41 \mathrm{E}-06$ & $1,01 \mathrm{E}-13$ & $1,56 \mathrm{E}-11$ & $7,52 \mathrm{E}-13$ & $1,89 \mathrm{E}-10$ & $6,79 \mathrm{E}-13$ & $4,53 \mathrm{E}-12$ & $2,53 \mathrm{E}-13$ & 1,41E-06 \\
\hline
\end{tabular}


Contexto de análise 2 por fluxo e por módulo de ACV

\begin{tabular}{|c|c|c|c|c|c|c|c|c|c|c|}
\hline \multicolumn{11}{|c|}{ Tipologia inglesa aplicada ao Reino Unido } \\
\hline & Total & A1 & A2 & A3 & A4 & A5 & C2 & C3 & C4 & D \\
\hline Fluxos & $1,85 \mathrm{E}+04$ & $7,68 \mathrm{E}+03$ & $3,12 \mathrm{E}+01$ & $-1,72 \mathrm{E}+02$ & $1,26 \mathrm{E}+02$ & $7,49 \mathrm{E}+02$ & $1,24 \mathrm{E}+02$ & $9,67 \mathrm{E}+03$ & $9,80 \mathrm{E}-01$ & $2,46 \mathrm{E}+02$ \\
\hline Recursos & $9,50 \mathrm{E}+03$ & $3,96 \mathrm{E}+03$ & $1,49 \mathrm{E}+01$ & $-1,79 \mathrm{E}+02$ & $6,25 \mathrm{E}+01$ & $6,64 \mathrm{E}+02$ & $6,16 \mathrm{E}+01$ & $4,67 \mathrm{E}+03$ & $4,98 \mathrm{E}-01$ & $2,46 \mathrm{E}+02$ \\
\hline Energia & $1,37 \mathrm{E}+01$ & $1,02 \mathrm{E}+01$ & 6,87E-01 & $3,28 \mathrm{E}-03$ & $7,30 \mathrm{E}-01$ & 4,78E-02 & 7,19E-01 & $1,27 \mathrm{E}+00$ & $2,13 \mathrm{E}-02$ & 0 \\
\hline Recursos não-renováveis & $1,37 \mathrm{E}+01$ & $1,02 \mathrm{E}+01$ & $6,87 \mathrm{E}-01$ & $3,28 \mathrm{E}-03$ & $7,30 \mathrm{E}-01$ & $4,78 \mathrm{E}-02$ & $7,19 \mathrm{E}-01$ & $1,27 \mathrm{E}+00$ & $2,13 \mathrm{E}-02$ & 0 \\
\hline Recursos renováveis & $2,41 \mathrm{E}-04$ & $2,41 \mathrm{E}-04$ & $1,14 \mathrm{E}-15$ & $8,92 \mathrm{E}-16$ & $5,93 \mathrm{E}-16$ & $1,31 \mathrm{E}-15$ & $5,84 \mathrm{E}-16$ & $9,68 \mathrm{E}-12$ & $4,90 \mathrm{E}-17$ & 0 \\
\hline Recursos materiais & $9,49 \mathrm{E}+03$ & $3,95 \mathrm{E}+03$ & $1,42 \mathrm{E}+01$ & $1,01 \mathrm{E}+02$ & $6,18 \mathrm{E}+01$ & $3,84 \mathrm{E}+02$ & $6,08 \mathrm{E}+01$ & $4,67 \mathrm{E}+03$ & 4,77E-01 & $2,46 \mathrm{E}+02$ \\
\hline Resíduos depositados & $1,11 \mathrm{E}+02$ & $4,43 E+01$ & $2,75 \mathrm{E}-02$ & $1,28 \mathrm{E}-01$ & 2,96E-02 & $8,42 \mathrm{E}+00$ & 2,92E-02 & $5,76 \mathrm{E}+01$ & $1,13 \mathrm{E}-03$ & 0 \\
\hline Stockpile goods & $1,11 \mathrm{E}+02$ & $4,43 \mathrm{E}+01$ & $2,75 \mathrm{E}-02$ & $1,28 \mathrm{E}-01$ & $2,96 \mathrm{E}-02$ & $8,42 \mathrm{E}+00$ & $2,92 \mathrm{E}-02$ & $5,76 \mathrm{E}+01$ & 1,13E-03 & 0 \\
\hline Emissões para o ar & $3,73 \mathrm{E}+02$ & $2,36 \mathrm{E}+02$ & $2,56 \mathrm{E}+00$ & $2,51 \mathrm{E}+00$ & $3,80 \mathrm{E}+01$ & $1,10 \mathrm{E}-01$ & $3,74 \mathrm{E}+01$ & $5,67 \mathrm{E}+01$ & $2,06 \mathrm{E}-02$ & 0 \\
\hline Metais pesados para o ar & $1,99 \mathrm{E}-05$ & 1,63E-05 & $4,18 \mathrm{E}-07$ & $1,09 \mathrm{E}-08$ & 4,82E-07 & $2,99 \mathrm{E}-07$ & $4,75 \mathrm{E}-07$ & $1,93 \mathrm{E}-06$ & $1,31 \mathrm{E}-08$ & 0 \\
\hline Emissões inorgânicas para o ar & $2,46 \mathrm{E}+02$ & $1,20 \mathrm{E}+02$ & $2,46 \mathrm{E}+00$ & $2,41 \mathrm{E}+00$ & $3,79 \mathrm{E}+01$ & $-7,33 \mathrm{E}-01$ & $3,73 \mathrm{E}+01$ & $4,69 \mathrm{E}+01$ & $1,66 \mathrm{E}-02$ & 0 \\
\hline Emissões orgânicas para o ar (grupo VOC) & $8,22 \mathrm{E}-02$ & $6,56 \mathrm{E}-02$ & 1,37E-03 & $5,04 \mathrm{E}-03$ & $2,54 \mathrm{E}-03$ & $3,01 \mathrm{E}-04$ & $2,50 \mathrm{E}-03$ & $4,81 \mathrm{E}-03$ & $4,13 \mathrm{E}-05$ & 0 \\
\hline Outros tipos de emissões & $1,27 \mathrm{E}+02$ & $1,16 \mathrm{E}+02$ & $9,43 E-02$ & $8,78 \mathrm{E}-02$ & $7,50 \mathrm{E}-02$ & $8,41 \mathrm{E}-01$ & $7,39 \mathrm{E}-02$ & $9,87 \mathrm{E}+00$ & $4,02 \mathrm{E}-03$ & 0 \\
\hline Partículas parao ar & 1,72E-02 & $5,00 \mathrm{E}-03$ & 7,21E-05 & $9,29 \mathrm{E}-03$ & $8,36 \mathrm{E}-05$ & $1,63 \mathrm{E}-03$ & $8,24 \mathrm{E}-05$ & $1,06 \mathrm{E}-03$ & $8,49 \mathrm{E}-07$ & 0 \\
\hline Emissões radioativas para o ar & $2,61 \mathrm{E}-08$ & 2,61E-08 & $3,37 \mathrm{E}-15$ & $2,14 \mathrm{E}-14$ & $8,27 \mathrm{E}-15$ & $5,21 \mathrm{E}-13$ & $8,15 \mathrm{E}-15$ & $4,54 \mathrm{E}-13$ & $1,22 \mathrm{E}-16$ & 0 \\
\hline Emissões para a água potável & $8,46 \mathrm{E}+03$ & $3,44 \mathrm{E}+03$ & $1,21 \mathrm{E}+01$ & $4,29 E+00$ & $2,48 \mathrm{E}+01$ & $7,70 \mathrm{E}+01$ & $2,44 \mathrm{E}+01$ & $4,88 \mathrm{E}+03$ & 4,09E-01 & 0 \\
\hline Medidas analíticas para a água potável & $8,77 \mathrm{E}-03$ & $8,07 \mathrm{E}-03$ & $3,25 \mathrm{E}-05$ & $1,38 \mathrm{E}-05$ & $4,08 \mathrm{E}-05$ & $5,28 \mathrm{E}-05$ & $4,02 \mathrm{E}-05$ & $5,18 \mathrm{E}-04$ & $1,05 \mathrm{E}-06$ & 0 \\
\hline Metais pesados para a água potável & $3,24 \mathrm{E}-03$ & 1,77E-03 & 1,93E-06 & $1,32 \mathrm{E}-06$ & $7,28 \mathrm{E}-06$ & $2,56 \mathrm{E}-05$ & 7,17E-06 & $1,42 \mathrm{E}-03$ & $6,20 \mathrm{E}-08$ & 0 \\
\hline Emissões inorgânicas para a água potável & $1,38 \mathrm{E}-01$ & $1,00 \mathrm{E}-01$ & $2,72 \mathrm{E}-03$ & $7,49 \mathrm{E}-05$ & $5,89 \mathrm{E}-03$ & $6,35 \mathrm{E}-04$ & $5,80 \mathrm{E}-03$ & $2,25 \mathrm{E}-02$ & $8,49 \mathrm{E}-05$ & 0 \\
\hline Emissões orgânicas para a água potável & $2,55 \mathrm{E}-03$ & $2,89 \mathrm{E}-04$ & $6,87 \mathrm{E}-06$ & $4,73 \mathrm{E}-07$ & $8,84 \mathrm{E}-04$ & 1,73E-05 & $8,70 \mathrm{E}-04$ & $4,86 \mathrm{E}-04$ & $2,15 \mathrm{E}-07$ & 0 \\
\hline Outras emissões para a água potável & $8,46 \mathrm{E}+03$ & $3,44 \mathrm{E}+03$ & $1,21 \mathrm{E}+01$ & $4,29 \mathrm{E}+00$ & $2,48 \mathrm{E}+01$ & $7,70 \mathrm{E}+01$ & $2,44 \mathrm{E}+01$ & $4,88 \mathrm{E}+03$ & 4,09E-01 & 0 \\
\hline Partículas para a água potável & $9,18 \mathrm{E}-02$ & $6,72 \mathrm{E}-02$ & $4,08 \mathrm{E}-04$ & $8,65 \mathrm{E}-06$ & $9,55 \mathrm{E}-03$ & $1,87 \mathrm{E}-04$ & $9,41 \mathrm{E}-03$ & 4,99E-03 & $1,27 \mathrm{E}-05$ & 0 \\
\hline Emissões radioativas para a água potável & 0 & 0 & 0 & 0 & 0 & 0 & 0 & 0 & 0 & 0 \\
\hline Emissões para o mar & $7,01 \mathrm{E}+00$ & $2,90 \mathrm{E}+00$ & $1,64 \mathrm{E}+00$ & $1,52 \mathrm{E}-03$ & $1,08 \mathrm{E}+00$ & $3,30 \mathrm{E}-02$ & $1,06 \mathrm{E}+00$ & 2,43E-01 & $5,09 \mathrm{E}-02$ & 0 \\
\hline
\end{tabular}




\begin{tabular}{|c|c|c|c|c|c|c|c|c|c|c|}
\hline Medidas analíticas para o mar & $2,15 \mathrm{E}-04$ & $7,18 \mathrm{E}-05$ & 5,92E-05 & 4,03E-08 & $3,68 \mathrm{E}-05$ & $1,16 \mathrm{E}-06$ & 3,62E-05 & $8,30 \mathrm{E}-06$ & 1,83E-06 & 0 \\
\hline Metais pesados para o mar & $2,69 \mathrm{E}-05$ & 1,09E-05 & $6,79 \mathrm{E}-06$ & $6,53 \mathrm{E}-09$ & $3,94 \mathrm{E}-06$ & $1,40 \mathrm{E}-07$ & $3,88 \mathrm{E}-06$ & $1,06 \mathrm{E}-06$ & $2,10 \mathrm{E}-07$ & 0 \\
\hline Emissões inorgânicas para o mar & $1,72 \mathrm{E}-01$ & 4,19E-02 & 5,64E-02 & $2,55 \mathrm{E}-05$ & $3,26 \mathrm{E}-02$ & $9,81 \mathrm{E}-04$ & $3,21 \mathrm{E}-02$ & $6,46 \mathrm{E}-03$ & 1,74E-03 & 0 \\
\hline Emissões orgânicas para o mar & $1,02 \mathrm{E}-04$ & $2,51 \mathrm{E}-05$ & $3,34 \mathrm{E}-05$ & $1,53 \mathrm{E}-08$ & $1,93 \mathrm{E}-05$ & 5,83E-07 & $1,90 \mathrm{E}-05$ & $3,84 \mathrm{E}-06$ & 1,03E-06 & 0 \\
\hline Outras emissões para o mar & $6,83 \mathrm{E}+00$ & $2,85 \mathrm{E}+00$ & $1,59 \mathrm{E}+00$ & $1,50 \mathrm{E}-03$ & $1,04 \mathrm{E}+00$ & $3,20 \mathrm{E}-02$ & $1,03 \mathrm{E}+00$ & $2,36 \mathrm{E}-01$ & 4,91E-02 & 0 \\
\hline Partículas para o mar & $3,42 \mathrm{E}-03$ & $2,12 \mathrm{E}-03$ & $3,65 \mathrm{E}-04$ & $1,06 \mathrm{E}-06$ & $3,81 \mathrm{E}-04$ & $1,52 \mathrm{E}-05$ & 3,76E-04 & 1,43E-04 & $1,13 \mathrm{E}-05$ & 0 \\
\hline Medidas analíticas para o mar & 0 & 0 & 0 & 0 & 0 & 0 & 0 & 0 & 0 & 0 \\
\hline Emissões para o solo agrícola & $3,26 \mathrm{E}-04$ & $3,10 \mathrm{E}-04$ & $8,04 \mathrm{E}-07$ & $8,45 \mathrm{E}-09$ & $-5,92 \mathrm{E}-07$ & $6,08 \mathrm{E}-07$ & $-5,83 \mathrm{E}-07$ & $1,59 \mathrm{E}-05$ & $3,45 \mathrm{E}-08$ & 0 \\
\hline Metais pesados para o solo agrícola & 3,26E-04 & $3,10 \mathrm{E}-04$ & $8,04 \mathrm{E}-07$ & $8,45 \mathrm{E}-09$ & $-5,92 \mathrm{E}-07$ & $6,08 \mathrm{E}-07$ & $-5,83 E-07$ & $1,59 \mathrm{E}-05$ & $3,45 \mathrm{E}-08$ & 0 \\
\hline Emissões para o solo industrial & 1,17E-02 & $1,10 \mathrm{E}-02$ & $3,88 \mathrm{E}-07$ & $6,26 \mathrm{E}-04$ & $3,33 \mathrm{E}-06$ & $2,90 \mathrm{E}-05$ & $3,28 \mathrm{E}-06$ & $4,22 \mathrm{E}-05$ & $1,65 \mathrm{E}-08$ & 0 \\
\hline Metais pesados para o solo industrial & $4,05 \mathrm{E}-06$ & $3,39 \mathrm{E}-06$ & $8,23 E-11$ & $6,51 \mathrm{E}-07$ & $3,93 \mathrm{E}-10$ & $2,52 \mathrm{E}-09$ & $3,87 \mathrm{E}-10$ & $3,95 \mathrm{E}-09$ & $2,83 \mathrm{E}-12$ & 0 \\
\hline Emissões orgânicas para o solo insdustrial & 1,17E-02 & $1,10 \mathrm{E}-02$ & $3,88 \mathrm{E}-07$ & $6,25 \mathrm{E}-04$ & 3,33E-06 & 2,90E-05 & $3,28 \mathrm{E}-06$ & 4,22E-05 & $1,65 \mathrm{E}-08$ & 0 \\
\hline Outras emissões para o solo industrial & $3,25 \mathrm{E}-07$ & $3,25 \mathrm{E}-07$ & $5,85 \mathrm{E}-13$ & $1,31 \mathrm{E}-12$ & $8,17 \mathrm{E}-13$ & $3,14 \mathrm{E}-11$ & $8,05 \mathrm{E}-13$ & $2,42 \mathrm{E}-10$ & $2,26 \mathrm{E}-14$ & 0 \\
\hline \multicolumn{11}{|c|}{ Tipologia inglesa aplicada ao Brasil } \\
\hline & Total & A1 & A2 & A3 & A4 & A5 & $\mathbf{C 2}$ & C3 & C4 & D \\
\hline Fluxos & $4,14 \mathrm{E}+03$ & $3,68 \mathrm{E}+03$ & $1,41 E+01$ & $-7,78 \mathrm{E}+01$ & $6,31 E+01$ & $4,02 \mathrm{E}+02$ & $6,20 \mathrm{E}+01$ & $-3,98 \mathrm{E}+01$ & $3,62 E+01$ & $2,72 E+00$ \\
\hline Recursos & $2,15 E+03$ & $1,90 \mathrm{E}+03$ & $6,74 \mathrm{E}+00$ & $-8,10 E+01$ & $3,12 E+01$ & $3,39 \mathrm{E}+02$ & $3,07 E+01$ & $-9,51 E+01$ & 1,81E+01 & $2,72 E+00$ \\
\hline Energia & $6,25 \mathrm{E}+00$ & $5,05 \mathrm{E}+00$ & $3,11 \mathrm{E}-01$ & $1,48 \mathrm{E}-03$ & $3,65 \mathrm{E}-01$ & 3,70E-02 & $3,59 \mathrm{E}-01$ & $1,40 \mathrm{E}-02$ & $1,10 \mathrm{E}-01$ & 0 \\
\hline Recursos não-renováveis & $6,25 \mathrm{E}+00$ & $5,05 \mathrm{E}+00$ & $3,11 \mathrm{E}-01$ & $1,48 \mathrm{E}-03$ & $3,65 \mathrm{E}-01$ & 3,70E-02 & 3,59E-01 & $1,40 \mathrm{E}-02$ & $1,10 \mathrm{E}-01$ & 0 \\
\hline Recursos renováveis & 2,41E-04 & 2,41E-04 & $5,15 \mathrm{E}-16$ & $4,04 \mathrm{E}-16$ & $2,96 \mathrm{E}-16$ & $1,09 \mathrm{E}-15$ & $2,91 \mathrm{E}-16$ & $1,07 \mathrm{E}-13$ & $2,57 \mathrm{E}-18$ & 0 \\
\hline Recursos materiais & $2,15 E+03$ & $1,90 \mathrm{E}+03$ & $6,43 \mathrm{E}+00$ & $4,60 \mathrm{E}+01$ & $3,08 \mathrm{E}+01$ & $2,12 \mathrm{E}+02$ & $3,03 \mathrm{E}+01$ & $-9,51 E+01$ & $1,80 \mathrm{E}+01$ & $2,72 \mathrm{E}+00$ \\
\hline Resíduos depositados & $3,23 E+01$ & $2,53 E+01$ & $1,25 \mathrm{E}-02$ & $5,81 \mathrm{E}-02$ & $1,48 \mathrm{E}-02$ & $6,24 \mathrm{E}+00$ & $1,45 \mathrm{E}-02$ & $6,38 \mathrm{E}-01$ & 4,87E-03 & 0 \\
\hline Stockpile goods & $3,23 \mathrm{E}+01$ & $2,53 \mathrm{E}+01$ & $1,25 \mathrm{E}-02$ & $5,81 \mathrm{E}-02$ & $1,48 \mathrm{E}-02$ & $6,24 \mathrm{E}+00$ & $1,45 \mathrm{E}-02$ & $6,38 \mathrm{E}-01$ & 4,87E-03 & 0 \\
\hline Emissões para o ar & $1,62 \mathrm{E}+02$ & $1,12 \mathrm{E}+02$ & $1,16 \mathrm{E}+00$ & $1,14 \mathrm{E}+00$ & $1,89 \mathrm{E}+01$ & $-3,37 E-01$ & $1,86 \mathrm{E}+01$ & $6,29 \mathrm{E}-01$ & $9,93 \mathrm{E}+00$ & 0 \\
\hline Metais pesados para o ar & 9,77E-06 & $8,77 \mathrm{E}-06$ & $1,89 \mathrm{E}-07$ & 4,92E-09 & $2,40 \mathrm{E}-07$ & $2,23 \mathrm{E}-07$ & $2,37 \mathrm{E}-07$ & $2,13 \mathrm{E}-08$ & $7,86 \mathrm{E}-08$ & 0 \\
\hline Emissões inorgânicas para o ar & $1,08 \mathrm{E}+02$ & $5,92 \mathrm{E}+01$ & $1,12 \mathrm{E}+00$ & $1,09 \mathrm{E}+00$ & $1,89 \mathrm{E}+01$ & $-9,71 \mathrm{E}-01$ & $1,86 \mathrm{E}+01$ & $5,19 \mathrm{E}-01$ & $9,92 \mathrm{E}+00$ & 0 \\
\hline Emissões orgânicas para o ar (grupo VOC) & 3,92E-02 & $3,30 \mathrm{E}-02$ & $6,23 E-04$ & $2,28 \mathrm{E}-03$ & 1,27E-03 & $2,29 \mathrm{E}-04$ & $1,25 \mathrm{E}-03$ & $5,33 \mathrm{E}-05$ & $5,25 \mathrm{E}-04$ & 0 \\
\hline
\end{tabular}




\begin{tabular}{|c|c|c|c|c|c|c|c|c|c|c|}
\hline Outros tipos de emissões & $5,35 \mathrm{E}+01$ & $5,26 \mathrm{E}+01$ & 4,27E-02 & $3,98 \mathrm{E}-02$ & 3,74E-02 & 6,33E-01 & $3,68 \mathrm{E}-02$ & 1,09E-01 & 9,25E-03 & 0 \\
\hline Partículas para o ar & 8,25E-03 & 2,70E-03 & 3,27E-05 & 4,21E-03 & 4,18E-05 & 1,21E-03 & 4,11E-05 & 1,17E-05 & 6,67E-06 & 0 \\
\hline Emissões radioativas para o ar & 2,61E-08 & 2,61E-08 & $1,53 \mathrm{E}-15$ & $9,71 \mathrm{E}-15$ & 4,13E-15 & $3,86 \mathrm{E}-13$ & 4,06E-15 & $5,03 \mathrm{E}-15$ & $1,86 \mathrm{E}-15$ & 0 \\
\hline Emissões para a água potável & $1,79 \mathrm{E}+03$ & $1,64 \mathrm{E}+03$ & $5,49 \mathrm{E}+00$ & $1,95 \mathrm{E}+00$ & $1,24 \mathrm{E}+01$ & $5,74 \mathrm{E}+01$ & $1,22 E+01$ & $5,41 E+01$ & $8,01 E+00$ & 0 \\
\hline Medidas analíticas para a água potável & 3,96E-03 & $3,85 \mathrm{E}-03$ & 1,47E-05 & 6,27E-06 & 2,04E-05 & 3,96E-05 & 2,00E-05 & 5,74E-06 & 7,05E-06 & 0 \\
\hline Metais pesados para a água potável & 1,32E-03 & $1,28 \mathrm{E}-03$ & 8,75E-07 & 5,98E-07 & 3,63E-06 & $1,90 \mathrm{E}-05$ & 3,57E-06 & 1,57E-05 & $2,55 \mathrm{E}-06$ & 0 \\
\hline Emissões inorgânicas para a água potável & 6,01E-02 & $5,10 \mathrm{E}-02$ & 1,23E-03 & 3,39E-05 & 2,94E-03 & 4,81E-04 & 2,89E-03 & 2,50E-04 & 1,30E-03 & 0 \\
\hline Emissões orgânicas para a água potável & $1,29 \mathrm{E}-03$ & 1,47E-04 & $3,11 \mathrm{E}-06$ & 2,14E-07 & 4,41E-04 & 1,28E-05 & 4,34E-04 & 5,38E-06 & 2,44E-04 & 0 \\
\hline Outras emissões para a água potável & $1,79 \mathrm{E}+03$ & $1,64 \mathrm{E}+03$ & $5,49 \mathrm{E}+00$ & $1,95 \mathrm{E}+00$ & $1,24 \mathrm{E}+01$ & $5,74 \mathrm{E}+01$ & $1,22 \mathrm{E}+01$ & $5,41 \mathrm{E}+01$ & $8,01 \mathrm{E}+00$ & 0 \\
\hline Partículas para a água potável & 4,36E-02 & $3,11 \mathrm{E}-02$ & $1,85 \mathrm{E}-04$ & 3,92E-06 & 4,77E-03 & 1,39E-04 & 4,69E-03 & $5,52 \mathrm{E}-05$ & 2,60E-03 & 0 \\
\hline Emissões radioativas para a água potável & 0 & 0 & 0 & 0 & 0 & 0 & 0 & 0 & 0 & 0 \\
\hline Emissões para o mar & $3,26 \mathrm{E}+00$ & $1,35 \mathrm{E}+00$ & 7,45E-01 & 6,91E-04 & 5,37E-01 & 2,68E-02 & 5,29E-01 & 2,69E-03 & 6,65E-02 & 0 \\
\hline Medidas analíticas para o mar & 1,01E-04 & $3,44 \mathrm{E}-05$ & 2,68E-05 & 1,83E-08 & 1,83E-05 & 9,35E-07 & $1,80 \mathrm{E}-05$ & 9,19E-08 & 1,80E-06 & 0 \\
\hline Metais pesados para o mar & $1,25 \mathrm{E}-05$ & 5,23E-06 & $3,08 \mathrm{E}-06$ & 2,96E-09 & 1,97E-06 & 1,13E-07 & 1,94E-06 & 1,17E-08 & 1,27E-07 & 0 \\
\hline Emissões inorgânicas para o mar & $7,98 \mathrm{E}-02$ & 2,01E-02 & 2,56E-02 & 1,16E-05 & 1,63E-02 & 7,95E-04 & $1,60 \mathrm{E}-02$ & 7,15E-05 & $1,00 \mathrm{E}-03$ & 0 \\
\hline Emissões orgânicas para o mar & 4,74E-05 & $1,20 \mathrm{E}-05$ & 1,52E-05 & 6,93E-09 & 9,64E-06 & 4,72E-07 & $9,48 \mathrm{E}-06$ & 4,26E-08 & 5,95E-07 & 0 \\
\hline Outras emissões para o mar & $3,17 \mathrm{E}+00$ & $1,33 \mathrm{E}+00$ & 7,19E-01 & 6,79E-04 & 5,21E-01 & 2,60E-02 & 5,12E-01 & 2,62E-03 & $6,55 \mathrm{E}-02$ & 0 \\
\hline Partículas para o mar & 1,63E-03 & 1,01E-03 & $1,66 \mathrm{E}-04$ & 4,82E-07 & 1,90E-04 & $1,18 \mathrm{E}-05$ & 1,87E-04 & 1,58E-06 & 5,63E-05 & 0 \\
\hline Medidas analíticas para o mar & 0 & 0 & 0 & 0 & 0 & 0 & 0 & 0 & 0 & 0 \\
\hline Emissões para o solo agrícola & 1,41E-04 & $1,40 \mathrm{E}-04$ & 3,65E-07 & 3,83E-09 & $-2,96 \mathrm{E}-07$ & 5,37E-07 & $-2,91 \mathrm{E}-07$ & 1,76E-07 & $-2,78 \mathrm{E}-07$ & 0 \\
\hline Metais pesados para o solo agrícola & 1,41E-04 & $1,40 \mathrm{E}-04$ & $3,65 \mathrm{E}-07$ & 3,83E-09 & $-2,96 \mathrm{E}-07$ & 5,37E-07 & $-2,91 \mathrm{E}-07$ & 1,76E-07 & $-2,78 \mathrm{E}-07$ & 0 \\
\hline Emissões para o solo industrial & $6,43 \mathrm{E}-03$ & 6,12E-03 & 1,76E-07 & 2,83E-04 & 1,66E-06 & 2,16E-05 & 1,63E-06 & 4,68E-07 & 8,70E-07 & 0 \\
\hline Metais pesados para o solo industrial & 3,26E-06 & 2,96E-06 & $3,73 \mathrm{E}-11$ & $2,95 \mathrm{E}-07$ & $1,96 \mathrm{E}-10$ & 1,87E-09 & $1,93 \mathrm{E}-10$ & $4,38 \mathrm{E}-11$ & $9,89 \mathrm{E}-11$ & 0 \\
\hline Emissões orgânicas para o solo insdustrial & $6,42 \mathrm{E}-03$ & $6,11 \mathrm{E}-03$ & 1,76E-07 & 2,83E-04 & 1,66E-06 & 2,16E-05 & 1,63E-06 & 4,68E-07 & 8,70E-07 & 0 \\
\hline Outras emissões para o solo industrial & 3,24E-07 & 3,24E-07 & $2,65 \mathrm{E}-13$ & $5,93 \mathrm{E}-13$ & $4,08 \mathrm{E}-13$ & $2,33 \mathrm{E}-11$ & $4,01 \mathrm{E}-13$ & $2,68 \mathrm{E}-12$ & $1,50 \mathrm{E}-13$ & 0 \\
\hline
\end{tabular}

